UNIVERSIDADE DE SÃO PAULO

FACULDADE DE FILOSOFIA, LETRAS E CIÊNCIAS HUMANAS

DEPARTAMENTO DE GEOGRAFIA

PROGRAMA DE PÓS-GRADUAÇÃO EM GEOGRAFIA HUMANA

LEIDA MARIA DE SOUZA LIMA

O PROCESSO DE (RE) CRIAÇÃO DO CAMPESINATO

EM ÁREAS DO LATIFÚNDIO: A FRAGMENTAÇÃO DA

TERRA EM RONDONÓPOLIS-MT

São Paulo 
UNIVERSIDADE DE SÃO PAULO

FACULDADE DE FILOSOFIA, LETRAS E CIÊNCIAS HUMANAS

DEPARTAMENTO DE GEOGRAFIA

PROGRAMA DE PÓS-GRADUAÇÃO EM GEOGRAFIA HUMANA

LEIDA MARIA DE SOUZA LIMA

O PROCESSO DE (RE) CRIAÇÃO DO CAMPESINATO

EM ÁREAS DO LATIFÚNDIO: A FRAGMENTAÇÃO DA

TERRA EM RONDONÓPOLIS-MT 
UNIVERSIDADE DE SÃO PAULO

FACULDADE DE FILOSOFIA, LETRAS E CIÊNCIAS HUMANAS

DEPARTAMENTO DE GEOGRAFIA

PROGRAMA DE PÓS-GRADUAÇÃO EM GEOGRAFIA HUMANA

LEIDA MARIA DE SOUZA LIMA

\section{O PROCESSO DE (RE) CRIAÇÃO DO CAMPESINATO EM ÁREAS DO LATIFÚNDIO: A FRAGMENTAÇÃO DA TERRA EM RONDONÓPOLIS-MT}

Tese apresentada ao Curso de Pós-Graduação em Geografia Humana da Faculdade de Filosofia, Letras e Ciências Humanas da Universidade de São Paulo - USP, como requisito parcial para obtenção do título de Doutora em Geografia.

Orientadora:

Profa. Dra. Iraci Gomes de Vasconcelos Palheta 
LEIDA MARIA DE SOUZA LIMA

O PROCESSO DE (RE) CRIAÇÃO DO CAMPESINATO EM ÁREAS DO LATIFÚNDIO: A FRAGMENTAÇÃO DA TERRA EM RONDONÓPOLIS-MT

Aprovado em:

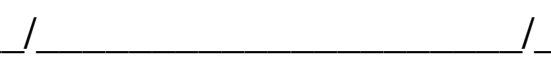

BANCA EXAMINADORA 


\section{DEDICATÓRIA}

Dedico este estudo às famílias AQUINO, FERREIRA, GIOVANINI, OLIVEIRA e SILVA, que através de seus relatos ajudaram a construí-lo; Aos meus pais ELVIRO (in memoriam) e ILDA, que eram trabalhadores rurais e foram expropriados;

Aos meus irmãos GUNNA, ANGÉLICA, DARCILIA, ELZA e MARTA, aos meus sobrinhos, que de uma forma ou outra deram força para eu continuar, em especial à Nathalia, que faz questão de tirar dez nas provas de Geografia e conta orgulhosa aos seus professores, com toda a simplicidade de uma criança, que vai ter uma tia/madrinha doutora nessa disciplina;

Ao JESUS/ZUZA, meu companheiro de vida, que muito me incentivou; À DANIELY e ao PAULO, meus filhos, razão do meu viver e motivo para eu não desistir desta ou de qualquer outra batalha; Enfim, a todos os que ao meu mau humor suportaram. 


\section{AGRADECIMENTOS}

À Universidade Federal de Mato Grosso - UFMT, por conceder-me o afastamento no período de 03/2003 a 03/2007 para capacitação em nível de doutorado;

Ao Programa Constitucional de Capacitação Docente - PICD da Coordenadoria de

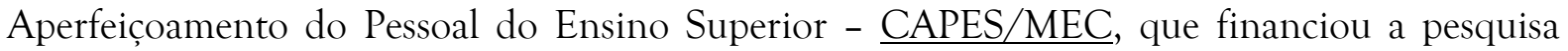
através da bolsa de estudo;

Ao Campus Universitário de Rondonópolis - CUR, em especial ao Departamento de Geografia/ICHS, pelo meu afastamento e por permitir minha ausência por mais uns dias para a conclusão da tese;

Aos professores do Departamento de Geografia que cobriram meus encargos, em especial à Profa. Marta S. Luedemann, que no momento em que pensei em desistir, mesmo seguindo uma linha diferente deu-me sustentáculo ajudando-me a encontrar o norte de minha pesquisa. Obrigada pelos momentos de estudo e discussão em seu lar, pelo material emprestado, pelas dúvidas esclarecidas. Obrigada, Sávio, pelos chás, cafezinho, água e lanches, para que não perdêssemos o pique. Valeu!;

Aos professores Denise, pelo incentivo, pelas palavras de conforto e encorajamento; Adenilce - minha "irmã", por ajudar-me no momento de maior sufoco, assumindo meus alunos de Prática; e Tarifa, que além de se dispor a ocupar meu horário aos sábados, neste final de corrida, não deixou de lado seu papel de bom mestre, realizando assim, a tradução do resumo deste trabalho. Vocês valem ouro!;

Ao Sr. Milton, ao Jorge e ao Luiz Mauro, motoristas do CUR, pelas caronas daqui para Cuiabá, a fim de que pudesse conseguir material para pesquisa;

Nas pessoas do Vimário e do Téo, agradeço aos funcionários da Biblioteca do CUR, pela atenção, procura de material e dedicação dispensada;

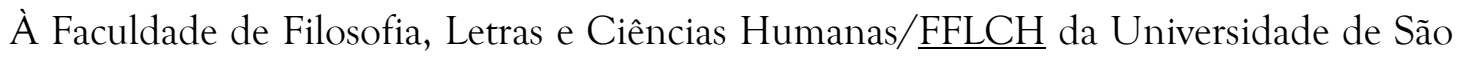
Paulo, pelo curso de pós-graduação em nível de doutorado;

Aos professores Dra. Iraci Gomes de Vasconcelos Palheta, pela orientação e Dr. Ariovaldo Umbelino de Oliveira, que mesmo com tantas atividades a desenvolver, dedicou um pouco de seu tempo a me orientar na redação final deste estudo para que o sonho se tornasse realidade, bem como pelo fato de assumir a presidência da banca na defesa;

Ao Prof. Dr. Wagner Costa Ribeiro, pela disciplina oferecida e pelos ensinamentos e discussões durante as aulas; ao Prof. Ari, que permitia a minha entrada em sua sala de aula para rever alguns conceitos;

Aos amigos conquistados durante a trajetória e permanência em São Paulo, em especial à Adélia A. de Souza Haracenko, de Maringá, que muito contribuiu para amenizar as angústias sentidas por estar longe de casa e pela força e incentivo que a mim dedica até hoje. Podes crer, amiga, nossa amizade será para sempre; 
À Profa. Dra . Marta Inez Medeiros Marques e ao Prof. Dr. Júlio César Suzuki, por fazer parte da comissão julgadora em meu exame de qualificação, especialmente pelas críticas, dicas e sugestões que mudaram os rumos de minha pesquisa. Muito obrigada!;

À Ana, Rosângela, Jurema e Cida, da Secretaria de Pós-Graduação, pela atenção dispensada;

Aos meus primos Hemerson Siqueira e Rosana Borges, pelas acolhidas em São Paulo no final do mestrado e início do doutorado; aos sobrinhos Elaine, Rogério, Isadora e Eder, por todas as vezes que me receberam em Osasco;

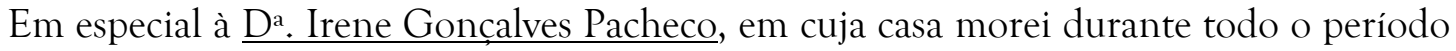
em que estive estudando e onde passo a temporada durante as várias idas a São Paulo, "meu lar paulista”. Muito mais que uma amiga, é minha terceira mãe;

À EMPAER/Rondonópolis, nas pessoas de Benjamim Silveira e Laércio Polizel, pelas informações e pela indicação de algumas famílias a serem entrevistadas. Valeu!;

Ao Sindicato dos Trabalhadores Rurais/Rondonópolis, na pessoa do Sr. Moacir, pelas informações repassadas;

Ao Ismael do Setor de Cadastro do INCRA em Cuiabá, pelas buscas realizadas;

À Luciene Moraes Paula, Gerente do Acervo Fundiário, ao Márcio Tadeu, Agente Fundiário e aos demais funcionários do Acervo no INTERMAT (Cuiabá), pela busca aos processos das famílias entrevistadas, para que se pudesse construir a trajetória de ocupação das terras dessas famílias;

Ao IBGE de Cuiabá, pelos dados conseguidos;

À Prefeitura Municipal de Rondonópolis, nas pessoas de Katiuscia e Sandra, da Assessoria Legislativa, pela ajuda na busca de documentos;

À Prefeitura de Poxoréo, nas pessoas de Beth Bellido, Recepcionista do gabinete do Prefeito e Garibaldi Toledo de Moraes, Coordenador de Mineração do Município de Poxoréo, pela busca e empréstimo de material;

Ao Cartório do 1० Ofício de Poxoréo, nas pessoas de Amanda Noleto e Roni de França, pela busca e levantamento de bens que realizaram;

Ao Cartório do $1^{\circ}$ Ofício de Rondonópolis, nas pessoas de Rosângela Auxiliadora Garcia Peres, Tabeliã Oficial, por permitir minha entrada no setor de arquivos do Cartório; Maria de Lourdes Almeida Cabral, Escrevente, por ter me atendido fora do expediente a fim de me possibilitar o acesso às matrículas de RGI, para compor a cadeia dominial das famílias, e Luvanêz Martins da Rocha, Escriturária, que além de fazer contato com duas das famílias, levoume até as propriedades em seus dias de folga para que pudesse realizar as entrevistas e aplicar os questionários. Você é peça especial deste quebra-cabeça; obrigada, "Neguinha”!;

À AGROSERV - Serviços Agronômicos e Topográficos S/C Ltda nas pessoas de Juarez Corrêa de Souza, Técnico Agrimensor e José Teodoro Silva, Operador de Computador/Cadista, pelas informações e pelos mapas confeccionados; 
Ao Adevaldo Narciso de Almeida, Engenheiro Agrônomo e Advogado, pelas dicas e pelo contato com o ex-prefeito e ex-deputado I. Barretos;

À minha secretária do lar Ivanete, por toda a dedicação, carinho e atenção com minha casa e minha família, principalmente durante minha ausência;

Às profas. Maria Margarida Corrêa Leite, LET/CUR/UFMT e Neusa Ferrer, pela revisão dos textos originais;

À cunhada Raquel, que dispunha seus momentos de folga para ajudar na digitação do texto e confecção dos organogramas;

À Josiane/Josi, minha filha postiça, pela ajuda nas buscas de material pela internet, pelo envio de e-mails, pelas idas aos locais das entrevistas para tirar as fotos, mesmo com o "barrigão", e ao Alex, que a "emprestava", às vezes sem saber: valeu, meus filhos;

À Thereza e ao Franklin (novos filhos), por trazerem o Caio Cezar - "meu neto", para ajudar na descontração e acalmar o estresse; muito obrigada, vocês estão em nossos corações;

À Marilda (pelas digitações), D. Vilma e Pedro Henrique, que mesmo em momento de dor foram comigo para o campo/fazenda ajudar na aplicação dos questionários e nas fotos, bem como à $\underline{D^{a}}$. Darcy, minha segunda mãe, à Meire, Cláudia, Jeannyne, Aline e aos demais pela força;

Minha mais profunda gratidão será para o Zuza (pelos leitinhos e cafezinhos quentes nas madrugadas), a Dany e o Paulo, que melhor do que ninguém puderam compreender minha ausência, falta de humor e de paciência, meu estresse. A vocês eu devo tudo. Obrigada por existirem. DEUS os abençoe sempre. Ao Everthon e Ana Rosa, por "cuidarem" com carinho de meus filhos;

À minha mãezinha ILDA, que infelizmente teve um AVC em 2005 e até o momento não voltou a andar. Desculpe, mãe, por quase não ter podido te ajudar. Às minhas irmãs, que à senhora estão se dedicando e não permitiram que eu desistisse nesse momento de fraqueza e dor; à Dany, que pegava suas folgas aqui para viajar e ajudá-las aí e aos demais que têm contribuído. DEUS sabe o quanto os amo e lhe agradeço por vocês;

Ao Gerson e Jessyka, Gráfica GR, que se dispuseram a trabalhar inclusive sábado e domingo, para conseguirem formatar e imprimir o trabalho em tempo hábil;

Serei eternamente grata às cinco famílias (38 pessoas) entrevistadas da região do Bananal, Beroaba, Belém, Aldeinha, Pequi, Naboreiro e Vila Bueno, que dispensaram sua atenção e paciência ao responderem os questionários e concederem entrevistas, expondo suas histórias de vida e emprestando documentação (escrituras, matrículas, formal de partilha, mapas); sem vocês o estudo não seria realizado;

A DEUS, que me deu força, coragem, paciência e persistência para levar este trabalho adiante, para que não desanimasse, pois na hora certa a luz iria brilhar;

Esta batalha vencida devo a todos vocês. Foram muitos os que colaboraram e que merecem meus agradecimentos; desculpem-me aqueles que porventura tenha esquecido de mencionar aqui. 


\section{A CERTEZA}

De tudo ficaram três coisas:

A certeza de que estamos sempre começando...

A certeza de que precisamos continuar...

A certeza de que seremos interrompidos antes de terminar...

Portanto devemos:

Fazer da interrupção um caminho novo...

Da queda um passo de dança...

Do medo, uma escola...

Do sonho, uma ponte...

Da procura, um encontro...

(Fernando Sabino) 
Vivendo na terra e do que ela produz, plantando e colhendo o alimento que vai para a sua mesa e para a do príncipe, do tecelão e do soldado, o camponês é o trabalhador que se envolve mais diretamente com os segredos da natureza. A céu aberto é um observador dos astros e dos elementos. Sabe de onde sopra o vento, quando virá a primeira chuva, que insetos podem ameaçar seus cultivos, quantas horas deverão ser dedicadas a determinada tarefa. Seu conhecimento do tempo e do espaço é profundo e já existia antes daquilo que convencionou chamar de ciência. (Margarida Maria Moura:1986) 


\section{RESUMO}

Esta tese investiga o estudo da (re) criação do campesinato em área de latifúndio a partir da fragmentação da terra por herança e doação em Rondonópolis/MT. Ela aborda as ações resultantes desse processo, e particularmente o significado desta conquista pelos sujeitos sociais. Rondonópolis é um município onde impera grandes latifúndios e uma enorme concentração fundiária, aliás, uma marca no território brasileiro. Nele está também presente, a expansão dos movimentos sociais no campo representados pelos assentamentos criados pelo Estado. A importância desta pesquisa deriva do processo de surgimento de áreas de fragmentação dos latifúndios que foram adquiridos por migrantes no auge da venda de terras pelo governo de Mato Grosso em meados do Século XX. As áreas pesquisadas têm como peculiaridade mais de quarenta e sete anos de história, pois estão nas mãos das mesmas famílias, passando de geração para geração. Este processo gerou paulatinamente, a transformação do latifúndio em pequenas propriedades. Nestes espaços os membros das famílias têm a preocupação em não deixar o patrimônio sair do domínio familiar. O estudo foi realizado nas localidades de Bananal, Beroaba, Belém, Aldeinha, Pequi, Núcleo Colonial de Naboreiro e Vila Bueno, no município de Rondonópolis-MT, e abrangeu cinco propriedades que se formaram pela junção de dez unidades através da compra e ou doação e que hoje estão divididas em sessenta e seis pequenas propriedades. Os resultados deste trabalho revelaram que a fragmentação tem seus benefícios, mas por outro lado, tem também suas conseqüências negativas, embora diferenciadas, do risco de formação de minifúndios.

PALAVRAS-CHAVE: fragmentação da terra, sucessão hereditária, transformação do latifúndio, (re) criação camponesa, trabalho familiar. 


\section{ABSTRACT}

This thesis research the (re)creation of peasant farming agriculture, in latifundium areas, through land fragmentation, by heritage and donation in Rondonópolis-MT. It analyze the actions resulting from this process, and emphasize the meaning of this conquer by the social actors. The importance of this work is based on the fact that Rondonópolis is a municipality with a great land area concentration, similar to great part of Brazilian territory. It also includes the expansion of social field movements, represented by many settlements created by the State. The importance of this research is related to the process of latifundium fragmentation, acquired by migrants in the peak of land selling by the government of Mato Grosso State in the middle of XX century. The researched areas have got a singular history aspect. More than 47 years has been kept in the same family ownership, from one to the next generation. This way, gradually have been changing from latifundium to small farming areas, therefore the family members are concerned about not to permit the properpty going out of family control. The study was carried out in the Rondonópolis municipality and in the Bananal, Beroaba, Belém, Aldeinha, Pequi, Nucleo Colonial de Naboreiro e Vila Bueno regions. It comprehends five properties that has been originated adding up (10) ten different areas through purchase and/or donation, otherwise now a days are divided in (66) sixty six small farming areas. The main results of this work have shown that the land fragmentation process has got their profits, but on the other hand can bring negative effects, although different. By the risk of minifundium formation.

KEY WORDS: Land fragmentation, inheritance succession, latifundium transformation, small farmers (re)creation, family labor. 


\section{SUMÁRIO}

1- INTRODUÇÃo.

2- BASES TEÓRICAS 32

2.1- Área e Tema: Razões da Escolha 32

2.2- Suporte Teórico: Transformações e Considerações ……………………........ 36

2.2.1- Abordagens e Interpretações Clássicas .................................................... 36

2.2.2- Contribuição Teórica Acerca da Realidade Brasileira .................................. 48

2.2.3- Contribuições Acerca da Temática em Questão ......................................... 70

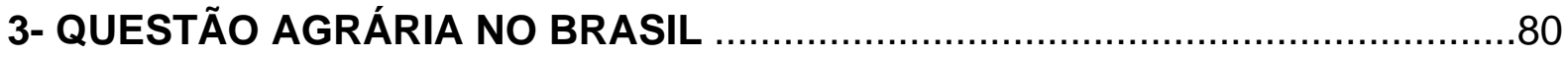

3.1- Origens da Propriedade da Terra e do Problema Fundiário no Brasil ...............81

3.2- Questão Agrária no Brasil: Um Problema ……........................................... 104

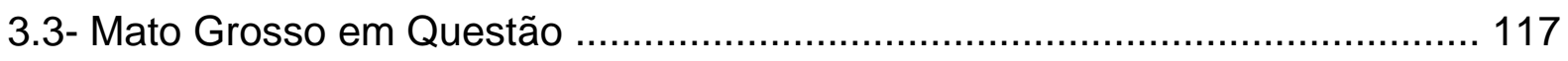

3.3.1- Características Gerais de Mato Grosso ……...................................... 117

3.3.2- Gênese do Campesinato em Mato Grosso ............................................ 121

3.3.3- Ocupação de Mato Grosso ................................................................. 123

4- RONDONÓPOLIS: FORMAÇÃO DO ESPAÇO GEOGRÁFICO …................. 143

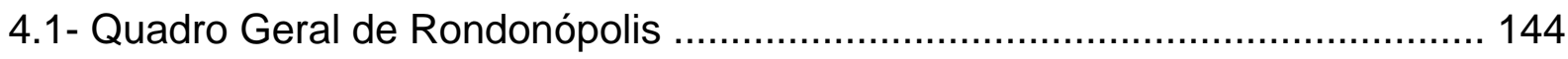

4.2- Formação Territorial de Rondonópolis: Gênese do Latifúndio e do

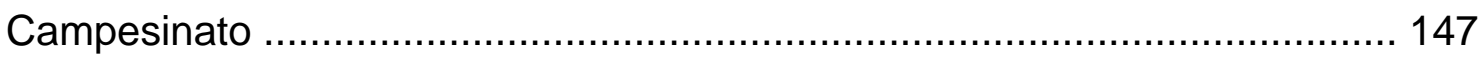

5- FRAGMENTAÇÃO DA TERRA EM RONDONÓPOLIS/MT …........................ 163

5.1- Fragmentação da Terra - Uma Revisão ...................................................... 164

5.2- As Características Gerais das Famílias ................................................... 185

5.3- As Famílias e suas Propriedades .......................................................... 165

6- FRAGMENTAÇÃO DA TERRA POR HERANÇA OU DOAÇÃO ...................... 330

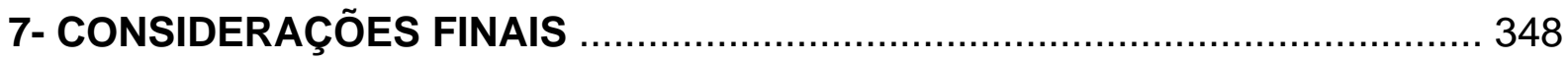

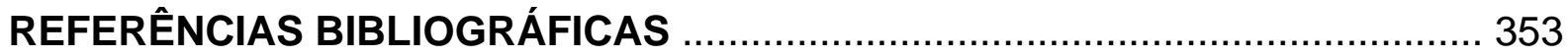

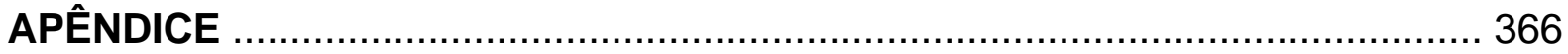

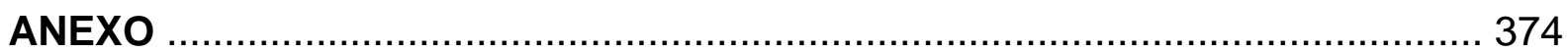




\section{LISTA DE MAPAS}

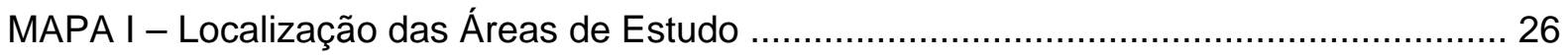

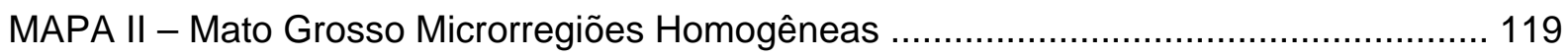

MAPA III - Localização de Rondonópolis em Relação a: ............................................ 145

MAPA IV - Localização Geográfica das Propriedades na Carta Topográfica do

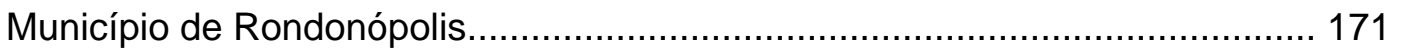

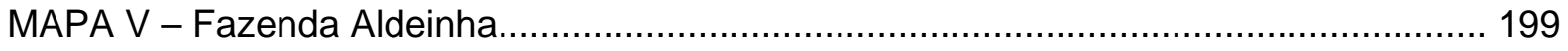

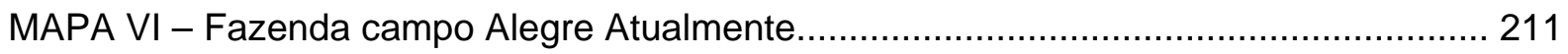

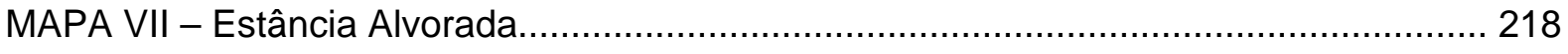

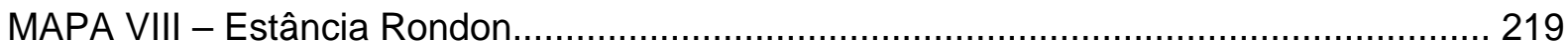

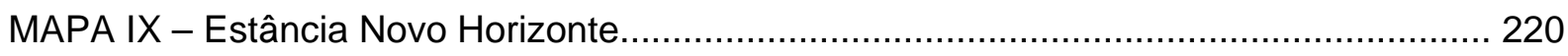

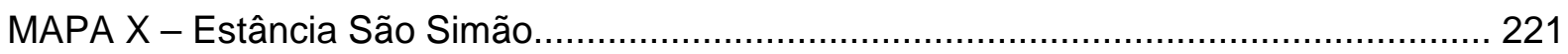

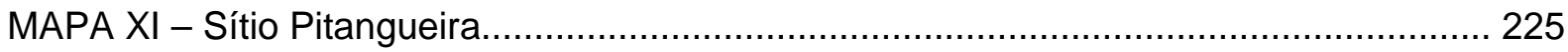

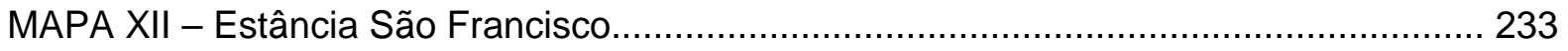

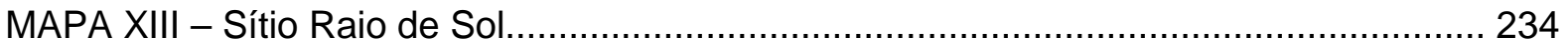

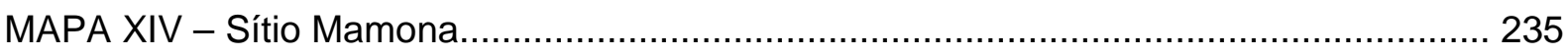

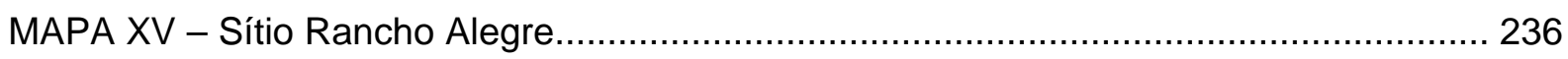

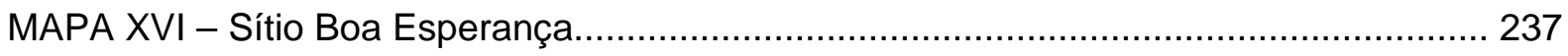

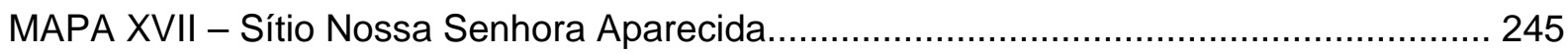

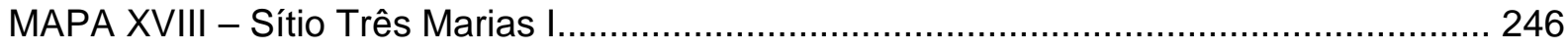

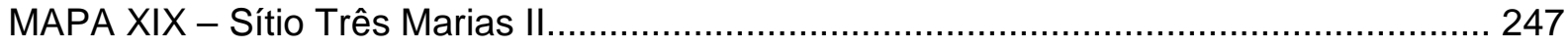

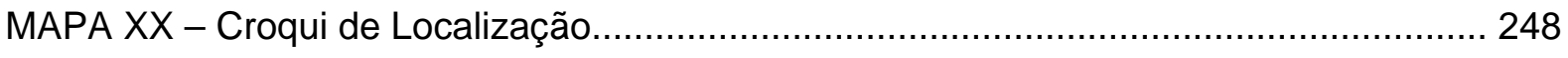

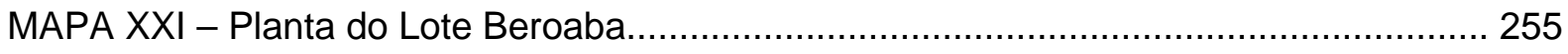

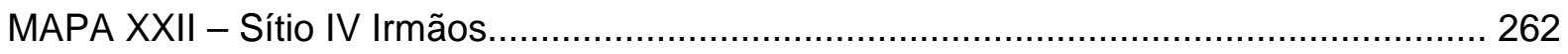

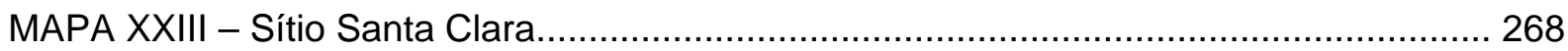

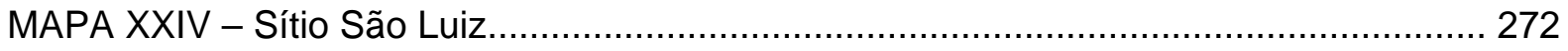

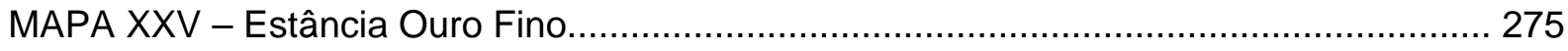


MAPA XXVI - Sítio São Pedro. 277

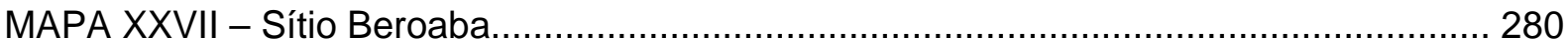

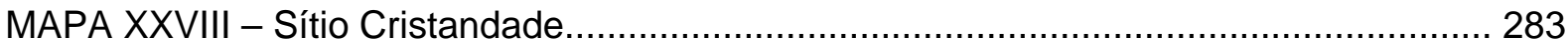

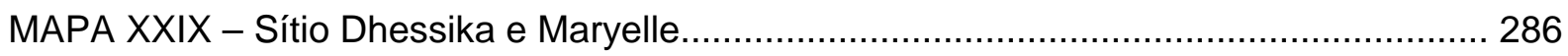

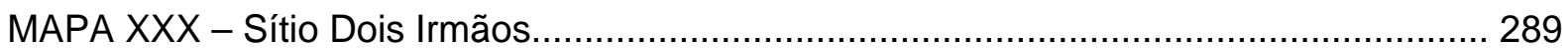

MAPA XXXI - Sítio Nossa Senhora de Fátima............................................................... 292

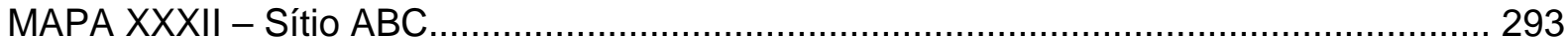

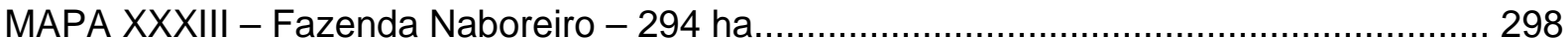

MAPA XXXIV - Fazenda Pé de Morro - 364 ha........................................................... 311

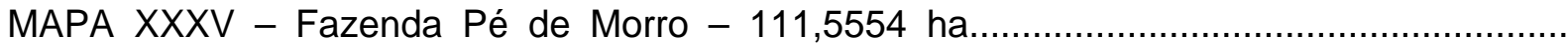

$312 \mathrm{bbb}$ 


\section{LISTA DE FOTOS}

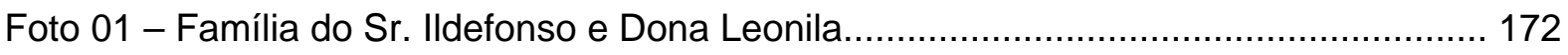

Foto 02 - Família do Sr. Otoni e Dona Maria.................................................................. 177

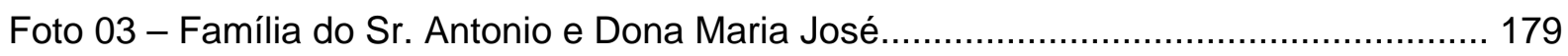

Foto 04 - Morro da Cotia - Sítio Três Marias................................................................ 194

Foto 05 - Cachoeira Córrego Mamona - Sítio Três Marias e Sítio Mamona....................... 194

Foto 06 - Centro Comunitário Rural Osório de Freitas Nunes - Associação e

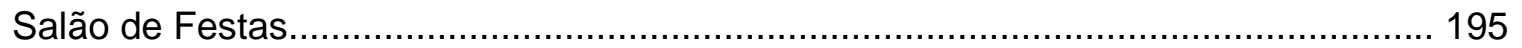

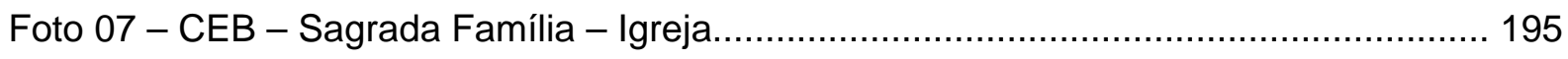

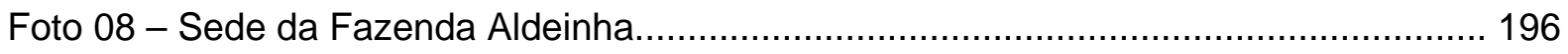

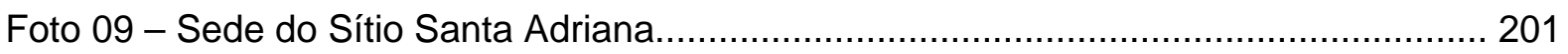

Foto 10 - Sede do Sítio São Francisco........................................................................ 203

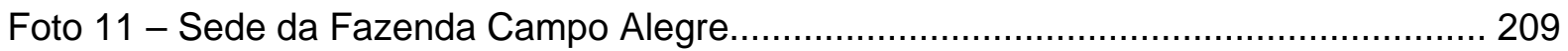

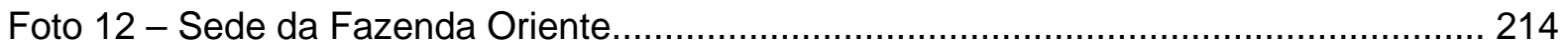

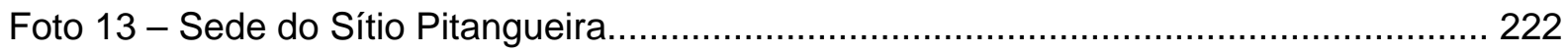

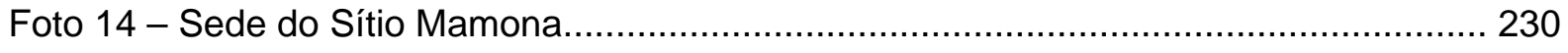

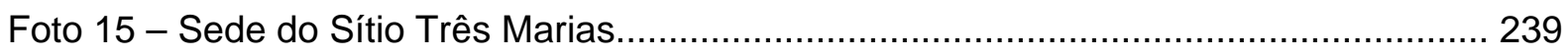

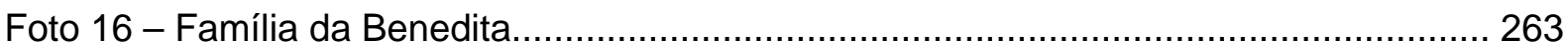

Foto 17 - Primeira casa de alvenaria - Benedita .......................................................... 263

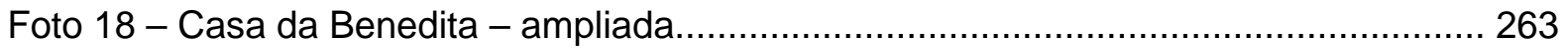

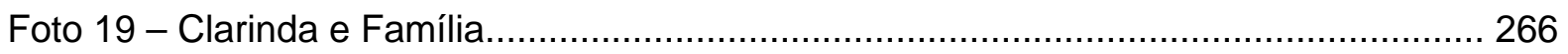

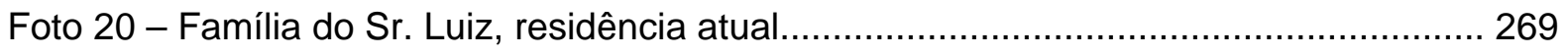

Foto 21 - Casa de Palha - Primeira Residência — Sítio São Luiz.................................. 271

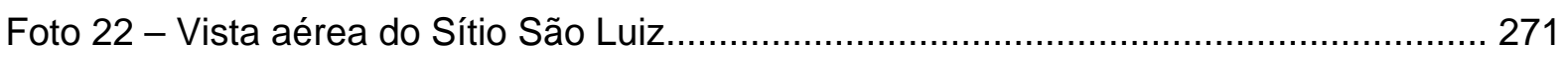

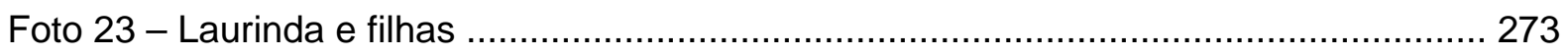

Foto 24 - Rancho de Palha, $1^{\mathrm{a}}$ casa do Sítio Ouro Fino................................................ 274 
Foto 25 - Varanda no Sítio Ouro Fino- residência atual.................................................. 274

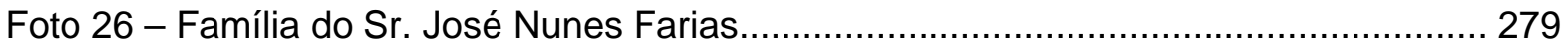

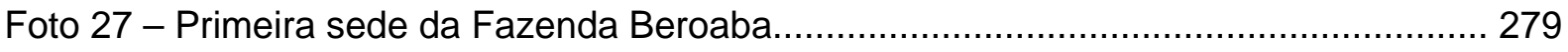

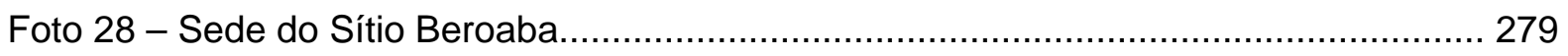

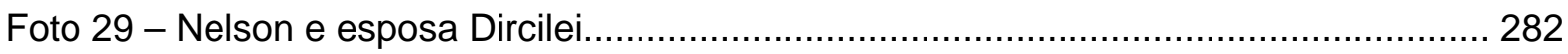

Foto 30 - Os filhos de Nelson quando criança................................................................. 282

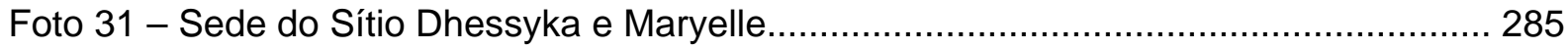

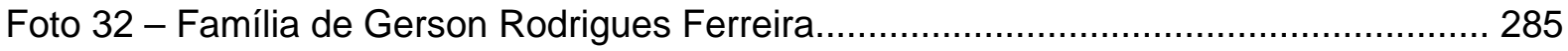

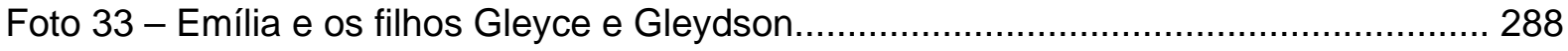

Foto 34 - Sede da Fazenda de Emília em Rondônia...................................................... 288

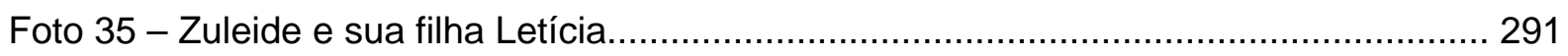

Foto 36 - João Nunes Ferreira e família.................................................................... 291

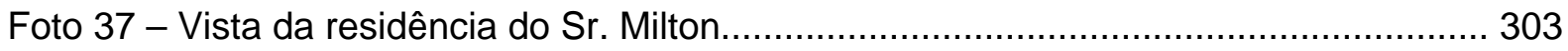

Foto 38 - Vista da residência de alguns irmãos.......................................................... 303

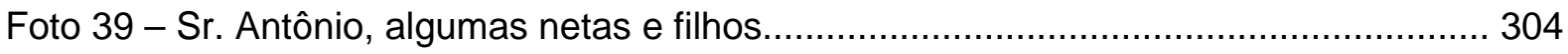

Foto 40 - Casa da farinha - trabalhos das netas........................................................... 304

Foto 41 - Casa da farinha - Sr. Milton no triturador................................................. 305

Foto 42 - Ilza e seus biscoitos feitos com produtos do Sítio........................................... 305

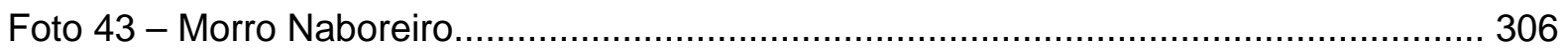

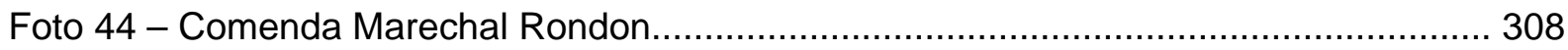




\section{PLANTAS}

PLANTA 01 - do Lote Aldeinha - 406 ha. Ildefonso Bernardino Oliveira.......................... 192

PLANTA 02 - Planta do Lote 1 - Fazenda Aldeinha................................................ 198

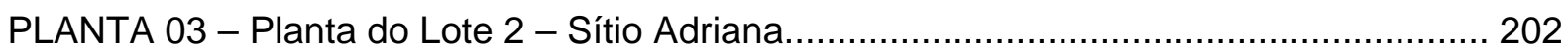

PLANTA 04 - Planta do Lote 3 - Sítio São Francisco................................................. 204

PLANTA 05 - Planta do Lote 1 - Fazenda Campo Alegre......................................... 210

PLANTA 06 - Planta do Lote 2 - Sítio Santa Rosa........................................................ 213

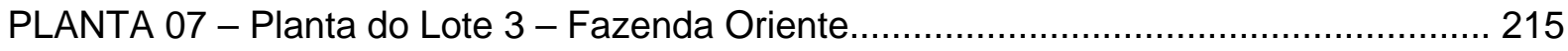

PLANTA 08 - Planta do Lote 4 - Sítio Pitangueira..................................................... 224

PLANTA 09 - Planta do Lote 5 - Sítio Campo Verde............................................... 228

PLANTA 10 - Planta do Lote 6 - Sítio Mamona............................................................ 232

PLANTA 11 - Planta do Lote 7 - Sítio Três Marias....................................................... 244

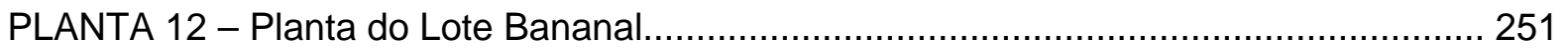

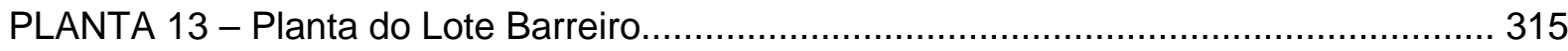

\section{CERTIDÕES}

CERTIDÃO 01 - Lote Belém - 305 ha - Leonila Pereira Oliveira.................................. 191

CERTIDÃO 02 - Lote Aldeinha - 406 ha - Ildefonso Bernardino de Oliveira..................... 193

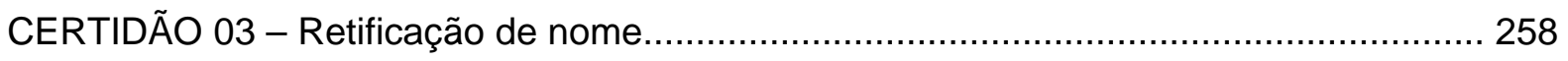

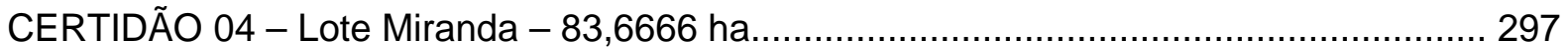

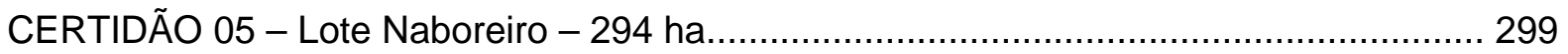

CERTIDÃO 06 - Lote №.107 - Núcleo Colonial de Naboreiro - 50 ha............................ 300

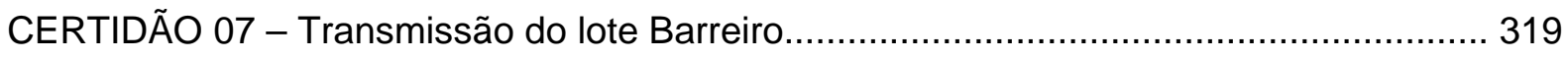

CERTIDÃO 08 - Lote Localizado na Fazenda Miranda - 36,30 ha................................. 327

CERTIDÃO 09 - Lote №. 86 - Núcleo Colonial de Naboreiro - 44 ha............................. 328 
CERTIDÃO 10 - Lote №. 87 - Núcleo Colonial de Naboreiro - 47 ha. 329

\section{REGISTROS}

REGISTRO 01 - №. 3026 - Fazenda Bananal............................................................. 252

REGISTRO 02 - №. 3027 - Fazenda Santa Paz........................................................... 253

REGISTRO 03 - No. Matrícula 16.864 (R. 1/16.864, R.2/16.864 de19/04/1983 e

R.5/16864 - 14/02/1991) e Averbação - 6/16.864 - 02/04/1991

\section{LISTA DE TÍTULOS}

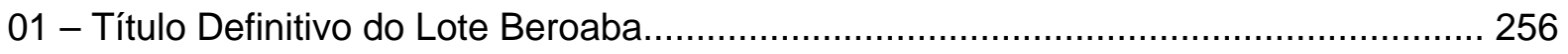

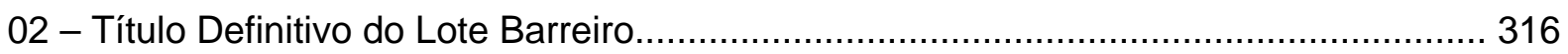

\section{LISTA DE TABELAS}

TABELA 1 - Brasil - Estrutura Fundiária / INCRA 1966 a 1998....................................... 90

TABELA 2 - Mato Grosso - Estrutura Fundiária / INCRA 1966 a 1998............................... 92

TABELA 3 - Condição do Responsável em Mato Grosso (50-95/96) ................................ 94

TABELA 4 - Distribuição dos Estabelecimentos em Rondonópolis/MT.............................. 98

TABELA 5 - Condição do Produtor em Rondonópolis: por Estabelecimento

e por Área

101

\section{LISTA DE OGANOGRAMAS}

Organograma 01- Árvore Genealógica Família AQUINO …........................................... 333

Organograma 02- Árvore Genealógica Família FERREIRA......................................... 335

Organograma 03- Árvore Genealógica Família OLIVEIRA............................................. 340

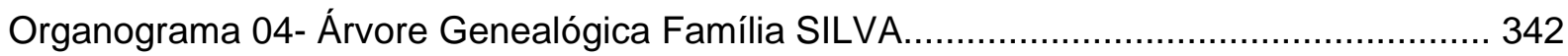


Organograma 05- Árvore Genealógica Família GIOVANINI

\section{LISTA DE ABREVIATURAS E SIGLAS}

ABRA - Associação Brasileira de Reforma Agrária

ADM - Archer Daniels Moland

ACARMAT - Associação de Crédito e Assistência Rural de Mato Grosso

AGROSERV - Serviços Agronômicos e Topográficos S/C LTDA Rondonópolis/MT

AVC- Acidente Vascular Cerebral

BEMAT - Banco do Estado de Mato Grosso

BR - Brasil

CASEMAT - Companhia Brasileira de Armazenamento

CER - Companhia de Estradas de Rodagem

CESUR - Centro de Ensino Superior de Rondonópolis

CIBRAZEM - Companhia de Armazenagens e Silos do Estado de Mato Grosso

CMDRS - Conselho Municipal de Desenvolvimento Regional Sustentável

CODEAGRI - Companhia de Desenvolvimento Agrícola de Mato Grosso

CODEMAT - Companhia de Desenvolvimento de Mato Grosso

CONTAG - Confederação Nacional dos Trabalhadores Agrícolas

COOPERCENTER - Cooperativa Agrícola do Centro-Oeste Rondonopolitano

COREXPORT - Corredores de Exportação

CPAC - Centro de Pesquisa Agropecuária do Cerrado

CPT - Comissão Pastoral da Terra

CUR/UFMT - Campus Universitário de Rondonópolis/Universidade Federal de Mato Grosso

DAS - Diretoria de Assentamentos

DNER - Departamento Nacional de Estrada de Rodagem

EDUFMT - Editora da UFMT

EMATER - Empresa de Assistência Técnica e Extensão Rural

EMBRAPA - Empresa Brasileira de Pesquisa Agropecuária

EMPAER - Empresa Mato-grossense de Pesquisa Agropecuária e Extensão Rural

EXPOSUL - Exposição Sul Mato-Grossense - Exposição Agropecuária, Comercial e Industrial de Rondonópolis

ET - Estatuto da Terra

FAMATO - Federação da Agricultura de Mato Grosso

FEA - Faculdade de Economia, Administração e Contabilidade

FEPAGRI - Feira de Pecuária e Agricultura / Araraquara 
FFLCH - Faculdade de Filosofia, Letras e Ciências Humanas

IBGE - Instituto Brasileiro de Geografia e Estatística

ICEN - Instituto de Ciências Exatas e Naturais

IMEA - Instituto Mato-grossense de Economia Agrícola

INCRA - Instituto Nacional de Colonização e Reforma Agrária

INTER - Instituto Jurídico de Terras Rurais.

INTERMAT - Instituto de Terras de Mato Grosso

ITR - Imposto Territorial Rural

MAB - Movimento dos Atingidos por Barragens

MDA - Ministério do Desenvolvimento Agrário

MIRAD - Ministério da Reforma Agrária e do Desenvolvimento Agrário

MR - Microrregião/IBGE

MS - Mato Grosso do Sul

MST - Movimento Nacional dos Trabalhadores Sem-Terra

MT - Mato Grosso

MTE - Ministério do Trabalho e Emprego

PAC - Projeto de Assentamento Criado

PCB - Partido Comunista Brasileiro

PIN - Programa de Integração Nacional

POLOAMAZÔNIA - Programa de Pólos Agropecuários e Agrominerais da Amazônia

POLOCENTRO - Programa de Desenvolvimento dos Cerrados

POLONOROESTE - Programa Integrado de Desenvolvimento do Noroeste do Brasil

PMDB - Partido do Movimento Democrático Brasileiro

PNRA - Plano Nacional de Reforma Agrária

PROBOR - Programa de Incentivo à Produção da Borracha Vegetal

PRODECER - Programa Nipo-brasileiro de Cooperação do Desenvolvimento do Cerrado

PRODEI - Programa de Desenvolvimento Industrial de Mato Grosso

PRODIAT - Programa de Desenvolvimento Integrado do Araguaia-Tocantins

PRODIEN - Programa de Desenvolvimento Integrado Eixo Norte

PRODOESTE - Programa de Desenvolvimento do Centro-Oeste

PROMAT - Programa Especial de Desenvolvimento do Estado de Mato Grosso

PRONAF - Programa Nacional de Fortalecimento da Agricultura Familiar

PROSOL - Promoção Social do Estado de Mato Grosso

PROTERRA - Programa de Redistribuição de Terras e Estímulo à Agricultura

PUC - Pontifícia Universidade Católica

RGI - Registro Geral de Imóveis

SAGRI - Secretaria Executiva de Agricultura 
SIPRA - Sistema de Informações dos Parceleiros de Reforma Agrária SR - Superintendência Regional

SUDAM - Superintendência do Desenvolvimento da Amazônia

SUDECO - Superintendência do Desenvolvimento do Centro-Oeste

UDR - União Democrática Ruralista

UNR - União dos Núcleos Rurais

USP - Universidade de São Paulo 


\section{1- INTRODUÇÃO}

Este trabalho é resultado de estudos e pesquisas desenvolvidos no sudeste de Mato Grosso, desde 1996, quando centrei a atenção em duas áreas de ocupação consolidadas, duas propriedades latifundiárias que foram transformadas em pequenas propriedades (a Fazenda Floresta - 5.073 ha, ocupada em 1970 por 350 posseiros e a Fazenda Vale do Bacuri - 622 ha, que foi entregue em 1997 a 30 famílias pertencentes ao MST). Nestas áreas as famílias puderam constituir seu território e viver.

A dissertação de mestrado, defendida em 2000 foi sobre "A Produção Camponesa e a Modernização da Agricultura em Rondonópolis-MT - Estudo em Áreas de Assentamento de Reforma Agrária: Gleba Cascata e Projeto de Assentamento Chico Mendes/Vale do Bacuri". A terminologia "repartição natural entre os descendentes", conforme Figueiredo $(1994)^{1}$, chamou minha atenção, e como estava trabalhando com produção camponesa, modernização da agricultura e reforma agrária, resolvi pesquisar e escrever a respeito da repartição, fragmentação e sucessão, que pode se dar inter vivos ou causa mortis, de acordo com o Código Civil Brasileiro, e que em sua maioria vem constituir uma classe entre os grandes proprietários e os trabalhadores sem-terra.

Nas viagens a campo, quando realizava as entrevistas para a dissertação, tive contato com Milton Jorge/Sítio Três Marias, neto de Leonila e Ildefonso/Fazenda Campo Alegre, e ele comentou que a terra onde moravam veio de doação de seu bisavô materno, Antonio Pereira dos Santos (Antonio Noca)/Fazenda Belém, que foi adquirida por ele em 1936, do Departamento de Terras e Colonização em Cuiabá. Esse fato e a expressão supracitada "repartição natural entre os descendentes", despertaram o interesse pelo estudo, no doutorado sobre a fragmentação da terra por doação (adiantamento de legítima) ou por herança e doação, caso comum em Rondonópolis.

\footnotetext{
${ }^{1}$ Em seu trabalho A propósito do boi, no capítulo 7- Nas invernadas do sul surge um novo Mato Grosso, Figueiredo fala a respeito da fragmentação dos latifúndios: “Os latifúndios, incapazes de melhor utilizar os espaços, se fragmentam pelo valor e procura das terras. Esse processo de fragmentação, inclusive, já vinha se operando lentamente com o desaparecimento dos antigos proprietários e na repartição natural entre os descendentes. Muitos desses descendentes, diante das primeiras ofertas tentadoras, encantados com o dinheiro e desiludidos com as asperezas da profissão, vendem as terras a novos capitalistas de São Paulo, ainda mais fortalecidos com a industrialização do estado. Prosperam aqueles que acreditam na terra e no boi”. Figueiredo, Aline. A propósito do boi. Cuiabá-MT: EdUFMT, 1994: 144. Grifo meu.
} 
Assim, nesta tese de doutorado, o foco estudo são as áreas onde ocorreu a fragmentação da terra por doação e por herança e doação, isto é, a sucessão do imóvel rural no município de Rondonópolis, no estado de Mato Grosso.

A pesquisa busca mostrar que o início da ocupação da terra em Rondonópolis se deu através da venda de terras devolutas pelo governo de Mato Grosso, com base e amparo legal na primeira Lei de Terra Estadual - "no. 20 de 20/11/1892", que dispunha sobre o processo de regularização fundiária e na Lei " $n^{\circ}$. 24 de 16/11/1892". Elas criaram a primeira "repartição pública de terras" e foram sancionadas por Manoel José Murtinho, primeiro presidente constitucional de Mato Grosso.

No caso específico do presente trabalho, trata-se de 10 (dez) áreas que foram unificadas através do processo de compra e doação, formando 5 (cinco) grandes áreas, que hoje estão fragmentadas em 66 (sessenta e seis) unidades camponesas.

A intenção inicial era focalizar como tema uma área de fragmentação da terra por doação, um assentamento do MST e um assentamento formado pelo Banco da Terra. Foi decidido, então, realizar a pesquisa com a família do Sr. Ildefonso e D. Leonila/Fazenda campo Alegre (cuja propriedade está desde 1936 com a família, passando de geração para geração), remanescente da Fazenda Belém; no assentamento Dom Osório/MST e na Fazenda COOPERCENTER/Banco da Terra. Acreditava estar realizando, assim, um estudo sobre a criação e recriação do camponês.

Desta forma, passaram-se dois anos empenhados nesse trabalho, mas, no exame de qualificação, fui dissuadida do intento original pelos membros da banca, que sugeriram apenas o estudo da fragmentação da terra pelos mencionados motivos de doação ou herança e doação.

Após concordar com a sugestão e fazer uma consulta na unidade da EMPAER/Rondonópolis ${ }^{2}$ para saber quais famílias haviam adotado esse procedimento - fragmentação da terra -, consegui uma relação de várias famílias e fui em busca do público-alvo. No início, foi um fracasso. Poucos mostraram interesse em participar da pesquisa e, assim, somente em meados de 2006 a mesma começou a tomar forma.

O estudo foi delimitado em cinco famílias, com as quais ocorreu a fragmentação da terra por doação e por herança e doação e foi dada preferência às

\footnotetext{
${ }^{2}$ Unidade da Empresa Brasileira de Pesquisa Agropecuária em Rondonópolis
} 
áreas onde as famílias vêm administrando essa terra há mais de quarenta anos. Sendo assim, o recorte geográfico contempla as seguintes áreas (Mapa I):

- Fazenda Beroaba - remanescente da Fazenda Bananal (1932): herança e doação, dividida para os onze filhos do Sr. Otoni Nunes Ferreira e dona Maria Rodrigues Ferreira - família FERREIRA;

- Fazenda Campo Alegre - região da Aldeinha - remanescente da Fazenda Belém (1936): doação para os dez filhos do Sr. Ildefonso Bernardino Oliveira e dona Leonila Pereira de Oliveira - família OLIVEIRA;

- Fazenda Naboreiro - remanescente do Núcleo Colonial de Naboreiro (1948): doação para os onze filhos do Sr. Antonio Alves da Silva e dona Maria Rosa da Silva - família SILVA;

- Fazenda Barreiro (1951) - região do Pequi: herança e doação, dividida para os quatorze filhos da senhora Orinda Souza de Aquino e Domingos Aquino - família AQUINO;

- Fazenda Miranda e outros Lotes Naboreiro (1961) - remanescente do Núcleo Colonial Naboreiro/Vila Bueno: doação para os oito filhos do Sr. José Giovanini e dona Maria da Encarnação Giovanini - família GIOVANINI.

Gostaria de ter contemplado na pesquisa o máximo possível de áreas nas quais tivessem ocorrido diferentes tipos de fragmentação (como a fração maior da propriedade para os filhos em relação às filhas), mas não foi possível, não só pelo tempo, que nessa altura dos acontecimentos estava limitado, mas, principalmente, pelo fato de algumas famílias não terem permitido a realização do trabalho. 


\section{MAPA I- LOCALIZAÇÃO DAS ÁREAS DE ESTUDO}

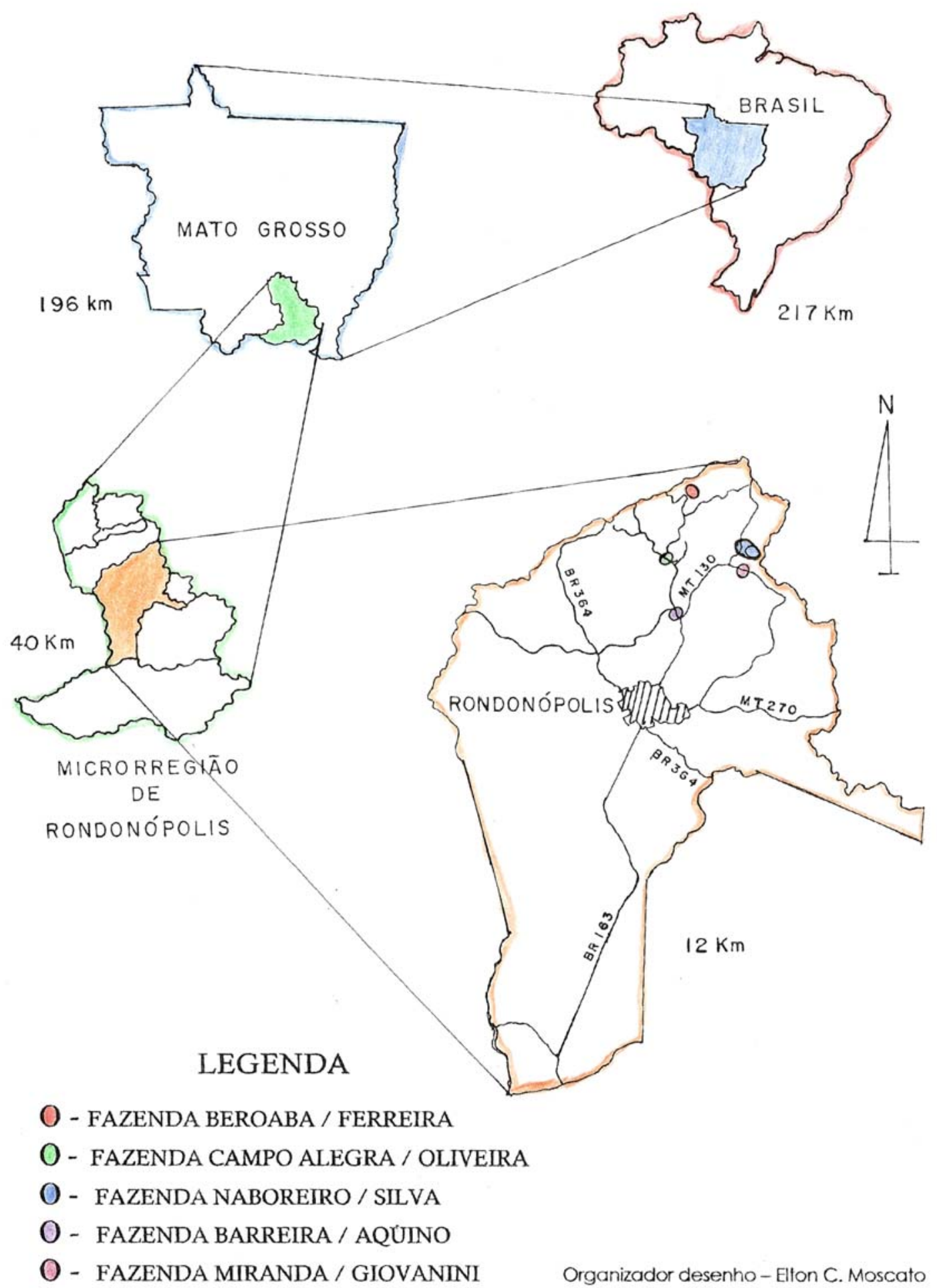


A hipótese principal da tese é que o processo de fragmentação da terra, seja por doação ou herança, que provoca uma subtração no número de grandes propriedades e um aumento das pequenas, ocasiona uma redução econômica, tendo como conseqüência final o êxodo rural dos jovens, que por conta da insustentabilidade dessas áreas tenderiam a ir para a cidade. Porém, a fragmentação em excesso passa a configurar, também, um problema social e econômico para a sociedade, visto que podem se constituir minifúndios.

Para entender esses problemas é necessário verificar as seguintes eventualidades: a fragmentação da terra nas áreas de estudo está relacionada à questão de doação e de herança e doação; essa fragmentação provocou uma redução do potencial produtivo, sobretudo por conta da substituição da atividade agrícola pela pecuária; o excesso de fragmentação dificulta ou impede a adoção de práticas diferenciadas de produção e principalmente a aquisição de recursos/financiamentos públicos.

De posse dessas problematizações que cercam o estudo da (re) criação do campesinato em áreas do latifúndio por conta da fragmentação da terra, busquei guiar a pesquisa objetivando analisar o processo de ocupação e fragmentação da terra através da sucessão nas áreas do Bananal, Beroaba, Belém, Aldeinha, Pequi, Naboreiro e Vila Bueno, regiões deste estudo que foram fragmentadas.

Houve o esforço de, na medida do possível, identificar as origens e as causas da ocupação dessas propriedades; entender como se deu e se como dá esse processo de diferenciação da fragmentação do espaço agrário em pauta com ênfase especial nos espaços que foram fragmentados originando a pequena produção, garantindo um espaço aos herdeiros ou donatários e a sucessão de exploração da terra, bem como conhecer através dos relatos de campo as condições gerais de vida dos herdeiros ou donatários que de filhos passaram a sucessores na propriedade, conseguindo se integrar e se manter no mercado.

Com vistas a contemplar mais detalhadamente essas problematizações, foi feita a opção por caracterizar e distinguir esse trabalhador rural de acordo com o contexto pesquisado, qual sua forma de organização seus traços marcantes e a dinâmica produtiva, salientando as semelhanças e diferenças, caso haja. Não foram esquecidas a visão do jovem rural e a questão da migração campo-cidade, e se verificou também quais são os níveis dos programas governamentais, municipal, estadual ou federal, que foram ou estão sendo utilizados pelos sujeitos da pesquisa. 
Com o intuito de melhor visualizar a situação desses camponeses diante da expansão da agricultura capitalista e das mudanças no uso da terra, nas técnicas produtivas e nas relações de trabalho, amparei-me em fatos concretos que fundamentaram os objetivos e embasaram as investigações.

Levantei a bibliografia sobre o assunto, ou seja, a documentação indireta, com o propósito de utilizar as fontes bibliográficas fundamentais sobre o tema em geral e aquelas que tratam da problemática no país, no estado e na área de estudo em particular.

Várias viagens a campo foram realizadas a fim de se ter um contato maior, mais esclarecedor com as áreas de estudo e poder definir com precisão as mesmas o que possibilitou, aos poucos, delimitá-las. Nessas andanças, foi possível observar o labor na terra, tipos de cultivos e outros usos, técnicas utilizadas, bem como as relações entre os homens e destes com a natureza. Enfim, tudo o que os camponeses já realizaram e quais suas perspectivas para o futuro.

Também foram buscados Levantei os dados estatísticos sobre a evolução da estrutura fundiária no Brasil, em Mato Grosso e Rondonópolis, bem como a condição do produtor neste município e verificada a contribuição dessas áreas em termos de produção, técnicas e comercialização nos mercados, etc. Tais dados se obtiveram através da observação direta intensiva, visto que, conforme palavras de $M$. de Andrade (1995:26), “na vida real - os fatos são observados 'em campo', no ambiente natural onde ocorrem".

Além disso, lancei mão de dados estatísticos e de outras informações levantadas, através da Secretaria de Agricultura, pelo Sindicato dos Trabalhadores Rurais, pela EMPAER do município, pelo IBGE, pelo INCRA/Cadastro de Imóveis e INTERMAT/Acervo Fundiário em Cuiabá, para saber como se deu a ocupação das terras estudadas e a legalidade dos títulos adquiridos. Pelo Cartório do $1^{\circ}$ Ofício, nas comarcas de Rondonópolis, Poxoréo e Cuiabá, onde se construiu a cadeia dominial das áreas estudadas, no Fórum Comarca de Rondonópolis, Prefeitura/Assessoria Legislativa de Rondonópolis, escritórios de agrimensor em Rondonópolis, Prefeitura de Poxoréo, entre outros.

Fui em busca de plantas, cartas e mapas base para a elaboração dos mapas e, ainda, procedi a uma análise da distribuição dos lotes (doação ou herança) no interior das fazendas fragmentadas. 
A investigação ficaria incompleta sem as entrevistas; desta forma, selecionei algumas pessoas para darem seus depoimentos e com isso, enriquecer o trabalho, pois, de acordo com Queiroz (1991:06), a entrevista é

(...) a forma mais antiga e mais difundida de coleta de dados orais, nas ciências sociais (...). Elas ora fornecem dados originais, ora complementam dados já obtidos de outras fontes. Na verdade, a entrevista está presente em todas as formas de coleta dos relatos orais, pois estes implicam sempre um colóquio entre pesquisador e narrador.

Aliada a isso, houve mais possibilidade de captar diferentes tipos de informações bem como comparar dados, já que, também segundo Queiroz (1991: 6; $21 ; 23)$, a história de vida -,

por sua vez, se define como o relato de um narrador sobre sua existência através do tempo, tentando reconstruir os acontecimentos que vivenciou e transmitir a experiência que adquiriu. (...) ela é, portanto, técnica que capta o que sucede na encruzilhada da vida individual com o social. (...) A história de vida pode tentar desvendar o ponto em que características destas coletividades se juntem às sensações cenestésicas, buscando a interação entre ambas, e esclarecendo quais os instrumentos sociais utilizados para a tradução.

No geral, optei por técnicas de pesquisa que, para Queiroz (1991), são as mais utilizadas nas pesquisas de campo - as entrevistas, que se constituem dos seguintes instrumentos: formulários, questionários e histórias de vida.

Foi escolhida a metodologia de pesquisa "in loco", com o emprego de questionário e de entrevistas com os moradores, o que viabilizou reconstruir suas histórias de vida, formas de produção, relações sociais, etc., num cenário geral de transformações postas pelo avanço do capitalismo no campo.

Procurei destacar três perguntas: "por quê?", "como?" e "para quê?", tendo em vista a afirmação de Sposito (2004:16 e 82) de que

Essas perguntas são básicas para qualquer reflexão científica. Assim, elas podem não comparecer explicitamente no texto, mas estarão sendo respondidas, subliminarmente, em vários momentos da nossa exposição. (...) provocam a reflexão sobre a pertinência e a necessidade de se repensar sempre o que se elabora cientificamente.

Como sujeitos da pesquisa foram definidos os sucessores residentes nas propriedades onde foram feitas visitas visando ao reconhecimento das áreas, à 
aplicação dos questionários e entrevistas e à participação em eventos, confraternizações e registros iconográficos.

Embora tendo procurado buscar, com empenho e rigor, atingir todos os objetivos propostos para a realização do trabalho, o estudo apresentou dificuldades que foram impostas pela metodologia adotada, pela própria natureza do objeto ou pelas circunstâncias típicas de trabalhos empíricos, devidas inclusive à riqueza de subsídios e à diversidade de situações de conquista da terra e (re) criação camponesa - seus modos de vida, base para a construção de seus territórios. Considero como relevantes a limitação de informações e discussões acerca do objeto abordado; a falta de confiança de algumas pessoas, que poderiam dar esclarecimentos, em relação às pesquisas científicas; a falta de acesso a materiais (mapas e títulos) no que dependesse de órgãos governamentais; e também a influência das condições climáticas durante o trabalho de campo, pois o excesso de chuva danificou as estradas e pontes, dificultando o acesso às propriedades. Todavia, a mais saliente foi minha limitação em relação ao tema estudado aliada à falta de orientação por motivos da doença de minha orientadora.

Não obstante, esta pesquisa insere-se em um eixo temático que ganha espaço em diversas áreas de estudo, tais como a Geografia, a Antropologia, a História, a Engenharia de Produção, a Engenharia Agrícola, etc. Vários são os pesquisadores que têm voltado seus estudos para o campo, principalmente para a questão agrária brasileira, para a ocupação e a fragmentação da terra. Portanto, ela poderá contribuir com dados e informações sobre a ocupação da terra em Rondonópolis e o surgimento da pequena propriedade e com o resgate das famílias de trabalhadores que ocupam o campo rondonopolitano.

A discussão aqui proposta visa fundamentalmente a esclarecer qual a origem da ocupação dessas terras, qual a base legal para os títulos que foram emitidos e como se deu a fragmentação dessas propriedades.

Para isso, a tese está organizada obedecendo ao encadeamento que se segue.

Após a introdução, item 1 apresentam-se as bases teóricas que deram suporte e contribuição para a compreensão do processo de (re) criação camponesa, no âmbito das ciências humanas de modo geral e nos estudos acerca da realidade brasileira; portanto, no item 2 buscou-se amparo não só em teóricos clássicos, mas 
também na literatura brasileira, no que concerne às pesquisas realizadas nas várias áreas de estudo há pouco mencionadas.

O item 3 procurou, através de estudos sobre a questão agrária no Brasil, realizar uma trajetória que resgatasse o processo de colonização das terras brasileiras e posteriormente a ocupação das terras de Mato Grosso com base nos projetos de colonização, referenciando o surgimento do latifúndio e do campesinato no estado, por conta do processo migratório; estes são fatores determinantes para a formação e construção do território mato-grossense.

A formação do espaço geográfico de Rondonópolis foi discutida no item 4, no qual se realizou o resgate histórico da ocupação deste espaço, devida principalmente à migração de goianos, mineiros, paulistas, nordestinos e, posteriormente e com maior ênfase, dos sulistas, cada qual com sua contribuição em fases e períodos diferenciados, mudando completamente a forma de ser e de viver do povo rondonopolitano. O cerrado foi transformado, dando lugar às enormes fazendas de gado e de produção de grãos, voltados para abastecer o mercado externo, assim como também surgiram as pequenas propriedades e a posteriori os assentamentos. O pequeno vilarejo do "Rio Vermelho", "Terra de Rondon", é hoje destaque nacional e internacional, por causa das atividades econômicas aqui desenvolvidas.

O item 5 apresenta o esforço de traçar um breve histórico sobre a fragmentação da terra, a sucessão hereditária e, com base na literatura do Direito e da Antropologia, entender o uso do Código Civil e do "direito costumeiro", aplicado em várias partes do território nacional, para enquadrar nosso público-alvo, desvendando assim a essência dessa fragmentação.

Após a identificação das famílias, os esforços centraram-se no sentido de evidenciar a fragmentação da terra por doação e por herança e doação, o que por sua vez reflete a (re) criação camponesa e um novo traçado no território ocupado, formando uma verdadeira "colcha de retalhos", onde a produção econômica e a reprodução social estão imbricadas. O trabalho de campo aparece de forma mais detalhada e efetiva nos itens 5 e 6 que mostram o resultado dessa fragmentação, da transformação do latifúndio em área de pequena produção. No item 6 as famílias foram divididas em dois grupos: o da fragmentação da terra por herança e doação e o grupo da fragmentação da terra por doação. No primeiro ocorreu a sucessão causa mortis e inter vivos, já no segundo grupo o processo foi realizado inter vivos, 
ou seja, a fragmentação por adiantamento de legítima no tocante à doação por ascendentes e descendentes; no item 7 tecemos algumas considerações acerca do que foi pesquisado em relação a esta fragmentação.

Cumpre ressaltar que foram superados os medos e anseios, o desânimo e o fracasso, sentidos no primeiro mês da realização do trabalho de campo, após aceitar o desafio de trabalhar a fragmentação da terra por doação ou herança.

Não poderia deixar de assinalar também que os meses de perambulação pelas áreas de estudo foram recompensadores, não só pelas belas paisagens com as quais deparei, mas pela receptividade e cordialidade das famílias, pela simplicidade, humildade e prazer da maioria das pessoas, principalmente dos idosos, ao exporem sua trajetória de vida, sua "caminhada no chão da noite": isto foi sem dúvida gratificante.

\section{BASES TEÓRICAS}

\section{1 Área e Tema: Razões da Escolha}

Rondonópolis, localizada no sudeste de Mato Grosso, é um município de tradição agrícola. Por suas culturas, já foi considerada "Rainha do Algodão"3, "Rainha do Arroz", "Princesinha do Leste", e no momento é reconhecida nacional e internacionalmente pela grande produção de soja e de milho, voltando a destacar-se novamente na produção de algodão ${ }^{4}$.

A pecuária começou a ser desenvolvida no século XVIII, como atividade secundária que servia exclusivamente para ajudar nas atividades - tarefas da

\footnotetext{
${ }^{3}$ A maioria dos municípios de Mato Grosso teve como fonte de atração as atividades mineradoras. Rondonópolis é exceção, já que as terras de cultura foram imprescindíveis para sua ocupação, pois sua formação espacial se inicia com o campesinato e os pecuaristas; historicamente o campesinato e a pecuária são os principais atores da expansão sobre as novas terras, tendo como fator de atração as terras de culturas, posteriormente ao longo das rodovias, após a década de 60, facilitando o escoamento de produção, o contato com os grandes centros e regiões do interior. “A cultura do algodão no município de Rondonópolis remonta da implantação no final da década de 40...”; confirma-se, portanto, que o algodão não é uma cultura tão recente para a região de Rondonópolis, embora até a década de 70 ela não tivesse uma grande importância econômica para o município que somente nesse período ficou conhecido como "Rainha do Algodão". Era cultivado no sistema familiar através de arrendamento em terras de cultura, pois $70 \%$ dos produtores eram arrendatários. A cultura era praticada nos municípios adjacentes São José do Povo, Nova Galiléia e Pedra Preta, que até então fazia parte do município de Rondonópolis. O desenvolvimento do município era marcado praticamente pelo domínio da agricultura familiar, onde se produzia algodão, arroz, milho, feijão e mandioca. Pereira, Lindanice C. Cultura do algodão em Rondonópolis no período de 1990 a 2001 - uma Contribuição para a história econômica de Rondonópolis. Monografia de Especialização. Rondonópolis: CUR/UFMT, 2001. Gostaríamos de ressaltar que Nova Galiléia não é município e sim distrito de Rondonópolis.

Em Carmo, Ailon. Reminiscências de Rondonópolis. $1^{\mathrm{a}}$ ed. Rondonópolis-MT: Gráfica Modelo Ltda, 2001, encontra-se nas páginas 202 e 203, que "Em 1982, no segundo carnaval de rua em Rondonópolis, a escola de samba Unidos da Vila, de mestre Pelé, buscou na principal riqueza local da época, o algodão, o tema para o samba-enredo de sua escola, sob o título "Rondonópolis - Rainha do Algodão". A letra peca no enredo, na gramática e na coerência; de algodão, só tem o nome, nada exaltando a seu respeito; ademais, fala de riquezas inexistentes neste município - ouro, cristais e diamantes, que também não fazem parte do enredo da escola (rainha do algodão).”

${ }^{4}$ Dados do IBGE, na safra de 2002/2003. (fontes: FAMAT e IMEA), registraram 7.111 ha de área plantada, com produção de 24.888t e rendimento de 3.500 q/ha; já em 2005 a área plantada foi de 11.762 ha, com produção de $61.200 t$ e rendimento de 4.500 kg/ha.
} 
mineração, subsídio alimentar e meio de transporte. Valendo-se de imensas áreas favoráveis a pastagens, alguns pioneiros vindos de Goiás, Minas Gerais e São Paulo transformaram-se em grandes fazendeiros pecuaristas ${ }^{5}$. Houve um desenvolvimento considerável da pecuária com o auxílio da plenitude do relevo associada às possibilidades de pastagens naturais e cultivadas ${ }^{6}$.

A produção de grãos apresenta atualmente recorde de produtividade, que resulta de investimentos em tecnologia e pesquisas efetuadas pelos produtores de sementes juntamente com a Fundação Mato Grosso e a Embrapa, passando o município a produzir e a exportar sementes de grãos de qualidade para o plantio, o que constitui um importante marketing das empresas de Rondonópolis.

Encontram-se em Rondonópolis, próximas às rodovias estadual e federal ou no Distrito Industrial, algumas empresas de grande porte no setor agroindustrial e de alimentos. Estão aqui instaladas as principais indústrias multinacionais de esmagamento de soja, como a ADM e a Bunge, e nacionais, como a Candeloro, fabricante de equipamentos e usinas completas para beneficiamento de algodão. Devido à grande produção de algodão no município e regiões circunvizinhas, instalou-se recentemente a Santana Têxtil do Brasil $^{7}$, onde será fabricado e comercializado jeans para o mercado interno e externo. Também a Nortox, produtora de defensivos agrícolas, óleos minerais e coadjuvantes, implantou uma unidade no município.

Esse movimento de ampliação do parque industrial de Rondonópolis é resultado de políticas recentes do governo estadual, visando o aumento do valor agregado na cadeia de produção local e a saída da crise do setor de mercado externo (soja e algodão). A instalação de muitas dessas empresas contribuirá então para a formação em Rondonópolis do primeiro pólo têxtil do estado de Mato Grosso. Além disso, o governo estadual organiza anualmente as feiras de exposição, a Exposul e a Agrishow Cerrado $^{8}$, os dois maiores eventos do agrobusiness da região

\footnotetext{
5 Sobre o assunto ler Tesoro (1993); Suzuki (1996); Nascimento (1997) e Peixinho (1998), todos relacionados nas Referências Bibliográficas.

${ }^{6}$ De acordo com o IMEA - Instituto Mato-grossense de Economia Agrícola, a pecuária de corte e de elite é considerada de primeiro mundo, pois tem um dos maiores núcleos de melhoramento genético do país.

${ }^{7}$ De acordo com o Boletim Agrishow Cerrado, do jornal A Tribuna (Rondonópolis-MT, 20/04/2006), o grupo Santana Têxtil pretende iniciar no final do mês de julho deste ano a produção de sua nova fábrica em Rondonópolis. A empresa vai utilizar 1,8 mil toneladas de pluma de algodão que irão produzir 3 milhões de metros de tecido (índigo) por mês e vai gerar cerca de 700 empregos diretos. Entrei em contato com a empresa em 18/04/2007 e fui informada de que a mesma foi inaugurada no dia 08/12/2006 e conta com um quadro de 300 funcionários, e como a fábrica será ampliada, a estimativa para 2008 é de 800 funcionários.

${ }^{8}$ Exposul - Exposição Sul Mato-Grossense - Exposição Agropecuária, Comercial e Industrial de Rondonópolis. Agrishow Cerrado - Feira de Tecnologia Agrícola - a maior feira de máquinas e implementos agrícolas do Centro-Oeste e a segunda maior do país.
} 
Centro-Oeste, os quais demonstram que o agronegócio é a bases da economia de Rondonópolis.

No entanto, a forte concentração fundiária de Rondonópolis, com grandes propriedades dedicadas à agropecuária, espelha a organização de seu espaço rural. No outro extremo, o camponês viu-se excluído das políticas que o próprio Estado brasileiro fomentou.

Neste contexto, sendo Rondonópolis um município onde imperam as grandes propriedades produtoras de algodão, soja e gado bovino para exportação, instigou a pesquisa sobre pequenas áreas, em especial as remanescentes de grandes propriedades que foram fragmentadas.

O motivo da escolha por pesquisar a fragmentação da terra por doação ou herança, isto é, a sucessão é o fato de acreditar que através desse processo ocorre a (re) criação do campesinato ou reprodução social da agricultura, caso comum em algumas propriedades tradicionais em Rondonópolis e, com certeza, em várias partes do país.

O pequeno e médio produtor rural, que vem se destacando na economia brasileira por ser fonte abastecedora de alimentos para o mercado interno, sofre com o tipo de política agrária implantado em nosso país, o qual visa a subsidiar as grandes propriedades com o propósito de produzir grãos e gado de primeira qualidade para abastecer o mercado externo.

No processo de fragmentação da terra o titular da grande propriedade transforma os filhos em proprietários rurais, e estes passam a ter seu pedaço de terra e a viver com sua família. Este fato consiste no desafio de garantir um espaço aos herdeiros, pois a transmissão de patrimônio os introduz no mundo do trabalho integração camponesa ao mercado - e à sucessão de exploração da terra (para trabalho, produção e não especulação); na maioria das vezes, os pais têm consciência e preocupação no tocante às dificuldades e aos parcos rendimentos profissionais da cidade. Como observa Moura (1986:25), "é nas práticas de herança que o camponês aciona para dar continuidade ao uso social da terra que habita e trabalha e à própria organização da vida".

Com o intuito de demonstrar o processo de fragmentação da terra, procurei os parâmetros históricos legais, pois assim, embasada na lei, foi possível discorrer sobre o modo como aconteceu e acontece em Rondonópolis essa fragmentação. 
Para prosseguir neste trabalho habituei-me com a terminologia do Direito das Sucessões.

Fiúza (2000:643), em seu trabalho Direito Civil, compreende o conceito de sucessão como "a continuação de uma pessoa em relação jurídica, que cessou para o sujeito anterior e continua em outro. É a transferência de direitos de uma pessoa para outra". Quanto à causa, a sucessão pode ser inter vivos - da qual cuida o Direito das Coisas e/ou Direito das Obrigações - ou causa mortis - de que trata o Direito das Sucessões. Este último encontra-se normatizado, sobre-tudo, nos arts. 1.572 a 1.807, Livro IV da Parte Especial do Código Civil e nos arts. 982 a 1.045 do Código de Processo Civil.

Dependendo da situação ou de sua regulamentação, esta sucessão pode ser legítima ou testamentária, singular ou universal, por cabeça ou por estirpe, termos que serão discutidos, de acordo com cada caso pesquisado, no item 6 .

O meio rural e o campo brasileiro tornou-se, desde final do século XIX, fonte de estudo para os pesquisadores tanto por geógrafos, como antropólogos, sociólogos, poetas, e outros admiradores e curiosos dos diferentes estilos de vida, de organização e relações sociais e outras abordagens relacionadas ao campo ${ }^{9}$.

Nessa perspectiva, destaco alguns trabalhos que considero relevantes para o entendimento e desenvolvimento da pesquisa, esclarecendo que não pretendo analisar cada obra em sua totalidade, muito menos de analisar a totalidade das obras existentes.

Durante séculos falava-se no Brasil em duas classes sociais que seria os fazendeiros e os trabalhadores rurais. Por meio de vários estudos realizados em diferentes regiões e por diversos pesquisadores, pode-se comprovar a existência no Brasil de uma classe social rural intermediária, além do fazendeiro e da mão-de-obra sem-terra, camada esta formada pelos sitiantes, pequeno produtor, caipira, agricultor familiar, camponês - conforme a região onde foi pesquisado -, que, aliás, sempre existiu, desde a colonização do país. Até então, não se discutia sobre a camada intermediária - dos sitiantes - do ponto de vista socioeconômica, pois a mesma só existia do ponto de vista étnico. O debate a respeito dos mesmos mudou-se.

Considerando o que foi exposto até o momento, bem como as realidades observadas, acredito na importância desse camponês, que com o seu trabalho

\footnotetext{
${ }^{9}$ Nice Lecoq Müller, Ariovaldo Umbelino de Oliveira, Bernardo M. Fernandes; Maria Isaura Pereira de Queiroz, Margarida Maria Moura, Bernadete A. C. Castro Oliveira, Ellen Fensterseifer Woortmann,; José de Souza Martins, José Vicente Tavares dos Santos; Patativa do Assaré, etc.
} 
árduo, produz para abastecer de alimentos o nosso país. Visto que a sua construção se faz a partir da existência e interação de determinações, que vão contribuir para a sua reprodução, através das relações não-capitalistas de produção, ou não.

Recorri ao dialogo com outras ciências, além de Geografia, com a antropologia, a sociologia, com a agronomia entre outras, pois através da interdisciplinaridade, pude avançar no processo de construção do objeto de pesquisa, ou seja, na discussão acerca da fragmentação da terra, seja ela por herança ou doação e o destino desse produtor. É nesta direção, e a respeito dessa temática que trilhei a caminhada, e vencer o desafio, é a razão fundamental da escolha deste tema para a realização de meu estudo.

\subsection{Suporte Teórico: Transformações e Considerações}

Não pretendo e nem é objetivo da pesquisa ficar presa ao reino dos conceitos, mas entendo ser necessário compreendê-los e contextualizá-los dentro da dimensão capitalista, na qual as mudanças ocorrem em ritmo bastante acelerado. Esta constatação leva à busca de legados anteriores, que contribuirão para auxiliar na análise dos fatos recentes.

Como classificar o produtor rural focalizado, entre os tipos de agricultores e lavradores já definidos? Isso posto, surge a preocupação com o enquadramento desse produtor rural. Estaria ele desaparecendo? Teria seus dias contados? Seria uma classe em extinção? Estes são temas discutidos nas ciências humanas, que criam uma polêmica entre os que se dedicam a seu estudo e seu entendimento. Apresenta-se a seguir, de acordo com alguns pesquisadores, a caracterização e distinção dessa categoria.

\subsubsection{Abordagens e interpretações clássicas}

Existem diversas expressões e maneiras para se referir ao camponês, o qual às vezes acaba sendo mistificado, e essas denominações variam conforme a região, o período histórico etc. em que o mesmo esteja inserido, como afirma Shanin (Estudos CEBRAP, $\left.\mathrm{n}^{\circ} 26,1980: 44\right)$ : 
Camponês é uma mistificação. Para começar "um camponês" não existe em nenhum sentido imediato e estritamente específico. Em qualquer continente, estado ou região, os assim designados diferem em conteúdo de maneira tão rica quanto o próprio mundo. (...) Uma conceituação mais estrita do contexto social salientará tudo isso ainda mais, pois, tomando alguns exemplos, significados semelhantes podem ser atribuídos a "um camponês" em diferentes períodos e sociedades (...). Finalmente, os termos gerais, ahistóricos e fora de contexto, costumam odiosamente se transformar em reificações da realidade ou, o que é ainda pior, em manipulações conscientes por políticos espertos ou acadêmicos caçadores de prestígio. Eis por que, e como, os camponeses se tornam uma mistificação.

Engels (1981:62) focalizando o camponês classifica esse trabalhador como "proprietário ou arrendatário - principalmente o primeiro - de um pedaço de terra não maior do que ele possa cultivar com sua própria família, nem menor do que o que possa sustentá-lo e aos familiares". ${ }^{10}$

Outros autores que se empenharam em construir uma teoria do campesinato foram Wolf e Mendras, os quais estudaram a sociedade camponesa. Wolf (1976:16) vê o camponês como "cultivador rural cujos excedentes são transferidos para as mãos de um grupo dominante", vinculando o campesinato a outras camadas sociais externas; acrescenta que "o termo camponês denota nada mais, nada menos, que uma relação estrutural assimétrica entre produtores de excedentes e o grupo dominante" (Idem: 24).

Mendras (1978), por sua vez, procura mostrar que o camponês existe e que possui uma economia própria, diferente da economia industrial e mercantil. Por meio de suas revoltas, suas agitações e seu peso político, essa massa camponesa é determinante no movimento histórico e pode, através das formas variadas de sociabilidade, servir de ensinamento para as sociedades urbanas.

Ressalta que, em qualquer época e local em que a classe camponesa for estudada, ela detém traços comuns, que permitem aos estudiosos falar de um modelo camponês de economia, de sociedade e de civilização.

\footnotetext{
${ }^{10}$ Este pequeno camponês é, portanto, como o pequeno artesão, um operário que se distingue do proletário moderno pelo fato de ter ainda a posse de seus meios de trabalho; é, conseqüentemente, um vestígio de um modo de produção de tempos pretéritos. De seu antepassado, o camponês servo, vassalo ou, muito excepcionalmente, do camponês livre sujeito a tributos e prestação de serviços, distingue-se em três aspectos. O primeiro é que a Revolução Francesa liberou-o das cargas de trabalho e tributos feudais que o endividavam com o dono da terra, entregando-lhe, na maioria dos casos, pelo menos na margem esquerda do Reno, a livre propriedade da terra que cultiva. O segundo é que perdeu a proteção da comunidade autônoma de que era membro e da qual deixou de fazer parte, com o que perdeu também sua participação no usufruto das terras dessa antiga comunidade. (...) A terceira circunstância que distingue o camponês atual é a perda da metade de sua atividade produtiva anterior. Antes, o camponês, com sua família, produzia com a matéria-prima de sua própria colheita a maior parte dos produtos industriais de que precisava; os demais artigos necessários eram subministrados por outros vizinhos do povoado, que praticavam um oficio ao mesmo tempo que se dedicavam à agricultura e que eram pagos geralmente em espécie ou em serviços prestados. A família, e mais ainda a aldeia, se bastava, produzia quase todo o necessário. Engels, F. O problema camponês na França e na Alemanha, 59 - 80 . In: Silva, J.G. \& Stolcke, V. (Org.). A questão agrária. 1981.
} 
Mendras (1978:13-44) comenta, ainda, que uma população tão importante não pode manter-se marginalizada e acrescenta:

A autarcia econômica, demográfica, social e cultural torna-se incompatível com o desenvolvimento de nossa sociedade. $O$ camponês transforma-se em agricultor, produtor agrícola que é, ao mesmo tempo, "empreiteiro" e "trabalhador", proprietário de seus meios de produção, mas que não utiliza - ou só em pequena escala - mão-de-obra assalariada. (...) Por camponês é necessário entender a família camponesa, a unidade indissociável que conta ao mesmo tempo os braços que trabalham e as bocas que têm de ser alimentadas; unidade que pode ser tratada do ponto de vista econômico como um agente.

A lógica interna desse produtor pode ser destacada por dois pesquisadores clássicos, Karl Marx e Alexander Chayanov, cujos trabalhos são fontes de subsídios teóricos importantes para a caracterização e o entendimento da lógica da reprodução camponesa.

Em termos de produção, de um lado temos a lógica capitalista regida pelo critério D-M-D, na versão simplificada e D-M-D', na versão ampliada, o que significa dizer: na propriedade privada capitalista os investimentos são realizados visando a adquirir, a obter lucro, ou seja, a um retorno monetário maior do que foi investido, tal qual concebera Marx (1978:90): “o capital é, como vimos, D-M-D', valor que se valoriza a si mesmo, valor que gera valor", enquanto na propriedade camponesa o que vigora é M-D-M, isto é, com a produção de mercadorias objetiva-se a conversão em dinheiro para que se possa obter outras mercadorias necessárias à satisfação das necessidades desta família camponesa. Marx (1978:73) esclarece que "o consumo deste trabalho equivale ao trabalho, ao próprio serviço", sendo que o "dinheiro funciona aqui unicamente como meio de circulação, não como capital".

Chayanov partiu da idéia de que a economia camponesa se caracteriza no âmbito das unidades de produção familiar, diferentemente da economia capitalista e no qual através do cálculo econômico camponês acompanhado de relações sociais específicas, passa a ocorrer uma combinação particular entre a apropriação real e a relação de propriedade.

Para Chayanov (1981:136), a teoria econômica capitalista consiste num sistema complexo de categorias $^{11}$, levando-se em consideração a renda bruta e o

\footnotetext{
${ }^{11}$ A teoria econômica da sociedade capitalista moderna é um complexo sistema de categorias econômicas inseparavelmente vinculadas entre si: preço, capital, salários, juros, renda, determinam-se uns aos outros, e são funcionalmente interdependentes. Se um elemento deste sistema é retirado, todo o edifício desaba. Na ausência de qualquer destas categorias econômicas, todas as demais perdem seu caráter específico e seu
} 
gasto com material e salários; após estes gastos serem deduzidos, se a soma for maior que zero, indica a existência de lucro líquido. Na ausência de uma destas categorias, as outras perderiam seu caráter específico, desagregando assim o sistema. Assim, na propriedade familiar isso não ocorre, pois não existe a presença da categoria salário, já que o serviço é realizado pelos membros da família ${ }^{12}$.

Portanto, Chayanov nos faz entender que a realidade capitalista é diversa da camponesa, a partir do momento em que na primeira a base do cálculo é a lucratividade, ao passo que na segunda a base está centrada no tamanho e composição da família: "quem trabalha e quem consome, na produtividade e no grau de esforço do trabalho"13.

Em face disso, entende-se que na realidade esse cálculo econômico camponês, se dá através de certa compensação. E pode-se acrescentar:

Com efeito, trabalhar para se nutrir aplica-se mais ao grupo que a cada um de seus membros: as crianças e os velhos são bocas a serem alimentadas, mas seus braços têm pouca utilidade no trabalho; os jovens e os adultos, ao contrário, produzem mais do que comem, e uma compensação se estabelece entre uns e outros, cada um sabendo que, no correr de sua vida, passará por todas as situações. (MENDRAS, 1978:44)

Ainda em relação à dualidade entre a realidade capitalista e a camponesa, principalmente no que toca ao trabalho excessivo e ao baixo consumo, Lênin (1981:98) comenta que "o pequeno camponês pode trabalhar e trabalha 14 horas e não 12; pode trabalhar e trabalha com uma tensão acima do normal". Diria que esse excesso de trabalho acontece principalmente onde as atividades a serem realizadas, como o plantio, a colheita, não podem passar da época e a mão-de-obra disponível é insuficiente. Sendo assim,

os filhos do pequeno agricultor ajudam-no desde o momento em que começa a andar. Até os velhos de mais de 70 anos 'substituem a mão-de-obra completa de um operário'. (...) O pequeno camponês,

conteúdo conceitual, e nem sequer podem ser definidas quantitativamente. Chayanov, A. V. Sobre a teoria dos sistemas econômicos não capitalistas: 136. In: Silva, José G. \& Stolcke V. (org.). A questão agrária. São Paulo: Brasiliense, 1981: (133-163.)

${ }^{12} \mathrm{Na}$ exploração agrícola familiar, a família, equipada com meios de produção, emprega sua força de trabalho no cultivo da terra e recebe como resultado de um ano de trabalho certa quantidade de bens. Uma simples observação da estrutura interna da unidade de trabalho familiar é suficiente para compreender que é impossível, sem a categoria salários, impor a esta estrutura o lucro líquido, a renda e o juro do capital, como categorias econômicas reais, no sentido capitalista da palavra. Com efeito, o camponês ou artesão que dirige sua empresa sem trabalho pago recebe, como resultado de um ano de trabalho, uma quantidade de produtos que, depois de trocada no mercado, representa o produto bruto de sua unidade econômica. (...) este produto do trabalho familiar é a única categoria de renda possível, para uma unidade de trabalho familiar camponesa ou artesanal, pois não existe maneira de decompô-la analítica ou objetivamente. Dado que não existe o fenômeno social dos salários, o fenômeno social de lucro líquido também está ausente. Assim, é impossível aplicar o cálculo capitalista do lucro.( Idem: 137138).

${ }^{13}$ A quantidade do produto do trabalho é determinada principalmente pelo tamanho e a composição da família trabalhadora, o número de seus membros capazes de trabalhar, e, além disso, pela produtividade da unidade de trabalho e - isto é especialmente importante - pelo grau de esforço do trabalho, o grau de auto-exploração através do qual os membros trabalhadores realizam certa quantidade de unidades de trabalho durante o ano. (Idem: 138). 
pelo menos durante a época de maior trabalho, pensa: Ah! Se o dia tivesse ao menos uma horinha a mais! (LÊNIN, 1981:99).

Diante de tal comentário, compreende-se que na propriedade camponesa o objetivo do trabalhador é o sustento da família, e com o fato de levar uma vida simples e trabalhar somente com os familiares, consegue obter, em alguns casos, um pequeno excedente, o que não lhe permite ser comparado com o grande proprietário capitalista. Este, além de levar uma vida de luxo, tem com os filhos despesas com escolas e outros gastos mais, sem contar que a mão-de-obra é assalariada.

Temos, assim, dois tipos de propriedade privada da terra: a capitalista, na qual a terra é vista como fonte de lucro, exploração do trabalho alheio e conseqüentemente extração da mais-valia, reserva de valor, objeto de negócio, até porque em alguns casos é mantida só como instrumento de especulação; e a propriedade camponesa que se restringe ao trabalho familiar, sendo a terra mantida para o trabalho e não para especulação.

Percebe-se que a lógica camponesa é diversa da capitalista. Que existe uma dualidade terra de negócio versus terra de trabalho, o que vem comprovar o caráter contraditório do desenvolvimento capitalista, que tem em si os dois tipos de propriedade privada: a capitalista e a camponesa.

De acordo com Martins (1995:151), "é improvável que alguém se atreva hoje a escrever ou falar sobre as características ou acontecimentos do mundo rural brasileiro sem atribuí-los à expansão do capitalismo no campo". Ou, como observa Amin, S. (1987:41): "Para discutir a dominação do capitalismo sobre a agricultura, seria preciso que, antes de tudo, se chegasse a um entendimento a respeito do que é o capitalismo" ${ }^{14}$. Amin (1987) argumenta ainda que a dominação capitalista na agricultura intensificou-se a partir da terceira fase do desenvolvimento capitalista, ou seja, com o imperialismo, quando a submissão da agricultura significa, essencialmente, a liquidação da renda fundiária. Quando, na realidade, o capital

\footnotetext{
${ }^{14}$ A Economia e a Sociologia convencionais o ignoram. Pode-se atingir o doutorado em Ciências Sociais nos Estados Unidos, sem saber que aí se vive numa sociedade capitalista! Os conceitos essenciais de base naquela sociedade são a-históricos: os três “fatores” de produção natureza, capital (sinônimo de equipamento) e trabalho - são incansavelmente combinados, segundo as fórmulas técnicas conhecidas da sociedade estudada. A ciência social dispensa a Historia; a História, quando não se reduz ao encadeamento imediato dos acontecimentos, não vai além da descrição comparativa de instituições e idéias sociais, morais e políticas, ou estéticas. A Sociologia enxerta-se neste magma para examinar, em termos de funcionalidade, a adequação ou inadequação aparente de bocados da vida social talhados assim ao acaso. Estudar o nascimento e o desenvolvimento do capitalismo nesse quadro é um desafio: se se confunde o capitalismo com o uso do chamado "fator capital” - as ferramentas - a dedução natural é de que ele terá existido desde sempre. Isto, quando não é confundido - como freqüentemente acontece - com a troca mercantil, resultando daí que o estudo do desenvolvimento do capitalismo em certo setor se resumiria, para alguns, à medida quantitativa do volume acrescido de ferramentas e da extensão das trocas ... Para ver a situação com clareza, há que aceitar, desde logo, outra visão da ciência social, fundamentada no conceito de modo de produção. Amin, S. O capitalismo e a renda fundiária. Pág.: 41 74. In: Imperialismo e desenvolvimento desigual, 1987.
} 
dominante começa a intervir no processo produtivo agrícola, bem como passa a ocorrer uma intromissão de natureza política, sendo que essa classe pode às vezes nunca estar associada ao poder político, até porque, caso isso ocorra, tal associação pode ameaçar o capital.

Daí Marx (1978:397) afirmar que os camponeses não constituem uma classe, pois, segundo ele, "na medida em que existe entre os pequenos camponeses apenas uma ligação local e em que a similitude de seus interesses não cria entre eles comunidade alguma, ligação nacional alguma, nem organização política, nessa exata medida não constituem uma classe". De acordo com esta autor, eles não se representam, ou seja, não podem representar-se, são incapazes de fazer valer seu interesse de classe, daí terem que ser representados; "a influência política dos pequenos camponeses, portanto, encontra sua expressão final no fato de que o Poder Executivo submete ao seu domínio a sociedade".(MARX, 1987:397).

Embora não seja possível falar de expansão do capitalismo sem mencionar Marx, Kautsky, Lênin e Chayanov, a pretensão aqui não é apresentar uma análise de suas obras, mas sim destacar alguns aspectos considerados importantes para a sustentação da tese de que a agricultura camponesa possui uma lógica econômica própria.

Devido à expansão do capitalismo no campo, Marx considerou que a produção camponesa estava fadada ao desaparecimento, pois ele não a via, não a entendia inserida nesse processo, nessa expansão. Para comprovar sua teoria o autor enumera as causas que julga ser responsáveis por esta destruição, que levaria os camponeses a ser tragados pela exploração capitalista:

Necessidade do pequeno produtor aplicar capital na compra de terra, elemento preponderante para poder apropriar-se do produto de seu trabalho, (...) extermínio da indústria camponesa doméstica, complemento normal dela, em virtude do desenvolvimento da grande indústria; empobrecimento progressivo e esgotamento do solo submetido a esse tipo de agricultura; usurpação pelos grandes proprietários de terras da propriedade comum que por toda parte constitui o segundo complemento da economia parcelaria, sem o qual não Ihe é possível a criação de gado; concorrência da agricultura em grande escala da empresa capitalista ou das plantações coloniais; ... melhoramentos introduzidos na agricultura que contribuem para baixar os preços dos produtos agrícolas ou exigem desembolsos maiores e condições materiais de produção mais avultadas. (MARX, 1985:924-5) 
Já K. Kautsky, ao estudar a realidade agrária alemã aplicando a teoria marxista do sistema de produção capitalista, em sua obra A questão agrária argumenta que a inferioridade da agricultura familiar deixava-a incapaz de concorrer com as grandes empresas agrícolas e que ela inevitavelmente seria tragada pelo capital, pois não era capaz de acompanhar a evolução tecnológica, tanto econômica como organizacional. Para ele, ocorreria um avanço, o progresso na industrialização da agricultura capitalista, em detrimento da produção camponesa, que seria extinta. Comenta, ainda, que

a revolução nas cidades não passou pelos "operários" sem deixar sua marca. Se fossem também atingidos pela febre da greve, ou se tentassem a socialização pelas próprias mãos, o que seria impossível sem destruição e saque, teríamos uma miséria espantosa como resultado. (KAUTSKY, 1981:130)

Quanto à socialização da agricultura, Kautsky (1981) considera que por causa da guerra e da revolução a agricultura alemã entrou numa nova fase, com outras necessidades e problemas e que para resolvê-los, era preciso a intervenção do Estado com todas as suas forças e com métodos que implicassem uma ampla socialização. ${ }^{15}$

Assim, para Kautsky (1980:187), o pequeno proprietário “... enfrenta as suas necessidades de dinheiro vendendo não o excesso dos seus produtos, mas o seu excesso de tempo. Representa no mercado o mesmo papel do proletário, que nada possui". Observa também o trabalho acessório realizado por esse agricultor, que, por falta de atividade em sua propriedade em certas épocas do ano, acabava executando trabalho em outras áreas, o que para o autor pode ser considerado como "trabalho agrícola assalariado", ou seja, ele é um "vendedor da força de trabalho".

\footnotetext{
${ }^{15}$ Esta socialização é tanto mais urgente por se constituir no meio mais seguro de conservar o “operário” agrícola em seu trabalho e canalizar para as grandes propriedades novas forças produtivas, em maior quantidade, que são necessárias em grande medida para que o desenvolvimento se processe com toda a sua potencialidade. (...) De nenhum modo deve o Estado deixar a agricultura por muito tempo abandonada à própria sorte, nem continuar com o sistema burocrático de coleta e repartição de víveres. (...) Nessas condições, a relação entre cidade e campo adota formas peculiares. Em decorrência do desenvolvimento do capitalismo industrial, produz-se uma fuga ininterrupta dos moradores do campo para os centros industriais. (...) Ocorre a fuga de operários da indústria para a agricultura, onde os esperam condições de vida menos miseráveis que nas cidades. Enquanto os operários, massas crescentes de trabalhadores, fogem da indústria socializada, contra essa indústria se levanta a rebelião camponesa que cresce a cada dia que passa. (...) Mas também necessita a mais intensa cooperação dos diversos países do mundo, pois o problema agrário tornou-se internacional desde que a agricultura deixou de ser auto-suficiente para depender de compra de matérias-primas como o adubo e a forragem, importados do mundo inteiro. Da mesma forma que a grande indústria, a agricultura moderna tampouco pode suportar o isolamento de um país em relação aos outros. Ainda quando as condições de vida do camponês estreitem sua visão para o âmbito dos problemas locais, as necessidades da produção o conduzem para os problemas da economia mundial. Kautsky, K. Socialização da agricultura. Prólogo à primeira edição: 127-131. In: Silva, J.G. \& Stolcke, V. (Org.). A questão agrária, 1981.
} 
Lênin, por sua vez, ao escrever sobre $O$ desenvolvimento do capitalismo na Rússia, deduz que o desaparecimento e aniquilamento do camponês estariam ligados à diferenciação entre produtores, segundo a qual um grupo, destacando-se econômica e socialmente, levaria, ou promoveria a extinção dos demais. Dessa maneira, Lênin (1981:61) expõe que a “... base de formação do mercado interior da produção capitalista é o processo de desagregação dos pequenos agricultores em patrões e operários agrícolas".

Lênin, todavia, considera que as grandes contradições do desenvolvimento capitalista se expressam entre os fazendeiros ricos e o proletariado, pois enquanto os pequenos produtores eram privados de permanecer nas terras, estas eram conseqüentemente aglutinadas pelos produtores mais ricos, e se formariam assim as grandes explorações agrícolas e aqueles se proletarizariam.

Quanto ao problema desta proletarização, Amin (1987:72) comenta que o camponês tanto pode ser considerado um "semi-proletário" como um "proletário": "semi-proletário porque conserva a aparência de um produtor livre, e proletário porque está submetido à dominação do capital que o explora e que às suas custas retira mais-valia". Amin acrescenta que, mesmo "objetivamente proletarizado, o camponês continua, ao nível de sua consciência de classe, um pequeno produtor".

Discorrendo sobre O capitalismo na agricultura (o livro de Kautsky e o artigo do senhor Bulgákov), Lênin (1981:87), reforça a teoria de Kautsky quando afirma que "Kautsky explica detalhadamente, em capítulos especiais, o caráter capitalista da agricultura moderna, a relação entre a grande produção e a pequena, e a proletarização do campesinato". A postura teórica adotada por Kautsky e Lênin segue a mesma linha de pensamento de Marx, no que concerne à manutenção da produção familiar; ambos são concordantes com o fato de o grande capital se apropriar das atividades agrícolas, levando o pequeno produtor ao desaparecimento.

Enquanto Kautsky trabalhava com a idéia de que a industrialização da agricultura provocaria a exploração da pequena unidade familiar por conta do grande capital, Lênin se deteve no pensamento de que o processo evolutivo de diferenciação social entre os pequenos produtores iria levá-los ao aumento do número dos trabalhadores assalariados e à exploração desta mão-de-obra. Ambos acreditavam que os pequenos produtores estavam com seus dias contados.

Acerca da destruição, da extinção do camponês, Engels (1981:63) esclarece que "nosso pequeno camponês, como tudo que seja resquício de um modelo de 
produção caduco, está condenado irremediavelmente a perecer. O pequeno lavrador é um futuro proletário". Para ele, o pequeno camponês estava condenado a desaparecer, pois, além de não contar mais com as terras comunais, não mais produzia em família os artigos de que necessitava, porque a produção capitalista pôs fim a isto mediante a introdução da economia monetária e da grande indústria ${ }^{16}$.

Shanin (1980:53) observa que "No estudo em que se debruça mais diretamente sobre os camponeses de sua época, Marx caracterizou e delineou 'a mais numerosa classe da sociedade francesa' através do conceito 'posse parcelaria' (parzellen)". "O que é parzellen senão o estabelecimento rural familiar camponês, devidamente descrito na continuação de sua tese?" Isto pode ser confirmado a seguir nas palavras de Marx (1978:396), em seus escritos sobre O 18 Brumário de Luís Bonaparte: "Bonaparte representa uma classe, e justamente a classe mais numerosa da sociedade francesa ${ }^{17}$, os pequenos (parzellen) camponeses". Esta frase nos leva a entender que Marx os considerava como uma classe.

Cumpre destacar o que foi salientado por Paulino (2003:29): Marx, em suas análises, não se deteve especificamente nas questões relativas à agricultura, sendo, portanto, muitas de suas interpretações consideradas, a posteriori, "mais como suposições e deduções do que propriamente apontamentos conclusivos desse pensador". Ou, segundo Almeida (2003:89), "Marx, quando analisou o campesinato, o fez de forma periférica porque não era sua preocupação central".

É mister, portanto, que se leve em conta a reflexão de Shanin (1980:55), no que se refere à abordagem de Lênin sobre o campesinato, alguns anos depois da publicação de seu livro:

Já por volta de 1907, ele (Lênin) declarava ter havido claro exagero em suas primeiras conclusões sobre a natureza capitalista da agricultura russa (...). Lênin foi além (embora mais implicitamente) na aceitação da permanência de traços camponeses. Esta mudança subjaz e explica as modificações dos programas do partido em 1917, 1921 e foi mais firmemente expressa nos últimos momentos da vida de Lênin.

\footnotetext{
${ }^{16}$ Mas, se o desfrute das terras comunais era uma das condições fundamentais para a existência desses pequenos camponeses, outra condição fundamental era a produção industrial acessória. E assim vemos como o camponês vai decaindo cada vez mais. Os impostos, as más colheitas, as partilhas devidas à transmissão de heranças, as questões judiciais atiram um número crescente de camponeses nos braços dos usurários, com o acúmulo das dívidas se generalizando cada vez mais e cada camponês individual se afundando mais nelas. (...) O pequeno lavrador é um futuro proletário. Como futuro proletário, deveria dar ouvidos à propaganda socialista. Mas há algo que o impede, no momento, e esse algo é o instinto de propriedade que está em seu sangue. Quanto mais difícil lhe parece a luta pelo seu quinhão de terra em perigo, mais violento é o desespero com que se agarra a ele e mais tende a ver no social-democrata, que lhe fala de entregar a propriedade da terra à coletividade, um inimigo tão perigoso quanto o usurário ou o advogado. Como deverá a social-democracia vencer este preconceito? Que pode oferecer ao pequeno camponês, convidado a desaparecer como classe, sem ser desleal consigo mesma? Engels, F. O problema camponês na França e na Alemanha: (59 - 80.) In: Silva, J.G. \& Stolke, V. (Org.). A questão agrária. 1981.

${ }^{17}$ Grifo meu.
} 
Com base nas ponderações sobre a questão agrária, o próprio Kautsky (1981:128) esclarece que sua obra deve ser refeita: "não que tenha mudado meu ponto de vista; é o mesmo de sempre. Mas desde a publicação de minha obra as circunstâncias na agricultura transformaram-se completamente. (...) Isso deu à questão agrária um aspecto novo, em muitos sentidos".

A destruição, a morte da pequena produção que era anunciada por Marx, Kautsky e Lênin em nível mundial, não se confirmou. Além dos mais, na contramão destes pensadores deparamo-nos com Chayanov, que vislumbrava caminhos e pistas importantes que nos levam a entender a permanência dessa agricultura nãocapitalista dentro das contradições específicas do capital, desvendando sua lógica interna, que está relacionada ao ciclo de vida deste camponês.

Chayanov chamou-nos a atenção para o fato de que a base do campesinato russo era o equilíbrio entre a satisfação das necessidades familiares e a própria penosidade do trabalho e não a obtenção ou acúmulo de lucros. ${ }^{18}$ E que o grau de exploração e equilíbrio interno entre as unidades camponesas é bastante variável e pode ser alcançado pelas "condições específicas reais de produção da unidade em relação aos mercadores (determinam o grau de fadiga do trabalho), ou pelo tamanho e composição da família e a permanência de suas necessidades que determinam a avaliação do consumo."19 (CHAYANOV, 1981:139).

Percebe-se que Chayanov fundamentou sua teoria no binômio trabalhoconsumo, com o qual procurou neste sentido, desvendar o cálculo camponês e diferenciá-lo da conduta capitalista. Os dados para fundamentar sua teoria explicativa do campesinato foram buscados diretamente nos campos russos, e seu apoio à resistência camponesa se dá justamente por dois motivos, dois fatores primordiais: era agrônomo e conhecedor do campo russo. Daí sua postura em defender a permanência da lógica camponesa centrada nas necessidades da

\footnotetext{
${ }^{18}$ Cada rublo adicional do crescente produto do trabalho familiar pode ser considerado de duas maneiras: em primeiro lugar, do ponto de vista de sua importância para o consumo, para satisfazer as necessidades da família; em segundo lugar, do ponto de vista da penosidade com que foi obtido. É evidente que com o aumento de produção obtido por trabalho árduo diminui a avaliação subjetiva do significado de cada novo rublo para o consumo; mas a penosidade do trabalho para ganhá-lo, que exigirá uma quantidade cada vez maior de auto-exploração, aumentará. Enquanto não se atingir o equilíbrio entre os dois elementos que estão sendo avaliados (ou seja, enquanto a penosidade do trabalho for subjetivamente estimada como inferior à importância das necessidades que o trabalho suportado satisfaz), a família que trabalha sem utilizar trabalho pago tem todo tipo de motivos para prosseguir em sua atividade econômica. Quando atinge este ponto de equilíbrio, porém, não terá interesse em continuar trabalhando, já que todo dispêndio adicional de trabalho torna-se mais difícil de suportar, pelo camponês ou artesão, do que a renúncia a seus efeitos econômicos. ( Idem: 139.)

${ }^{19}$ Assim, por exemplo, cada acréscimo de produtividade do trabalho tem como conseqüência a obtenção da mesma quantidade de produtos com menos trabalho. Isto permite à unidade econômica aumentar sua produção e satisfazer plenamente a demanda familiar. Por outro lado, numa economia familiar onerada por membros incapazes de trabalhar aumenta a importância de cada rublo de renda bruta para o consumo. Isto faz com que aumente a auto-exploração da mão-de-obra familiar, de modo que o nível de vida da família, ameaçado pela maior demanda, mantenha-se de certa maneira igual. (Idem 139.)
} 
família, sugerindo inclusive a compra e venda da força de trabalho como um processo de funcionamento de busca de equilíbrio da família camponesa.

Enquanto Kautsky e Lênin entendiam o campesinato como uma classe em vias de extinção devido ao desenvolvimento do capitalismo, Chayanov o compreendia como parte de uma lógica interna em que se daria a sua reprodução e não sua extinção.

Não podemos esquecer que as discussões acerca do campesinato russo travadas entre Lênin e Chayanov produziram, como observa Almeida (2003:73), "resultados díspares e isso é possível porque partem de concepções diferentes quanto à compreensão do que representava o campesinato no capitalismo". Almeida (2003:89) nos lembra que "os fundamentos explicativos da transformação da renda pré-capitalista em renda capitalizada e de que a sociedade dominada pelo capital abre possibilidades de (re) criação de formas não-capitalistas foi dado pelo próprio Marx".

O enfoque dado pelos grandes clássicos, dentro de suas perspectivas teóricas, previa que o grande capital se apropriaria de toda a atividade agrícola, numa relação de possuídos/possuidor. Eles não poderiam antever a interação entre o capitalismo e a agricultura, na qual o campesinato manteria e fortaleceria as estruturas existentes, ou seja, sua identidade social frente ao avanço das relações capitalistas na agricultura.

Desta forma, embora tivesse sido prevista por Marx e seus seguidores, em suas bases teóricas, a desintegração do campesinato, uma "descamponesação" por conta do avanço, da exploração do capitalismo, "transformando em capitalismo tudo que tocasse", vê-se o que Teodor Shanin (1980:57) destaca:

À luz do que realmente encontramos hoje, tudo isso parece um
grande exagero. É indubitável a capacidade dos centros capitalistas
de explorar todos e tudo à sua volta; mas sua capacidade ou sua
necessidade (em termos de maximização dos lucros) de transformar
tudo ao redor à sua semelhança não o é. Os camponeses são um
exemplo.

A análise teórica empreendida até o momento nos permite entender que os pesquisadores, ao formularam suas teses na crença do desaparecimento da agricultura camponesa frente ao capitalismo - devido às mudanças que este provocaria no campo a posteriori -, passaram a ver com novos comportamentos, a repensar seus escritos, em busca da produção de uma nova teoria, contrária à 
elaborada outrora. $\mathrm{Na}$ realidade, o desenvolvimento do capitalismo no campo prosseguiu numa trajetória diferente da enunciada por Marx.

O avanço das transformações que aconteceram posteriormente provocou o oposto do que fora anunciado: os camponeses não foram extintos e estão aí, presentes nos dias de hoje; o que ocorre é a permanência ou a recriação ou reprodução camponesa.

No trabalho Imperialismo e desenvolvimento desigual, Amin (1987:41 a 74) dedicou parte de seu estudo ao capitalismo e a renda fundiária, esclarecendo que a diferenciação entre as formações capitalistas e as pré-capitalistas "se prende ao fato de que a lei fundamental do modo capitalista tende a desintegrar os outros modos, a fazê-los desaparecer, o que não acontece nas formações pré-capitalistas". De acordo com o autor, enquanto as formações capitalistas apresentam a tendência à homogeneidade, ou seja, a se reduzirem ao modo capitalista, as pré-capitalistas permanecem heterogêneas; no primeiro caso as alterações, as transformações, as desfigurações, são profundas, e no segundo, as formações não perdem seu conteúdo. Para o camponês, a terra não difere do arado nem da vaca, pois ela é um meio de trabalho, para ele a vida agrícola é essencial, daí a necessidade social de regulamentar essa terra; por outro lado, para os capitalistas, ou melhor, para as empresas capitalistas, o essencial, o primordial são os equipamentos, ficando a terra/terreno relegada ao segundo plano. Para o camponês a terra é vital e as ferramentas são acessórias, mas para o capitalista dá-se o contrário.

Não se pode e nem se deve comparar o campesinato russo com o brasileiro, pois lá os camponeses eram apegados, ligados à terra, ou seja, estamental de acordo com Lênin, mas aqui o campesinato é uma classe, que deseja entrar na terra. Se lá o campesinato estava alheio ao capitalismo, fora e contra ele, aqui é constituído com a expansão capitalista, como produto das contradições dessa expansão. Como lembra Martins (1995:17), "Nosso camponês não é um enraizado. Ao contrário, (...) é um desenraizado, é migrante, é itinerante". Quanto mais o capitalismo avança sobre a terra, mais o posseiro e o pequeno proprietário se deslocam em busca de terra, cada vez mais distante, sendo criado, recriado ou reproduzido em outro território, mas não desaparece.

A expansão das relações sociais capitalistas de produção no campo não leva a produção familiar camponesa às vias de extinção, ao desaparecimento, como previa Marx e os representantes, os seguidores da interpretação marxista ortodoxa, 
ainda que as idéias por eles desenvolvidas sejam diferenciadas entre si. Em se tratando do campesinato brasileiro, em especial as áreas pesquisadas, acredito haver uma relação entre as causas enumeradas por Marx, relacionadas à expansão do capitalismo no campo, e a da fragmentação da terra, pois este fracionamento aponta para algumas daquelas causas. A questão é que há mais de quarenta anos, mesmo a terra sendo fragmentada, as propriedades que foram objeto desta pesquisa, em sua maioria, estão nas mãos das famílias, passando de geração para geração. A fragmentação ocasionou a diminuição das parcelas/lotes e, por outro lado, aumentou o número de proprietários. Sendo assim, não os considero em extinção ou em vias de desaparecimento.

\subsubsection{Contribuição teórica acerca da realidade brasileira}

Vários estudiosos contribuíram para mostrar que havia mais uma camada social rural desde o Brasil Colônia, além do fazendeiro e da mão-de-obra escrava e do latifundiário e do trabalhador assalariado rural. Era uma camada intermediária, que sempre existiu em nosso país.

Lecoq Müller (1951) realizou uma pesquisa a respeito dos Sítios e sitiantes no estado de São Paulo, em duas áreas, uma de povoamento antigo (Vale do Paraíba São José dos Campos e Central - Campinas) e outra de povoamento recente (Alta Araraquarense - Rio Preto, Nhandejara e Fernandópolis e Alta Sorocabana Presidente Venceslau e Presidente Prudente). A preocupação e iniciativa de tal estudo surgiram a partir do momento em que as grandes propriedades nas regiões de terra esgotada pela monocultura do café começaram a ser fracionadas, isto é, fragmentadas, surgindo assim a policultura e um novo tipo de homem rural, "o pequeno produtor policultor, ou seja, o sitiante" (LECOQ MÜLLER, 1951:13).

O objeto de estudo de Müller não foi a evolução histórica, econômica ou social deste sitiante, mas sim quem é ele, como se distribui, como ocupa a terra, qual seu gênero de vida e quais as paisagens por ele criadas. O trabalho, além de definir e estudar os pequenos lavradores em São Paulo, refere-se à importância 
desses sitiantes como responsáveis pelas plantações que cultivam com a família e, às vezes, com um ou dois assalariados.

Assim, Müller (1951:27-28) define sitiante como, "todo o pequeno produtor rural que, responsável pela lavoura, trabalha direta e pessoalmente a terra com a ajuda de sua família e, ocasionalmente, de alguns empregados remunerados". Ressalta que, ao analisar a definição em partes, percebeu que o interesse do produtor rural é o volume da produção e a área plantada e não o regime da terra.

Além do sitiante proprietário, Müller (1951:30) aborda também o caso do posseiro ou morador, definindo-os como "moradores que se instalam onde quer que haja terras de onde não sejam expulsos imediatamente, dando-lhes tempo para a colheita". A autora menciona, ainda, uma outra espécie de sitiante, os arrendatários e parceiros, que "têm de cumprir certo número de obrigações em troca da terra que ocupam".

A partir de investigações que foram iniciadas em 1947 e terminadas em 1954, Antônio Cândido (1975) publicou, pela primeira vez em 1964, a pesquisa Os parceiros do Rio Bonito, na qual verificou a tradição oral comunicada pelos velhos caipiras, que estava passando por um momento de transição:

\begin{abstract}
as modalidades antigas que se caracterizavam pela estrutura mais simples, a rusticidade dos recursos estéticos, o cunho coletivo da invenção, a obediência a certas normas religiosas, estavam cedendo lugar às atuais que se manifestavam no individualismo e secularização crescentes, desaparecendo inclusive o elemento coreográfico socializador, para ficar o desafio na sua pureza de confronto pessoal. (ANTÔNIO CÂNDIDO, 1975: 9)
\end{abstract}

O autor percorreu nesse período de investigações algumas áreas caracteristicamente de caipiras, não só no estado de São Paulo - Bofete, onde realizou seu trabalho -, mas também em Santa Catarina, Rio Grande do Sul e em Mato Grosso, estado no qual em 1954, visitou muito rapidamente as zonas rurais de Cuiabá e Várzea Grande. Esclarece que sua intenção não foi pesquisar a vida social e cultural dos agrupamentos de caipiras por ele visitados, mas sim "determinar quais unidades mínimas de vida econômica e social, em que as relações encontram um primeiro ponto de referência; para isso, tomei um agrupamento de parceiros, como poderia ter tomado de um bairro de sitiantes". (Antônio Cândido, 1975:20)

Antônio Cândido (1975:60) menciona três tipos de moradores da zona rural: para o "cultivador nômade, ocupação é precária; o agregado, onde a ocupação é 
consentida e o posseiro, ocupação de fato". Todos se enquadram no que ele chamou de morador transitório ${ }^{20}$, pois como não possuem o título legal da terra, podem a qualquer momento perder o local de morada. Além deles, existem os moradores permanentes: os sitiantes, podendo ser proprietários ou arrendatários, e o fazendeiro, que é proprietário. O autor esclarece que o dono da terra só é sitiante ou fazendeiro conforme empregue ou não mão-de-obra estranha à família, embora em princípio a designação distinga a importância e a extensão da propriedade.

O trabalho em foco observa também como era ilusória a impressão de isolamento dos caipiras, pois se notava uma organização de vizinhança, organização essa que se percebia principalmente através das formas de solidariedade, mediante o trabalho coletivo, da ajuda mútua, realizada por intermédio do mutirão ou da traição, ambos caracterizados pelos caipiras estudados como "tempo de caridade", pois estavam prestando serviço, ou seja, auxiliando na lavoura àquele que solicitasse. Esse tipo de ajuda ocorria também na luta contra incêndios que se iniciavam no capim seco e se alastravam, ameaçando as plantações e os animais.

Atualmente não é comum encontrar grupos de famílias entre os quais ainda se realiza um dos elementos estruturais mencionados por Tavares dos Santos (1978) em Colonos do vinho, a "ajuda mútua", que os camponeses através de mutirão ou troca pura de dias de trabalho entre si, empregam para suprir a força de trabalho familiar.

José de Souza Martins (1996), na entrevista Revisando a questão agrária ${ }^{21}$, relata sua experiência, sua vivência no que se refere à agricultura familiar, em especial a esse companheirismo, a essa sociabilidade, a essa ajuda mútua mencionada não só por Antônio Cândido (1975), como também por Tavares dos Santos (1978) e Oliveira (1995). Declara o entrevistado:

Uma coisa que aprendi em casa mesmo, na roça, com meus avós, meus tios e primos, é que a agricultura familiar é, sobretudo, uma forma básica de cooperação econômica e é, também, uma comunidade. Nos momentos de colheita, quatro gerações da família se reuniam para executar o trabalho dos mais fracos, sobretudo dos velhos. Eram muitas semanas de trabalho e também de muita

\footnotetext{
${ }^{20}$ Chama-se transitório ao morador que, não tendo títulos legais, pode a cada momento perder a terra onde mora. As origens de sua fixação podem ser muitas; em nossa formação destaca-se o foragido das autoridades, por infrações quaisquer, e, por isso mesmo, interessado em se isolar. O agregado, como se sabe, distingue-se do posseiro porque tem permissão do proprietário para morar e lavrar a terra, sem qualquer paga, salvo alguma prestação eventual de serviço. O posseiro não tem permissão e freqüentemente ignora a situação legal da terra que ocupa: pode ser terra sem proprietário, pode ser terra com proprietário, pode ser terra que virá a ter proprietário. Cândido, Antônio. Os parceiros do Rio Bonito. $3^{\text {a }}$ ed. São Paulo: Livraria Duas Cidades, 1975: 59. 
alegria. Um momento, propriamente, de comunhão. (MARTINS, 1996:53)

O Campesinato brasileiro foi estudado por Queiroz em 1976, quando a autora se empenhou em dar um enfoque crítico-histórico, análogo e ao mesmo tempo complementar a uma outra obra, Homem, cultura e sociedade no Brasil. Queiroz (1976:capa) procurou mostrar "a evolução do campesinato brasileiro, sua estruturação antropológica, sua evolução e posição social diante e em comparação com a cultura dos centros urbanos e do litoral brasileiro", além de expor um denso quadro de dados históricos e descritivos sobre o que realmente constitui a realidade da vida e da cultura dos grupos rústicos do Brasil.

Queiroz (1976:26) comenta que no Brasil durante muito tempo se negou a existência de uma camada camponesa, mas,

(...) $\mathrm{Na}$ verdade, houve em todos os tempos um campesinato livre brasileiro, coexistindo tanto com as fazendas monocultoras, quanto com as fazendas de criação de gado e tendo a seu cargo a produção de abastecimento para estas empresas e para os povoadores. (...) Não raro, o fazendeiro admitia em suas terras moradores que cultivavam para sua própria subsistência, pagando o aluguel da terra com parte da colheita e dando ainda dias de trabalho nas plantações do proprietário; constituíam assim viveiros de mão-de-obra. Nas fazendas de gado acontecia o mesmo. Porém estes moradores tinham por obrigação constituir uma espécie de "milícia" do criador de gado, defendendo-o nas lutas de família, nas lutas pela posse de terra, nas lutas políticas, pois o trabalho com os rebanhos não exigia quantidade exagerada de mão-de-obra.

Vê-se em Queiroz (1976:26), ainda, que existiam, nas fazendas monocultoras e nas fazendas de gado, sitiantes independentes, que ocupavam as faixas de terra menos fértil, quando a zona era de monocultura, ou então os vales úmidos e as beiras dos rios, nas zonas secas de criação. Contribuíam para o abastecimento das fazendas com qualquer tipo de serviço. A autora verifica que a subordinação aos plantadores e criadores de gado era característica, pois eram estes seus protetores, padrinhos de seus filhos, seus banqueiros, seus advogados, seus chefes políticos, isto é, seus elementos e fatores de ligação e integração com a sociedade global.

Não pára por aí a observação de Queiroz (1976:28), que menciona ainda os posseiros, os quais se localizavam em terras devolutas ou em terras já apropriadas, mas sem autorização do proprietário; os parceiros, que pagavam o aluguel da terra com uma porcentagem da colheita ou o equivalente em dinheiro; e os moradores ou 
agregados, que habitavam as propriedades monocultoras, porém cultivando nelas gêneros, com permissão do proprietário e dando a este, em pagamento, dias de serviço.

Além desses tipos rurais já citados, Queiroz (1976:29 - 30) define o camponês como o

Trabalhador rural cujo, produto se destina primordialmente ao sustento da própria família, podendo vender ou não o excedente da colheita, deduzida a parte do aluguel da terra quando não é proprietário; devido ao destino da produção, é ele sempre policultor. O caráter essencial da definição de camponês é, pois, o destino dado ao produto, pois este governa todos os outros elementos com ele correlatos. Economicamente, define-se, pois o camponês pelo seu objetivo de plantar para o consumo. Sociologicamente, o campesinato constitui sempre uma camada subordinada dentro de uma sociedade global - subordinação econômica, política e social.

Assim como Antônio Cândido (1975), Queiroz (1976) demonstra que realmente o isolamento dos camponeses era ilusão, pois pôde verificar que os sitiantes não ficavam restritos ao âmbito do município, mas estavam em constante circulação, servindo de todos os pretextos - religiosos, sociais ou econômicos - para não ficarem isolados, mesmo que fosse para vender o excedente de um produto qualquer.

No período de 2004 a 2006, observei e participei na região da Aldeinha, do Bananal/Rondonópolis/MT, de vários festejos religiosos (santos protetores: Nossa Senhora Aparecida, Santo Antônio, São João, São Pedro) e outras festas familiares ou da comunidade, das quais participam os moradores das regiões circunvizinhas, bem como parentes e amigos que moram na cidade. Constata-se, portanto, que esse isolamento do camponês é realmente um ledo engano.

Santos (1975:172), por seu lado comenta sobre a ambigüidade deste camponês, pois "ao mesmo tempo em que é proprietário da terra e do capital é também o trabalhador". Andrade (1989:6 e 59), em seu livro Lutas camponesas no ordeste, o enquadra como "trabalhador rural. (...) Este ainda complementa a renda trabalhando, nos períodos de paralisação do trabalho em suas pequenas explorações, para os grandes e médios proprietários, sem vínculo empregatício". Já a ênfase de Carvalho (1978:52) é mais abrangente, pois se refere ao camponês como "arrendatário, foreiro, rendeiro, colono, parceiro, porcenteiro, meeiro, agregado, morador, posseiro, ou sitiante. Sejam eles proprietários reais ou não do 
todo ou de parte da terra em que trabalham". E conclui: "Pode-se afirmar, então, que o camponês é um pequeno produtor rural. Um produtor rural de baixa renda".

Ao abordar a questão da estrutura arcaica brasileira, Lambert ${ }^{22}$ (1978:110111) percebeu em 1939 que a maioria da população brasileira era rural e definiu-a como sendo composta de

\begin{abstract}
Indivíduos isolados, organizados em pequenas comunidades muito homogêneas, que não participam diretamente, nem da vida econômica, nem da vida política nacional. (...) É bem diferente dos camponeses da Europa Ocidental, mas é mais diferente ainda da população rural dos países novos anglo-saxões em sua resistência à mudança (...) explica-se o atraso cultural do homem do interior do Brasil pela repugnância dos primeiros colonos ao trabalho manual, pelas deficiências dos governos, pelos princípios disciplinadores do catolicismo, pela tendência à mestiçagem, etc.
\end{abstract}

Lambert (1978) chama a atenção para as pequenas plantações existentes em nosso país, naquele período, as quais mal produziam para a própria subsistência. Mas ao tratar da monocultura e da policultura no Brasil, reconhece a importância do lavrador, caracterizando a pequena propriedade como aquela que “... ocupa a maior parte do território brasileiro, a policultura é ainda mais importante, porque fornece alimentação aos (...) habitantes do Brasil e emprega a maioria dos homens do campo". Enaltece ainda mais este lavrador em relação ao latifundiário que abastece o mercado externo, quando afirma que "as grandes culturas de exportação cobrem apenas três milhões e meio de hectares, as culturas de víveres ocupam 14 milhões" (LAMBERT, 1978:136 - 137).

Prado Júnior (1987), ao discorrer sobre a sociedade colonial brasileira ${ }^{23}$, comenta a respeito do pequeno proprietário que lavra terras próprias e é pouco mais que um servo, tendo sua gleba mais como dependência do grande domínio do que como outra coisa qualquer. Ao lado do pequeno proprietário, ele se refere à presença dos agregados, que são "indivíduos - em geral escravos libertos ou mestiços espúrios - que vivem nos grandes domínios prestando aos senhores toda sorte de serviços: guarda de propriedades, mensageiros etc." (PRADO JÚNIOR, 1987:28-9).

Observa, ainda, que, além dos agregados, existem os rendeiros, que "pagam seus aluguéis em dinheiro ou mais comumente em produtos naturais ou em

\footnotetext{
${ }^{22}$ Lambert, Jacques. Os dois Brasis. 10a ed. São Paulo: Nacional, 1978, publicado primeiramente em 1959.

${ }^{23}$ Prado Júnior, Caio. Evolução política do Brasil: Colônia e Império. 18ª ed. São Paulo: Brasiliense, 1987.
} 
serviços. A situação é a mais precária possível. Raramente se faziam contratos escritos, e mesmo se os fizessem não havia autoridades para os sancionar." (PRADO JÚNIOR, 1987:28-9)

Portanto, Prado Júnior considera que tanto os proprietários de pequenas glebas mais ou menos dependentes como os simples rendeiros, todos em linhas gerais se equivalem.

Ao escrever sobre a Vida material, mais especificamente sobre a Agricultura de subsistência ${ }^{24}$, Prado Júnior (1996:159) menciona as lavouras especializadas, que se dedicavam unicamente à produção de gêneros alimentícios e eram consideradas como um tipo de exploração rural diferente e separada da grande lavoura, sendo às vezes até insignificantes conhecida como roça, chácara ou sítio, onde não existia a presença de escravos ou assalariados e cujo proprietário ou ocupante - e sua família - é ao mesmo tempo o proprietário e o trabalhador.

Prado Júnior (1996:159) distingue estas duas categorias, proprietário e ocupante, esclarecendo que este último ocorre sob a forma de agregado:

O agregado é um trabalhador rural a quem o proprietário cede, em geral a título gratuito e em troca apenas de uma espécie de vassalagem e prestação de pequenos serviços, o direito de se estabelecer e explorar uma parte inaproveitada do domínio. (...) sob o aspecto econômico, ele faz as vezes de um pequeno produtor autônomo.

Na mesma obra, Prado Júnior (1996:160) verifica que esse tipo de cultura, de exploração é destinado ao abastecimento interno da colônia, sendo assim um setor subsidiário da economia colonial, com baixo nível econômico, produtividade escassa, e a mão-de-obra "é o próprio lavrador, modesto e mesquinho, às vezes conta com o auxílio de um ou outro preto, (...) ou índio, ou mestiço semi-servil". Naturalmente, encontra-se localizado próximo ao grande centro urbano a que serve.

Por outro lado, a lógica do campo nos dias de hoje mostra que o processo de modernização acelerada já provocou transformações na pequena produção rural na sociedade capitalista. Esta reflexão é corroborada pela análise de A. U. Oliveira (1991:11), em seu estudo sobre $A$ agricultura camponesa no Brasil, quando esclarece que “... o desenvolvimento desigual do modo capitalista de produção na formação social capitalista (...) só será possível se articulada com relações sociais

\footnotetext{
${ }^{24}$ Prado Júnior, Caio. Formação do Brasil Contemporâneo. 24a ed. São Paulo: Brasiliense, 1996. Publicado pela primeira vez em 1942. É considerado seu principal trabalho, um clássico ensaio sobre a Historiografia Brasileira, foi talvez o primeiro a dar lugar na paisagem social do meio rural a uma camada intermediária, ou seja, a uma camada que nem fosse fazendeiro e nem trabalhador escravo.
} 
não-capitalistas". Isto porque esse produtor acabou subordinado ao capital a partir do momento em que ocorreu uma captação de sobretrabalho da produção familiar, através da absorção de parcelas significativas do excedente por ele gerado, ocasionando assim um desenvolvimento desigual. Oliveira (1991:11) acrescenta que “...o campo tem sido um dos lugares privilegiados da reprodução dessas relações de produção não-capitalistas".

Se por um lado houve a expropriação do trabalhador do campo devido à modernização, por outro, houve um aumento, um avanço do trabalho familiar praticado pelo camponês, ou seja, ao mesmo tempo em que se estabelecem as relações de produção capitalistas, avançam também as relações de produção nãocapitalistas.

Contemplando essas questões, passa a ocorrer um debate no qual as vertentes teóricas vão se tornando mais claras. Alguns autores vêem o processo de desenvolvimento do modo capitalista de produção em sua etapa monopolista através do processo de generalização; outro grupo o entende através do processo de penetração de relações capitalistas de produção no campo; já um terceiro grupo compreende as relações não-capitalistas de produção hoje como criadas e recriadas pelo próprio processo contraditório de desenvolvimento do modo capitalista de produção. (OLIVEIRA, 1991:45-46)

Em seu trabalho já mencionado, Oliveira (1991:48), ao se referir à questão das vertentes teóricas, expõe: “... entendemos o desenvolvimento do modo capitalista de produção na sua etapa monopolista como um processo contraditório de reprodução ampliada do capital". Esta é uma relação conflituosa, pois, ainda conforme Oliveira (1991:48), o modo capitalista de produção não tem limitação determinada somente à produção, mas também à circulação de mercadorias. Tal fato indica que, na realidade, a essência do capitalismo está na produção da maisvalia e não na produção de mercadorias.

Buscando compreender a lógica de funcionamento da produção e reprodução camponesa sob o modo capitalista de produção, Oliveira empenhou-se em suas pesquisas e em 1995 publicou um novo estudo acerca do Modo capitalista de produção e agricultura, no qual discutiu as diferentes correntes que abordam a agricultura capitalista, partindo da premissa de que o desenvolvimento do modo capitalista de produção é desigual e contraditório. 
Nesse trabalho, Oliveira (1995:72) não deixa perder de vista a questão camponesa e destaca três componentes considerados por ele fundamentais no processo de reprodução da produção camponesa: os proprietários de terras; o Estado; e as cooperativas no campo; assim explicita ele:

... os proprietários de terras, que especulam com a terramercadoria; ao vender a terra, fazendo, principalmente, loteamentos e colonização agrícola, acabam por criar, contraditoriamente, condições para a recriação do camponês-proprietário.

... o Estado, que atua como agente distribuidor de terras em projetos de colonização, e, ao fixar preços mínimos agrícolas, ou cotas de produção, garante condições mínimas contraditórias para que o camponês se reproduza.

... as cooperativas no campo. Nasceram (...) como instrumento de defesa dos agricultores contra o comerciante, que, de certo modo atuando como comprador e usuário, explorava os camponeses, levando-os à proletarização.

Essas variáveis nos permitem entender que a lógica inerente à propriedade capitalista e à camponesa consiste em que, na primeira, a terra é vista como ou constitui-se em objeto de negócio, de exploração do trabalho alheio e extração da mais-valia, voltada para a especulação, reserva de valor, e na segunda, a terra é considerada um instrumento de sobrevivência da família, terra de trabalho, onde se utiliza a mão-de-obra familiar, sendo poucos os casos em que se contrata mão-deobra de terceiros.

Sobre a construção teórica do campesinato, Martins possui relevantes trabalhos publicados que inspiram muitos estudiosos e pesquisadores do campesinato no Brasil. Em Os camponeses e a política no Brasil, o autor destaca as lutas populares no campo e a incorporação do problema camponês e da questão agrária, constituindo uma história política do campesinato brasileiro, destinada a localizar as raízes dos impasses atuais.

Em se tratando da apropriação da renda da terra pelo capital, Martins (1995:175) expõe o seguinte:

(...) O capital tem se apropriado diretamente de grandes propriedades ou promovido a sua formação em setores econômicos do campo em que a renda da terra é alta, como no caso da cana, da soja, da pecuária de corte. Onde a renda é baixa, como no caso dos setores de alimentos de consumo interno generalizado, (...), o capital não se torna proprietário da terra, mas cria as condições para extrair o excedente econômico, ou seja, especificamente renda onde ela aparentemente não existe. 
Entendo ser estas as razões para os inúmeros conflitos existentes no território brasileiro, em especial nas frentes pioneiras, pois, de acordo com Martins (1995:176), "Enquanto o lavrador luta pela terra de trabalho, a grande empresa capitalista luta pela renda da terra".

Ao observar as mudanças ocorridas na economia camponesa, notei que a família se encontra em um processo de dependência no que se refere a financiamentos bancários e em relação ao intermediador. Possui terra para o trabalho e não para uso capitalista. Esta situação é assim analisada por Martins (1995:176):

... O que hoje acontece com a pequena lavoura de base familiar é que o produtor está sempre endividado com o banco, a sua propriedade sempre comprometida como garantia de empréstimos para investimento e, sobretudo para custeio de lavouras. (...) o lavrador entrega ao banco anualmente os juros dos empréstimos que faz, tendo como garantia não só os instrumentos, adquiridos com os empréstimos, mas a terra. Por esse meio, o banco extrai do lavrador a renda da terra, sem ser o proprietário dela. O lavrador passa imperceptivelmente da condição de proprietário real a proprietário nominal, pagando ao banco a renda da terra que nominalmente é sua. Sem o perceber, ele entra numa relação social com a terra mediatizada pelo capital, em que além de ser o trabalhador é também de fato o arrendatário.

Acredito que tal situação seja o motivo por que o camponês se vê subordinado ao capital. Esta é uma forma de exploração, pois a riqueza que ele cria converge para mãos estranhas. Além dessa exploração, o camponês, que põe a terra para produzir, ainda sofre a influência das intempéries e demais agentes perturbadores que podem colocar a produção agrícola em risco, não esquecendo a exploração sofrida por intermédio do atravessador, que, mesmo não possuindo terra, abocanha parte do lucro que por direito seria do produtor.

A partir do momento em que o destino da produção camponesa se modifica, em que o produtor se disponha a produzir para vender, sua organização de trabalho altera-se, pois se o intuito é, além de suprir as necessidades da família, abastecer o mercado interno, sua produção deverá ser bem maior e, para tal, precisará contar com uma ajuda extra, com mão-de-obra não familiar.

Martins (1995), no estudo Camponeses e a política no Brasil, relata a questão das lutas sociais no campo e seu lugar no processo político. Ao discutir as origens sociais do campesinato, esclarece que existem diferentes formas de campesinato na 
sociedade brasileira, particularmente aquelas destituídas da propriedade da terra e, na concepção de camponês, ele não inclui o trabalhador assalariado do campo.

Enquanto na Europa e em partes da América Latina um trabalhador do campo era classificado como camponês, no Brasil, segundo Martins, ele era conhecido de acordo com a região onde se encontrava, como caipira, caiçara, tabaréu, caboclo, denominações essas que em determinados locais tinha duplo sentido, significando ao mesmo tempo rústico, atrasado, ingênuo, inacessível, tolo, tonto, preguiçoso, ou seja, tais alcunhas desvalorizavam esse trabalhador.

A palavra camponês é de cunho político e veio expressar a unidade da classe e, que inclusive, procurou dar unidade às lutas dos camponeses.Nas palavras de Martins (1995:25),

Definam-no como aquele que não está em outro lugar, no que se refere ao espaço, e como aquele que não está senão ocasionalmente, e nas margens, nesta sociedade. Ele não é de fora, mas também não é de dentro. Ele é, num certo sentido, um excluído. (...) Às vezes será encarado como um perigo, outras vezes como um incapaz de fazer história, de definir e atuar no processo histórico senão no sentido de contê-lo.

No que se refere à origem do campesinato tradicional, de acordo com Martins, o que caracteriza os camponeses brasileiros durante todo o tempo é ser ele um produtor de gêneros alimentícios para o consumo interno, em uma "lavoura de pobre", expressão que costumamos ouvir ainda hoje, em contraposição à agricultura de "produtos nobres", voltados para abastecer o mercado externo.

No Brasil Colonial, o campesinato era constituído pelo agregado da fazenda, formado pelo índio e pelo mestiço, que eram excluídos do direito de propriedade, sendo obrigados ao pagamento de tributos variados, em serviços ou gêneros alimentícios, dependendo da época, das circunstâncias e das condições do fazendeiro; pelos "moradores de favor", que existiam e existem, ainda em várias partes do país e a respeito dos quais Martins (1995:36) comenta que " ...a morada de favor esconde (...) o verdadeiro agregado, o mestiço, excluído do direito de propriedade e de herança, e o parente, que o morgadio excluiu da herança, mas que permaneceu na terra (...)"; pelo posseiro, cuja condição dizia respeito à relação jurídica com a terra, quando o camponês tinha posse, mas não o domínio; e pelo sitiante, que era o pequeno agricultor independente, dono de um sítio, de um lugar 
na terra, e não de uma sesmaria, e que geralmente praticava uma agricultura itinerante; tanto o agregado como o morador eram tidos como sitiantes.

Pode-se dizer que o campesinato tradicional foi formado essencialmente por três grupos distintos: o índio, o mestiço, quer fosse filho de branco com índia ou de branco com negra/escrava, isto é, os de "sangue impuro", e os parentes eliminados pelo morgadio. Todos estavam excluídos da herança. Aliás, essa exclusão era não apenas social, mas também econômica e política.

Assim como os trabalhadores do campo tinham diferentes denominações, o mesmo acontecia com os proprietários da terra, que eram conhecidos como estancieiros, fazendeiros, senhores de engenho, seringalistas, dependendo da região onde estavam inseridos.

No momento em que a questão camponesa, a situação do campesinato, passou a fazer parte do debate político nacional, tanto os trabalhadores rurais como os proprietários da terra passaram a ser conhecidos como camponeses e latifundiários, palavras de cunho político que procuram expressar a situação das respectivas classes.

No trabalho Camponeses, Moura (1996) cita várias maneiras de definir ou descrever o camponês; optei pela seguinte:

Trabalhador que se envolve mais diretamente com os segredos da natureza. A céu aberto, é um observador dos astros e dos elementos. Sabe de onde sopra o vento, quando virá a primeira chuva, que insetos podem ameaçar seus cultivos, quantas horas deverão ser dedicadas a determinadas tarefas. (...) cultivador de pequenas extensões de terra, as quais controlam diretamente com sua família. (MOURA, 1986:9, 12)

O motivo de tal escolha se deve ao fato de que esta definição aproxima-se do trabalhador das regiões fragmentadas em Rondonópolis.

O estudo intitulado Tempo de travessia, tempo de recriação: Profecia e trajetória camponesa, de Bernadete A. C. Castro Oliveira, defendido em 1998, mostra a realidade dos sitiantes de Mirassol D'Oeste e de São José dos Quatro Marcos-MT, em que a autora vê, especificamente, a recriação do sítio camponês. De acordo com Oliveira, essa condição

...foi gestada no interior de um processo de expropriação em massa, de arrendatários no noroeste paulista, onde não só se encontrava a atuação política do Partido Comunista Brasileiro, mas também, o movimento sócio-religioso do "Aparecidão", cuja "visão profética" 
antevia a possibilidade da "recriação de uma geração melhor", neste "Reino de Deus, que é essa terra mesmo".

Com esse trabalho Oliveira faz um levantamento da trajetória de vida desses sitiantes, descobrindo, assim, que muitos deles eram oriundos das formas nãocapitalistas, ou seja, se recriaram através delas. Os que não eram arrendatários tinham sido trabalhadores no regime de porcentagem.

Por conta do processo de transformação pelo qual estava passando o noroeste paulista, ocorreu a expulsão dos arrendatários e dos porcenteiros do campo, bem como a prisão de lideranças e trabalhadores rurais. Muitos dos trabalhadores foram imbuídos pela interpretação do "Aparecidão", de que os mesmos deveriam sair em busca da terra prometida. Sendo assim, inúmeras famílias migraram nos anos de 1960 e 1970 para a região de Cáceres-MT, estabelecendo-se ali e refazendo o caminho arrendatário-sitiante, restabelecendo assim a sociabilidade do modo de vida com padrões semelhantes aos que tinham sido por eles utilizados em São Paulo, em locais conhecidos como bairros rurais paulistas ou sítios de São Paulo.

No que se refere à reforma agrária e à agricultura familiar no Brasil, Martins (dez. 2001) ${ }^{25}$ comenta a reprodução social da família, regulada por valores da tradição familiar, segundo os quais as estratégias de reprodução não se limitam a reproduzir, isto é, a subsistir, a permanecer, mas também dão conta de novas necessidades e novos desafios que são gerados pelas transformações econômicas e sociais.

Em relação às conseqüências do desenvolvimento econômico, Martins (2001:1) acrescenta:

A agricultura familiar, além da produção agrícola propriamente dita, inclui as retribuições rituais dos filhos e netos em relação aos pais e avós e dos pais e avós em relação a filhos e netos. Isso quer dizer doações periódicas e remessas econômicas oriundas de ganhos obtidos em outros setores da economia. Sem contar subsídios compartilhados pela família com base nos deveres da reciprocidade e da dependência pessoal, desde a aposentadoria ou a pensão até a bolsa-trabalho.

Cumpre ressaltar que essa complexidade de fontes e distribuição de ganhos e de acumulação familiar de patrimônios, descrita por Martins, só se explica e se

\footnotetext{
${ }^{25}$ Martins, apresentou no Seminário Interno sobre Dilemas e Perspectivas para o Desenvolvimento Regional no Brasil, com ênfase no Agrícola e Rural na Primeira Década do Século XXI, o trabalho Impasses sociais e políticos em relação à reforma agrária e à agricultura familiar no Brasil. Dezembro de 2001.
} 
compreende se for levada em conta a questão da espacialidade e da temporalidade da família agrícola.

Observei, na pesquisa Identidade, distinção e territorialização: O processo de (re) criação camponesa no Mato Grosso do Sul, a preocupação de Almeida (2003) em estudar os acampamentos e assentamentos como processo de (re) criação camponesa em MS - Mato Grosso do Sul, levando em consideração não só as ações resultantes desse processo, mas o significado da luta para seus agentes. Para tanto, analisou o período de 1985 a 2000, que de acordo com ela "compreende momentos de avanços e recuos da organização camponesa no Mato Grosso do Sul" (ALMEIDA, 2003:32). Em face disso, estudou cinco assentamentos e oito acampamentos em MS, com o foco não sobre o assentamento em si, mas no processo de territorialização da luta pela terra, no entendimento do mesmo enquanto unidade territorial, espelho da (re) criação e potencialidade camponesa.

Paulino, por sua vez, com a pesquisa Terra e Vida: A geografia dos camponeses no norte do Paraná (2003) procurou mostrar que mesmo sendo o modo capitalista de produção contraditório, seu desenvolvimento não tem provocado o desaparecimento do campesinato, mas sim sua recriação. Para realizar o estudo e comprovar sua tese, Paulino analisou o Norte Novo do Paraná, onde, segundo ela, está "uma das áreas de maior índice de tecnificação e produtividade agrícola do país" (Paulino, 2003:6).

Foram pesquisados pela autora em pauta trinta e três municípios, sendo visitados 292 sítios. As análises foram baseadas em dados estatísticos publicados pelo IBGE, Censos Agropecuários; e como terra para os camponeses é sinônimo de vida, de existência e que esta se estrutura sobre parcelas de terra, a investigadora pensou o processo de recriação do campesinato vinculado à dinâmica que envolve a propriedade, da posse e uso.

Essas parcelas são entendidas por ela como parte de um todo, qual seja, o seu território capitalista, do qual essas frações do território camponês são integrantes, integram-se a essa ordem dominante.

Mais recentemente e complementando sua pesquisa de mestrado $O$ bairro: reforma agrária e o processo de territorialização camponesa, Bombardi empenhouse em seu doutorado com a Tese Campesinato, luta de classe e reforma agrária ( $A$ Lei de Revisão Agrária em São Paulo), defendida em 2005, em que a autora abordou os assentamentos implantados a partir desta Lei de Revisão Agrária, 
promulgada pelo governo Carvalho Pinto em 1960. Por intermédio desta Lei, cinco municípios tiveram áreas desapropriadas para a implantação dos assentamentos.

De acordo com Bombardi (2005:XV):

A reforma agrária, que é buscada através da luta camponesa por sua reprodução cria marcas no território. Territorializa-se e transforma a experiência das famílias que a vivenciam. Desta forma, o campesinato, ao ser assentado, transforma frações do território tornando-as unidades territoriais específicas: os sítios camponeses.

As reflexões de Patativa do Assaré (2005) ${ }^{26}$ - o "Poeta da Roça", em relação a Serra de Santana, no sertão do Ceará, refletem bem a realidade objetiva camponesa do ponto de vista desse poeta:

Não há maior injustiça como eu digo, do que o camponês viver sem terra para trabalhar. Ana você veja que é muito triste, é muito injusto e é quase como que um crime nascer um camponês aqui, viu. $E$ trabalhar até o fim da sua vida, sem possuir um palmo de terra. Nem um quadrozinho que ele faça uma casa e dizer isso aqui é meu. Isso é contra Deus, é um dos crimes grande.

A desapropriação de áreas para a implantação dos assentamentos estudados por Bombardi contribuiu para eliminar parte dos problemas sociais surgidos em nosso país e descritos por Assaré ao mencionar o caso do Nordeste.

Após a realização da pesquisa bibliográfica inicialmente empreendida e que necessita ser aprofundada, observei que existem várias vertentes e divergências de idéias que podem promover discussões ou polêmicas muito vastas e, além disso, definir é sempre tarefa difícil. Contudo para me aproximar do assunto, na pesquisa $A$ produção camponesa e a modernização da agricultura em Rondonópolis-MT Estudo em áreas de assentamento de reforma agrária: Gleba Cascata e Projeto de Assentamento Chico Mendes/Vale do Bacuri, conceituei camponês como sendo

Todo e qualquer trabalhador possuidor de uma pequena propriedade rural ou que, não a possuindo, tenha acesso a terra através da parceria, arrendamento ou posse, e a explore diretamente com o trabalho familiar, visando fundamentalmente à reprodução da família, o autoconsumo, e a venda do excedente de forma a adquirir o que não produz e de que necessita sua família. Muitos são "migrantes temporários" em busca de uma vida melhor, migrantes estes que sabem de onde e por que vieram, mas não sabem quanto tempo permanecerão nas terras que ocupam.

(LIMA; 2000:21-22).

\footnotetext{
${ }^{26}$ Entrevista cedida a Ana Dalla Pria ao Programa Globo Rural (Rede Globo) em 1999 e reprisado em 20/03/2005.
} 
Pelo fato de ter sido observada a significativa ocorrência, a reprodução e exploração agrícola baseada em relações de produção não mais especificamente capitalistas, que é o caso dos pequenos produtores rurais, em particular os oriundos da fragmentação da terra, tornou-se necessário repensar esta definição de camponês. São vários os termos empregados, conforme as abordagens teóricas utilizadas pelos pesquisadores ao tratarem desta categoria social.

Não pretendo entrar em ponderações de caráter terminológico, por isso optei por uma conceituação mais abrangente de camponês, de modo que a mesma se adequasse aos propósitos desta discussão.

Para tanto, revendo as classificações e conceituações do INCRA, bem como dos pesquisadores acima mencionados e repensando o conceito por mim elaborado, julguei pertinente acrescentar àquela definição, o trabalhador rural possuidor da terra por intermédio da herança ou doação, bem como o problema da exploração do imóvel rural não só pela mão-de-obra familiar mas, eventualmente, com a ajuda de terceiros, o que não caracteriza o camponês como comprador de mão-de-obra, como capitalista - pois, conforme Martins (1975:16-7), "nem mesmo o pequeno proprietário pode configurar-se como comprador de força de trabalho, já que quase sempre explora apenas o trabalho familiar" - e reforçar que na atualidade a produção camponesa não visa só à reprodução familiar, o autoconsumo, mas também à venda do excedente - que também de acordo com Martins (1975:12), "não é o produto que sobra do consumo, mas o produto dos fatores de produção excedentes dos que foram utilizados na subsistência" - para o mercado interno, o que irá contribuir para que ele possa efetuar a compra dos produtos necessários à sua manutenção e que não são por ele produzidos.

Em o Cativeiro da terra, Martins (1996) aborda a produção capitalista de relações não-capitalistas de produção: o regime de colonato nas fazendas de café; percebe-se ali, que as transformações históricas, isto é, a troca do escravo, trabalhador cativo, pelo imigrante europeu, para trabalhar no sistema de colonato, como trabalhador livre, não eliminou o campesinato no Brasil; pelo contrário, abriu possibilidades para sua re-criação. Mesmo com a Lei de Terras, essa classe se manteve e se garantiu. ${ }^{27}$

\footnotetext{
${ }^{27} \mathrm{O}$ capitalismo engendra relações de produção não-capitalistas como recurso para garantir a sua própria expansão, como forma de garantir a produção não-capitalista do capital, naqueles lugares e naqueles setores da economia que se vinculam ao modo capitalista de produção através das relações comerciais. (...) Marx assinalou, em mais de uma ocasião, a questão do ritmo das transformações históricas com o advento do capitalismo, indicando que as relações capitalistas de produção, uma vez instauradas, se disseminam pouco a pouco, de forma até imperceptível, como se nenhuma transformação estivesse ocorrendo. (...) no Brasil, o estabelecimento das novas relações de produção
} 
Em relação à presença significativa de camponeses na agricultura em países capitalistas, Oliveira (1995:67) adverte que "o caminho para entendermos essa presença camponesa é pela via de que tais relações não-capitalistas são produtos do próprio desenvolvimento contraditório do capitalismo". ${ }^{28}$ Continua afirmando que, "o camponês e o latifundiário são criação do próprio capitalismo, e não algo estranho, externo a ele".

Pode-se considerara afirmação de Queiroz (1976:29), no trabalho O campesinato brasileiro, de que onde a autora afirmou que:

O campesinato brasileiro encontra-se em vias de desaparecimento. Persiste ainda em certas regiões devido às condições locais. Noutras, porém, entram os sitiantes tradicionais em decadência, pois a produção hoje tende mais e mais a se organizar sob a forma capitalista, voltada para o lucro e para o mercado.

No cenário recente, porém a existência do campesinato é vista e entendida como parte integrante do capitalismo, seja nos assentamentos, seja nos pequenos sítios que já existiam ou em outros que foram ou estão surgindo com a fragmentação da terra.

Reconheço que Queiroz (1976) foi correta ao observar que "Na medida em que o meio urbano vai produzindo mercadorias cada vez mais cobiçadas, o consumo do sitiante tradicional se desequilibra, pois vê-se impelido a consumir muito mais mercadorias e muito mais caras". Agora, que ele consome "a fim de demonstrar seu prestígio econômico" e que "esta é uma das causas da sua decadência, fruto do desenvolvimento em que se encontra o país", levando em consideração o objeto de estudo desta pesquisa, não concordo. É fato que hoje o camponês busca na cidade boa parte ou quase tudo o que era produzido no campo em outros tempos, mas não com o intuito de mostrar seu "prestígio econômico".

Neste contexto, é importante destacar que as novas relações sociais de produção e de trabalho no campo alteraram substancialmente o modo de vida do camponês e o destino da produção. Observa-se o decréscimo da produção

combinou-se com a imigração de trabalhadores europeus, como recurso não só para constituir a força de trabalho necessária à cultura do café, mas também como recurso para pôr no lugar do trabalhador cativo um trabalhador livre cuja herança não fosse a escravidão. (...) Devido justamente à modalidade das relações de produção aí vigentes, no chamado colonato, a imigração constituiu um requisito de importação constante e maciça de trabalhadores em grupos familiares. O colonato, diversamente das relações de produção caracteristicamente capitalistas, criou uma subpopulação relativa no campo, que tornou a imigração subvencionada pelo Estado um dos seus ingredientes básicos. Martins, 1996:21-2.

${ }^{28}$ A expansão do modo capitalista de produção, além de redefinir antigas relações, subordinando-as à sua produção, engendra relações nãocapitalistas igual e contraditoriamente necessárias à sua reprodução. Na agricultura, esse processo de subordinação das relações nãocapitalistas de produção se dá, sobretudo pela sujeição da renda da terra pré-capitalista existente na agricultura; ele agora apropria-se dela, transformando-a em renda capitalizada da terra. É neste contexto que devemos entender a produção camponesa: a renda camponesa é apropriada pelo capital monopolista, convertendo-se em capital. Oliveira, 1995:67. 
agropecuária e a inclusão marginal do trabalhador rural na economia de mercado; para atender às suas necessidades, ele recorre ao mercado, mesmo quando precisa comprar alimentos (como arroz, feijão, farinha, etc.) que antes produzia. Só que,

Mesmo com todas as dificuldades que existia no início da ocupação, às vezes eu tenho saudades, pois naquela época a gente tinha fartura, produzia de tudo. Hoje, que a gente tem água encanada, luz elétrica, estrada, escola e casa boa, a gente tem que comprar na cidade quase tudo que era produzido aqui antes. ${ }^{29}$

Isso ocorre, como se vê, não pelo fato de o camponês querer mostrar "prestígio econômico", mas sim pela presença e desenvolvimento do capitalismo no campo, pela substituição da agricultura pela pecuária, além da falta de opção para os filhos jovens e do tamanho da propriedade, o qual acaba interferindo no momento de se fazer um financiamento.

Finalmente, pode-se concordar com Shanin (1980:58), que, discorrendo sobre o campesinato no Brasil, afirma ter havido um crescimento dessa classe nos últimos anos, ou seja, uma real recamponesação, processo no qual "os camponeses continuam a existir, correspondendo a unidades agrícolas diferentes, em estrutura e tamanho, do clássico estabelecimento rural familiar camponês". Sem contar que o mercado interno recebe do campo mão-de-obra e alimentação baratas.

Ainda em relação à importância dessa força de trabalho familiar, Oliveira (1995:6), salienta o fato de exercer "um papel muito significativo e vem aumentando numericamente de modo expressivo. (...) No caso brasileiro, mais de $80 \%$ da força de trabalho empregada na agricultura".

Convém, neste ponto, relembrar que, conforme exposto anteriormente, essa idéia da importância da agricultura familiar camponesa já havia sido mencionada por Lambert, desde 1959 e foi ressaltada por Martins (1995).

No tocante, ainda, ao pequeno produtor, Nascimento (1997: 287-8) argumenta que o agricultor familiar que obtiver uma renda um pouco maior pode se destacar, mas que alguns podem enfrentar a minifundização, dependendo da vulnerabilidade do mercado.

Mesmo enfrentando esse processo de minifundização, contudo, os camponeses continuam se expandindo como classe social que são. Não se sentem

\footnotetext{
${ }^{29}$ Relato feito por uma moradora da Gleba Cascata para a autora em agosto de 1998. In LIMA, L. M. de S., 2000.
} 
levados ao extermínio, nem à extinção, muito pelo contrário, eles estão exercendo um papel importante e cada vez mais significativo em nosso país ${ }^{30}$.

Com base nos dados publicados em artigos, tais como "Agricultura familiar pequenos notáveis", o qual esclarece que $40 \%$ da riqueza gerada no campo brasileiro em 2003 foram produzidos pela agricultura familiar; "Agricultura familiar produz mais que o agronegócio", que destaca que 27\% do PIB do Rio Grande do Sul foram provenientes da riqueza produzida pela agricultura familiar e "Agricultura familiar é responsável por 10\% do PIB nacional", entendo e acredito na força desse produtor.

O desenvolvimento capitalista da agricultura, segundo o modelo econômico e político excludente (com incentivos fiscais, créditos subsidiados, etc.) adotado pelo Estado nos últimos anos, agravou ainda mais a situação de muitos camponeses, excluindo-os de tudo aquilo que Ihes pertencia por direito. Expulso do campo e dividido entre o trabalho rural e o urbano, o camponês vive momentos de grandes incertezas. Como trabalhador rural foi transformado em bóia-fria, como trabalhador urbano veio engrossar o proletariado urbano dos despossuídos, que, para sobreviver, recorrem à coleta de restos de feira ou de objetos e restos de alimentos depositados nos lixões, demonstrando a sua miséria absoluta e os riscos de vida que correm. E, no entanto, sobram terras inaproveitáveis a serem cultivadas. Sobressaem-se alguns daqueles que foram beneficiados por doações, por heranças, por terras devolutas, etc. Boa parte deles são realmente excluídos e, por isso, migram constantemente em busca da terra prometida.

\footnotetext{
${ }^{30}$ A propósito, leiam-se os seguintes trechos de noticiários. Agricultura Familiar - Pequenos Notáveis - Em um Estado onde a agricultura é marcada por gigantes, muitas vezes, acaba-se esquecendo a importância social que a agricultura familiar exerce na economia. Apesar de pequenos, os agricultores familiares apresentam números notáveis ao Brasil. Conforme o Ministério da Agricultura, Pecuária e Abastecimento (Mapa) e o Ministério do Desenvolvimento Agrário (MDA), 40\% da riqueza gerada no campo brasileiro é produzida pela agricultura familiar. (...) estima-se que existam no país cerca de quatro milhões de famílias de pequenos produtores. Em Mato Grosso, segundo a Secretaria Adjunta de Agricultura Familiar, da Secretaria de Estado de Desenvolvimento Rural (SEDER), são cerca de 150 mil famílias de pequenos agricultores, sendo que a maior parte está em projetos de assentamentos. Especialistas afirmam que os investimentos no setor são importantes porque a agricultura familiar é um instrumento eficaz para manter os trabalhadores no campo. Segundo o Ministério da Agricultura, Pecuária e Abastecimento (Mapa), a agricultura familiar responde por $70 \%$ dos empregos no campo. Conforme estudos realizados pelo Ibasa (Instituto Brasileiro de Análises Sociais e Econômicas), as operações de crédito do Programa Nacional de Fortalecimento da Agricultura Familiar (Pronaf) em 2003 mantiveram 3,3 milhões de agricultores em seus postos de trabalho e geraram 650 mil novos empregos no campo. Edição especial do jornal A Tribuna - Agrishow Cerrado. 2005: 32.

Agricultura familiar produz mais que agronegócio A riqueza produzida pela agricultura familiar foi responsável por $27 \%$ do Produto Interno Bruto (PIB) do Rio Grande do Sul, em 2003, enquanto que o agronegócio - voltado principalmente para a exportação - representou 23\% do PIB gaúcho. Hoje, a agricultura familiar integra mais de 4 milhões de produtores em todo o País, sendo 440 mil no Rio Grande do Sul. Em oito anos, o setor cresceu 52\% no RS. E já é responsável, por exemplo, por 97\% na produção de milho, 99\% dos laticínios, 74\% do milho e $58 \%$ da soja. Esses dados desmentem alguns mitos e comprovam que a agricultura familiar tem uma real importância econômica, não cumprindo apenas a função de garantir a subsistência dos pequenos agricultores. Do Sindijus-PR, 16/3/2005.

Agricultura familiar é responsável por $\mathbf{1 0 \%}$ do PIB nacional - Pesquisa inédita no país revela que, em 2003, a agricultura familiar respondeu por $10,1 \%$ do Produto Interno Bruto (PIB) do Brasil. O levantamento encomendado à Fundação Instituto de Pesquisas Econômicas (Fipe) pelo Ministério do Desenvolvimento Agrário (MDA) demonstra que o PIB do setor cresceu R\$ 13,4 bilhões no ano passado, um incremento de 9,37\% em relação a 2002. "O estudo mostra a força da agricultura familiar na economia brasileira. Poucos setores têm essa representatividade perante o PIB nacional e garantem 13 milhões de postos de trabalho para o país", afirmou o ministro do Desenvolvimento Agrário, Miguel Rossetto. Do MDA, 21/12/2004.
} 
Martins (1995:25), ao fazer um comentário sobre esse camponês excluído, declara:

\begin{abstract}
... Ele não é de fora, mas também não é de dentro. Ele é, num certo sentido, um excluído. É assim, excluído, que os políticos vão encontrá-lo, como se fosse um estranho chegando retardatário ao debate político...

A exclusão do camponês do pacto político é o fato que cercará o entendimento da sua ação política. Mas essa exclusão não é, como às vezes tem sido entendida, mera exclusão política. Por isso, é necessário entender a história dessa exclusão, seus mecanismos econômicos, sociais, políticos. Essa exclusão define justamente o lugar do camponês no processo histórico... ${ }^{31}$
\end{abstract}

Não se pode perder de vista a questão do modo de vida desse camponês que, ao ser recriado, reproduzido historicamente, acaba sofrendo transformações, imputadas pelo modo capitalista de produção. Bernadete A. C.C. Oliveira (1990:103) expõe sua visão deste assunto:

... o camponês é expresso como categoria social a partir de relações capitalistas de produção, mantendo, entretanto, os valores do modo de vida camponês, oferecendo resistência às mudanças impostas pela economia de mercado. Essa resistência se manifesta em várias esferas da vida dos grupos camponeses, como uma vivência contraditória.

O capitalismo em si só pode ser contraditório, pois, ao mesmo tempo em que expulsa o homem do campo, transforma-o num trabalhador temporário (sem direitos jurídicos assegurados) desse mesmo campo, para explorá-lo e dele extrair maisvalia e reproduzir o capital. Como os trabalhadores estão, no mercado, livres dos meios de produção, sendo proprietários unicamente de sua força de trabalho, acabam entregando-se, alienando-se, vendendo sua força de trabalho ao capitalista, ao patrão. E, a ideologia capitalista aliena-os de tal forma que os mesmos não conseguem se ver na riqueza que criam e que cresce como forma de capital.

Não há, portanto, exagero em se caracterizar o novo espaço rondonopolitano como uma realidade de destruição e superexploração da mão-de-obra e das terras, uma vez que quase todas as riquezas dali extraídas ou ali produzidas pelos nossos trabalhadores são apropriadas pelos capitalistas, após comercializarem a produção. Com a modernização, a estrutura sócio-político-econômica da região acabou alterando-se completamente. Vê-se atualmente a transformação de latifúndios modernos em verdadeiras empresas capitalistas, cujos proprietários tiveram e têm

\footnotetext{
${ }^{31}$ Os destaques são meus.
} 
enorme influência nas políticas do governo para o setor agrário (incentivos fiscais e creditícios, pagamento de ITR, rolagem de dívidas, etc.).

O perfil do agricultor, notadamente o camponês, o pequeno, foi radicalmente alterado: mudou sua maneira de encarar a natureza, em especial a terra - seu principal meio de produção - e a vida, sua maneira de trabalhar esta terra e mudou, até, sua forma de morar e de viver.

De acordo com Palheta (2001: 36), em seu artigo "O novo Brasil agrário moderno e ... do atraso", a situação do camponês é complicada,

pois ao não conseguir saldar as dívidas com o banco, com o latifundiário, com o agiota comerciante, acaba entregando ou vendendo suas terras, partindo para as cidades, onde, por falta de recursos, se sujeita a relações de exploração.

Ocasiona-se, deste modo, a concentração de terras pelo latifundiário, por conta do endividamento do camponês.

O processo de fragmentação da terra constitui uma das formas da reprodução do camponês que ocorre no campo brasileiro, mesmo com o desenvolvimento do capitalismo no campo, com o progresso e a modernização da agricultura. Entendo que o camponês consegue viver e se reproduzir com dignidade, acabando assim com o mito de que é uma classe fadada ao desaparecimento.

Refletindo sobre o assunto, afirmo que a idéia errônea que tinha nos idos de 1995 sobre ser o camponês uma classe em extinção desapareceu por completo. Estou ciente de que hoje, além de se reproduzir pela fragmentação da terra via assentamento, herança ou doação, a classe está cada vez mais fortalecida. Só no município de Rondonópolis, no período de 1988 a 1998, foram assentadas em programas de Reforma Agrária 735 famílias (que se encontravam sem terra para trabalhar e produzir), em 20.642,5710 Ha de terras desapropriadas ${ }^{32}$, sem contar as 197 famílias que se encontram na Gleba Cascata. Acrescento ainda as famílias das áreas pesquisadas, que de cinco propriedades se fragmentaram em sessenta e seis.

Em resumo, no processo capitalista, alguns desses camponeses são transformados em trabalhadores que passam a vender sua força de trabalho, além de necessitarem agora, comprar no mercado a maior parte daquilo que produziam. É

\footnotetext{
${ }^{32}$ Assentamentos e número de famílias beneficiadas de 1988 a 1998 no município de Rondonópolis: Gleba Cascata - 197; Gleba Rio Vermelho - 320; Assentamento Chico Mendes - 30; Assentamento Santa Luzia - 30; Assentamento São Francisco - 50; Assentamento Carimã - 205; Assentamento Primavera - 50; Assentamento Coqueiro - 50. Dados extraídos de LIMA, L.M.S., 2000.
} 
a questão da expropriação, em épocas e fases diferentes de nossa história, mas não de sua extinção.

A venda da força de trabalho de alguns membros da família camponesa ocorre em situações esporádicas, sendo considerada como trabalho acessório e constitui um recurso para sua manutenção. Esse fato não os descaracteriza como sujeitos sociais, assim como não podemos considerá-los ausentes das relações de mercado, pois para satisfazerem as necessidades da família praticam pequenas trocas mercantis. Isso lhes dá possibilidade de adquirir no mercado o que ocupa tempo, recursos financeiros e principalmente terra, que entre eles é escassa; por este último motivo, utilizam mais a prática da pecuária do que a agricultura.

Por outro lado, existe a diferenciação interna do campesinato, que é verificada quando o camponês que já possui uma situação financeira mais estabelecida utilizase de raciocínio simples e passa a executar o processo de reprodução da produção camponesa, como elucida Oliveira (1995:71):

Quando o camponês já está em situação privilegiada no mercado, ele pode acumular dinheiro, como produto do trabalho familiar, e assim procurar garantir para os filhos a possibilidade de também reproduzirem-se como camponeses, e com isso assegurar 0 processo de reprodução ampliada do camponês.

Essa diferenciação interna, esse processo de transformação do campesinato pode levá-lo, sim, à pauperização, processo denominado por Martins (1975:73 a 82), na obra Capitalismo e tradicionalismo: Estudos sobre as contradições da sociedade agrária no Brasil, como expropriação sucessiva, pela qual entendo que o camponês vai aos poucos se desfazendo de seus bens, inclusive a terra, podendo se transformar num proletário. Tal fato não ocorre somente no campesinato, pois em Rondonópolis - e acredito que em outras regiões - vários latifúndios foram desapropriados e vendidos ao Estado, por endividamento, para que se transformassem em assentamentos: Fazenda Vale do Bacuri, Fazenda Primavera, Fazenda Carimã, Fazenda Boa Esperança, Fazenda São Francisco e Fazenda Coqueiro, todas em Rondonópolis, no período de 1996 a 1998.

Em face do exposto, é interessante resgatar o fato de que o processo de desenvolvimento do capitalismo no campo está marcado pela intensa relação entre a indústria e a agricultura, em que o capital, através da expansão da produção capitalista, concebe o latifúndio, por um lado, e a reprodução camponesa, por outro. Nas regiões pouco industrializadas, a falta de alternativas no setor urbano pode 
determinar que parte da população, que em outras circunstâncias teria abandonado a produção agrícola, permaneça dentro dela.

Todavia o sistema de fragmentação termina por gerar suas contradições e inviabilizações, ocasionando a crise da reprodução social desse produtor rural.

Pode-se lembrar ainda que alguns dos herdeiros, após receber a terra parcela que lhes cabe por lei -, acabam vendendo-a e saindo em busca de uma terra maior e melhor em outra região, ou mesmo comprando casa na cidade. Posteriormente, não sendo bem sucedidos, quando recebem a outra parte que lhes cabe, por herança ou doação, voltam a fixar residência no campo e, depois, criticam os que realizam o mesmo sistema, a troca do campo pela cidade.

Os depoimentos revelaram como a própria lógica interna da pequena propriedade estimula a migração, principalmente dos mais jovens. Alguns saem para que outros permaneçam, mas quem saiu não se desfez da terra, está trabalhando para angariar recursos que estão sendo empregados na propriedade, cuidada pelos familiares que ficaram e para onde voltarão quando não mais precisarem do trabalho extra fora da propriedade herdada. Este é um caso comum e que faz reforçar a teoria de que o camponês não está em extinção. Vejo-o como uma fênix ${ }^{33}$, que, além de transportar pesados fardos, renasce aos pouco das próprias cinzas, representando o "sol, que morre em chamas toda tarde e emerge a cada manhã." (Origem: Wikipedia, a enciclopédia livre, 22/04/2007).

\subsubsection{Contribuições acerca da temática em questão}

Quando os membros da Banca do exame de qualificação sugeriram-me trabalhar com a questão da "repartição natural entre os descendentes", mudando-a para "fragmentação da terra por herança", confesso que no princípio relutei um pouco, pelo fato de praticamente desconhecer uma bibliografia que desse suporte para o embasamento teórico.

Sobre esse assunto, ou seja, especificamente sobre doação ou herança, meu conhecimento limitava-se aos trabalhos realizados por Moura - Os herdeiros da terra e por Wortmann - Herdeiros, parentes e compadres. Sendo assim, saí à

\footnotetext{
${ }^{33}$ Fênix é um pássaro da mitologia grega que quando morria entrava em autocombustão e passado algum tempo renascia das próprias cinzas. Outra característica da fênix é a capacidade de transportar em vôo cargas muito pesadas, havendo lendas segundo as quais chegava a carregar elefantes. www.winipedia.org
} 
procura de outras fontes, outros temas relacionados à sucessão, a fragmentação da terra por herança ou doação mais diretamente ligada à temática, para a qual os estudiosos e pesquisadores, de certa forma, voltaram a atenção e que vem tomando espaço na discussão da questão agrária, da recriação e reprodução camponesa.

$\mathrm{Na}$ Antropologia, busquei respaldo no trabalho de Moura (1978), que, no intuito de contribuir para o debate, em especial no que tange ao campesinato brasileiro, pesquisou uma comunidade em São João da Cristina, interior de Minas Gerais, onde "a herança da terra passou a ser núcleo (...) da reprodução da área como camponesa" (Moura, 1978:2). Existia a idéia de que a propriedade deveria ser poupada da fragmentação, em especial nas áreas onde a terra era escassa. Havia, então, segundo Moura (1978:58), "um mecanismo antifragmentação por excelência, ou exclui definitivamente as mulheres da propriedade da terra ou exclui, além dela, irmãos do sexo masculino". E mesmo poupando a propriedade da fragmentação, esta se deu, muito lentamente, pois o tamanho das famílias diminuiu, não em função de um controle de natalidade, mas da migração dos herdeiros. No caso do campesinato essa passagem da propriedade de geração a geração pode assumir um caráter complexo.

Em São João da Cristina, esse acesso à propriedade se concretiza de fato somente com o acesso à terra. De acordo com Moura (1978:3), "ela pode ser deflagrada a partir da maturidade ou logo após, em função do matrimônio do indivíduo, fatos que preparam ou inauguram a sua condição camponesa independente."

Em sua pesquisa Moura observa que a passagem da terra de geração para geração, isto é, de ascendentes a descendentes, deu-se por intermédio de transações verticais, quando os pais passam para os filhos, denominadas como herança, ou mesmo nas transações de compra e venda ou troca de terras, de propriedades entre os colaterais, de um irmão para outro, caracterizadas como transações horizontais.

A autora detectou que nas regras de herança da terra, a divisão do trabalho na unidade familiar é um fator de distinção entre as atribuições dos dois sexos. Cabe à mulher atuar nos afazeres da casa, na unidade de consumo, e ao homem, agir no âmbito da produção. Ou seja, o trabalho com a terra é tarefa do sexo masculino, já a mulher lida com o que foi produzido nessa terra. Portanto, à mulher é negada desde a negociação da venda de um bem produzido na terra e principalmente a 
negociação dessa terra. Sendo assim, é negada à mulher a posse ou propriedade dessa terra, que passa às mãos de um parente. A exclusão da mulher da propriedade da terra se dá, conforme Moura (1878:29), “aproveitando-se a circunstância de um casamento por comunhão de bens, que transfere de fato a direção do empreendimento produtivo para as mãos masculinas, seja invocando claramente a impossibilidade de uma mulher solteira dirigir este empreendimento."

Em São João da Cristina, Moura (1978:40) deparou com duas formas de transações com a terra, a realizada entre parentes e aquela entre não-parentes, ambas de caráter social, na primeira delas, prevalece a preferência, tratando-se portanto de transações preferenciais, ao passo que, na segunda, a preferência vai para a negociação com pessoas de dentro do próprio bairro. Nessas transações, leva-se em conta o preço da terra, que para os parentes é sempre mais baixo, e para o não-parente é cobrado o preço do hectare regional, considerando-se ainda a fertilidade e a localidade da área.

A situação descrita pela investigadora quanto à venda da terra das irmãs para os irmãos chamou a atenção pelo fato de ser negado a elas o direito de negociar com essa terra. Moura (1978:41) expõe que, "com o matrimônio, a mulher poderá simplesmente juntar sua terra de herança à que seu marido originalmente possuía, que obviamente não será uma junção física porque em geral se trata de lotes distanciados entre si". A autora observa também que muitos dos maridos, ao invés de manter os dois patrimônios, vendem o lote da esposa para o cunhado e com o dinheiro compram o de sua irmã, que é anexo ao seu. Um fato comum, que pode prosseguir indefinidamente.

Segundo Moura, a herança da terra é concebida pelos camponeses de São João da Cristina de acordo com regras estabelecidas por dois códigos: o Civil e o local. Os camponeses dessa região colocam como ponto de partida para a herança a idade de dezoito anos para os filhos homens da família. É como se fosse um presente pela maioridade que o pai doa ao filho. A partir de então, este é responsável pela parcela de terra recebida, retirando dela sua despesa. Como o pai provê as filhas de todo o sustento, elas nunca recebem dele uma parcela de terra por completar a maioridade e nem a "casa de morada" na propriedade paternal, pois esse fato tem que ser colocado em prática pelo marido; Moura comenta que o fato de a filha estar morando na propriedade do pai só acontece caso o noivo seja muito pobre ou tenha vindo de fora do bairro. 
Em São João da Cristina, onde as mulheres, como se viu, são excluídas do direito à propriedade, Moura (1978:57) aponta que

A mulher poderá aparecer efemeramente como proprietária jurídica independente da terra logo a seguir a uma partilha de terras paternais, isto é, como herdeira. E será inapelavelmente meeira do patrimônio conjugal, já que os casamentos na área são sempre por comunhão de bens. Mesmo neste caso é proprietária jurídica junto com um homem, mas não reconhecida no bairro como proprietária, já que a terra onde um casal cultiva e reside é sempre terra do "seu fulano" (do homem).

No caso de morte de um dos cabeças (o pai ou a mãe), de acordo com o Código Civil seria feito o inventário, pelo qual o sobrevivente receberia a metade (como meeiro) e os filhos, independentes de serem homens ou mulheres ficariam com o restante, em partes iguais. Sobre o Código, Moura (1978:5) acrescenta que

As regras de herança nesse bairro rural não se organizam num outro código que não se deixa contaminar por um de caráter envolvente com pretensões a dominá-lo. Elas se configuram, em última instância, numa malha entretecida de duas realidades, onde uma delas (a local) procura prevalecer sempre que a outra (prescrições do Código Civil) não incidir inevitavelmente sobre situações determinadas.

A autora constatou que, mesmo tendo esses moradores conhecimento do Código Civil, o qual prevalece para toda a sociedade brasileira, na hora da divisão da herança esse Código é cumprido somente em parte, pois os costumes locais simplificam ou ignoram as leis, utilizando as regras "locais".

Ainda na Antropologia, amparei-me em Ellen F. Woortmann (1988) ${ }^{34}$, que, com a intenção de dar ênfase ao mundo camponês, com uma proposta original, embora não inteiramente nova (pois já havia sido precedida por duas pesquisadoras), em seu trabalho Herdeiros, parentes e compadres: Colonos do Sul e sitiantes do Nordeste privilegiou as relações que interligam grupos domésticos, ou melhor dizendo, famílias; a autora pouco usou dessas unidades enquanto produtoras ou consumidoras e muito se ocupou delas no que diz respeito a valores. Procurou alcançar a questão da reprodução através das relações de parentesco.

Woortmann discute não só a teoria do campesinato como também a teoria do parentesco; através do debate, da discussão, procura mostrar que, na primeira, às vezes não é levada em consideração a dimensão do parentesco como organizador

\footnotetext{
${ }^{34}$ Woortmann, Ellen F. Colonos e sitiantes: Um estudo comparativo do parentesco e da reprodução social camponesa. Tese defendida em 1988 e publicada como livro: Herdeiros, parentes e compadres: Colonos do Sul e sitiantes do Nordeste, em 1995.
} 
social e como elemento central da reprodução social do campesinato, enquanto na segunda teoria se destacam certos componentes relevantes para o entendimento do campesinato, como por exemplo a descendência.

Sobre a teoria do campesinato, Woortmann (1995) comenta que os teóricos ao se empenharam sobre esse estudo consideraram a dimensão do parentesco, que por ela é vista como o elemento central para a reprodução camponesa.

Ainda a respeito da teoria do campesinato, a autora discute as teorias de alguns economicistas europeus, que segundo ela contribuíram com suas linhas de pensamento para a análise das formas camponesas no Brasil, enquanto os antropólogos culturalistas norte-americanos em que ela buscou amparo introduzem, em seu modo de perceber o campesinato, o componente étnico.

Em se tratando das teorias do parentesco, Woortmann desenvolve algumas considerações com base na teoria da dependência cujo foco central é o grupo social, ou seja, o grupo de descendência, levando em conta os direitos e deveres das pessoas enquanto elemento de tais grupos; já na teoria da linguagem vê um outro modo de conceber o parentesco, no qual se ordenam certas relações sociais fundamentais em uma sociedade e que possuem um conteúdo próprio.

Woortmann (1995) vê o parentesco como aliança e como prática; a primeira visão conduz à questão da reciprocidade, por onde ela vai analisar os grupos camponeses, e na segunda o casamento é uma prática que assegura a sucessão.

Para estudar os colonos do sul, Woortmann faz uma retrospectiva no contexto geral, de como se deu o processo de ocupação daquela região desde o início do século XIX, quando poder e capital se concentravam nas mãos de uma oligarquia pecuarista. Ressalta aspectos da emigração alemã e das migrações internas no Brasil, relacionando movimento e parentesco.

Quanto à emigração de alemães para o Brasil, Woortmann (1995:112) destaca que "a emigração original da Alemanha (...) caracterizou-se pela instalação de famílias, e não indivíduos, e, ademais, de famílias aparentadas entre si". Esses emigrantes não se instalaram na mesma área, mas em regiões circunvizinhas e iam se casando em sua maioria com os próprios parentes; sendo assim, essa migração forma-se pelo parentesco, relacionado aos padrões de herança.

De acordo com o estudo em foco, nas categorias simbólicas os colonos teutobrasileiros pensam o parentesco, e nele se fundamentam para entender as práticas do casamento; a rigor, não são dois indivíduos que se casam, mas duas famílias que 
entram em acordo. "Ao contrário do casamento moderno, concebido como o resultado de decisões individuais, na Colônia e em boa medida continua sendo, arranjado pelas famílias (...)" (Woortmann, 1995:158).

Enquanto na região de São João da Cristina, estudada por Moura (1978), a mulher era excluída do direito à terra, ao patrimônio, assim como alguns dos irmãos do sexo masculino, nas colônias de Novo Hamburgo e São Leopoldo, pesquisadas por Woortmann (1995:188), "as mulheres passaram a ter direito à herança, começando a se desagregar o princípio da unigenitura e da indivisão do patrimônio. Não só as mulheres, mas os outros irmãos passaram a ter esse direito".

Mas nem todos recebiam ou gozavam dos mesmos direitos, visto que “através da 'expulsão' dos filhos para as colônias novas possibilitava-se alianças entre 'casa-mãe' e uma 'casa-filha', ao mesmo tempo em que se afastavam possíveis herdeiros (pois, de acordo com a lei, a partilha era igualitária)" (WOORTMANN, 1995:191).

Ao mencionar a questão da sucessão feminina, Woortmann não deixa perder de vista as tensões domésticas provocadas por tal sucessão, ao se transferir a autoridade do lar, já que, em alguns casos, sogra e nora não se identificam, surgindo os conflitos.

Woortmann comenta que o próprio sistema adotado por esses imigrantes alemães gerou suas contradições e inviabilizou a reprodução social camponesa, pois de acordo com suas tradições "a terra deve ser vendida, se necessário, a parentes, pois isso viabiliza sua reprodução como camponês. Vendê-la a estranhos, não colonos, 'é um crime', 'é uma traição' às tradições” (WOORTMANN, 1995:198).

Além dos colonos do sul, Woortmann estuda os sitiantes do nordeste, da região de Sergipe, descendentes de portugueses e focaliza outra modalidade camponesa, que foi expropriada pela grande propriedade pecuarista.

Segundo Woortmann (1995), a ocupação das terras do sertão do São Francisco não se deu só pelos grandes proprietários criadores, pelos "currais" e "sesmarias", mas também pelos posseiros, pelos brancos livre-pobres ou pelos caboclos e negros, que contribuíram para a ocupação e povoamento da região.

Woortmann distingue em sua pesquisa três significados básicos para o sítio: em seu sentido mais restrito, corresponde ao espaço ou conjunto casa-quintal, que é fundamentalmente o espaço da "mãe da família"; no segundo significado, leva-se em conta o ciclo evolutivo da família extensa; já o terceiro refere-se a um bairro rural, ou 
seja, a um conjunto de sítios. Woortmann reforça que não é simplesmente um bairro rural, mas sim, à um "território de parentesco".

No que se refere ao casamento e à herança no sítio, Woortmann (1995:257) esclarece que existem dois princípios básicos que são fundamentais, a descendência e a residência; "para que se tenha direito à terra, seja chão de roça, seja como chão de morada, é preciso obedecer esses princípios. Consangüinidade, territorialidade, residência e endogamia são a base dos direitos". No contexto geral, Woortmann enumera três práticas que se consagram em suas áreas de estudo para assegurar a reprodução do patrimônio: que são casamento, migração e herança.

Ao escrever sobre Herança e gênero entre agricultores familiares, nas regiões de Nova Pádua/RS e Nova Friburgo/RJ, Carneiro (2001) mostra a importância de mencionar que existem diferentes formas de transmissão do patrimônio e que estas mudam de acordo com o contexto histórico, econômico, geográfico, institucional, etc. Segundo a inserção na economia e na sociedade, dáse então a transmissão dos direitos sobre a propriedade, que vão passando de uma geração a outra. Podem ocorrer contradições e tensões, dependendo da situação vivida. Comenta, ainda, que as questões relativas à transmissão da herança podem ser resolvidas conduzindo à fragmentação do patrimônio familiar, inviabilizando a manutenção da unidade de produção ou atuando no sentido de favorecer a integridade do patrimônio.

Os artigos "Agricultura familiar e sucessão profissional: Novos desafios", de Abramovay et al. (2001) ${ }^{35}$ e "Sucessão hereditária e reprodução social da agricultura familiar", de Mello et al. (2003) ${ }^{36}$, fazem parte de uma pesquisa mais abrangente sobre a questão sucessória na agricultura familiar, a qual vem sendo desenvolvida por um grupo de pesquisadores no oeste de Santa Catarina que discute a permanência na profissão paterna dos filhos dos agricultores familiares desta região, pois a dificuldade de acesso à terra é um grande obstáculo. O grupo constatou que o atraso educacional é um dos motivos que dificulta o desempenho da atividade agrícola e a organização e desenvolvimento de novas atividades para o meio rural, o

\footnotetext{
${ }^{35}$ Ricardo Abramovay - Sociólogo, doutor, professor titular do Departamento de Economia da FEA e do Programa de Pós-Graduação em Ciência Ambiental da USP; Milton Luiz Silvestre; Márcio Antonio de Mello - Engenheiro Agrônomo, mestre, pesquisador científico da EPAGRI/Centro de Pesquisa para Agricultura Familiar (Cepaf); Clovis Dorigon; Ivan Tadeu Baldissera. Pesquisadores do Centro de Pesquisa para as Pequenas Propriedades.

${ }^{36}$ Márcio Antonio de Mello - Engenheiro Agrônomo, mestre, pesquisador científico da EPAGRI/Centro de Pesquisa para Agricultura Familiar (Cepaf); Ricardo Abramovay - Sociólogo, doutor, professor titular do Departamento de Economia da FEA e do Programa de PósGraduação em Ciência Ambiental da USP; Milton Luiz Silvestre; Clovis Dorigon; Dilvan Luiz Ferrari e Vilson Marcos Testa.
} 
que acaba ocasionando implicações na mudança dos padrões sucessórios. Verificou-se também que a agricultura familiar da região começou a enfrentar problemas que não existiam até o final da década de1960, período em que o padrão reprodutivo das unidades familiares estava fundamentado no minorato ${ }^{37}$.

De acordo com os autores, a partir de fins da década de 1970, começou a haver uma ruptura do padrão anterior, sem um padrão alternativo claramente definido e legitimado pelos membros da família, o que trouxe como conseqüências os conflitos que surgiam durante o processo sucessório. Acrescentam ainda que

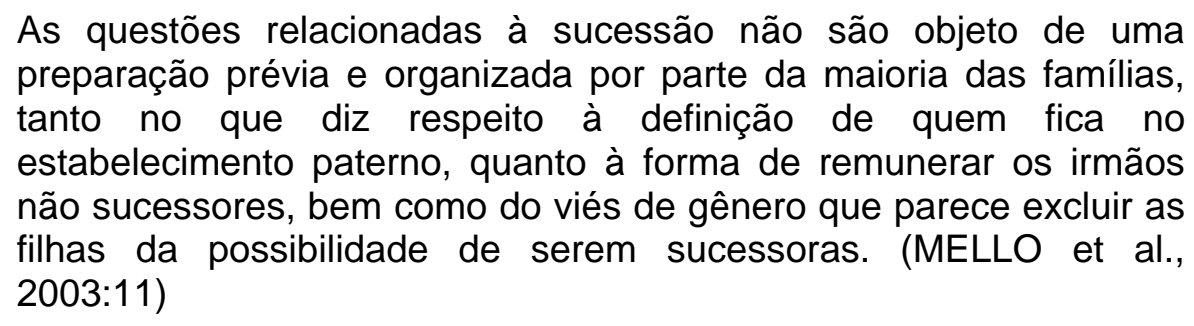

Sendo assim, o atraso educacional dos jovens e a questão sucessória estão colocando em risco a reprodução econômica e social da agricultura familiar da região, bem como provocando um vazio demográfico que compromete o desenvolvimento regional da área pesquisada por este grupo.

Neumann (2003) em "O Impacto da fragmentação e do formato das terras nos sistemas familiares de produção" na região compreendida pelo Conselho Regional de Desenvolvimento do Centro do Rio Grande do Sul, constatou que a origem e as causas do surgimento dos problemas com o formato das terras estão relacionadas ao processo de ocupação do solo, ocorrido mediante a divisão dos lotes de forma retangular. Expõe que "o fracionamento é decorrente do processo de sucessão ou de venda de partes das terras (...) e a fragmentação das parcelas é decorrente tanto da sucessão como da pressão pela sobrevivência econômica".

Em relação à sucessão e herança, Santos, M. O. (2006) estudou um grupo de famílias descendentes de portugueses oriundos da llha da Madeira que migraram para uma área rural do Rio de Janeiro e que por isso são caracterizados como "migrantes para a agricultura". O objetivo da pesquisadora era saber como dividir igualmente mantendo a desigualdade.

\footnotetext{
${ }^{37}$ Instituição pela qual a terra paterna é transferida ao filho mais novo, que, em contrapartida, responsabiliza-se por cuidar dos pais durante a velhice.
} 
Santos observa que os papéis sociais são bem definidos, cabendo à mulher as atividades reprodutivas e o trabalhando na lavoura. Seu trabalho é computado como "ajuda" e, portanto, hierarquicamente é menos importante que o do homem.

No caso pesquisado a autora percebeu os arranjos que foram feitos para ao mesmo tempo cumprir as leis brasileiras, pelas quais a partilha tem que ser igualitária para os herdeiros, e a tradição camponesa, que trouxeram de Portugal. Santos esclarece que, no final da partilha, a divisão foi igualitária, pois todos receberam bens de igual valor econômico, no entanto as filhas e um filho que mora na cidade receberam casas e lojas, mas não as terras de dois sítios contíguos que o pai cultivava com os demais filhos. Assim, a partilha da herança obedeceu não ao Código Civil, mas ao "direito costumeiro".

As áreas por mim pesquisadas iniciaram-se como latifúndio e foram se fragmentando por doação ou herança. Existem ainda em Rondonópolis os latifúndios que foram ocupados por posseiros e que, por esse fato, foram apropriados pelo Estado a fim de fragmentá-los e transformá-los em assentamentos, caso da Fazenda Floresta - Gleba Cascata ${ }^{38}$, ocupada em 1970 e da Fazenda Rio Vermelho ou Estância Alcina - Gleba Rio Vermelho ${ }^{39}$, ocupada em 1988. Existem, ainda, os latifúndios que por motivo de endividamento aos bancos foram vendidos ao INCRA, para a criação de novos assentamentos do MST.

Através dessa fragmentação houve a criação de um campesinato ou 0 processo de (re) criação camponesa, o crescimento numérico da pequena produção que comprova esse processo de (re) criação e permanência do camponês no campo, o qual será detalhado nos itens 5, 6 e 7 deste trabalho.

É por acreditar na força e na importância desse produtor, que resolvi homenageá-lo com os versos da música Grã-Fino na Roça, com os quais Dino Franco e Nhô Chico retratam a importância desse caipira trabalhador.

\footnotetext{
${ }^{38}$ A Gleba Cascata foi desmembrada de uma porção maior, a Fazenda Floresta (8.200 ha), pertencente aos “Figueiredos”. È uma área de ocupação, cujo processo judicial teve início em 1975 e foi arquivado em 1985. Esse nome "Cascata" deve-se ao fato de muitos posseiros duvidarem que o processo de ocupação fosse dar certo, ou seja, jamais acreditavam que iriam ter a posse definitiva das terras. Aproximadamente 350 famílias ocuparam a propriedade no início. Em 2000, época da realização da pesquisa, a Gleba Cascata contava com 175 propriedades e 197 famílias, incluindo os filhos que se casaram e construíram suas moradias no lote do pai. Lima, L.M.S. 2000 ,: 15 e 98.

${ }^{39}$ A Fazenda Rio Vermelho ou Estância Alcina (10.545,5589 ha) foi ocupada por posseiros em 1988 e dividida em 338 lotes, para 320 famílias.
} 


\section{Grã-Fino na Roça}

Fui criado na cidade. Estudei na faculdade e cheguei a ser doutor Me casei com a Cristina, uma jóia de menina, mais bonita que uma flor. Como era nosso intento logo após o casamento deixamos a capital Pensando em nosso futuro, procuramos o ar puro aqui na zona rural

Faz um ano mais ou menos que moramos neste ermo Já estou arrependido. Espinhos de carrapichos, carrapato e outros bichos Deixa a gente aborrecido.

Foi pensando na estiagem que eu plantei arroz na vargem

Lá na beira do riacho. Depois que o arroz cacheou o riacho

Transbordou levou tudo rio abaixo.

Na cidade onde vivia o trabalho que eu fazia pra mim era brincadeira Mas no cabo de uma enxada sinto a barra mais pesada Quase morro de canseira.

Nas noites que não tem lua o meu drama continua Até outro dia cedo. Só com luz de lamparina coitadinha da Cristina Chega até chorar de medo.

A saudade me devora me recordo toda hora meus amigos e meus pais. Estou magro feito um grilo, já perdi catorze quilos isso é sofrer demais. Merece a nossa homenagem o ilustre personagem

Que sacia nossa fome. Só depois de meu tropeço eu fiquei sabendo do preço Do feijão que a gente come.

Vou deixar essa palhoça, e não quero mais a roça Chega de serviço bruto.

Pra cidade vou voltar nem que seja pra morar no porão de um viaduto É certo o que o povo diz a grandeza do país é o caipira que constrói Pois o nosso alimento vem da garra e do talento Desse nosso irmão herói. 
3- QUESTÃO AGRÁRIA NO BRASIL 


\subsection{Origens da Propriedade da Terra e do Problema Fundiário no Brasil}

Antes mesmo da descoberta oficial do Brasil em 1500, os portugueses já haviam assegurado boa parte dessas terras, graças a um conflito provocado por D. João II entre as coroas portuguesa e espanhola, por ter se considerado lesado com a descoberta da América em 1492 por Cristóvão Colombo. O impasse foi resolvido dois anos depois, através do tratado de Tordesilhas, pelo qual o papa Alexandre VI, por intermédio da bula Inter Coetera, decidiu que as terras a Oeste do Meridiano de Tordesilhas pertenceriam à Espanha, enquanto as do Leste pertenceriam a Portugal.

A 22 de abril de 1500, foi registrado o primeiro encontro da esquadra lusitana de Pedro Álvares Cabral em terras "portuguesas", onde encontraram os indígenas que já habitavam essas terras. Afirmo, então, que as terras brasileiras já possuíam donos há muito tempo. Esses donos eram as nações indígenas.

Após a descoberta oficial e para assegurar o direito definitivo sobre as terras "descobertas", bem como evitar a invasão por parte de outros interessados, seria necessário ocupá-las definitivamente, bem como criar e respaldar o Direito Agrário Brasileiro $^{40}$. Portanto, em 1534, o rei de Portugal regulou, por intermédio de uma Lei, o uso da terra no Brasil, doando terras aos portugueses que estivessem interessados em vir povoá-las.

Eram imensas áreas conhecidas como Capitanias Hereditárias ${ }^{41}$. capitão/donatário, por meio das cartas ou forais, era investido de poderes quase absolutos, ou seja, tinha certa autonomia ${ }^{42}$ para doar parte das terras - as sesmarias $^{43}$ - a quem tivesse dinheiro para colonizá-las, defendê-las, bem como

\footnotetext{
${ }^{40}$ O gérmen do direito Agrário Brasileiro encontra-se já no regime das sesmarias, implantado para a ocupação de terras abandonadas em Portugal, pelas Ordenações Afonsinas em 1446. No Brasil, o sistema foi introduzido em 1512 pelas Ordenações Manuelinas. O regime perdurou até 1822, amparado pelas Ordenações Filipinas de 1603, que revogou as anteriores. De 1822 a 1850 , não havia qualquer lei agrária regulamentando a questão das terras devolutas. Fiuza, C. Direito Civil. 2000:490.

${ }^{41}$ Com relação ao Brasil, a coroa empregou o tipo hereditário como a fórmula capaz de atrair a atenção e a cobiça das pessoas de fortuna em condições de enfrentarem a arriscada empresa de sua colonização. Assim mesmo, alguns donatários não vieram para cá, e outros, malsucedidos nas primeiras tentativas, desistiram de empreendimento tão temerário e de resultados tão duvidosos. Borges, F.C. Origens Históricas da Propriedade da Terra. In: A Questão Agrária no Brasil: Textos dos Anos Sessenta. 1980:2.

${ }^{42}$ Os poderes e privilégios concedidos aos donatários, no entanto, tinham um limite: os interesses do poder absoluto da coroa portuguesa a que estavam submetidos os donatários e a que deveriam prestar contas de seus atos. Poder absoluto que se exerceu desde os primeiros dias da colonização, inicialmente restringindo os direitos e privilégios outorgados aos donatários, originalmente expressos nas cartas de doação e nos forais, e depois revogando-os completamente e passando as capitanias para a posse e administração da coroa. Idem, pág.: 3.

${ }^{43} 1$. O donatário e seus sucessores darão sesmarias de todas as terras da capitania a qualquer pessoa, contanto que seja católica, livres de foro e direitos, salvo o dízimo a Deus, de acordo com as Ordenações, não podendo tomá-las para si, sua mulher ou filho herdeiro. Idem, pág.: 6.

“A primeira Lei sesmarial data de 26 de junho de 1375, durante o reinado de D. Fernando, rei lusitano. (...) No Brasil, as sesmarias eram propriedades que variavam muito em medida, podendo atingir de 3 a mais de 100 léguas de extensão. Considerando a abundância de terras
} 
fiscalizar o seu uso. Em resumo, àquele que pudessem administrá-las, construindo toda infra-estrutura como engenho, senzala, entre outros, não esquecendo do fator principal, a compra de escravos para o trabalho nas lavouras e nos engenhos. Entre as sesmarias distribuídas durante a capitania hereditária e a capitania real (período em que a capitania passou para a administração direta da metrópole), existiram diferenciações ${ }^{44}$.

Apesar disso, todos os proprietários passaram a se chamar sesmeiros e as propriedades ficaram conhecidas como sesmarias ${ }^{45}$, só que nem todas estavam sujeitas ao pagamento do dízimo, do foro, tributo ou pensão; no entanto, não poderiam sofrer parcelamentos. É o caso de algumas sesmarias doadas durante a capitania real. Esse fator contribuía para que se mantivesse o latifúndio e dificultava o surgimento da pequena propriedade territorial.

Nota-se que, durante o Brasil Colônia, só se poderia requerer terra mediante a autorização do representante do rei de Portugal que se encontrava instalado aqui na Colônia. Esse foi o Regime de Sesmarias e com ele surgiram os latifúndios, podendo ser confirmado em Borges (1980: 8), quando afirma que: “(...) o donatário e seus sucessores foram investidos do poder de dar sesmarias a qualquer pessoa (...). Aí, reside, principalmente, a origem da propriedade privada da terra em Pernambuco".

Caso o sistema de Capitanias Hereditárias fracassasse, as doações voltariam para o domínio da coroa. Sendo assim, em 1759, pelo fato de somente duas terem conseguido prosperar (Pernambuco no Nordeste e São Vicente em São Paulo), esse sistema foi extinto. Na realidade, sabe-se que as terras não foram doadas aos nobres, elas continuaram pertencendo à Coroa Portuguesa até 1822 e depois ao Império Brasileiro até 1850. A Lei de Sesmarias foi extinta pela Independência, por intermédio da Resolução nº 76 de julho de 1822, com a vitória dos liberais.

na colônia brasileira, o rei de Portugal era bastante benevolente na concessão delas. (...) Nas regiões onde existiam minas de ouro, as terras eram doadas mais fartamente. No caso de Minas Gerais, Goiás e Mato Grosso, temendo que terrenos auríferos fossem doados aos colonos, o rei de Portugal somente consentia que tivessem elas até 6 léguas de terra em quadra, ou seja, a mesma quantia de frente como de fundo”. Siqueira, E.M. 2002:39.

${ }^{44}$ As sesmarias durante a capitania hereditária: a) Sesmarias completamente livres de foro, tributos ou pensão, salvo o dízimo à Ordem de Cristo; b) Sesmarias com a obrigação dos sesmeiros nelas cultivarem a cana-de-açúcar, o algodão, estabelecerem engenhos ou fundarem vilas, dentro de determinado prazo, em geral de 3 a 6 anos, além do pagamento do dízimo a Deus; c) Sesmarias com a condição dos sesmeiros pagarem determinado foro anual por légua, pensão anual pelo estabelecimento de engenho, ou tributo sobre a produção de açúcar. Sesmarias durante a capitania real: a) Sesmarias completamente livres de foro, pensão ou tributo, salvo o dízimo a Deus; b) Sesmarias sob a condição do pagamento de determinado foro anual, por légua; c) sesmarias com a condição de que, por razão nenhuma, passassem às mãos de religiosos ou ordens religiosas; d) sesmarias com a condição de as mesmas não sofrerem parcelamento. Borges, F.C. 1980:8 a 15.

${ }^{45}$ Sobre Capitanias Hereditárias e Sesmarias, ver texto de BORGES, F. C.in: Marigule, Carlos et al. A Questão Agrária no Brasil: Textos dos anos 60. São Paulo: Brasil Debates, 1980 ou Stedile, João Pedro (org.) A Questão Agrária no Brasil: O Debate Tradicional - 1500 a 1960. São Paulo: Expressão Popular, 2005. 
Por estudos já realizados, sabe-se que vieram, para colonizar o Brasil, os fidalgos abastados, os portugueses degredados e os negros escravos, trazidos da África. No início da colonização, já se encontravam no Brasil alguns povoadores (na Bahia - Diogo Álvares, em São Paulo - João Ramalho), cujas chegadas nunca ficaram bem esclarecidas.

A população brasileira era formada, então, pelos índios isolados, que se encontravam distribuídos em muitas tribos ao longo de nosso território e viviam, basicamente, sob o modo de produção primitivo; pelos povos brancos, europeus, que invadiram o território brasileiro e impuseram o trabalho escravo e o sistema de produção conhecido como plantation, pelo qual tentaram escravizar os indígenas, ocorrendo, assim, um verdadeiro genocídio e etnocídio desse povo, reduzindo em muito esse grupo, transformando-os em índios integrados; pelos trabalhadores negros trazidos da África, que foram escravizados, além de brancos e mestiços, frutos da política do colonizador.

Portanto, além dos grandes fazendeiros e dos escravos, existia uma população que não se enquadrava nem na categoria escrava e nem na de donos de engenhos. Mesmo sem a concessão (que às vezes ocorriam depois), parte dessa população ocupava terras para produzir o suficiente a sua sobrevivência, vendendo ou trocando o que lhe sobrava da produção. Estes foram, então, os primeiros posseiros, os agregados, os caboclos, os pequenos agricultores, os camponeses que não tinham a propriedade legal da terra, mas que a faziam produzir, ou seja, os homens livres ${ }^{46}$.

Com a extinção do sistema sesmarial (já havia a presença de camponeses dentro ou fora da grande propriedade monocultora escravocrata) em 1822, inicia-se a definição e o domínio do público e do particular, onde o primeiro pertence ao Estado e o segundo aos proprietários de terra; abre-se também o que é chamado pelos antropólogos de "brecha camponesa" que deu acesso livre dos camponeses às terras devolutas até 1850. Por que, até esse período? Porque a partir de 18 de setembro de 1850, Dom Pedro II promulga a Lei $\mathrm{n}^{\circ}$. 601, conhecida como a Lei de

\footnotetext{
${ }^{46}$ Garantida a entrada contínua de trabalhadores para a cafeicultura, tornava-se possível expandir as plantações. Para essa tarefa eram mobilizados caboclos e caipiras ou outros trabalhadores "nacionais", como então dizia. Ao menos o trabalho de desmatamento, queima e limpeza do terreno era invariavelmente feito por esses trabalhadores. Nesse sentido, quase não havia diferença entre a época de vigência do trabalho escravo e a vigência do trabalho livre. A preparação do terreno era preferencialmente feita por homens livres, agregados dos fazendeiros ou antigos posseiros das áreas em que as fazendas vieram a se estabelecer. (...) Os fazendeiros preferiam, na medida do possível, poupar seus escravos dessas tarefas. (...) O fazendeiro optava pelo trabalho de homens livres, agregados de sua fazenda ou não, caboclos ou caipiras. O dispêndio monetário era restringido, dado que os trabalhadores deslocavam-se com suas famílias para os locais de derrubada, onde armavam seus ranchos. Sua subsistência era fornecida pelo fazendeiro e descontada da quantia pela qual fora feita a empreitada. Martins, J.S. O Cativeiro da Terra. 6 a ed. São Paulo: Hucitc, 1996, pág.: 69, 70-1.
} 
Terras $^{47}$, e o Decreto $n^{\circ}$. 1.318 que disciplinaram a questão da terra, ou seja, que instituíram a propriedade privada e a compra e venda de terras no Brasil. Eram vários os objetivos desta lei, porém dois deles mais significantes, ou seja, corrigir as deformidades criadas pelo sistema sesmarial e impedir o aumento de minifúndios pela multiplicação das posses em terras públicas ${ }^{48}$.

A partir de 1850, com a criação da Lei de Terras, o sistema de plantation entra em crise e os trabalhadores escravizados começam uma luta por sua liberdade. Passa a ocorrer um esvaziamento no campo. Para solucionar o problema, o governo brasileiro começa a incentivar a vinda de trabalhadores camponeses pobres da Europa, pois essa mão-de-obra poderia suprir o trabalho que era, até então, realizado pelos negros. Como afirma Martins (1996:60), "Além da abundância de terras era necessária a abundância de mão-de-obra disposta a aceitar a substituição do escravo". A partir de 1851, intensifica-se a imigração de trabalhadores de várias partes da Europa, que se integraram às lavouras de café, de cana-de-açúcar e à produção de alimentos para a cidade, no sistema de colonato. Alguns imigrantes receberam lotes de terra, mas tiveram que trabalhar muito para pagá-la, fazê-la produzir e comprar ferramentas.

Em 1888, com a promulgação da Lei Áurea, consolida-se a legalidade daquilo que já vinha acontecendo: escravos se rebelando, fugindo, formando quilombos. Agora, passaram a ser livres, mas impedidos legalmente de se transformarem em camponeses $^{49}$. Com isso, intensifica-se a substituição da mão-de-obra escrava pelo camponês europeu. De acordo com Stedile (2005:25), no período entre 1875 a 1914, mais de 1,6 milhão de camponeses pobres da Europa foram atraídos para o

\footnotetext{
${ }^{47}$ Sobre o assunto ver: Stedile, J. P. (org.). A Questão Agrária no Brasil: O Debate Tradicional - 1500-1960. São Paulo: Expressão Popular, 2005, pág.: 283 a 291.

${ }^{48}$ Ainda no mesmo ano de 1850, foram adotados procedimentos legais com vistas à substituição dos trabalhadores cativos. O objetivo sugerido foi o de promover a livre imigração do exterior. (...) Se a escravidão cessasse nada poderia prevenir o deslocamento dos antigos e novos trabalhadores para as terras livres da fronteira agrícola, onde poderiam tornar-se trabalhadores autônomos em suas próprias terras. (...) Por essa razão, a Lei de Terras definiu todas as terras devolutas como propriedades do Estado, cuja ocupação se sujeitaria à compra e venda. (...) Após setembro de 1850, os que estivessem na posse de terras não legitimada antes da lei, ou que não viessem a ser compradas ao governo corriam o risco de expulsão mediante ação dos "verdadeiros" proprietários, isto é, os possuidores do título de compra. A terra tornou-se acessível apenas ao possuidor de dinheiro. Generalizou-se, assim, o capital como o mediador na aquisição da propriedade territorial. Martins, J.S. O Cativeiro da Terra. 6ª ed. São Paulo: Hucitc, 1996, pág.: 122.

${ }^{49}$ Com a libertação dos trabalhadores escravizados - oficializada pela Lei Áurea, de 1888 - e, ao mesmo tempo, com o impedimento de os mesmos se transformarem em camponeses, quase dois milhões de adultos ex-escravos saem das fazendas, das senzalas, abandonando o trabalho agrícola, e se dirigem para as cidades, em busca de alguma alternativa de sobrevivência, agora vendendo "livremente" sua força de trabalho. Como ex-escravos, pobres, literalmente despossuídos de qualquer bem, resta-lhes a única alternativa de buscar sua sobrevivência nas cidades portuárias, onde pelo menos havia trabalho que exigia apenas força física: carregar e descarregar navios. E, pela mesma lei de terras, eles foram impedidos de se apossarem de terrenos e, assim, de construírem suas moradias: os melhores terrenos nas cidades já eram propriedade privada dos capitalistas, dos comerciantes etc. Esses trabalhadores negros foram, então, à busca do resto, dos piores terrenos, nas regiões íngremes, nos morros, ou nos manguezais, que não interessavam ao capitalista. Assim, tiveram início as favelas. A lei de terras é também a "mãe" das favelas nas cidades brasileiras. Stedile, J.P. A Questão Agrária no Brasil. O Debate Tradicional - 1500 a 1960. São Paulo: Expressão Popular, 2005, pág.: 24.
} 
Brasil, com a promessa do "eldorado", graças à terra fértil e barata. Nesse sentido, Martins (1996:22) aponta que "mais de um milhão e seiscentos mil imigrantes vieram para o país no espaço de pouco mais de 30 anos, entre 1881 e 1913, a maioria dos quais para trabalhar como colonos nas fazendas de café".

Mas, a Lei de Terras não os impediram de concretizar o sonho de possuir uma terra. Mesmo com a lei, surge no Brasil, o campesinato que pode ser compreendido através de duas vertentes. A primeira formou-se com a vinda dos camponeses pobres migrantes da Europa para trabalhar na agricultura, e a segunda foi se formando, ao longo desse período, pelos mestiços, com a miscigenação entre brancos e negros, negros e índios, índios e brancos e seus descendentes.

Por estarem impedidos de se transformarem em pequenos proprietários devido à Lei de Terras, pois não possuíam capital para adquiri-las, esses trabalhadores passaram a migrar para o interior do país em busca de terra, onde pudessem ocupá-la, fazê-la produzir, dedicar-se à atividade de produção agrícola de subsistência. Não tinham a propriedade privada da terra, mas, ao ocupá-la, seja na forma individual ou coletiva, faziam-na produzir.

A Lei de Terras foi, então, a base, o marco jurídico-institucional para a transição de um modelo agro exportador que se encontrava em crise, para um novo exemplo, o qual se consolidou com a revolução de 1930. Isto é, foi imposto um novo modelo econômico para o país, o de industrialização dependente. Esse período se caracteriza pela subordinação econômica e política da agricultura à indústria ${ }^{50}$.

Nota-se que, mesmo com o impedimento da lei, passou a expandir em nosso país o minifúndio e esse novo modelo econômico induz o camponês a se vincular totalmente às regras do mercado e a se integrar à indústria. O modelo reservou ao camponês algumas funções claramente determinadas, ou seja, seria fornecedor de mão-de-obra barata para as indústrias, o que ocasionaria baixos salários, além de

\footnotetext{
${ }^{50}$ As oligarquias rurais continuam donas das terras, continuam latifundiárias e produzindo para a exportação, mas não mais detêm o poder político. As elites - a burguesia industrial, agora no poder - fazem uma aliança com a oligarquia rural, tomam seu poder, mas a mantêm como classe social, por duas razões fundamentais: primeiro, porque a burguesia industrial brasileira tem origem na oligarquia rural, da acumulação das exportações do café e do açúcar, ao contrário dos processos históricos ocorridos na formação do capitalismo na Europa e nos Estados Unidos. A segunda razão: o modelo industrial, como era dependente, precisava importar máquinas, e até operários, da Europa e dos Estados Unidos. E a importação dessas máquinas era possível pela continuidade das exportações agrícolas, que geravam divisas para seu pagamento, fechando o ciclo da lógica da necessidade do capitalismo dependente. Surge, então, um setor da indústria vinculado à agricultura, as indústrias produtoras de insumos para a agricultura, como ferramentas, máquinas, adubos químicos, venenos etc. E outro, da chamada agroindústria, que foi a implantação da indústria de beneficiamento de produtos agrícolas. Stedile, J.P. A Questão Agrária no Brasil. O Debate Tradicional - 1500 a 1960. São Paulo: Expressão Popular, 2005, pág.: 28-9.
} 
produzir alimentos para as cidades, em especial para os trabalhadores das indústrias, sem contar a produção de matéria-prima ${ }^{51}$.

Como conseqüência da Lei, os ex-escravos, os brasileiros pobres, os posseiros e os imigrantes não poderiam se tornar proprietários e passariam a constituir a mão-de-obra assalariada necessária às indústrias e aos latifúndios. Passa a ocorrer, em nosso país, a ocupação e exploração policultora do território por parte dos camponeses, que, juntamente com suas famílias, geralmente numerosas, pois os filhos eram os braços para o trabalho, acabavam invadindo as piores terras e as mais distantes, já que as demais, na maioria das vezes, já haviam sido ocupadas por latifundiários.

Normalmente, as grandes propriedades ocupavam não só as maiores extensões, mas também as áreas de mais fácil acesso aos meios de transporte. $\mathrm{E}$ a vida econômica e política dos novos Estados era controlada por esses proprietários, não diferindo muito dos dias atuais.

Em seus estudos, Andrade (1995) demonstra a dificuldade do trabalhador em obter a propriedade da terra após a Constituição de $1891^{52}$. Segundo o autor, o artigo 64 dessa Constituição esclarece que as terras públicas passariam para 0 Estado onde estavam situadas. Esse fator veio contribuir para que fossem apropriadas por pessoas que detinham o poder econômico e político, o que não contribuiu em nada para solucionar o problema agrário em nosso país. Andrade comenta, ainda, que, em leis posteriores à Constituição, o sistema de compra e venda da terra foi fortalecido pelo Código Civil de $1^{\circ}$ de janeiro de 1916 em seu artigo 530 o qual admitia "a aquisição de propriedade pela transcrição da transferência de contrato de compra e venda no Registro de Imóveis, por acessão, por usucapião ${ }^{53}$ e por herança". Andrade (1995:57)

\footnotetext{
${ }^{51}$ Dessa forma, a lógica do modelo de industrialização dependente atuava permanentemente de forma contraditória e complementar, em que os camponeses, ao mesmo tempo em que se reproduziam e se multiplicavam enquanto classe, tiveram parcelas crescentes de seus membros, migrando para as cidades e se transformando em operários. Na estrutura da propriedade da terra, a lógica contraditória se repetia. Por um lado, havia a multiplicação de pequenas propriedades, pela compra e venda e reprodução das unidades familiares. Stedile, J.P. A Questão Agrária no Brasil. O Debate Tradicional - 1500 a 1960. São Paulo: Expressão Popular, 2005, pág.: 30.

${ }^{52}$ A Constituição de 1891 transferiu as terras devolutas aos Estados e instituiu outras normas agrárias, tais como a competência dos estados para a cobrança de tributos, a transmissão da propriedade e assim por diante. Fiuza, C. 2000:490.

${ }^{53}$ Na Constituição de 1988, no Capítulo III da Política Agrícola e Fundiária e da Reforma Agrária, o Art. 191 diz-nos o seguinte: Art. 191. Aquele que não sendo proprietário de imóvel rural ou urbano, possua como seu, por cinco anos ininterruptos, sem oposição, área de terra, em zona rural, não superior a cinqüenta hectares, tornando-a produtiva por seu trabalho ou de sua família, tendo nela sua moradia, adquirir-lhe-á a propriedade. Parágrafo Único. Os imóveis públicos não serão adquiridos por usucapião. (Constituição de 1988: 100. Atualizada em 1996)
} 
A concentração de terras e a grande propriedade continuaram crescendo durante a Primeira República (1889 a 1930) ${ }^{54}$. A população menos favorecida, os excluídos desse processo, intensificava seus protestos, suas lutas, mas o governo continuava alheio a essas reivindicações. A apropriação de terras por parte dos poderosos era feita tanto em terras antigas, tradicionais, como nas áreas novas já ocupadas pelos indígenas, caso estudado por Andrade (1995).

Oliveira (1991: 28-9) declara que os princípios que marcaram a concentração fundiária nunca deixaram de existir e a Constituição de $1946^{55}$, vigorada até 1967 e mesmo as antecessoras definiam em 10 mil hectares a área de terra devoluta máxima a ser vendida a brasileiros natos ou a imigrantes naturalizados. A Constituição de 1967 baixou a área máxima para 3 mil hectares. Mas nem sempre a mesma era respeitada. Oliveira (1991: 28-9) cita como exemplo a venda de terra pelo governo de Mato Grosso, em Aripuanã, onde, com autorização do Senado, vendeu cinco áreas de 200 mil hectares, sendo que um milhão de hectares de terra deveria ser entregue apenas a cinco proprietários.

De acordo com Martins (2000:6) ${ }^{56}$, o ocultamento da ilegalidade e a fraude no sistema fundiário brasileiro são alarmantes e requerem providências rápidas por parte do Ministério do Desenvolvimento Agrário. No documento o "Livro Branco da Grilagem da Terra no Brasil" (MDA/INCRA, 2000) ${ }^{57}$, Martins comenta sobre a correção histórica na política fundiária brasileira, onde os dados mostraram após o levantamento feito pelo MDA - Ministério do Desenvolvimento Agrário - em várias regiões do país, em especial na Amazônia Legal, as irregularidades nas propriedades. Após a convocação dos proprietários para apresentar a documentação e assim provar que a terra lhes pertence de fato, apenas um terço cumpriu a convocatória. Isso me leva a entender que os demais não possuem

\footnotetext{
${ }^{54}$ De 1988 a 1930, a estrutura fundiária permaneceu a mesma, ou seja, imensa massa camponesa, composta de minifundiários e sem-terra, e uns poucos aristocratas rurais. Houve, entretanto, várias tentativas de elaboração de um código rural. Fiuza, C. 2000:490.

${ }^{55}$ Em 1946, a Constituição Federal contemplou a hipótese de desapropriação por interesse social, além dos casos de necessidade ou utilidade pública, programando a justa distribuição da propriedade, com igual oportunidade para todos. De 1946 a 1964, vários foram os avanços e tentativas quando, finalmente, em 1964, promulgou-se o estatuto da Terra, que vigorou até nossos dias, acompanhado de farta legislação complementar. Fiuza, C. 2000:490.

56 “Uma Correção Histórica na Política Fundiária Brasileira” - Palestra proferida durante a cerimônia em que foi anunciado o cancelamento dos cadastros de 3.065 grandes imóveis rurais - e publicada no livro: Balanço Final.

${ }^{57}$ O Livro Branco da Grilagem de Terra no Brasil. Balanço da Grilagem no Brasil. Brasília 2000. É um Documento produzido pelo Ministério do Desenvolvimento Agrário - MDA, Instituto Nacional de Colonização e Reforma Agrária - INCRA e Assessoria de Comunicação Social INCRA/MDA. Na cerimônia, além de J.S. Martins, encontravam-se presentes: Candido Grzybowski - Diretor do IBASE; Manoel dos Santos - Presidente da CONTAG; Alcides Rodrigues Filho - Vice-governador de Goiás; José Gregório - Ministro da Justiça; Raul Jungmann - Ministro do Desenvolvimento Agrário; Geraldo Brindeiro - Procurador Geral da República; Antônio de Pádua Ministro do Superior Tribunal de Justiça; José Abrão - Secretário Executivo do Ministério do Desenvolvimento Agrário; Orlando Muniz Presidente do INCRA e Assis Miguel - Coordenador de Agricultura Familiar do INCRA.
} 
documentos legais; sendo, portanto, donos fictícios e as terras são usadas para a especulação e ganhos indevidos à custa de todo país.

O Ministro do Desenvolvimento Agrário Raul Jungmann esclareceu, no Documento Balanço da Grilagem no Brasil (Brasília, 2000:9), que o "objetivo desta publicação é apresentar ao público um balanço dos resultados do programa de recadastramento dos grandes imóveis do meio rural brasileiro".

Em se tratando da grilagem de terras em Mato Grosso, Oliveira (2005) apontou, durante a conferência Transformações sócio-ambientais no Mato Grosso, no III Festival Ecológico e Cultural das Águas de Mato Grosso, que "cerca de 90\% dos títulos de terra na região de Mato Grosso não resistiriam a uma investigação".

O Brasil, então, é um país recordista em concentração de terras, onde os trabalhadores rurais são excluídos do acesso a terra, contribuindo, assim, para sua pobreza, devido ao poder político do latifúndio e para as situações de conflitos por terras que se perpetuam e ampliam-se.

Portanto, a injusta e irracional estrutura fundiária em nosso país tem suas raízes no período colonial, a partir do momento em que o Brasil herdou de Portugal o regime de sesmarias, cuja lei não foi utilizada corretamente. Com isso, surge o latifúndio, sem contar que houve a interferência do poder pessoal na distribuição de terras, da qual a população pobre, os escravos, os índios administrados e os mestiços alocados ao latifúndio como moradores e, os dois últimos, pagantes de renda em trabalho, bem como os imigrantes, foram privados ${ }^{58}$.

A estrutura fundiária retrata a forma como os estabelecimentos ou imóveis rurais estão distribuídos em nosso país e, ao longo do tempo, sempre se constituiu num dos problemas do espaço agrário brasileiro.

Com o intuito de amenizar a questão problemática da distribuição de terra em nosso país, ou seja, a injusta estrutura fundiária em que o Brasil se encontrava, o governo Itamar Franco resolve em 25 de fevereiro de 1993, sancionar a Lei nº. 8.629, que regulamentava os dispositivos legisladores sobre a reforma agrária. Sendo assim, a partir de então, passa a vigorar, com base no módulo rural, correspondendo à propriedade familiar, as definições sobre dimensões e classificações dos imóveis rurais, adotando-se o conceito de módulo fiscal, que

${ }^{58}$ Sobre o assunto ler: Grilagem de Terra. Balanço Final. 2000. Citado na Bibliografia. 
corresponde ao tamanho médio do módulo rural do município que, no Brasil, varia de 5 a 110 hectares.

No município de Rondonópolis (MT), um Módulo Fiscal equivale a 30 hectares, enquanto um Módulo Rural corresponde a 60 hectares ${ }^{59}$. No caso de Rondonópolis, cujo módulo rural é de 60 ha, um imóvel rural, com área total de 801,6 ha, terá um módulo fiscal equivalente a 13,36 ha e a parcela mínima é de 2,0 $\mathrm{ha}^{60}$.

De acordo com o INCRA, após a Lei n. 8.629, quanto ao tamanho os imóveis rurais são assim classificados e conceituados:

Minifúndio: o imóvel rural com área inferior a 1 (um) módulo fiscal.

Pequena Propriedade: o imóvel rural de área compreendida entre 1 (um) a 4 (quatro) módulos fiscais.

Média Propriedade: o imóvel rural de área superior a 4 (quatro) e até 15 (quinze) módulos fiscais.

Grande Propriedade: o imóvel rural de área superior a 15 (quinze) módulos fiscais.

Conforme o INCRA e com base na mesma Lei, o Módulo Fiscal e a Propriedade Familiar são:

Módulo Fiscal: a unidade de medida expressa em hectares, fixada para cada município ${ }^{61}$, considerando os seguintes fatores: tipo de exploração predominante no município; renda obtida com a exploração predominante; outras explorações existentes no município que, embora não predominantes, sejam significativas em função da renda e da área utilizada e o conceito de propriedade familiar. Propriedade Familiar: o imóvel rural que, direta e pessoalmente explorado pelo agricultor e sua família, Ihes absorva toda a força de trabalho, garantindo-lhes a subsistência e o progresso social e econômico, com área máxima fixada para cada região e tipo de exploração, e eventualmente trabalhada com a ajuda de terceiros $^{62}$. (INCRA, 1992)

A estrutura fundiária é considerada um dos mais graves problemas no Brasil, limitando o seu desenvolvimento, ou melhor, o progresso da agropecuária brasileira. E essa distorção, essa desigual distribuição teve seu embrião no período colonial, com a implantação do capitalismo comercial e, posteriormente, reafirmado na atual

\footnotetext{
${ }^{59}$ Informação colhida na entrevista com o engenheiro agrônomo Laércio Benedito Polizel, Coordenador da EMPAER em Rondonópolis, 15/02/2006.

${ }^{60}$ Dados fornecidos por Juarez Corrêa de Souza, Técnico Agrimensor - CREA 2.987.

${ }^{61}$ Grifo meu.

${ }^{62}$ INCRA. Estatísticas Cadastrais - Municipais - Recadastramento 1992 - Volume I. www.incra.gov.br, 13/01/2006. Grifo meu. Encontrase também no Capítulo XIV - Direito das Coisas: Introdução. Direito de Propriedade. No item 2.11-Propriedade Imóvel; no subitem b) Propriedade Territorial Rural, às páginas 492-3, em Fiuza Cezar. Direito Civil. Belo Horizonte: Del Rei, 2000.
} 
fase do desenvolvimento do capitalismo no Brasil, em função do processo histórico ao qual nosso país foi submetido.

Os princípios que marcaram a concentração de terras - capitanias hereditárias e seus donatários, as sesmarias, a Lei de Terras de 1850 - e as Constituições que definiam um limite de área a ser vendida, deixavam brechas para que o senado federal pudesse autorizar a venda de uma área maior em nosso país.

Apresento, a seguir, cinco tabelas para que se tenha noção da estrutura fundiária em nosso país, em Mato Grosso e em Rondonópolis, bem como da condição do responsável em Mato Grosso e Rondonópolis. Os dados da tabela abaixo apenas reforçam o que já foi dito, ou seja, que existem muitas pessoas com pouca terra e poucos proprietários com terra em abundância, significando que os latifúndios só têm aumentado.

TABELA 1 - BRASIL - ESTRUTURA FUNDIÁRIA / INCRA 1966 A 1998

\begin{tabular}{|c|c|c|c|c|c|c|c|c|c|c|c|c|}
\hline \multirow{2}{*}{$\begin{array}{c}\text { Classe de } \\
\text { Ćrea Total (há) }\end{array}$} & \multicolumn{12}{|c|}{ NÚMER0 DE INÓVEIS } \\
\hline & 1966 & $\%$ & 1972 & $\%$ & 1978 & $\%$ & 1985 & $\%$ & 1992 & $\%$ & 1998 & $\%$ \\
\hline Menos de 10 & 965.796 & 36,1 & 1.052 .080 & 31,1 & 875.120 & 28,5 & 1.313 .331 & 29,8 & 907.764 & 31,0 & 1.144 .642 & 31,9 \\
\hline 10 a - de 100 & 1.378 .669 & 51,4 & 1.852 .328 & 54,7 & 1.706 .718 & 55,5 & 2.363 .516 & 53,6 & 1.601 .071 & 54,7 & 1.916 .883 & 53,5 \\
\hline $\begin{array}{c}100 \mathrm{a}-\mathrm{de} \\
1000\end{array}$ & 295.465 & 11,0 & 431.209 & 12,7 & 432.711 & 14,2 & 641.556 & 14,6 & 373.918 & 12,8 & $468.56 \mathrm{l}$ & 13,0 \\
\hline $\begin{array}{c}1000 a-d e \\
10000\end{array}$ & 36.377 & 1,4 & 48.074 & 1,4 & 53.185 & 1,7 & 81.847 & 1,9 & 39.546 & 1,4 & 55.203 & 1,5 \\
\hline $10.000 \mathrm{a}$ mais & 2.119 & 0,1 & 2.474 & 0,1 & $3.36 \mathrm{l}$ & 0,1 & 4.550 & 0,1 & 1.905 & 0,1 & 2.678 & 0,1 \\
\hline Total & 2.678 .426 & 100 & 3.386 .173 & 100 & 3.071 .095 & 100 & 4.404 .800 & 100 & 2.924 .204 & 100 & 3.587 .967 & 100 \\
\hline Classe de & \multicolumn{12}{|c|}{ ÁREA TOTAL (HÁ) } \\
\hline Área Total (há) & 1966 & $\%$ & 1972 & $\%$ & 1978 & $\%$ & 1985 & $\%$ & 1992 & $\%$ & 1998 & $\%$ \\
\hline Menos de 10 & 4.112 .134 & 1,4 & 5.004 .290 & 1,4 & 4.167 .149 & 1,0 & 6.089 .497 & 1,0 & 4.430 .642 & 1,4 & 5.418 .085 & 1,4 \\
\hline $10 \mathrm{a}-$ de 100 & 46.524 .170 & 16,2 & 59.540 .610 & 16,1 & 55.772 .481 & 13,2 & 79.559 .025 & 13,3 & 52.154 .231 & 16,5 & 62.549 .414 & 15,7 \\
\hline $\begin{array}{c}100 a-d e \\
1000\end{array}$ & 79.094 .576 & 27,4 & 115.428 .922 & 31,1 & 113.938 .650 & 27,2 & 166.490 .235 & 28,0 & 102.548 .873 & 32,4 & 120.092 .215 & 30,3 \\
\hline $\begin{array}{c}1000 \text { a }- \text { de } \\
10000\end{array}$ & 100.891 .964 & 35,0 & 119.844 .739 & 32,4 & 132.284 .370 & 31,5 & 200.412 .904 & 33,7 & 97.449 .692 & 30,9 & 126.100 .224 & 31,8 \\
\hline 10.000 a mais & 57.787 .852 & 20,0 & 70.456 .627 & 19,0 & 113.739 .221 & 27,1 & 142.819 .737 & 24,0 & 59.271 .068 & 18,8 & 82.479 .644 & 20,8 \\
\hline Total & 288.410 .696 & 100 & 370.275 .188 & 100 & 419.901 .871 & 100 & 595.371 .398 & 100 & 315.854 .506 & 100 & 396.639.582 & 100 \\
\hline
\end{tabular}

Em se tratando do número de estabelecimentos, pela Tabela 1, percebe-se que houve aumento significativo das propriedades enquadradas nas categorias minifúndio, pequena e média propriedade (a soma das classes de menos de 10 até 100 hectares). No ano de 1966, o número de estabelecimentos, nestas categorias, era igual a 2.344,465, equivalente a $87,5 \%$ do total. Já em 1998, existiam 3.061,525 estabelecimentos, correspondendo a $85,4 \%$ do total geral. 
Por outro lado, a grande propriedade (a soma das classes de 1.000 a mais de 10.000 hectares), que antes da Lei Agrária de 1993 era conhecida como latifúndio por dimensão, por exploração e empresa rural, também cresceu. O que em 1966 somava 38.496 estabelecimentos (1,5\%), no ano de 1985 subiu para 86.397 (2\%), caindo para $57.881(1,6 \%)$ no ano de 1998. Em contrapartida, quanto à área ocupada, em 1966, de minifúndio à pequena e média propriedade, atingia uma área equivalente a 50.636,304 ha. (17,6\%), passando no ano de 1985 para 85.648,522 $(14,3 \%)$ hectares, caindo para $67.967,499(17,1 \%)$ ha. no ano de 1998 , o que nem pode ser comparado com a grande propriedade que, de 158.679,816 (55\%) ha., em 1966, passou para 343.232,641 (57\%) ha. em 1985 e, daí, saltou para 208.579,868 $(52,6 \%)$ ha. no ano de 1998. Portanto, o que o Brasil conheceu nesses 32 anos foi um aumento da estrutura fundiária, bastando observar os dois últimos grupos de área extremas da distribuição de terras e do número de estabelecimentos nos anos de 1996 e 1998.

Essa desigualdade condiz, historicamente, com os momentos distintos em que cada região do país foi sendo ocupada. No Mato Grosso, a distribuição de terras está ligada ao processo histórico de ocupação de seu território, onde as políticas governamentais que regulamentava o acesso a terra, incluindo, aí, a colonização, a venda de terras devolutas e a regularização de ocupações, exerceram forte influência.

Em seu trabalho "Os Dois Brasis", Lambert (1978:114) expõe que "não há dúvida de que as grandes propriedades de mais de 1000 hectares ainda ocupam a maior parte do território (51\% em 1950)". O autor acrescenta, ainda, que essas grandes propriedades estão "sobretudo nos Estados pouco povoados e explorados, os dominados pela grande propriedade - 82\% na Amazônia, e mais ainda nos antigos e imensos territórios de Guaporé e do Acre e 92\% em Mato Grosso."

Passaram-se os anos, mudaram os períodos históricos, novas formas de produzir foram surgindo e o problema da posse da terra, principalmente em Mato Grosso, acentuou-se, o que pode ser confirmado pela Tabela 2. 
TABELA 2 - MATO GROSSO - ESTRUTURA FUNDIÁRIA/INCRA 1966 A 1998

\begin{tabular}{|c|c|c|c|c|c|c|c|c|c|c|c|c|}
\hline Classe de & \multicolumn{12}{|c|}{ NÚMERO DE INÍVEIS } \\
\hline Área Total (ha) & 1966 & $\%$ & 1972 & $\%$ & $1978(*)$ & $\%$ & 1985 & $\%$ & 1992 & $\%$ & 1998 & $\%$ \\
\hline Menos de 10 & 5.469 & 9,8 & 6.641 & 9,1 & 6.860 & 8,5 & 3.789 & 4,7 & 2.166 & 3,5 & 3.595 & 3,8 \\
\hline 10 a - de 100 & 23.901 & 42,8 & 32.999 & 45,4 & 32.442 & $\overline{40,5}$ & 30.205 & 37,6 & 26.906 & 43,2 & 39.353 & 41,5 \\
\hline 100 a - de 1000 & 14.278 & 25,7 & 20.232 & 27,8 & 26.622 & 33,1 & 30.835 & 38,4 & 24.612 & 39,5 & 37.105 & 39,2 \\
\hline 1000 a - de 10000 & 10.913 & 19,6 & 11.603 & 16,0 & 12.979 & 16,2 & 14.343 & 17,8 & 8.071 & 12,9 & 13.806 & 14,6 \\
\hline 10.000 a mais & 1.169 & 2,1 & 1.227 & 1,7 & 1.371 & 1,7 & 1.224 & 1,5 & 588 & 0,9 & 853 & 0,9 \\
\hline TOTAL & 55.730 & 100 & 72.702 & 100 & 80.274 & 100 & 80.396 & 100 & 62.343 & 100 & 94.712 & 100 \\
\hline Classe de & \multicolumn{12}{|c|}{ Á́REA TOTAL (HA) } \\
\hline Área Total (ha) & 1966 & $\%$ & 1972 & $\%$ & $1978\left({ }^{*}\right)$ & $\%$ & 1985 & $\%$ & 1992 & $\%$ & 1998 & $\%$ \\
\hline Menos de 10 & 27.724 & 0,0 & 36.237 & 0,0 & 35.417 & 0,0 & $20.76 \mathrm{I}$ & 0,0 & 12.011 & 0,0 & 19.092 & 0,0 \\
\hline 10 a - de 100 & 718.155 & 1,0 & 1.184 .575 & 1,5 & 1.226 .621 & 1,5 & 1.250 .962 & 1,5 & 1.217.979 & 2,7 & 1.802 .957 & 2,4 \\
\hline 100 a - de 1000 & 5.349 .765 & 6,8 & 7.160 .373 & 9,0 & 9.029 .511 & 10,3 & 9.927 .059 & 11,0 & 7.908 .100 & 17,3 & 12.332 .844 & 17,0 \\
\hline 1000 a - de 10000 & 41.473.918 & 52,6 & 38.001 .334 & 47,2 & 40.709 .994 & 46,5 & 44.802 .374 & 50,0 & 22.422 .768 & 49,1 & 38.801 .392 & 53,3 \\
\hline 10.000 a mais & 31.255 .523 & 39,6 & 34.010 .963 & 42,3 & 36.527 .357 & 41,7 & 33.689 .401 & 37,5 & 14.127 .862 & 30,9 & 19.858.157 & 27,3 \\
\hline TOTAL & 78.825 .085 & 100 & 80.393.439 & 100 & 87.528 .900 & 100 & 89.770 .557 & 100 & 45.688 .720 & 100 & 72.814 .442 & 100 \\
\hline
\end{tabular}

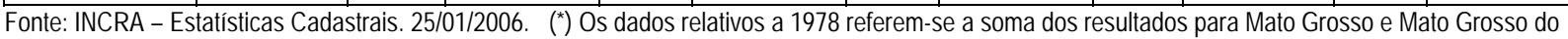
Sul para efeito de comparação.

Considerando Mato Grosso como um todo, nota-se que, em 1996 as instituições enquadradas como minifúndio, pequena e média propriedade correspondiam a 29.370 estabelecimentos agrícolas, ou seja, 52,6\%, e ocupava área de 745.879 ha., equivalente a 1,0\% do total da área agrícola do Estado. Em contrapartida, observa-se, na outra extremidade, que 1.169 estabelecimentos têm área superior a 10.000 ha, correspondendo a 2,1\%; cujo total ocupa área de $31.255,523$ ha, ou seja, 39,6\% da área total dos estabelecimentos.

Comparando-se os dados de 1966 e 1978, verifica-se uma alteração na distribuição dos estabelecimentos em Mato Grosso. Enquanto as classes que compreendem as áreas menores de 10 a 100 hectares eram em número de 29.370 em 1966, passando para 39.302 em 1978, as classes que variam de 100 a mais de 10.000 hectares e eram em número de 35.360 no ano de 1966, chegaram em 1978 no total de 40.972 estabelecimentos. Esse aumento, tanto de uma categoria quanto da outra, está vinculado ao fato de que, nesse período, ou seja, a partir de 1970, Mato Grosso passava por um intenso processo de ocupação de suas terras, direcionado pelas políticas governamentais de expansão da fronteira agrícola ${ }^{63}$, caso que será discutido no item Gênese do Campesinato em Mato Grosso.

O leitor deve estar intrigado com a brusca redução do número de estabelecimentos e de área ocupada em Mato Grosso no período de 1978 até 1985. Essa diminuição aconteceu por conta da divisão do Estado em 1977, que

\footnotetext{
${ }^{63}$ Fronteira Agrícola no Estado brasileiro é de grande importância para o entendimento da reprodução e/ou manutenção da unidade familiar e para a compreensão da luta pela terra empreendida pelos segmentos sociais envolvidos nesta produção. Devido a sua importância dentro do nosso processo histórico, a fronteira é uma questão que remete a sua analise a varias dimensões. Castro, Sueli P. et al. A Colonização Oficial em Mato Grosso: A Nata e a Borra da Sociedade. Cuiabá. 1994, pág.: 31.
} 
representou não apenas uma cisão territorial, mas um marco histórico no processo de ocupação e crescimento de novas áreas, onde a expansão da ocupação e da economia foi evidenciada. Com essa divisão, todo o Estado de Mato Grosso passou a fazer parte da Amazônia Legal. Assim, o Estado que possuía área total de 1.264.965,6 Km², com a divisão, ficou assim definido: Mato Grosso do Sul, capital Campo Grande, com área equivalente a 358.158,7 Km², enquanto Mato Grosso, capital Cuiabá, detém agora, área correspondente a 906.806,9 Km². Daí, a redução do número de estabelecimentos nesse período.

Analisando a mesma tabela, em relação ao ano de 1998, percebe-se que os estabelecimentos de menos de 10 a 100 hectares eram 42.985 (45,3\%), ocupando área de 1.922,049, ou seja, $2,4 \%$ do total geral. Entretanto, os grandes estabelecimentos de 10.000 a mais correspondiam a 1.169 (2,1\%), ocupando $31.255,523(39,6 \%)$ da área agricultável do Estado.

Enquanto os dados de 1985 e 1992 nos mostram redução na categoria grandes proprietários, pois de 46.422 (57,7\%) em 1985, que ocupavam 88.498,834 $(98,5 \%)$ da área, caíram para 33.273 (53,3\%) em 1992, correspondendo a 44.458,730 (97,3\%) hectares. Já os dados de 1992 e 1998 mostram pequeno aumento na distribuição de terras entre as classes que variam de menos de 10 a 100 hectares. O que era 29.072 (46,7\%) em 1992, ocupando 1.229,990 (27\%), passou em 1998 para 42.948 estabelecimentos, ou seja, 45 \% do número total, ocupando área equivalente a 1.822,049 (24\%) hectares. Só que, mesmo apontando a redução das áreas dos grandes estabelecimentos no período de 1985 e 1992 e um acréscimo nas pequenas unidades, os dados não indicam grandes mudanças na estrutura fundiária em Mato Grosso. Alguns dos municípios que foram surgindo no período de colonização, principalmente na porção Norte do Estado, na década de 1970/1980, mostram tendência à reconcentração das propriedades na classe de área entre 100 e 1.000 hectares ou mais.

A concentração de terras nas mãos de poucos é extremamente exagerada, comprometendo até a alimentação da população brasileira. Por isso, durante muito tempo - principalmente depois da década de 70, período em que começou a expansão das "fronteiras agrícolas" do Brasil para a região Amazônica - Mato Grosso foi tido como o maior palco de tensões sociais do Brasil.

Por causa da fronteira agrícola, houve crescimento demográfico e econômico em Mato Grosso. De acordo com Nascimento (1997:87-88), "O desenvolvimento da 
fronteira agrícola é a expansão do capitalismo no campo, processo complexo, com particularidades, como a criação de relações capitalistas e não-capitalistas em função da acumulação". A expansão da fronteira vai levando à concentração de terras e o movimento deste processo é pleno de conflitos. Portanto, os conflitos não vêm depois da concentração de terras, e sim, junto com ela.

Sabe-se que a estrutura fundiária é o traço fundamental para a concentração da terra e que isso se dá mais fortemente quando passa do nível regional para o estadual, principalmente, quando se refere ao Estado de Mato Grosso, onde essa concentração é fortíssima. E essa desigual distribuição de terras acaba provocando, também, desigualdade nas relações de trabalho no campo. Tanto uma quanto a outra têm raízes históricas. Já comentei anteriormente sobre as diferentes relações de trabalho em nosso país: escravismo, camponês, colonato, trabalho familiar, sem contar o morador, o agregado, o meeiro, o parceiro etc.

O número de estabelecimentos, segundo a condição do responsável em Mato Grosso, será apresentado a seguir na Tabela 3.

TABELA 3 - CONDIÇÃO DO RESPONSÁVEL EM MATO GROSSO (50-95/96)

\begin{tabular}{|c|c|c|c|c|c|c|c|c|c|c|c|c|}
\hline \multirow{2}{*}{$\begin{array}{c}\text { Classe de } \\
\text { Área }\end{array}$} & \multicolumn{12}{|c|}{ ESTABELECINENTOS } \\
\hline & 1950 & $\%$ & 1960 & $\%$ & 1975 & $\%$ & 1980 & $\%$ & 1985 & $\%$ & $1995 / 96$ & $\%$ \\
\hline Proprietário & 3485 & 68,8 & 7789 & 60,4 & 22052 & 39,3 & 31467 & 49,6 & 42007 & 54,0 & 57731 & 73,2 \\
\hline Arrendatário & 68 & 1,3 & 791 & 6,1 & 15142 & 26,9 & 13355 & 21,1 & 15128 & 19,4 & 2349 & 3,0 \\
\hline 0cupante & 1267 & 25,0 & 3661 & 28,4 & 16796 & 30,0 & 13613 & 21,5 & 13552 & 17,4 & 7746 & 9,9 \\
\hline Administrador & 247 & 4,9 & 643 & 5,1 & 2126 & 3,8 & 4948 & 7,8 & 7234 & 9,2 & 10935 & 13,9 \\
\hline Sem Declaração & 1 & 0,0 & 1 & 0,0 & - & 0,0 & - & 0,0 & - & 0,0 & 1 & 0,0 \\
\hline TOTAL & 5068 & 100 & 12885 & 100 & 56116 & 100 & 63383 & 100 & 77921 & 100 & 78935 & 100 \\
\hline \multirow{2}{*}{$\begin{array}{c}\text { Classe de } \\
\text { Área }\end{array}$} & \multicolumn{12}{|c|}{ ÁREA OCLPADA (HA) } \\
\hline & 1950 & $\%$ & 1960 & $\%$ & 1975 & $\%$ & 1980 & $\%$ & 1985 & $\%$ & $1995 / 6$ & $\%$ \\
\hline Proprietário & 4563764 & 64,8 & 5101418 & 65,3 & 9439726 & 43,0 & 12499728 & 36,2 & 14007069 & 37,0 & 21070249 & 42,3 \\
\hline Arrendatário & 339112 & 4,9 & 414964 & 5,3 & 183124 & 0,8 & 392733 & 1,1 & 372740 & 1,0 & 579799 & 1,1 \\
\hline Ocupante & 411747 & 5,8 & $30898 \mathrm{I}$ & 4,0 & 641307 & 2,9 & 1169456 & 3,4 & 695363 & 1,8 & 628478 & 1,3 \\
\hline Administrador & 1722546 & 24,5 & 1980863 & 25,4 & 11684989 & 53,3 & 20492630 & 59,3 & 22760471 & 60,2 & 27561104 & 55,3 \\
\hline Sem Declaração & 100 & 0,0 & 77 & 0,0 & - & 0,0 & - & 0,0 & - & 0,0 & - & 0,0 \\
\hline TOTAL & 7037269 & 100 & 7806303 & 100 & 21949146 & 100 & 34554547 & 100 & 37835651 & 100 & 49839630 & 100 \\
\hline
\end{tabular}

Fonte: Censo Agropecuário 1995/1996/IBGE. Organizada por Leida M. S. LIMA/2005.

Por intermédio dos dados censitários sobre a estrutura fundiária, percebem-se as mudanças nas relações de produção e de trabalho, pelos quais se pode identificar a condição do produtor, do responsável, através do proprietário, do arrendatário, do ocupante, do administrador e dos trabalhadores permanentes e temporários em relação ao emprego rural. Pela Tabela 3, nota-se que, a partir de 1950, houve aumento na proporção do número dos estabelecimentos explorados por 
proprietários, saltando de 3.485 (68,8\%) em 1950, para 57.731 (73,2\%) em 1975. Isso, em parte, resulta da aceleração da ocupação da fronteira agrícola em 1960, mantendo-se a política de colonização. No período de 1950 até 1960, as colônias criadas pelas colonizadoras eram desorganizadas, pelo fato de não cumprirem corretamente seu planejamento, deixando a desejar no tocante à assistência em saúde, educação, transporte, bem como à vida social das famílias migrantes que chegavam a fim de constituir a colônia.

De 1975 para 1995, houve aumento no número de estabelecimentos explorados por proprietários, pois de 22.052 (39,3\%) em 1975 passou para 57.732 $(73,2 \%)$ no ano de 1995 , elevando-se em menor proporção a área ocupada, que em 1975 era 9.439 .726 (43,0\%), chegando a 21.070.249 (42,3\%) em 1995. Entendo que, nesse período, houve, por parte do governo de Mato Grosso a legalização de ocupações ou a legitimação de posse, que conforme Moreno (1993:366): "A legalização estadual conservou o direito à legitimação de posse, desde que ficasse configurada a morada permanente e cultura efetiva, pelo prazo mínimo de 01 ano, e pelo trabalho familiar tenha tornado a área produtiva, dentro do limite constitucional". Muitas resultaram de atos de grilagem (Oliveira (1991), Moreno (1993), Becker (1994), entre outros), em decorrência da política adotada pelo governo federal de regularizar as terras públicas ocupadas.

Analisando os dados relacionados às categorias arrendatário e ocupantes, é perceptível que, em ambos os casos, houve aumento no período entre 1950 até 1975, época em que o acesso à terra, em Mato Grosso, não era ainda tão restrito. E, por ser um Estado com terras em abundância e pouco povoadas, muitos migrantes vinham em busca de terra para morar e, assim, constituir família. Nota-se que o número de arrendatário no período entre 1950 até 1960 é bem menor do que o de ocupante. Enquanto o primeiro, nesse período, somava $859(7,4 \%)$, totalizando $754.076(10,2 \%)$ da área, o segundo existia em número de 4.928 (53,4\%), absorvendo 720.728 (9,8\%) da área total. Porém, de 1975 para 1985, ou seja, nesses 10 anos, a proporção de ambas as categorias mantive-se quase equiparada, ou inalterada, em virtude do arrendamento de terras como forma de explorar o trabalhador na agricultura, principalmente para a formação de pastagens. Por esse mesmo motivo, houve diminuição drástica na categoria arrendatário que, de 15.128 (19,4\%), no período de 1985 para 2.349 (3,0\%) em 1995, apesar de a área ocupada por esse arrendatário ter aumentado nesse período. 
Em relação ao ocupante, que chagou a explorar 13.552 (17,4\%) dos estabelecimentos em 1985, teve sua participação reduzida para 7.746 (9,9\%) unidades. O mesmo tendo ocorrido com a área ocupada, que, em proporções bem menores, também foi diminuída, caindo de 695.363 (1,8\%) em 1985, para 628.478 $(1,3 \%)$ em 1995. Esta redução se deu em prol da transformação dessas categorias em proprietários, os quais foram beneficiados pelos projetos oficiais de colonização, que, aliás, foi extensiva também aos proprietários.

No que se refere aos administradores, cuja proporção subiu de 247 (4,9\%) em 1950 para $10.935(13,9 \%)$ em 1995, constata-se que esta categoria passou a responder pelo gerenciamento dos estabelecimentos rurais, principalmente após a década de 1975. Nesse período, o capitalismo no campo mato-grossense estava se expandindo e a organização da produção estava, agora, não mais diretamente nas mãos do proprietário, mas, sim, do administrador, principalmente nas empresas rurais com áreas acima de 2 mil hectares. Sendo assim, a modernização do campo em Mato Grosso já estava se evidenciando.

Nesses 45 anos, houve aumento expressivo do número de proprietários em Mato Grosso, pois os governos incentivaram a vinda de pessoas (com poder aquisitivo) para este Estado, incumbindo-se ele próprio de pedir autorização ao senado federal para vender terras que, sabidamente, eram indígenas ${ }^{64}$ e/ou já ocupadas por posseiros.

Conseqüentemente, os arrendatários ou ocupantes que viviam na terra, visando, principalmente, atender às necessidades de subsistência da família, aqueles que faziam parte das velhas formas não capitalistas, foram sendo expulsos dessas terras e se transformando, nos últimos anos, em trabalhadores assalariados temporários, passando a fazer parte das novas relações capitalistas de produção.

Os trabalhadores permanentes que antes existiam estão sendo substituídos por mão-de-obra especializada - o administrador, o contador, o operador de máquinas e implementos agrícolas etc., sem contar o aumento do trabalho análogo

\footnotetext{
${ }^{64}$ Esse processo de ocupação do norte mato-grossense, assentado na abertura dos projetos agropecuários e nos projetos de colonização privados, teve sua base na grilagem das terras e em verdadeiros massacres de nações indígenas inteiras. A maioria dos povos indígenas daquele estado teve suas terras griladas e tomadas à força pelos grupos econômicos e especuladores que, lançando mão de documentos falsos (certidões ou declarações atestando a não-existência de índios e/ou posseiros), foram obtendo títulos de terras dos vários governos do estado do Mato Grosso. Qualquer pesquisa elementar nos documentos de titulação de terras daquele estado (ainda hoje) atesta a imensidão de documentos falsos presentes nos processos. (...) O governo mato-grossense incumbiu-se, em 1973, de pedir autorização ao senado Federal para vender 2 milhões de hectares de terras em Aripuanã, um município sabidamente indígena. Este é um dos muitos episódios das falcatruas existentes no Mato Grosso, pois era cláusula contratual que se a empresa que adquirisse as terras não implantasse no prazo de 5 anos (até 1978 portanto) os referidos projetos, as terras voltariam para o patrimônio público. Oliveira, A U. A Agricultura Camponesa no Brasil. 1991. Pá.: 146.
} 
ao de escravo, vulgarmente conhecido como "trabalho escravo", que é a anulação da liberdade individual ${ }^{65}$. É, pois, o domínio completo ou a sujeição absoluta de uma pessoa, do trabalhador ao empregador, ao "patrão", onde este comete o crime de retirada da dignidade do trabalhador, de seus direitos trabalhistas e, principalmente, o direito à liberdade. Não se pode confundi-lo com a super-exploração do trabalho.

No texto "Sociedade e Governo vão a Mato Grosso reivindicar combate ao trabalho escravo", lene Lôbo (07/03/2006) esclareceu que, pelo fato de Mato Grosso ser uma das principais fronteiras agrícolas no país hoje, é também líder em mão-deobra escrava, pois foi neste Estado que um grupo móvel de fiscalização libertou o maior número de trabalhadores da escravidão. Segundo Lobo, o problema agravase por conta dos conflitos pela terra e pela quantidade de latifúndios que praticam a monocultura e que aliciam mão-de-obra de outras regiões para realizar o trabalho. A CPT considera Mato Grosso como a maior área de conflito agrário do país.

Em Mato Grosso, o governo do Estado, juntamente com várias entidades parceiras, elaborou um manual a fim de divulgar conceitos, normas técnicas e legislação, com a finalidade de levar esclarecimentos, orientações e informações a toda sociedade, principalmente aos empregadores e trabalhadores rurais. Deixa claro em um dos capítulos da revista informativa: Cidadania, Legislação e Trabalho Rural $^{66}$ que os trabalhadores libertados do regime de escravidão terão prioridade em programas de crédito, como o Programa Nacional de Agricultura Familiar PRONAF ${ }^{67}$. Sendo assim, pretendem buscar para esses trabalhadores - que em sua maioria foram excluídos do mercado de trabalho e estão em vulnerabilidade social e suas famílias, uma vida digna, melhoria na qualidade de vida, bem como geração de trabalho e renda.

Rondonópolis, assim como muitos municípios de Mato Grosso, passou por um processo de transformação acelerado, em relação às mudanças ocorridas no espaço natural, e em relação aos aspectos econômico e social. Pelas Tabelas 4 e 5, tem-se uma noção do que aconteceu em relação à distribuição dos estabelecimentos, bem como à condição do produtor neste município.

\footnotetext{
${ }^{65}$ Mato Grosso foi o estado brasileiro em que mais trabalhadores foram resgatados do trabalho escravo no ano passado. Segundo dados do Ministério do Trabalho e Emprego (MTE), foram libertados 1.411 trabalhadores no estado. Em todo o país foram 4.113 libertações. Mato Grosso está na fronteira agrícola brasileira e possui conflitos em relação a sua questão agrária. Fonte: www.brasiloeste.com.br/noticia/1765/trabalho-escravo. Texto: "Mato Grosso lidera casos de liberação de trabalhadores escravos no país". Autora: Irene Lôbo. 07/03/2006.

${ }^{66}$ Revista: Cidadania, Legislação e Trabalho Rural. Cuiabá: Governo do estado de Mato Grosso. 2005.

${ }^{67}$ Linha de crédito para trabalhadores libertados do regime de escravidão. Editado pela Secretaria de Comunicação de Governo e Gestão Estratégica da Presidência da República, nº.. 307 - Brasília, 13 de maio de 2005.
} 
Em 1960, com o advento dos geradores, inaugura-se em Rondonópolis o sistema de iluminação elétrica, um dos fatores que vieram contribuir para a vinda de migrantes a este município. Até então, os pequenos produtores rurais viviam em suas propriedades, em seus pequenos sítios que variavam entre 20 a 50 hectares, divididos ou loteados no sistema de $\operatorname{colônias}^{68}$, adquiridos a partir de 1920, tendo sido acelerado a partir de 1950, por conta dos incentivos governamentais para a expansão da fronteira agrícola. De acordo com Tesoro (1993:99), nesse período, a esperança estava no pasto e começam a surgir, a se formar outras propriedades que variavam entre 100 até 300 alqueires ${ }^{69}$. Verifique a seguir como se procedeu a distribuição dos imóveis rurais em Rondonópolis a partir de 1960.

TABELA 4 - DISTRIBUIÇÃO DOS ESTABELECIMENTOS EM RONDONÓPOLIS/MT

\begin{tabular}{|c|c|c|c|c|c|c|c|c|c|c|}
\hline \multirow[t]{2}{*}{ Grupos de Área Total (ha) } & \multicolumn{10}{|c|}{ EST A B ELECIMENTOS } \\
\hline & 1960 & $\%$ & 1970 & $\%$ & 1975 & $\%$ & 1980 & $\%$ & 1985 & $\%$ \\
\hline 0 a - de 20 & 520 & 37,4 & 3.585 & 74,8 & 3.760 & 73,6 & 1.445 & 57,8 & 1.046 & 50,1 \\
\hline 20 a - de 100 & 581 & 41,8 & 732 & 15,3 & 782 & 15,3 & 580 & 23,2 & 541 & 25,9 \\
\hline 100 a -de 1000 & 260 & 18,7 & 392 & 8,2 & 456 & , & 380 & 15,5 & 401 & 19,2 \\
\hline 1000 a - de 5000 & 23 & 1,6 & 63 & 1,3 & 88 & 1,7 & 76 & 3,0 & 87 & 4,2 \\
\hline Mais de 5000 & 07 & 0,5 & 20 & 0,4 & 23 & 0,4 & 14 & 0,5 & 14 & 0,6 \\
\hline Total & 1.391 & 100 & 4.792 & 100 & 5.109 & 100 & 2.503 & 100 & 2.089 & 100 \\
\hline \multirow[t]{2}{*}{ Grupos de Área Total (ha) } & \multicolumn{10}{|c|}{ ÁREA 0CUPADA (ha) } \\
\hline & 1960 & $\%$ & 1970 & $\%$ & 1975 & $\%$ & 1980 & $\%$ & 1985 & $\%$ \\
\hline 0 a - de 20 & 5.124 & 2,2 & 19.712 & 3,9 & 20.050 & 3,3 & 8.686 & 1,8 & 6.229 & 1,4 \\
\hline 20 a - de 100 & 24.196 & 10,5 & 31.873 & 6,4 & 33.218 & 5,4 & 12.271 & 2,5 & 24.827 & 5,5 \\
\hline 100 a -de 1000 & 77.185 & 33,7 & 130.217 & 26,0 & 153.080 & 25,0 & 123.716 & 25,6 & 127.075 & 28,0 \\
\hline 1000 a - de 5000 & 30.948 & 17,0 & 135.307 & 27,0 & 189.475 & 31,0 & 155.051 & 32,1 & 156.703 & 35,1 \\
\hline Mais de 5000 & 83.845 & 36,6 & 183.614 & 36,7 & 215.192 & 35,3 & $183.76 \mathrm{l}$ & 38,0 & 133.187 & 30,0 \\
\hline Total & 229.298 & 100 & 500.723 & 100 & 611.023 & 100 & 483.485 & 100 & $448.02 I$ & 100 \\
\hline
\end{tabular}

Fonte: Organizada por Lima, L.M.S/2005. Adaptado de Nascimento, F.A. S. 1997. Pág: 133.

A Tabela 4 mostra claramente que o ápice da ocupação de terras em Rondonópolis foi o período de 1960 para 1970, quando, por conta da caracterização da fronteira capitalista, novos espaços foram sendo incorporados ao processo

\footnotetext{
${ }^{68}$ Fato que será discutido no Item: Formação Territorial de Rondonópolis: Gênese do Campesinato.

${ }^{69}$ Em meados da década de 50, a propaganda sobre a qualidade das "terras de cultura" da região de ROO atingia os pequenos fazendeiros paulistas e mineiros, que se interessam e formam propriedades de 100, 200 e 300 alqueires, em resultado da aquisição de áreas novas e do processo de aglutinação dos lotes coloniais antigos, sobretudo de Mata Grande, Lageadinho e Naboreiro. Tanto os paulistas como os mineiros estavam a serviço do capital industrial, sendo notória a presença de empresas como a Brasmen e a Brasway com postos de compra de algodão na cidade, além da existência de empresas de grande porte de Uberlândia, encarregadas pela comercialização do arroz da região rondonopolitana. Até o início dos anos 70, estabeleceu-se às “terras de cultura” de ROO uma certa vocação pecuária, imposta pelos fazendeiros que preferiam a cria e recria de bovinos às "incertezas da agricultura”, como eles próprios costumam dizer. Tesoro, LLM. Rondonópolis-MT: Um Entroncamento de Mão Única. 1993:99.
} 
produtivo. Nesse ínterim, o pequeno produtor (0 a menos de 100 hectares) que era em número de 1.101 (79,2\%) em 1960, ocupando 29.320 hectares (12,7\%) da área, passa em 1970 para 4.317 (90,1\%), absorvendo 51.585 (10,3\%) do total. O médio produtor (100 a menos de 1000) subiu de 260 (18,7\%) em 1960, ocupando área equivalente a 77.185 (33,7\%) para 392 (8,2\%), com área igual a 130.217 (26,0\%) em 1970. Já o grande proprietário (1000 a mais de 5000), que em 1960 possuía 30 estabelecimentos (2,1\%) com área igual a 122.793 (53,6\%), passou para 83 estabelecimentos (1,7\%) em 1970, com espaço correspondente a $319.021(63,7 \%)$ da área total. A incorporação é por conta da última classe, concluindo-se que a fatia maior do bolo estava para a porção menor dos proprietários rurais.

Nota-se que, de 1960 para 1975, devido à fronteira agrícola, passa a ocorrer, neste município, maior abertura de terras, pois em todos os grupos de área houve acréscimo no número de estabelecimentos, sinal de que o espaço agrícola rondonopolitano, por intermédio da política de ocupação de suas terras, estava se expandindo. Mesmo assim, a partir de 1960, por causa do desmatamento para o plantio de pastagens, o pequeno agricultor começa a perder importância e, a partir de 1975, inicia-se a abertura dos cerrados para a cultura, inicialmente, do arroz e, em seguida, a entrada da soja.

Tanto no que se refere ao número de estabelecimentos quanto à área ocupada, os dados do período de 1960 para 1975 demonstram a evolução estrutural da classe de estabelecimentos inferiores a 100 hectares, embora no período de 1970 para 1975, em ambas as categorias (estabelecimentos e área ocupada), o crescimento foi bem menor, pois a concentração de terras começava a dar seus primeiros passos.

Pelos dados de 1975 e 1985, percebe-se que houve um declínio, ou seja, uma marginalização do pequeno produtor (0 a 100 hectares) em relação aos grandes proprietários, devido a essa modernização. Em 1975, os camponeses que eram 4.542 (88,9\%) foram reduzidos para 1.587 (76,0\%) em 1985, ocupando 53.268 $(8,7 \%)$ da área em 1975, caindo para 31.056 (6,9\%) no total em 1985. Comportamento semelhante ocorreu com os estabelecimentos com área entre 1000 a mais de 5000 hectares que diminuíram nesse período. Em 1975 eram 111 estabelecimentos (2,1\%), ocupando 404.667 hectares (66,3\%), enquanto em 1985 baixou para 101 estabelecimentos $(4,8 \%)$, ocupando 289.890 ha $(65,1 \%)$ do total. 
Voltando a analisar a Tabela, verifica-se que, de 1975 para 1980, houve redução no número de estabelecimentos, bem como na área ocupada neste município em todos os grupos de área, fato explicado pelo desmembramento de $3.906,90 \mathrm{Km}^{2}$ de sua extensão territorial para a criação do município de Pedra Preta $^{70}$.

A rápida conquista do cerrado, principalmente pelos sulistas a partir de 1970, fez com que muitos produtores passassem a procurar os bancos para poderem desenvolver seus projetos. Sendo assim, saíam em busca de empréstimos e financiamentos tanto para a agricultura quanto para a pecuária, os quais, no início, eram obtidos com juros baixos, contribuindo, a posteriori, para o endividamento de muitos agricultores que acabaram tendo suas terras confiscadas pelos bancos.

Um dos programas do governo militar era a incorporação das áreas periféricas do país às localidades mais desenvolvidas, ou seja, à região Sudeste e Sul. Portanto, a ocupação do cerrado foi uma política territorial do próprio Estado, pois, por intermédio da expansão da fronteira agrícola para o Centro-Oeste brasileiro, amenizaria os problemas que estavam sendo criados no campo, por causa da modernização da agricultura, da concentração fundiária que expulsava, expropriava do campo os trabalhadores permanentes sulistas e nordestinos. Sendo assim, começa a consolidar-se a fronteira capitalista no cerrado e Rondonópolis, por estar em local privilegiado em relação às vias de acesso (BR 163 e BR 364), foi escolhida por vários migrantes, contribuindo, então, para maior concentração de terras neste município.

Com esse advento, ou seja, com o desenvolvimento do capitalismo no campo rondonopolitano, passam a acontecer os grandes empreendimentos agrícolas, e com eles também os problemas, os conflitos sociais no campo. Pode-se citar, como exemplo, a ocupação das terras da Fazenda Floresta por posseiros, na década de 1970, dando origem ao Assentamento Gleba Cascata. Sem contar que isso leva os pequenos proprietários à forte estagnação econômica, resultante de uma série de problemas enfrentados pelo pequeno produtor o qual fica sempre em desvantagem em relação ao latifundiário, impulsionando-o a realizar trabalhos ocasionais, temporários nas grandes propriedades.

\footnotetext{
${ }^{70}$ A Lei $\mathrm{n}^{\circ}$. 3.688, de 13 de maio de 1976, de autoria do deputado estadual Afro Stefanini, criou o município: “Artigo $1^{\circ}$ - Fica criado o município de Pedra Preta, desmembrado de área do município de Rondonópolis, com sede na localidade do mesmo nome... Artigo $3^{\circ}$ - Nos termos da Lei Complementar $\mathrm{n}^{\circ}$.. 1, o município será instalado no dia 31 de janeiro de 1977, com a posse do prefeito, vice-prefeito e vereadores, a serem eleitos no dia 15 de novembro de 1976”. Ferreira, JCV. Mato Grosso e seus Municípios. Cuiabá, 1997. Pág.: 503.
} 
TABELA 5 - CONDIÇÃO DO PRODUTOR EM RONDONÓPOLIS: POR ESTABELECIMENTO E POR ÁREA

\begin{tabular}{|c|c|c|c|c|c|c|c|c|c|c|c|c|}
\hline CLASSSES & \multicolumn{12}{|c|}{ ESTABELECIMENTOS } \\
\hline Proprietário & 1.090 & 84,8 & 1.642 & 34,2 & 1.553 & 30,4 & 1.251 & 50,8 & 1.483 & 71,0 & 1.368 & 92,6 \\
\hline Arrendatário & 179 & 14,0 & 2.265 & 47,2 & 2.647 & 51,0 & 656 & 26,6 & 312 & 14,9 & 52 & 3,5 \\
\hline Parceiro & 00 & 0,0 & 328 & 6,8 & 365 & 7,2 & 129 & 5,2 & 75 & 3,6 & 05 & 0,4 \\
\hline TOTAL & 1.285 & 100 & 4.798 & 100 & 5.110 & 100 & 2.463 & 100 & 2.88 & 100 & 1.477 & 100 \\
\hline \multirow[b]{2}{*}{ CLASSES } & \multicolumn{12}{|c|}{ ÁREA OCUPADA (HА) } \\
\hline & 1960 & $\%$ & 1970 & $\%$ & 1975 & $\%$ & 1980 & $\%$ & 1985 & $\%$ & 1996 & $\%$ \\
\hline Proprietário & 144169 & 94,9 & 483095 & 94,0 & 501127 & 95,1 & 426464 & 94,4 & 421952 & 94,1 & 350559 & 97,0 \\
\hline Posseiro & 1.786 & 1,2 & 9.330 & 1,8 & 5.830 & 0,9 & 8.299 & 1,9 & $2.90 \mathrm{l}$ & 0,6 & 1.337 & 0,4 \\
\hline TOTAL & 151896 & 100 & 513865 & 100 & 611.120 & 100 & 451.488 & 100 & 448.063 & 100 & 360.757 & 100 \\
\hline
\end{tabular}

Fonte: Censo Agropecuário de 1960 a 1995/96. LIMA, L.M.S (2005)

A Tabela 5 nos mostra a classificação dos produtores e sua distribuição pelo território rondonopolitano no período de 1960 para 1996.

Com a criação do primeiro Código de Terras de Mato Grosso, em 1950, prevendo a implantação de colônias agrícolas em terras desocupadas e às margens das ferrovias (hoje, Mato Grosso do Sul) e das rodovias, grande contingente de agricultores de várias regiões foi atraído para diferentes regiões no Estado, impulsionando a fronteira agrícola.

A doação de terras em Rondonópolis, num período de mais ou menos 30 anos, entre as décadas de 1920 para 1950, época do surgimento de várias colônias neste município, encerrou-se a partir de 1950, quando o governo estadual Fernando Correa da Costa suprime a doação de terras devolutas no Mato Grosso. Mesmo assim, inúmeros foram os trabalhadores rurais que vieram em busca de terra para trabalhar e morar ${ }^{71}$.

Pelos dados contidos na Tabela 5, verifica-se que, de 1960 para 1970, época em que começa a desencadear o processo de modernização no campo, em que grande capital está sendo injetado no cerrado mato-grossense com a vinda de grupos econômicos paulistas e de grandes produtores de arroz e soja, muda

\footnotetext{
${ }^{71}$ No início dos anos 50, a nova política do Governo extingue o sistema de doação de lotes de terras devolutas do Estado, medida que permite que a leva de migrantes que chagava em ROO (principalmente mineiros e capixabas) formasse um verdadeiro exército de mão-de-obra disponível para a lavoura: trabalhadores assalariados, arrendatários, meeiros e posseiros. A grande quantidade de mato da região e a falta de mecanização da lavoura requisitavam muitos braços, tanto para o desmatamento quanto para as roças e formação de pastos. Tesoro, LLM. Rondonópolis-MT: Um Entroncamento de Mão Única. 1993: 88.
} 
totalmente o comportamento econômico e social deste município. E todas as classes de áreas, isto é, o número de proprietários, arrendatários, parceiros (que era nulo em 1960) e posseiros, elevaram-se.

Nesse período, o destaque maior é por conta dos arrendatários que, de 179 (14,0\%) em 1960 passam para $2.265(47,4 \%)$ em 1970, seguidos pelos posseiros, pois, de 16 (1,2\%) aumentaram para $563(11,3 \%)$ e, até os parceiros que não existiam em 1960 (pelo menos nos registros por mim verificados), já em 1970 estavam representando 328 (6,9\%) do total dos estabelecimentos em Rondonópolis.

Até 1970, as atividades agropecuárias eram realizadas manualmente, e depois desse período começam a se modernizar, a utilizar equipamentos mais modernos e sofisticados. Uma boa parte dos proprietários trabalhava mais com a pecuária do que a agricultura, sendo que esta acabava ficando por conta dos menos favorecidos. O sistema de arrendamento passa a consistir num bom negócio, tanto para a agricultura quanto à pecuária, pois a família do arrendatário permanecia na fazenda por muitos anos, entregando-a, posteriormente, formada de capim para o gado. 72

Além dos arrendatários, passam a figurar neste município os posseiros os quais, normalmente, trabalham uma porção maior de terras que os arrendatários. Esse parceiro tinha por obrigação não deixar o mato crescer em torno da plantação e colher, manualmente, na época exata, para que não houvesse perda da plantação.

Os trabalhadores dispensados da terra, devido ao Estatuto do Trabalhador Rural em 1963 e pelo Estatuto da Terra em 1964, bem como deslocados das glebas por fazendeiros e empresários por intermédio da modernização no campo, foram instalando-se nas áreas desocupadas, fazendo crescer o número de posseiros neste município, cuja mentalidade era trabalhar no sistema familiar.

De 1975 para 1996, houve redução em todas as categorias. Nesses vinte e um anos, ocorreram alterações que influenciaram a diminuição de todas elas. Em 1976, aconteceu o desmembramento do município de Pedra Preta; em 1989, reduzse novamente o município de Rondonópolis, perdendo 485,25 km² de sua extensão

\footnotetext{
${ }^{72} \mathrm{Na}$ medida em que "formavam um talhão" (ou seja, deixavam plantado o capim no terreno), logo passavam para outro, e assim sucessivamente. (...) Para o sr. Martinez, um dos fatores que alterou a continuidade desse processo foram as Leis do Estatuto da Terra; aprovadas na época do presidente Castelo Branco, beneficiam os arrendatários que, em permanecendo a partir de dois anos em terras de terceiros, plantando lavoura e efetuando qualquer tipo de melhoria, podem vir a requerer a posse da área ou uma indenização proporcional, ou seja, prevê que o legítimo proprietário da terra é aquele que nela trabalha. Estas leis - segundo o entrevistado - embora justas despertaram a desconfiança nas relações entre proprietários e arrendatários, decorrendo daí a dispensa da grande maioria desses trabalhadores que, então, passaram a ir tentar a vida na cidade. Idem. Pág.: 104/105.
} 
territorial para a criação do município de São José do Povo ${ }^{73}$; e de 1970 para 1996, surgem, neste município recém-criado, os Assentamentos: Gleba Cascata (1970), Gleba Rio Vermelho (1988) e Vale do Bacuri (1996), onde 700 famílias foram beneficiadas.

Pela Tabela 5, pode-se avaliar que o período entre 1970/75 foi caracterizado por um acréscimo do número de estabelecimentos de proprietários em Rondonópolis, época em que os solos do cerrado passaram por processo de transformação, dando lugar à monocultura de soja. Nesse período, o número de pessoas vindas de outras áreas, principalmente do Sul, foi muito grande. Os dados permitem inferir que esse mesmo período marca o avanço geral da participação dos camponeses arrendatários, bem como dos camponeses parceiros e mesmo dos camponeses posseiros. Acredito que isso esteja relacionado ao fato de os mesmos terem sido expropriados de outras regiões do país e continuarem existindo com as mesmas características. A participação deste último na agropecuária de Rondonópolis era expressiva, e acentuou, mais ainda, por causa dos conflitos que já vinham ocorrendo em Mato Grosso, em virtude da não realização da reforma agrária e de sua exploração pelos grandes latifundiários. Não se deve esquecer de que tanto ao arrendatário, quanto ao parceiro e ao posseiro, é negada a propriedade capitalista da terra.

De 1980 para 1996, houve decréscimo acentuado dessas três categorias, pois, com o capitalismo, passa a ocorrer a modernização da agricultura. Assim, o homem é substituído pela máquina e aquele compadrio existente anteriormente, ou seja, aquela cordialidade em que o proprietário cedia um cantinho de sua terra para que esse trabalhador pudesse morar e produzir, em troca de prestação de serviços, da entrega de parte dos produtos por ele produzidos ou mesmo da entrega em dinheiro (renda pré-capitalista) $)^{74}$, aquelas relações de apadrinhamento, de

\footnotetext{
${ }^{73}$ A Lei Estadual $n^{\circ}$.. 5.486, de 04 de julho de 1989, de autoria da Bancada do PDS, PFL e PMDB, criou o município: “Artigo $1^{\circ}$ - Fica criado o município de São José do Povo, desmembrado do município de Rondonópolis... Artigo $2^{\circ}$ - O município criado é constituído de um só distrito, da sede... Parágrafo Único - O município somente será instalado com a eleição e posse do prefeito, vice-prefeito e vereadores, realizada de conformidade com a Legislação Federal”. Ferreira, JCV. Mato Grosso e seus Municípios. Cuiabá, 1997. Pág.: 592.

${ }^{74}$ As formas da renda pré-capitalista na origem são três: renda-em-trabalho, renda-em-produto e renda-em-dinheiro. A renda-em-trabalho, consiste na forma mais simples de renda fundiária, pois o produtor direto, com seus instrumentos de trabalho (que lhe pertencem de fato ou de direito), durante parte da semana, mês ou ano, trabalha as terras de outrem, muitas vezes coercitivamente, recebendo em troca apenas o direito de lavrar parte dessas terras para si próprio. Ou seja, o trabalhador dá gratuitamente (coercitivamente) dias de trabalho a outrem. A renda-em-produto se origina do fato de que o trabalhador cede parte de sua produção pela cessão do direito de cultivar a terra de outrem. Aqui, a coerção desaparece, substituída pelo direito. Muitas vezes essa cessão é feita através de contratos. Essa forma de renda, evidentemente redefinida pelo próprio capital, está presente na agricultura brasileira através das diferentes formas de parceria: a meação, a terça, a quarta etc. ela nada mais é do que a renda-em-trabalho convertida em produto.

A renda-em-dinheiro se origina da conversão, da simples metamorfose da renda-em-produto em renda-em-dinheiro. Assim, ela difere da renda capitalista da terra, que é sempre excedente acima do lucro médio. Ou, em outras palavras, o trabalhador, em vez de entregar parte do produto colhido ao proprietário da terra, converte esse produto em dinheiro e o entrega a esse mesmo proprietário. Para que essa forma de renda pré-capitalista exista é necessário que os produtores diretos convertam sua produção em mercadoria, isto é, é preciso que eles sejam
} 
testemunha nas cerimônias religiosas do casamento e do batismo, que lhes dava o título oficial de padrinho, afilhado, compadre, entre o proprietário e o parceiro, o meeiro, o morador, vai aos poucos desaparecendo. Muitos deles passaram a integrar os movimentos sociais surgidos nesse ínterim, em busca de um pedaço de terra. Exemplificando, citam-se, em Rondonópolis, os Assentamentos São Francisco, Carimã e Primavera, criados em 1997, os quais beneficiaram 400 famílias e o Assentamento Coqueiro, criado em 1998, favorecendo mais 50 famílias. Sinal de que a luta pela terra de trabalho continua e, assim, como disse Oliveira (1991:140): "os posseiros vão se enxergando como classe, se unindo e colocando em marcha seu projeto futuro".

Pelas tabelas apresentadas, foi possível ter noção de como se deu a concentração fundiária em nosso país, em Mato Grosso e em Rondonópolis, bem como a desigual distribuição das terras de trabalho no campo, onde a reconcentração em algumas áreas do país contribuiu para o aumento do trabalho familiar e do trabalho assalariado. Motivos que edificam a contradição do processo de desenvolvimento do capitalismo no campo, pois, ao mesmo tempo em que amplia o espaço para as pequenas unidades camponesas se reproduzir com suas famílias por intermédio da criação dos assentamentos, recebe também os assalariados nas grandes unidades capitalistas, nas grandes empresas rurais. Daí, ser importante e necessário estudar a questão agrária, para entender os processos sociais ocorridos no campo.

\subsection{Questão Agrária no Brasil: Um Problema}

A questão agrária é vista, entendida e interpretada sob diferentes enfoques, seja na literatura política na qual se vêem os problemas da concentração da propriedade da terra; seja na sociologia, cujo conceito é utilizado para explicar as formas como se desenvolvem as relações sociais; seja na história, que ajuda a explicar a evolução da luta política e a luta de classes; ou na geografia, que explica a forma como as sociedades vão se apropriando e ocupando a terra, um bem natural, que deveria pertencer igualmente a todos, sem distinção.

produtores diretos de mercadorias, daí essa ser a forma mais desenvolvida da renda pré-capitalista. Essa forma de renda, transformada pelo capital, é também comum na agricultura brasileira, onde um grande número de trabalhadores expropriados de suas terras arrendam terras de outros proprietários, a fim de produzir através do trabalho familiar. Oliveira. 1995:77-78. 
Em relação à questão agrária no Brasil, é mister citar dois problemas agrários, considerados fundamentais por Martins (1975:51-2) nesta temática e com os quais concordo plenamente: "o rompimento da combinação entre relações de trabalho e produção direta, pelos próprios trabalhadores, dos seus meios de vida (...) e, a ocupação de novas terras nas fronteiras econômicas do país".

No primeiro caso, pode-se citar como exemplo o incremento de alguns produtos agrários, em especial a cana-de-açúcar, cuja parte do salário passa a ser paga em dinheiro, não mais em espécie, ocorrendo, assim, redução no padrão de vida dos trabalhadores. Esse tipo de problema afetou em especial a região açucareira do Nordeste, onde passaram a ocorrer manifestações por parte dos movimentos políticos e sociais.

Em relação ao segundo problema, a ocupação nas fronteiras ${ }^{75}$, o caso geralmente se dá a partir do momento em que o trabalhador rural é expulso, excluído da terra onde trabalhava e produzia para seu sustento e de sua família e sai à procura de novas terras. Esse trabalhador passa a ocupar terras indígenas, ou seja, um posseiro tentando ocupar as terras dos primeiros posseiros. Geralmente, o proprietário "legalmente titulado", ao descobrir que as terras já foram abertas por posseiros, passa a requerer seus direitos e, assim, começam os atritos, tendo os posseiros lutando contra os indígenas, e também contra os capitalistas latifundiários.

Têm-se, pois, duas fronteiras: a demográfica e a econômica, e o posseiro situado entre ambas, constituindo, assim, a conhecida frente de expansão ${ }^{76}$, que, para Martins (1997:158), é "a frente da população não incluída na frente econômica". À medida que a fronteira econômica avança sobre a fronteira demográfica, passa a instaurar os empreendimentos econômicos, ou seja, as empresas imobiliárias, as ferroviárias, as comerciais, as bancárias etc., pois a frente de expansão não está descolada dos avanços da produção capitalista. E, nesse embate, não se pode negar o caráter social e histórico estabelecido no momento de contato da população

\footnotetext{
${ }^{75}$ A fronteira é, sobretudo, no que se refere aos diferentes grupos dos chamados civilizados que se situam “do lado de cá”, um cenário de intolerância, ambição e morte. É, também, lugar de elaboração de uma residual concepção de esperança, atravessada pelo milenarismo da esperança no advento do tempo novo, um tempo de redenção, justiça, alegria e fartura. O tempo dos justos. Já no âmbito dos diversos grupos étnicos que estão “do outro lado”, e no âmbito das respectivas concepções do espaço e do homem, a fronteira é, na verdade, ponto limite dos territórios que se redefinem continuamente, disputados de diferentes modos por diferentes grupos humanos. Na fronteira, o chamado branco e civilizado é relativo e sua ênfase nos elementos materiais da vida e na luta pela terra também o é. Martins, J.S. Fronteira: A Degradação do Outro nos Confins do Humano. 1997: 11-12.

${ }^{76}$ (...) Os antropólogos, (...), sobretudo a partir dos anos cinqüenta, definiram essas frentes de deslocamento da população civilizada e das atividades econômicas de algum modo reguladas pelo mercado, como frentes de expansão. Como sugere Darcy Ribeiro, (...) elas constituem as fronteiras da civilização. (...) Ela expressa a concepção de ocupação do espaço de quem tem como referência as populações indígenas, enquanto a concepção de frente pioneira não leva em conta os índios e tem como referência o empresário, o fazendeiro, o comerciante e o pequeno agricultor moderno e empreendedor. Martins, J.S. Fronteira: A Degradação do Outro nos Confins do Humano. 1997:152.
} 
indígena, do posseiro, da fronteira demográfica e da fronteira econômica. Contato esse que resultou no extermínio de grande parte da população indígena e da expropriação dos trabalhadores pobres, ou seja, dos lançadores dos germes da ocupação territorial da fronteira demográfica. Enquanto a frente demográfica é constituída da população que ocupava a fronteira - caso das populações indígenas, dos camponeses, dos peões, dos caboclos, dos sem-terra -, a frente econômica constitui-se por uma ocupação mais mercantil da terra, efetuada pelo pioneiro, ou seja, pelo empresário, o fazendeiro, o comerciante e o pequeno agricultor moderno e empreendedor.

Portanto, quando a frente pioneira sobrepõe-se à frente de expansão ${ }^{77}$, passam a ocorrer os conflitos que, no Brasi,I marcaram as regiões do Oeste do Paraná; do Norte de Mato Grosso e do Araguaia; Contestado, Porecatu, Pato Branco, Francisco Beltrão (Santa Catarina e Paraná); Trombas e Formoso em Goiás; Vale do Murici em Minas Gerais e, mais recentemente, as regiões de Corumbiara em Rondônia e Eldorado dos Carajás no Pará. Tais conflitos vêm evidenciar como a questão agrária tem sido tratada pelos nossos governantes. E essa violência só vem comprovar, ou seja, revelar o que disse Oliveira (1996:113): "Os latifundiários dizem que as terras são suas, mas qualquer apuração jurídica nos processos de aquisição de terras públicas particularmente na Amazônia, vai revelar os mecanismos de burla, falsificação e grilagem". Fato comum no Brasil desde o período das sesmarias, intensificando-se em 1850 com a Lei de Terras $^{78}$.

O problema de grilagem, da falsificação, da expropriação e da exploração do trabalho humano e da acumulação de terras por parte de uma minoria, não é recente. $\mathrm{E}$ hoje, concretamente, pode-se dizer que, desde o período colonial, a propriedade capitalista da terra e o trabalho livre são as duas bases fundamentais da questão agrária no Brasil, onde a primeira adquiriu forma e força, a partir de 1850, com a Lei de Terras e a segunda, a partir de 1888, com a promulgação da Lei da

\footnotetext{
${ }^{77}$ A distinção entre frente pioneira e frente de expansão é, na melhor das hipóteses, um instrumento auxiliar na descrição e compreensão dos fatos e acontecimentos da fronteira. É um instrumento útil quando as duas concepções são trabalhadas na sua unidade, quando destaca a temporalidade própria da situação de cada grupo social da fronteira e permite estudar a sua diversidade histórica não só como diversidade estrutural de categorias sociais, mas também, como diversidade relativa aos diferentes modos e tempos de sua participação na História. Martins, JS. 1997:159-160.

${ }^{78}$ Os ocupantes de terras e os possuidores de títulos de sesmarias ficaram sujeitos à legitimação de seus direitos, o que foi feito em 1854 através do que ficou conhecido como “registro paroquial”. Tal registro validava ou revalidava a ocupação da terra até essa data. Isso não impediu o surgimento de uma verdadeira indústria de falsificação de títulos de propriedades, sempre datados de época anterior ao registro paroquial, registrados em cartórios oficiais, geralmente mediante suborno aos escrivães e notários. Martins, J.S. O Cativeiro da Terra. $6^{a}$ ed. São Paulo: Hucitc, 1996, pág.: 29.
} 
Abolição da Escravatura. A última veio contribuir para a criação do mercado de trabalho livre de força de trabalho.

Por um lado, ocorreu sua expropriação da terra já que não era mais um trabalhador permanente, pois fora substituído pelo trabalhador imigrante e, por outro, não poderia ser proprietário, por não dispor de capital para a compra, para a aquisição da terra, já que a Lei assim o exigia.

Portanto, sob qualquer concepção, a questão agrária é importante porque aparece como um problema que deve e precisa ser resolvido por toda a sociedade, através de ações políticas concretas e não com medidas técnicas. É, pois, uma questão política, que envolve não só os trabalhadores do campo, mas a sociedade como um todo, pois, como lembrou Oliveira (1991:7): "As greves no campo e nas cidades mostram que cidade e campo não podem ser separados (...) Movimento dos trabalhadores rurais sem-terra caminham pelas estradas, acampam e lutam no campo, e na cidade marcham pela reforma agrária. A luta pela terra no campo só pode ser feita na cidade". Daí, afirmar que necessária se faz a participação da sociedade no debate político, que vem se intensificando nas últimas décadas, pois, "terra e poder estão juntos na sociedade brasileira". (Martins: 1986:16).

No item Origens da Propriedade da Terra e do Problema Fundiário no Brasil, foi visto como se deu o processo de ocupação das terras brasileiras e, conseqüentemente, suas implicações. Ocasionando no início a acumulação de terras por parte dos portugueses, em virtude das capitanias hereditárias ${ }^{79}$ e das sesmarias, que deram origem, em Pernambuco, à propriedade privada da terra; o tráfico negreiro, pelo qual a mão-de-obra escrava foi usada, explorada intensamente para satisfazer as necessidades de uma minoria detentora do poder; o aprisionamento e extermínio de índios para serem utilizados também como mão-deobra; a exploração e esgotamento dos solos ocupados, principalmente, pela monocultura; a posteriori, o incentivo à vinda de imigrantes para trabalhar, especialmente, nas lavouras de café; intensificação, ou seja, expansão do capitalismo no campo, modernização da agricultura, através não só da introdução de maquinários, como também de diferentes produtos químicos nas lavouras e nos pastos, que contribuíram para a expropriação e exclusão do homem do campo,

\footnotetext{
${ }^{79}$ Com a instituição das capitanias hereditárias, a coroa portuguesa alcançava duplo objetivo: garantir a posse e colonização das terras recémdescobertas e livrar-se das despesas dessa mesma colonização, ao tempo em que lançava as bases de novas fontes de renda. Borges, Fragmon Carlos. Origens Históricas da Propriedade da Terra. In: A Questão Agrária no Brasil. Textos dos Anos Sessenta. 1980.
} 
culminando, assim, com a revolta desses trabalhadores que lutam por uma reforma agrária justa e igualitária.

Mas, afinal, o que é reforma agrária e por que ela é aceita por uns e temida por parte dos grandes latifundiários?

Reforma agrária é, pois, quando ocorre "a transformação na estrutura da propriedade da terra, não do capital" (Minc, 1985: 17-8). O autor acrescenta, ainda, que o que está em "jogo na reforma agrária é a passagem da propriedade da terra de uma classe social (latifúndio) para outra (camponesa)", e é justamente aí que se encontra o cerne da questão. Os problemas, envolvendo latifundiários e camponeses, em relação à reforma agrária, dão-se pelo fato de os primeiros irem acumulando enormes extensões de terras e provocando a desapropriação, a exclusão da classe trabalhadora rural, enquanto os segundos lutam a fim de permanecerem na terra de trabalho, para conquistar essa terra.

Para Gancho et al (1991:71), são as "mudanças na estrutura fundiária de um país, com vistas a aumentar a produção e redistribuir a renda e o poder". Isso significa dizer que, em nosso país, a estrutura agrária é deficitária, ocorrendo, inclusive, a má distribuição da terra, pois muita gente tem pouca terra para trabalhar, enquanto poucas pessoas controlam muita terra e nem sempre a utilizam para o bem público. Reforma agrária é, portanto, uma transformação na estrutura da propriedade da terra e não do capital. É a transferência da propriedade da terra de uma classe social para outra, ou seja, do latifundiário para o camponês, para o semterra.

Este é um fato verdadeiro em nosso país e tende a agravar-se. Daí, a necessidade de se fazer uma reforma agrária, ou seja, de redistribuir as terras não utilizadas, principalmente, aos trabalhadores, aos lavradores que foram expulsos das terras onde trabalhavam. Expulsões estas, ocorridas não só pela concentração da terra por parte dos grandes proprietários, mas também por conta das mudanças internas em várias propriedades, nas quais as lavouras (que requeriam muita mãode-obra) foram substituídas por pastagens; máquinas substituindo os homens e conseqüentemente, o êxodo rural desse trabalhador para a cidade, onde passa a engrossar a massa de trabalhadores disponíveis na cidade, ou seja, o "exército de reserva".

Esses trabalhadores, com certeza, querem e lutam por uma reforma agrária distributiva, onde possa ter acesso à terra e aos recursos para nela trabalhar, 
passando a ter condições de decidir sobre sua vida, não só como trabalhador, mas, principalmente, como cidadão.

O interesse pela reforma agrária é só do homem do campo? Acredito que não, pois, se o trabalhador rural expropriado fosse incluído em um programa de distribuição de terras, com certeza, haveria diminuição nas pressões do desemprego, menor exploração do trabalhador da cidade, melhoria nos salários, aumento na produção de alimentos, diminuição dos preços desses alimentos e melhor qualidade de vida para ambos. Sem contar que, no assentamento, é beneficiado por lei, por normas ou regras de organização, o que dificulta a desagregação familiar; fatores não existentes em áreas consideradas como "ocupações indevidas".

$\mathrm{Na}$ verdade, penso que a reforma agrária interessa até mesmo aos capitalistas, pois, assim, o mercado interno estaria fortalecido, e eles poderiam continuar investindo na agricultura através da empresa rural, protegida pela lei, sem se sentirem "culpados" pela falta de alimentos no mercado interno.

Enfim, a reforma agrária interessa a toda a sociedade que entende representar mudanças no processo de consolidação da democracia. Daí, ser necessária a participação de todos nesse debate, pois cidade e campo estão articulados. Na cidade existe a força dos oprimidos da cidade e do campo, onde a questão política do primeiro centra-se no eixo da exploração, enquanto o eixo da questão política no campo baseia-se na expropriação.

A reforma agrária é, pois, a esperança para milhões de camponeses, trabalhadores rurais, sem-terra ou com pouca terra, de possuírem um local onde não mais sejam jogados de um canto a outro, para que não se sintam mais estranhos fora do ninho, uma ave de arribação que migra constantemente, realizando a "caminhada no chão da noite" 80 em busca de um futuro melhor.

Todavia, é obvio que a reforma agrária não interessa aos grandes latifundiários, detentores de extensas propriedades, aos capitalistas que mantêm suas propriedades somente para fins de especulação, pois estes veriam seu poder e domínio diminuídos, caso a democratização do acesso à terra ocorresse. Esses vêem a reforma agrária como uma ameaça, pois sabem que suas terras não estão cumprindo a função social prescrita em lei.

\footnotetext{
${ }^{80}$ Martins, J.S. Caminhada no Chão da Noite. São Paulo: Hucitec, 1989.
} 
Portanto, o latifundiário com terras improdutivas tem medo da reforma agrária e deseja manter um Brasil atrasado, um agricultor expropriado e por que não, explorado. De uma coisa tenho certeza, o capitalista, o latifundiário que põe sua terra para produzir, que cumpre a função social através da lei, este não teme a reforma agrária.

Desde os tempos iniciais, a história da propriedade da terra no Brasil tem sido uma história de exclusão e marginalização de populações, começando pelos povos indígenas, depois os escravos negros, os brancos que vieram deportados de Portugal e, posteriormente, os inúmeros imigrantes europeus vindos para cá. E isso proporcionou, com o passar do tempo, o crescimento de um excedente populacional útil, mas que acabava, às vezes, sendo excluído do processo de trabalho, bem como do meio pelo qual poderia realizá-lo, ou seja, a terra.

O tema reforma agrária é visto e entendido por alguns como palavra do passado, em virtude das transformações na agricultura nos últimos anos; mas, na realidade, é uma bandeira atualíssima e bem sustentada. É obvio que existem opiniões divergentes, pessoas equivocadas nos meios acadêmicos, político, na mídia etc. Pessoas que, como disse Martins (2000:88), "prestam um grave desserviço aos trabalhadores rurais que, não raro arriscando a vida, optam pelo enfrentamento e pelas ocupações como última alternativa para sair da pobreza e viver com dignidade".

A primeira vez que se debateu, na Constituinte, a necessidade da reforma agrária, foi em 18/06/1946, quando o senador Luiz Carlos Prestes apresentou em seu discurso ${ }^{81}$ na assembléia Nacional Constituinte a Proposta de Reforma Agrária da Bancada do PCB e esta foi derrotada pela maioria conservadora do parlamento.

Segundo o senador Prestes, as causas do atraso na economia brasileira se davam por conta do monopólio da terra, na propriedade privada e na concentração da propriedade, e, se não houvesse uma modificação no conceito de propriedade monopolista da terra, a miséria da grande massa camponesa sem-terra continuaria determinando a miséria da renda nacional e, conseqüentemente, da renda pública.

Sua proposta determinava que as terras mal utilizadas, ou que não estivessem sendo usadas de forma alguma, deveriam ser desapropriadas, voltar ao patrimônio estatal para que fossem redistribuídas a quem nelas soubesse trabalhar,

${ }^{81}$ O discurso pronunciado pelo senador Luiz Carlos Prestes está contido em: Stedile, J.P. (org.). A Questão Agrária no Brasil: Programas de Reforma Agrária 1946-2003. São Paulo: Expressão Popular, 2005: 17 a 28. 
soubesse fazê-las produzir. A propriedade da terra deveria estar vinculada ao uso social para produção e não ao uso particular para especulação.

A proposta foi derrotada e, sem ela, a concentração fundiária aumentava, bem como os conflitos sociais e os movimentos migratórios de camponeses pobres, que passaram a ocupar terras em áreas de colonização. E a colonização, geralmente, é visualizada em função da fronteira demográfica e da fronteira econômica onde a especulação e a apropriação de terras sobrepõem-se aos desígnios democráticos e sociais. Ao invés de uma oferta abundante de terras livres nas quais centenas de milhares de famílias iriam constituir pequenas e médias propriedades, com apoio e assistência técnico-financeira, enfim, uma reforma agrária natural, surge, porém, o novo latifúndio e aumentam os conflitos sociais.

Por conta de vários debates políticos e científicos que estavam acontecendo no governo de João Goulart, em 1962, emergiu a preocupação nas formas de concentração do problema agrário. Assim, a Reforma agrária foi incluída entre as reformas de base de que o Brasil necessitava e que acabariam contribuindo para seu desenvolvimento. A partir daí, a luta pela terra ganha novos aliados com o apoio dos sindicatos urbanos. Em 2 de março de 1963, o governo João Goulart reconheceu a organização dos sindicatos de trabalhadores rurais e promulga a Lei $\mathrm{n}^{\circ}$. 4914, publicada no Diário Oficial, em 18 de março, dispondo sobre o Estatuto do Trabalhador Rural ${ }^{82}$, que, conforme Prado Júnior (1981:143):

Apesar das graves falhas que apresenta a lei promulgada, ... seus efeitos serão consideráveis, pois se efetivamente aplicada com o devido rigor, promoverá por certo uma das maiores transformações econômicas e sociais já presenciadas neste país. Será, ... uma verdadeira complementação da lei que aboliu a escravidão em 1888.

Prado Junior disse bem, "se efetivamente aplicada com o devido rigor", mas as conseqüências da promulgação desse Estatuto até hoje são objeto de polêmica. A falta de efetividade contribuiu para o surgimento da categoria dos bóias-frias e trabalhadores volantes, e o aumento dos encargos trabalhistas, como férias e $13^{\circ}$ salário passaram a ser considerados os responsáveis pelo desenraizamento e

\footnotetext{
${ }^{82}$. Foi quase de surpresa, pode-se dizer, a promulgação da lei dispondo sobre o ESTATUTO DO TRABALHADOR RURAL (Lei nº. 4.914, de 2 de março de 1963, publicada no Diário Oficial, de 18 de março). Sabia-se que transitavam no Congresso Nacional grande número de projetos relativos ao trabalhador rural. Mas não se tinham notícias seguras a respeito, uma vez que as informações veiculadas pela imprensa acerca do assunto são extremamente escassas. Prado Júnior, C. O Estatuto do Trabalhador Rural. In: A Questão Agrária no Brasil. São Paulo: Brasiliense, 1981, pág. 143 a 160.
} 
expulsão de milhares de trabalhadores do campo, causando, assim, transformações nas relações sociais de trabalho na agricultura brasileira.

Os trabalhadores rurais acreditavam que, a partir daí, seus direitos estariam regulamentados, graças a esse Estatuto. Minc (1985:16) comenta que "O ETR veio de fato acelerar a tendência, (...), de substituir o trabalhador permanente pelo trabalhador temporário, (...) como forma de burlar a legislação e não assumir qualquer encargo trabalhista". Era comum a contratação de trabalhadores rurais por intermediários, por empreiteiros ou "gato", como se costuma dizer. Na realidade, o ETR fez criar uma grande massa de trabalhadores sem direito algum, pois muitos ficaram desempregados a partir de então, ou com empregos temporários, pois os empregadores, os fazendeiros, os patrões, recusavam-se a cumpri-lo.

Juntamente com o golpe e a instalação da ditadura militar em 1964, aprovouse o Estatuto da Terra - ET, Lei №.. 4.504, de 30/11/64, cuja meta era regular os direitos e obrigações concernentes aos bens imóveis rurais, para os fins de Reforma Agrária e promoção da Política Agrícola. Esse fato não deixa de ser contraditório, pois, parafraseando Minc, ao mesmo tempo em que o golpe militar massacrou sindicatos e Ligas Camponesas, entre outras coisas, o Marechal Castelo Branco promulgou o ET.

Em se tratando dos objetivos e dos meios de acesso à propriedade rural, 0 Artigo 16 do Estatuto da Terra propõe que:

A Reforma Agrária visa estabelecer um sistema de relações entre o homem, a propriedade rural e o uso da terra, capaz de promover a justiça social, o progresso e o bem-estar do trabalhador rural e o desenvolvimento econômico do país, com a gradual extinção do minifúndio e do latifúndio.

Estabelecendo uma comparação entre os dados das Tabelas do item anterior, pode se dizer que a realidade agrária em nosso país, em nosso Estado e em nosso município destoa do que propunha o Art. 16 do ET, pois nem o minifúndio e muito menos o latifúndio foram extintos.

O Estatuto da Terra é visto por Gancho (1991:46) como "as boas intenções do inferno", porque, na realidade, ele veio responder às necessidades de expansão do capitalismo no campo, atendendo aos interesses do grande capital industrial e financeiro. 
O debate tradicional ${ }^{83}$ sobre a questão agrária no Brasil, de 1500 até 1960 , expõe, principalmente, "as diferentes interpretações de como se desenvolveu a posse, a propriedade, o uso da terra e a organização da atividade agrícola no Brasil" (Stedile, 2005:16).

A partir da década de 1970, com o intuito de povoar o Norte do país, o governo Médici criou vários projetos de colonização. Mato Grosso foi uma das regiões escolhidas, passando a ser caracterizada como a "nova fronteira agrícola". Mas, com o passar do tempo, o governo, por meio de sua política de implantação da colonização, acabou trazendo para várias regiões, os transtornos a seguir:

Ao promover a penetração da agricultura numa área de fronteira brasileira, o Governo Federal preparou na realidade, a estrutura de posse da terra de maneira que permitiu a sua apropriação pelos novos agentes econômicos que chegaram à região. Demarcando os espaços a serem utilizados pelos diversos agentes sociais antigos e novos (reservas ecológicas, sociedades indígenas, extrativismo vegetal e mineral, áreas para grandes projetos agropecuários, áreas para colonização, forças armadas), o governo Federal acabou por ser o grande responsável pelos conflitos notórios e a violência, presentes nestas áreas de fronteira. (Castro et al, 1994: 18).

Conforme Oliveira (1991), Morissawa (2001), além de outros, a maioria desses projetos de colonização acabou se transformando em fonte de corrupção e escândalo de mau uso do dinheiro público. Em mais de 50 deles, as empresas se apropriaram das terras, fundaram cidades e criaram latifúndios, dando origem a outros milhares de famílias sem-terra.

Para que a terra fosse realmente distribuída, com o Decreto Lei no. 1.179, de 6 de julho de 1971, o governo cria o PROTERRA ${ }^{84}$, no qual fica claro que, a partir daí, os latifundiários que possuíssem grandes propriedades poderiam ter parte dela

\footnotetext{
${ }^{83}$ (...) O primeiro grande debate de idéias e teses que interpretavam, de maneira diferente, as origens e as características da posse, da propriedade e do uso da terra no Brasil somente aconteceu na década de 1960. E aconteceu não pelo desenvolvimento da ciência nas universidades, nas academias - embora as universidades tenham também sido envolvidas por esse debate - mas, sim, pela necessidade política e sociológica dos partidos políticos. Antes da década de 1960, surgiram alguns estudos da realidade agrária, pelo viés da história econômica. (...) nesse contexto, trataram do processo de evolução da posse e da propriedade da terra no Brasil. As obras de Roberto Simonsen, A História Econômica do Brasil - 1500-1820, publicado pela primeira vez em julho de 1937, pela Companhia Editora Nacional. No seu conteúdo, o livro nos mostra a interpretação de Simonsen sobre a evolução da questão agrária no país, defendendo a tese de que sempre predominaram relações de produção capitalistas no desenvolvimento da agricultura brasileira. E as obras de Celso Furtado, com diversos livros que trataram da formação econômica do país, e de Caio Pardo Júnior, com seu clássico Formação do Brasil Contemporâneo (Editora Brasiliense), surgidos na década de 1950, estudaram sobre a economia do Brasil. Stedile, J.P (org.). A Questão Agrária no Brasil: O Debate Tradicional - 1500-1960. $1^{\text {a }}$ ed. São Paulo: Expressão Popular, 2005.

${ }^{84}$ Programa de Redistribuição de Terras e de Estímulo à Agroindústria do Norte e Nordeste, criado pelo Decreto-Lei no ${ }^{\circ . .1}$ 1.179, de 06/07/71, em complementação ao PIN, visando facilitar o acesso à terra, criar melhores condições de emprego da mão-de-obra no campo e fomentar a agroindústria nas áreas de atuação da Sudan e da Sudene. Os recursos financeiros do programa destinavam-se à abertura de linhas de crédito agrícola, à infra-estrutura básica e à aquisição de insumos e equipamentos para a agroindústria. (...) O programa trouxe poucos benefícios aos trabalhadores rurais, sendo quase nulos os efeitos da redistribuição de terras aos pequenos produtores e muitos dividendos aos latifundiários daquela região, com as indenizações feitas em dinheiro, quando o Estatuto da Terra (1964) previa desapropriações somente mediante o pagamento com títulos da dívida agrária - TDAs. Moreno, G \& Higa, T.C.S. Geografia de Mato Grosso: Território, Sociedade e Ambiente. Cuiabá: Entrelinhas, 2005, p. 40.
} 
desapropriada. Ledo engano, pois, de acordo com Moreno (2005: 40), "em Mato Grosso, o Proterra financiou a implantação de projetos particulares de colonização em áreas de contato entre a floresta e os cerrados, nas regiões centro-norte e leste do estado".

Durante os 20 anos da ditadura militar (1964 até 1984), os governantes militares deixaram dois caminhos, duas saídas sociais a serem seguidas pelos camponeses pobres que acreditavam na reforma agrária: um, a migração para a cidade, onde serviriam de mão-de-obra barata para o setor industrial que, devido ao apoio recebido pelo governo, estava deslanchando e, portanto, necessitando de mão-de-obra; o outro, seria mudar para as regiões mais longínquas e despovoadas ao Norte de Mato Grosso e, especificamente, para a região Norte do país, onde os mesmos eram induzidos por propagandas falsas e enganosas ${ }^{85}$ sobre a construção de grandes estradas e outros subsídios que em breve os tornariam prósperos trabalhadores e produtores rurais.

No início da Nova República, em maio de 1985, o presidente José Sarney anunciou uma proposta para a elaboração do que seria o $1^{\circ}$ Plano Nacional de Reforma Agrária - PNRA, a fim de tentar aliviar as tensões sociais, os conflitos pela terra que se espalhavam de Norte a Sul do Brasil. Esse plano foi aprovado em outubro de 1985, através do Decreto 91.766. A esse respeito, Oliveira (1996: 88) comenta o que realmente aconteceu por conta do Ministro da Fazenda no governo do Marechal Castelo Branco, em 1964:

O acordo de aprovação do Estatuto foi selado entre os latifundiários e o governo militar. Só recentemente foi revelado que o então Ministro Roberto Campos garantira aos latifundiários que o Estatuto aprovado não seria implantado. Passados vinte anos descobriu-se a realidade deste acordo: o Plano Nacional de Reforma Agrária não havia sido elaborado.

Bastou o anúncio da proposta, para que os grandes proprietários rurais, os latifundiários de todas as regiões do país reagissem. Com o apoio da imprensa escrita e falada, eles colocavam a sociedade em geral a par do que estava acontecendo. Com a mídia em seu favor, os grandes latifundiários veiculavam as informações conforme seus próprios interesses.

O governo de José Sarney escolhe em 1987, para seu Ministério da Reforma Agrária e do Desenvolvimento Agrário (MIRAD), o ex-governador do Pará, Jader

\footnotetext{
${ }^{85}$ Estamos nos referindo ao caso de Rondonópolis/MT. Sobre o assunto ver: Tesoro, LLLM. Rondonópolis-MT - Um Entroncamento de Mão-Única. 1993. Suzuki. JC. De Povoado à Cidade. 1996. Ambos citados na Bibliografia.
} 
Barbalho que, logo após assumir o cargo, baixa o Decreto-Lei $n^{0}$. 2.363, em 23/10/87, para extinguir o INCRA, criando em seu lugar o INTER - Instituto Jurídico de Terras Rurais. Ao falar sobre o fim do INCRA e o destino dos programas de reforma agrária, Oliveira (1996:98-9) ${ }^{86}$ comenta que "este mesmo decreto-lei transferiu para o MIRAD toda "a supervisão, coordenação e execução das atividades relativas à Reforma Agrária", antes sob o controle do INCRA". Dois meses após sua criação, o MIRAD também foi extinto, recriando o INCRA ${ }^{87}$.

A criação e fusão de órgãos e institutos não atingiram e nem beneficiaram os agricultores sem-terra, os pequenos produtores, pois a terra não estava sendo distribuída devidamente e a produção agrícola estava voltada para abastecer o mercado externo.

Na década de 1990, houve muita expectativa para os trabalhadores rurais brasileiros. O então presidente da república Fernando Collor de Melo afirmava em seus discursos que iria assentar, em todo o país, no período de 1990 até 1994, pelo menos 500 mil famílias de trabalhadores sem-terra (Oliveira: 1996:104). Os trabalhadores rurais observaram com preocupação, pois, além, de reduzir as metas para a reforma agrária, o presidente Collor escolhera, para exercer a pasta do Ministério da Agricultura, o Sr. Antonio Cabrera, proprietário de latifúndios e também associado à UDR ${ }^{88}$.

Com a renúncia de Collor de Melo, o vice-presidente Itamar Franco assumiu o poder e nomeou Fernando Henrique Cardoso para o Ministério da Fazenda. No

\footnotetext{
${ }^{86}$ Esse decreto-lei acabou por "ferir" o Estatuto da Terra em vários de seus artigos, satisfazendo assim reivindicações da UDR e dos latifundiários do país, pois as áreas em produção não poderiam mais ser desapropriadas para fins de Reforma Agrária. O mesmo passou a acontecer com a desapropriação de áreas de até 1.500 ha na Amazônia, 1.000 ha no Centro-Oeste, 500 ha no Nordeste e até 250 ha no Sul/Sudeste. Além disso, a desapropriação passava a incidir sobre $70 \%$ da superfície do imóvel, podendo os $25 \%$ restantes ficar sob controle do latifundiário/proprietário (isto para imóveis de até 10.000 ha). (...) Nova propaganda foi veiculada na imprensa brasileira para justificar estas medidas. De novo, era o uso da propaganda como instrumento ideológico para tentar "encobrir" os resultados que refletiam, de fato, a não realização da Reforma Agrária. Na realidade, o que se assistia, já no meio do mandato, era a pressão dos latifundiários e a "falta de vontade política" do governo da "Nova República" em implantar o tímido Plano de Reforma Agrária no país. Oliveira, A.U. Geografia das Lutas no Campo. São Pulo: Contexto, 1996. p. 98/99.

${ }^{87}$ Vitoriosa a política fundiária dos latifundiários brasileiros, tratou o governo Sarney de praticamente 'sepultar' o Plano Nacional de Reforma Agrária. Através da Medida Provisória №.. 29 de 15/01/1989, extinguiu o cargo de Ministro de Estado da Reforma Agrária e do Desenvolvimento Agrário, transferindo as atribuições do MIRAD para o Ministério da Agricultura e, dois meses depois, pela Lei No .. 7.739, de 20/03/1989 extinguiu também o MIRAD. Em seguida, através do Decreto Nº.. 97.886, de 26/06/1989, determinou a recriação do INCRA, a partir de então vinculado ao Ministério da Agricultura. A Reforma Agrária da 'Nova República' terminava institucionalmente da mesma forma como os governos militares a tinham tratado. Oliveira, A.U. A Geografia das Lutas no Campo. Contexto: São Paulo, 1996:103.

${ }^{88}$ UDR- União Democrática Ruralista, nasceu em agosto de 1985quando da realização, em Goiânia, de um leilão de bois, pratica adotada para arrecadar fundos. Estes fundos ao que se anunciava, eram destinados à luta contra a reforma agrária. Nasceu como movimento organizado pelo setor latifundiário para fazer frente de um lado à implantação do Primeiro PNRA, (...) e do outro lado, via de regra pela violência, aos movimentos dos posseiros e dos trabalhadores rurais sem-terra. (...) Assim, podemos afirmar que a UDR nasceu para manter esta estrutura concentrada da terra, defendendo seus proprietários: os latifundiários. (...) na década de 90 a atuação da UDR declinou até a sua extinção legal. Oliveira, A.U. A Geografia das Lutas no Campo. Contexto: São Paulo, 1996:92-96. Depois de um período de desmobilização, entre $94^{\text {a }}$ 96, voltou a se organizar devido ao recrudescimento das ações da organização dos sem-terra. Suas atividades no agronegócio são desenvolvidas no Pontal do Paranapanema, em São Paulo, e na região de fronteira agrícola de Sorriso, em Mato Grosso. Entrevista com Luiz Antonio Nabhan Garcia - Presidente da UDR, para o Portal do Fazendeiro. www.fazendeiro.com.br
} 
governo de Itamar Franco, aprovou-se a Lei Agrária nº 8.629 de 25/02/93, cujo objetivo era redefinir ou reclassificar as propriedades rurais no Brasil que já haviam sido classificadas pelo Estatuto da Terra.

Ao assumir a presidência em 1995, Fernando Henrique Cardoso adota políticas neoliberais para seu governo, inclusive, para o setor agrário. No programa de governo do primeiro mandato, havia o objetivo de reduzir os conflitos agrários e assentar, num período de quatro anos, 280 mil famílias (Oliveira: 1996:105) em várias partes do país, bem menos do que o previsto pelo governo Sarney em seu Primeiro PNRA.

A reforma agrária realizada no governo de Fernando Henrique ocorreu, também, por conta das invasões e das vidas ceifadas de muitos trabalhadores. Como o Massacre de Corumbiara, em julho de 1995, onde 514 famílias ocuparam a fazenda Santa Elina ${ }^{89}$ e, por isso, vários trabalhadores foram humilhados, torturados e executados após a ocupação; o mesmo pode-se observar sobre o Massacre de Eldorado dos Carajás ocorrido em abril de 1996.

Pelo Boletim do INCRA ${ }^{90}$, o compromisso do Governo Lula em relação à Reforma Agrária está na inclusão, na geração de emprego e renda às várias famílias assentadas, procurando fortalecer a agricultura familiar bem como democratizando o acesso à terra. Isso pode ser possível através de instrumentos legais de desapropriação e aquisição de imóveis para que se transformem latifúndios improdutivos em propriedades de agricultores familiares, contribuindo, então, para a erradicação da fome, da miséria e construção da plena cidadania no meio rural. Para tanto, conta com o INCRA que, em parceria com outros órgãos do Governo Federal, Estadual e Municipal, Movimentos Sociais e as ONGs, busca apoiar os projetos de assentamento, a fim de que possam garantir a função social da terra.

Desde os tempos iniciais, a história da propriedade da terra no Brasil tem sido uma história de exclusão e marginalização de populações, começando pelos povos indígenas, depois os escravos negros, os brancos que vieram deportados de Portugal e, posteriormente, os inúmeros imigrantes europeus que para cá vieram. Isso acabou, com o passar do tempo, por causa dos fatos e acontecimentos históricos, criando um excedente populacional útil, mas que acabava, às vezes,

\footnotetext{
${ }^{89}$ Sobre este assunto ler e assistir ao documentário: Corumbiara: O Massacre dos Camponeses. Rondônia 1995. Ambos de Mesquita, Helena Angélica. 2001. Citado na Bibliografia. 
sendo excluído do processo de trabalho, bem como do meio utilizado, ou seja, do meio necessário para realizá-lo, que seria a terra.

\subsection{Mato Grosso em Questão}

\subsubsection{Características Gerais de Mato Grosso}

De acordo com o processo de evolução político-administrativo, Mato Grosso, capital Cuiabá, em 1940, possuía área total equivalente a 1.477 .041 Km²; em 1950, baixou para $1.231 .549 \mathrm{~km}^{2}$, devido ao desmembramento do município de Porto Velho, a Noroeste do Estado, para a constituição do território Federal de Guaporé, atual Rondônia. O último processo de divisão desse Estado ocorreu em 1977, quando se criou uma nova unidade federativa - Mato Grosso do Sul, cuja capital é Campo Grande ${ }^{91}$. Está localizado a Oeste da Região Centro-Oeste, e diante de sua grande extensão territorial - 903386,1 km²/IBGE:2000 - é considerado o $3^{\circ}$ maior Estado da Federação Brasileira.

Possui dois tipos climáticos predominantes: o Equatorial Úmido e o Clima Tropical Alternadamente Seco e Úmido. Em relação ao relevo, as terras matogrossenses são formadas por planaltos, serras, depressões e planícies, com grande variedade de solo, desde os mais férteis aos mais pobres, com predomínio de Latossolos. No tocante à hidrografia, aparece como divisor de águas, onde nascem rios das bacias hidrográficas do Amazonas, do Paraná e de Tocantins, sendo separadas pelas Chapadas dos Guimarães e dos Parecis. Esse conjunto contribuiu na formação dos domínios morfoclimáticos que, em terras mato-grossenses, tem o cerrado como ecossistema dominante, aparecendo, também, o Pantanal e os Complexos do Caximbo e do Xingu.

Desde 1680, já existiam núcleos de povoamento no espaço mato-grossense. A partir de 1718, com a descoberta do ouro em Mato Grosso, esse povoamento acelerou-se. Em 1748, com o objetivo de garantir a nova fronteira, Portugal cria a Capitania de Mato Grosso. No início do século XIX, a produção de ouro começa a cair, a situação da região se agrava, provocando a intervenção federal. Na metade do século XIX, começam a chegar os seringueiros, os pecuaristas e exploradores de erva-mate e o Estado retoma o desenvolvimento.

\footnotetext{
${ }^{91}$ Miranda, L. \& Amorim, L. Mato Grosso Atlas Geográfico. 2000.
} 
Na segunda metade do século XX, em especial a partir da década de 1970, o Estado passa a receber estímulo para a ocupação de seu território, através de diversos programas federais e estaduais, os quais desencadearam a interiorização da economia, do crescimento populacional e, conseqüentemente, intensa urbanização, que, juntamente a outros fatores, sobretudo políticos, contribuíram para as divisões territoriais. Em 1970 contava com 34 municípios, passando posteriormente para 93. Em 1977, parte do Estado foi desmembrada, ficando, a partir da disso, com 38 municípios. Em 1986, devido à ocupação acelerada nas áreas de fronteira agrícola, houve a criação de mais 46 municípios, perfazendo um total de 84 , que se encontravam agrupados em onze microrregiões homogêneas. Em 1991 surgiram mais 22 municípios, com isso o Estado sofre uma nova divisão regional, sendo os 118 municípios agrupados em vinte e duas microrregiões. De 1994 até 2000, foram criados mais 25 municípios, passando a totalizar 142 no contexto geral ${ }^{92}$, agrupados pelo IBGE em 5 grandes mesorregiões e 22 microrregiões (Mapa II).

Sendo assim, ao longo de seu processo histórico, ou seja, de seu processo de regionalização, foi necessário que se fizessem em Mato Grosso novas subdivisões regionais, levando em consideração as formas de organização e produção.

\footnotetext{
${ }^{92}$ PIAIA, I. I. Geografia de Mato Grosso. 2003. Ressaltou esses aspectos.
} 
MAPA II- MATO GROSSO MICRORREGIÕES HOMOGÊNEAS

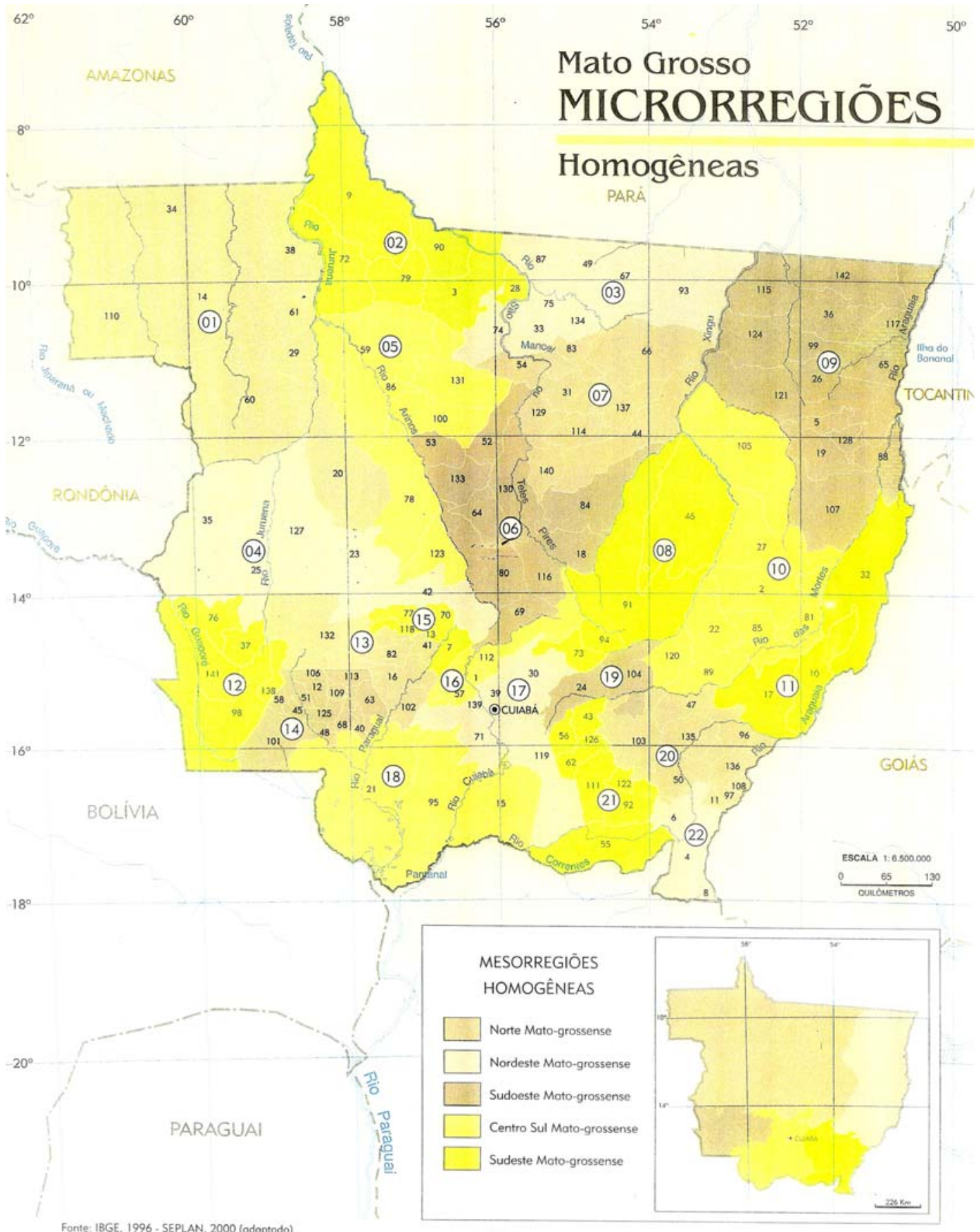




\section{Mato Grosso}

\section{MICRORREGIÕES HOMOGÊNEAS}

\begin{tabular}{|c|c|}
\hline 01 & $\begin{array}{l}\text { MICRORREGIĀO DE ARIPUANÃ } \\
14 \text { - Aripuoná } \\
20 \text { - Brasnorte } \\
29 \text { - Costonheira } \\
34 \text { - Colniza } \\
38 \text { - Cotriguaçu } \\
60 \text { - Juino } \\
61 \text { - Juruena } \\
110 \text { - Rondolândia }\end{array}$ \\
\hline 02 & $\begin{array}{l}\text { MICRORREGIÃO DE AITA FLORESTA } \\
3 \text { - Alta Floresta } \\
9 \text { - Apiacás } \\
28 \text { - Corlinda } \\
72 \text { - Nova Bandeirantes } \\
79 \text { - Nova Monte Verde } \\
90 \text { - Paranaito }\end{array}$ \\
\hline (03) & $\begin{array}{l}\text { MICRORREGIĀO DE COLIDER } \\
\text { 33- Colider } \\
49 \text { - Guorantã do Norte } \\
67 \text { - Matupá } \\
74 \text { - Novo Conaá do Norte } \\
75 \text { - Novo Guarito } \\
87 \text { - Novo Mundo } \\
93 \text { - Peixoto de Azevedo } \\
134 \text { - Terra Nova do Norte }\end{array}$ \\
\hline 04 & $\begin{array}{l}\text { MICRORREGIÄO DE PARECIS } \\
23 \text { - Campo Novo do Parecis } \\
25 \text { - Compos de Júlio } \\
35 \text { - Comodoro } \\
\text { 12- Diamantino } \\
127 \text { - Sopezal }\end{array}$ \\
\hline 05 & $\begin{array}{l}\text { MICRORREGIÃO DE ARINOS } \\
59 \text { - Juara } \\
78 \text { - Novo Maringó } \\
86 \text { - Novo Horizonte do Norte } \\
100 \text { - Porto dos Gaúchos } \\
123 \text { - Sōo José do Rio Claro } \\
\text { 131 - Tabaporá }\end{array}$ \\
\hline (06) & $\begin{array}{l}\text { MICRORREGIĀO DO ALTO TELES PIRES } \\
18 \text { - Boa Esperança do Norte } \\
52 \text { - Ipiranga do Norte } \\
53 \text { - itanhangá } \\
64 \text { - Lucas do Rio Verde } \\
69 \text { - Nobres } \\
80 \text { - Nova Mutum } \\
84 \text { - Nova Ubirotá } \\
116 \text { - Sonta Rita do Trivelato } \\
130 \text { - Sorriso } \\
133 \text { - Topurah }\end{array}$ \\
\hline 07 & $\begin{array}{l}\text { MICRORREGIÃO DE SINOP } \\
31 \text { - Cláudia } \\
44 \text { - Feliz Notal } \\
54 \text { - Itaúbo } \\
66 \text { - Marcelîndia } \\
83 \text { - Nova Santa Helena } \\
114 \text { - Santa Cormem } \\
129 \text { - Sinop } \\
137 \text { - Uniấo do Sul } \\
140 \text { - Vera }\end{array}$ \\
\hline
\end{tabular}

\author{
(08) MICRORREGIĀO DE PARANATINGA \\ 46- Gaúcha do Norte \\ 73 - Nova Brasilândia \\ 91 - Poranatinga \\ 94 - Planalto da Serra
}

(09) MICRORREGIĀO DO NORTE ARAGUAIA
5 - Alto Boa Vista
19 - Bom Jesus do Araguaia
26 - Canabrava do Narte
36 - Confresa
65 - Luciara
88 - Novo Santo Antốnio
99 - Porto Alegre do Norte
107 - Ribeirāo Cascalheirc
15 - Santa Cruz do Xing
117 - Santa Terezinha
121 - Scao Félix do Aragucio
124 - São José do Xingu
128 - Serra Nova Dourada
142 - Vila Rica

(10) MICRORREGIĀO DE CANARANA
2 - Águo Boa
22. Campinápolis
27 - Canarano
81 - Nova Nazaré
85 - Nova Xavantina
105 - Querência
20 - Santo Antônio do Leste

(11) MICRORREGIĀO DO MÉDIO ARAGUAIA

10 - Araguaianc

17 - Barra do Garças

32 - Cocolinho

(12) MICRORREGIĀO DO ALTO GUAPORE

$$
\begin{aligned}
& 37 \text { - Conquista d'Oeste } \\
& 76 \text { - Nova Locerda } \\
& 98 \text { - Pontes e Locerda } \\
& 138 \text { - Vale de São Domingos } \\
& 141 \text { - Vila Bela da Ss. Trindode }
\end{aligned}
$$

(13) MICRORREGIÃO DE TANGARÁ DA SERRA 16 - Barra do Bugres

41 - Denise

82 - Nove Olimpi

102 - Porto Estrela

132 - Tangará da Serra

(14) MICRORREGIĀO DE JAURU

12. Araputanga

45 - Figueirópolis d'Oeste

48 - Glória d'Oeste

51 - Indiovai

58 - Jauru

68 - Mirassol d'Oeste

101 - Porto Esperidióa
106 - Reserva do Coboçal

106 - Reserva do

113 - Salto do Céu

125 - São José dos Quatro Marcos
(15) MICRORREGIÃO DO ALTO PARAGUAI

7. Alto Paraguai

13 - Arenápolis
70 - Nortelândie

70 - Nortelândia
77 - Nova Marilândia

118 - Sonto Afonso

(16) MICRORREGIĀO DE ROSÁRIO OESTE

$$
\begin{aligned}
& \text { 1- Acorizal } \\
& 57 \text { - Jangada } \\
& 112 \text { - Rosário Oeste }
\end{aligned}
$$

(17) MICRORREGIÃO DE CUIABÁ

30. Chapada dos Guimarões

39. Cuinbá

39 - Cuinbá
71 - N. Senhora do Livromento

71 - N. Senhora do Livromento
119 - Sonto Antônio de Leverger

139 - Vórzea Grande

(18) MICRORREGIĀO DO ALTO PANTANAL 15- Baroao de Melgaço

21 - Cóceres

95 - Poconé

(19) MICRORREGIÃO DE CA DO LESTE 24 - Compo Verde 104 - Primovero do Leste

(20) MICRORREGIĀO DE TESOURO
11 - Aroguainha
47. General Carneiro
50 - Guiratinga
96 - Pontal do Aroguaio
97. Ponte Branco
103 - Poxoréo
108 - Ribeirōozinho
135 - Tesouro

136 - Torixoréu

(21) MICRORREGIĀO DE RONDONÓPOLIS

43-Dom Aquino

55 - Itiquiro

56 - Jaciara

62 - Juscimeiru

92 - Pedra Preto

122 - Sóo Jusé do Povo

126. Sáo Pedro do Cipa

(22) MICRORREGIĀO DO ALTO ARAGUAIA 4 - Alto Araguacia 6- Alto Garças 
A sociedade colonial mato-grossense era composta pela elite, incluindo-se aí: os fazendeiros - os homens bem sucedidos, que reivindicaram grandes extensões de terras através das cartas de sesmarias assim que chegaram; os grandes comerciantes, que praticavam o comércio local e com o exterior, ou seja, importavam e exportavam; e os burocratas do Estado - composta pelos políticos de carreira, pelo alto clero e os funcionários públicos com cargos elevados. A camada média que compreendia: os profissionais liberais, o baixo clero, professores e funcionários públicos, militares e pequenos comerciantes. A camada de homens livres pobres era composta por militares com baixa ou nenhuma patente, mineiros (trabalhadores das minas) e pequenos agricultores que praticavam agricultura de subsistência e a pesca, não possuindo emprego fixo. Como as relações de trabalho eram escravistas, basicamente não existia o trabalhador assalariado, a não ser o capataz, o feitor. Entre os homens livres pobres, existiam os soldados que, geralmente, eram de famílias de poucas posses.

Os escravos constituíam uma parcela significativa na sociedade matogrossense. A essa camada somavam-se os negros africanos, seus descendentes e os índios, conhecidos por muitos como "negros da terra". Eram tidos como mercadorias, podendo ser vendidos e até mesmo mortos por seu proprietário a qualquer momento.

Além do trabalho escravo, extinto em 1850 para ampliar o mercado consumidor $^{93}$, havia também o trabalho livre, realizado pelos camaradas e agregados que, juntamente com os escravos e índios, compunham a mão-de-obra dos senhores e aqueles que trabalhavam por conta própria, e assim davam o sustento a suas famílias.

O campesinato faz parte da realidade mato-grossense e é conhecido ou identificado como morroquiano, sesmeiro, lavrador, agricultor familiar. Além dessa categoria de trabalhadores, de agricultores existentes em Mato Grosso, que se diferenciam na forma de se relacionar com a terra, há os quilombolas e os

\footnotetext{
${ }^{93}$ O Brasil, em meados do século XIX (1850), possuía metade de sua população composta de escravos africanos. Como as regras da expansão do capitalismo exigiam que maior número de indivíduos se tornasse consumidores, a Inglaterra pressionou e acelerou o processo da abolição da escravatura. A Lei Beel Aberdeen (proposta por Lorde Aberdeen que autorizava à marinha britânica a apreensão de todo navio brasileiro que transportasse escravos), é uma prova disso. Com os escravos libertos e com a implantação do trabalho assalariado, todos seriam, em potencial, consumidores de mercadorias. Dessa forma, com a abolição há um aumento relativo de compradores de mercadorias européias. Siqueira, E.M. et al. 1990:222.
} 
sesmeiros; e aparecem, hoje, os assentados da reforma agrária, para os quais o objetivo é a terra para o sustento da família.

Assim, a formação ou gênese do campesinato mato-grossense se deu em virtude da presença dos sesmeiros, dos quilombolas, dos seringueiros, dos índios que passaram a se dedicar às atividades agropecuárias e dos antigos posseiros que se faziam presentes neste Estado durante o período colonial (mais especificamente durante os séculos XVIII e XIX), por isso são conhecidos como camponeses tradicionais.

Ao assumir o governo (século XX), o presidente Getúlio Vargas adota a política de colonização a fim de povoar as áreas mais distantes do centro administrativo do país, bem como integrá-las à economia nacional. Nesse cenário, e por causa da fronteira agrícola, passa a existir um outro tipo de camponês: os posseiros que, por serem expropriados de suas terras, tomam posse das terras desocupadas em Mato Grosso, e o colono, que veio por intermédio dos vários projetos de colonização criados no Estado.

De 1970 para cá, devido aos debates políticos e das muitas lutas pela posse da terra acontecendo em nosso país, a fim de que se concretizasse a reforma agrária, outro tipo de camponês passa a fazer parte da história de Mato Grosso - os assentados da reforma agrária, os inúmeros sem-terra fixados pelo MST, ou por outro tipo de movimento social que atuou ou ainda atua no Estado.

Essas diversas categorias enquadram-se no campesinato mato-grossense e concordo com Aguiar, M.V. (2005:125) ${ }^{94}$, quando afirma que "são necessários estudos mais aprofundados que dêem conta da gênese do campesinato matogrossense ressaltando as relações interétnicas (...), as diferentes caras dos assentados da reforma agrária (...)", pois cada qual possui sua importância quanto ao segmento social, de acordo com a forma de ocupação de cada grupo ou categoria.

\subsubsection{Ocupação de Mato Grosso}

\footnotetext{
${ }^{94}$ Na seção 2.1.9. O Campesinato no Estado de Mato Grosso (p. 125 a 157), Aguiar, Maria Virginia de Almeida escreve sobre os sesmeiros, os “camponeses indígenas", os "pretos" ou "remanescentes de quilombos", os "seringueiros", os posseiros, os novos posseiros, os "novos camponeses”, os colonos do Estado Novo, os colonos da colonização dirigida, os assentados da reforma agrária e os sem-terra do MST, todos encontrados no cenário mato-grossense. In: Carvalho, Horácio Martins de. O Campesinato no Século XXI: Possibilidades e Condicionantes do desenvolvimento do Campesinato no Brasil. Petrópolis, Vozes, 2005. Carvalho expõe que: "Para que esse livro fosse publicado vimos a necessidade de reunir um imenso compêndio da literatura sobre o campesinato no Brasil, vista da realidade das famílias camponesas, tendo elas a posse ou não de terras e como forma de reprodução social a produção agrícola, a criação de animais, o extrativismo, a pesca artesanal. Enfim, diferentes formas de manutenção e reprodução social, utilizando-se para isso o trabalho familiar”.
} 
A Capitania de Mato Grosso foi criada em 09/05/1748 para garantir de perto a fiscalização, o povoamento e a expansão da fronteira. A grande extensão de terras, a existência de riquezas minerais e sua posição geográfica atraíram muitos colonos que passaram a residir em Mato Grosso e a sonhar com uma região protegida militarmente, bem como em vê-la abastecida com alimentos e outros benefícios.

Como o índice populacional na Capitania, no século XVIII, era baixo, "vários estímulos foram oferecidos aos colonos do outras regiões para virem para Mato Grosso: diminuição e até suspensão de cobrança de impostos, doações de patentes e cargos" (Siqueira, et al. 1990:210); mesmo assim, esse processo para a colonização, para o povoamento não obteve sucesso.

No século XIX, com a fronteira e abastecimento passa a ocorrer uma nova ordem, inclusive, com o apoio da Inglaterra que influenciou "na importação de seus produtos industrializados; na abolição da escravatura, para obtenção de maior número de consumidores; na difusão de novas idéias; e nas novas formas de relações de trabalho" (Siqueira, et al. 1990:214). Percebe-se que, a partir de então, Mato Grosso passou a integrar-se em um novo contexto nacional e internacional, através da expansão do comércio ultramarino.

Como a principal atividade econômica da Capitania era a mineração, tanto o índio quanto o negro foram usados como força de trabalho escrava. Portanto, o modo de produção escravista se fez sentir na formação social mato-grossense.

A introdução dos trabalhadores negros como escravos, em Mato Grosso, remonta do século XVIII, quando vieram para trabalhar nas minas, no momento em que o ouro foi descoberto em Minas Gerais, Mato Grosso e Goiás. Posteriormente, passaram a trabalhar também nas plantações de cana-de-açúcar e outras atividades agrícolas. Como o trabalho era árduo e o tratamento recebido, ou seja, dispensado a eles era violento e desrespeitoso, os mesmos acabavam fugindo (quando conseguiam) o que os levaram a construir os quilombos ${ }^{95}$, principalmente, durante 0

\footnotetext{
${ }^{95}$ Quilombos em Mato Grosso: Quilombo do Piolho ou Quariterê, surgido por volta de 1770/71 na região de guaporeana, próximo ao rio Piolho ou rio Quariterê, tornou-se um povoado composto de negros fugidos, de índios, de crioulos e de caburés. Quilombo de "Joaquim Félix" e do "Mutuca" - foram dois quilombos destruídos, nos quais foram capturados cerca de 200 escravos homens, além de muitas mulheres e crianças. Outros quilombos, surgidos principalmente a partir de 1775, ocasião em que a Companhia de Comércio do Grão-Pará e Maranhão deixaram de abastecer a Capitania de Mato Grosso com escravos e as fugas passaram a ser uma constante; foram: Mutuca e Pindaituba - situados na Chapada dos Guimarães; Rio Manso - na região de Cáceres. No total, foram registrados 11 quilombos em Mato Grosso durante os séculos XVIII e XIX, sendo que o último a ser destruído foi o do rio Manso, em 1873, a mando do Presidente da Província, José de Miranda Reis. SIQUEIRA, E. M. et al. 1990:131 a 138. Direitos Conquistados. Quilombolas Tomam Posse de Terras no Mato Grosso: Os 14.622 mil hectares de terras localizados no quilombo Mata Cavalo pertencem às 418 famílias que há mais de 20 anos ocupam a área. O Instituto de Colonização e Reforma Agrária (Incra) do Mato Grosso (MT) reconheceu oficialmente no dia 7 de fevereiro a posse das terras aos remanescentes de quilombos. 10/02/2006. www.consciencia.net/arquivo/br-matogrosso
} 
período (1748/1821) em que Vila Bela da Santíssima Trindade manteve-se como capital. Além dos quilombos, existiram, em Mato Grosso, as regiões de sesmarias, onde os sesmeiros ${ }^{96}$, mesmo com as modificações ocorridas em seu espaço, mantiveram as relações sociais do grupo como a terra, e a forma de como os grupos se organizaram economicamente ali. De acordo com Cury (1973), foi na sesmaria do Morro Redondo, nos campos de Mimoso - Sul de Mato Grosso, que nasceu em 5 de maio de 1865, Cândido Mariano da Silva Rondon, o Marechal Rondon.

De acordo com Siqueira (2002:37), em novembro de 1726, Rodrigo Moreira César de Menezes (governador da Capitania de São Paulo) veio a Mato Grosso em monção, com uma expedição composta de 308 embarcações e uma tripulação de 3.000 pessoas, onde deu início ao controle administrativo fiscal da zona mineradora. Em 1728, antes de retornar à Vila de São Paulo, Rodrigo Menezes regularizou a questão das terras em Mato Grosso, fazendo a doação de cartas de sesmarias, principalmente àqueles colonos que já habitavam as terras mato-grossenses, desenvolvendo a agricultura e a pecuária. Dá-se, então, o início da legalização da propriedade das terras em Mato Grosso onde, através desse documento - cartas de sesmaria - o posseiro passa a ser dono ou proprietário legítimo da terra.

Em 11 de janeiro de 1751, chega a Cuiabá o primeiro Capitão-Geral de Mato Grosso, D. Antônio Rolim de Moura que também concedeu quase cem cartas de sesmaria aos habitantes de Cuiabá e regiões circunvizinhas. Todavia, esse processo foi extinto com a promulgação da Lei de Terras em 1850.

Após a Constituição de 1891, o Estado assume o domínio das terras devolutas; sendo assim, caberia a ele determinar sobre a questão fundiária. Essa Constituição dá força e poder aos Estados, onde a classe dominante passa a influir na distribuição de terras, de acordo com seus interesses econômicos e políticos. Dessa forma, sanciona-se, em 16 de novembro de 1891, a Lei nº. 24, a primeira Lei de Terras de Mato Grosso, que cria a Diretoria de Obras Públicas, Terras, Minas e Colonização, ou seja, a primeira instituição estadual responsável pela resolução das questões fundiárias em terras mato-grossenses. Posterior a ela, surge uma nova lei, de $n^{\circ}$. 20, que regulamenta a transformação das antigas cartas de sesmarias em títulos de propriedade de terra.

\footnotetext{
${ }^{96}$ Sobre Sesmarias em Mato Grosso, ler: Ribeiro, Iselda Correa. Sesmeiros. Cuiabá:EdUFMT, 1998.
} 
Pelo fato de o governo de Mato Grosso, Manuel José Murtinho, ter concedido àqueles que conseguissem escriturar suas posses a possibilidade de reivindicarem terrenos adjacentes às mesmas, desde que fossem terras devolutas, passa a ocorrer o favorecimento à ampliação dos latifúndios, já que as sesmarias eram propriedades de grande extensão territorial. A legislação só previa a posse de 900 hectares, para áreas destinadas à agricultura e 3.600 hectares para o desenvolvimento da pecuária (Siqueira, 2002); porém, a legislação não foi cumprida e o número de latifúndios improdutivos, bem como a especulação de terras cresceram em Mato Grosso. A partir de 1893, o governo mato-grossense implanta um processo de venda de terras devolutas no Estado.

Para se entender o Mato Grosso, hoje, deve-se lembrar de três aspectos fundamentais: os bandeirantes; os projetos de colonização e a concentração de terras com a vinda dos sulistas. O processo de ocupação das terras deste Estado ocorreu a partir do século XVIII, com o ciclo das bandeiras, durante o qual a população era composta pelos povos indígenas em um território ocupado de forma pontual e dispersa por tais povos.

Ao analisar a evolução política do Brasil: colônia e império, Prado Júnior (1987:24) aponta para o fato de que com os bandeirantes,

inicia-se a caça do homem pelo homem (...) foram expedições preadoras do gentio, que percorreram o território brasileiro de norte a sul e de leste a oeste, descendo do sertão milhares e milhares de cativos a serem iniciados nas 'belezas da civilização'.

De acordo com alguns historiadores mato-grossenses ${ }^{97}$, os índios tiveram importância fundamental para a História de Mato Grosso e os bandeirantes já conheciam, de passagem e de lutas, a zona onde os jesuítas haviam localizado as suas reduções ${ }^{98}$ de índios, o que favoreceu a captura travada pelos bandeirantes.

Uma das principais finalidades das bandeiras era aprisionar os índios para vendê-los no lucrativo comércio de escravos, principalmente nas regiões Nordeste e

\footnotetext{
${ }^{97}$ Siqueira, E. M. et al. 1990 e Mendonça, R. de. 1982.

${ }^{98}$ Reduções - locais onde as Ordens Religiosas pertencentes à Igreja Católica, especialmente à Companhia de Jesus, durante o período colonial retinha populações indígenas. Nela os índios estariam resguardados dos ataques dos colonos, porém perdia grande parte de sua cultura original. Os jesuítas que obstinadamente, perseguiam os índios para aldeá-los, através de Missões ou Reduções, locais onde os índios sofriam um processo violento de desaculturação, pois era-lhes ensinada a religião católica, os usos e os costumes ocidentais e a língua portuguesa. Aos índios cabia todo o processo de produção que, em parte, era consumida nestes aldeamentos e o excedente, comercializado pelos inacianos. Assim, os jesuítas constituíam o terceiro grande império dentro das Américas. Siqueira, E. M. et al. 1990:213 e 271. Os primeiros jesuítas vieram para Mato Grosso com D. Antônio Rolim de Moura. O local escolhido para o estabelecimento da missão indígena foi o alto da serra de São Jerônimo, também conhecida como Serra da Canastra, atual Chapada dos Guimarães e a missão erigida tomou o nome de Missão de Santana de Chapada. Siqueira, E. M. 2002:42.
} 
Sudeste. De acordo com Piaia (2003), este era o papel do "bandeirismo apresador", enquanto ao "bandeirismo prospector" ficou a incumbência de descobrir, no interior do Brasil, ouro e pedras preciosas ${ }^{99}$.

Com a descoberta das primeiras minas de ouro em Mato Grosso, no ano de 1718, praticamente morre ali o "nomadismo preador"100, para dar lugar à atividade garimpeira. A notícia dessa descoberta espalhou-se com a mesma intensidade das de Minas Gerais. Portanto, o movimento migratório de pessoas vindas de Minas Gerais, Rio de Janeiro e de toda a Capitania de São Paulo, deixando casas, fazendas, mulheres e filhos, foi intenso ${ }^{101}$.

Do ponto de vista demográfico, a ação dos bandeirantes contribuiu não só para dizimar as tribos indígenas, mas também com a formação dos primeiros núcleos populacionais e o estabelecimento de fazendas agropastoris, semelhante ao processo ocorrido em Minas Gerais e Goiás. Em vista do crescimento da atividade econômica, em 1748, a Coroa Portuguesa cria a Capitania de Mato Grosso, desmembrando-a da Capitania de São Paulo. Em 1763, Rolim de Moura governador da Capitania de Mato Grosso - teve de resistir às investidas dos castelhanos. Já em 1801, ocorreu a consolidação das fronteiras.

Por conta dos problemas surgidos durante o período da mineração no século XVIII - preços exagerados, falta de mão-de-obra, de equipamentos para o trabalho de mineração do ouro (pois o diamante que havia sido descoberto também no século XVIII estava proibido de ser explorado por parte da Coroa Portuguesa, a fim de que não ocorresse um despovoamento na fronteira), pragas nas lavouras de milho, mandioca, feijão etc., doenças malignas e maleita, a distância e as

\footnotetext{
${ }^{99}$ Siqueira (1990: 270), afirma que: Para atingir Mato Grosso, os bandeirantes utilizaram o sistema de monções, bandeiras, cujo meio de transporte eram as canoas e o seu roteiro se fazia exclusivamente através de rios. Nesse tipo de atividade, o saber indígena foi de fundamental importância para seu sucesso. (...) Assim, os índios tornaram-se os verdadeiros GUIAS DAS MONÇÕES. Foi apoiado na mãode-obra indígena que se desencadeou todo o processo de ocupação de Mato Grosso, cujo território já era habitado por muitas nações indígenas. Sobre esse assunto ler também: Siqueira, E. M. 2002 e Tesoro, LLLM. 1993. ${ }^{100}$ Com a descoberta aurífera, teve início uma nova etapa de atividade em nossa região. A função de caçar índios ficou relegada para segundo
plano, cedendo lugar às atividades mineradoras, praticadas de forma rudimentar, pois não contavam os bandeirantes com instrumentos de
minerar. (...) com a junção das bandeiras de Pascoal Moreira Cabral e a bandeira dos irmãos Antunes (Gabriel, Antônio, Felipe e João), o
grupo se revigorou e formaram o primeiro núcleo de povoamento: Arraial da Forquilha, situado às margens do rio Coxipó. Esse aglomerado
humano exigiu uma organização social, em bases diversas da fase do anterior do bandeirismo nômade de preação de índios. (...) as nações
indígenas: Caiapó, Paiaguá e Guaicuru lutaram e resistiram, de forma heróica, à dominação do colonizador, até o século XIX, momento em
que, com o avanço da fronteira econômica e humana, terminaram por ceder, vindo a, praticamente, desaparecer enquanto nação indígena.
SIQUEIRA, E. M. et al. 1990:11 e 15 .

${ }^{101}$ A dispersão pelo interior, intensa e rápida, é da primeira metade do séc. XVIII, quando o ouro, descoberto sucessivamente em Minas Gerais (último decênio do séc. XVII), Cuiabá, em 1719, e Goiás seis anos depois, desencadeia o movimento. Afluem então para o coração do continente levas sobre levas de povoadores. Alguns são colonos novos que vêm diretamente da Europa; outros, os escravos trazidos da África. Muitos, porém acorrem dos estabelecimentos agrícolas do litoral, que sofrem consideravelmente desta sangria de gente e cabedais. É este um período sombrio para a agricultura litorânea, que assiste então ao encerramento do seu primeiro ciclo de prosperidade, tão brilhante até aquela data. Terras abandonadas, engenhos em ruínas; a vida cessara aí quase, para renascer, vigorosa e pujante, no eldorado das minas. Prado Júnior, CP. 1996:39.
} 
dificuldades de viagem até São Paulo ${ }^{102}$-, a febre do ouro durou pouco, pois, da metade do século XVIII em diante, a mineração se fez declinar ${ }^{103}$. O período entre meados do século XIX e início do século XX marca a transição entre a decadência da mineração, vinculada ao mercado internacional, com o desenvolvimento da pecuária extensiva e da agricultura de subsistência, bem como da importância das Casas Comerciais ${ }^{104}$.

Desde o fim do Império, por causa dos seringais amazônicos, cuja extração do látex se deu na $2^{\mathrm{a}}$ metade do século XIX (período em que Mato Grosso abre as portas para o comércio mundial) na Amazônia e em Mato Grosso, acelera-se a ocupação das terras mato-grossenses e os migrantes, especialmente nordestinos ${ }^{105}$ e nortistas, chegavam a todo o momento. Siqueira (1990:63) menciona que, desde 1870, já se extraía o látex da mangabeira, na região de Diamantino e que, por isso, as terras mato-grossenses valorizaram-se. Então, as posses de terras começam a sofrer legalização por compra ou arrendamento, bem como o surgimento das grandes propriedades, capazes de assentar o homem a terra.

A comunicação com outras áreas dava-se primeiro pela via fluvial Tiete ${ }^{106}$. Prado Júnior (1996:251) comenta sobre a "exploração dos rios que levam ao Amazonas, procurando aproveitá-los para as comunicações comerciais". Para que

\footnotetext{
${ }^{102}$ Segundo alguns historiadores, por conta deste último fato, o período imperial durou mais tempo em Mato Grosso que no Brasil, pois a notícia da Proclamação da República só chegou aqui no dia 9 de dezembro de 1889.

${ }^{103}$ Façamos um balanço rápido do que sobrava da mineração. Explorava-se ainda o ouro, últimos espasmos da agonia, nas quatro capitanias centrais. Minas Gerais, em primeiro e principal lugar; Goiás, Mato Grosso, e muito pouco na Bahia, em seguida. (...) Em Mato Grosso, embora ainda fosse a mineração a única fonte de produção e riqueza da capitania, muito pouco sobrava do passado. Lavrava-se algum ouro nas antigas minas das cercanias de Cuiabá e Vila Bela (Mato Grosso), bem como no Alto Paraguai, cujas jazidas, vedadas desde 1746 porque aí se descobriram diamantes, assim se conservaram apesar dos insistentes e sempre renovados pedidos dos habitantes da capitania, até 1805 , quando são afinal franqueadas e repartidas as datas pelo Governo Abreu e Meneses. As minas do Alto Paraguai reserva que o acanhado espírito da administração por acaso conservou até o séc. XIX, reanimaram um pouco a mineração decadente da capitania; em 1828 - não temos dados para antes - trabalhavam ainda nestas minas cerca de 3.000 escravos, segundo avaliações D’Alincourt. Em Vila Bela, eles não passavam na mesma ocasião de 400, e em Cuiabá havia apenas escravos faiscadores. Prado Júnior, CP. 1996:172-3.
}

${ }^{104}$ Em Mato Grosso a presença dessas Casas Comerciais em Corumbá (1858), Cuiabá (1865), Cáceres (1871), Nioaque (1871) etc., era facilitada pelo predomínio da navegação fluvial nos rios tributários do Paraguai. Até as últimas décadas do Século XX, Mato Grosso exportava basicamente dois produtos, a borracha e o açúcar; enquanto outros quatro produtos, o mate, o gado, o caldo de carne e a ipecacuanha, limitava-se às trocas com as cidades limítrofes da bacia platina. Assim sendo, a importância regional destas Casas Comerciais, na segunda metade do século, caracteriza-se, principalmente, pela concentração do capital em Mato Grosso e pela sua complexidade estrutural. Não fica difícil perceber que é a partir do excedente gerado pela Casa Comercial que se instalam os primeiros empreendimentos em Mato Grosso, à exceção das primeiras indústrias, já estabelecidas, uma usina de açúcar (1880) e uma indústria para produção de caldo de carne em Descalvados. Ferreira, Onorina Fátima. Indústria In: IBGE. Geografia do Brasil. Região Centro-Oeste. Vol. 1, RJ. 1989: 171-172.

\footnotetext{
${ }^{105}$ A "febre da borracha" foi alvo de extensa propaganda, ocasião em que se ventilava que os trabalhadores poderiam enriquecer com esse trabalho. A eles eram oferecidas as condições básicas para o deslocamento até as regiões Norte e Centro-Oeste: passagem, adiantamento em dinheiro, etc. Com isso, mais de 200 mil trabalhadores se deslocaram do Nordeste, via Amazônia, levando consigo a falsa esperança de uma vida melhor. Nem só a Amazônia foi palco da extração do látex, Mato Grosso possuía nativas, as famosas MANGABEIRA, árvores das quais se extraía o látex branco-azulado, com o qual se fabricava borracha de excelente qualidade. Siqueira, E. M. et al. 1990:62-3.

${ }^{106}$ O primeiro de 1719 a 1724, era o seguinte: Tiete (antigamente conhecido como Anhembí) rio Grande, rio Anhanduí, rio Pardo, travessia, por terra dos Campos das Vacarias, rio Meteteu, rio Paraguai, rio Cuiabá. O segundo roteiro foi utilizado pela primeira vez, no ano de 1725 e perfazia o seguinte trajeto: rio Tiete, rio Paraná, rio Pardo, rio Miranda, rio Sanguessuga, travessia, por terra do Varadouro de Camapuã, rio Coxim, rio Taquari, rio Paraguai, rio São Lourenço e finalmente, rio Cuiabá. (Siqueira, E.M. et al. 1990:13-15); Ler também: Caio Prado Júnior. Formação do Brasil Contemporâneo. 1996.
} 
Mato Grosso se interligasse a São Paulo, ou seja, à porção mais desenvolvida do país a fim de fortalecer o escoamento dos produtos mato-grossenses, é construída a Estrada de Ferro Noroeste do Brasil ${ }^{107}$ que teve sua construção iniciada em 1908, cuja inauguração oficial foi em 14/11/1914. Todavia, só em 31 de julho de 1909, Mato Grosso foi beneficiado com o serviço telefônico.

Com os subsídios acima, mais a vinda de migrantes para Mato Grosso, passa a ocorrer um adensamento populacional a partir de 1908, principalmente na porção Sul de Mato Grosso, pelo fato "de que na medida em que se erguiam estações e postos ferroviários, um determinado número de pessoas, ficava residindo na região. Estas vilas e arraiais terminavam por se tornar cidades, relativamente populosas" (Siqueira, et al. 1990:253), em conseqüência, abastecer esta população com alimentos e vestuário estava se tornando algo difícil, pois a atividade agrícola e a pecuária acabaram sendo insuficientes.

Para melhor entendimento das mudanças ocorridas no espaço matogrossense, necessário se faz relembrar que, até a década de 30, o sistema econômico produtivo que vigorava no Brasil era o agrário-exportador o qual, por sinal (nos últimos anos), vivia fragilizado devido às oscilações do setor de mercado externo como, por exemplo, as crises do café. Na década de 1930, formam-se, principalmente em São Paulo, duas classes distintas: a classe média próspera que conseguiu acumular capital com a comercialização do café e a classe baixa, formada pela mão-de-obra que, por não estar em efetivo exercício, acabava sendo disponibilizada das fazendas de café, devido às crises. Enquanto a primeira detinha o poder de compra, de consumo, a segunda se transformava em mão-de-obra barata, como operários para as indústrias ${ }^{108}$ ou trabalhadores do comércio e serviços que surgiam nas cidades.

Por causa do golpe de Estado, assume a presidência da república Getúlio Vargas - governo militar da década de 1930 até metade de 1940 - o qual passa a articular um novo projeto econômico para a nação. O governo resolve implantar, a partir de 1930, o sistema de COLÔNIAS AGRÍCOLAS FEDERAIS. Para intensificar a

\footnotetext{
${ }^{107}$ A construção dessa ferrovia desagradou, aos comerciantes platinos, estabelecidos com suas Casas de Comércio em Corumbá. Esse descontentamento se justificava, pois o eixo de interesses comerciais se transferia da área fluvial, para a ferroviária e Corumbá deixaria de ser o agente catalisador do comércio em Mato Grosso. A ferrovia não chegou a Cuiabá. Siqueira, E. M. et al. 1990:250.

${ }^{108}$ Sobre o assunto ler: Martins, JS. O Cativeiro da Terra. São Paulo: Hucitc, 1996.
} 
política de colonização, Getúlio $\operatorname{Vargas}^{109}$ criou o projeto Marcha para o Oeste ${ }^{110}$, com o objetivo de estimular os migrantes a se estabelecerem em Mato Grosso e Goiás. Uma das metas era o sistema de assentamento do trabalhador brasileiro em solo mato-grossense. Assim, Mato Grosso, que era pouco habitado e detentor de extensas proporções de terras ociosas, passa a ser alvo de especuladores imobiliários.

Pelo projeto getulista, só seriam assentados os trabalhadores cuja vontade fosse a de avançar, desenvolver-se. Portanto, deveriam trabalhar de maneira "produtiva, ordeira e sem conflitos" (Siqueira, et al. 1990:255). A preferência de Vargas era pelos migrantes sulistas, seus conterrâneos que, de acordo com ele, eram possuidores de mentalidade empresarial, do tipo europeu e, sobretudo, porque além de terem experiência com a terra possuíam também organização do empreendimento. Exemplificarei com Woortmann (1995:217) que cita: "descendentes de alemães, de italianos e poloneses, dirigiram-se para o Brasil Central e Amazônia, já como farmers modernos, ou até mesmo, excepcionalmente, como grandes proprietários". Com a Marcha para o Oeste, os detentores do capital investiram em terras mato-grossenses com objetivos diversos.

O crescimento demográfico de Mato Grosso, iniciado no século XVIII e que passou por um período de estagnação por conta do declínio e esgotamento das minas de ouro na Província, retoma, a partir da década de 1940, com a implantação da política de colonização. De acordo com Ferreira (1984:50), foi "assumida de forma decisiva, porém mal planejada, pelo estado, cuja decisão prévia do Estado foi no sentido de que parte das terras seria destinada à colonização pública e privada". Sendo assim, de acordo com a política de colonização, parte dessas terras deveria ser reservada aos futuros núcleos de povoações.

\footnotetext{
${ }^{109}$ Getúlio Vargas, fez um longo sobrevôo na região do Araguaia, a convite do então governador de Goiás, Pedro Ludovico. Ao ver uma vastidão de florestas cortadas por rios imensos, concluiu abismado: "É o branco do Brasil Central". Para mudar essa realidade, o presidente encarregou o ministro da Coordenação de Mobilização Econômica, João Alberto Lins de Barros, de promover a interiorização do Brasil. Assim nasceu a Fundação Brasil Central, FBC. Em seguida, foi anunciada a criação da Expedição Roncador-Xingu, cujo objetivo era ser ponta de lança do avanço progressista, com a função de mapear o centro do país e abrir caminhos que ligassem a região ao resto do país. A Marcha para o Oeste - A maior aventura do século 20. Fonte: Rota Brasil Oeste. 28/11/2004. www.brasiloeste.com.br

${ }^{110} \mathrm{O}$ ministro João Alberto foi um dos maiores incentivadores da colonização do Centro-Oeste, principalmente por ter conhecido toda a região como revolucionário da Coluna Prestes. Ele vislumbrava o futuro econômico do Vale do Araguaia, apontando a terra como ideal para pecuária. Além disso, o ministro sonhava em ver uma urbanização planejada e ordenada que, ao seu entender, traria assistência, riquezas e qualidade de vida ao interior do país. Em boa parte, o sonho progressista do militar se concretizou. Transcorrida por cerca de quarenta anos, a Marcha Para o Oeste fundou cerca de 43 vilas e cidades, construiu 19 campos de pouso, contatou mais de cinco mil índios e percorreu 1,5 mil quilômetros de picadas abertas e rios. A Marcha para o Oeste - A maior aventura do século 20. Fonte: Rota Brasil Oeste. 28/11/2004. www.brasiloeste.com.br O projeto Marcha para o Oeste contava com algumas exigências (...) estes colonos receberiam provisoriamente as terras e, somente depois de três anos, teriam o título definitivo de posse delas. Este título somente poderia ser conseguido caso ele mantivesse o cultivo da terra e se comportasse de maneira correta, não infringindo as leis. Siqueira, E. M. et al. 1990:255.
} 
Com o objetivo de colonizar definitivamente o Estado, o governo inicia a política de venda de terras ou, como disse Ferreira (1984:55), "o Estado abre plenamente as comportas de acesso à terra (...) um marco da 'nova história' que irá fortalecer a estrutura agrária da 'velha história' - o latifúndio”. Na década de 1950, criou-se a Colônia Agrícola de Dourados (MS), a Colônia Taquari-Mirim e a Colônia Ministro João Alberto (hoje Nova Xavantina). ${ }^{111}$ Contudo, muitos dos camponeses da Colônia de Dourados acabaram contraindo dívidas e, com isso, abandonaram as terras da colônia. Para que as mesmas não ficassem paradas, num outro momento, (1950) elas sofrem uma nova divisão e disso decorre grande concentração de terras nas mãos de poucos proprietários, onde muitos casos se deram por meio de concessões $^{112}$. Isso ocorreu porque os camponeses não detinham recursos e nem assistência do governo e, para sobreviverem, vendiam sua força de trabalho aos mais bem sucedidos, que também, dessa forma, acumularam mais riqueza.

Moreno (1993:199-201) comenta que Fernando Corrêa da Costa, ao assumir o governo de Mato Grosso em 1951, realizou algumas mudanças ${ }^{113}$ no Código de Terras de 1949, alargando o espaço de manobra nos negócios da terra e, em seus discursos à Assembléia Legislativa, não escondia sua posição favorável à presença da iniciativa privada no Estado. Ele achava estar em jogo, até o momento, os interesses partidários, criticando a desorganização do Departamento de Terras e Colonização e a Delegacia de Terras em Campo Grande.

Do início da criação das colônias até 1963, Siqueira (1990:259-260) enumera dezessete Colônias implantadas pelo governo de Mato Grosso e vinte e cinco Colônias implantadas pela iniciativa privada ${ }^{114}$, autorizadas a funcionar durante a década de 1970/1980.

\footnotetext{
${ }^{111}$ Sobre Colônias Agrícolas ver Piaia, I.I. Geografia de Mato Grosso. 2003; Geografia do Brasil. Centro-Oeste. IBGE, 1988; Siqueira, E. M. et al. 1990; Tavares dos Santos. J.V. Matuchos: exclusão e luta: do sul para a Amazônia. 1993, entre outros.

${ }^{112}$ Muitas concessões eram feitas somente por interesses políticos, especialmente, em anos eleitorais. Este foi o caso do ano de 1953, ocasião em que foram concedidos 14 contratos de terra, sem que ao menos tivessem seus donos, conhecimento das áreas concedidas, pois as mesmas não estavam discriminadas. Siqueira, E. M. et al. 1990:256.

${ }^{113}$ Sobre a Lei $\mathrm{N}^{\circ}$.. 336, de 6 de dezembro de 1949 que dispõe sobre o Código de Terras do Estado e a Lei Nº.. 461 , de 10 de dezembro de 1951, que modifica o Código de Terras, ver: Código de Terras e Leis Complementares, do Estado de Mato Grosso, Departamento de Terras e Colonização. 1959.

114 Colônias implantadas pelo Governo de Mato Grosso: Rio Pardo/Poxoréu/1943, Leonor/Cuiabá/1945, Fátima de São Lourenço/Jaciara/1947, Paulista/Rondonópolis/1948, Coronel Ponce/Cuiabá/D.Aquino/1948, Antonio João/Poconé/1950, Jarudore/Poxoréu/1951, Macacos/ Rondonópolis/1952, Lambarí/Poxoréu/1952, Rio Branco /Cáceres/1953, Nogueira/Alto Paraguai/ 1953, Bocaina/Chapada dos Guimarães/1953, Jamaica/Chapada dos Guimarães/1956, Rio Mutum/D.Aquino/1958, Bauxi/Rosário Oeste/1963, Pascoal Ramos/Cuiabá, Retiro /Rosário Oeste. Colonizadoras de Iniciativa Privada: Barbados/V.B.S.T, Brasilândia, Jatibá, Marron, Palmitos, Monte Verde, Rio Alegre, Bandeirantes, Iguaçu e Mundo Novo em Chapada dos Guimarães, Taquaral I, Taquaral II, Carvalho, Tabajara, Ibitira, Rio dos Peixes e Meu Brasil em Porto dos Gaúchos, Beija Flor, Gleba Trivellato, Sorriso I e Sorriso II em Nobres, Salto do Poente/Santo Antonio do Leverger, Franco e Sucupira em Barra do Garças, Saturnino Coelho em Rosário Oeste. Siqueira, E. M. et al. 1990:259/260.
} 
A transferência da capital do país para a região central do Brasil, no governo de Juscelino Kubitschek (1956-1961), estimulou a migração para a porção Norte de Mato Grosso, devido às melhorias nos meios de comunicação, nos transportes, na educação e na saúde.

A partir de 1960, começa a construção das rodovias federais através do Plano de Integração Nacional: a BR 158, que liga Barra do Garças a São Félix do Araguaia, foi a primeira delas, assim como as BR-364, BR-163, BR-070, além das estaduais, que vieram facilitar o transporte de passageiros e cargas até esse Estado. Com isso, os produtores e pecuaristas que conseguiram acumular dinheiro, aproveitaram essas melhorias de acesso a terra nos cerrados de Mato Grosso e começaram a ocupá-lo.

Para muitos, era a junção do "Cerrado e Chimarrão", por causa dos agricultores gaúchos que se deslocaram para Mato Grosso, motivados pelos incentivos do PROTERRA. Eram os componentes da Expedição Roncador-Xingu e da Fundação Brasil Central que construíram rodovias e edificaram cidades, promovendo a criação de novas fronteiras econômicas no Planalto Central Brasileiro, bem como criaram a Cooperativa 31 de Março ${ }^{115}$ que se fez presente em Água Boa e Canarana. De acordo com Elcides Salamoni"116, "a colonização aconteceu devido ao alto preço da terra no sul. Não viemos por amor ao país, e sim para ficar rico." Esclarece, ainda, que naquela época, enquanto lá no Rio Grande do Sul o tamanho médio da pequena propriedade era de 2,5 ha, um colono da Cooperativa 31 de Março recebia um lote rural de 400 ha, sem contar os três lotes urbanos com $800 \mathrm{~m}^{2}$ cada.

Além deles, vieram os migrantes do próprio Estado e de outras áreas do Sul do Brasil. Estas pessoas são como andorinhas, estão em constante movimento, concentrando-se e se dispersando/migrando em busca de um novo local em terras livres, onde possam plantar e sobreviver com suas famílias. Vale lembrar que, tanto Tavares dos Santos (1993), quanto Tesoro (1993), Moreno (1993), Suzuki (1996) e

\footnotetext{
${ }^{115}$ Capítulo IV - O Programa de Colonização CANARANA. In: Tavares dos Santos, J.V. Os Matuchos: exclusão e luta: do Sul para a Amazônia. 1993, pág. 65 a 113.

${ }^{116}$ Segundo Elcides Salamoni (Cooperativa 31 de Março), as cidades de Água Boa e Canarana foram planejadas em Tenente Portela (RS), antes mesmo da vida dos colonos. Fizemos que nem Brasília, com ruas largas e espaço de sobra. Apesar de todos os incentivos, as dificuldades encontradas foram grandes. Aqui não tinha nada, nem posto de gasolina. Tínhamos que trazer o diesel para as máquinas de Barra do Garças. Tivemos que construir toda a infra-estrutura das cidades, desde escola, igreja até as pontes. De 1974 a 1980 , duas mil famílias gaúchas vieram para região de Água Boa (MT). Destas 35\% tiveram sucesso e permaneceram. (...) Não trouxemos empresários, mas sim agricultores. Houve muitas frustrações e mesmo assim fomos bem sucedidos. Cerrado e Chomarrão. Água Boa e Canarana. Fonte: Rota Brasil Oeste. 13/05/2001. Entrevista com Elcides Salamoni. www.brasiloeste.com.br
} 
Peixinho (1998), em seus estudos, fazem importante abordagem sobre esse migrante que veio à procura de terras em Mato Grosso.

Os projetos de colonização dirigida foi uma das maneiras que os capitalistas acharam para a não realização da reforma agrária. Aliás, tanto os projetos oficiais de colonização quanto os privados podem ser considerados projetos de "contra reforma agrária", conforme designação de lanni $(1979: 136)^{117}$ sobre a ocupação das terras na Amazônia. Isso é complementado por Tavares dos Santos (1993:62) quando expõe que: "a colonização foi imposta para retirar do campo dos possíveis a execução de uma premente reforma agrária, reforma que, não obstante continua na ordem das prioridades na questão agrária brasileira".

Como Mato Grosso estava sendo privilegiado com projetos de colonização implantados pelo INCRA ou por empresas particulares que, de acordo com Oliveira (1990), foram uns dez projetos criados pelo Incra e mais de cinqüenta que se estabeleceram através das empresas particulares ${ }^{118}$, colonos e ex-colonos do Sul do país migraram para este Estado a fim de conseguir um pedaço maior de terra.

A partir desse processo, Oliveira (1990:67) esclarece que "a implantação dos projetos agropecuários na Amazônia têm também que ser entendido como uma das estratégias dos governos militares no sentido de patrocinarem o acesso à terra na região pelos grandes grupos econômicos". Nesse mesmo viés, Piaia (2003:30) comente que "Mato Grosso transforma-se na grande fronteira que recebe excedentes populacionais expulsos pela economia rural de outros estados, aliviando assim, possíveis tensões sociais nas áreas de origem". Em alguns casos, os projetos governamentais acabavam trazendo problemas aos indígenas ${ }^{119}$.

\footnotetext{
${ }^{117}$ Ianni (1979:136) afirma que: Em forma breve, pode-se dizer que a política de colonização dirigida, que o Estado brasileiro foi levado a adotar nos anos 1964-78, foi uma contra-reforma agrária. Tanto ideológica como, praticamente, essa política efetivou uma contra-reforma agrária que bloqueou, distorceu ou simplesmente suprimiu a reforma agrária espontânea, ou de fato, que os trabalhadores rurais e as suas famílias estavam realizando por seus meios. Sob vários aspectos, a colonização dirigida, oficial e particular, efetivou-se como tal contrareforma agrária.

${ }^{118}$ De acordo com Oliveira (1990:15, 91,) Os grandes projetos lá chagaram. Estão se apropriando de tudo. Explorando tudo. Exportando tudo. A exportação é a palavra mágica que faz mover esse processo de rapina. (...) A presença dos projetos de colonização na Amazônia tem obedecido a processos diversos, porém todos com raízes fincadas na questão da estrutura fundiária concentrada do país. (...) Embora o estado de Mato Grosso seja uma espécie de "paraíso" da colonização particular, lá também o INCRA implantou projetos oficiais de colonização: PAC - Projeto de Ação Conjunta; PA - Projeto de Assentamento; PAC - Projeto de Assentamento Conjunto; PEA - Projeto Especial de Assentamentos; PAR - Projeto de Assentamento Rápido/foram cinco projetos. Os projetos particulares de colonização foram: Porto dos Gaúchos, Canarana, Água Boa, Nova Xavantina, Vila Rica, Nova Mutum, Sorriso, Sinop e Vera, Marcelândia, Matupá, Alta Floresta, Nova Bandeirantes, Colider, Terra Nova, Juara e Novo Horizonte do Norte, Tapurah e Eldorado, São José do Rio Claro, Brasnorte e Juruena e Cotriguaçu. Ver com detalhes esses projetos de colonização em: Oliveira, AU. Amazônia: Monopólio, Expropriação e Conflitos, 1990; Becker, BK. Amazônia. 1994; Piaia, II. Geografia de Mato Grosso. 2003; Moreno \& Higa (org.) Geografia de Mato Grosso. 2005. Tavares dos Santos, JV. Matuchos: Exclusão e Luta. : do sul para a Amazônia. 1993.

${ }^{119}$ Oliveira (1991: 146-7) resume assim a causa de um desses problemas: (...) o governo mato-grossense incumbiu-se, em 1973, de pedir autorização ao Senado Federal para vender 2 milhões de hectares de terras em Aripuanã, um município sabidamente indígena. Este é um dos muitos episódios das falcatruas existentes no Mato Grosso, pois era cláusula contratual que se a empresa que adquirisse as terras não implantasse no prazo de 5 anos (até 1978, portanto) os referidos projetos, as terras voltariam para o patrimônio público. Os povos indígenas foram sendo destruídos com a tomada de seus territórios e, gradativamente, tiveram que marchar para o confinamento das reservas e parques.
} 
Assim como estas, existiram outras áreas de colonização particular que deram origem a muitas cidades ${ }^{120}$ onde, conforme Moreno e Higa (2005:68) "os núcleos urbanos, implantados na Selva ou no Cerrado, possibilitaram apropriação capitalista do campo e a aceleração da reestruturação espacial do território matogrossense" e o INCRA acabou se incumbindo de legalizar a titulação desses milhões de hectares de terras. Tavares dos Santos (1993:57) informa que o INCRA não só regularizou a participação das cooperativas agropecuárias em certos Programas de Colonização da Amazônia, como também lhes impunha a tarefa de controlar o território. Enfim, cabia ao INCRA transferir diretamente os títulos provisórios de propriedade aos colonos estabelecidos nos projetos das cooperativas.

A fim de atender a demanda de matéria-prima e alimentos dos mercados internos e externos, bem como a diversificação do parque industrial do país, a partir de 1970, a economia brasileira passa a ser inserida no processo de internacionalização do capitalismo. Sendo assim, requer a incorporação de novas áreas ao processo produtivo nacional.

Moreno, G. (2005:34 a 51) comenta que o PIN - Programa de Integração Nacional - "criado pelo Decreto-Lei n. 1.106, de 16/06/70, foi considerado o mais importante instrumento de ação no processo de integração da Amazônia às regiões mais 'desenvolvidas' do país, durante o período militar". Além do PIN, a autora comenta ainda sobre outros programas como PROTERRA - Programa de Redistribuição de Terras e de Estímulo à Agroindústria do Norte e Nordeste, criado pelo Decreto-Lei no. 1.179, de 16/07/71; sobre o PRODOESTE - Programa de Desenvolvimento do Centro-Oeste criado pelo Decreto-Lei $n^{\circ}$. 1.192 de 08/11/1971, bem como dos programas integrados de desenvolvimento regional, como 0 POLOAMAZÔNIA - Programa de Pólos Agropecuários e Agrominerais da Amazônia, criado pelo Decreto-Lei no. 74.607, de 25/09/74; do POLOCENTRO - Programa de Desenvolvimento dos Cerrados, criado pelo Decreto-Lei no. 75.320, de 29/01/75.

Genocídios e etnocídios de nações e povos foram se sucedendo. Era o capital aprisionando os indígenas no espaço-prisão das reservas, através da apropriação violenta de seus territórios.

${ }^{120}$ A formação do núcleo urbano de Sapezal está ancorado numa proposta de colonização do Grupo Maggi, que deu esta denominação ao município recentemente instalado, em referencia ao Rio Sapezal. A Lei nº 6.534, de 19 de setembro de 1994, cria o município de Sapezal, com 13.692,88 Km² de extensão territorial. O senhor André Maggi, foi o primeiro prefeito, representando o segmento empresarial. Sapezal já nasceu com infra-estrutura de cidade; posto telefônico, posto de combustível, hotel, churrascaria, restaurantes, farmácia, supermercado e modernas escolas. A energia elétrica era fornecida inicialmente por uma usina hidrelétrica de 400 Kwa, sendo auxiliada por outra, de maior porte. Ambas foram construídas pelo Grupo Maggi, no Rio Juruena. As famílias que compõem a comunidade de Sapezal são oriundas dos Estados do sul do Brasil, fato comprovado pela tez, cor de olhos e sobrenomes. São principalmente agricultores, pessoas afeitas à dura realidade do campo. Ferreira, JCV. Mato Grosso e seus Municípios. 1997:609-10. 
Entre outros programas, existem os setoriais de desenvolvimento regional que também afetaram Mato Grosso, os quais são destacados por Moreno ${ }^{121}$ : o Polonoroeste - acelerou a apropriação capitalista da terra por grupos empresariais e o aumento do processo migratório em Mato Grosso; o Corexport - possuía duas metas principais: aumentar a capacidade de exportação de produtos agropecuários e viabilizar o acesso aos quatro portos principais de escoamento; o Prodecer - por causa da intervenção deste programa, Mato Grosso destacou-se como maior produtor do país nos anos de 2001 a 2004; o Probor - em Mato Grosso, o programa buscou revitalizar a atividade nos seringais nativos e recuperar os seringais de cultivos; o Prodiat - em Mato Grosso, a área abrangida pelo programa era de 227 mil Km² no raio de influência das rodovias federais BR-070 e BR-158; o Prodien tinha a finalidade de dotar de infra-estrutura viária a região de influência da BR-163; o Prodei - objetivava fomentar, por meio de incentivos fiscais, a implantação e expansão do setor industrial; o Promat - teve por objetivo consolidar a organização administrativa e complementar as ações dos demais programas especiais. Sua vigência foi de 10 anos.

Fora esses, havia os programas de desenvolvimento sustentável, que foram implantados e desenvolvidos com financiamento de recursos nacionais e estrangeiros: o Prodeagro - Programa de Desenvolvimento Agroambiental do Estado de Mato Grosso (1992/2003) e o Programa de Desenvolvimento Sustentável do Pantanal.

Até a década de 1970, o espaço agrário da região sudeste mato-grossense, de acordo com Silva (2003:69), "tinha como suporte a pequena produção agrícola de subsistência e a pecuária extensiva. Nessa época a renda fundiária era o principal fator de acumulação capitalista". Mas, com os incentivos oferecidos pelo Estado, através dos programas acima citados, passa a ocorrer um processo de reestruturação no espaço agrário do Mato Grosso, principalmente no eixo CuiabáRondonópolis onde Silva (2003:69) esclarece que esse espaço: "expressava na forma de latifúndios, destruição da biodiversidade, uso pouco intenso das terras com

\footnotetext{
${ }^{121}$ POLONOROESTE - Programa Integrado de Desenvolvimento do Noroeste do Brasil, criado no início da década de 1980, teve vigência até 1988; COREXPORT - Corredores de Exportação, criados pelo Decreto-Lei nº. 5.727, de 04/11/1971; PRODECER - Programa Nipobrasileiro de Cooperação do Desenvolvimento do Cerrado, criado em 1974; PROBOR - Programa de Incentivos à Produção da Borracha Vegetal, instituído em 1972, pelo Decreto-Lei n ${ }^{\circ}$. 1.232; PRODIAT - Programa de Desenvolvimento Integrado do Araguaia-Tocantins; PRODIEN - Programa de Desenvolvimento Integrado Eixo Norte - BR-364 foi criado em 1984 pelo governo estadual; PRODEI - Programa de Desenvolvimento Industrial de Mato Grosso foi criado em 1988 pelo governo estadual; PROMAT - Programa Especial de Desenvolvimento do Estado de Mato Grosso foi instituído pela Lei Complementar $\mathrm{n}^{\circ}$. 31/77, que dividiu Mato Grosso. Ver os programas em detalhes em: Moreno, G. \& Higa, TCS. (2005:34 a 51) Políticas e Estratégias de Ocupação. In: Geografia de Mato Grosso. 2005.
} 
a pecuária extensiva, expulsão e marginalização dos pequenos produtores proprietários e sem-terra, o que, de certa forma, agravou a questão fundiária na região".

Com recursos do PRODOESTE, a BR-364 foi asfaltada; a CIBRAZEM e CASEMAT viabilizaram a implantação de armazéns $^{122}$ para estocagem de grãos, bem como abriu linhas de crédito rural, tanto pelo Banco do Brasil como pelo BEMAT (o banco do Estado), e outros particulares. Entre 1976/77, empresas e centros de pesquisas como EMBRAPA, EMATER-MT, CODEAGRI - Companhia de Desenvolvimento Agrícola de Mato Grosso, CPAC - Centro de Pesquisa do Cerrado e a SAGRI-MT, passaram a exercer atividades neste Estado, a fim de melhorar geneticamente as sementes de soja, bem como de arroz, milho, algodão e feijão, para que pudessem atender à demanda. A primeira safra de soja colhida em Mato Grosso foi em 1979 e, de acordo com Silva (2003:70e 82), "é exatamente nessa época que André Maggi começa a escrever um novo capítulo de sua história no cerrado de Mato Grosso. (...) A empresa Sementes Maggi fazia o papel de banco junto aos produtores descapitalizados"123. Assim como André Maggi, vários grupos (Sementes Girassol, Sementes Adriana, etc.) vieram se instalar em Mato Grosso e ocupar as terras de cerrado com a monocultura de soja, contribuindo, assim, para a expropriação do pequeno produtor, a exclusão e exploração da mão-de-obra familiar $^{124}$ e a concentração fundiária ${ }^{125}$.

\footnotetext{
${ }^{122}$ Verificando o potencial de produção e de comercialização de grãos de soja da região, em 1983, seu André construiu o primeiro armazém na Fazenda SM3, em Itiquira, para receber soja de produtores locais. Era o maior armazém graneleiro de Mato Grosso, próximo à rodovia BR-163. Além disso, foi construída uma pequena usina hidrelétrica, devido ao alto custo da energia a diesel naquela época. A usina de 1000 KWA e uma outra de 300 KWA atendiam a demanda local e as demandas domésticas da fazenda. Silva, CAF da, Grupo André Maggi: Corporação e Rede em Áreas de Fronteira. 2003:74.

${ }^{123}$ Não se contentando com as fracas oportunidades de ampliação de seus negócios no oeste paranaense, André Maggi partiu, em 1979, para o cerrado. $\mathrm{O}$ alto preço da terra, a baixa disponibilidade de terras e a imensa capacidade de antever o futuro no presente lançaram-no ao norte do país. De início, sobrevoou de avião áreas no Amazonas, mas dada a experiência fracassada optou pela região de Rondonópolis, no sudeste de Mato Grosso. No entanto, acabou comprando uma fazenda no município de Itiquira com 2,4 mil hectares de terra (hoje chamada de SM1). Intuição, espírito empreendedor e coragem para arriscar eram fatores determinantes na sua marcha rumo ao cerrado. (...) De início, seu André Maggi não optou por Itiquira para sede dos seus novos empreendimentos em Mato Grosso (...) em razão da distância de aproximadamente $100 \mathrm{Km}$ da fazenda que comprara até a sede do município e da BR-163. Rondonópolis já apresentava uma boa infra-estrutura para ser a sede administrativa dos negócios da Sementes Maggi na Região. (...) Seu André nunca morou na cidade. (...) Blairo Maggi, seu filho, morava numa casinha na segunda fazenda adquirida em 1980, chamada SM2. (...) André Maggi consegui um financiamento do ex-BRDE para a construção de um armazém, mas não se beneficiou do POLOCENTRO. A compra da fazenda SM1se deu em função de o antigo proprietário estar com problemas financeiros junto ao banco do Brasil S/A. André Maggi assumiu a dívida e o Banco deu um prazo maior para a quitação dos encargos. (...) A contrapartida desse mecanismo é que algumas terras compradas por André Maggi foram originadas de dívidas de agricultores junto ao Banco do Brasil que, nesse caso, funcionava como intermediário na compra da terra. Silva, CAF da. 2003:71-2 e 82.

${ }^{124}$ Do ponto de vista social, o sucesso dos grandes produtores no avanço da soja em Rondonópolis significava uma redução da participação da mão-de-obra familiar. De um total de 13.079 trabalhadores em 1975, houve uma significativa diminuição para 3.931, em 1985. O número de empregados temporários também diminuiu de 1.218 para 539, conforme dados do Censo Agropecuário do IBGE (1975 e 1985). Esses dados refletiram a expulsão do pequeno produtor e a intensa mecanização que a lavoura da soja requeria. Silva, CAF da. 2003:78.

${ }^{125}$ O crédito rural subsidiado, que beneficiou os grandes produtores, e o prestígio político de André Maggi eram parte de um processo de valorização e concentração das terras e a sua revenda a preços vantajosos. Muitos pequenos e médios proprietários ficaram à margem dos mecanismos de incentivos fiscais e acabaram se endividando, vendendo suas fazendas e migrando para outras áreas do país. Na chegada de André Maggi, já havia no sudeste mato-grossense um processo de concentração fundiária em curso. Em 1975, a região de Rondonópolis
} 
Várias cooperativas: Coopercana /Cooperativa Agropecuária Mista de Canarana Ltda., que em 1978 cria os projetos Terra Nova I e II, para resolver os conflitos advindos da expulsão dos colonos das reservas indígenas de Nanoai e Gaurita, no Rio Grande do Sul, bem como outros migrantes vindos do Paraná e do próprio Estado; a Cooperativa 31 de Março/Cooprecol (já citada anteriormente), implantou, na região entre 1979 e 1980, os projetos Canarana I, II e III para assentar os colonos sem-terra de Tenente Portela/RS; Cooperativa Paranaense obteve prorrogação dos prazos, vencidos em 1978, e, na década de 1990, implanta o projeto que deu origem ao município de Cotriguaçu. Estes são alguns exemplos de cooperativas citados por Moreno e Higa (2005:68 a 70) as quais se empenharam, também, no papel de colonizadoras no Estado de Mato Grosso e, como sempre, também se beneficiaram muito com isso, prejudicando aqueles que realmente trabalhavam a terra.

Os projetos de colonização e assentamento eram criados e implantados pelo INCRA, pela CODEMAT e INTERMAT ou por empresas particulares, mas o resultado nem sempre era aquilo que a população esperava ${ }^{126}$, pois, em alguns casos, as políticas governamentais não davam a assistência devida e os camponeses, às vezes, abandonavam o projeto e/ou retornavam para sua terra de origem ou saíam à procura de um outro pedaço de terra.

Mesmo com a implantação das superintendências e, principalmente, do INCRA, o assentamento de colonos em Mato Grosso não atingiu os objetivos esperados. Isso porque o futuro dos colonos, em especial os que vieram do Sul, continuava sem definição. Tavares dos Santos (1993: 112-13) comenta sobre a história inacabada do Programa Canarana, na região de Barra do Garças, a Leste do Estado de Mato Grosso, lançado em 1972, onde fala sobre o futuro dos colonos: a armadilha e o retorno ou abandono, pois "a maioria dos colonos teve que submeter-se a esse modelo unívoco de modernização da agricultura; outros foram obrigados a partir para novas zonas de colonização; enquanto alguns dentre eles tentaram pôr em prática uma outra forma de produção agrícola". Esse é apenas um

possuía 5.110 propriedades agrícolas para uma área média das fazendas em torno de 119,59 hectares. Em 1985 esses números mudaram radicalmente. O número total de propriedades caiu para 2.089 e o tamanho médio de hectares por unidade agrícola aumentou para 214,48, conforme dados do IBGE (Censo Agropecuário, 1975, 1985). Silva, CAF da. 2003:73.

${ }^{126}$ Toda colonização traz consigo os mesmos mecanismos estruturais. Primeiro, projeta-se através dos mapas a delimitação da fração do território a ser tomada. Em seguida, todos os meios são válidos para justificar a conquista. Esse processo traz em seu bojo o conflito entre etnias e/ou classes ou frações de classes que sempre culminam com a domesticação cultural. 'Domesticados', os novos trabalhadores da fronteira são submetidos à dominação. Dominação essa que se estrutura através das empresas de colonização e se consolida com a sua herança: a emancipação desses projetos de colonização e a sua transformação em municípios. O Estado que vai se constituindo é a expressão da dominação existente. Os proprietários das colonizadoras tornam-se os novos ‘coronéis’ da política local. Oliveira, $1991:$ 156. 
exemplo, mas foram inúmeras as famílias que viram seus sonhos de se tornarem produtores em Mato Grosso não dar em nada. Além de perder as terras, perderam também a dignidade, a coragem de voltar para o seio da família - história comentada por um aluno de Geografia Agrária em 2002, sobre sua família que veio do Sul por conta de um programa de colonização e acabou perdendo tudo. Como os pais não tiveram coragem de voltar ao Estado de origem, instalaram-se em Rondonópolis, onde pais e filhos passaram a trabalhar em diferentes atividades fora da agricultura.

De certo modo, esses programas, ou seja, as políticas governamentais acabam contribuindo para o processo de expropriação e migração contínua dos trabalhadores rurais, dos camponeses, dos pequenos proprietários, em benefício dos grandes e médios empresários ${ }^{127}$.

Tanto os posseiros quanto os meeiros, os arrendatários e os indígenas ficavam numa situação intratável diante desse processo de "ocupação", desta nova versão da Marcha para o Oeste que aconteceu em Mato Grosso, pois eles acabavam sempre expulsos de suas terras por causa da nova fronteira agrícola, indo em busca de terras cada vez mais distantes. Devido a isso, os conflitos sociais não cessam.

Das muitas pessoas que vieram para Mato Grosso, algumas conseguiram adquirir grandes extensões de terras, pois, além de serem baratas, existiam em abundância e para isso havia incentivos fiscais e crédito fácil. Vieram não só migrantes do campesinato nordestino e sulista, como também personalidades representantes do grande capital que, devido à modernização da agricultura e valorização - principalmente - das terras do Sul, não tiveram mais condições de manter suas pequenas, médias e grandes propriedades ${ }^{128}$.

\footnotetext{
${ }^{127}$ Essas evidências foram captadas por Andrade (1995:75), que afirma: Não se pode negar que as políticas governamentais agrícolas são sempre destinadas a beneficiar os grandes e médios empresários, tanto em conseqüência do poder de pressão e da conivência dos técnicos e administradores que legitimam essa atitude com um discurso que a justifica, como em virtude da defesa da economia de escala e da melhor qualificação tecnológica da grande lavoura. Há uma tendência no país, bastante acentuada após 1964, a uma concentração tanto da produção agrícola como da propriedade da terra. Da produção, porque os proprietários passaram a administrar toda a propriedade, utilizando mão-deobra assalariada, fazendo desaparecer a agricultura de parceiros e arrendatários que foram desalojados dos seus sítios; concentração da propriedade da terra, porque os grandes grupos econômicos vêm conseguindo obter grandes porções de terra nas áreas em ocupação, nas chamadas frentes de expansão localizadas no Centro-Oeste, na Amazônia e no Maranhão, ou adquirir, por preços baixos, terras nas próprias áreas tradicionalmente ocupadas.

${ }^{128}$ Quando se pôs em movimento o avanço sulista em direção ao norte, dois grupos sociais se apresentavam. De um lado, uma classe de grandes fazendeiros, que dirigia empresas importantes e acumulava significativo papel político. De outro lado, a marcha pioneira formada por pequenos proprietários e sem-terra. (...) A marcha pioneira para o Centro-Oeste foi marcada pela chegada de produtores com grandes problemas em suas regiões de origem, tais como desemprego estrutural, expropriação, valorização das terras e busca de novas áreas para expansão de seus negócios, dentre outros. As dificuldades atingiam tanto os fazendeiros descapitalizados quanto os já capitalizados. E é nesse ponto que se insere a importância de André Maggi. Como é sabido, as fortunas são instáveis. A fraca disponibilidade de terras no oeste paranaense impedia maior dinamismo dos negócios da Empresa Sementes Maggi Ltda. Isso porque a dinâmica da fronteira agrícola estava
} 
O problema fundiário, tanto em Mato Grosso, como no país, é sério e gera muitas desigualdades econômicas e sociais. Fazendo um levantamento sobre isso, Oliveira (1991) ${ }^{129}$ verificou que existem áreas com problemas mais graves, como os casos dos municípios que apresentam conflitos devido à concentração de terras ser extremamente exagerada.

Se as tensões sociais aumentaram e a produção alimentar diminuiu, para que serviram os latifúndios que se formaram em Mato Grosso? Os donos de alguns desses latifúndios estavam à espera de melhorias na região (construção e ou, asfaltamento de rodovias, melhorias nas vias de transportes para o escoamento das futuras safras, mercado de trabalho, exército de mão-de-obra, construção de indústrias, melhoria no abastecimento de energia elétrica, etc.), para que pudessem vendê-los a preços elevadíssimos, pois terra em Mato Grosso não era problema. Outros transformaram suas propriedades em enormes empresas agrícolas voltadas totalmente para abastecer o mercado externo (caso dos grandes produtores e exportadores de soja e outros grãos, bem como os criadores de gado para exportação). Sendo, portanto, boa parte deles latifúndios improdutivos, terras para especulação e não para produção.

A busca pela terra em Mato Grosso, a partir das décadas de 1970 e 1980, foi muito grande, e seus preços elevaram-se assustadoramente. Muitos latifundiários realizaram excelentes negócios. Sabe-se que algumas concessões foram feitas pelo Estado, somente por interesses políticos, especialmente em anos eleitorais, causando inúmeros escândalos ${ }^{130}$.

Com a especulação de terras e o avanço da tecnologia no campo a partir da década de 70, o nível de desemprego do homem do campo aumentou. Os camponeses saíam à procura de terras improdutivas e praticamente abandonadas.

\footnotetext{
associada à geografia, visto que, em virtude dos novos desbravamentos, incorporarem terras e mão-de-obra ainda era um requisito básico para o avanço da frente pioneira capitalista. Silva, C.A.F da. 2003:64.

${ }^{129}$ Sobre o assunto ler Oliveira (1991), Agricultura Camponesa no Brasil.

${ }^{130}$ O governo estadual através da CODEMAT - Companhia de Desenvolvimento do Estado de Mato Grosso S/A, implantou vários projetos. A atuação da CODEMAT em Juína esconde muitos escândalos e violência, mas o maior deles envolve a ocorrência de diamante na área. Uma empresa multinacional já opera no vale do Juruena, extraindo diamante do cascalho do fundo do rio. Ao que se comenta na cidade, altos funcionários da CODEMAT, entre eles um parente próximo do ex-governador Júlio Campos, teriam ficado com os lotes onde o mineral ocorre. (...) o segundo grande projeto do INCRA no Mato Grosso é Lucas do Rio Verde. (...) Lucas é uma das grandes falcatruas da colonização oficial, e há quem diga por lá que há “gente grande de Brasília no meio da muamba”. Segundo a legislação em vigor, o INCRA poderia anular a concessão dos títulos, pois eles são provisórios. Entretanto, o ex-executor do INCRA, demitido do cargo por processo administrativo, partiu para a articulação política, criando o diretório do PMDB em Lucas e apoiando o governador eleito em 1986, Carlos Bezerra. Em troca pediu, simplesmente, a "anistia” para tudo o que ocorreu em Lucas do Rio Verde. Conclusão: estamos outra vez diante da oficialização de mais um escândalo. Oliveira, A.U. 1991:152 a 154.
} 
Até 1975, a base de sustentação econômica de Mato Grosso era a agropecuária desenvolvida em áreas de projetos de colonização empresarial, com predomínio para a pecuária. Desse período até 1995, devido às exigências e demanda do mercado externo, as terras mato-grossenses, utilizadas com pastagens naturais, precisaram aderir às novas técnicas que estavam impulsionando o mercado. As áreas ocupadas pelo rebanho bovino eram imensas, "daí a expressão cunhada para definir a colonização das terras no Estado, no século XX: 'Mato Grosso foi ocupado pela pata do boi"' (Moreno \& Higa, 2005:48). Assim como as áreas de lavouras que, com a intensificação da modernização agrícola, acabaram transformando os estabelecimentos em empresas agrícolas, muitos produtores se destacam no ranking mundial, entre eles Blairo Maggi ${ }^{131}$.

A intensificação da modernização, da industrialização da agropecuária, principalmente da agricultura, vem contribuindo para que Mato Grosso tenha destaque nacional e internacional neste setor, em especial na produção de soja, algodão, milho, chegando a ser considerado o "celeiro do Brasil", onde a chamada "moeda verde" - a soja - tem mais importância e significado que o Banco do Brasil. De acordo com Silva (2003:81-2), "é a exclusão financeira imposta pelo crédito agrícola o principal fator para a instituição da moeda verde"132. É comum se ouvir ainda hoje, principalmente pelos trabalhadores ou pequenos e médios produtores que foram expropriados da terra, que "onde o boi e a soja entram o homem sai".

Mesmo com o destaque para os grandes latifundiários, Mato Grosso ainda conta com a presença numérica de pequenos agricultores que buscam programas governamentais para se manterem no campo, cuja produção carece de incentivos financeiros para o seu fortalecimento.

Em Mato Grosso, pode-se citar, como exemplo de contribuição ao aumento, ao crescimento, ao fortalecimento dessa classe camponesa, o Programa "Nossa Terra Nossa Gente", criado e instituído através do Decreto Lei no. 7.271, de 19 de abril de 2000, no governo de Dante de Oliveira, por João Mariano, presidente do INTERMAT ${ }^{133}$ - Instituto de Terras de Mato Grosso. Esse programa está buscando

\footnotetext{
${ }^{131}$ Blairo Maggi: Governador reeleito de Mato Grosso em 01/10/2006 e maior produtor individual de soja do mundo.

${ }^{132}$ A moeda verde nem sempre é acionada. Antes o grupo comprava soja verde dos agricultores, ou seja, era uma forma de compra antecipada da soja antes da produção. Na hora em que o agricultor buscava financiamento para plantar, ele já comprometia parte da produção com o grupo. Atualmente, o mercado inviabiliza o produtor a vender soja antecipada. Hoje se antecipa dinheiro ao produtor e ele compromete uma parte do produto sem fixar o seu preço. Silva, 2003:89.

${ }^{133}$ Instituto de Terras de Mato Grosso/INTERMAT tem como missão executar as políticas agrária e fundiária do Estado de Mato Grosso, garantindo ao trabalhador rural e urbano o acesso à terra e melhoria na qualidade de vida. Serviços prestados: Regularização Fundiária de
} 
levar dignidade a trabalhadores que, devido ao êxodo rural, estão hoje desempregados na cidade. Visa atender, prioritariamente, através de vilas rurais ${ }^{134}$, comunidades tradicionais $^{135}$ e assentamentos convencionais $^{136}$, famílias desempregadas que tenham aptidão para trabalhar com a terra.

A ocupação e uso do espaço mato-grossense, desde o período colonial até nossos dias, têm provocado degradação ambiental associada à injustiça social. $O$ cerrado mato-grossense foi ocupado e suas riquezas naturais foram exploradas durante longos anos, iniciando-se com a exploração das riquezas minerais (ouro, diamante), posteriormente, dos recursos vegetais (borracha, poaia etc.), a prática extensiva da pecuária e, atualmente, com a exploração do solo para a prática da agricultura, especificamente a produção de grãos, não se esquecendo da exploração indevida da madeira.

Todo processo de ocupação tem seus benefícios, mas também prejuízos, pois, sendo um processo de transição de uma situação à outra, acarreta, ou seja, requer nova compreensão por parte dos envolvidos. Ocorrem, pois, mudanças nos modelos de produção e tecnologias que vão surgindo a fim de facilitar o novo modo de apropriação da natureza, bem como um outro perfil do hábito de consumo das famílias envolvidas.

áreas rurais; Expedições de certidões e mosaicos de localização de áreas e outros documentos pertinentes ao domínio de terras do Estado de Mato Grosso.

\begin{abstract}
134 “Programa Nossa Terra Nossa Gente”: A implantação de vilas rurais busca levar dignidade a trabalhadores que devido ao êxodo rural, estão hoje desempregados na cidade. O Projeto visa atender prioritariamente, famílias cujos pais possuam acima de 45 anos, desempregados, que não tenham imóvel na cidade e que demonstrem aptidão para a lida com a terra. As áreas destinadas à criação de vilas rurais estão localizadas nos entornos dos centros urbanos e são adquiridas pelo Governo do Estado ou em parceria com os municípios contemplados. Os lotes de 1,2 a 2,5 hectares (1), são destinados, preferencialmente, para homens e mulheres com mais de 45 anos, que depois de selecionados, cadastrados e registrados no Sistema de Informações de Projetos de Reforma Agrária (Sipra/Incra), tornam-se habilitados à concessão de créditos destinados à agricultura familiar e à reforma agrária. Até maio de 2005, este programa implantou Vilas Rurais em 17 (dezessete) municípios, por intermédio de compra, disponibilização convênio ou desafetação, 22 (vinte e dois) projetos, beneficiando 1.156 famílias. Fonte: DAS-INTERMAT. Maio de 2005.
\end{abstract}

\footnotetext{
135 “Programa Nossa Terra Nossa Gente”: O Projeto de Revitalização de Comunidades Tradicionais beneficiou comunidades rurais da Baixada Cuiabana. A intenção do Projeto é melhorar as condições de habitação das famílias de pequenos produtores rurais, que moram em casas de pau-a-pique e adobe por gerações. O convênio é uma parceria entre o Instituto Nacional de Colonização e Reforma Agrária (Incra), Intermat, Secretaria de Estado de Infra-Estrutura (Sinfra). Sendo O Intermat responsável pela implantação dos projetos de assentamentos nos municípios. O agricultor beneficiado pelo projeto recebe uma casa de alvenaria com $42 \mathrm{~m}^{2}$, com sala, cozinha, dois quartos, banheiro e varanda. O beneficiário ainda receberá auxílio plantio e crédito alimentação. Já quem não quiser fazer parte do projeto ou não se inserir nos critérios exigidos pelo programa, poderá receber a titulação definitiva da terra e participar do Programa Nacional de Fortalecimento da Agricultura Familiar (Pronaf). Até maio de 2005, este programa implantou Projetos de Assentamentos de Comunidades Tradicionais em 9 (nove) municípios, por intermédio de arrecadação, 67 (sessenta e sete) projetos, beneficiando 3.447 famílias. Fonte: DAS-INTERMAT. Maio de 2005.

${ }^{136}$ O Instituto de Terras de Mato Grosso (Intermat) desenvolve dentro do Programa Nossa Terra, Nossa Gente projetos de Assentamentos Rurais, em parceria com o Instituto Nacional de Reforma Agrária (Incra), para assegurar o acesso à terra a famílias de trabalhadores semterra. O Intermat executa uma política de resgate à cidadania das famílias de pequenos produtores, dando apoio ao desenvolvimento rural sustentável. Até maio de 2005, este programa implantou Projetos de Assentamentos Rurais em 23 (vinte e três) municípios, por intermédio de compra, arrecadação, permuta, doação e desapropriação, 30 (trinta) projetos, beneficiando 4.796 famílias. Fonte: DAS-INTERMAT. Maio de 2005.
} 
Assim sendo, as novas formas de apropriação dos recursos naturais e o novo modelo agrário-exportador provoca a rebeldia do homem no campo e na cidade, pois, na maioria das vezes, o direito à terra aos que realmente nela sabem trabalhar é negado. Daí, dizer, com propriedade, que a modernização provoca não só impactos sociais, como ambientais e culturais, é uma necessidade. Do ponto de vista social, a preferência pela monocultura e a mecanização substituiu a mão-deobra e as culturas alimentares. A prática de parceria, arrendamento, colonato, morador, bastante utilizadas até então, foram aos poucos desaparecendo.

Os inúmeros trabalhadores que antes vendiam sua força de trabalho aos latifundiários, foram substituídos por máquinas e, com isso, cresce o emprego formal, no qual o trabalhador exerce suas atividades somente durante um período do ano, ou seja, na colheita da soja e na capina do algodão, caso comum em Rondonópolis. Após esse período, passa a contribuir com o aumento do número de desempregados. Adão Hipólito - Secretário de Agricultura e Pecuária de Rondonópolis $^{137}$ - explicou que "embora trate de uma mão-de-obra temporária, a maioria dos trabalhadores empregados na agricultura é contratada com carteira assinada. São contratos feitos por um período pré-determinado de tempo". Comentou, ainda, que, geralmente, esses contratos têm duração de noventa dias, podendo ser contratados e demitidos novamente, conforme as necessidades.

Sem contar que, fora isso, a concentração fundiária, em Mato Grosso, é um exemplo determinante. Esses fatores, aliados a outros, levaram muitos dos pequenos produtores ao endividamento e, conseqüentemente, ao desemprego. A combinação do efeito desemprego e concentração de terras concorreu a fim de que muitas pessoas migrassem para as cidades. Em decorrência disso, a degradação da qualidade de vida nas cidades se acelera, provocando, assim, uma revolta social.

Do ponto de vista ambiental, a drasticidade é praticamente a mesma. Induzidos pelos padrões produtivos da Revolução Verde, os ecossistemas brasileiros foram afetados, pois o cerrado foi devastado, o solo degradado pela prática extensiva da agricultura, havendo o empobrecimento da genética dos cultivares, das plantas e dos animais, contaminação dos alimentos e dos consumidores, por diferentes produtos químicos.

\footnotetext{
${ }^{137}$ Emprego: Demissões no campo puxam saldo negativo. Diário Regional. Rondonópolis e Região Sul. 26/04/2007. Economia/Agronegócio. P. 7.
} 
No que se refere aos impactos sociais, poder-se-ia dizer que, a partir do momento em que o Brasil adotou um modelo agrário-exportador, com base nos padrões europeus como sendo o único a ser seguido, foi como se tivesse amputado mãos e pernas dos trabalhadores tradicionais cuja experiência foi adquirida durante longos anos. Em Mato Grosso, sabe-se da existência de grupos indígenas e de quilombolas que empregavam seus saberes e, em sincronia com a natureza, dela retiravam o suporte para sua sobrevivência, sem se preocupar com o acúmulo de produção, pois a lógica desses camponeses era o sustento da família. Com o processo de modernização, seus conhecimentos foram desprezados, marginalizados e seus processos de reprodução desestruturados.

Todo esse processo de ocupação e modernização contribuiu para o aumento dos latifúndios, para exploração e subaproveitamento, gerando problemas econômicos e sociais. Foi o que aconteceu com os posseiros da Gleba Cascata/Fazenda Floresta e os sem-terra do MST/Fazenda Aliança - áreas por mim pesquisadas durante o mestrado. Espaços esses, onde, na maioria das vezes, os donos só aparecem para reclamar a terra, depois de certo tempo em que os posseiros encontram-se no local, quando alguns benefícios, algumas melhorias já haviam sido feitas na área. Pensando em modificar a realidade agrária brasileira e mato-grossense, muitos goianos, mineiros, paulistas, nordestinos e sulistas acreditaram e apostaram nas terras do cerrado rondonopolitano, vindo ocupá-las. Caso das cinco famílias pesquisadas neste estudo, as quais são o testemunho de que Mato Grosso foi e ainda é palco de atração para os migrantes que vêm à procura de vida melhor, seja para trabalhar no campo ou na cidade. 
4- RONDONÓPOLIS: FORMAÇÃO DO ESPAÇO GEOGRÁFICO 


\subsection{Quadro Geral de Rondonópolis}

Localizado na Mesorregião Sudeste mato-grossense, Rondonópolis ocupa a porção Sul de Mato Grosso na Microrregião de Rondonópolis (correspondente a 24.054 $\mathrm{Km}^{2}$, ou seja, 2,66\% da área do Estado), juntamente com os municípios de Dom Aquino, Itiquira, Jaciara, Juscimeira, Pedra Preta, São José do Povo e São Pedro da Cipa (Mapa III). Assim, Rondonópolis limita-se ao Sul com Itiquira, a Sudeste com Pedra Preta, a Nordeste com São José do Povo, ao Norte com Poxoréo e São Pedro da Cipa, a Noroeste com Juscimeira e a Sudoeste com Santo Antonio do Leverger.

A cidade localiza-se entre as coordenadas de 16⒉" e 16030"S e 54⒊" e 543'"W, estando aproximadamente a 1440 km de distância do Oceano Atlântico. Apresenta área de $4.258,61 \mathrm{Km}^{2}$, que corresponde a 0,62\% do Estado de Mato Grosso, não se enquadrando entre os maiores municípios em extensão no Estado, mas, em se tratando de população, de acordo com do IBGE até $1^{\circ}$ de julho de 2006 , era de 169,514 mil habitantes, terceira maior população do Estado.

Em relação à estrutura física de Rondonópolis, SETTE e TARIFA (2001: $9,10,17)$ relatam que (...) o quadro físico da cidade estende-se num sítio convergente, de topografia plana e levemente ondulada da confluência (margem esquerda) dos rios Arareau e Vermelho. Esta posição, num nível morfológico rebaixado ou de depressão, tem importantes implicações no clima local, na estrutura do clima urbano e no ritmo dos atributos climáticos. O entorno próximo (distância entre 20 até $100 \mathrm{~km}$ ) é constituído por um anfiteatro de terras altas (chapadas e serras) cujos topos variam de 700 até 800 metros. Rondonópolis encontra-se regionalmente localizada numa área de clima tropical continental quente (megatérmico), alternadamente úmido e seco, em função do ritmo de atuação dos sistemas tropicais, equatoriais e extratropicais.

Conta com expressivo potencial hídrico, pois a maior parte do município é banhada pelos rios da bacia do São Lourenço. O principal é o rio Vermelho ou Poguba, o qual atravessa todo o município. Possui vários afluentes: rios Arareau, Areia, Tadarimana, Ponte de Pedra e Jurigue.

Originalmente, a cobertura vegetal da superfície, hoje urbanizada, era formada por cerrado, veredas e matas ciliares. Atualmente o que resta é apenas 
MAPA III- LOCALIZAÇÃO DE RONDONÓPOLIS EM RELAÇÃO À:

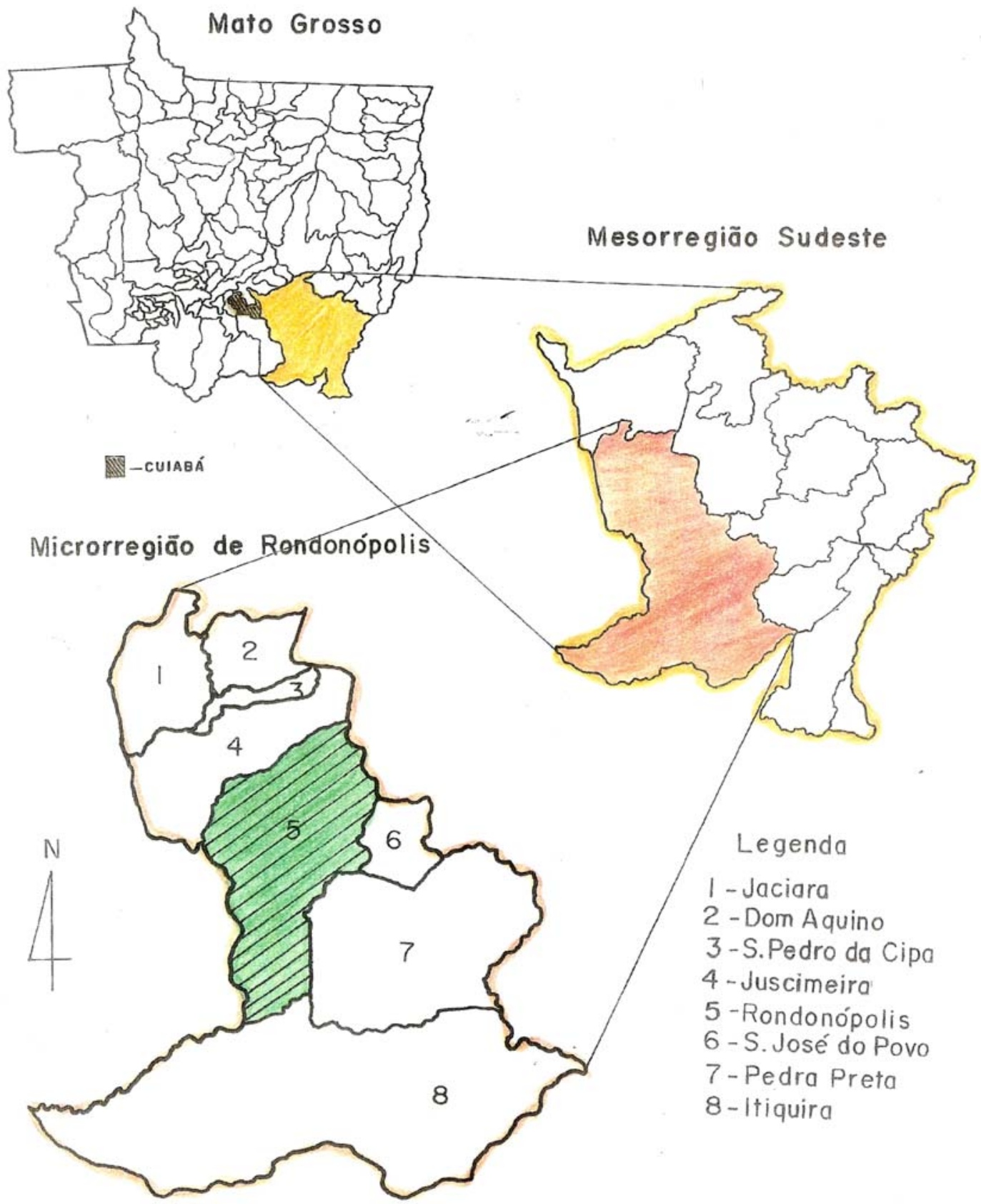

ESCALA : 인 $35 \mathrm{~km}$ 
uma reserva de 11 hectares com vegetação natural. Nos fundos dos vales do ribeirão Arareau e rio Vermelho, não foi preservada sequer a faixa protetora das margens, previstas na Lei 1.511 (complementar ao Código Florestal) de 07 de julho de 1986.

Aliás, o que se presencia hoje, é um total descumprimento aos Artigos 15 e 16 elaborados e estabelecidos em 5 de fevereiro de 1918, como instruções para a "Construção da Povoação do Rio Vermelho e a Conservação do seu Patrimônio, organizadas por autorização do Exmo. ${ }^{\circ}$ Sr. Dr. Secretário da Agricultura, referendado, pelo Agrimensor O. Pitaluga", que estabelecia o seguinte:

Artigo $15^{\circ}$ - para garantia dos mananciais dos córregos do Patrimônio, Canivete e Bonito, não poderão ser utilizadas as suas matas em lavoura, e somente em extração de alguma madeira útil, contanto que não fiquem comprometidos o desenvolvimento das árvores miúdas, nem o renascimento da árvore derrubada.

Artigo $16^{\circ}$ - Fica proibida a derrubada das matas marginais ao rio São Lourenço, Vermelho e ribeirão Arareau até a distância mínima de 10 metros da barranca ou do leito, salvo o caso de ser necessário abrir um porto (sic) ou uma passagem para outro serviço público. Cury, 1973:42.

$\mathrm{Na}$ verdade, por conta do crescimento e desenvolvimento da cidade, sabe-se que, tanto os córregos Patrimônio, Canivete e Bonito, como os rios Vermelho e Arareau, estão não só com suas margens comprometidas, como também com suas águas poluídas. Na realidade, são receptores clandestinos, visíveis a olhos nus, de esgotos domésticos e resíduos industriais, bem como lixo e entulhos despejados constantemente às suas margens e transportados, posteriormente, pelas águas da chuva para seus leitos. Isso, sem contar o estrago provocado por dragas nos rios Vermelho e Arareau. São inúmeras, também, as construções ao longo desses córregos e rios, chamando a atenção pelo padrão social, variando de casebres à beira dos rios Vermelho e Arareau, aos "Ranchos Nobres" para descanso em finais de semana ao longo do rio São Lourenço, cujos donos (políticos, juizes, advogados etc.) já foram autuados, mas, além disso, nada foi concretizado.

A respeito dos solos de Rondonópolis, Eli (1998:44) salienta que, de modo geral, possui Latossolos Vermelho-Amarelo álico, havendo predomínio do solo Podzólico Vermelho-Amarelo eutrófico e a presença, ao Sudoeste, de Areias Quartizosas álicas. Genericamente, estes solos são profundos, bem drenados, bem 
estruturados, de baixa capacidade de retenção de água, altamente intemperizados e de baixa fertilidade natural, que dão sustentação à cobertura vegetal do cerrado.

Por intermédio de seus valores, seu modo de vida, sua cultura e sua história, o homem interfere nas paisagens. Em relação à compartimentação e estruturação da paisagem do município de Rondonópolis, Eli (1998:108) nos esclarece a utilização exacerbada dos compartimentos, promovida pela agressão ativada pelas atividades humanas através do desmatamento, das queimadas, das práticas agropecuárias, da construção de estradas e edificações. Isso determinou uma paisagem degradada e em estado de resistasia, deixando-a à mercê das relações processuais, que foram identificadas pela presença de ravinamentos, voçorocamentos, escoamentos superficiais e difusos, além da erosão de subsuperfície e remontante.

Porém, tanto as áreas de matas como de cerrados e cerradões estão sofrendo intensas modificações, dando lugar às pastagens e às lavouras de soja e algodão que, atualmente, voltou a figurar em nossa região.

Por abrigar um distrito industrial de porte considerável, sediando as maiores empresas do agronegócio de Mato Grosso e uma diversificação no comércio, Rondonópolis é considerada como o centro polarizador da economia regional. Segundo dados do Ministério do Desenvolvimento, Indústria e Comércio Exterior MDIC, no Brasil, o município ocupa a $22^{\mathrm{a}}$ posição no ranking de exportadores. Restringindo-se ao saldo da balança comercial (exportação menos importação), salta para a $11^{\mathrm{a}}$ posição no país e, em relação a Mato Grosso, mantém a liderança, bem à frente de Cuiabá $^{138}$.

\subsection{Formação Territorial de Rondonópolis: Gênese do Latifúndio e do Campesinato}

As relações que os homens estabelecem entre si e com a natureza, durante ou ao longo do processo histórico, são determinantes para a construção da paisagem de um determinado território. Às vezes, a postura adotada pelo homem compromete profundamente toda a sociedade, que acaba, em parte, tornando-se co-

${ }^{138}$ Rondonópolis é a maior exportadora de MT. Matéria exibida no A TRIBUNA, Ano 36- Nº.6257, de 3 de fevereiro de 2006, na página A8. 
responsável pelos problemas vivenciados pela comunidade em geral. Por intermédio dessas relações, conforme afirma Gonçalves, Carlos V.P. (2000:94-6), "é importante sublinhar que no interior de cada povo-cultura, dependendo da natureza de sua organização social, desenvolvem-se tensões, conflitos e lutas de caráter variado".

Nesse sentido, empenhei-me em estudar o espaço rondonopolitano e sua organização social, com base em estudos já desenvolvidos por vários pesquisadores. Sendo assim, busquei em Cury $(1973)^{139}$ que registrou uma trajetória, descrevendo desde os primeiros migrantes que para cá vieram em 1902, a fim de formar um novo território, até os 20 anos de Rondonópolis; em Tesoro $(1993)^{140}$, que mostra, através de relatos de lembranças e experiências dos pioneiros, o resgate histórico de Rondonópolis a partir da visão deles; em Suzuki (1996), que procurou desvendar e defender a idéia de que a transformação dos povoados em cidades está vinculada à transição do rural ao urbano, e que essa transição pode ampliar e (re)criar condições necessárias ao desenvolvimento de atividades extrativas e produtivas, mudando, inclusive, o modo de vida das pessoas, dos moradores; em Nascimento (1997), mostrando que, pela aceleração temporal, a rapidez do processo histórico é a característica fundamental, pois Rondonópolis, em um espaço de cinqüenta anos, caminhou do isolamento ao agrobusiness, em função das demandas do desenvolvimento econômico, da ação estatal sobre a região e das relações socais entre capitalismo e a produção camponesa. Destacou, também, que a apropriação da renda da terra modificou profundamente as características sócioculturais iniciais da região, compelindo os índios, os camponeses e trabalhadores a adotarem novas estratégias de sobrevivência; em Peixinho (1998), com suas "onças vermelhas e amarelas", fez-me entender o quanto as máquinas contribuíram para a exploração do cerrado, bem como a expropriação da mão-de-obra existente neste município. Além desses, existem outros trabalhos acadêmicos relevantes, que fazem uma reflexão sobre a estruturação do espaço rondonopolitano.

\footnotetext{
139 Carmelita Cury nasceu um ano após a criação deste município, sendo, portanto, fonte viva desse contexto histórico "Para escrever este livro, tive de ocultar muitas lágrimas, procurei ser forte, senti-me às sombras da loucura, mas queria terminar porque minha vontade imperava. Lutei, sacrifiquei, conheci o sabor de uma batalha, mas me sinto feliz por haver terminado nos meus 19 anos, aquilo que a tanto tempo eu pesquisava. (...) Quando escrevi este livro não fui levada, pelo sabor de uma fama, ela não me dominaria a mente. (...) Quis realizar este trabalho, porque sou filha de Rondonópolis, amo esta minha terra, pedacinho do meu Brasil, potencia (sic) de Mato Grosso. Rondonópolis, eis o meu presente dos teus 20 nela esta toda a minha mensagem de carinho e de amor. Que teus anos sejam de glórias e de prosperidades perpétuas.” Cury, 1973:242-244.

${ }^{140}$ Luci Lea Lopes Martins Tesoro é migrante paulista, filha de imigrante espanhol, que se radicou em terras rondonopolitanas desde meados dos anos 50. Ela mudou-se para Rondonópolis em 1980 e desde então, vem prestando relevantes serviços como educadora e escritora neste município.
} 
Procurei, assim, mostrar as relações estabelecidas entre os elementos que contribuíram para a formação deste município e, ainda, que o espaço rondonopolitano teve sua ocupação a partir do século XVIII, quando surgiram os primeiros povoados.

Historicamente, a colonização e a ocupação humana de Rondonópolis, com base em Tesoro (1993:12-3), embora tenham sido como nos demais municípios do Centro-Oeste, por causa do movimento da Marcha para o Oeste, enquanto os outros municípios de Mato Grosso foram formados com base na extração garimpeira, ele se inseriu no contexto capitalista de produção como fronteira agrícola e sua ocupação pode ser dividida em três períodos distintos: a vinda de migrantes com o objetivo de povoar a região de Mato Grosso conhecida como Terra de Rondon, na década de 1920; sua migração acentuou-se na década de 1930 até 1945 com a chamada Marcha para o Oeste, durante o governo de Getúlio Vargas; mas, o que contribuiu decisivamente para a ocupação humana das terras de Rondonópolis, foi a cultura da soja, principalmente por sulistas, a partir da década de 1970.

Já Cury (1973:11), ao comentar sobre a ocupação e o povoamento de Rondonópolis, menciona como primeiros habitantes os Bororo Coroados que "ocupavam a grande faixa banhada pelos rios Poguba, Poguba-Xoréu, São Lourenço, e iam até o Araguaia"141. Cury refere-se, ainda, à vinda dos primeiros goianos (João Arenas Teixeira e Manuel Conrado dos Santos) ${ }^{142}$ já em princípios de 1902. O objetivo de Teixeira era a procura de ouro e diamante; já Conrado, veio com a esposa, sete filhos e mais um parente, à procura "da terra dos cerrados, pássaros e horizontes diferentes" (Cury, 1973:15), uma terra boa, onde pudesse produzir e viver tranqüilo com a família. Vieram tocando boiada e abrindo estradas. Cury (1973:14) comenta que: "A viagem foi longa. Depois de quatro meses de cavalgada (...), perdendo objetos, morrendo novilhas, chegaram ao seu destino. (...) estacaramse perto da nascente de uma cachoeira a margem esquerda do rio Vermelho".

\footnotetext{
141 “Atacavam os bandeirantes e moradores. Para combatê-los foi organizada a bandeira que, chefiada pelo tenente Duarte, depois de muito matar conseguiu a paz graças a intervenção da menina Rosa Bororo, mãe do Cacique José Coroado, que prestou auxilio ao tenente Pirineus no Paranatinga. (...) as aldeias de nossos bororos avizinhavam-se do rio Arareau (quer dizer Peraputanga) e Poguba (rio Vermelho), passavam a maior parte do tempo caçando e pescando, subindo e descendo de canoa”. Cury, 1973:11-12.

142 “João Arenas Teixeira, descobriu manchões dos famosos garimpos das Pombas, de São Pedro e outros de onde se originaram os povoamentos de Poxoréu. No final localizou-se em Rondonópolis, por alguns meses, para explorar melhor as terras férteis encravadas em majestosas planícies onduladas pertencentes ao município de Poxoréu, região Ouro-Diamante. (...) Manuel Conrado dos Santos, vindo de Palmeiras foi o primeiro goiano a residir definitivamente em Rondonópolis com sua familia e mais um parente Luiz Esteves Rodrigues dos Santos”. Cury, 1973:13.
} 
Em janeiro de 1903, nasce o primeiro rondonopolitano, filho de Manuel Conrado que, segundo Cury, por vontade do pai, recebe o nome de Antonio Rodrigues dos Santos. Em 1906, outros grupos de famílias, Rodrigues e Esteves, vieram se juntar aos que aqui já se encontravam para formar o Vale do Rio Vermelho. Em 1907, mais famílias radicaram-se para compor a população de Rondonópolis: vieram parentes dos pioneiros, amigos e pessoas de outras regiões do país ${ }^{143}$. Em 1910, o Sr. Antonio Pereira dos Santos (Antonio Noca) veio da Bahia em busca de uma terra para trabalhar e onde pudesse constituir sua família. Sendo assim, ocupou as terras da Fazenda Belém, que depois foi doando aos filhos. A mesma autora (1973: 25-6) comenta que "as famílias iniciavam os seus cálculos, removendo as matas como se transportassem montanhas. (...) durou muitos anos para ser concretizado o sonho dos pioneiros goianos". Nessa época, o sonho de todos era elevar o Vale do Rio Vermelho a patrimônio. Portanto, uma comissão dirigiu-se até a capital a fim de falar com o Governador do Estado. E, no dia 10 de agosto de 1915, foi promulgado o Decreto - Lei $N^{\circ} 395$, pelo qual 2.000 hectares de terras foram doados ao povoado do Rio Vermelho. Cury, 1973:36.

Cury (1973) ressalta que, a partir de então, começa a se desenvolver o povoado. Constrói-se a primeira estrada ${ }^{144}$. Em 1916 tem início a construção da primeira casa de comércio do povoado ${ }^{145}$. Em 1917, Pitaluga, que era agrimensor, assinalou a trajetória que demarcaria os pontos a serem registrados no mapa e, em 1918, arquiteta modernamente o traçado do povoado do Rio Vermelho. Via ele a necessidade de transferir as fazendas para a zona rural, a fim de proporcionar melhores acomodações para a população e o desenvolvimento da região.

Por causa de Marechal Rondon, em março de 1919 resolveram mudar o nome do povoado para Rondonópolis. Isso foi motivo de discórdia entre algumas famílias. A adaptação à nova designação demorou um pouco, pois já estavam todos habituados ao nome Vale do Rio Vermelho ${ }^{146}$. Aliás, a homenagem não era

\footnotetext{
143 “José Furtado, Manuel Lopes da Silva, Fermino Rodrigues dos Santos, Gregório Rodrigues dos Santos, uma senhora viúva com vários filhos, Maria Rosa Barbosa e os dois primeiros matogrossenses (sic) Marculino Delgado vindo da capital e um primo de Rondon João Lucas Evangelista, o qual a mais de um ano havia preparado campo para a fixação de sua familia, cuja residência ainda permanece como um dos centro de visão conhecida por antiga Fazenda Velha do Rondon, nas proximidades da casa de Manuel Conrado”. Cury, 1973:25.

144 "Essa estrada carroçável que eles abriram passava pelo Tugore, Areia, Panturra, São Lourenço, Correnteza, Brilhante, Cab. do Amaral, Cabeceira do Rio Manso, São José da Serra, São Vicente, descendo a serra seguiam para Cuiabá”. Cury, 1973:36.

145 “Construída por José Rodrigues, o proprietário. Alguns de seus irmãos e parentes ajudaram-no. (...) A idéia de fazer uma casa de comércio neste lugar foi apenas para diminuir um pouco as necessidades”. Cury, 1973:38.

146 "Grandes fatos ocorreram nesse período, tendo como principal, sua elevação à categoria de Distrito de Paz do Município de Santo Antônio de Leverger e comarca de Cuiabá, fato que se deu pela resolução $n^{\circ}$. 814, de 8 de outubro de 1920, que também lhe altera o nome de Rio Vermelho para Rondonópolis, em Homenagem a Rondon”. Cury, 1973:48.
} 
somente a Rondon; a princípio a origem do nome deveu-se aos índios Bororo. Conforme Cury (1973:48), "os índios jamais contestariam esse nome, pois eles adoravam, amavam e só confiavam neste grande chefe e amigo que era General Rondon, o grande Pagmejera" que é da mesma origem indígena.

Em $1^{\circ}$ de fevereiro de 1920, Rondon manda para Rondonópolis a primeira lancha "Rosa Bororo" que serviria como meio de transporte e comunicação para essa comunidade. Em 1921, chega a lancha "13 de Junho" e, nesse mesmo ano, Benjamim Rondon constrói a $1^{\mathrm{a}}$ balsa do rio Vermelho. Em 22 de janeiro de 1922, nomeia Francisco Candido Pereira, o juiz, como o chefe das comunicações telegráficas da localidade e criou-se também o Correio. Em 1925 o Sr. João Nunes Ferreira - vaqueiro numa fazenda em Rio Verde - GO, na época casado, mas não tinha filhos - veio com a esposa e mais dois irmãos em busca de uma terra para viver melhor com sua família. Radicou-se na região do Bananal onde a terra foi sendo dividida e continua ainda hoje nas mãos dos familiares. Em 1926, na administração de Mário Correa da Costa, foi liberada a abertura de diversas estradas, bem como a construção da balsa do rio Vermelho ${ }^{147}$.

Cury (1973) relata ainda que, mesmo com a doação da terra, com a agricultura e pecuária que se desenvolviam aceleradamente na região, com o xerife nomeado, com o desenvolvimento do comércio, os problemas não deixavam de surgir. Nem tudo era glória nas terras do povoado. Havia por aqui muitos insetos (mosquitos) que acabavam infernizando a vida das pessoas, provocando vários tipos de doenças infecciosas, principalmente, a malária (parasitose tropical), a febre amarela, a lepra (fogo selvagem). Isso tudo contribuía para que muitos abandonassem suas terras e desistissem do sonho de progredir nas terras de Rondon. Em 1930, ocorre uma fase de paralisação e queda do pequeno vilarejo que estava quase abandonado. Aliando-se a isso, em final de 1932 e início de 1933, houve uma grande enchente que, além de destruir as plantações, inundou as estradas e ruas, bem como carregou equipamentos utilizados no transporte da balsa.

Por causa dos estragos nas estradas, em 1930, o governo enviou a primeira Companhia de Conservação de Estradas e foi construído, também, o campo de

\footnotetext{
${ }^{147}$ As estradas ligavam: “Chapada dos Guimarães a Rondonópolis, Cuiabá a Rondonópolis e Campo Grande a Rondonópolis seguindo em frente até a fronteira de Goiás. Antes de iniciar a abertura da estrada à Rondonópolis foi construída a primeira balsa do Rio Vermelho”. Cury, 1973:64.
} 
Avião de Rondonópolis. Nesse mesmo ano, o senhor Ildefonso Bernardino de Oliveira que morava em Santa Rita do Araguaia (GO), ao saber que terra em Rondonópolis era barata, mesmo com tantos problemas, resolveu se aventurar. Requereu do governo terras na região da Aldeinha, onde viveu até falecer e ainda hoje as terras estão com a família. Devido à construção das estradas, a partir de 1933, com muitas pessoas vindas para trabalhar e outros migrantes que aqui chagaram, o povoamento intensifica-se, vindo a contribuir para o desenvolvimento e a criação, em 1938, do Distrito de Rondonópolis ${ }^{148}$. A lenda do rio Vermelho histórias do Nego d'água -, a seca prolongada, a falta da balsa que havia sido carregada pelas enchentes em 1933, as pestes e as enfermidades que ainda permaneciam fizeram com que alguns habitantes se mudassem para outras regiões.

Enfatiza Cury (1973) que, mesmo assim, em $1^{\circ}$ de janeiro de 1940, Moisés Cury Mussy marca a era do renascimento de Rondonópolis, estabelecendo-se no comércio, onde dispunha de todos os tipos de mercadorias. A Cia. Sapadora disponibiliza a primeira jardineira para transportar passageiros de Cuiabá a Campo Grande, Santa Rita do Araguaia. Aos poucos, a população vai crescendo e ainda em 1940 o Sr. Antonio Alves da Silva veio de Bom Sucesso/Biara (Bahia), onde possuía 5 alqueires de terra. Seu destino era o garimpo de Poxoréo, mas, ao ver que era só ilusão, mudou-se com a esposa, a mãe e as irmãs para Rondonópolis, na região onde fica hoje o Núcleo Colonial de Naboreiro. Sua propriedade foi dividida para seus 11 filhos. Outra família que se radicou em Rondonópolis nesse mesmo ano foi a do Sr. Domingos de Aquino que veio do Piauí cujo destino primeiro foi o garimpo de Poxoréo, onde conseguiu juntar dinheiro, comprou terra na região do Pequi em Rondonópolis para onde se mudou com a família. A propriedade foi dividida aos seus quatorze filhos. Em 1942, foi construída a primeira ponte de madeira do rio Vermelho, que não chegou a completar um ano ${ }^{149}$.

\footnotetext{
148 “Conforme o Decreto lei nº 208 de 26 de outubro de 1938, fixou o quadro territorial, passando Rondonópolis a ser Distrito de Poxoréo integrando-lhe Coronel Ponce (ex-Capim Branco) Ponte de Pedra e Rondonópolis, hoje Ponte de Pedra distrito de Rondonópolis”. Cury, 1973:73.

${ }^{149}$ Nem a jardineira e nem a ponte obtiveram muito sucesso. "No dia $1^{\circ}$ de janeiro, quando o comerciante colocava os últimos caixotes de sua mercadoria dentro da casa, gritos abafaram-se pelo estrondoso barulho da água. Os homens e índios (*) que enrolavam com esforços os cabos de aço nos morões, soltaram ao verem que os guindastes no meio do rio Vermelho em plena cheia, afundavam-se com a pequenina jardineira que comportava 15 pessoas. A balsa ficou soterrada partindo por alguns lados enquanto a jardineira parecia um monstro preguiçoso a afundar. (...) Só depois de 7 dias puderam tirar a jardineira do rio Vermelho. (...) Depois de a tirarem, reencostando-a desparafuzaram-na retiraram as lamas e lavaram peça por peça. Até o carro funcionar já passava de uma semana. (...) Infelizmente a ponte não durou nem um ano completo, foi carregada pelas fortes enchentes. A ponte havia sido o primeiro arco das sombras de uma criação artificial sobrepostas sob o rio Vermelho. Devido ao seu desmoronamento a balsa que havia ficado encostada, continuou a sua trajetória transportando anualmente de 15 ao máximo 20 veículos”. Cury, 1973:77 a 81. (*) Grifo meu. Isso deixa evidente que em tempos idos, o índio não era considerado homem.
} 
Rondon não perdia as esperanças e continuava lutando pelo desenvolvimento de Rondonópolis. Tanto é que, em princípios de 1947, a Companhia Sapadora instalou sua construtora nessa cidade, passando a chamar-se CER - Companhia de Estradas de Rodagem de Mato Grosso, formando um acampamento, com mais de 300 homens próximo ao córrego Laurencino. Cury (1973:84) comenta, ainda, que Rondon trouxe consigo, em julho de 1947, repórteres, fotógrafos e jornalistas, a fim de promover o crescimento da cidade. De acordo com relatos dessa autora, o repórter Tertuliano encarregou-se de desenhar um mapa imaginário da região de Rondonópolis e de fazer a propaganda por várias partes do país, principalmente em São Paulo, Paraná e Bahia. Ao vender os lotes, prometia não só os documentos como também cópia do mapa para que a pessoa pudesse se localizar assim que chegasse ao ponto referido. O mesmo lote era vendido várias vezes e sempre com os mesmos truques. Como o preço da terra era baixo, não faltava comprador, sem contar que a propaganda "enganosa" estava sendo bem feita, atraindo cada vez mais pessoas.

De acordo com estudos de Cury (1973:101), Rondon continuava planejando a colonização de Rondonópolis. Em 28 de setembro de 1947, chega a primeira leva de migrantes, vindos do Estado de São Paulo. Por isso, o local a eles destinado recebeu o nome de Vila Paulista ${ }^{150}$.

Além dos migrantes abastados, possuidores de capital, vieram também alguns camponeses pobres tentando se desvencilhar da dominação pessoal dos fazendeiros, dos coronéis, bem como da expropriação territorial que já estava sendo efetuada por latifundiários através da ajuda de grileiros e empresários, sem contar que a exploração econômica, por parte da grande empresa capitalista, já era bastante evidente.

Suzuki (1996: 121) esclarece que o segundo tipo de migrante a chegar a Rondonópolis não teve a mesma sorte que os primeiros vindos de Goiás, pois, enquanto estes tinham geralmente alguma reserva de dinheiro para investir na produção, os segundos (Paulistas, como eram conhecidos), devido a sua situação original de pobreza e busca de terra de trabalho, precisavam de ajuda do Estado. Não Ihes era possível empreender a produção agrária, enfrentando o longo período

\footnotetext{
150 "Chegaram a terra prometida. A espera, a angustia, o entusiasmo davam origem ao nervosismo que se desencadeavam no coração e na mente daquelas pessoas. O lugar reservado para a colonização indicado por Rondon era a alguns quilômetros do centro de Rondonópolis”. Cury, 1973:101.
} 
que se estabelece entre o preparo da terra até a venda da produção; para tanto, seria necessário reserva de dinheiro ou produto que eles não possuíam. Suzuki ressalta, ainda, o fato de esses migrantes terem sido impulsionados por conversas de conhecidos ou por propaganda enganosa da Colonizadora Noroterra (do Tertuliano Albergaria). Quando aqui chegavam, além de não conseguirem encontrar os lotes, existia a presença dos mosquitos e o sol escaldante. Com isso, cresciam as revoltas e agitações cada vez que chegavam mais migrantes. Rondon se mostrou contrário às falsas propagandas que estavam sendo realizadas por Albergaria $^{151}$, pois não concordava com os métodos adotados.

Alguns dos aventureiros voltaram de imediato; outros, mais curiosos, resolveram ficar e ver no que daria, principalmente, quando pegavam a terra úmida nas mãos e já começavam a imaginar como fazê-la produzir. Mas, nem tudo estava resolvido e o que "em 1946 eram um total de 60 pessoas (entre velhos e crianças); em 1948 ultrapassava de 150 pessoas" (Cury, 1973:104). Começaram, então, a passar por sérias dificuldades, inclusive, fome e, para solucionar parte dos problemas, pediram auxílio e, posteriormente, puderam contar com a ajuda do governador Arnaldo Estevão de Figueiredo durante todo o seu período administrativo $^{152}$.

Outros núcleos de colonização instalados em Rondonópolis, de acordo com Cury (1973:104 e 110), foram a Colônia do Macaco ${ }^{153}$, para onde se dirigiram, em 1948, mais de 50 famílias e para a Colônia Mata Grande ${ }^{154}$, local para onde foram, em 1949, os migrantes vindos principalmente de Poxoréo, Guiratinga, Cuiabá, Itiquira, e do Nordeste do país.

Tesoro (1993:28) conta que, "a partir a Lei 336/49, o Estado, através do Governador Arnaldo Estevão de Figueiredo, estabelece as condições legais para

\footnotetext{
151 "Rondon não demorou muito tempo em saber das trapaças feitas por Albergaria, ele que estava em estado enfermo não deixou de dirigir por certo as palavras à Albergaria. Mas o professor era esperto demais já havia dado o seu golpe como grande propagandista”. Cury, 1973:105.

152 “A mais de 150 pessoas foram distribuídos víveres. O caminhão superlotado chamava a atenção de todos os colonos. De tudo o que imaginassem foi repartido, açúcar, arroz, feijão, farinha, carne seca, óleo, querosene, sabão, vela, cebola, alho, ferramentas para a lavoura, cereais em geral, até roupas chegaram a ser distribuídas, menos bebida. (...) os pães multiplicavam-se como se estivessem caindo do céu. A euforia dominava a grande massa de colonos emigrantes”. Cury, 1973:108. poderem desmatar o local abrirem campo e tentarem abertura de lavoura”. Cury, 1973:104.

154 “Muitos animavam-se em vir para Rondonópolis quando percebiam a dedicada atenção do governador. O afluxo de pessoas era grande ao ponto de se unirem uma variada camada, sintetizando o núcleo colonial. Muitos vinham comprar terras aqui, mas era tudo grátis, para que não fizessem casas dentro da área de Rondonópolis, Dr. Arnaldo deu outras glebas de terra: além da Vila Paulista e colônia Macaco houve também uma outra parte que se denominou Mata Grande”. Cury, 1973:110.
} 
aquisição das terras devolutas e uma avalanche de gente se projeta para aquele pouco antes desconhecido vale (...)". Em fins de 1949, esse governador doou os títulos provisórios das terras das colônias de Vila Paulista, Colônia do Macaco e Mata Grande, além dos 10.000 hectares de terras doados aos índios Bororo. Os migrantes ocuparam a zona rural e não a parte central da cidade.

Na década de 50, o Estado de Mato Grosso incentivou a política de ocupação de suas terras e a expansão de suas fronteiras agrícolas. Mesmo com o incentivo, poucas colonizadoras conseguiram se destacar, sendo que as inadimplentes tiveram que devolver as terras para o Estado, segundo obrigações contratuais. Nesse período, de acordo com Vilarinho Neto (1985:14): "O Estado também implementou a implantação de Colônias como: Rondonópolis, Paulista, Naboreiro ${ }^{155}$, Campo Limpo; todas atualmente integram o município de Rondonópolis. [...]".

Os colonos, constantemente, recebiam visitas de pessoas enviadas pelo governo Estadual a fim de saberem se estavam se sentindo bem ali. A resposta foi a seguinte: “Aqui chegamos, mandaram abrir a porta para nós entrarmos, mas não nos entregaram a chave."156 Disse-Ihes, então, o doutor Fragelli que ele mesmo viria entregar-Ihes a chave.

De acordo com os relatos de Cury, após alguns meses de administração, o Dr. Fragelli chegou com sua comitiva, isso em 1951 e, conforme havia prometido aos colonos, veio pessoalmente entregar os 400 títulos definitivos aos mesmos. "Sendo que uma parte dos últimos títulos coube ao inteligente Fragelli, que entregou a CHAVE com suas próprias mãos não só a Moisés Rodrigues dos Santos como aos demais companheiros de desbravamento 50 títulos definitivos". (Cury(1973:

\footnotetext{
155 Sobre a Colônia Naboreiro, encontramos em Cajango (1992) que o Projeto ou Colônia Naboreiro em Rondonópolis/MT, foi implantada em 1949, de acordo com Decreto 714-13/0/49. Implantada nos anos 50. Regularização da titulação a partir de 1957. Área: 8.000 hectares. $\mathrm{N}^{\circ}$. de lotes: 144. Em conversa com o Sr. Deralicio Martins Ferreira, 72 anos (migrante que veio de Brejinho de Oliveira/Bahia, onde o pai era dono de um pedacinho de terra, plantavam e não produziam quase nada. Daí ter vindo à procura de um recurso, de uma vida melhor e que veio para Mato Grosso com 18 anos de idade, chegando a Rondonópolis em 1953), ele relatou que: “Os 107 lotes foram cortados em 1952, mas não colocaram fogo. No ano seguinte, fizeram a distribuição da terra. O último lote do Núcleo é o do Sr. Antonio Alves da Silva, Antonio Baiano. Tem muita conversa sobre esse loteamento, mas a história verdadeira é essa. Em 1952, eu comprei o direito do Lote de ${ }^{\circ}$. 100 e estou até hoje. A Vila Bueno era lote da Colônia Naboreiro, que o Benedito e o João Bueno lotearam e queriam transformar num vilarejo, mas como não registraram, não fizeram as coisas certas, não virou nada. O Sr. Daniel Martins Moura - primeiro prefeito eleito em Rondonópolis, mais ou menos em 1957, mandou um recenseador fazer um levantamento para saber quem estava nas terras para receber o título definitivo e ele mesmo, trouxe esses títulos de Cuiabá para Rondonópolis. Entrevista no dia 08/04/2007. toda história foi confirmada pelo Sr. Antonio Alves da Silva.

156 "Palavras filosóficas de um colono para o Dr. Atayde de Bastos, médico pediatra, que veio em visita ao povoado de Rondonópolis, juntamente com o ex-deputado José Fontanilla Fragelli, em 1950”. CURY, C. Cuiabá, 1973, p. 127.
} 
128) ${ }^{157}$. Esse fato deixou os colonos bastante esperançosos, pois, a partir de então, eram eles verdadeiros proprietários de suas terras. O Governador, além de dar títulos, concedia às pessoas que quisessem protocolos para serem recebidos e assinados na capital.

Mesmo depois de receberem os títulos definitivos de suas terras, e estarem produzindo até suficientemente bem, os moradores ainda passavam por certas dificuldades citadas anteriormente. Alguns colonos venderam suas terras, outros abandonaram com o intuito de voltar, caso a região progredisse; houve também aqueles que nunca mais apareceram por aqui.

Em 25/01/1952, através do Decreto $n^{\circ} .230$, cria-se definitivamente a Colônia Pública chamada "Macaco", para onde já havia se dirigido em 1948 mais de 50 famílias. A região do "Marajá" decorreu de um loteamento particular realizado pelo Coronel Goulart.

Além dos colonos brasileiros, Cury $(1973: 129,130)$ destaca a presença dos imigrantes que para cá vieram a partir de 1950. Menciona José Salmen Hanze (Zé Turquinho), um libanês que comprou mais de 12.000 hectares de terra e construiu por conta própria o Campo de Avião onde aterrissavam os grandes aviões ${ }^{158}$; e o japonês Massao Oshizuka que chegou em setembro de 1952 e fundou a Colônia Japonesa em Rondonópolis, também influenciando na área agrícola, destacando-se no plantio de diferentes verduras e temperos ${ }^{159}$. Desse período em diante, muito migrante chegou a fim de (re) construir sua vida nesta nova terra.

Em 1953, através da Lei №. 666 de 10 de dezembro, cria-se definitivamente o município de Rondonópolis, desmembrando-se de Poxoréo ${ }^{160}$. Aos poucos, as novidades e as modernidades foram aparecendo, o índice populacional aumentando

\footnotetext{
${ }^{157}$ Foi "repartido a cada família 50 hectares de terra. Como outros ambicionavam o mesmo lugar foi dividido pela metade em 25 hectares, sendo o local das terras doadas: Paulista, Macaco, Mata Grande e Campo Limpo, Naboreiro onde hoje se desenvolvem grandes e inúmeras chácaras, sítios e principalmente fazendas”. Cury, 1973: 128. 158 "Para favorecer aqueles que chagavam e não tinham possibilidade de comprarem, enviava o engenheiro para medirem suas terras e
loteava-as, a preço mínimo, (...) favorecendo ainda ao comprador prazos longos. (...) José Turquinho estava sempre atento as novidades para
trazer a Rondonópolis. Doou para o governo 28 mil metros quadrados, deixando ainda a disposição da escolha de suas terras. As partes de
doação serviram para o beneficiamento de diversas coisas entre elas a residência da DNR e o local da ponte do Rio Vermelho como também
Vila Birigui etc.”. Cury, 1973:129.

159 "Massao voltou sua atenção para as plantas que fez com que seu prêmio com o estrangeiro elevasse ao ponto mais alto de grande agricultor. (...) Devido aos seus grandes esforços Massao teve a honra de sentir seu nome gravado na Cultura da Pimenta do Estado de Mato Grosso”. Cury, 1973:130.

160 “Conforme o serviço de estatística de Poxoréo, Rondonópolis em 1953 possuía 25 logradouros públicos e 442 prédios, os principais o Educandário Sagrado Coração de Jesus, a prefeitura e o Cine Meridional. (...) possuía uma população de 2.888 habitantes, sendo 1.426 homens e 1.194 mulheres. Sua sede contava, na mesma data com 744 pessoas de cinco e mais anos. Desse total 387 (215 homens e 172 mulheres) sabiam ler e escrever, enquanto que 357 (180 masculinos e 117 femininos) não sabiam ler. O seu quadro eleitoral em 1956 era representado por 3.600 cidadãos. Em comparação com as demais cidades, Rondonópolis achava-se classificada em $27^{\circ}$ lugar”. Cury, 1973:151e 155.
} 
e o município se deslanchando. Reportei-me a Cury (1973:157) sobre o desenvolvimento do município a qual expõe: "as camponesas deixaram os colonos nas roças trabalhando para (...) dar melhores condições e possibilidades aos filhos para estudarem (...) chegavam várias casas de comércio, os primeiros colonos de 1947 e 48, já refeitos de suas economias, desde que havia um município, era fácil vender e comprar terras". Os imigrantes também continuavam chegando e Cury comenta que, em 1955, vieram os primeiros espanhóis (entre eles: Alexandre Marino Amil) que fundaram a primeira cerâmica e o português Adolfo Augusto de Moraes que, em 7 de novembro de 1955, fundou a primeira Associação de Rondonópolis $^{161}$. Cury destaca, ainda, o surgimento do primeiro estabelecimento federal em Rondonópolis, o DNER - Departamento de Estradas e Rodagem, em 15 de novembro de 1957 o qual teve como engenheiro chefe o paraguaio Dr. Miguel Angel Rodas Ortiz ${ }^{162}$ (que até hoje é Vigário da Paróquia Bom Pastor). Em 1958, Rondonópolis recebia o pouso do primeiro avião de grande porte, chamado REAL, mais tarde substituído pela VARIG e, posteriormente, pela VASP.

No período compreendido entre as décadas de 1950/1960, geralmente, a região era composta por sítios que variavam de 20, 30 até 50 hectares. Com o passar dos anos, as coisas foram melhorando. A vontade de vencer era tanta, que os mesmos não se cansavam de trabalhar. Fixaram-se nas terras de cerrado do Leste mato-grossense e, aos poucos, foram tornando-se grandes produtores de gado, como também de cana-de-açúcar (José Rodrigues dos Santos) e café (Moisés Rodrigues dos Santos). O Sr. José Giovanini de Jales (SP) mudou-se com a família em 1960. Ficou sabendo que aqui terra era barata, então, vendeu o pedacinho de terra que tinha lá e veio em busca de uma vida melhor para todos. Comprou lotes de terceiros no Núcleo Colonial Naboreiro/Vila Bueno e está lá até hoje.

Conforme aumentava a população do local, outras extensões de matas eram derrubadas, a fim de construírem novas casas, plantações de lavouras, construções

\footnotetext{
161 “Alexandre Marino Amil primeiro espanhol a entrar a fixar-se definitivamente em Rondonópolis, dividiu a cerâmica em duas, a São Pedro e Nossa Senhora Aparecida. (...) Tomando as iniciativas de lutas Adolfo Augusto de Moraes, lutou pelos grandes direitos de nossa terra, principalmente um de grande importância: lutou, implorou e exigiu impacientemente a elevação deste município na qualidade de Comarca. Graças a ele muitos foram orientados no comercio para o seu desenvolvimento. (...) Nos últimos cinco anos de colonização intensificou-se em todos os quadrantes do município, para onde continuam a convergir num rítmo (sic) cada vez mais acentuado, lavradores nacionais (vindos ultimamente de todos os cantos do país, Minas Gerais, São Paulo, Recife, Maranhão, Goiás, Bahia, João Pessoa e Rio Grande do Sul), estrangeiros, japoneses, espanhóis (sic), sírios (sic), italianos, russos, poloneses, alemães, checoslováquos (sic) e americanos”. Cury, 1973:161 a 163 e 209.

162 “O engenheiro Miguel foi o primeiro comandante e organizador dos times de futebol em Rondonópolis, bem como o primeiro padre a ser ordenado nesta cidade em 26 de março de 1966, pelo Bispo D. Vunibaldo Taller (sic)”. Cury, 1973:171 e 182.
} 
de currais para as invernadas, novos caminhos. O que mais existiam eram sítios, mas as grandes fazendas, aos poucos, começavam a se destacar. Mesmo assim, em 1957, Rondonópolis, em relação aos municípios do Estado, ocupava a $27^{a}$ colocação $^{163}$. Em 8 de outubro de 1962, inaugura-se o Banco Agro Pecuário de Campo Grande Sociedade Cooperativa; dois anos depois, mudou-se o nome para Sociedade Cooperativa e passou a chamar-se Banco Agro Pecuário S/A ${ }^{164}$. Em 1963, para melhorar a vida dos agricultores e pecuaristas, chega a Rondonópolis a primeira firma de tratores, a Massey-Ferguson MWM. Em 1965, no período de 23 até 27 de setembro, com o empenho dos japoneses Massao Oshizuka e Tamakary Ditada, aconteceu a primeira exposição agropecuária e industrial em Rondonópolis $^{165}$. Cria-se, em 1966, a ACARMAT - Associação de Crédito e Assistência Rural de Mato Grosso e, por intermédio da mesma, a equipe de veterinários e agrônomos veio prestar relevantes serviços à zona rural do município. Em 1968, inaugura-se o Parque de Exposição, onde, no período de 21 até 24 de setembro, os rondonopolitanos puderam expor e também presenciar os diferentes produtos agropecuários e industriais do município.

Cury (1973) fala, ainda, da importância do PRODOESTE - Programa de Desenvolvimento do Centro-Oeste, instituído em 1971 no governo de Médici, cujo destino era incrementar o desenvolvimento econômico dessa região e que, ao executar a obra asfáltica das BRs 163 e 364, tendo Rondonópolis como eixo intermediário $^{166}$ entre as duas, veio "influenciar o desenvolvimento central de Rondonópolis, onde o prolongamento das principais ruas e avenidas estão sendo asfaltadas"(Cury, 1973:189). Além desse programa, Cury comenta sobre a integração de Rondonópolis no Plano de Desenvolvimento da Bacia Amazônica, através do projeto de Lei $\mathrm{n}^{\circ}$. 654, de 1972, da SUDAM - Superintendência de

\footnotetext{
163 “Rondonópolis perdeu para o Distrito único de Itiquira, parte do Distrito de Ponte de Pedra. Perdeu para o município de Jaciara e parte do Distrito sede. Ganhou parte do Distrito de Ponte de Pedra, perdeu para o novo Distrito de Irenópolis, do município de Jaciara perdeu para o Distrito de Nova Galiléia (ex-Petrovina). Era certo que Rondonópolis em fins de 50 ainda não tinha classificação nenhuma no estado com suas grandes cidades”. Cury, 1973:188.

164 “Quando começou a funcionar havia comentário de todos os lados. Gente de todo tipo. Uns de chapéu de palha com um baita do cigarrão lançando nuvens como a rita fumaça. Outro, mais bacanão, aspecto de fazendeiro, botas compridas, calça bombacha e empaletoado de gravata, exibia as suas notas ao caixa. O banco Agro Pecuário veio a galgar com os problemas dos nossos emigrantes que aqui residiam, proporcionando maior alegria e segurança”. Cury, 1973:175.

165 “Na abertura da primeira exposição (...) sua Excelência o Sr. Governador do estado que um dia em anos já transcorridos havia doado títulos aos colonos, e assinado o decreto de criação do município, no seu último governo depois de tantos anos, soltava o laço, verde e amarelo, que abria as portas dos primeiros produtos a serem mais tarde exportados, para posteriormente reforçarem e solidificarem os esteios econômicos do seu próprio estado”. Cury, 1973:180.

166 “Rondonópolis constitui, conforme a previsão de Rondon, o maior tronco Rodoviário de Mato Grosso. Uma previsão que se torna em realidade, onde o comércio desenvolve, e a economia acumula-se para o estado. Constituindo o maior eixo Rodoviário do norte do estado,
} conta com as BRs 364 e 163, Mt 9 e Mt 10”. Cury, 1973:191. 
Desenvolvimento da Amazônia ${ }^{167}$, pois "Rondonópolis, estava integrada na Amazônia legal, ela merecia esta ligação, pois dela parte e nela é explorada em larga escala a pecuária e agricultura". (Cury, 1973:189).

Foi com muito sacrifício, esperança e força de vontade de sobreviver e fazer a terra de Rondon progredir e se tornar conhecida, que surgiram as primeiras fazendas e os primeiros colonos $^{168}$, onde a "Agro-Pecuária constitui a base econômica de Rondonópolis. A fertilidade das terras foi o alvo de interesse da exploração agrícola. Há predominância de pequenas e médias propriedades neste último tipo de exploração". (Cury, 1973:207).

Em se tratando da estrutura agrária ou fundiária de Rondonópolis, em 1973, o município tinha o seguinte cadastramento no INCRA de acordo com Cury (1973:215): “1246 propriedades entre 1 a 50 hectares; 281 propriedades entre 50 a 100 hectares; 199 propriedades de 101 a 200 hectares; 226 propriedades entre 201 a 500 hectares; 96 propriedades de 501 a 1000 hectares; 7 propriedades entre 1001 a 5000 hectares; 13 propriedades entre 5001 a 10000 hectares e 6 propriedades acima de 10000 hectares", perfazendo um total de 2074 propriedades rurais. Ao observar a quantidade de propriedades entre 1 até 100 hectares, confirmo o que foi dito acima por Cury, ou seja, o predomínio da pequena e da média propriedade.

Com os migrantes pioneiros, surgiram os povoados - futuras cidades e apareceram as primeiras fazendas de gado, na maioria das vezes, foram doações, pois a terra era muita, mas os dispostos a enfrentar as precariedades da vida rural eram poucos. Além do mais, era preciso doar terras para se ter a garantia e a posse do território. Das enormes fazendas de gado, dos enormes latifúndios, muitos se fragmentaram, ou pela repartição natural entre os descendentes ${ }^{169}$, ou porque seus proprietários não puderam aprimorar os rebanhos e aproveitar melhor seu espaço. Algumas das pessoas que receberam terras, por herança ou por doação, acabaram vendendo-as, não resistindo às ofertas tentadoras dos novos capitalistas que

\footnotetext{
167 “A noticia (sic) foi retransmitida pelo parlamentar matogrossense (sic) na Câmara Federal, através do deputado Emanuel Pinheiro”. Cury, 1973:189.

168“"Rondonópolis nos últimos anos, vem sendo assistida por vários grupos de agronomos (sic), assim como também os nossos agricultores, já sentem-se realizados pela atenção e a assistência que o governo está lhes voltando, como os soldados do campo. Infelizmente ainda encontram-se desprovidos de assistência médica, o qual é raro no ano haver a presença de um médico ou assistência social. (...) A assistencia (sic) nas zonas rurais chega através de religiosos e missionários, que aliam-se aos pastores e padres tentando com seu espírito de solidariedade humana, dar um pouco de saúde a quem vive a lutar no escaldante sol de nossa terra”. Cury, $1973: 208$.

${ }^{169}$ Nas Invernadas do Sul Surge um Novo Mato Grosso. “Os latifúndios, incapazes de melhor utilizar os espaços, se fragmentam pelo valor e procura das terras. Esse processo de fragmentação, inclusive, já vinha se operando lentamente com o desaparecimento dos antigos proprietários e na repartição natural entre os descendentes. Muitos desses descendentes, diante das primeiras ofertas tentadoras, encantados com o dinheiro e desiludidos com as asperezas da profissão, vendem as terras a novos capitalistas de São Paulo, ainda mais fortalecidos com a industrialização do estado. Prosperam aqueles que acreditam na terra e no boi”. Figueiredo, 1994:144. Grifo meu.
} 
começavam a surgir em Rondonópolis.

Com isso, passa a ocorrer uma transformação muito grande não só na anterior ocupação humana do espaço como também no meio ambiente. O cerrado que antes possuía uma pastagem natural, foi sendo destruído para dar lugar às extensas lavouras de algodão, de soja, às vezes consorciadas com a pecuária. Os solos que antes só serviam para alguns tipos de culturas, com a modernização da agricultura, passaram por um processo de correção e, hoje, fazem com que Rondonópolis seja destaque nacional pela quantidade de grãos produzidos.

Muitas propriedades adquiridas da década de 1930 para cá foram transformadas, mais tarde, em pequenas propriedades, pois os pais as dividiam com os filhos, que mais tarde as dividiram também com os netos. Exemplifico com as famílias: FERREIRA, que em 1932 requereu do governo do Estado $874 \mathrm{Ha}$, denominado Fazenda Bananal e, posteriormente, em 1942, mais um membro da família requereu $735 \mathrm{Ha}$, Fazenda Beroaba, cujos títulos definitivos Ihes foram entregues em 1939 e 1954 consecutivamente. A propriedade já foi repassada para os filhos e netos. A família OLIVEIRA, onde um requereu $3.194 \mathrm{Ha}$, denominada Fazenda Belém em 1939 e o outro comprou mais 406 Ha conhecida como Aldeinha, em 1945. Os títulos definitivos foram concedidos em 1947 e 1953. Já foi dividida com os filhos, netos e, hoje, também com os bisnetos. A família SILVA comprou 294 Ha na região de Naboreiro em 1948, tendo recebido o título definitivo somente em 1955 e, posteriormente, recebeu de doação do governo um lote no Núcleo Colonial de Naboreiro em 1957, mesmo ano em que recebeu o título definitivo. A propriedade foi dividida com os filhos.

Também a família AQUINO comprou em 1951, de outra família (recebida de herança), uma área com $390 \mathrm{Ha}$, que havia requerido do governo em 1939 e recebido título definitivo em 1949. Essa propriedade também foi dividida com os filhos. A família GIOVANINI comprou três áreas na região de Naboreiro, uma foi fragmentada pela família que havia comprado do governo em 1949 e o direito dos Lotes 86 e 87 do Núcleo Colonial de Naboreiro foi doado a duas famílias em 1957. A propriedade com 127, 30 Ha foi dividida para os filhos. Além dessas, outras famílias das regiões de Água Fria, Barra da Água Quente, da região das Três Pontes etc., utilizaram o mesmo processo, a fragmentação da terra, seja ela por herança, por doação, ou pelas duas formas.

Não estou querendo dizer com isso que os grandes latifúndios não existam 
em Rondonópolis, pelo contrário. Podem-se observar, no panorama rura,I enormes extensões de chapadões aplainados, cobertos por um mar de soja e/ou algodão, em algumas propriedades intercaladas com grandes quantidades de bovinos/pecuária extensiva.

Passam a existir, juntamente, com esse grande e médio proprietário, o arrendatário, o parceiro, o meeiro. Por quê? Devido à falta de recursos financeiros e às dificuldades para a abertura das terras, o médio e o grande proprietário acabavam arrendando suas terras para que os camponeses sem-terra trabalhassem nelas e as devolvessem, posteriormente, desmatadas e com o plantio do capim (pastagem) para o gado. A parte recebida variava de acordo com o contrato e o trabalho, realizado com instrumentos rudimentares, geralmente era lento.

Assim como existem os latifundiários, existem também o médio e o pequeno agricultor nas áreas de mata, bem como os posseiros e os sem-terra. Muitos deles eram pequenos sitiantes, trabalhadores assalariados rurais, parceiros ou arrendatários, que vinham à procura de terras devolutas para se instalarem com suas famílias. Assim, como sucessores das terras citadas anteriormente, realizando com sua família todas as atividades da propriedade.

Aos poucos, esses trabalhadores foram se organizando, primeiro em Associações de Pequenos Produtores, depois as Associações uniram-se em Núcleos Rurais, para que pudessem somar forças e buscar soluções para seus problemas, pois perceberam que só assim poderiam ver seus direitos respeitados.

Os trabalhadores permanentes, que antes existiam na grande propriedade rural, foram e estão sendo substituídos por mão-de-obra especializada em certas tarefas empresariais como, por exemplo, o motorista, o contador, o tratorista e por mão-de-obra temporária.

A modernização da agricultura nesta região implicou uma nova dinâmica e reorganização do espaço rural: a destruição do espaço anterior, mais calmo e organizado de acordo com a lógica do trabalho e vida camponesa em terras libertas; a destruição de latifúndios tradicionais de pecuária extensiva, dirigidos por gerentes de fazendas, do trabalho dos peões que se ocupam do gado, e dos boiadeiros que, de quando em vez, rasgavam os sertões de Mato Grosso, conduzindo a boiada de uma fazenda à outra, de um município a outro, para a engorda ou o abate. Em seu lugar surgiu a agricultura moderna, especializada na produção de sementes (de 
soja, milho e feijão), onde o rugido das onças "vermelhas e amarelas" ${ }^{\text {"170 }}$ e o barulho dos caminhões "boiadeiros" quebram o silêncio e a monotonia dos chapadões. Num futuro bem próximo, o apito do trem de ferro (Ferronorte) contribuirá também para essa quebra desse silêncio característico do interior.

O meio rural passou, portanto, a ter sua dinâmica ditada pela expansão capitalista e pelos circuitos cada vez mais acelerados do capital. Afinal, foi do próprio campo que se extraiu a maior parte da mão-de-obra barata e expropriada (pequenos proprietários, ocupantes, trabalhadores temporários, rendeiros, parceiros), transformada em trabalhadores bóias-frias, utilizados nas grandes plantações monocultoras, pois os trabalhadores permanentes e especializados em geral vêm de fora.

A terra passou a ser vista como fonte de lucro, na especulação pura e simples ou na exploração econômica, principalmente aos que possuem terra e moram na cidade, esperando somente o momento exato de poder vendê-la (e realizar a renda capitalizada), ou àqueles que só produzem para exportar e não para abastecer o mercado interno. Mas, não se pode negar o apego de muitos familiares pela terra que foi adquirida por seus antepassados há anos atrás.

${ }^{170}$ Denominação dada por alguns agricultores moradores desta região aos tratores que quebravam o cerrado e que foram trazidos pelos “gaúchos”. Sobre o assunto, ler Peixinho, D. M. 1998. 
5- FRAGMENTAÇÃO DA TERRA EM RONDONÓPOLIS-MT 


\subsection{Fragmentação da Terra - Uma Revisão}

O marco teórico adotado para o presente estudo parte do princípio de que a fragmentação da terra por doação ou herança, isto é, a sucessão, constitui uma lógica de reprodução do campesinato, diferente da redistribuição da terra para assentamentos, ou seja, a desapropriação por interesse social para a reforma agrária. Enquanto lá a terra foi adquirida e fragmentada pela família, aqui os assentados tiveram que lutar por ela, ocupando-a e, às vezes, obrigando o Estado a intervir por eles, a fim de que pudessem possuir terra de trabalho e morada.

Nesses dois casos, o acesso à propriedade rural é promovido mediante a distribuição ou redistribuição de terras. Porém, mesmo acreditando que em ambos ocorra a reprodução camponesa, vê-se que, no primeiro, permanece a reprodução da família, o apego dos parentes por parte da maioria, enquanto que, no segundo tipo de fragmentação, reúnem-se trabalhadores rurais de várias famílias, cujo objetivo é estabelecer o sistema de relações entre o homem, a propriedade rural e o uso da terra, que seja capaz de promover a justiça social, bem como o progresso e o bem-estar desse trabalhador rural.

Embora no primeiro caso isso também ocorra, acontece que lá existe o apego a terra, em manter o patrimônio que vem de anos, passando de geração a geração. Como observa Fiuza (2000:647), a sucessão é, pois, "o desejo de segurança que inspira a acumulação patrimonial; a proteção da prole inspira sua transmissão".

Antes de trabalhar especificamente com a fragmentação da terra em Rondonópolis, é interessante dizer que, já na Antigüidade, tanto os hebreus quanto os gregos e os romanos praticavam normas do direito agrário. Exemplificando, tomese o caso de Moisés que, ao distribuir a Terra Prometida, acabou beneficiando 20.000 famílias. De acordo com Fiuza (2000:489), no ano de 61 a.C. "editou-se em Roma a Lex lulia Agrária Campania, que mandava distribuir terras da Campânia a cidadãos pobres e veteranos de guerra, com três filhos pelo menos".

O direito agrário, cuja criação, como se vê, é antigo, atualmente busca sintetização e autonomia, sendo um dos ramos do Direito e possuindo normas de caráter público e privado. O Código Agrário Brasileiro é o Estatuto da Terra (Lei no. 4.504 de 30 de novembro de 1964), que examina em muitos artigos não só o problema da reforma agrária, mas também o da política fundiária, adotando o 
método liberal e democrático para a solução dos problemas. Em linhas gerais, 0 Direito Agrário garante o direito de propriedade e a posse da terra rural, regulamentando a divisão racional dessa terra.

O germe de direito agrário, isto é, sua base jurídica original está centrada na legislação das sesmarias portuguesas, quando esse direito foi transferido de Portugal para o Brasil, durante o período colonial.

Essas normas são regidas, hoje, pelo Código Civil, a Lei fundamental do cidadão que, segundo Euclides B. Oliveira (2003:1): "é como um catecismo para o cidadão brasileiro" e, em alguns casos, não é cumprido à risca.

É importante ressaltar que o Código deve ser respeitado, pois ele rege a vida do cidadão, desde que este nasce até sua morte. Oliveira vê nisso uma meia verdade, pois, segundo ele, "a lei estende seus efeitos para depois da morte da pessoa, na esfera patrimonial e da sucessão hereditária" (Oliveira, 2003:2).

Em se tratando de herança, o Código Civil estabelece que para todos os membros da família, a saber, os filhos, independentemente da idade ou sexo, no momento da partilha dos bens deixados por um dos pais, esta deve ser igualitária.

No trabalho Os herdeiros da terra, Moura (1978) descobriu que, apesar de o Código Civil regular a herança da terra no meio rural, nas áreas por ela pesquisadas o que prevaleceu foi o direito costumeiro, formando-se uma complexa teia de regras e relações de parentesco.

No bairro rural investigado por ela, desenvolveram-se regras complementares ou antagônicas que desrespeitam a igualdade estabelecida pelo Código Civil, criando até uma espécie de desigualdade compensatória, na qual homens e mulheres, na fragmentação da propriedade, receberam parcelas diferenciadas.

A pesquisadora constatou que o bairro rural São João da Cristina é regido pelo binômio "casa-roça", combinado com "produção-e-consumo" e, sendo assim, quem cuida da casa e do consumo é a mulher, e quem se responsabiliza pela roça e pela produção é o homem. Sendo a terra o meio de produção no mundo rural e a principal fonte econômica camponesa e estando ligada ao trabalho masculino, 0 acesso a ela se dá preferencialmente ao homem; nesse caso, a mulher é excluída de tudo que diz respeito à propriedade fundiária. Foi aí que ela verificou o desrespeito e o descumprimento ao Código Civil Brasileiro: 
O Código é cumprido de forma degradada porque os costumes simplificam ou ignoram as leis. (...) As regras 'locais' de herança da terra desenvolveu uma lógica própria, que se baseia no conhecimento desse código e cujo fim último é poupar ao máximo a integridade dos patrimônios territoriais. Visa em última instância a assegurar a manutenção da área como camponesa, agindo como fator de reprodução da propriedade parcelar independente. São João da Cristina faz parte de um todo social abrangente. Cujo 'jurídico' vai impor inarredavelmente ali toda uma série de condutas. (...) Assim, as regras 'locais' implicam numa continuidade lógica que sempre se manifesta através de uma descontinuidade cronológica. (Moura, 1978:47-48).

No que se refere ao acesso à propriedade rural, o art. 17 do Estatuto da Terra estabelece que ele seja promovido mediante a distribuição ou a redistribuição de terras, de acordo com:

"a) desapropriação por interesse social; b) doação; c) compra e venda; d) arrecadação dos bens vagos; e) reversão à posse do Poder Público de terras de sua propriedade, indevidamente ocupadas e exploradas, a qualquer título, por terceiros; f) herança ou legado". (Lei №. 4.504 de 30 de novembro de 1964 - Estatuto da Terra. In: Zenun, Augusto. Legislação Agrária e sua Aplicação, 1970:100).

Quanto a esta pesquisa, seu objetivo central é estudar o processo de fragmentação da terra em Rondonópolis, o que contribui para a reprodução camponesa e é promovida pela distribuição ou redistribuição de terras por intermédio da doação e da herança ou legado. Sendo assim, não houve situação de conflito e expropriação do trabalhador, caso comum na conquista dos assentamentos, nem o descumprimento ao Código Civil com base no direito costumeiro.

Nossos entrevistados estão agrupados em dois blocos de fragmentação, sendo que três famílias tiveram acesso a terra por doação e duas foram contempladas com a terra por herança e doação. Deste modo, conforme o art. 17 do Estatuto da Terra - ET -, a fragmentação, ou seja, o acesso à propriedade rural se deu mediante a distribuição ou redistribuição da terra, pelos itens: b) doação e f) herança ou legado, todos cumprindo as regras do Código Civil Brasileiro. Tais casos serão detalhados nos itens 6 e 7 do presente estudo. Os proprietários são sucessores, que estão dando continuidade ao que cessou juridicamente à pessoa anterior. Em outras palavras, o pai ou a mãe, ou ambos, transferiram aos filhos o direito a uma porção de terra ou lote, para que passassem a ser proprietários. 
Woortmann (1995), ao estudar pelo método comparativo os habitantes da Lagoa da Mata, em Sergipe e os colonos teuto-brasileiros do Rio Grande do Sul, percebeu notáveis semelhanças entre eles. Tanto numa como na outra, as instituições do casamento e da herança apresentam características do mundo rural. Sendo o casamento "uma prática que assegura a sucessão" (Woortmann, 1995:92), ele não pode ser visto apenas como um modo de assegurar a reprodução social. Nesse caso, o objetivo maior é preservar o patrimônio representado pela terra.

Ao concluir sua pesquisa, Woortmann (1995:312) destacou que a terra é vista como a concretude da descendência:

Se na situação nordestina estudada a terra é do Sítio, entre os colonos do Rio Grande do Sul ela é da casa, mais do que do indivíduo. (...) Não é, todavia, qualquer terra que é patrimônio, mas aquela que poderíamos chamar, no Sítio ou na Colônia, de 'terra ancestral'. Enquanto outras terras podem ser vendidas, o patrimônio deve 'ficar na família'.

Foram ressaltadas pela autora, ainda, as regularidades do habitus que produz as práticas individuais e coletivas engendradas pelo "senso comum" e pelo "senso prático", ajustadas à lógica de determinado "campo":

(...) No Sítio, tanto temos a regra - a prescrição do casamento endogâmico entre primos, sob pena de ostracismo - como temos a regularidade, isto é, a preferência como uma prática. Entre os Colonos do Sul temos o Schicksal (o destino) e o Geschick (a 'aptidão'). Temos então, 'preferências' não apenas matrimoniais, mas de carreiras de vida, como a de herdeiro, de padre, ou operário, que são construídas pelo habitus, e não apenas pelos pais que querem realizar a tradição. (Woortmann, 1995:315)

Isso mostra que, nas regiões estudadas por Woortmann (1995), o direito costumeiro também prevaleceu sobre o Código Civil, pois, a partir do momento em que os pais impunham sobre o filho a preferência por "carreiras de vida", este era praticamente deserdado de seus direitos como herdeiro. Era, pode-se dizer, um "expulso"; mas isso não implica que ele deixe de existir. Assim,

De um lado, ele existe na figura do "expulso" pelo patrimônio; a indivisão e a subsunção do indivíduo a terra dentro da comunidade produz o indivíduo fora da comunidade. O deserdado é o indivíduo produzido pela totalidade interna para viver no mundo externo. $O$ expulso é necessário para que a totalidade se reproduza, e para que se reproduza o não-indivíduo no interior da ordem hierárquica. (Woortmann, 1995:314) 
Tanto no "casamento arranjado" como na preferência por "carreiras de vida", percebe-se que a preocupação está relacionada à questão da terra, do patrimônio, pois, enquanto o primeiro é visto como "uma estratégia para reaglutinar a terra" (Woortmann, 1995:316), a segunda nega aos seguidores dessas carreiras o direito à própria herança, o que não é permitido pelo Código Civil. Isso porque todos têm direito garantido por lei aos bens pertencentes à família, sendo, portanto, sucessores um dia. E a deserdação, o ato pelo qual se exclui algum herdeiro de sua sucessão, só pode acontecer, a partir do art. 1.961 do Código Civil, por meio de testamento constando detalhadamente os motivos da deserdação, que são as seguintes ações:

Ter sido autor ou cúmplice de homicídio voluntário, ou tentativa desse crime; tê-lo (a) acusado (a) caluniosamente, em juízo, ou praticado crime contra sua honra; por ter usado de violência ou fraude que o impediram de dispor, livremente, de seus bens, em testamento ou o impediram de exercer atos de última vontade. (Oliveira, E.B, 2003)

Para que ocorra o direito à sucessão, não é necessário que o pai ou a mãe tenha falecido. Portanto, como afirmado na Introdução deste estudo, ela pode se dar inter vivos ou causa mortis, ocorrendo, assim, a transmissão de sucessão patrimonial, que será desdobrada em partes específicas, a saber: fragmentação da terra por doação pura e simples inter vivos; e fragmentação da terra por herança, sendo que por ambas comprova-se a (re) criação camponesa.

De acordo com o Novo Código Civil, em seu art. 538 (2002:160), "Considerase doação o contrato em que uma pessoa, por liberalidade, transfere do seu patrimônio bens ou vantagens para o de outra". Ainda nesse mesmo Código, o art. 541 estabelece que "a doação far-se-á por escritura pública ou instrumento particular".

A fragmentação da terra por doação pura e simples é aquela pela qual "nada é exigido do donatário, que recebe o bem doando sem qualquer condição de encargo" (Fiuza, 2000:276) e é realizada inter vivos, pois, no Direito Brasileiro, como regra, a doação é negócio jurídico, apesar de se falar em doação causa mortis. (Fiuza, 2000:277).

Já a fragmentação da terra por herança se dá quando "o conjunto patrimonial é transferido por causa mortis". (Fiuza, 2000:645).

A vida familiar, as relações de parentesco, de herança ou doação, a transmissão de patrimônio são regidas por códigos flexíveis, adaptados às mais 
diversas relações que surgem entre parentes. A doação e a herança da terra consistem, segundo Moura (1986:28-9), "num dos fundamentos sobre os quais se apóia a reprodução social do campesinato parcelar". Portanto, concordando com a autora, para compreender a família camponesa, deve-se recorrer às regras de herança ou doação da terra.

A herança ou doação é uma das formas pelas quais se mantém a reprodução física e social do camponês, evitando a sua expropriação. A terra passa a ser fragmentada, num ritmo lento, a partir do momento em que os filhos começam a se casar e construir sua morada dentro da propriedade do pai.

A fragmentação do patrimônio territorial com base no Código Civil Brasileiro, cujas regras asseguram a existência dessa fragmentação em escala menor, vem também assegurar a reprodução da área como camponesa, porque a doação inter vivos e/ou a herança causa mortis desempenham papel importante e estratégico nesse sentido.

A doação inter vivos, ou seja, a doação feita em vida pelo (s) autor (es) da herança aos filhos, constitui-se em adiantamento de herança, regido pelo Código Civil Brasileiro em seu artigo 544: "A doação de ascendentes a descendentes, ou de um cônjuge a outro, importa adiantamento do que lhes cabe por herança". Foi o que aconteceu nas famílias Oliveira, Silva e Giovanini e, em parte, nas famílias Ferreira e Oliveira, que receberam, em primeira instância, parte de suas propriedades através da sucessão causa mortis e, num segundo momento, a doação por parte da mãe.

Vê-se em Oliveira (2003:2) que o Direito das Sucessões tem fundamento na Constituição Federal, em seu artigo $5^{\circ}$, inciso XXX, que:

\begin{abstract}
consagra o direito de herança. Trata-se, portanto, de direito fundamental, que não pode ser negado pela legislação infraconstitucional. A matéria é tratada no Livro $\mathrm{V}$ do vigente Código Civil, entre os artigos 1.784 a 2.027, compreendendo os títulos: Disposições Gerais, Sucessão Legítima, Sucessão Testamentária, Inventário e Partilha. Na esfera processual, aplicam-se as normas do Código de Processo Civil, artigos 982 a 1.045.
\end{abstract}

Mas o direito das sucessões que viabiliza a fragmentação da terra por meio da doação ou da herança também tem seus limites. Conforme o artigo 65 do $\mathrm{ET}^{171}$,

\footnotetext{
${ }^{171}$ Art. 65. O imóvel rural não é divisível em áreas de dimensão inferior à constitutiva do módulo de propriedade rural. obs.dji.grau.2: Art. 60, § 1ㄹ "b" e "e" a "g", Lançamento e Cobrança do Imposto Territorial Rural - Critérios Básicos para a Tributação Regulada no Estatuto da Terra e Art. 57, Disposições Gerais e Transitórias - Tributação da Terra - Política de Desenvolvimento Rural - D056.792-1965 - Regulamento; Art. 8º Sistema Nacional de Cadastro Rural - L-005.868-1972; Art. 97 e Art. 98, Desmembramento de Imóveis Rurais - Colonização e Outras Formas de Acesso à Propriedade - D-059.428-1966 - Regulamento; Art. 39, Disposições Gerais e Transitórias - Sistema Nacional de Cadastro Rural - D-072.106-1973 - Regulamento obs.dji.grau.3: Art. 88, Bens Divisíveis - Bens
} 
o imóvel rural não pode ser fragmentado em medida inferior ao módulo da propriedade rural, para que não ocorra o processo de minifundização, isto é, para que não se constituam novos minifúndios, tipo de propriedade que "é um imóvel rural de área e possibilidades inferiores às da propriedade familiar" (ET, art. 4º IV).

Dessa forma, observa-se que a unidade fundamental da terra, ou seja, a medida mínima permitida por lei a uma fragmentação é o módulo rural, que tem por função a estabilidade econômica e o bem-estar do agricultor. Para isso, é necessário que se aplique a política agrícola fundiária, garantindo o mínimo de renda a esse agricultor, com o fim de assegurar a ele e a sua família não apenas a subsistência, mas o progresso social e econômico, limitando o direito de propriedade das terras rurais.

Considerados em Si Mesmos - Diferentes Classes de Bens - Bens, Art. 166, Invalidade do Negócio Jurídico - Negócio Jurídico - Fatos Jurídicos e Art. 1.320, \& $1^{\circ}$, Direitos e Deveres dos Condôminos - Condomínio Voluntário - Condomínio Geral - Propriedade - Direito das Coisas - Código Civil - CC - L-010.406-2002

\$ $1^{\circ}$ Em caso de sucessão causa mortis e nas partilhas judiciais ou amigáveis, não se poderão dividir imóveis em áreas inferiores às da dimensão do módulo de propriedade rural. obs.dji.grau.2: Art. 97, Parágrafo único, Desmembramento de Imóveis Rurais - Colonização e Outras Formas de Acesso à Propriedade - D-059.428-1966 - Regulamento

\$ $2^{\circ}$ Os herdeiros ou os legatários, que adquirirem por sucessão o domínio de imóveis rurais, não poderão dividi-los em outros de dimensão inferior ao módulo de propriedade rural.

$\S 3^{\circ}$ No caso de um ou mais herdeiros ou legatários desejar explorar as terras assim havidas, o Instituto Brasileiro de Reforma Agrária poderá prover no sentido de o requerente ou requerentes obterem financiamentos que lhes facultem o numerário para indenizar os demais condôminos.

\$ $\mathbf{4}^{\mathbf{0}} \mathrm{O}$ financiamento referido no parágrafo anterior só poderá ser concedido mediante prova de que o requerente não possui recursos para adquirir o respectivo lote.

§ $\mathbf{5}^{\mathbf{0}}$ Não se aplica o disposto no caput deste artigo aos parcelamentos de imóveis rurais em dimensão inferior à do módulo, fixada pelo órgão fundiário federal, quando promovidos pelo Poder Público, em programas oficiais de apoio à atividade agrícola familiar, cujos beneficiários sejam agricultores que não possuam outro imóvel rural ou urbano. (Acrescentado pela L-011.446-2007)

$\S \mathbf{6}^{\circ}$ Nenhum imóvel rural adquirido na forma do $\S 5^{\circ}$ deste artigo poderá ser desmembrado ou dividido. (Acrescentado pela L-011.446-2007) 
MAPA IV - LOCALIZAÇÃO GEOGRÁFICA DAS PROPRIEDADES NA CARTA TOPOGRÁFICA DO MUNICÍPIO DE RONDONÓPOLIS

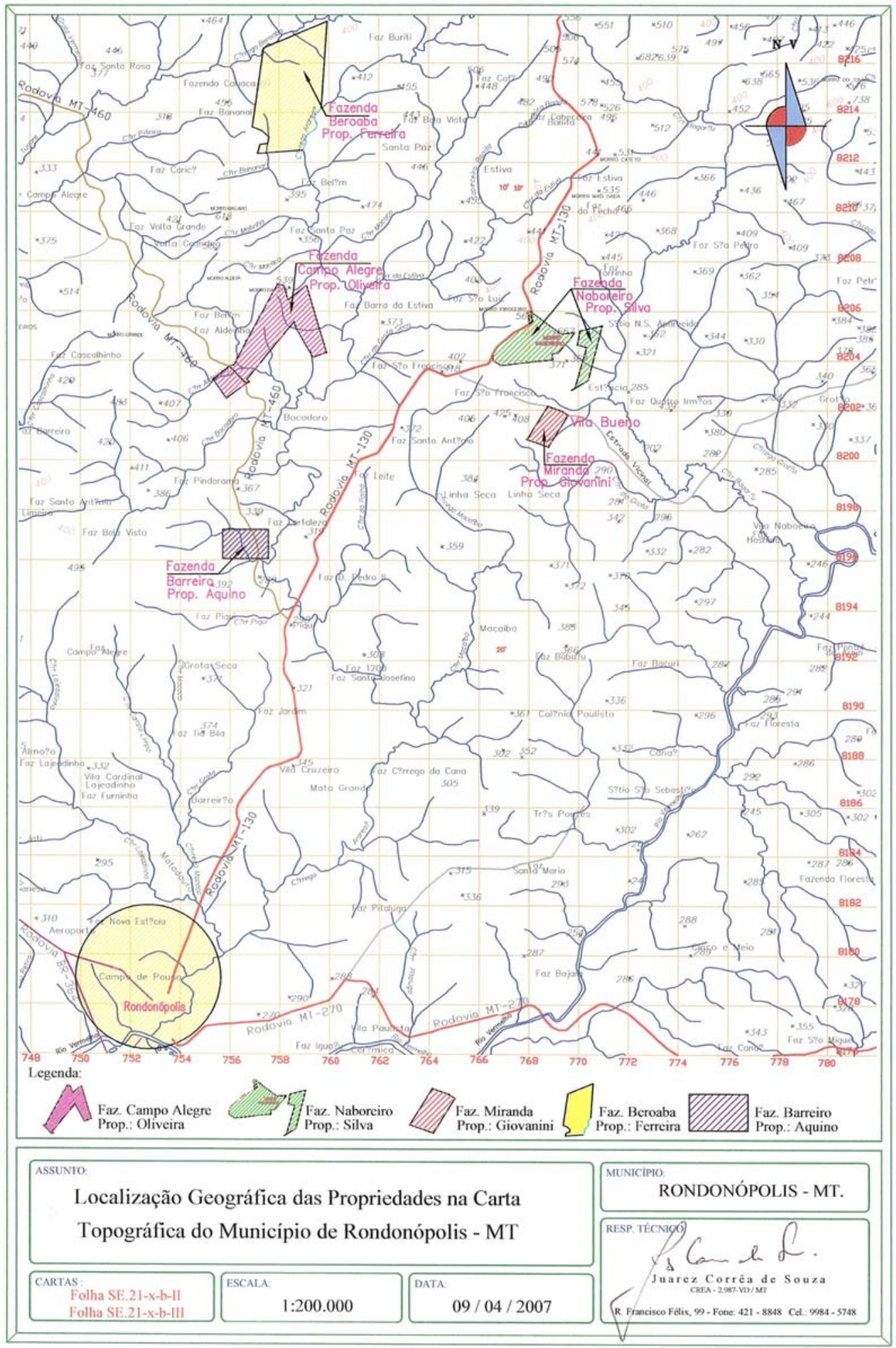




\subsection{As Características Gerais das Famílias}

A ocupação do espaço rondonopolitano deu-se por intermédio de correntes migratórias procedentes dos Estados de Goiás, Minas Gerais, São Paulo, Bahia, Piauí e, posteriormente, do Rio Grande do Sul, Paraná, Santa Catarina, entre outros, passando a constituir uma miscigenação de povos procedentes, geralmente, da zona rural. E essa migração aconteceu por estarem impulsionados pelo sonho e pela expectativa de adquirir um pedaço de terra onde pudessem constituir família e proporcionar-Ihe vida digna. O objetivo deste item é mostrar a procedência, a constituição e alguns episódios vividos pelas famílias Oliveira, Ferreira, Silva, Aquino e Giovanini em Rondonópolis, os quais vieram de locais e em épocas diferentes.

A família Oliveira teve sua origem em Rondonópolis com o Sr. Ildefonso Bernardino de Oliveira, oriundo de Santa Rita do Araguaia/GO, aqui chegando em 1930 à procura de terras, pois naquela época, além da facilidade para conseguir, era mais barata. Em 1934, casou-se no regime de comunhão de bens com Leonila Pereira dos Santos (hoje com 94 anos), natural de Rondonópolis, que passou a se chamar Leonila Pereira de Oliveira. Dessa união nasceram dez filhos (Foto 01), sendo seis homens: Daniel, Gumercindo, Teodoro, Silvio, Pedro e Maurino e quatro mulheres: Eliete, Elizete, Rita e Maria Anunciação. $D^{a}$. Leonila é filha do Sr. Antônio Pereira dos Santos, morador da Fazenda Campo Alegre.

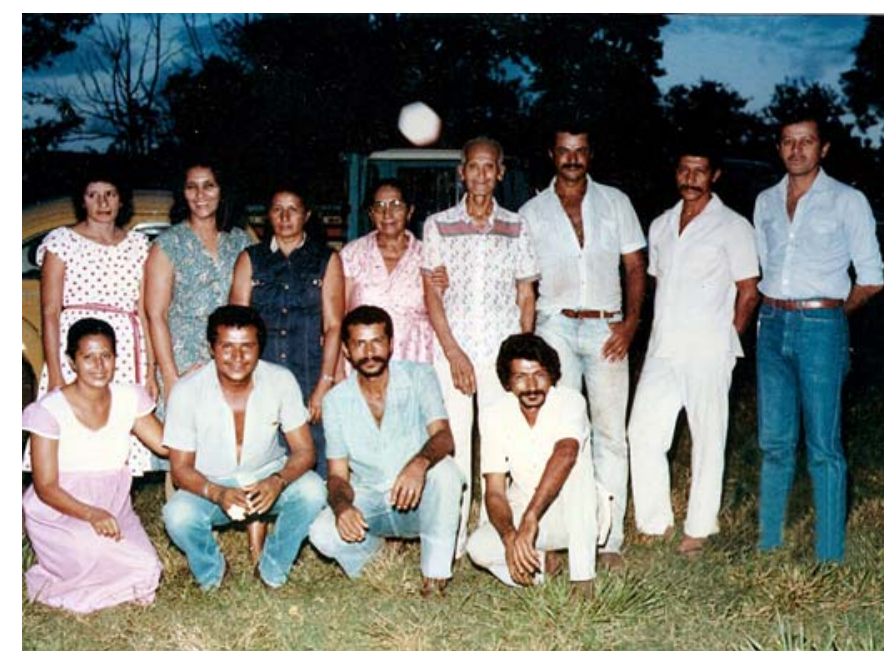

Foto 01 - Família do Sr. Ildefonso e $D^{a}$. Leonila. Em 20/05/1983. (Cedida por Maurino). 
O Sr. Ildefonso contratava professor particular para ensinar seus filhos, pois não existia escola na região e algumas crianças da vizinhança acabam estudando ali também. Geralmente o professor morava na própria fazenda. De acordo com Elizete, estudavam o dia todo: “acabava o livro da $1^{\text {a }}$ Série, já passava para o da $2^{a}$ e assim por diante. Não existia boletim, o que indicava se estava apto para a série seguinte (sem terminar o ano letivo), era saber ler, bem como as quatro operações".

Em 1954 compraram uma casa na cidade. No início, Da . Leonila veio morar com os filhos para que pudessem estudar. Elizete e Rita fizeram um teste e entraram na $2^{\mathrm{a}}$ Série; os demais foram matriculados na $1^{\mathrm{a}}$ Série. Geralmente, após concluir a $4^{\text {a }}$ Série, os filhos acabavam voltando para a fazenda. O Gumercindo e a Elizete passavam a maior parte do tempo com o pai que lá ficara juntamente com seu compadre Euzébio. Em entrevista, Elizete comentou que:

O Sr. Euzébio era solteiro, veio de Chapada dos Guimarães e ficou morando na fazenda conosco, mas tinha um barraquinho dele, pois gostava de fazer um foguinho, ajudava nos trabalhos da fazenda, capinando o quintal e ajudando com a meninada. Ele ficou na fazenda até falecer, com mais ou menos uns 60 anos e foi enterrado no cemitério que fica nas terras do Silvio, no Sítio Mamona.

Os anos foram passando, os filhos se transformando em homens e mulheres, casando-se e construindo suas casas na própria fazenda, cada qual em uma área. Diferente das regras observadas por Moura (1978:55) em São João da Cristina: "é raro que mais de dois filhos homens se casem e passem a morar na terra paterna, sem que ocorra a morte de um dos pais". Dos dez filhos, só uma não contraiu matrimônio. Eliete, aos 15 anos de idade, foi a primeira a se casar e com a permissão dos pais construiu sua casa em uma parte da fazenda. Pedro, ao se casar, morou na casa dos pais, depois em uma casinha no quintal da Eliete e, ao receber a terra, construiu a casa onde mora hoje. Com exceção de Teodoro e Maria Auxiliadora, que se casaram e foram morar na cidade, os demais foram se casando e construindo sua morada nas terras dos pais, ocorrendo, aí, a passagem de patrimônio territorial, que se concretizou de fato em 1978.

A família Ferreira teve seu início em Rondonópolis quando o Sr. João Nunes Ferreira, goiano de Rio Verde, casou-se com dona Aurora Rosa Batista e migrou para Mato Grosso em 1919, juntamente com dois irmãos solteiros, Manoel Nunes Ferreira e José Moreira Nunes Ferreira. A prole dessa união era formada por onze filhos, sendo seis homens - Sebastião, Otoni, Gerson, Valdevino, Odálio e José e 
cinco mulheres - Antonia, Otilia, Arminda, Erontina e Odalice, todos matogrossenses.

De acordo com entrevista realizada com Benedita Nunes Ribeiro (56 anos), com seus tios Valdivino Nunes Batista (69) e Gerson Nunes Batista (79), cada um dos irmãos veio em seu carro de boi. Durante o percurso de Goiás a Mato Grosso, passaram por muitas dificuldades, não havia estradas, somente picadas na mata. Trouxeram muitos alimentos, além da tropa e paravam no caminho durante uns dois ou três dias para o descanso dos animais. Gastaram em torno de um mês e meio para chegar a Rondonópolis.

O Sr. Gerson lembrou dos relatos do pai sobre a chegada deles no município:

Meu pai contava que quando chegou do outro lado do rio Vermelho, o povo falou que o Marechal Rondon não queria que mais ninguém entrasse aqui para não ocupar as terras, então eles deram a volta por outra picada, cortaram aquela madeira chamada jangada, pois ela é leve e construiu uma jangada para as mulheres, e os mantimentos serem atravessados. Os homens passaram a nado. Primeiro lá em cima no rio Vermelho, depois aqui no rio Arareau.

Segundo Sr. Gerson, ao adentrarem nas "terras de Rondon", "povoado do Rio Vermelho", seus pais foram se instalar:

Primeiro nas terras da dona Olímpia, região do Pequi (hoje Fazenda Barreiro da família Aquino), onde nasceram os dois filhos mais velhos, eles ficaram ali dois anos, ajudando o irmão José Moreira, depois foram para a região do Bananal, onde nasceu os outros filhos. O tio Manoel mudou-se para a região da Cabeceira do Café (vizinho do Bananal), onde ocupou aquelas terras e os filhos estão até hoje.

Durante a entrevista, Benedita mencionou a presença de índios na região e o Sr. Valdivino acrescentou:

Quando meu pai chegou aqui nas terras do Bananal, havia na região duas aldeias indígenas, uma próxima ao córrego Bananal (margem direita) e a outra próxima ao morro Naboreiro. Na primeira os índios eram mais pacíficos, mais civilizados, portanto, conviviam bem com nossa família. Os que habitavam a região do Naboreiro eram mais rebeldes. Os que moravam na região do Bananal eram mais ou menos em torno de 20 pessoas. Como a aldeia ficava bem próxima à nossa residência (margem esquerda do córrego Bananal), eles plantavam mandioca e outros mantimentos nas terras de meu pai e não pagavam nada por isso. $\mathrm{Na}$ época do preparo da terra, do plantio e da colheita, meu pai os contratava como mão-de-obra. Meu pai teve facilidade pra conviver com eles, pois quando meus avós morreram, ele e os irmãos eram pequenos e ele foi criado por um 
fazendeiro rico lá de Goiás, o Sr. José Ferreira e na fazenda desse senhor já morava um indiozinho bororo e meu pai aprendeu a falar a língua deles. Por isso, quando chegou aqui mais meus dois tios, teve facilidade para se adaptar com esses indígenas. A convivência entre nossa família e os índios era tão grande, que meu pai e minha mãe (dona Aurora) foram padrinhos de batismo de um deles. Meu pai tinha o respeito, o carinho e a admiração da tribo e nós vivíamos pacificamente com eles. Era até engraçado ver o bate-papo de meu pai com eles. Com o tempo os índios foram embora, alguns para a região do rio Vermelho e outros para a região de Sangradouro, próximo a Primavera do Leste, no paredão. Dos quatros últimos que ficaram, dois casais, após a mulher de um deles ter sido picada por uma cobra, o que a fez perder o pé e depois a vida, os outros três foram embora e nunca mais vieram para a região.

Esta fala do Sr. Valdivino é prova de que as terras ocupadas por seu pai não eram totalmente devolutas, já que se fazia presente no Bananal uma tribo indígena. Assim como esta, existiam outras espalhadas pelo município. Em 1949, o governador Arnaldo Estevão de Figueiredo doou 10.000 ha de terras às margens do rio Vermelho, onde construíram suas moradas, formando uma grande tribo; assim, as pequenas foram desaparecendo.

De acordo com Sr. Gerson, o pai sempre se recordava de como foi criado:

O pai contava que eles eram cinco irmãos que foram criados sem pai e sem mãe. O Sr. Ferreira, um fazendeiro bem de posses em Goiás, pegou eles para criar e o Jerônimo/índio, também morava lá. Meu pai trabalhou de vaqueiro até quando casou, aí resolveu mudar para Mato Grosso. Um tempo depois que meus pais vieram, o Jerônimo veio e ficou morando com os índios na região do Bananal. Meu pai queria que ele ficasse morando na fazenda com a gente, mas ele preferiu ficar na tribo. Esses índios eram muito conhecidos na cidade. Era o Malagueta, o Jerônimo, o Martim, o Jorge, pai do Rafael que era afilhado de meus pais, esse mora hoje em Rondônia.

Benedita acrescentou que um de seus irmãos encontrou, por acaso, com esse índio em Rondônia e que Rafael o reconheceu, pois o achou parecido com o pai, o Sr. Otoni.

Em tempos idos, houve um grupo de aterrorizadores conhecidos como "Revoltosos" que saíam apavorando a população, em busca principalmente de ouro e diamante, pois muitos dos moradores das terras do "povoado de Rio Vermelho" eram procedentes dos garimpos de Poxoréo. Benedita lembrou da história sobre os "Revoltosos" que sua avó Aurora contava:

Esses "revoltosos" eram homens que chegavam a cavalo, invadiam as casas, comiam os mantimentos, matavam gado para comer, manteavam a carne, deixavam no sol para secar e levavam. Batiam 
nas pessoas para saber onde estava guardado o dinheiro, o ouro, o diamante e outras coisas de valor. Ficavam às vezes de dois a três dias no mesmo lugar, aterrorizando as famílias. Quando os vizinhos ficavam sabendo da presença dos "revoltosos" na região, escondiam as ferramentas e mantimentos e se escondiam também.

O Sr. Valdivino acrescentou que:

Os revoltosos já chegaram a passar pela nossa fazenda, mas como a gente ficou sabendo da presença deles na região, levamos muitas coisas para o esconderijo, o estrago foi pequeno. Minha família ficou dias no morro do Bagaro, levaram pra lá tudo que conseguiram. Depois de uns dois ou três dias, algumas pessoas subiam no morro pra ver se os revoltosos já haviam saído pra eles poderem voltar.

Em 1959, o Sr. João Nunes faleceu e, em 1963, Da . Aurora fez a divisão das terras das fazendas "Bananal" 874 hectares e "Santa Paz" com 500 hectares, herança sem usufruto, para os 10 filhos em que nove receberam 140 ha e $6000 \mathrm{~m}^{2}$ cada, e um deles recebeu 108 ha e $6000 \mathrm{~m}^{2}$, conforme registro de imóveis $\mathrm{n}^{\circ} .3 .026$ e 3027 e Certificado em anexo.

Sobre a divisão das terras, Benedita comentou que:

$\mathrm{Na}$ época da divisão da terra, o tio Sebastião que era casado com a tia Maria Gomes já havia falecido. Como ele já possuía terra na região do Aldeinha, vizinho do Daniel Bernardino de Oliveira, e não tinha filhos, minha avó abriu mão da herança que ela teria que receber por parte dele e minha tia abriu mão da parte que ela teria que receber por conta da morte de meu avô. O acordo foi firmado no cartório e nenhuma delas saiu prejudicada. Por isso que o nome dele não aparece nos Registros nº. 3.026 e 3.027.

O Sr. Valdivino ainda conserva a propriedade herdada do pai que vai ficar para os filhos por direito. Por sua vez, o Sr. Gerson, comentou que:

vendi a parte da herança para comprar essa casa e aplicar o dinheiro, pois como não temos filhos (a gente pegou uma menina grande já, para acabar de criar, a Cida que hoje já é casada e tem uma filha, ela que cuida de nós) aqui na cidade era mais fácil. Mas o Collor veio e carregou tudo o dinheiro e nunca mais. Hoje, da herança do meu pai, tenho só essa casinha aqui.

Em 1946, o Sr. Otoni Nunes Ferreira casou-se com Da. Maria Rodrigues Ferreira e constituíram uma família com onze filhos sendo seis homens: Luiz, José, Orlando, Pedro, Nelson e Gerson e cinco mulheres: Clarinda, Benedita, Emília, Odília, Laurinda (Foto 02). 


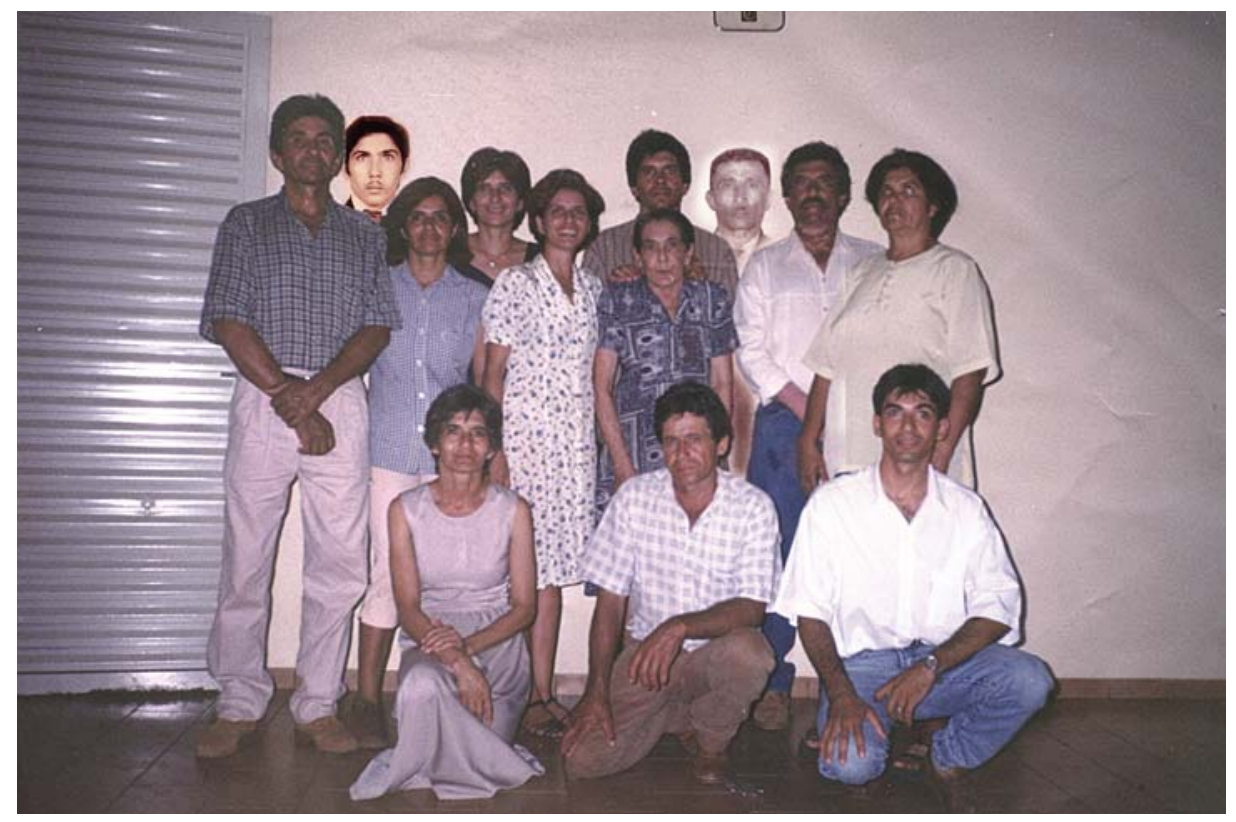

Foto 02- Família do Sr. Otoni e $D^{a}$. Maria. (Cedida por Benedita).

Nessa fala, Benedita Nunes Ribeiro, filha do Sr. Otoni e Da. Maria, conta como o pai conseguiu a terra:

Em 1954, meu pai já havia requerido do governo de Mato Grosso, pelo Departamento de Terras uma área equivalente a 735 hectares. Com a morte de meu avô em 1959, minha avó Aurora resolveu dividir tudo com os filhos, herança sem usufruto. Sendo assim, meu pai recebeu um lote de 140 ha e $6000 \mathrm{mts}^{2}$, que logo após receber, ele fez a troca das terras da Beroaba pelas terras do Bananal, com a irmã dele, tia Odalice, a medida, ou seja, o tamanho do lote era o mesmo. O pai comprou ainda de dois irmãos. Do tio José Nunes comprou tudo (140 ha e $6000 \mathrm{mts}^{2}$ ) e da tia Erontina comprou uma área de 28 ha, da parte que ela recebeu de herança de meu avô. Só sei que juntando a terra que ele requereu do governo 735 ha mais a herança e a parte compra 449,80 hectares, ele ficou com 1.184,80 hectares.

Percebe-se então que, ao mesmo tempo em que cessava o direito para um, $\mathrm{D}^{\mathrm{a}}$. Aurora iniciava para outro, no caso o Sr. Otoni e sua família. Com a partilha da terra, $D^{a}$. Aurora transformou a fazenda Bananal em vários lotes. O patrimônio que antes era gerenciado pelo Sr. João Nunes, com o falecimento deste, foi assumido por ela e, a posteriori, a administração ficou para os filhos, que deram (ou não) continuidade à posse.

O Sr. Otoni faleceu em 1969 e onze anos depois, em 1980, realizou-se o inventário cujo formal de partilha foi expedido pelo juiz a favor da meeira Maria Rodrigues e dos herdeiros. Em 1999, Da . Maria fez a doação de sua parte aos filhos e, em outubro de 2000, realizou-se a divisão amigável para extinção de condomínio. 
A vinda da família Silva para Rondonópolis foi marcada pela expectativa de vida melhor e teve seu início com o Sr. Antônio Alves da Silva (atualmente com 89 anos), que relatou os motivos de sua migração.

Vim de Bom Sucesso/Biara/Bahia, com 21 anos de idade, sai de lá
no dia 29/07/1939. Andei 15 léguas a pé, até Macaúbas/Bahia,
depois vim de caminhão até Montes Claros/MG. De Minas, peguei o
trem de ferro até Campo Grade/MS. De Mato Grosso do Sul vim
direto para Poxoréo, cheguei em janeiro de 1940. A gente tinha lá na
Bahia, uma terrinha de 5 alqueires, era pequena, plantava roça, mas
por conta da seca, não colhia quase nada, então resolvemos vender
e vir embora. Meu destino era Poxoréo por conta do garimpo que
me atraiu, mas vi que era só ilusão, então desisti e vim comprar
terra aqui.

Nota-se nesta fala o que acontece com muitos habitantes nordestinos e de outras regiões a "troca do incerto pelo duvidoso", mencionado por Martins \& Vanalli (1994:82-3): "migram na esperança de encontrar uma vida mais digna, o que nem sempre acontece. (...) as áreas de atração, depois de um certo tempo, podem se transformar em áreas de expulsão, quando os fatores responsáveis pela produção de riquezas se esgotam".

Depois de realizar sua caminhada, e chegar ao destino que o atraiu, o garimpo, Sr. Antônio, percebendo não poder radicar-se em Poxoréo com sua família, migra novamente, desta vez para terras rondonopolitanas, na tentativa de mudar de vida. Expõe ele: "Em 1943, vim-me embora para Rondonópolis. Eu e mais cinco pessoas compramos na região do Naboreiro 500 ha, era Fazenda Miranda. Ah! Antes de comprar essa terra, fui na Bahia e busquei minhas irmãs e minha mãe, que era viúva, meu pai morreu eu tinha 10 anos".

A mudança de local, a troca do garimpo pela terra de cultura significa a possibilidade de propiciar, através do trabalho, vida melhor e mais farta para a mãe e as irmãs. Agora já estruturado, Sr. Antônio retorna à Bahia com outro intuito:

Em 1943, voltei lá e me casei com Maria Rosa da Silva e vim definitivo para Mato Grosso. Tivemos 11 filhos, 9 homens: José, Nivaldo, Milton, Eduardo, Valdemir, Sebastião, João, Nilson e Aurino e duas mulheres: Ilza e Lucília, todos vivos. Minha esposa faleceu em 14/02/1989. Eu moro aqui na casa, a sede que na divisão ficou para minha filha llza.

De posse de uma terra e agora casado, Sr. Antônio e $\mathrm{D}^{\mathrm{a}}$. Rosa passaram a constituir nova família - a familia elementar (Foto 03). Nessa época, já ocupavam as terras anexas à que possuíam. Como a prole era grande, procurou recursos para aumentar a propriedade e garantir o futuro da família, dos filhos. 


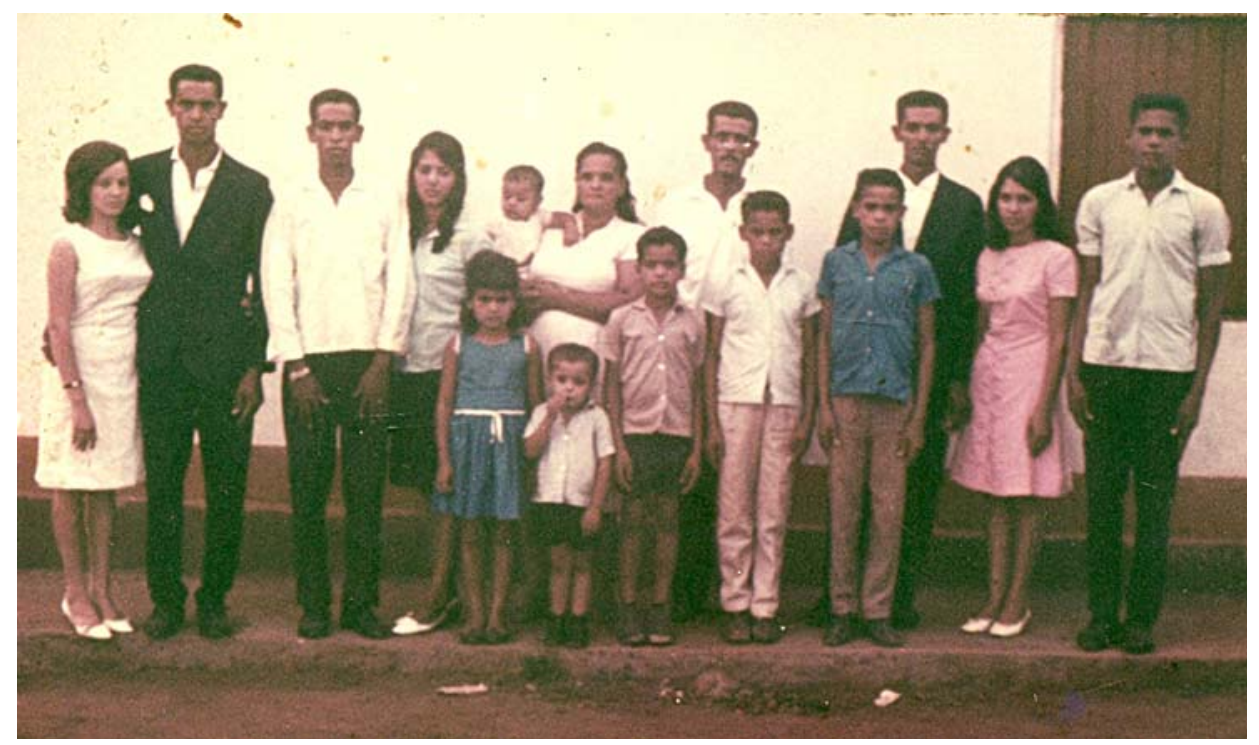

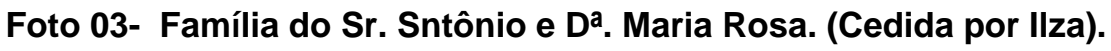

Para isso, desmembrou a sociedade na terra e foi em busca de novas áreas. Como tinha uma reserva em dinheiro, ainda que fosse pequena, Sr. Antônio tomou a seguinte decisão:

\begin{abstract}
Passado um tempo, não me lembro o ano, dividimos a terra para que cada um tivesse seu lugar, ficamos cada um com mais ou menos 83,5 ha. Em 1948, requeri do governo de Mato Grosso uma área de 294 ha, era terra devoluta, paguei 500 reis por ha, acho que a senhora nunca viu esse dinheiro, reis (Risos), só recebi o título definitivo em 1955. Antes do governo do Dr. Arnaldo Estevão, eu tentei requerer uma área de 2000 ha, aqui da região, o governo anterior disse que conseguiria pra mim, mas ele perdeu a eleição e o Dr. Arnaldo que ganhou, não concedeu a área. Eles (o governo) pegaram mais 6000 hectares, juntou com os 2000 ha que eu queria requerer e criou o Núcleo Colonial Naboreiro, foi bom, porque beneficiou várias famílias. No total era 8000 ha de terras devolutas. Desse total eu consegui em 1957, por doação o lote $n^{\circ} .107$, com 50 ha. Depois comprei uns outros pedacinhos que formou o patrimônio que tenho e que o ano passado dividi, doei pros filhos.
\end{abstract}

Esse foi um período em que o governo incentivou a vinda de migrantes para Mato Grosso, e Rondonópolis foi beneficiada com algumas colônias municipais e o Núcleo Colonial de Naboreiro ${ }^{172}$ foi uma delas. Com o lote ganho do governo, Sr.

\footnotetext{
${ }^{172}$ Projeto ou Colônia Naboreiro em Rondonópolis/MT, implantada em 1949, de acordo com Decreto 714-13/0/49. Implantada nos anos 50. Regularização da titulação a partir de 1957. Área: 8.000 hectares. №. de lotes: 144 . Encontramos no registro de imóveis - Cartório do $1^{\circ}$ Ofício Registro Geral livro 2, comarca de Rondonópolis, matrícula n ${ }^{\circ}$. 19.528 (cedida pelo setor de Leis da Prefeitura Municipal de Rondonópolis), que “por força da Lei no. 2872 de 19 de novembro de 1968 publicada no Diário Oficial, cuja lei é do teor seguinte: O governador do Estado de Mato Grosso - faço saber que a Assembléia Legislativa do estado decreta e eu sanciono a seguinte lei: Artigo $1^{\circ}$. Passam a pertencer a Prefeitura Municipal de Rondonópolis os terrenos urbanos recebidos para criação de Patrimônio nos núcleos coloniais de Campo Limpo, Naboreiro e Paulista, já demarcados pela extinta C.P.P. - Artigo $2^{\circ}$. A Prefeitura Municipal de Rondonópolis fica obrigada a expedir os títulos definitivos aos posseiros que já tinham realizado benfeitorias. Artigo $3^{\circ}$. Esta entrará em vigor na data da sua publicação. Cuiabá 19 de novembro de 1968. Neste mesmo documento consta que os imóveis objetos das matrículas que constituem o patrimônio
} 
Antônio ampliou sua propriedade (total 475,5554 ha) e, juntamente com a família, trabalhou com afinco e recebia as pessoas que por ali passavam. Comentou ele:

Aqui na fazenda passava a linha telegráfica de Rondonópolis a Poxoréo e Guiratinga ${ }^{173}$. No período de 1947 a 1958, as pessoas que transportavam toda a colheita de Jarudore/Poxoréo para Rondonópolis, no lombo dos burros usavam como estrada a picada do linhão feita pela equipe de construção da Linha Telegráfica, mais ou menos no ano de 1922. O ponto de parada era aqui em casa, onde paravam para descansar os animais, para comer e dormir. Tinha vez que passava de 20 a 25 ou até 30 pessoas. Tudo era de graça e tanto eu quanto a Maria Rosa minha mulher fazia as refeições com gosto e não cobrava e nem reclamava. $\mathrm{O}$ arroz era socado no pilão (que hoje está furado, de tanto que foi socado). O Milton que na época era criança reclamava.

Sobre este depoimento, Milton acrescentou: Eu reclamava porque às vezes a gente já tava dormindo e tinha que levantar e socar arroz, pra esse monte de gente e o que era pior, no claro da lamparina que o vento apagava toda hora.

Há duas coisas importantes a serem ressaltadas a partir das falas do Sr. Antônio e do Milton: a primeira, é sobre a questão da cidadania e solidariedade: comprova-se que a terra era de fartura, pois o que produziam era suficiente para alimentá-los e sobrava aos viajantes que, além de se alimentarem também, dormiam pra descansar; a segunda é o fato da obediência, do respeito aos mais velhos, a tarefa de socar o arroz era realizada pelas crianças que, mesmo dormindo, acordavam para trabalhar.

É notável o orgulho do Sr. Antônio ao dizer "tudo era de graça, fazia com gosto e não cobrava nem reclamava". Por essas benevolências, pelos relevantes

\footnotetext{
Naboreiro, cujas cartas de aforamento expedidas pela Prefeitura Municipal de Rondonópolis serão registradas e anotadas na planta do projeto de desmembramento arquivado neste cartório”.

${ }^{173}$ Quanto à construção do Posto Telegráfico que passa por Rondonópolis, encontramos em Tesoro, 1999, que existe uma polêmica comentada pelos irmãos Nair e Bittencourt, onde esclarece que na realidade essa rede teria sido instalada pelo Major Otávio Pitaluga e não por Marechal Rondon como consta a versão oficial.

'Para o Sr. Bittencourt, é muito claro o que passou naquele momento. Pelo projeto original, a linha telegráfica não deveria passar por Rondonópolis. A rede local que vem de Thereza Cristina, próximo a São Lourenço, foi tirada do ramal Cuiabá - Campo Grande, e deveria seguir daquele ponto (exatamente do Córrego Tribial - barra do Tugore) em linha reta para o Naboreiro (morro alto, situado antes de Jarudore, e que pode ser visto de Rondonópolis), passando por Guiratinga, Alto Araguaia, Jataí, até Goiânia; ou seja, não incluía Rondonópolis. Acontece que, enquanto a Comissão esteve acampada próximo ao São Lourenço, Rondon adoeceu e foi para o Rio de Janeiro se recuperar, e Pitaluga assumiu o comando dos trabalhos, quando então alterou o projeto; em outras razões, por amizade a José Rodrigues e aos goianos da região, que lhe teriam pedido para incluir o povoado naquele traçado (em troca passaram a ser o mais fiel reduto eleitoral de Pitaluga). Isso significa, em outras palavras, que entre o Córrego Tribial e o Morro Naboreiro far-se-ia uma volta, um contorno, fora da rota traçada por Rondon. Para evitar complicações, Pitaluga, que nessa época era deputado, apresentou um novo projeto incluindo o Rio Vermelho e o submeteu à aprovação da Assembléia, de modo que, quando Marechal retornou, o serviço já estava pronto e o caso não tinha mais volta. Entretanto, mesmo assim, ele ordenou que fosse posto tudo abaixo e que se retomasse novamente do São Lourenço. Porém, como o projeto fora aprovado pelos deputados, ele se viu forçado a concordar e retroceder. (...)' Dona Nair diz: ‘Então, tentando contornar o problema, foi que Otávio Pitaluga mudou o nome do povoado para RONDONÓPOLIS, em homenagem a Rondon'. (...) 'Assim, Rondon obteve ao mesmo tempo duas glórias: a homenagem pela instalação do telégrafo e o título de "Patrono Honorário' de Rondonópolis, ou cidade de Rondon. Esta, sem dúvida, foi a grande peça que ironicamente, a história pregou ao Major Otavio Pitaluga, responsável direto pelas homenagens conferidas a Rondon’. Tesoro, L.L.L.M. (1993:73 - 4 e 5).
} 
serviços prestados, o Sr. Antônio foi reconhecido e agraciado com dois Títulos de Cidadão Rondonopolitano, ambos concedidos pela Câmara Municipal de Rondonópolis, um em 09/12/1986 e o outro em 10/12/1991 ${ }^{174}$, bem como o Título de Cidadão Mato-Grossense, concedido a pedido do Deputado Estadual J. Barreto em 12/03/2003. São honrarias que enchem a família de orgulho, fez questão de colocálos na moldura e dependurá-los na parede da sala de visitas.

Após o falecimento da esposa Maria Rosa (14/02/1989), Sr. Antônio continuou morando na fazenda juntamente com os filhos solteiros. Não fez inventário e em 2006 realizou a divisão das terras da Fazenda Naboreiro ou Pé da Serra, que está com ele desde 1949, ou seja, há 58 anos, através do processo de doação, pela qual ocorreu a repartição amigável para extinção de condomínio.

A Família Aquino também teve sua instalação em Rondonópolis por intermédio do processo de migração. O Sr. Domingos de Aquino é natural do Piauí e dona Orinda Souza Aquino é de Barreiros/Bahia. Comprou a terra que os filhos possuem hoje.

Em entrevista, Maria Dolores, filha do casal, informou que:

Meu pai veio do Piauí para Poxoréo e minha mãe veio de Barreiros/Bahia. Primeiro meus avós maternos vieram para Goiás, posteriormente para Poxoréo. Nesta época minha mãe tinha 13 anos e casou-se com meu pai aos 15 anos e com 16 anos foi mãe. Meu pai era administrador de um garimpo de seu irmão em Poxoréo, e com o dinheiro que foi arrecadando, veio a Rondonópolis em 1950, e comprou a Fazenda de 390 ha, que na época era conhecida como Santo Antônio. Em 1951, no final do ano, mudamos para esta fazenda.

Maria Dolores comenta ainda que: "como aqui não tinha escola na época, meu pai pagava uma professora particular pra dar aulas para os filhos dele e dos moradores da fazenda também". Pela fala de Dolores, percebe-se a preocupação e a necessidade de educar os filhos. A presença de uma professora na propriedade dava a garantia de que os filhos não cresceriam analfabetos, já que moravam na zona rural e não podiam estudar na cidade.

Pelos relatos de Dolores e demais filhos, em 1955, o Sr. Domingos faleceu e deixou dona Orinda com dez filhos e grávida de quatro meses da Domingas. Em 1960, ela casou-se novamente e teve mais 5 filhos.

\footnotetext{
${ }^{174}$ A Câmara Municipal de Rondonópolis, Estado de Mato Grosso, em conformidade com a Lei Municipal $n^{\circ} .1 .326$ de 08 de dezembro de 1986, e em obediência ao Decreto Legislativo $n^{\circ} .456$ de 27 de novembro de 1991 de autoria do Vereador Ananias Martins de Souza, outorga ao Senhor Antonio Alves da Silva a Comenda Marechal Rondon pelos relevantes serviços prestados a Rondonópolis.
} 
Em relação à morte do pai, Gervásio contou-nos um episódio que até hoje não consegue esquecer.

Quando meu pai faleceu, eu era bem pequeno e lembro-me que na hora de levarem o corpo para o cemitério (na própria fazenda), como era mês de outubro as cigarras cantavam muito e isto ficou gravado em minha memória. Todos os anos, quando as cigarras começam a cantar eu relembro esta cena.

Também lembra de coisas boas, como por exemplo:

Que muitas vezes, depois de crescidos e que estudávamos na cidade íamos de bicicleta para a fazenda. Tinha o time do Vasquinho, existe até hoje naquela região/no Brocodoro. Ao lado do campo de futebol, que ficava no Sítio do Bimba, tinha o boteco do Duquinha, após o jogo a gente se reunia para conversar. Joguei muito futebol ali e cultivei muitas amizades.

Com uma prole grande, muitos deles pequenos e uma fazenda para "tocar", $\mathrm{D}^{\mathrm{a}}$. Orinda acabou casando-se novamente e do segundo casamento teve mais cinco filhos. Ao todo foram 16 filhos. Morreram dois, um do primeiro e outro do segundo casamento. Ficaram sete homens: Gilberto, Gervásio, Benedito, Rubens, Gildásio, Paulo Henrique e sete mulheres: Maria Dolores, Eva, Odelita, Odete, Domingas, Maria Paula e Sandra. Dona Orinda viabilizou o processo de herança nos termos de inventário, em 1973, onde entrou como meeira do Sr. Domingos e herdeira de seu filho Adão que faleceu em 1971 e era solteiro. Em 1991, Da . Orinda passou aos seus filhos/donatários o que Ihes coube por direito da herança de seu esposo Domingos e de seu filho.

A Família Giovanini 175 entra no cenário rondonopolitano com a chegada dos senhores José Giovanini (cujos pais são imigrantes italianos) e Maria da Encarnação Giovanini (o pai veio da Itália e a mãe de Portugal), casados no regime de comunhão de bens, que migraram do Estado de São Paulo após ficarem sabendo que, em Mato Grosso, era fácil conseguir terra.

Da união do Sr. José e $D^{a}$. Maria nasceram oito filhos, cinco homens: Osvaldo, Renato, Edson, Nelson, Odair e três mulheres: Lurdes, Alzira e Irene.

Apesar de serem procedentes de Jales/SP, e terem vindo para Rondonópolis em 1961, não são integrantes do "movimento sócio-religioso do 'Aparecidão"'

\footnotetext{
${ }^{175} \mathrm{O}$ sobrenome correto é GIOVANINI, mas alguns dos filhos foram registrados Giovanine.
} 
descrito por Oliveira (1998) em seu trabalho "Tempo de travessia, tempo de recriação: profecia e trajetória camponesa".

Ao chegarem a Rondonópolis, Sr. José comprou três lotes: um da Fazenda Miranda com 36,30 ha e os lotes 86 com 44 ha e o 87 com 47 ha, todos na região do Naboreiro e Vila Bueno ${ }^{176 .}$

Senhor Osvaldo177, filho mais velho do Sr. José e $D^{a}$. Maria, relatou-me que:

Meus pais vieram do município de Jales/SP em 1961, onde eram agricultores e possuíam uma propriedade de 20 alqueires (48.4 ha). Ficaram sabendo que aqui era fácil conseguir terra, então vieram em busca de uma vida melhor para eles e os sete filhos que já possuíam. O Edson que era o caçula nasceu aqui em Rondonópolis. De Jales nós viemos direto para essa região - Vila Bueno, onde o pai comprou 56 alqueires (135,52 ha), que foi 55 alqueires (133.1 ha) no sítio e um alqueire (2.42 ha) aqui na Vila, onde montou uma máquina para beneficiamento, que beneficiou arroz para toda a região num período de dez anos. Meu pai foi comprando partes pequenas de 20 alqueires, que as pessoas haviam recebido de doação do governo na época da Colônia Naboreiro. Outras partes que ele comprou, já ia passando para os filhos.

Além das terras em Rondonópolis, o Sr. José também comprou no município de Planalto da Serra (era município de Chapada dos Guimarães, passou para município de Nova Brasilândia e hoje é Planalto da Serra). Sr. Osvaldo acrescentou:

Antes de falecer, ele e a mãe resolveram doar as terras. Quando fez a doação, os filhos ficaram com as terras de Rondonópolis e as filhas com a terra de Planalto da Serra.

Em entrevista, Lourdes informou que no Planalto da Serra: "o pai tinha 285 alqueires, quando ele comprou de terceiros só 90 eram documentados, $\underline{\text { o excesso }}$ era de 195 alqueires, sendo assim, cada uma das irmãs recebeu 95 alqueires, somente 30 alqueires de cada era documentada". O argumento de Lourdes vem comprovar o que já foi pesquisado e concretizado por José de S. Martins, Ariovaldo U. Oliveira, Bernadete A. A. C. Oliveira, Gislaene Moreno que em seu último trabalho (2007): Terra e Poder em Mato Grosso: Política e Mecanismos de Burla/1892-1992

\footnotetext{
${ }^{176}$ Seu Osvaldo disse que: “a Vila Bueno surgiu a mais de 46 anos, não me lembro direito, só sei que quando aqui chegamos em 61, já existia. Os Srs. Antonio Bueno, Benedito Bueno da Silva e Antonio Bueno Filho, lotearam a terra para fazer uma Vila (o tamanho dos lotes variavam entre 17, 18 a 20 alqueires), só que não fez projeto, não mediu os lotes, não fez mapa e nem registrou. Venderam alguns lotes, mas sem documento. Na época que o Bezerra era prefeito, ele veio falar comigo pra gente legalizar, já que a maior parte está comigo. Só que ele queria organizar, mas as nossas custas, sem a Prefeitura arcar com nada, assim eu não quis, pois eu só teria gasto. Eu acho que a prefeitura deveria arcar com isso, pois aqui tem água encanada, tem luz elétrica, as pessoas podiam estar pagando os impostos em dia, seria bom pra todos, inclusive para a prefeitura, mas ele não quis e está tudo sem documento até hoje. Quanto a carta de aforamento que a senhora falou, eu não tenho conhecimento.”

${ }^{177}$ Por ser um morador antigo na região, o Sr. Osvaldo é um homem muito respeitado e querido por todos os moradores. É presença marcante e influente na Vila Bueno, por seus serviços prestados à comunidade, já recebeu o "Título de Cidadão Rondonopolitano", concedido pela Câmara Municipal de Rondonópolis em obediência ao Decreto Legislativo Nº 458 de 28 de novembro de 1991.
} 
coloca em evidência a mensagem do INTERMAT, orientando os interessados na transação de terras a procurar o órgão e verificar a origem da documentação antes de fechar qualquer tipo de negociação. Dizia o anúncio exposto em outdoors espalhados por vários locais no Estado: "Não compre gato por lebre. Antes de adquirir terras em Mato Grosso, consulte o INTERMAT".

Vê-se que, na família Giovanin, a forma de partilha, ou seja, de divisão dos bens foi diferenciada das demais famílias estudadas, caso que será discutido a posteriori.

\subsection{As Famílias e suas Propriedades}

Após apresentação das famílias, far-se-á a seguir a identificação das propriedades na qual será destacada a sua origem e dos descendentes de cada família estudada. É importante relembrar que essas famílias apresentam trajetória migratória rural, pois todas tinham como experiência anterior o trabalho em 
atividades agrícolas, embora o patriarca de duas delas tenha migrado a priori em busca da riqueza mineral - garimpos de Poxoréo.

Para homenagear os protagonistas desta história, destaco a pedido deles os versos de músicas que lhes trazem recordações.

\section{FAMÍLIA OLIVEIRA}

\section{Poeira}

ZédoRandhoeZédoPinho

Composição: Serafim Colombo Gomes e Luís Bonan

O carro de boi lá vai gemendo lá no estradão Suas grandes rodas fazendo profundas marcas no chão Vai levantando poeira, poeira vermelha, poeira Poeira do meu sertão

Olha seu moço a boiada, em busca do ribeirão

Vai mugindo, vai ruminando, cabeças em confusão

Vai levantando poeira, poeira vermelha, poeira

Poeira do meu sertão

Olha só o boiadeiro montado em seu alazão

Conduzindo toda a boiada com seu berrante na mão Seu rosto é só poeira, poeira vermelha, poeira Poeira do meu sertão

Barulho de trovoada coriscos em profusão A chuva caindo em cascata na terra fofa do chão Virando em lama poeira poeira vermelha,poeira Poeira do meu sertão

Poeira entra em meus olhos, não fico zangado não Pois sei que quando eu morrer meu corpo vai para o chão Se transformar em poeira, poeira vermelha, poeira Poeira do meu sertão, poeira do meu sertão, poeira Poeira do meu sertão

A propriedade da família Oliveira teve sua origem em Rondonópolis com o patriarca Antônio Pereira do Santos (Antônio Noca), casado em regime de comunhão de bens com Antônia Pereira dos Santos, migrantes baianos radicados em solo rondonopolitano desde 1910, em busca de terra onde pudessem trabalhar, produzir e constituir a família. Ao chegar a Rondonópolis, o casal ocupou uma área de terras devolutas, conhecida a posteriori por fazenda Belém. 
Com base no Processo: Título Definitivo, Livro 024, fls. 156 de 07/05/1948, INTERMAT/Cuiabá-MT, o Sr. Antônio Pereira dos Santos solicitou, em 24/02/1936, a compra do Lote Belém com área aproximada de 1000 ha. Em 12/08/1937, ele recebeu o Título Provisório. Após medição em 22/08/1939, concluiu-se que esse lote de terras perfazia um total de 3.194 ha.

Como a medida ultrapassou os mil hectares, depois de observadas as exigências do Código de Terras de Mato Grosso, o pedido foi liberado. O Estado só depende de autorização do Senado Federal para as vendas de terras com área superior a 10.000 ha $^{178}$ nos termos do art. $156 \S 6^{\circ}$ da Constituição Federal. Em 07/05/1947, foi expedido pelo Departamento de Terras e Colonização, subscrito pelo governador Arnaldo Estevão de Figueiredo, o despacho a favor do Título Definitivo em prol do Sr. Antônio Pereira dos Santos. O imóvel encontra-se cadastrado no Registro de Imóveis - Cartório do $1^{\circ}$ Ofício, Registro Geral livro 3-A, fls. 188Vo, sob Registro $n^{\circ}$. 1.293 (ANEXO - A). A Fazenda Belém foi sendo fragmentada por doação e por venda, o que contribuiu para a extinção do imóvel rural e, conseqüentemente, com a matrícula no RGI.

Os oito filhos do casal são frutos dessa terra que, na época, era território jurisdicionado ao município de Cuiabá. A segunda filha desse casamento, Leonila Pereira dos Santos (hoje com 94 anos), casou-se com Ildefonso Bernardino de Oliveira e passou a se chamar Leonila Pereira de Oliveira.

Por intermédio de doação, $\mathrm{D}^{\mathrm{a}}$. Leonila recebeu de seu pai um lote da fazenda Belém com 305 ha (Certidão 01), transcrita sob no. 1.556 (ANEXO - B), fls. 249, Lo 3-A, de acordo com Escritura Pública de Doação de 31/12/1960, fls. 130Vo e 132 do Livro $n^{\circ} .12$ das Notas do $2^{\circ}$ Ofício da cidade de Rondonópolis, protocolado sob $\mathrm{n}^{\circ}$. 1.783 fls. 35 no R.G.I. Duas áreas dessa fazenda, apensas ao lote de Da. Leonila, passaram a pertencer ao Sr. Ildefonso por compra feita de seu sogro: uma área de 711 ha conforme transcrição 9.339 (ANEXO-C), fl. 22, livro 3-I, e outra com 447 ha, transcrita sob $n^{\circ}$. 12.147 (ANEXO-D) à fl. 48 do livro 3-K. Além dos lotes mencionados anteriormente (Certidões em Anexo), consta no Processo 14.924, Título Definitivo, INTERMAT/Cuiabá-MT que em 13/02/1945 o Sr. Ildefonso requereu do governo uma área de terras devolutas, denominado Aldeinha, com 406 ha (Planta

\footnotetext{
${ }^{178}$ Artigo 15 - As terras devolutas serão vendidas em lotes maiores ou menores, nunca superiores a 10.000 hectares, salvo com autorização expressa do Senado Federal, tendo em vista: a) - a indústria a que se destinarem; b) - a distância a povoados, a vias de comunicação fluviais ou terrestres. Lei $N^{\circ}$. 336, de 6 de dezembro de 1949. Dispõe sobre o Código de Terras do Estado. Capítulo III - Das Vendas de Terras Devolutas. Código de Terras e Leis Complementares. Departamento de Terras e Colonização Mato Grosso, 1959 , página 8.
} 
01 e Certidão 02), tendo recebido o título provisório em 23/01/1946. E o título definitivo em 279/07/1953, expedido pelo Departamento de Terras e Colonização, devidamente registrado sob $n^{\circ}$. 21.921, fl. 17 do livro 3-T em 27/12/1949, no RGI de Rondonópolis. A junção dessas áreas mais dois lotes adquiridos de terceiros (ANEXO - E e ANEXO - F) deu origem à Fazenda Campo Alegre, com matrícula nº. 45.312 no RGI de Rondonópolis.

O Morro da Cotia e a cachoeira no córrego Mamona (Fotos 04 e 05) chamam a atenção por suas belezas naturais. Em relação ao córrego e ao morro, Elizete lembrou:

dos banhos na cachoeira do Córrego Mamona, das muitas vezes que subimos no Morro da Cotia, de uma vez em que o senhor Alípio Xavier - pedreiro que construiu nossa casa de alvenaria/sede da fazenda subiu até lá com uma cruz grande e pesada nas costas, numa Sexta-Feira da Paixão para enterrá-la em cima do morro por conta de uma promessa que ele havia feito. Nunca esqueci de um anjo muito lindo que ele desenhou com carvão (pois não havia tinta) em uma das paredes da sala, todos que nos visitavam ficavam admirados com tamanha beleza.

Os filhos têm papel fundamental para a família, ainda mais quando a prole é grande. Além das travessuras, todos tinham os seus afazeres e pela fala de Rita percebe-se essa importância: "a gente andava pelo meio dos pastos indo levar comida ao meu pai e irmãos que estavam trabalhando na roça". Quando ela diz "a gente", está se referindo às filhas que ficavam em casa cuidando dos afazeres domésticos, enquanto os irmãos iam para a roça com o pai.

O Sr. Ildefonso era goiano e sempre gostou muito de festas. Dona Leonila e suas filhas Eliete, Elizete e Rita teceram alguns comentários em relação a acontecimentos e fatos ocorridos em épocas remotas, das quais sentem muita saudade, como, por exemplo, as festas de traição. ${ }^{179}$ Disse a Eliete: "Na época de meu pai fazíamos muita treição para ajudar na colheita".

Mesmo com idade avançada, $\mathrm{D}^{\mathrm{a}}$. Leonila lembrou um pedaço da música que cantavam no final da festa:

'cabou o mutirão, cabou o mutirão, o muitão acabou. Só no outro
ano se Deus quiser'. Os homens vinham com os instrumentos, às
ferramentas batendo umas nas outras. Tinha também a dança do
catira e o recortado, que eram os versos que falavam no final do
catira. Só que hoje eu já tô muito velha e a cabeça não ajuda mais,
por isso eu não me lembro direito. Seria bom se pudesse juntar

\footnotetext{
${ }^{179}$ Muxirão e ou mutirão realizado pelos roceiros da vizinhança de um sitiante necessitado de auxílio. BUENO, Francisco da Silva. Dicionário Escolar da Língua Portuguesa. 1986.
} 
todos os filhos, porque aí cada um lembraria uma coisa e o livro ia ficar muito bom.

Em relação à festa popular chamada traição, Rita afirmou que:

Quando chegava o fim do dia e o serviço ainda não tinha sido terminado, amarrava o dono da casa, o que significava que tinha que fazer novamente a treição para acabar o serviço. Como meu pai era goiano, herdou tudo isso de seus parentes, pois os goianos é que gosta desse tipo de festa.

O programa Globo Rural apresentado em um dia de domingo, trouxe uma "festa de treição" realizada pelos parentes e amigos de um fazendeiro de Goiás. O repórter fez questão de diferenciar a "festa de treição" do mutirão. Disse ele que, na primeira, os participantes levam de tudo para comer e, inclusive, instrumentos de trabalho, pois o dono da propriedade é pego de surpresa. Após a chegada, enquanto as mulheres vão para a cozinha preparar o café, o almoço e a merenda, os homens vão realizar as atividades no campo: roçar, colher, mexer com gado etc. Já no mutirão, o dono da propriedade é que faz o convite, prepara os comes e bebes, bem como determina quais atividades devem ser realizadas. Para ambas, existem as músicas adequadas, quem sabe são os recortados de que falou dona Leonila.

Segundo os filhos, Sr. Ildefonso "unia o útil ao agradável", pois, ao mesmo tempo em que realizava as tarefas que não puderam concluir em tempo hábil, aproveitava para fazer uma festa e reunir os parentes e amigos, tentando com isso, não perder de vista uma prática bastante comum entre seus familiares no Estado de Goiás. São muito religiosos e herdaram dos pais, que herdaram dos avós essa religiosidade. Era comum a presença dos padres em tempos idos na propriedade do Sr. Ildefonso, assim como na vizinhança, onde realizavam casamentos, batizados etc.

Tanto o Daniel quanto a Elizete disseram que, na propriedade do Sr. Ildefonso, tinha meeiro e arrendatário que permaneciam num período de um a dois anos, onde faziam seus barracos e viviam com suas famílias, construíam suas roças e pagavam na meia ou na quarta (Elizete), isto é, renda em produto. Segundo eles, não existia contrato escrito. "No tempo do papai homem tinha que ter palavra, então não precisava de contrato, era o respeito, a confiança" (Daniel B. Oliveira). Com esta fala, ele não quis dizer que hoje o homem não tenha palavra, mas sim que os costumes mudaram, os tempos são outros. 
"Pagar na meia ou na quarta" é uma das três formas distintas da renda da terra pré-capitalista analisadas por Oliveira (1986:80-1)

A renda em produto, (...) origina-se do fato de que o trabalhador cede parte de sua produção ao proprietário da terra, pelo fato deste (o proprietário) ter cedido o direito para que ele cultivasse a terra. (...), nessa forma de renda da terra pré-(não)-capitalista a coerção (elemento fundamental da renda em trabalho) é substituído pelo direito, muitas vezes, expresso em contratos (verbais ou escritos).

Os filhos desses trabalhadores, "morador de favor", como diz Martins (1995:36, em Os camponeses e a política no Brasil), ou simplesmente "morador" mencionado por Queiroz (1976:26, em O campesinato brasileiro), conviviam em harmonia com os filhos do proprietário, estudavam na mesma escola, brincavam com os mesmos brinquedos, na maioria das vezes, eram seus padrinhos.

A fazenda Campo Alegre, na realidade foi formada pela juntura das seguintes áreas: 305 ha - parte da doação Sr. Antônio para sua filha Leonila, 447 ha, mais 711 ha, que o Sr. Ildefonso comprou do sogro, 406 ha que requereu do governo, mais os lotes com 48,40 ha na Aldeinha e 27 ha na Barra da Estiva, comprados de terceiros, totalizando 1.944,00 ha. Quando ocorreu a fragmentação das terras, estavam com 1.411 ha, que foi distribuído aos 10 filhos pelo processo de doação, ou seja, adiantamento de legítima, em que filhas e filhos receberam partes iguais. Duas venderam seus direitos a terceiros, os demais continuam com suas propriedades, alguns hoje, com uma porção menor, por terem vendido parte dela. Os filhos P, R e S já realizaram a divisão das propriedades com seus descendentes, faltando apenas lavrar as escrituras. Assim, o que cessou a eles, juridicamente seus sucessores darão continuidade.

Em relação à fragmentação da propriedade, em entrevista, o Maurino comentou: "A Eliete, o compadre Daniel, o Pedro e o Silvio já haviam construído suas casas antes da doação. Pra mim, a Rita, a Elizete, a Anunciação e o Teodoro foi o pai que estipulou o local. Para o Gumercindo que sempre morou com o pai, ficou a sede, ele achava que era o correto".

A doação da terra na família Oliveira passou a ser um núcleo que, embora despercebido por muitos, é tido por mim como a transformação do latifúndio para a (re) criação do campesinato. Parte da Fazenda Belém (que foi ocupada pelo Sr. Antônio Pereira dos Santos em 1910 e requerida em 1936) que deu origem à 
Fazenda Campo Alegre, encontra-se hoje em poder da quarta geração - dos netos de $\mathrm{D}^{\mathrm{a}}$. Leonila e Sr. Ildefonso; portanto, há 97 anos nas mãos da família.

Existe na região uma Associação/Núcleo de Pequenos Produtores Rurais de Aldeinha, com sede na antiga escolinha: Escola Municipal Rural Aldeinha (Mapa XXCroqui de Localização, p: 248), ao lado da Igreja Sagrada Família (Fotos 06 e 07) onde hoje funciona o Centro Comunitário Rural Osório de Freitas Nunes - local no qual atualmente as festas são realizadas pela comunidade.

A seguir serão apresentadas algumas Certidões, a Planta do Lote Aldeinha uma das áreas que deu origem à Fazenda Campo Alegre e algumas fotos.

Após a apresentação iconográfica, serão destacadas as propriedades, de acordo com a numeração dos Lotes na Planta de Doação, sendo que o senhor Daniel, o Teodoro e a Eliete receberam os lotes de números 01, 02 e 03 respectivamente, desmembrados das terras da Aldeinha. O Gumercindo, a Anunciação, o Pedro, o Maurino, a Elizete e a Rita receberam terras desmembradas da Fazenda Campo Alegre, sendo os lotes de números: 01, 02, 03, 04, 05 e 07 respectivamente, e o Silvio recebeu o lote de número 06, desmembrado da Fazenda Campo Alegre e Fazenda Belém, conforme consta nas Plantas dos Lotes de Doação que serão apresentados juntamente com o texto.

\section{CERTIDÃO 01- Lote Belém - 305 Ha Leonila Pereira de Oliveira}




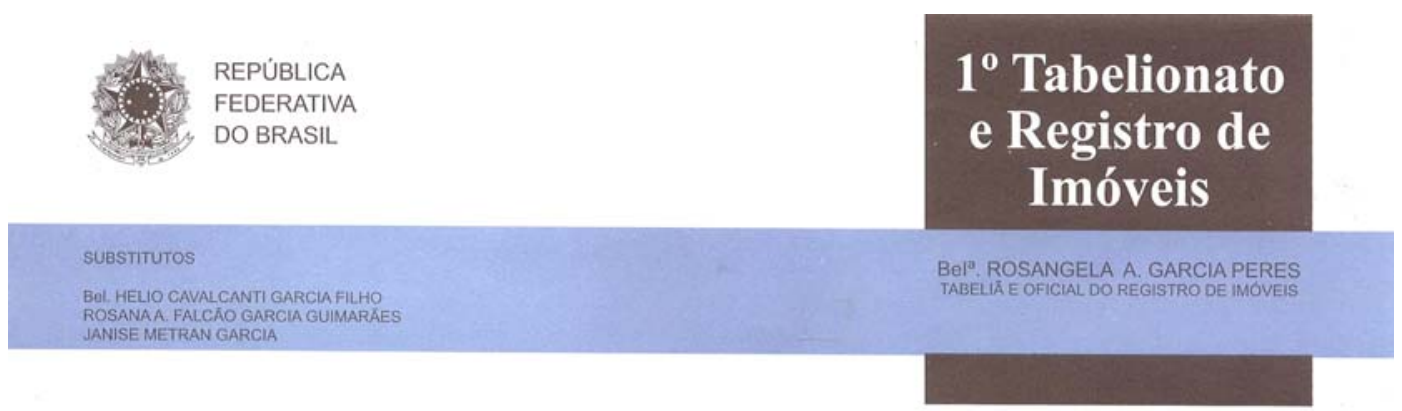

C E R T I D Ã O

Certifico a pedido verbal de parte interessada que revendo nesta Serventia Registral os livros de Registro Geral, verifiquei que a Sra LEOLINA PEREIRA DE OLIVEIRA, adquiriu uma área de terras pastais e lavradias com área de 305,00has, desmembrada de maior área (Belém), situada na zona rural deste Municipio, que adquiriu por Doação de Antonio Pereira dos Santos, conforme Escritura Pública de Doação de 31 de Dezembro de 1960, ás fls. $130 / 132$ do livro 12 , do $2^{\circ}$ Tabelionato de Notas local, devidamente registrada sob $\mathrm{n}^{\circ} 1.556$, fls. $248 \mathrm{v}^{\circ}$ livro $3 \mathrm{~A}$, em 24/01/1961, no RGI local.

ANTONIO PEREIRA DOS SANTOS, adquiriu 3.194 has., do Estado de Mato Grosso, conforme Titulo Definitivo expedido pelo Departamento de Terras e Colonização, em 07 de Maio de 1947, devidamente registrado sob no

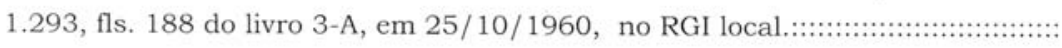

O referido é verdade e dou fé.

Rondonópolis-MT, 30 de Março de 2007.

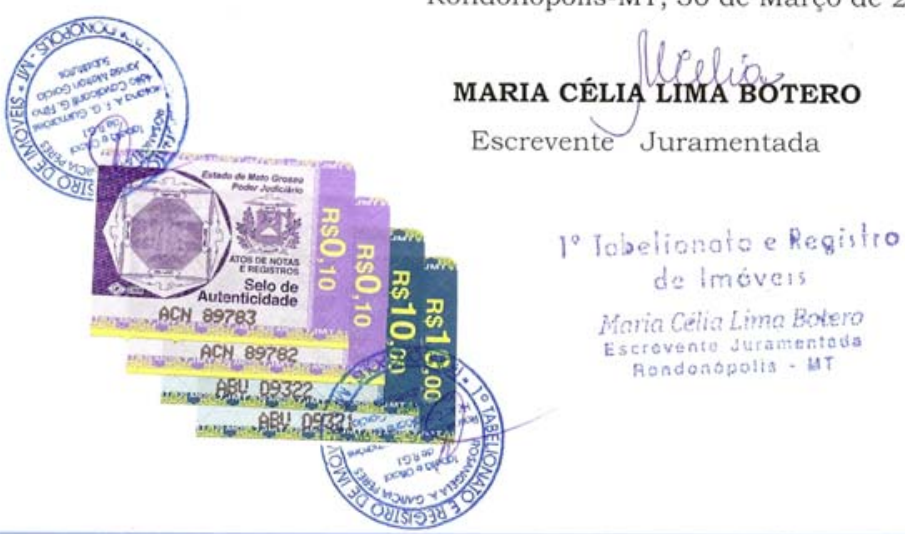


Planta 01- do Lote ALDEINHA - $406 \mathrm{Ha}$ - Ildefonso Bernardino de Oliveira

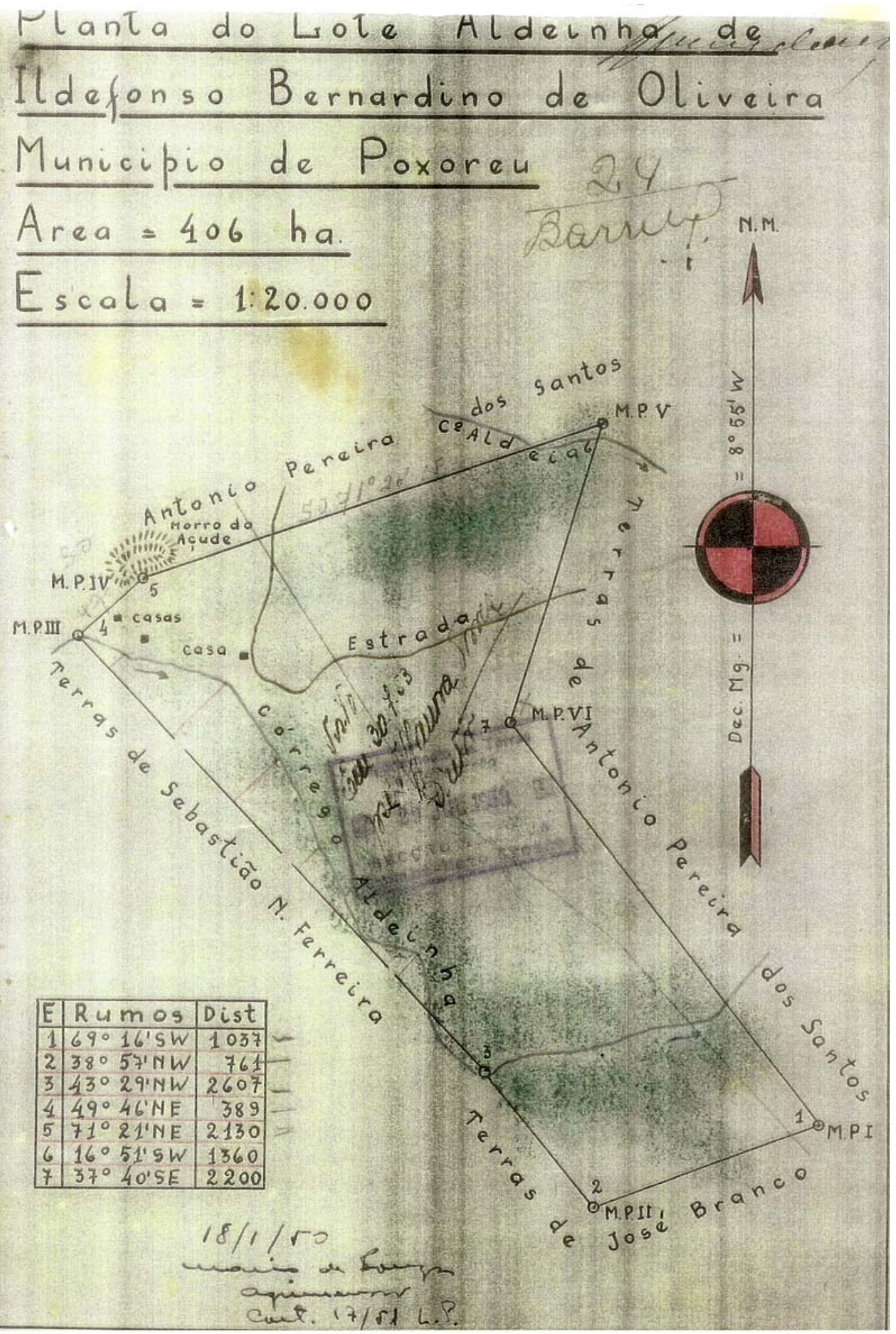




\section{CERTIDÃO 02- Lote ALDEINHA - $406 \mathrm{Ha}$ - Ildefonso Bernardino de Oliveira}

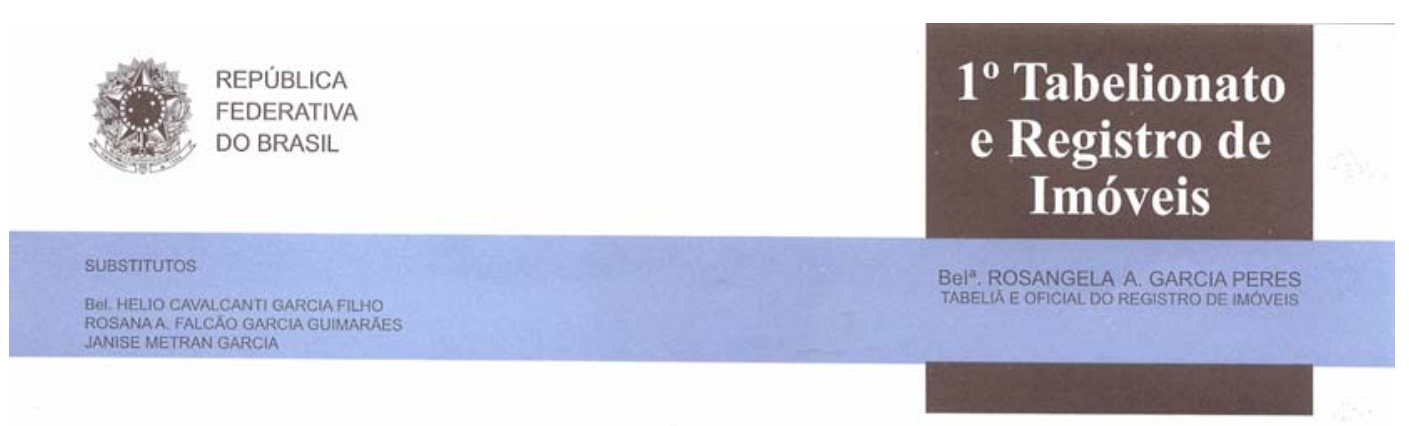

C E R T I D Ã O

Certifico a pedido verbal de parte interessada que revendo nesta Serventia Registral os livros de Registro Geral, verifiquei que o Sr IDELFONSO BERNARDINO DE OLIVEIRA, adquiriu um lote de terras pastais e lavradias denominado "Aldeinha", com 48,40 has, na zona rural deste Municipio, que adquiriu por compra feita de Maria Gomes de Jesus Ferreira, conforme Escritura de 19 de Outubro de 1965, ás fls. 99/100 do livro 37, do $2^{\circ}$ Tabelionato de Notas local, devidamente registrada sob $\mathrm{n}^{\circ} 8.884$, fls. 191 do livro 3-H, em 20/10/1965, no RGI local.::

MARIA GOMES DE JESUS FERREIRA, por ser casada com SEBASTIÃO NUNES FERREIRA, adquiriram 858 has., do Estado de Mato Grosso, conforme Titulo Definitivo expedido pelo Departamento de Terras e Colonização, em 24 de Julho de 1954, devidamente registrado sob no 122, fls. 18 do livro 3-A, em 14/07/1959; posterior Escritura Certidão de Adjudicação de 712,80 has., em 29 de Março de 1962, devidamente registrada sob n 3.359 , fls. 137 do livro 3-C, em 03/05/1962, no RGI local.

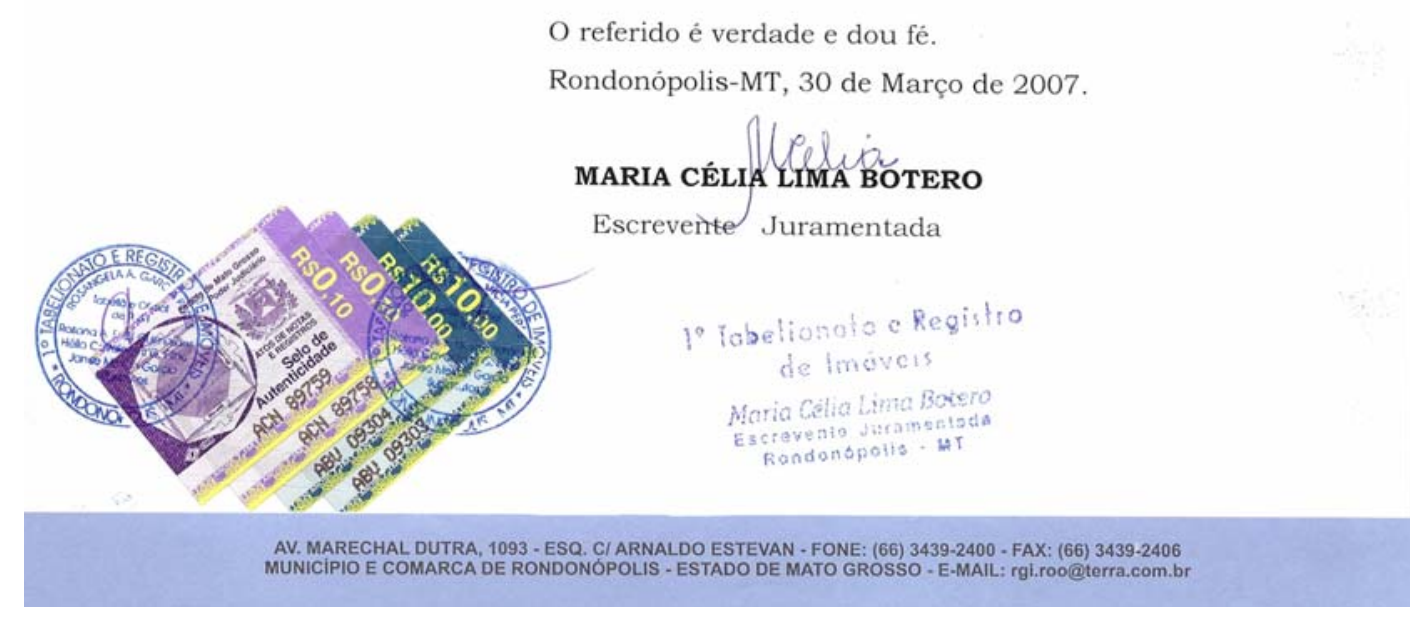




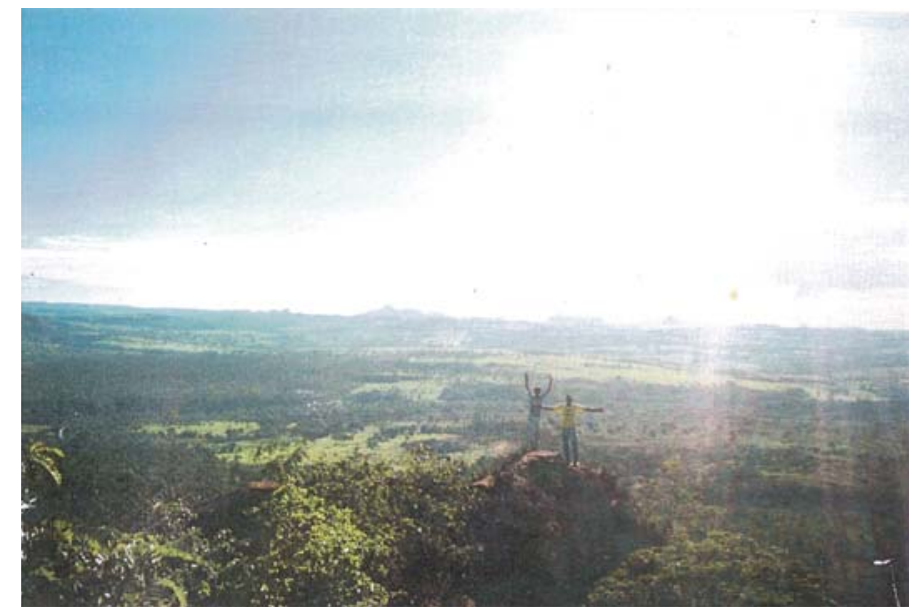

Foto 04 - Morro da Cotia Sítio Três Marias. (Foto Milton Jorge/2002).

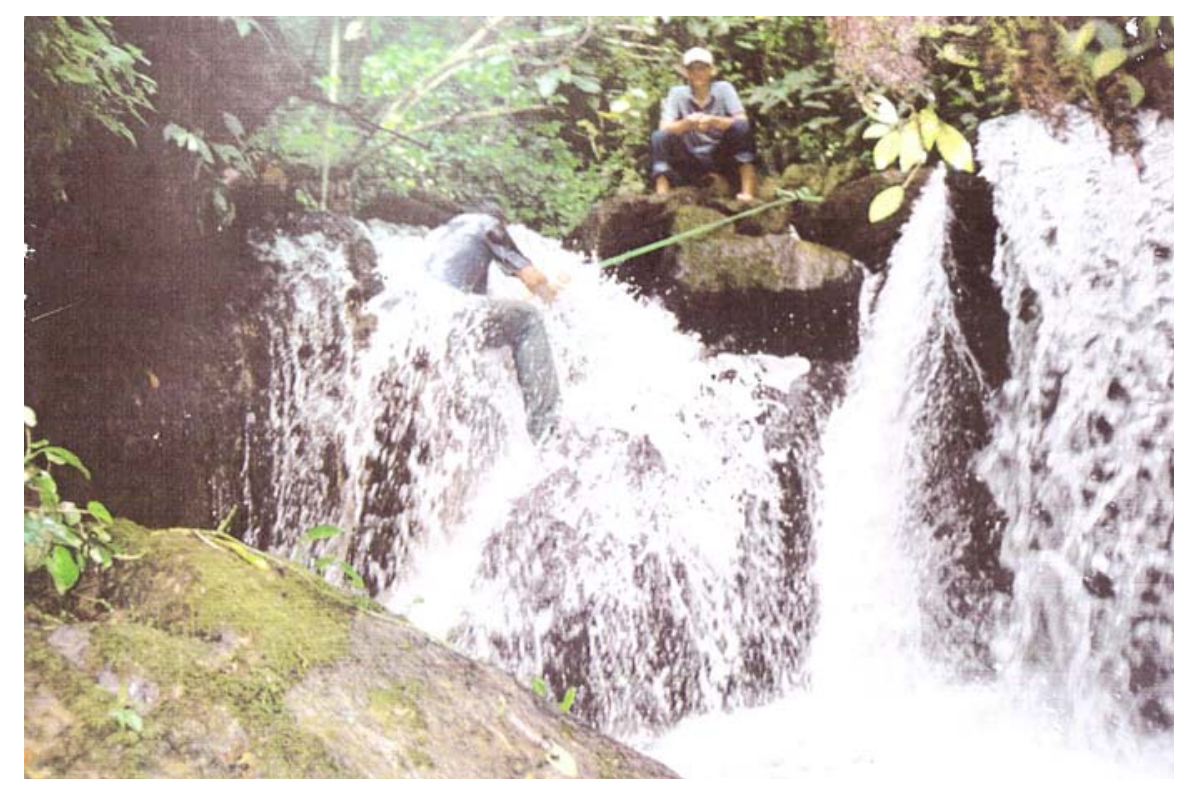

Foto 05 - Cachoeira no córrego Mamona - Sítio Três Marias e Sítio Mamona. (Foto Milton Jorge/2002). 


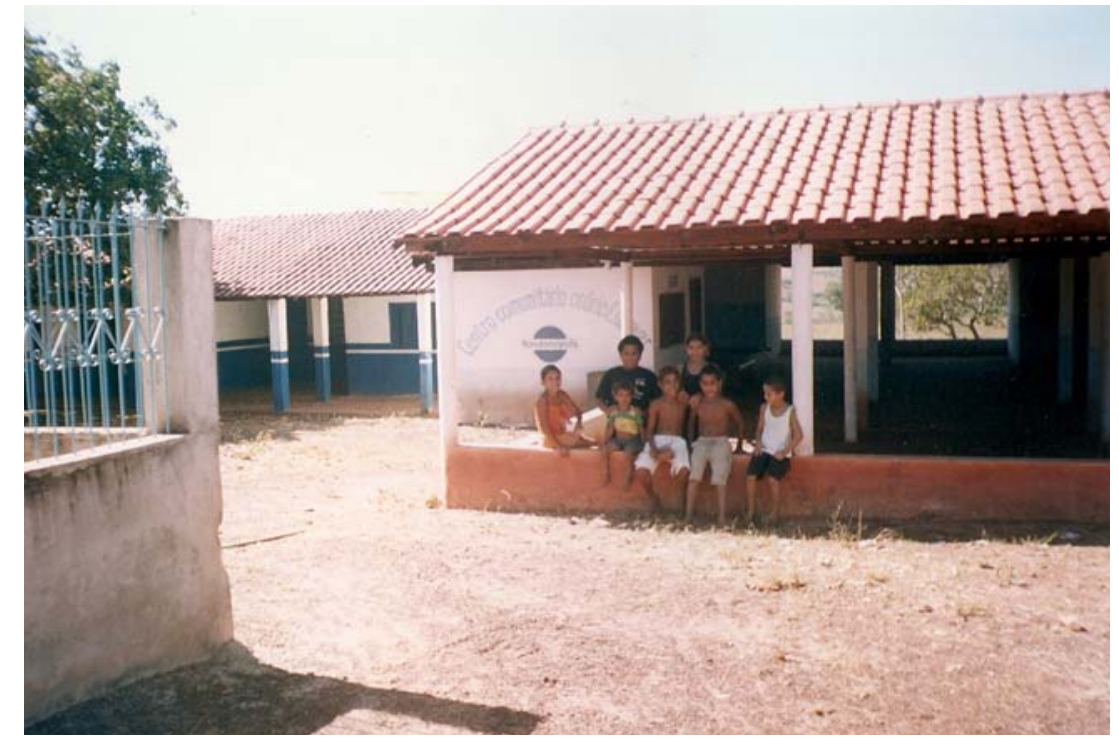

Foto 06 - Centro Comunitário Osório de Freitas Nunes - Associação e Salão de festas. (LIMA, LMS//2005).

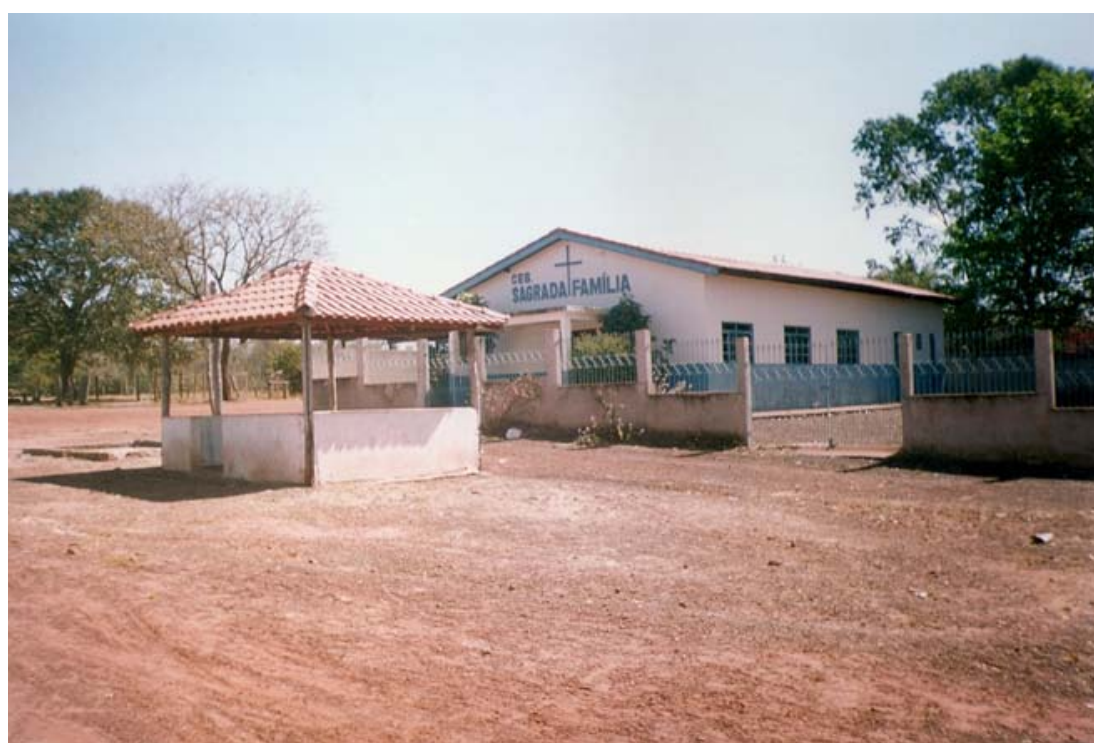

Foto 07- CEB Sagrada Família - Igreja. (LIMA, LMS//2005).

Daniel Bernardino de Oliveira, casado com Essiene Pereira Oliveira desde 1967, recebeu de doação de seus pais, em 1978, o Lote 1 (Planta 02), desmembrado do Lote Aldeinha com 108,62 ha e mais 48,40 ha desmembrados da Fazenda de Sebastião Nunes Ferreira, perfazendo o total de 157,02 ha, que, após doação, passou a chamar-se Fazenda Aldeinha. Recebeu de doação 140,08 ha e comprou 16,94 ha de duas irmãs.

Daniel e Essiene têm dois filhos: Adriana e Daniel Filho, ambos casados. A Adriana tem duas filhas: Maira e Tâmara e mora no Assentamento Santo Expedito em Juscimeira/MT. Daniel Filho mora em Pedra Preta (MT), tem um casal de filhos, 
Murilo e Fernanda, e quase todo final de semana está na fazenda do pai e no Assentamento Chico Mendes, onde moram os familiares de sua esposa Sueli.

Em relação à Fazenda Aldeinha, Daniel e Essiene relataram o seguinte:

Mudamos para cá em 1967 quando casamos. A casa era um barraco próximo ao córrego, era aconchegante e até hoje eu tenho muita saudade. Lá nasceu minha primeira filha que infelizmente morreu. Em 69, construímos essa casa aqui, (mostrou ela) no início era só de pau a pique depois fomos colocando adobe. Passado uns tempos, construímos esta casa (Foto 08) e passamos para cá. Temos também o córrego Aldeinha. Luz elétrica, televisão, telefone celular com antena, água encanada que vem da mina pela força da gravidade, para abastecer a casa, não temos carro, esse aí é do filho, a gente usa o trator que acaba sendo nosso meio de locomoção por aqui.

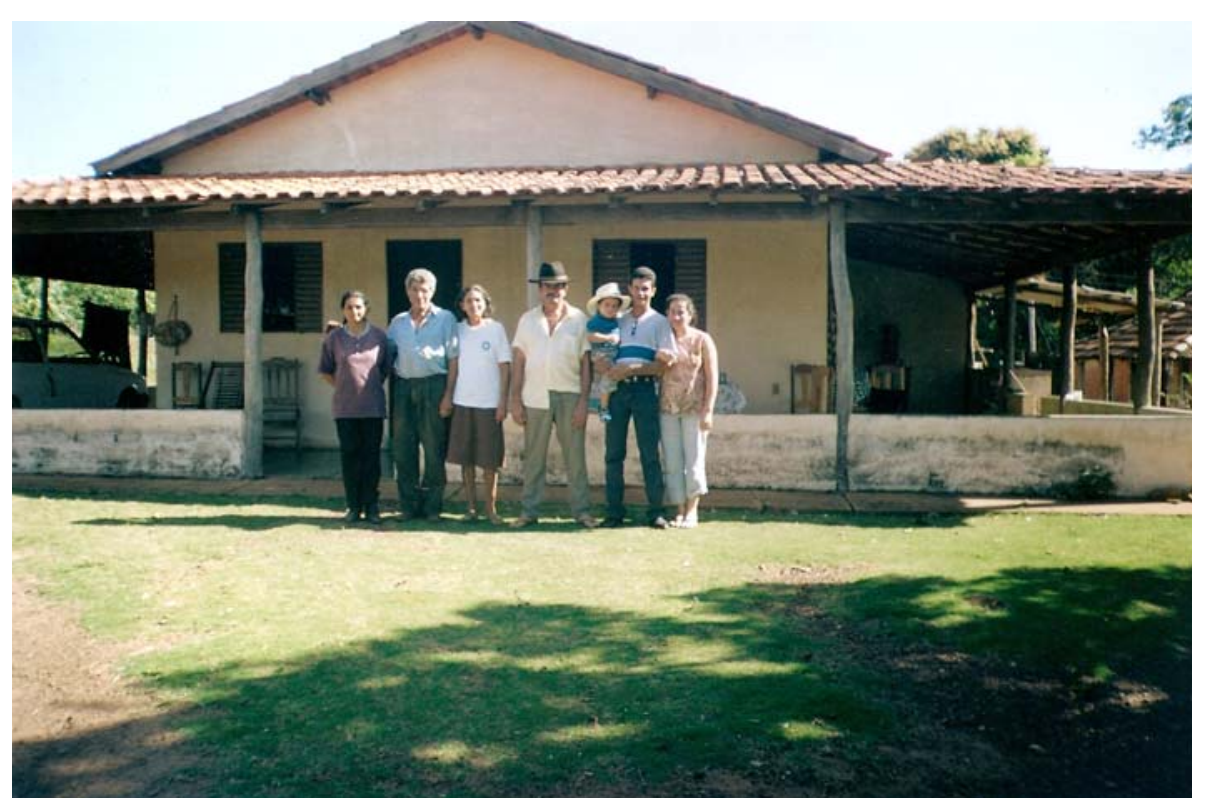

Foto 08 - Sede da Fazenda Aldeinha. Eliete, Daniel, Essiene, Zé Riola, Danielzinho, Murilo e Sueli. (LIMA, LMS//2004) 
Através dessa fala, é possível visualizar como a família de Daniel vivenciou os primeiros anos na propriedade. Mesmo passado por dificuldades no início, em se tratando da casa em que morava, é possível perceber pelo relato de Essiene e pela foto que houve progresso.

Em entrevista, Daniel e Essiene falaram sobre as atividades agropecuárias desenvolvidas na propriedade e o destino da produção:

Criamos porcos e galinhas somente para o nosso consumo, assim como as frutas e as hortaliças do quintal. O gado é pouco, o leite que tiramos, mais ou menos 50 litros diários é vendido para o Laticínio Nutribom de Rondonópolis. Essiene lembrou-se de que: Também plantamos mandioca, tem cana-de-açúcar, não se esquecendo da rocinha de milho, pois eu sou louca por pamonha, mas o forte é o leite. Vivemos somente com a renda da fazenda.

O Sr. Daniel deposita o leite no resfriador do Laticínio Nutribom (1.000 litros) que fica na propriedade de sua irmã Eliete. O gado que possui recebe todas as doses de vacinas recomendadas e toda atividade é realizada por ele e Essiene. Não praticam queimadas e para não prejudicar o meio ambiente, contratou um engenheiro para fazer a regularização da fazenda (Mapa V), destacando as áreas de reserva legal e preservação permanente, bem como a área remanescente para exploração.

Quanto à política agrícola do governo federal, estadual e municipal, Daniel relutou um pouco e comentou que: "Eu não sei nem explicar pra senhora, mas aos trancos e barranco vai indo. Se bem que já recebi ajuda do PRONAF para formar pasto, comprei triturador e construí a casa".

Daniel acha viável fazer a divisão da terra com os filhos antes da morte, pois evita aborrecimentos e gastos posteriores, mas não tem pretensão de fazê-lo por enquanto, pois ele e Essiene ainda estão novos, a não ser que fosse com usufruto. Daniel Filho comenta que, quando o pai fizer a divisão da terra, ele irá assumir sua parte e mudar-se novamente para o campo. 
PLANTA 02 - PLANTA DO LOTE 1 DESMEMBRADO DO LOTE ALDEINHA FAZENDA ALDEINHA

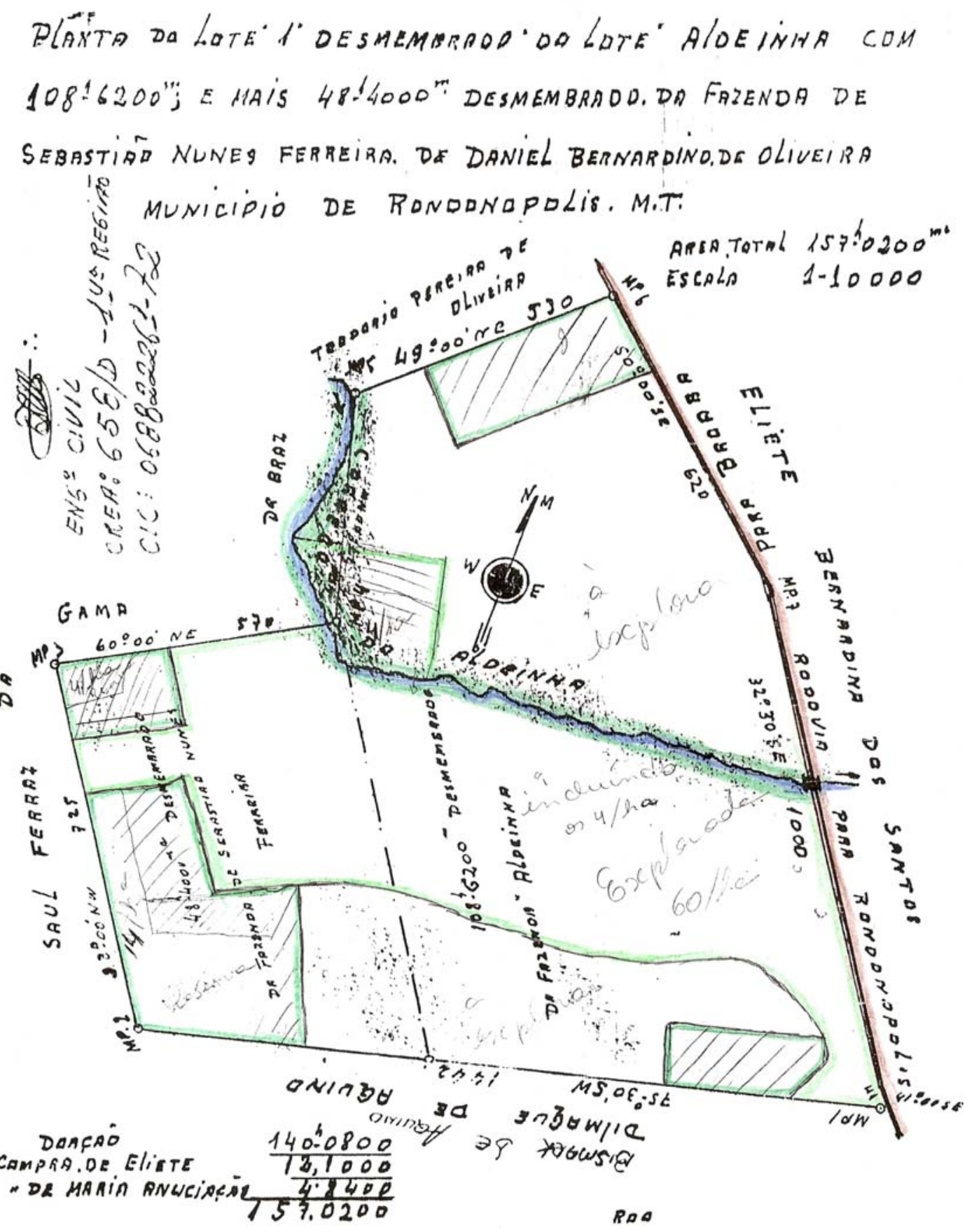


MAPA V - FAZENDA ALDEINHA

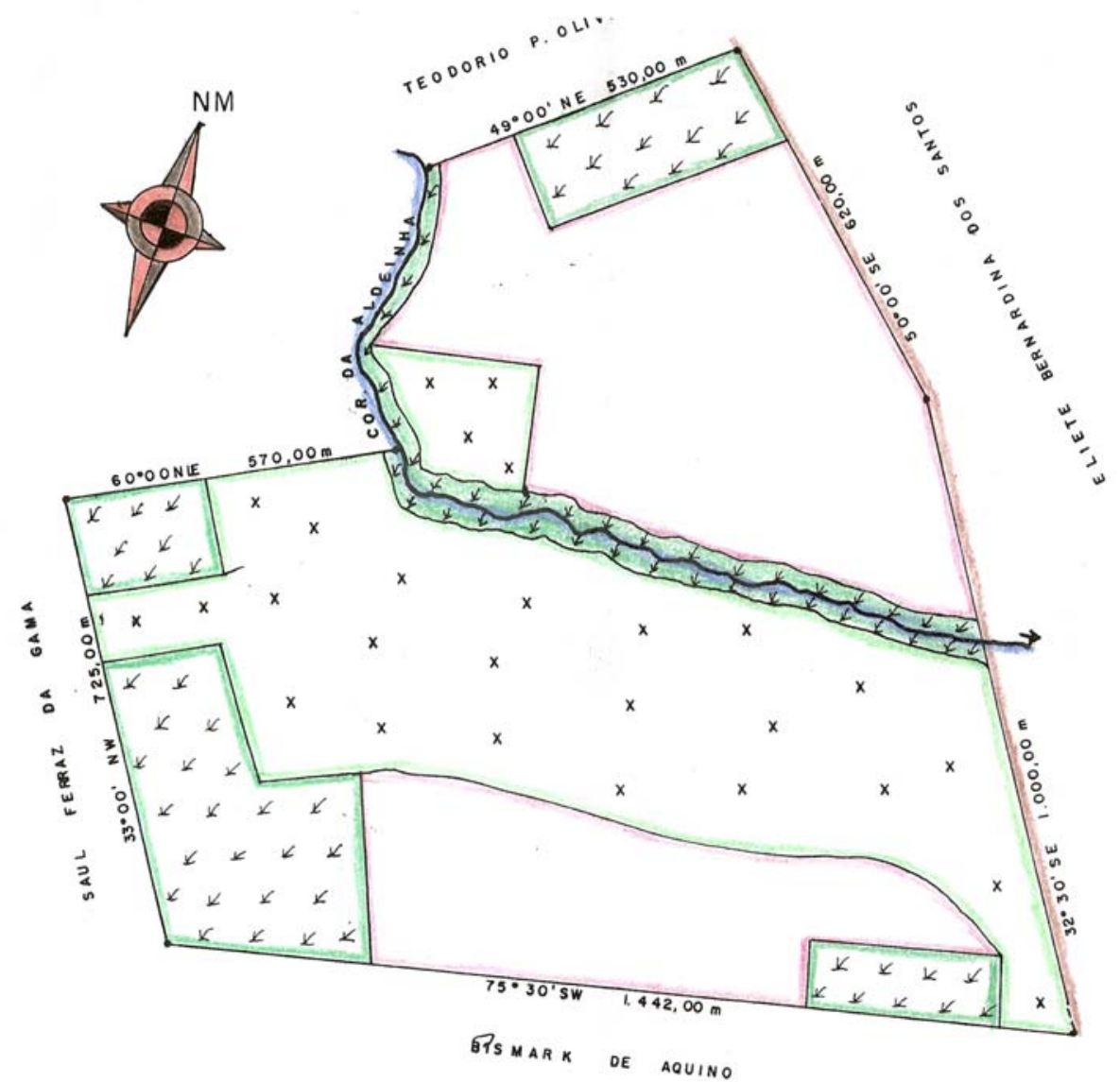

$L E G E N D A$

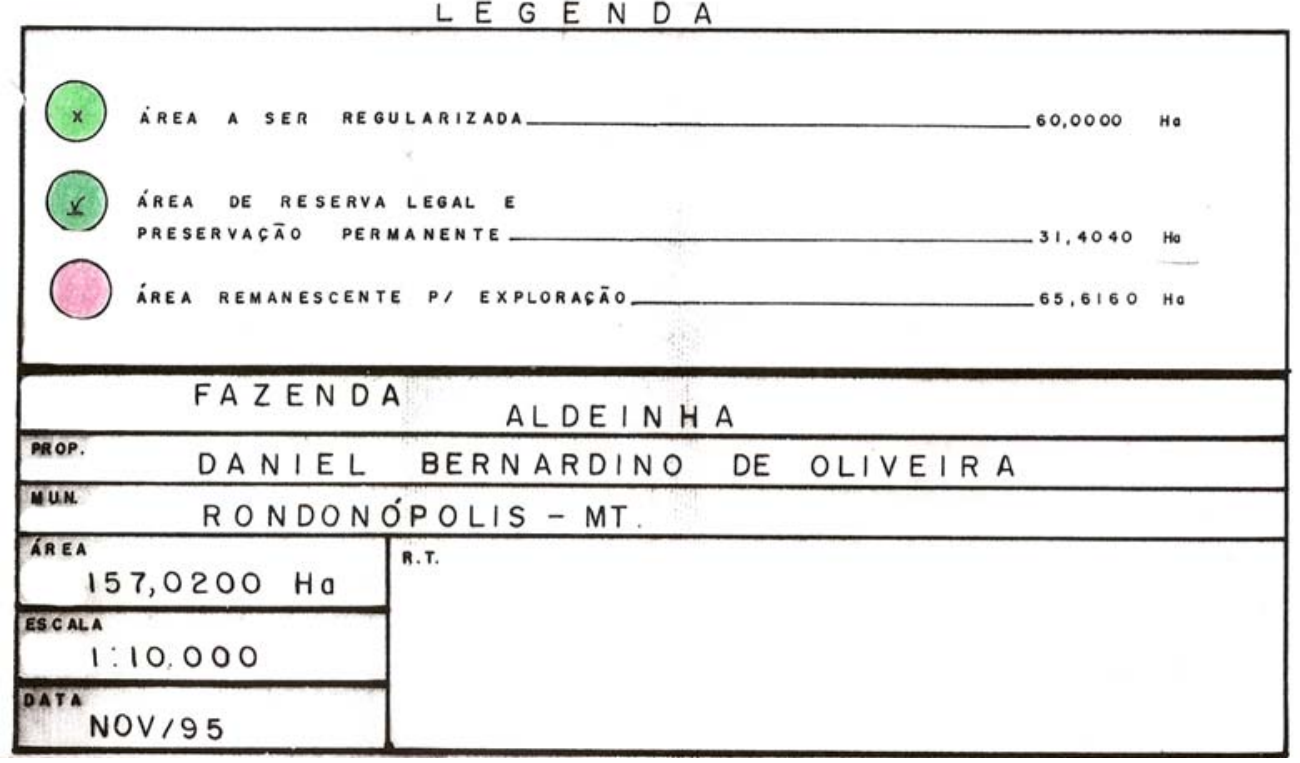


Teodoro Pereira de Oliveira, casado com Marlene Bambil de Oliveira desde 1971, recebeu o Lote No. 2, desmembrado do Lote Aldeinha - Sítio Santa Adriana cuja área era correspondente a 140,08 ha. Nesse mesmo período, comprou de seus irmãos Gomercindo, Pedro, Maurino, Elizete, Silvio e Rita, a área equivalente a 29,04 ha, sendo 4,84 ha de cada um. Assim ficou com uma propriedade de 169,12 ha (Planta 03), que recebeu o nome de Sítio Santa Adriana.

Por ser funcionário de um Banco, Teodoro migrou várias vezes, o que o fez morar fora do sítio, até se aposentar em 1999. Seu filho Teodoro Júnior ${ }^{180}$ mora nos Estados Unidos há seis anos, onde trabalha. Os outros filhos moram na cidade em Rondonópolis. A Adriana Paula já é casada e tem três filhos: duas meninas e um menino. O Joedilson ainda é solteiro.

Não faz parte de Associação e nem é filiado ao Sindicato dos Trabalhadores Rurais. Vive da renda do sítio e de sua aposentadoria. No momento não estão desenvolvendo nenhum projeto na propriedade. O sítio fica bem próximo à Rodovia MT 460 (Ver Mapa XX- Croqui de Localização, p: 248). Tem duas casas de alvenaria, uma próxima à outra. Atualmente, moram na casa grande (Foto 09), bem ampla, bastante arejada, toda de cerâmica, quartos com ar condicionado.

Em entrevista, Teodoro nos informou que:

Aqui, temos água encanada da mina. O córrego Aldeinha nasce na serra aqui no fundo, onde está a Antena da Embratel. O sítio está na cabeceira do rio. A luz elétrica foi feita por conta própria. Como meio de transporte tenho uma camionete, temos também um trator para trabalhar na propriedade. Em termos de comunicação temos um celular com antena, temos televisão colorida. Em relação ao lazer, sou muito caseiro, quase não saio.

É notável que Teodoro seja o oposto daquele camponês bucólico que existia antigamente, descrito por Antônio Cândido, por Moura, Queiroz, entre outros. O estilo de vida é diferente dos demais irmãos, fato que associo ao longo período que passou migrando por muitas cidades, apesar de hoje viver no campo. Mas, o conhecimento necessário adquirido ao longo do tempo, juntamente com o pai e demais irmãos, não ficou esquecido. Isso me faz reportar Bombardi (2004:158) que disse:

O processo de passagem do conhecimento é feito ao longo de toda uma vida; desde criança o menino vai aprendendo as técnicas

\footnotetext{
${ }^{180}$ De acordo com Elizete e dona Leonila, o Júnior casou-se lá com uma brasileira/paulista, que já faz oito anos que mora lá.
} 
necessárias para o cultivo, as maneiras de lidar com o meio natural e o saber sobre a natureza no próprio processo de trabalho. Além disso tudo, o pai também ensina ao filho como lidar com o mundo exterior à unidade familiar.

Na fala a seguir, Teodoro expõe o tipo de atividade que desenvolve em sua propriedade e quais os cultivos lá existentes:

Em se tratando de pecuária, recrio e engordo gado, compro para engordar. O leite é para uso. Agricultura de subsistência. Temos alguns pés de frutas no quintal, como coco, jabuticabeira, acerola, ingá de metro, jaca, etc. criamos porcos e galinhas para o gasto.

Não é adepto ao sistema de queimadas, até porque seu pai não utilizava essa prática. Reclamou que ultimamente tem aparecido "um percevejo que dá na raiz do capim, que inclusive os técnicos da EMPAER vão fazer uma palestra para falar sobre o mesmo, para sabermos como combatê-lo. Fora isso, não tem problema". Diz acreditar na política governamental em prol dos agricultores: "Eu ponho fé, porque o INCRA está desapropriando terra e por isso eu acredito". Em se tratando da doação aos descendentes, comentou o seguinte: "É bom, é viável, pois é uma prática que vem desde meu avô. E com certeza daremos continuidade".

Será feita a seguir a exposição de fotos e a Planta do Sítio Santa Adriana.

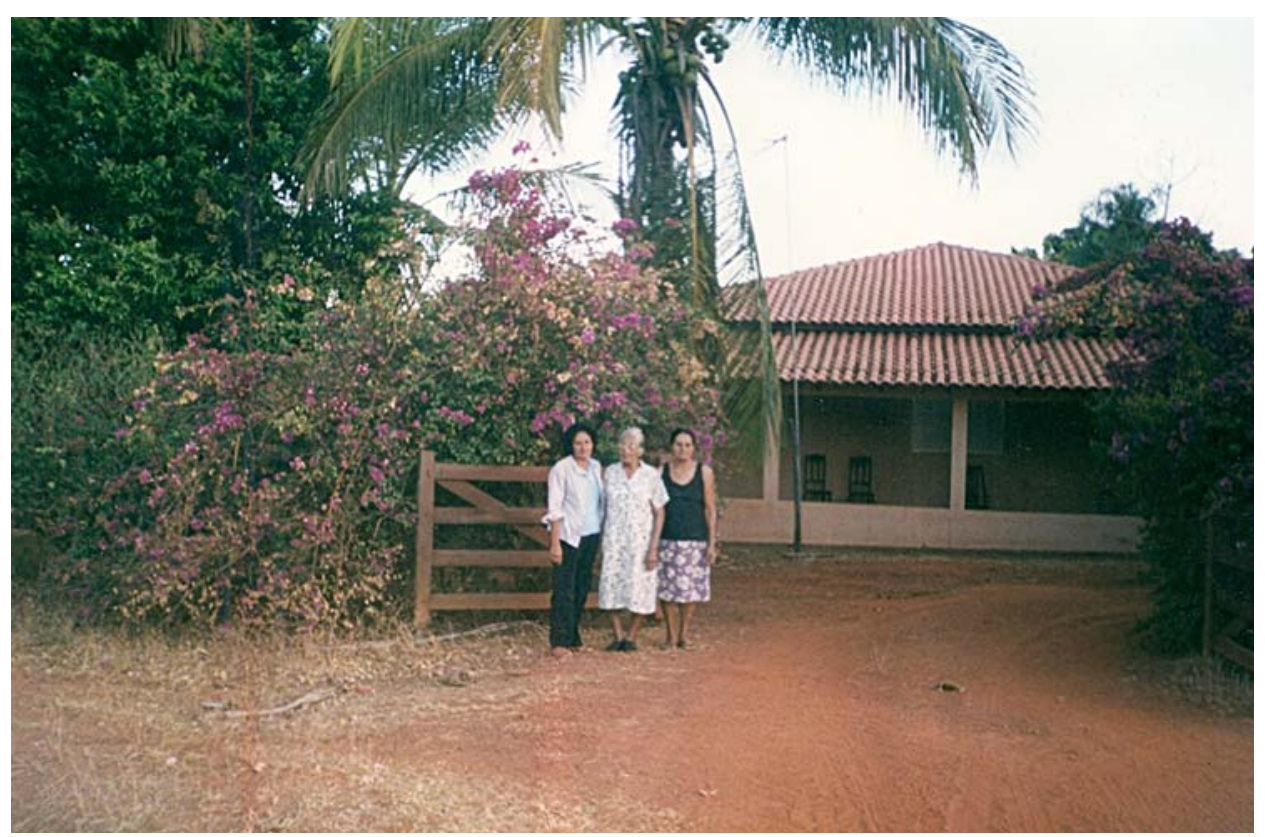


PLANTA 03 - PLANTA DO LOTE 2 DESMEMBRADO DO LOTE ALDEINHA - SÍTIO SANTA ADRIANA

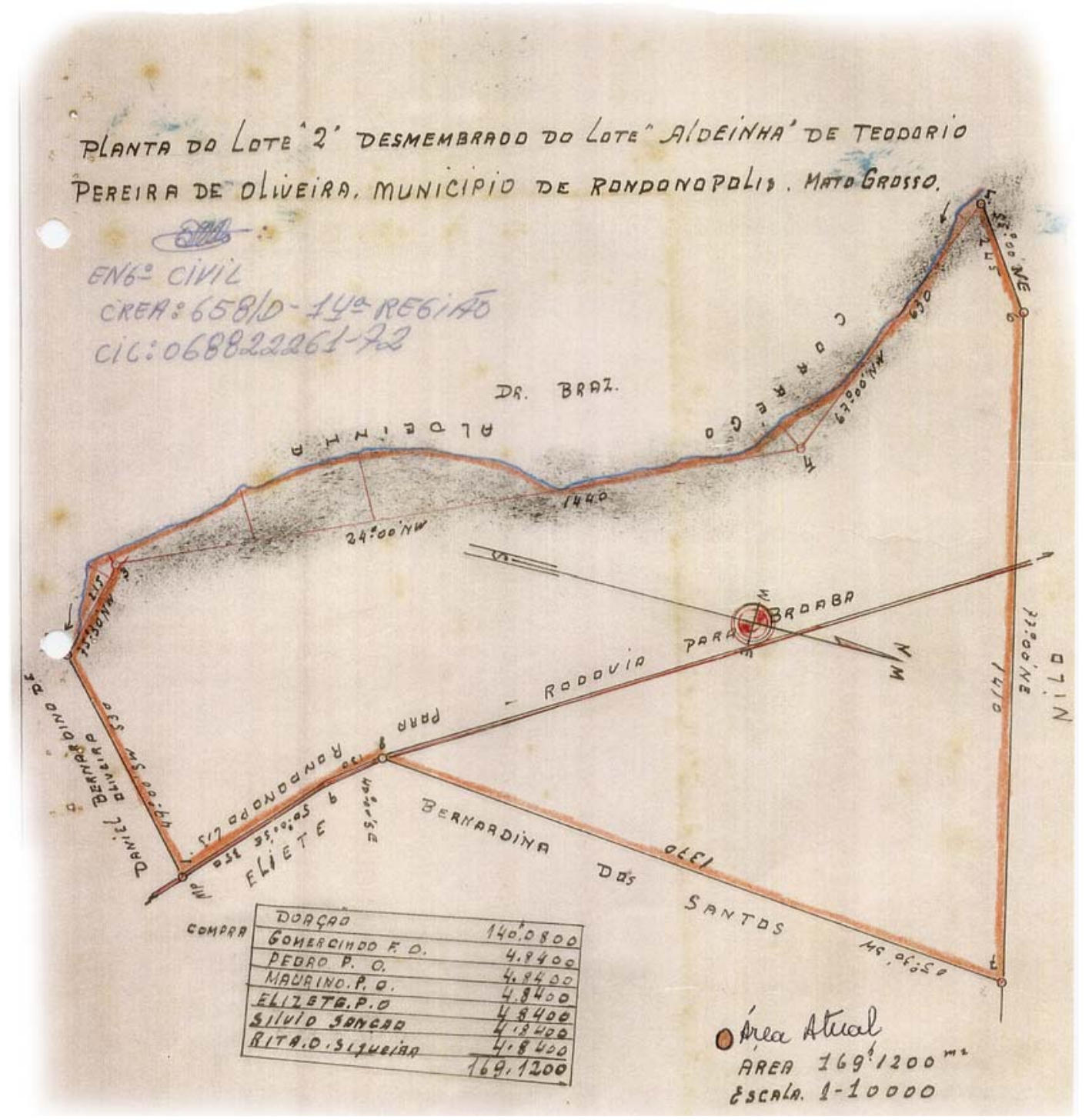


Eliete Bernardino dos Santos casou-se aos 15 anos com o senhor Francisco Lopes dos Santos em 1.950 e, com o consentimento de seus pais Ildefonso e Leonila, construíram uma casa (Foto 10) ao longo da Rodovia MT 460, onde nasceram seus dez filhos (dois são falecidos). Como a prole era grande e a renda do sítio era pouca, migravam constantemente para fazendas de terceiros a fim de trabalharem como caseiros e sustentarem a família. Durante o período em que moravam fora, o sítio ficava sozinho, garantindo-Ihes morada quando retornassem, ou seja, quando passasse o período de carência. Esse tipo de trabalho extra, essa migração pendular era realizado por vários moradores da região.

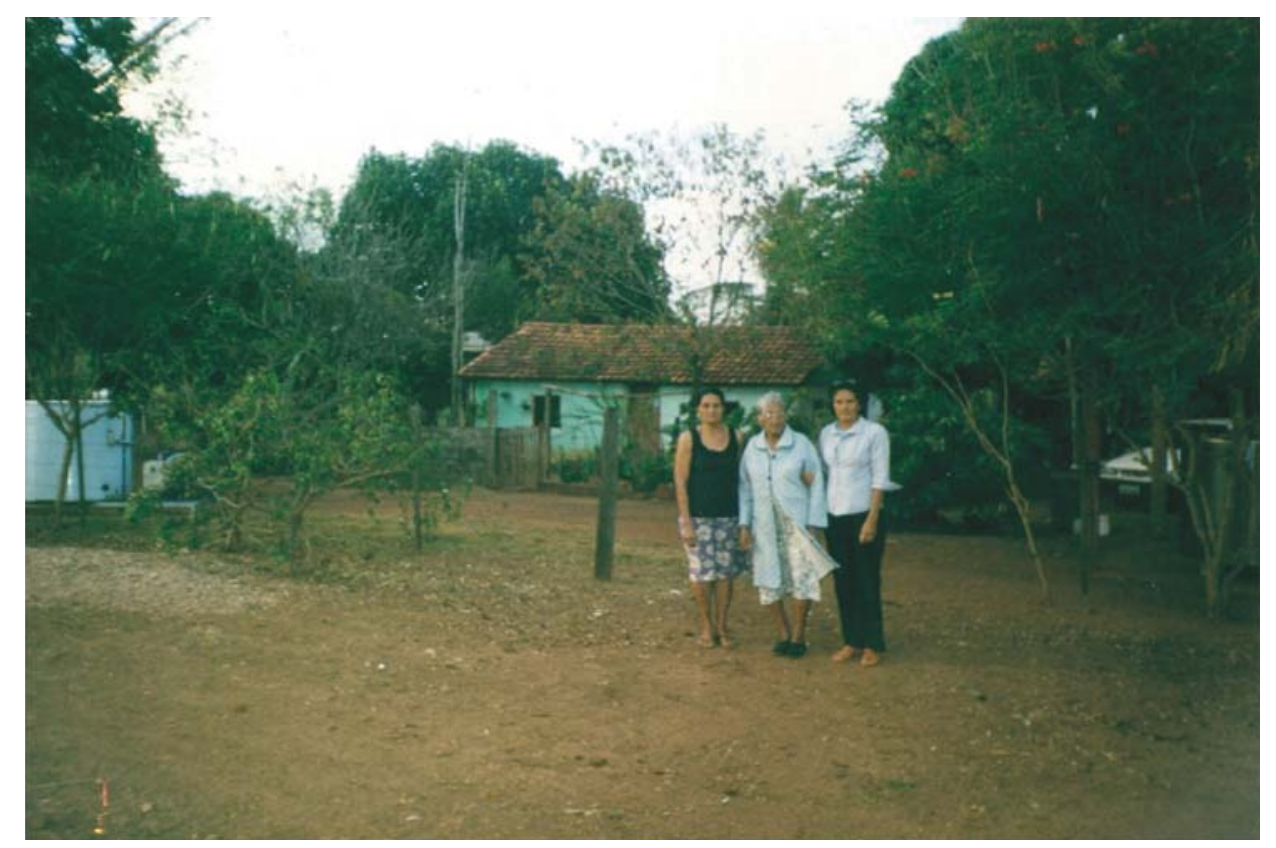

Fotos 10 - Sede do Sítio São Francisco. Eliete, D. Leonila e Elizete. No canto esquerdo da foto encontra-se o resfriador de leite da Nutribom. (LIMA, LMS//2005).

Em 1978, quando seus pais fizeram a doação da fazenda para os filhos, como já moravam nessa área,nela permaneceram. Sendo assim, recebeu como doação de seus pais o Lote 3 desmembrado do Lote Aldeinha com área de 127, 98 ha (Planta 04), que, após isso, passou a chamar-se Sítio São Francisco. 
PLANTA 04 - PLANTA DO LOTE 3 DESMEMBRADO DO LOTE ALDEINHA - SÍTIO SÃO FRANCISCO

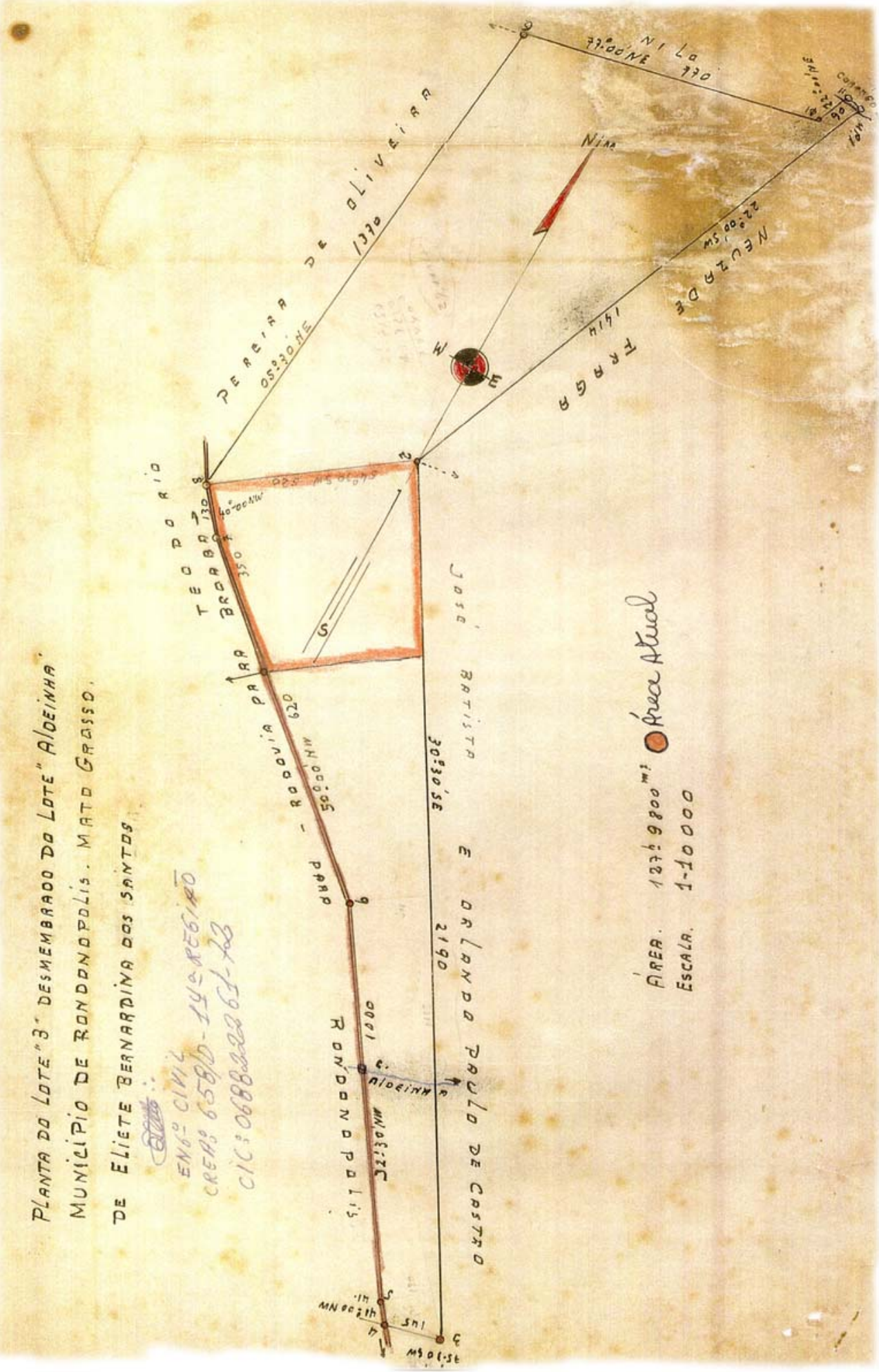


Eliete é viúva desde 1986 e em relação às atividades desenvolvidas no sítio, em entrevista, comentou que:

Aqui só praticamos agricultura de subsistência, somente para o nosso sustento. Criamos porcos e aves para o consumo, tem uma horta com alguns tipos de verduras, uns pés de frutas no quintal. Enquanto era mata a gente tocava lavoura de arroz e milho. Naquela época passava um caminhão para recolher os mantimentos, que eram vendidos pelo meu marido lá na cidade. A gente pagava o frete para eles levarem as sacas de produtos. Já tinha os compradores nos armazéns, era o senhor Homero Vilas Boas e o senhor João Borges. O leite que a gente tira é praticamente todo vendido para o Laticínio Nutribom, tiramos poucos litros diários, agora na época da seca diminuiu mais ainda. Meu neto que mora comigo é o tirador de leite. Esse resfriador de leite aí, (mostrou ela), é do Laticínio, cabe 1.000 litros de leite que é pego pelo caminhão dia sim dia não. Nele vai o nosso leite e dos vizinhos. Agora na seca são 10 litros nosso (vendido a $R \$ 0,30$ o litro) durante as águas da pra tirar uns 20 litros (ela riu, pois achou que eu havia entendido que eles colocavam água no leite), são 150 litros do Dr. Brás; 120 litros do Sr.Zanildo; 90 litros do Dr. Fernando Tenório e 50 litros de meu irmão Daniel. O Alessandro Henrique, meu neto, recolhia o leite dos sítios vizinhos no carro dele, um pampinha, para trazer até o resfriador. O laticínio pagava o frete para ele, mas como a produção caiu muito por conta da seca, o Zanildo traz o dele no carro, o Dr. Brás traz no trator, o Dr. Fernando Tenório comprou um burro e uma carroça para trazer o leite deles e o Daniel, meu irmão,também traz de trator. A energia, mais da metade também é paga pelo laticínio.

Escolhi essa longa fala porque traz elementos muito significativos para a realidade do camponês com baixa renda. O primeiro ponto a ser ressaltado é a questão da produção de subsistência e o trabalho familiar, pois ela e o neto realizam todas as atividades, sendo a principal a ordenha das vacas, onde aparece claramente a exploração do laticínio sobre o produtor, pois o leite que eles entregam a $\mathrm{R} \$ 0,30$ o litro, é vendido nos mercados por, no mínimo, $\mathrm{R} \$ 1,20$. Está evidente neste ato o enriquecimento em cima do trabalho alheio. É o capital se apropriando da renda do camponês, quando este passa a lidar com o mercado.

Percebe-se também, pela fala de Eliete, a presença do atravessador, o que acabava contribuindo para a redução de seus ganhos, pois para que o produto chegasse até aos mercados e dali para a mesa do consumidor, eles dispunham de parte dos lucros para o pagamento do frete. Sem contar que, em se tratando de uma propriedade pequena, a produção é pouca. 
A renda da família é obtida pela venda do leite, mais dois salários, a pensão de seu marido e o outro de aposentadoria. O dinheiro do leite fica para o Alessandro (neto). Além do sítio, Eliete tem uma casa na cidade, onde mora uma de suas filhas.

Em relação a dividir as terras com os filhos, Eliete mostrou-se muito preocupada, pois, desde que o marido faleceu, nunca fizeram o inventário e como a terra é pequena e os filhos são muitos, acha que não vai dar a medida exata para cada um, pois sabe que tem um limite a ser respeitado. Mesmo assim, comentou que:

Acho importante, pois foi uma prática herdada de meu avô materno e que meu pai copiou que foi dividir a terra com os filhos antes de falecer. O bom foi porque não teve briga. Não dividi ainda com meus filhos porque não tenho condições de fazer o inventário, sem contar que a terra é pouca e os herdeiros são muitos. Meu marido vendeu 28 alqueires para o doutor Brás; 03 alqueires para o Sr. Orlando de Castro que já faleceu, agora é dos filhos; 04 alqueires para o Dr. Tenório, sem contar que na época da doação ele vendeu 05 alqueires da parte da Aldeinha para meu irmão Daniel. Hoje, temos, eu e os filhos, somente 13 ha.

Em se tratando de infra-estrutura, Eliete comentou na entrevista as benfeitorias que já conseguiram para o sítio:

Aqui a gente tem luz elétrica, conseguimos por intermédio da Cooperativa CERGO - Cooperativa de Eletrificação Rural da Região da Grande Rondonópolis Ltda. A água é encanada e vem direto da mina, através da força da gravidade. Por incrível que pareça, em todos esses anos que moramos aqui, é a primeira vez que ficamos sem água. Meu neto está buscando água de carro, lá no sítio do Teodoro meu irmão a uns $2 \mathrm{Km}$. Vai dia sim dia não. Essa água é para os serviços da casa e tomar banho, o gado bebe água na represa. Estou bastante preocupada, pois nunca aconteceu isso antes. Temos aqui também o carro do meu neto, uma televisão colorida e um rádio. Meu neto tem telefone celular com antena.

A falta da água se justifica pela ausência de rios ou córregos em sua propriedade. Eliete comentou que a parte da propriedade onde existia o rio, seu marido vendeu para o Daniel seu irmão e o motivo das vendas de parte da propriedade foi justificado pela falta de recursos; então, para suprir as necessidades, os gastos por conta da família numerosa, foram vendendo as melhores partes do sítio.

Eliete foi beneficiada com o PRONAF cujo investimento foi aplicado na propriedade da seguinte maneira: 
Por intermédio do PRONAF, consegui um empréstimo em 2002 para comprar gado. Foram quatro vacas leiteiras. Paguei a $1^{a}$ parcela, restam três. Foram três anos de carência e cinco anos para pagar. Pagarei 1.150 reais por cada parcela. Como a renda é pouca e o gado é barato, tive que vender duas vacas das mais velhas para pagar a dívida. O projeto para a compra foi feito pela EMPAER.

Acredita que os programas, as políticas agrícolas de nossos governantes em prol aos camponeses, possam até ser bons, mas não dá para confiar, pois os financiamentos são caros e o risco de perder a terra é muito grande.

Eliete falou a respeito da família numerosa e que os filhos são todos casados. Quatro moram na cidade de Rondonópolis, um em Santa Bárbara D'Oeste (SP), um em Rio Verde (Goiás); o que morava e trabalha num sítio aqui perto, mudou-se para uma fazenda no Pantanal; uma outra mora no Sítio Boa Sorte, vizinho do Assentamento Chico Mendes, na mesma estrada que passa em frente ao sítio de Eliete.

Comentou conosco que, quando o seu filho Roberto casou, ficou morando na casa com eles até construir a casa dele no quintal do sítio. Moraram uns cinco anos, depois, por conta da escassa renda do sítio, resolveu mudar-se para a cidade. Com o tempo, comprou um terreno e construiu uma meia-água, que está melhorando aos pouco, pois todos trabalham. Hoje, quem mora na casinha no sítio é o sogro do Roberto, que alias tem duas filhas casadas com dois filhos de Eliete, o Roberto com a Conceição e o João com a Maria Vilacina (casal que mudou para o Pantanal).

Eliete e $D^{a}$. Leonila relembraram o período em que elas engravidavam ao mesmo tempo. Uma amamentava o filho da outra. Era irmã, avó e mãe de leite ao mesmo tempo. Portanto, alguns de seus filhos têm a mesma idade que os tios e cresceram todos juntos. Essa prática de aleitamento era comum em tempos idos, principalmente em família numerosa. O respeito dos irmãos em relação à Eliete, em parte, deve-se ao fato desse aleitamento, pois, além de irmã mais velha, é mãe de leite.

Eliete casou-se muito cedo, teve dez filhos, sendo que dois deles falecidos; hoje tem oito filhos, dezenove netos e dez bisnetos. Diz ser tanta gente que tentou lembrar o nome de todos, mas não conseguiu, principalmente, dos bisnetos. 
Gumercindo Fabiano de Oliveira é casado com Orminda Prata Sales Oliveira desde 1981. Dessa união nasceram dois filhos: o Alberto que mora em Rondonópolis e o Fabiano que é sargento militar em Cuiabá, e tem filhos gêmeos.

Orminda, a esposa, é pedagoga, trabalha com alunos do Ensino Fundamental na escola Municipal Rural 14 de Agosto no Assentamento Chico Mendes, para onde vai,na maioria das vezes, de ônibus escolar. Durante muito tempo lecionou na cidade; portanto, não morava na fazenda. Após conseguir esta vaga na escola rural, voltou a viver no campo.

Gumercindo recebeu de doação de seus pais o Lote 1, desmembrado da Fazenda Campo Alegre no município de Rondonópolis, cuja extensão era de 135,24 ha (Planta 05); em seguida, vendeu para seu irmão Teodoro uma área equivalente a 4,84 ha, que não está inclusa nesta planta.

Em janeiro de 1987, nove anos após receber a doação, Gumercindo vendeu 67, 76 ha, local onde estava a sede da antiga fazenda, ficando com uma propriedade de 62,64 ha, denominada Fazenda Campo Alegre (Mapa VI), desde o período em que recebeu a doação.

Nessa fala, Gumercindo opina sobre a doação de terra feita por seu avô e seu pai e expõe suas intenções em relação a sua propriedade.

Foi ótimo o que meu avô e meu pai fizeram, dividir com os filhos. Por enquanto ainda não dividi, só vendi, mas no momento não tenho intenção de vender mais. É para os filhos, só que vai depender do interesse deles. Eu tenho 65 anos, portanto, têm 65 que moro na região, pois nasci e cresci aqui, na parte onde ficava a sede, onde todos os meus irmãos nasceram. Lá eu vendi 30 alqueires. Agora aqui nesta parte, ou seja, onde eu fiz minha sede já tem 29 anos que eu moro.

Em relação às atividades econômicas da fazenda, em entrevista, Gumercindo relatou que:

Tudo o que produzimos aqui é para o consumo. Temos umas vacas de leite e umas galinhas, uma horta no fundo do quintal, um pomar com várias frutas. Compro ração para o gado na época da seca, compro também o sal mineral para o gado. Aliás, na cidade a gente compra tudo o que não produz aqui.

Gumercindo também não é adepto à prática de queimada, e faz questão de preservar o ambiente "Não faço queimada, preservo as nascentes, as cabeceiras dos rios, deixei 11 ha só de reserva". $E$, em se tratando de políticas públicas em prol dos agricultores, mostrou-se desanimado. "Do jeito que está não tem como acreditar mais nesse 
povo. Só se vê passar na televisão confusão deles. Acaba em nada e logo vem pedir voto novamente".

Sobre a infra-estrutura da fazenda, teceu o seguinte comentário:

Aqui a gente tem água encanada que vem da mina por força da gravidade, é uma grota. A casa é boa, bem arejada (Foto 11). Tem luz elétrica, onde eu fiz particular o rebaixamento, agora a CEMAT requereu a rede pra ela. Temos um celular com antena, uma televisão colorida com antena parabólica, a gente tem carro e se precisar de médico vamos até a cidade.

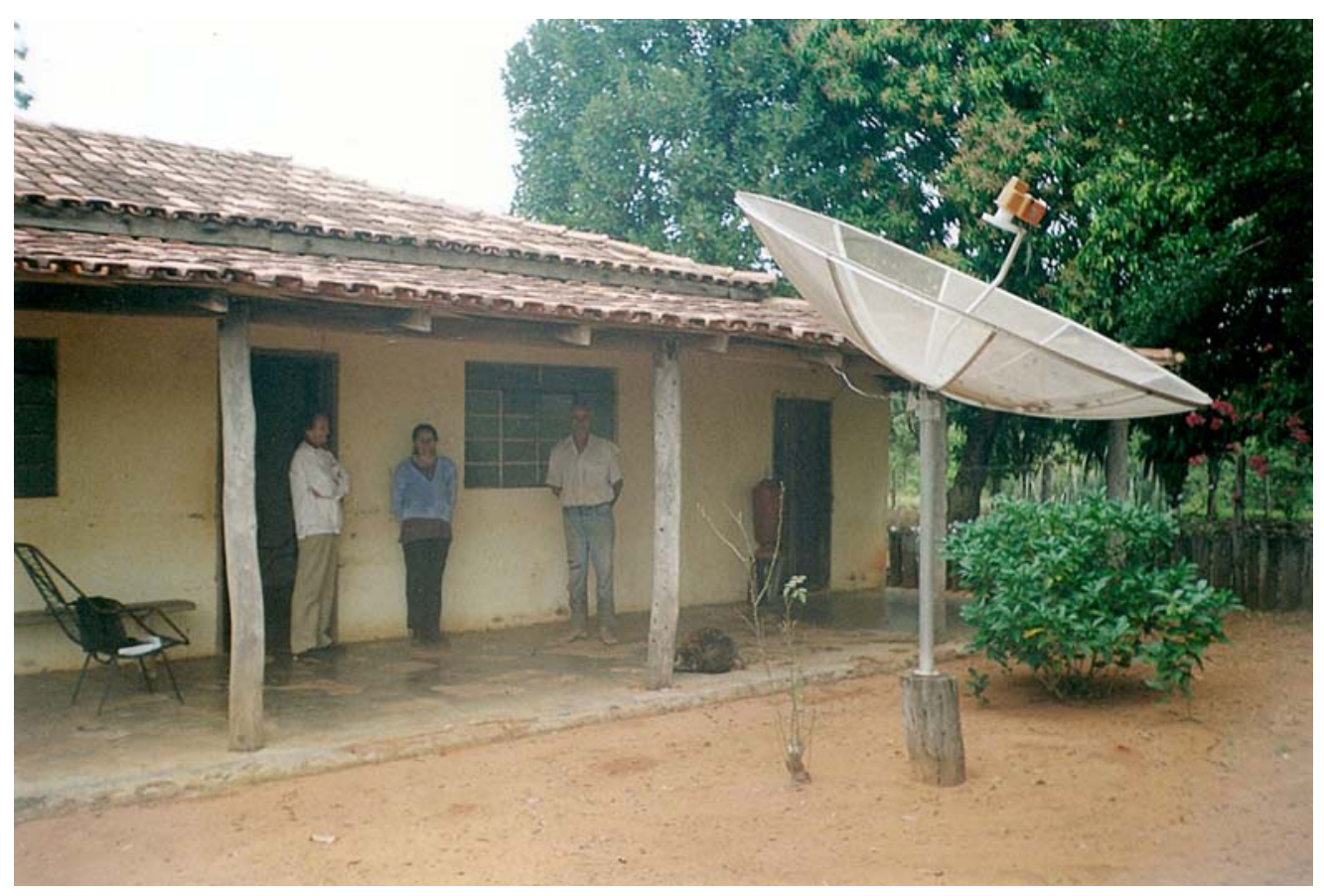

Foto 11 - Sede da Fazenda Campo Alegre. Orminda, Eliete e Gumercindo. (LIMA, LMS//2004).

Pelas falas transcritas anteriormente e pela foto acima, nota-se que o padrão da casa é revelador de uma situação econômica positiva, em geral mais ampla e confortável. E que a preocupação de Gumercindo, em relação à divisão da propriedade, deve-se ao fato de os filhos morarem na cidade,e pode não ser um atrativo para eles manter o patrimônio que tem quase um século com a família. 
PLANTA 05 - PLANTA DO LOTE 1 DESMEMBRADO DA FAZENDA CAMPO ALEGRE - FAZENDA CAMPO ALEGRE

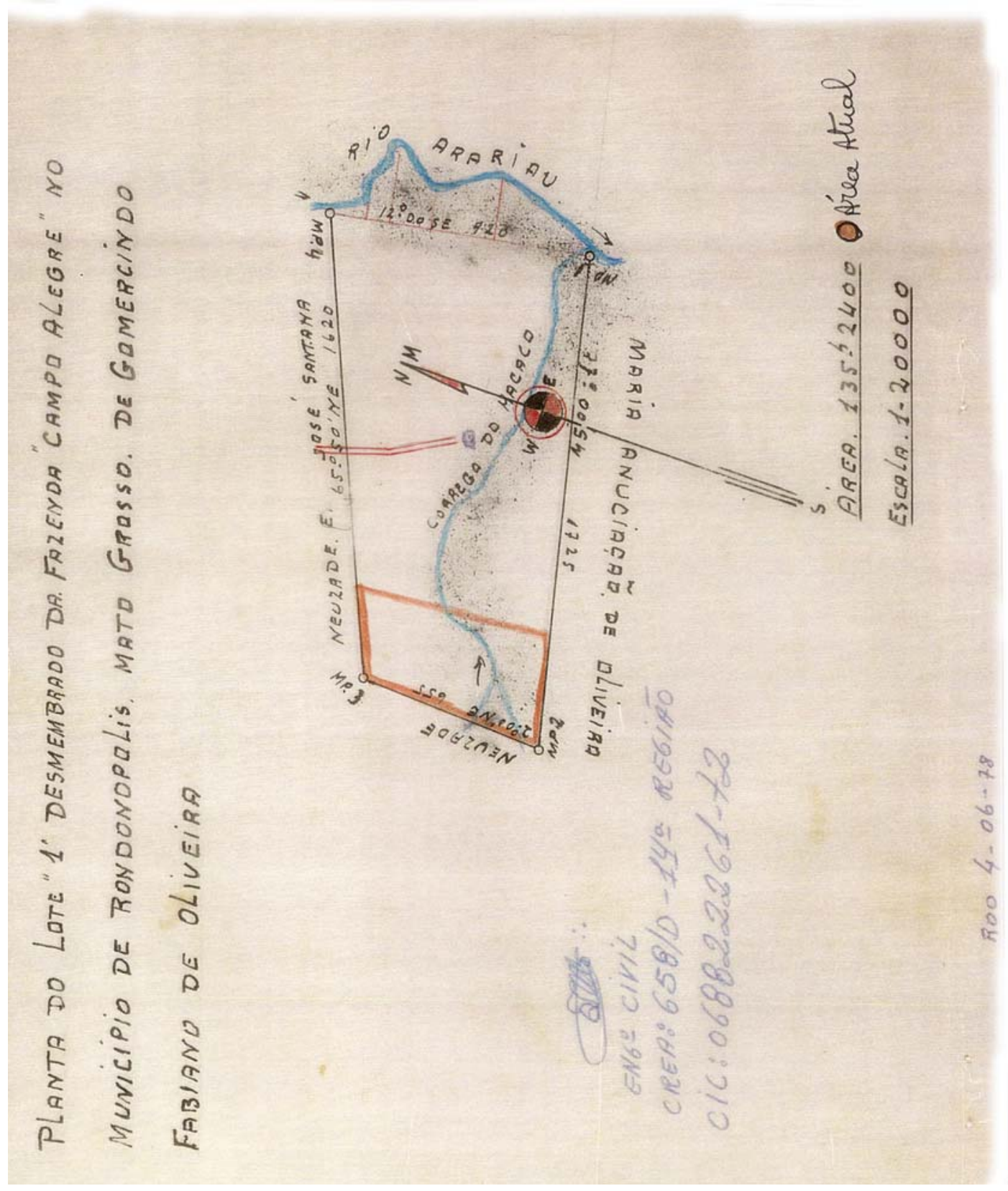


MAPA VI - FAZENDA CAMPO ALEGRE ATUALMENTE

fie.

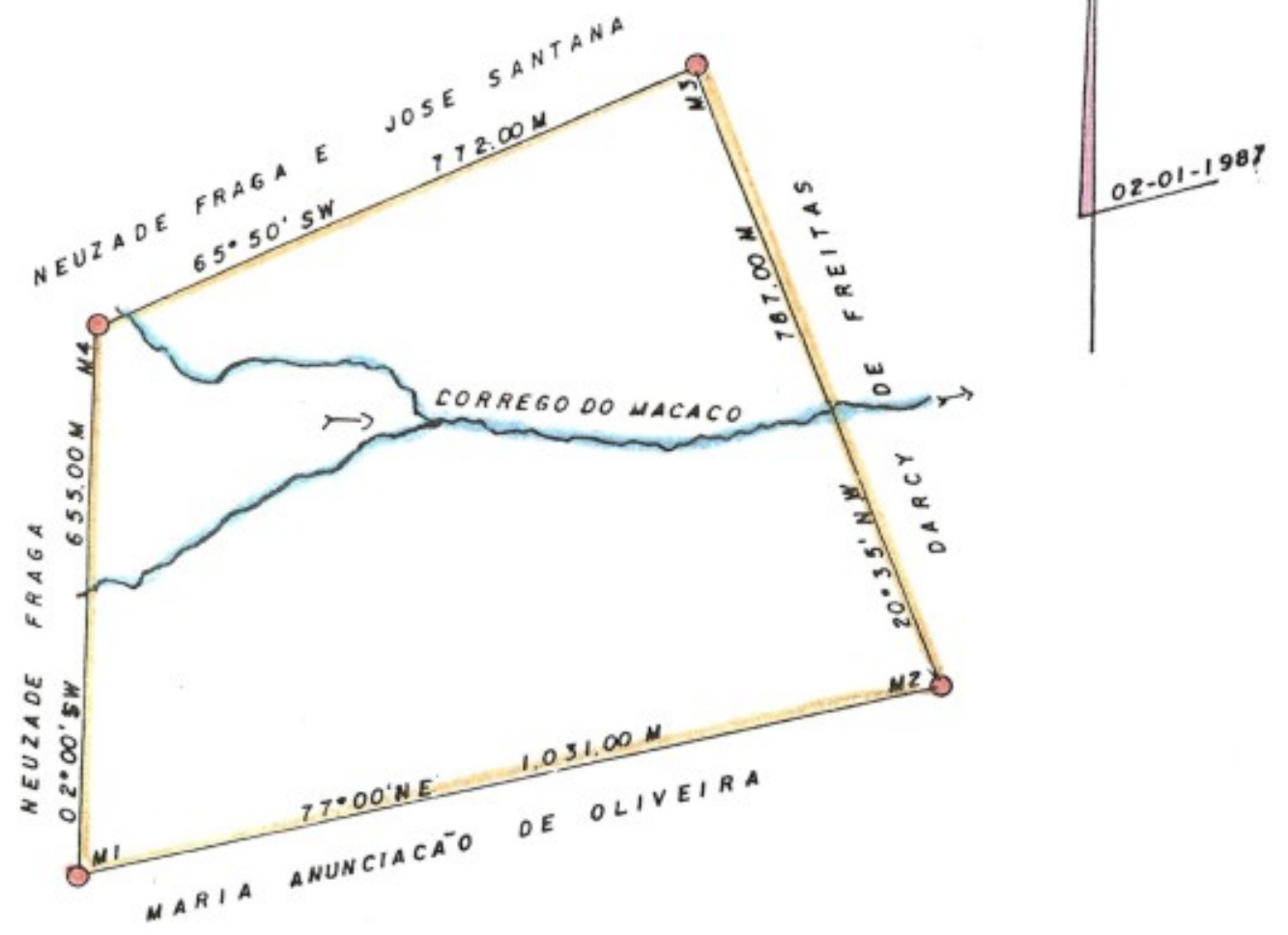

AHEA REMANESCENTE DO LOTE DENOWINAOO DE LOTE NEI-DESNENBRADO FAZENDA CANPO ALEARE

PROPRIETARIO

OOMERCINDO FABIANO DE OLIVEIRA

\begin{tabular}{|c|c|}
\hline $\begin{array}{l}\text { AREA } \\
\text { C2.6400 HA }\end{array}$ & $\begin{array}{l}\text { ESCALA } \\
1=10.000\end{array}$ \\
\hline $\begin{array}{l}\text { MUNICIPIO } \\
\text { RONOONOPOLIS }\end{array}$ & $\begin{array}{l}\text { ESTAOO } \\
\text { MATO BROSSP }\end{array}$ \\
\hline 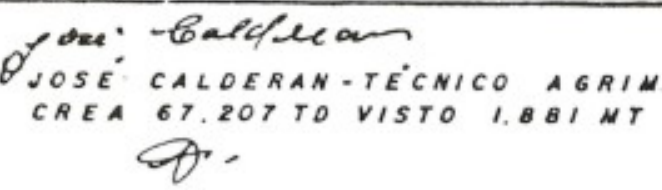 & $S O R$ \\
\hline
\end{tabular}


Maria Anunciação de Oliveira recebeu, em 1978, o Lote № 2 desmembrado da Fazenda Campo Alegre (Planta 06), com área equivalente a 135,2400 ha, denominado Sítio Santa Rosa. Vendeu assim que o recebeu. Em 1980, casou-se com Joaquim Assunção dos Santos e mudou-se para Cuiabá. Em entrevista, relatou-me o seguinte:

Eu estou sabendo pela minha irmã Elizete, que a senhora está escrevendo um livro sobre nossa família. Fiquei muito contente. Nunca morei no 'meu sítio', pois vendi assim que ganhei de meus pais, pois era nova, solteira e morava com eles. Acho que foi bom o que eles fizeram, de repartir com os filhos antes de falecer. Acredito que meus irmãos que ainda tem a terra vão fazer do mesmo jeito, pois fomos criados assim. Infelizmente, não toquei o sítio, não teve como. Moro em Cuiabá desde que me casei. Tenho três filhos, todos solteiros. O Andersom fez Matemática na UFMT e hoje faz mestrado em Matemática em Goiânia. A Fernanda também faz Matemática na UFMT, o Tiago, faz Ciências Contábeis numa faculdade que agora não me lembro o nome. Meu esposo é representante comercial de uma indústria de Minas Gerais e São Paulo, que vende lustres, antenas, reatores, enfim, materiais elétricos. Eu trabalho em casa mesmo, ajudando nos afazeres de casa, bem como atendendo telefone, passando e recebendo fax para ajudar o marido. A gente quase não vai a Rondonópolis, não porque não gosta, mas por conta do trabalho do meu marido, fica meio inviável.

Pela fala acima, nota-se que aquela prática relatada por Moura (1978:54): "as filhas nunca recebiam parcelas de terra do pai, já que este as provê de todo o 'sustento"', não ocorreu na família de Oliveira, pois Maria Anunciação, mesmo morando com os pais e tendo de tudo para prover suas necessidades pessoais, recebeu a doação que lhe era de direito. Quando Anunciação diz "infelizmente, não toquei o sítio, não teve como", está querendo dizer que, pelo fato de ser mulher e solteira, não via possibilidade em dar continuidade ao patrimônio, por isso o vendeu.

Como havia conseguido a Planta do Lote que foi de Maria Anunciação, coloquei-o para completar a quadro da fragmentação. 
PLANTA 06 - PLANTA DO LOTE 2 DESMEMBRADO DA FAZENDA CAMPO ALEGRE - SÍTIO SANTA ROSA
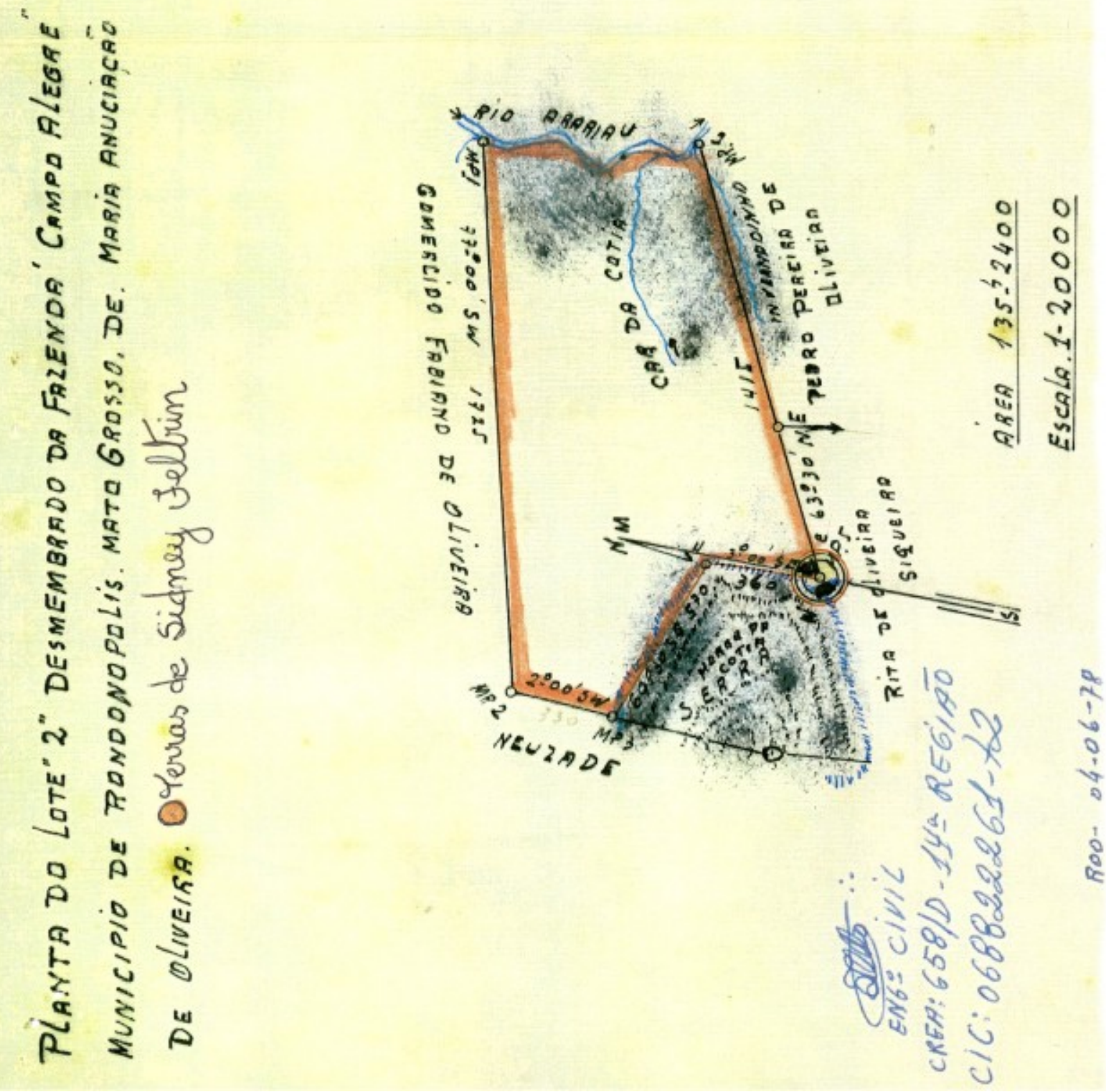
Pedro Pereira Oliveira, casado com Hortência Santos Oliveira desde 1973. Ao casar-se, morou na sede junto com os pais, depois se mudou para Aldeinha nas proximidades da casa da irmã Eliete, onde foi professor na Escola Rural Mista Aldeinha. Somente em 1978, após receber o lote de doação, construiu sua casa e mudou-se. São 30 anos morando na propriedade. Recebeu o Lote №. 3 cuja parte na doação era correspondente a 135,24 ha, desmembrado da Fazenda Campo Alegre (Planta 07), que, após isso, passou a chamar-se Fazenda Oriente. Na época da doação, vendeu para seu irmão Teodoro o correspondente a 4,84 ha, o qual não entrou no mapa em anexo. Hoje, possue 114,67 ha, que, como se verá adiante, foi doado aos seus filhos.

Como se pode ver (Foto 12), possuem uma casa simples, de alvenaria e que na divisão ficou para sua filha Márcia (Mapa VIII).

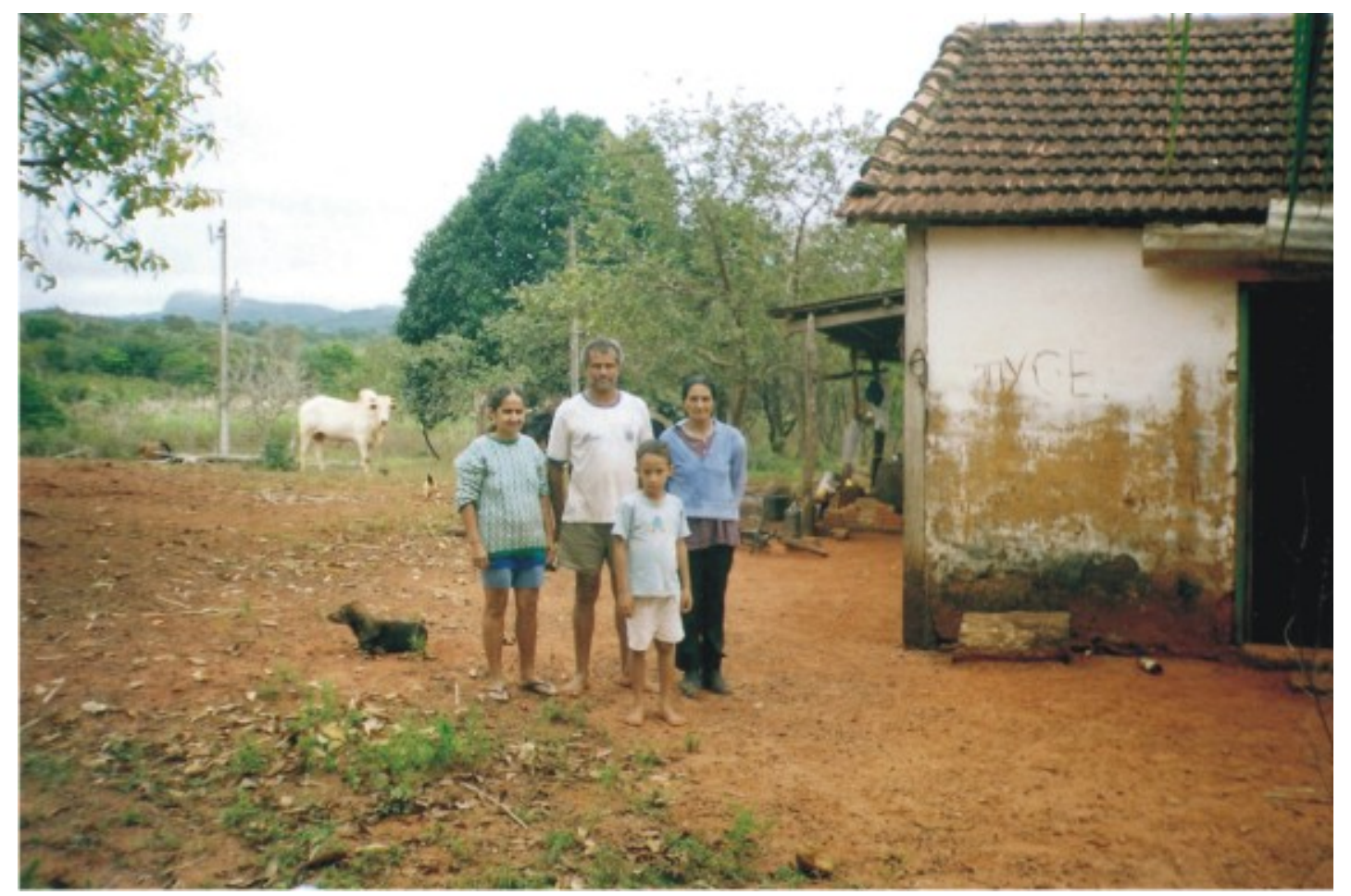

Foto 12 - Sede da Fazenda Oriente. Hortência, Pedro, José Pedro (neto) e Eliete. (LIMA, LMS//2004). 
PLANTA 07 - PLANTA DO LOTE 3 DESMEMBRADO DA FAZENDA CAMPO ALEGRE - FAZENDA ORIENTE

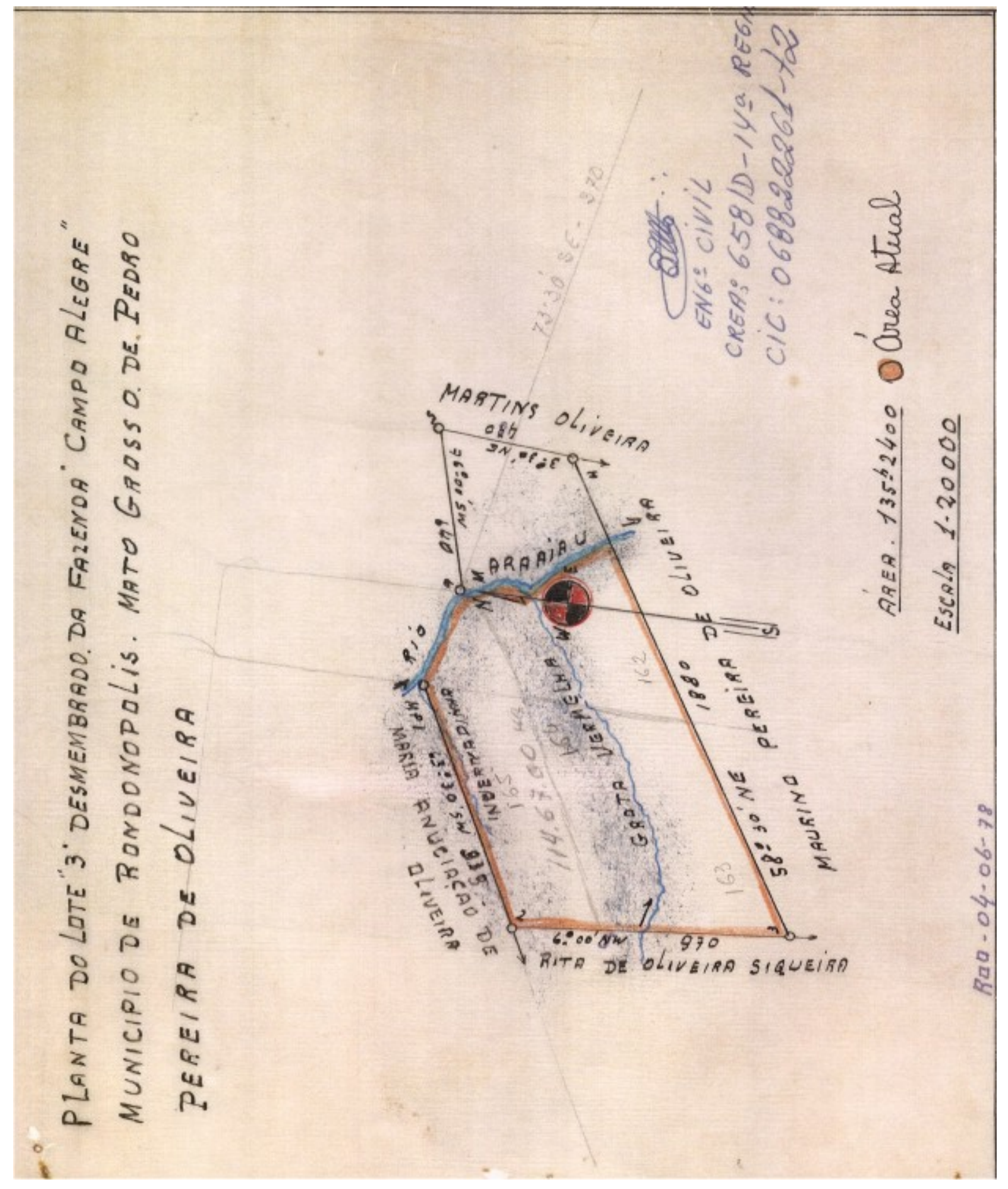


Pedro e Hortência tiveram quatro filhos: três mulheres e um homem, os quais moram na cidade e três já estão casados. O Ildefonso Pedro de Oliveira é Técnico Agrícola e trabalha na BÜNGE. É casado com a Elza e tem três filhos: a Érica, a Elen e o Everton. A Márcia Sandra de Oliveira é casada com Joaquim Rodrigues Filho e tem duas meninas, a Joice e a Maires. A Keila Santos de Oliveira é casada com Keiderson Nunes Rodrigues e tem um filho, o Diego. A Sandra Regina Oliveira é solteira e trabalha como doméstica na cidade. Tem um filho, o José Pedro de Oliveira de 10 anos, que mora com os avós na fazenda. José Pedro estuda a $2^{\mathrm{a}}$ Série na Escola 14 de Agosto no Assentamento Chico Mendes e vai de ônibus escolar. Além da fazenda, seu Pedro possui uma casa na cidade, onde moram as filhas e onde ficam quando precisam ir até lá.

No momento, não estão desenvolvendo nenhum tipo de projeto na propriedade, mas comentaram a respeito do PRONAF. Pedro lembrou que:

No ano de 1997, recebemos uma ajuda do PRONAF para a plantação de mandioca. Fabricávamos farinha, polvilho e vendia uma boa parte na cidade. Com a renda da mandioca, pagamos o financiamento e ainda compramos um triturador. Fora isso, tudo o que foi ou está sendo feito em sua propriedade é por conta própria. Mesmo assim, por conta da burocracia é uma dificuldade danada.

A respeito da infra-estrutura da fazenda Pedro, informou que:

Temos água encanada que vem com a força da gravidade, direto da mina. São várias minas, além da Grota Vermelha, do Córrego Invernadinha e do rio Arareau. A Luz elétrica, fizemos o rebaixamento, agora a rede é da Cemat. Temos um carro, como meio de transporte para as necessidades. Além da televisão colorida, tem um celular com antena. Quando precisamos de médico, vamos até o PS do Bananal, que fica na antiga escolinha na propriedade da professora Benedita. O médico vem duas vezes por mês. Em se tratando de lazer, a gente se diverte nadando no rio Arareau que passa pela propriedade e participamos das festividades no salão social.

Em se tratando da produção agrícola e pecuária da fazenda, bem como do destino da mesma, Pedro comentou:

Temos gado de corte e leiteiro, onde tiramos mais ou menos uns 50 litros diários, que é vendido para o Laticínio Nutribom de Rondonópolis, infelizmente por um preço muito baixo. Criamos galinhas somente para o consumo da família, assim como as frutas e hortaliças do quintal. Nossa renda é só daqui. 
Em se tratando da fragmentação da terra entre os descendentes, Pedro fez o seguinte comentário:

É uma boa, existe a vantagem de não precisar gastar com advogado e outras coisas mais. Tenho quatro filhos: três mulheres e um homem. Todos moram e trabalha na cidade. Eu e minha mulher sentamos, conversamos e decidimos fazer a mesma coisa que meu avô e meu pai fizeram, ou seja, dividir a terra com nossos filhos antes de morrer. É pouco, cada um ficou com 28,6675 ha, mas já é um começo pra eles. Não foi entregue ainda, pois estou esperando sair minha aposentadoria para depois passar a escritura, mas já foi feita a divisão e os mapas estão prontos. (Mapas VII, VIII, IX e X)

De acordo com o Pedro, a filha Márcia, que ficou com a sede, já comprou algumas cabeças de gado e cada filho já fez a cerca de arame dividindo a propriedade; todos têm energia elétrica.

Veja a seguir os mapas de cada uma das áreas desmembradas da Fazenda Oriente, com suas respectivas denominações e proprietários, além do quadro demonstrativo dos mesmos. 
MAPA VII - ESTÂNCIA ALVORADA

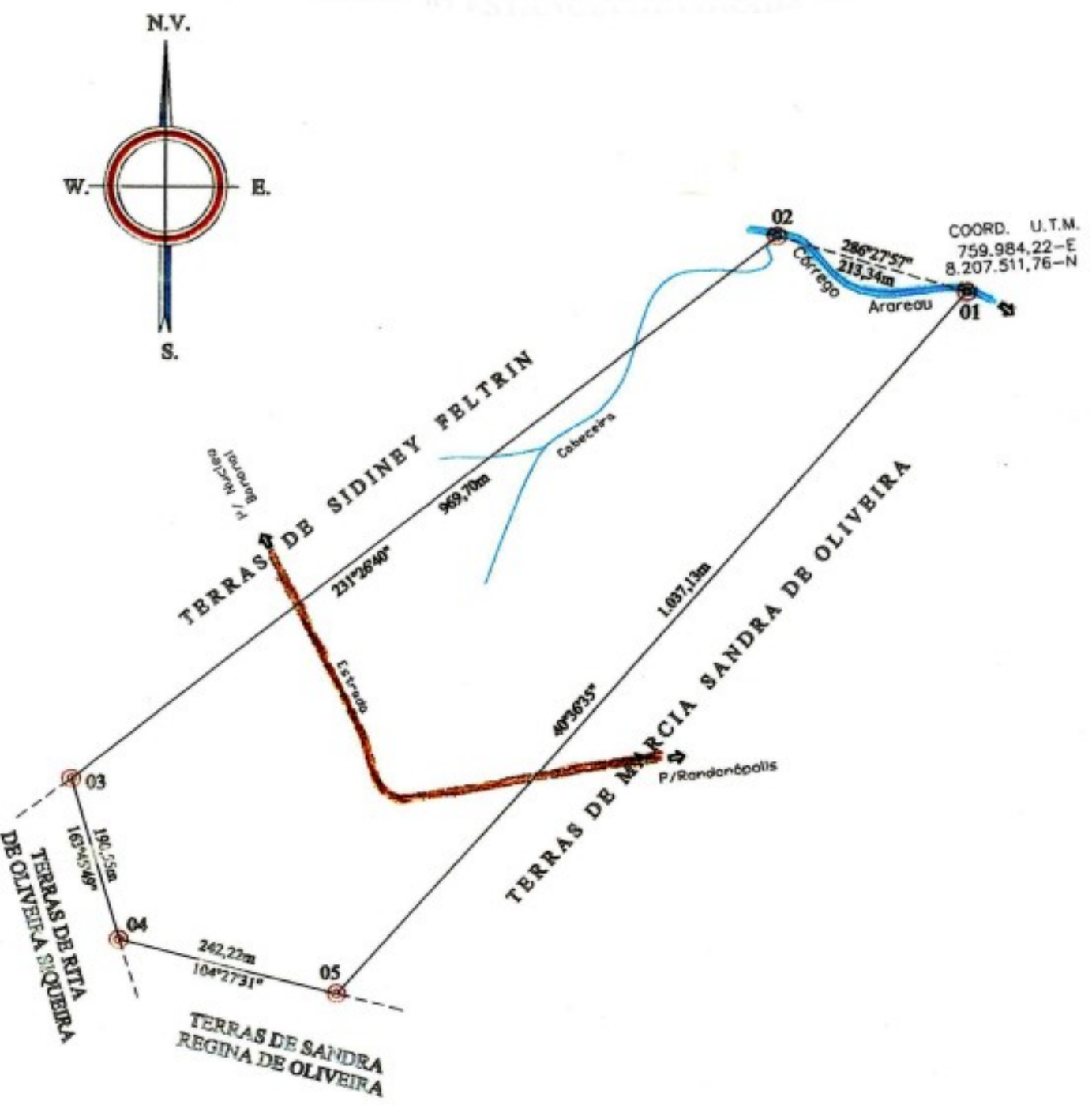

Bscala Gráfica:

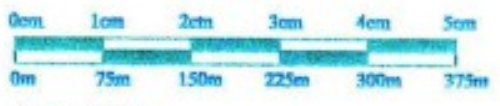

$1 \mathrm{~cm}-75,00 \mathrm{~m}$

\begin{tabular}{|c|c|c|c|c|}
\hline \multicolumn{4}{|l|}{ IMÓvBLA } & Munichin: \\
\hline \multicolumn{2}{|c|}{$\begin{array}{r}\text { ORIGBM: DESMEMBRADO DA FAZENDA } \\
\text { CAMPO ALEGRB - MATRICULA NO } 45.312\end{array}$} & \multicolumn{2}{|c|}{$\begin{array}{l}\text { PROPRIITLARAO: } \\
\text { KEILA SANTOS DE OLIVEIRR }\end{array}$} & \\
\hline ARTA: 28,6675 hat & BSCALA: & & DATA: $02 / 05 / 2001$ & O Pellx, 99 - Foee: 421 - 8848 Ca \\
\hline
\end{tabular}




\section{MAPA VIII - ESTÂNCIA RONDON}

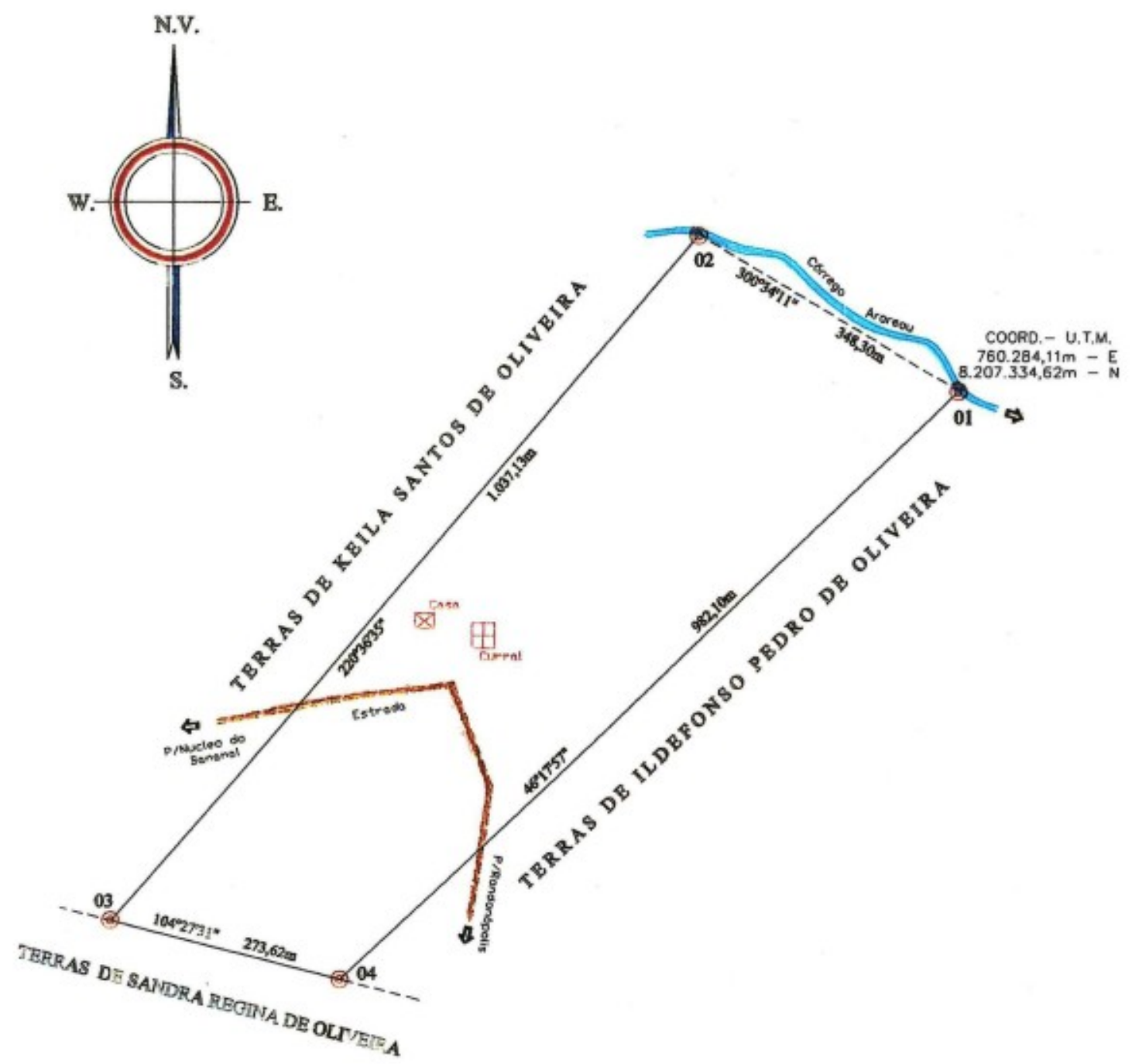

Escala Gráfica:

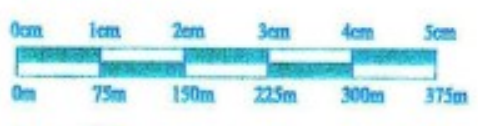

$1 \mathrm{~cm}-75,00 \mathrm{~m}$

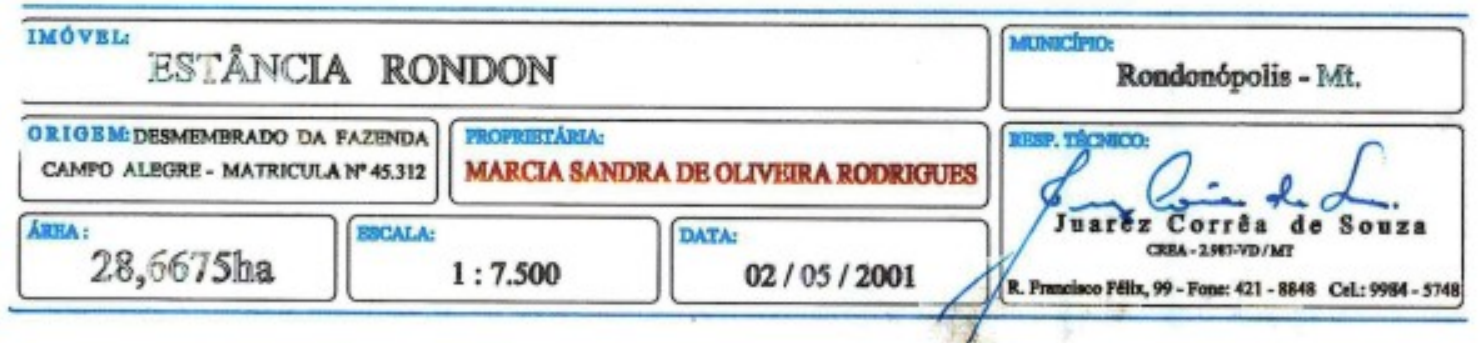




\section{MAPA IX - ESTÂNCIA NOVO HORIZONTE}

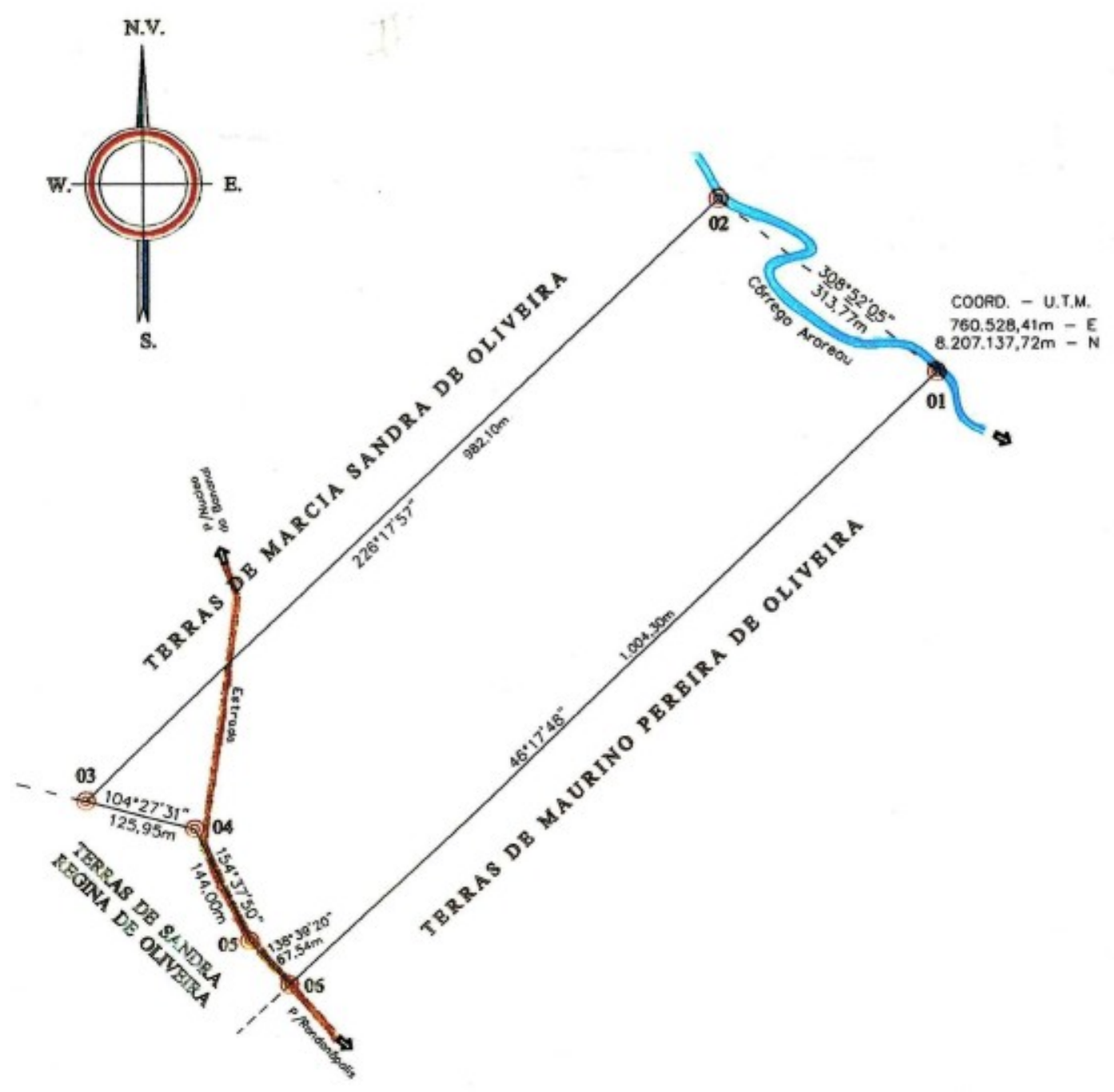

Becala Gráfica:

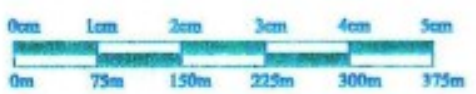

$1 \mathrm{an}-75,00 \mathrm{~m}$

\begin{tabular}{|c|c|c|c|c|}
\hline \multicolumn{4}{|c|}{${ }^{\text {Móvel: }}$ ESTÂNCIA NOVO HORIZONTE } & Rondonópolis - Mt. \\
\hline \multicolumn{2}{|c|}{$\begin{array}{l}\text { ORIGBM: DESMEMBRADA DA FAZERDA } \\
\text { CAMPO ALEGRE - MATRICULA NP 45.312 }\end{array}$} & \multicolumn{2}{|c|}{$\begin{array}{l}\text { FOIFUETARTO: } \\
\text { ILDEFONSO PEDRO DB OLIVEIRA }\end{array}$} & gad \\
\hline AREA: $28,6675 \mathrm{ha}$ & BSALA: & & $02 / 05 / 2001$ & 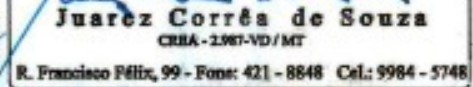 \\
\hline
\end{tabular}




\section{MAPA X - ESTÂNCIA SÃO SIMÃO}

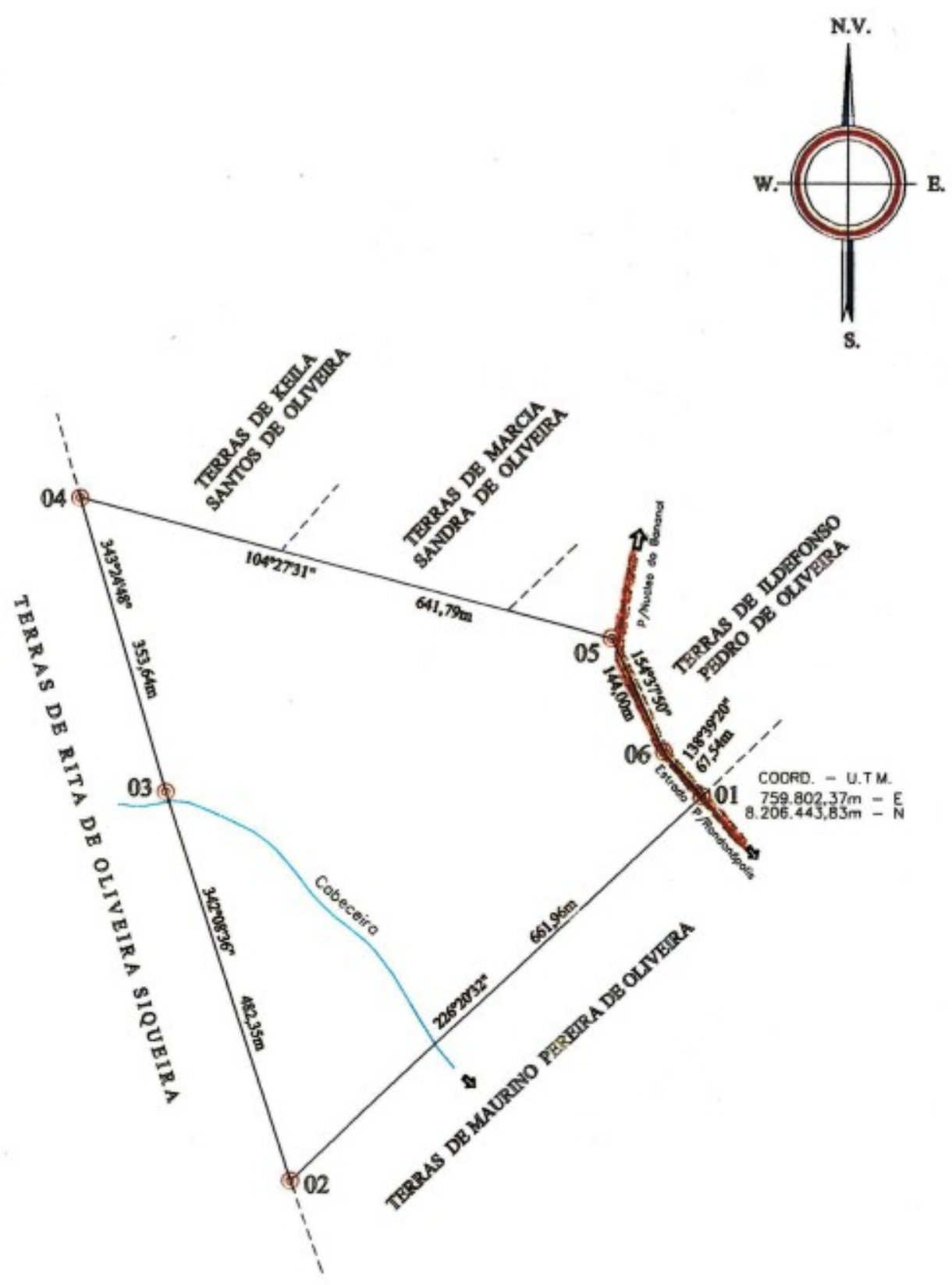

Bscala Gráfica:

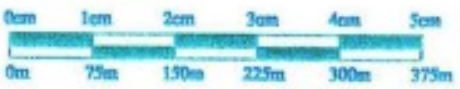

$1 \mathrm{~m}=75,00 \mathrm{~m}$

\begin{tabular}{|c|c|c|c|c|}
\hline \multicolumn{4}{|c|}{ 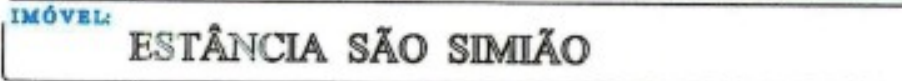 } & Rondonópolis - Mt. \\
\hline \multicolumn{2}{|c|}{$\begin{array}{r}\text { ORIOEME DESMEMBRADO DA FAZBNDA } \\
\text { CAMPO ALEGRE MATRICULA NP } 15.312\end{array}$} & \multicolumn{2}{|c|}{$\begin{array}{l}\text { PMOFPUETRRIO: } \\
\text { SANDRA REGINA DE OLIVEIR }\end{array}$} & \\
\hline 28,6675 hat & \multicolumn{2}{|c|}{$1: 7.500$} & $02 / 05 / 2001$ & 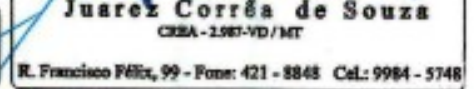 \\
\hline
\end{tabular}


Maurino Pereira de Oliveira, casado com Maria do Carmo Garcia Oliveira desde 1984, recebeu como doação o Lote 4, desmembrado da Fazenda Campo Alegre, naquela época, com área equivalente a 135,24 ha (Planta 08), que, posteriormente, passou a chamar-se Sítio Pitangueira. Na atualidade, a propriedade possui uma área de 126,51ha (Mapa XI), onde se encontram, em destaque, os limites, a área de reserva que corresponde a 25,30 ha; a área explorada que é de 101,20 ha e a área para limpeza de pasto que equivale a 30,00 ha. Observa-se também, o rio Arareau e o Córrego Mamona que banham a propriedade. Na época da doação, o Maurino, assim como alguns de seus irmãos, vendeu a Teodoro 4,84 ha, corresponde ao Lote Aldeinha.

Aparece neste depoimento de Maurino como foi o início de sua vida no Sítio.

Em 1978 quando eu recebi o lote como doação, não existia casa na propriedade. Em 1984, casei e fui morar na cidade. Em 1990, construí a casa e em 1993 mudei-me para cá. Faz 14 anos que estamos na propriedade. Era pouco o pasto, somente 16 hectares. O restante era cerrado. Em 2003, vendi o carro, 30 vacas e 20 bois de 2 anos e meio para fazer benfeitorias no Sítio, como formação de pastagens. O curral eu já tinha. O Sítio possui uma casa de alvenaria, muito boa, bem arejada e aconchegante. (Foto 13)

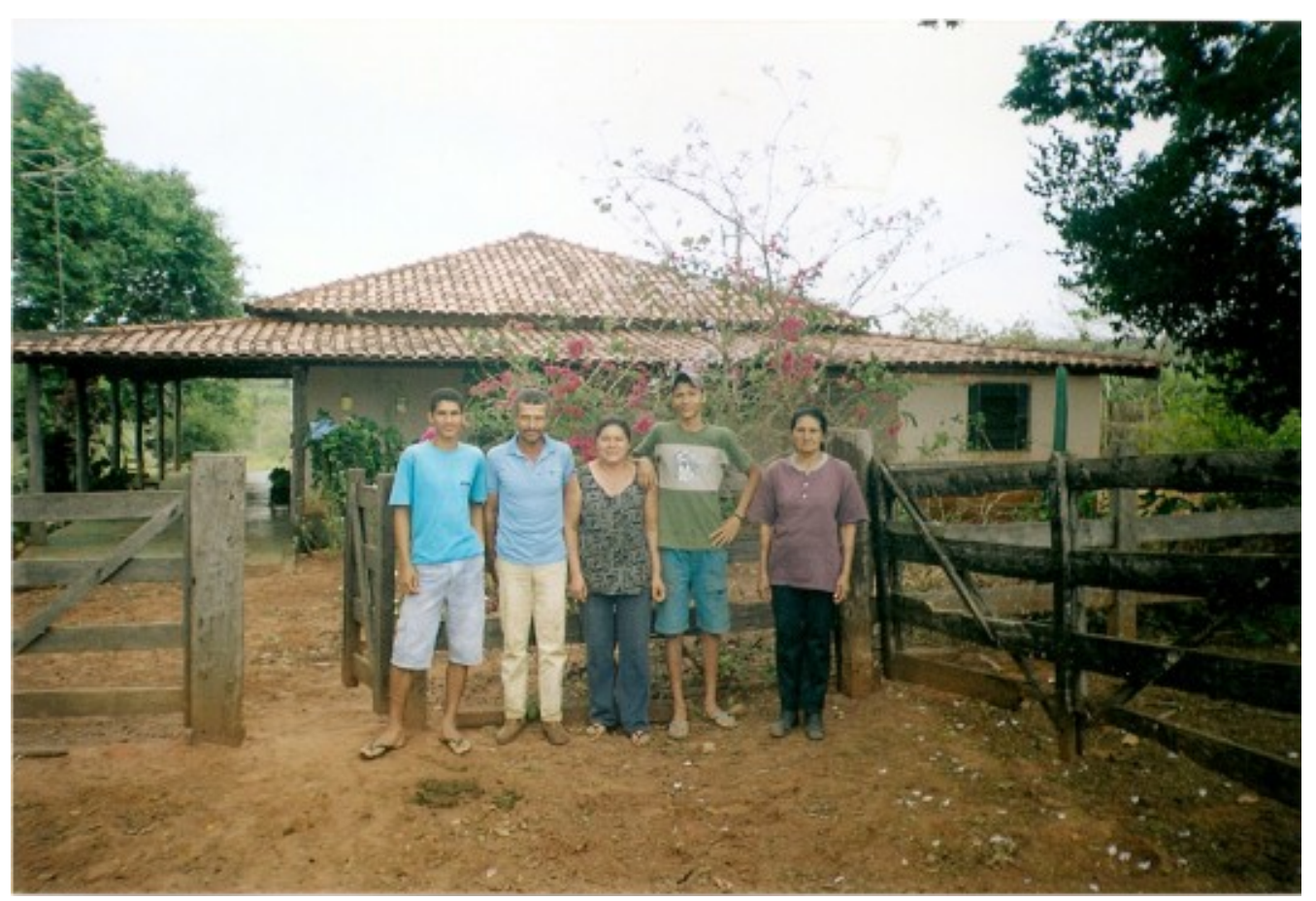

Foto 13 - Sede do Sítio Pitangueira. Eduardo, Maurino, Maria do Carmo, Maurino Guilherme e Eliete. (LIMA, LMSI/2004). 
Em se tratando de vida camponesa, é comum a venda de alguns bens para investir na propriedade e ter um mínimo de conforto. $E$ até mesmo pensar no futuro dos filhos, na divisão da propriedade.

A venda de alguns produtos da propriedade camponesa é vista como uma faca de dois gumes. Se por um lado diminui o patrimônio, caso da "venda do carro, do gado", por outro, em se tratando de benfeitorias em sua propriedade, Maurino afirma que:

Aqui nós temos água encanada para o uso diário que vem da mina, através da força da gravidade. Tem a Grota Vermelha, o Córrego Mamona e o rio Arareau. Temos luz elétrica, comprei o transformador e mandei fazer o rebaixamento. $O$ ano passado doei para a CEMAT, que agora dá assistência de graça, pois antes tínhamos que pagar para eles virem aqui caso acontecesse algum problema, temos televisão colorida, telefone celular com antena. Nossa renda é basicamente só do leite.

Quanto à produção agrícola e pecuária do sítio, bem como o destino de ambas, Maurino comentário que:

\begin{abstract}
Possuo aqui no sítio algumas cabeças de gado de corte e principalmente vaca leiteira, cujo leite é vendido ao Laticínio Nutribom, sendo que durante o período das águas conseguimos tirar até 80 litros diários, infelizmente o valor venal do mesmo está entre $R \$ 0,43$ a 0,36 o litro. Além do gado, possuímos no sítio galinhas que são criadas somente para o consumo da família, vários pés de frutas bem como hortaliças.
\end{abstract}

No que se refere à política governamental em prol dos camponeses, Maurino comentou "hoje estão mais abertos ao pequeno produtor, pois antigamente era muito difícil fazer o PRONAF". Para comprovar a abertura por parte dos governantes em facilitar o acesso a esse programa, Maurino comentou o que:

Através do PRONAF eu comprei quatro vacas. Já fiz o pagamento da primeira parcela no valor de $R \$ 1$ 125.81. As quatro parcelas são iguais. Tivemos um período de carência de dois anos para pagar. Graças a Deus não tive problemas, pois tinha a renda do pasto que eu alugava.

Em relação à família, Maurino possui dois filhos, o Eduardo Juliano Garcia Oliveira que faz Administração em uma faculdade particular em Rondonópolis e o Maurino Guilherme Garcia Oliveira que faz o $3^{\circ}$ Ano do $2^{\circ}$ Grau na Escola do Assentamento Chico Mendes. 
PLANTA 08 - PLANTA DO LOTE 4 DESMEMBRADO DA FAZENDA CAMPO ALEGRE - SÍTIO PITANGUEIRA

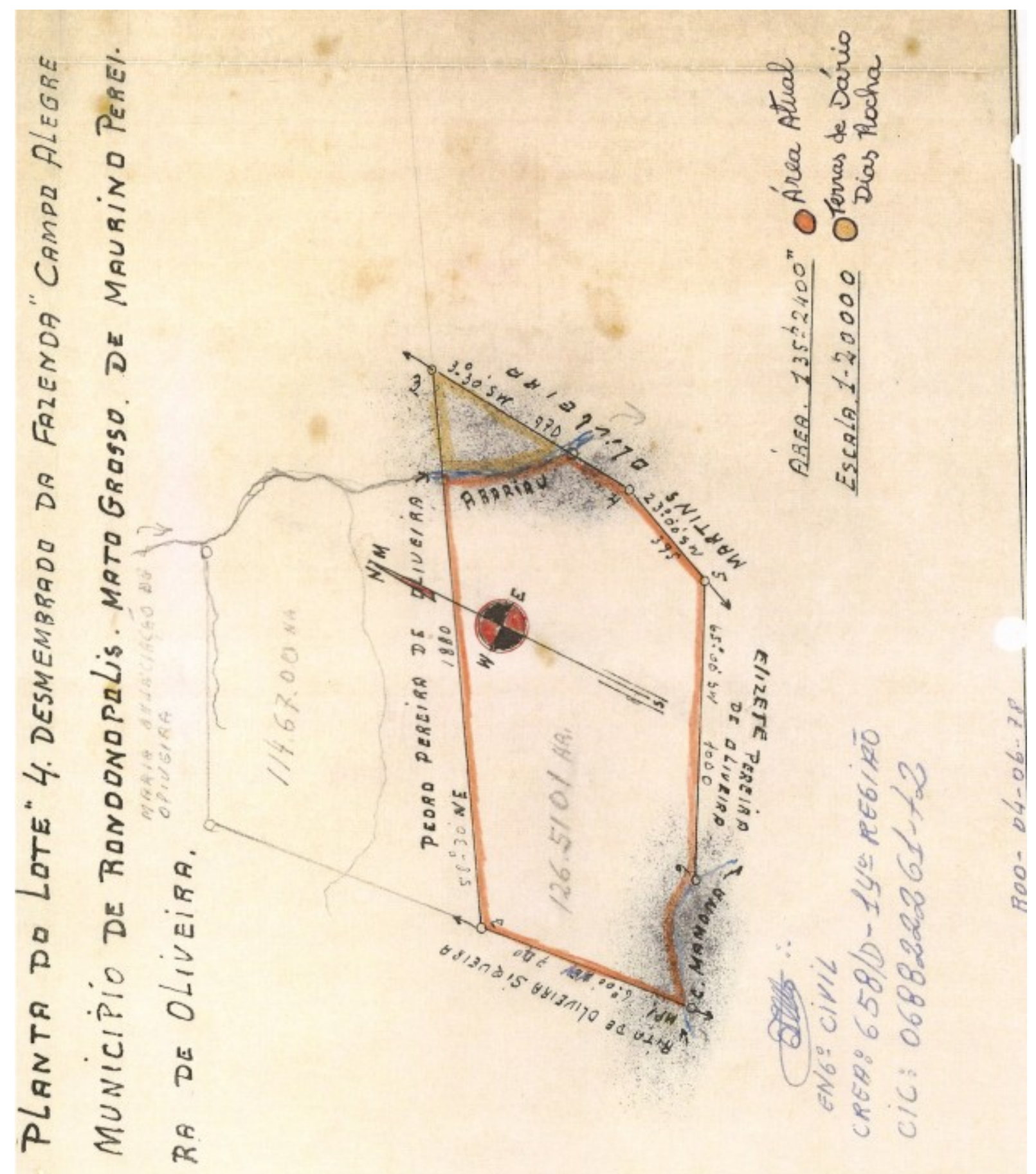




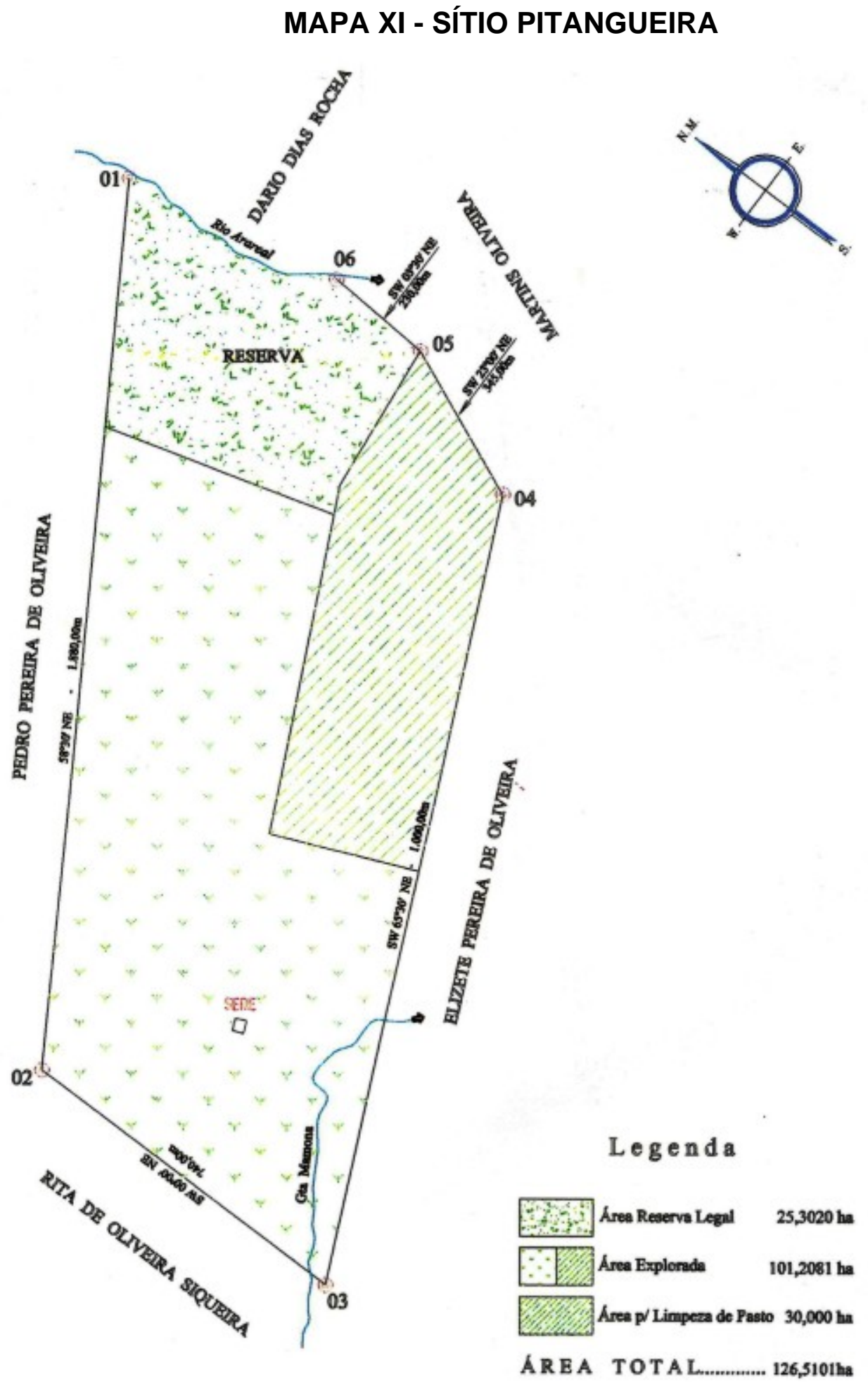

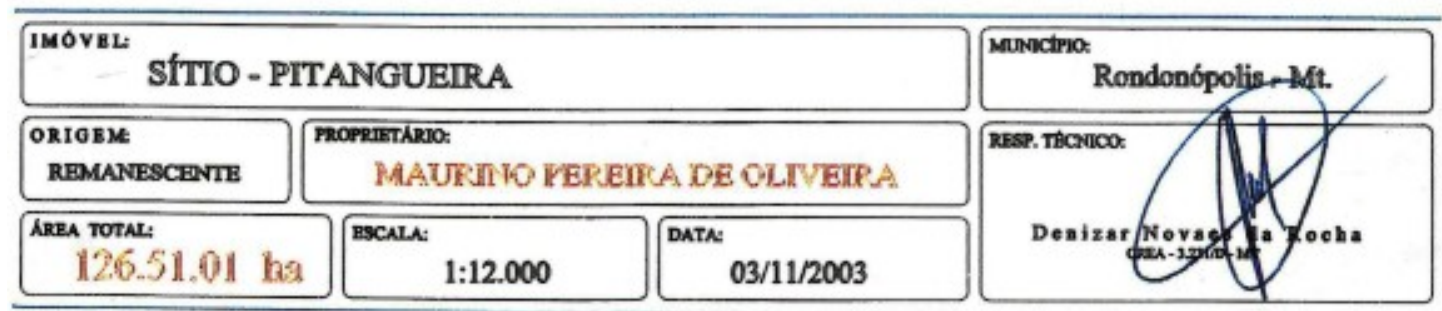


Maria do Carmo passa a maior parte do tempo na cidade, onde faz crochês, tricô, bordados (vagonite), faz bonecas, ou seja, confecciona trabalhos artesanais que são comercializados em uma banca na calçada no centro da cidade, juntamente com outros ambulantes. Além disso, ministra cursos de bordados e crochês em uma loja de aviamentos na cidade.

Maurino participa da Associação que existe na região e é filiado ao Sindicato dos Trabalhadores Rurais em Rondonópolis, mas disse-nos que está inadimplente, ou seja, faz tempo que não contribui.

Não tem projeto em desenvolvimento ou para ser executado. Mas falou a respeito de um linhão, uma Rede de Transmissão que vem de Itumbiara, cortando sua propriedade e indo até Cuiabá. Ele acredita que seja um projeto do governo federal e que o mesmo será indenizado por conta disso. Os engenheiros já passaram fazendo as medidas.

Em relação à divisão da propriedade, Maurino tem a seguinte opinião: "é muito bom, pois os doadores dão onde os filhos querem e isso evita brigas. No futuro pretendo também dividir com meus filhos como meu avô e meu pai fizeram". 
Elizete Pereira de Oliveira recebeu de seus pais, em 1978, o Lote $N^{0} .5$ Desmembrado da Fazenda Campo Alegre com área equivalente a 135,24 ha. Na época da doação, vendeu 4,84 ha da parte da Aldeinha a seu irmão Teodoro. Esta parte não consta no mapa de doação e, após o desmembramento passou a se chamar Sítio Campo Verde.

Elizete, assim como Maria Anunciação, vendeu a propriedade. Em entrevista, relatou-me o seguinte:

Eu nunca morei na área, na propriedade que recebi como doação, que era um sítio de 56 alqueires - Sítio Campo Verde, nem coloquei alguém para tomar conta. Assim que recebemos a doação, vendemos (eu e mais cinco irmãos) $4 \mathrm{~h}$ e $8.400 \mathrm{~m}^{2}$ cada, da parte da Aldeinha para o Teodoro meu irmão. Se não me engano essa venda foi para pagarmos a parte do engenheiro que fez a divisão. Logo em seguida, vendi 40 alqueires e posteriormente vendi os outros 16 alqueires que restavam. Com a venda do Sítio, comprei duas casas em Rondonópolis, uma delas eu alugo, a outra é esta aqui onde eu moro juntamente com minha mãe. Em 1965, dei aulas na Escola Rural Mista de Aldeinha para mais ou menos 80 crianças, que se dividiam em dois períodos. Era um tanto quanto difícil, pois as turmas eram todas misturadas, da $1^{a}$ a $4^{a}$ Série. Durante o período da colheita, boa parte dos alunos parava de estudar para ajudar os pais no trabalho na roça. A partir de 1970, entraram outros professores, sendo assim, ficou mais fácil trabalhar. Tinha um professor que faltava muito, e por isso alguns pais queriam tirar seus filhos da sala dele para estudar comigo, dizia não ser possível, pois ficaria muito apertado para mim. Realizávamos muitas festas com a criançada. Era festa junina, festa da páscoa, dia da criança e assim por diante, tínhamos um calendário com as datas comemorativas. Tem uma prima minha que foi minha aluna lá na Aldeinha durante os quatro anos. Hoje ela é diretora em uma escola lá em Rondônia, e me disse outro dia em que veio passear aqui, que faz as festas do mesmo jeito em que aprendeu comigo e que a criançada e os pais gostam muito. Isso para mim é motivo de orgulho.

Conversei com a senhora que hoje é dona do Sítio Campo Verde e ela me emprestou a Planta (Planta 09) original do sítio - já bastante gasta -, para ilustrar este trabalho. 
PLANTA 09 - PLANTA DO LOTE 5 DESMEMBRADO DA FAZENDA CAMPO ALEGRE - SÍTIO CAMPO VERDE

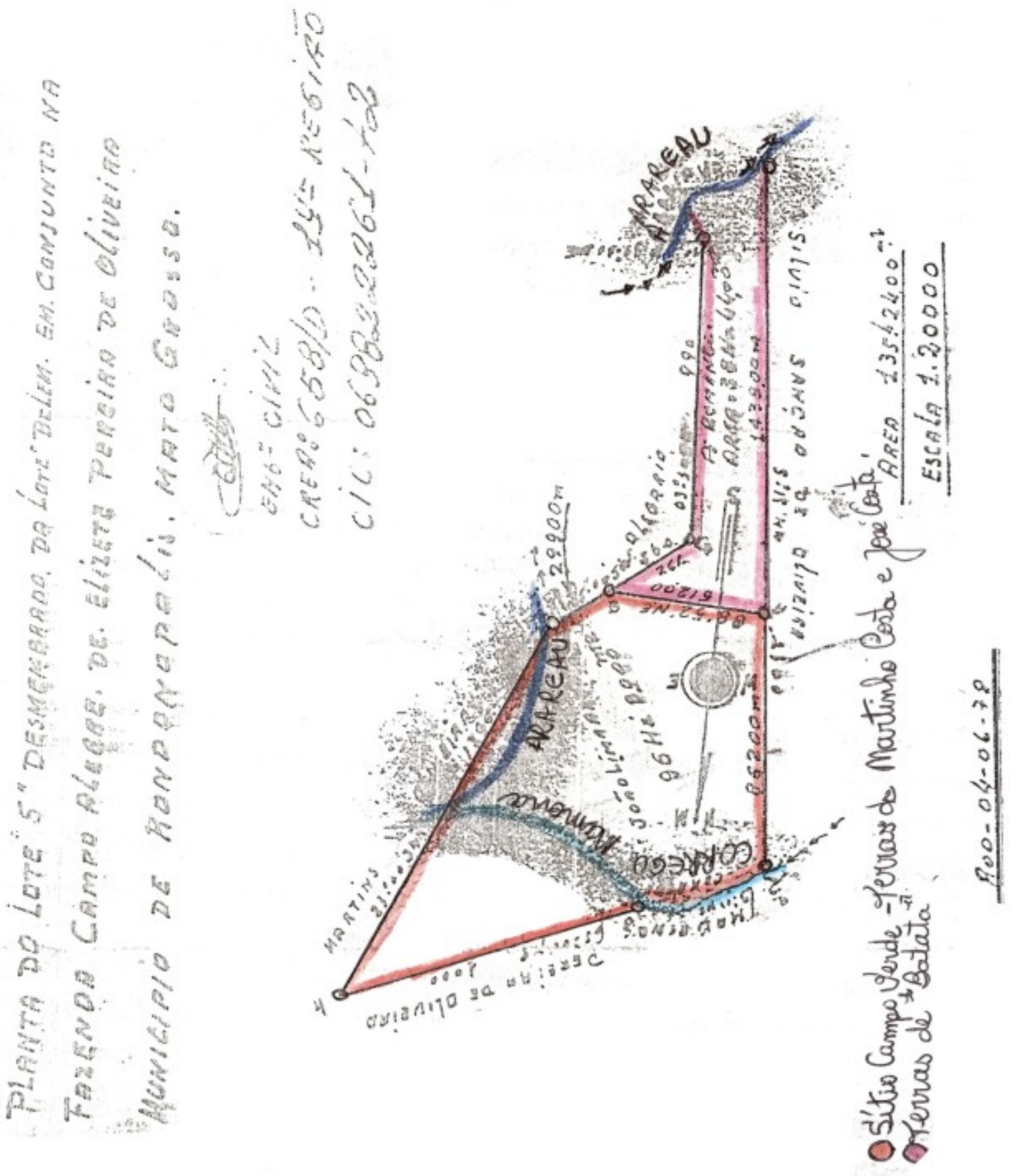


Silvio Sanção de Oliveira, casado com dona Olga Sales de Oliveira ${ }^{181}$ desde 1970, receberam como doação de seus pais, em 1978, o Lote № 6 desmembrado do Lote Belém em conjunto na Fazenda Campo Alegre que, após doação, passou a chamar-se Sítio Mamona, com área equivalente a 135,24 ha (Planta 10). Assim como alguns irmãos, Silvio também vendeu a Teodoro uma área correspondente a 4,84 ha, parte da Aldeinha.

Dos 135,24 ha que recebeu de doação do pai, Silvio tem hoje 86,84 ha, pois, posteriormente, vendeu mais 48,40 ha para o Sr. Edmilson N. Bezerra.

Silvio e Olga têm cinco filhos, quatro mulheres e um homem: Maria Aparecida de Oliveira tem três filhos, Silvia Sales de Oliveira, tem dois filhos, Silvana Sales Oliveira, tem três filhos, Silvanete Sales de Oliveira e Marcos Antônio de Oliveira, que têm dois filhos cada um.

A "Cida" hoje é casada com Milton Jorge (seu primo, filho de Rita) e mora no sítio da tia, vizinho aos pais, a mais ou menos $01 \mathrm{~km}$. Silvia e Silvanete moram na cidade. O filho já é casado e mora, em casa separada, no sítio do pai. Durante o dia ajuda o pai em todas as atividades desenvolvidas e à noite, estuda na Escola do Assentamento Chico Mendes, onde sua irmã "Cida" é diretora e seu primo/cunhado é um dos professores. Ele vai de moto de casa até a Associação, dali vai de ônibus escolar que fica a distância de uns $05 \mathrm{Km}$. As crianças também estudam no Chico Mendes e estão todas no Ensino Fundamental.

Dona Olga comentou que, além dela e do marido, moram com eles um casal de netos (deste filho casado). "É com a gente que as crianças gostam de morar. Sem contar que os filhos da Cida também não saem daqui, pois a mãe e o Jorge trabalham o dia todo e até a noite lá na Escola. Nossa casa é simples, mas é grande (Foto 14) e cabe muita gente". Silvio acrescentou: "Adoro isso aqui, vou na cidade só para vota".

Tinha cinco netos e um sobrinho do Silvio (Eduardo, filho do Maurino), brincando de "Jogo de Bete" no pasto na porta da casa. Do Sítio Três Marias da Rita, podíamos ver e ouvir as crianças brincando e gritando na casa do Silvio, assim como também avistamos as casas do Maurino, do Pedro e dos sítios que eram de Elizete e Anunciação.

\footnotetext{
181 Olga Sales de Oliveira é irmã da Orminda Prata Sales Oliveira que é casada com o Gomercindo/Fazenda Campo Alegre; portanto são duas irmãs casadas com dois irmãos.
} 


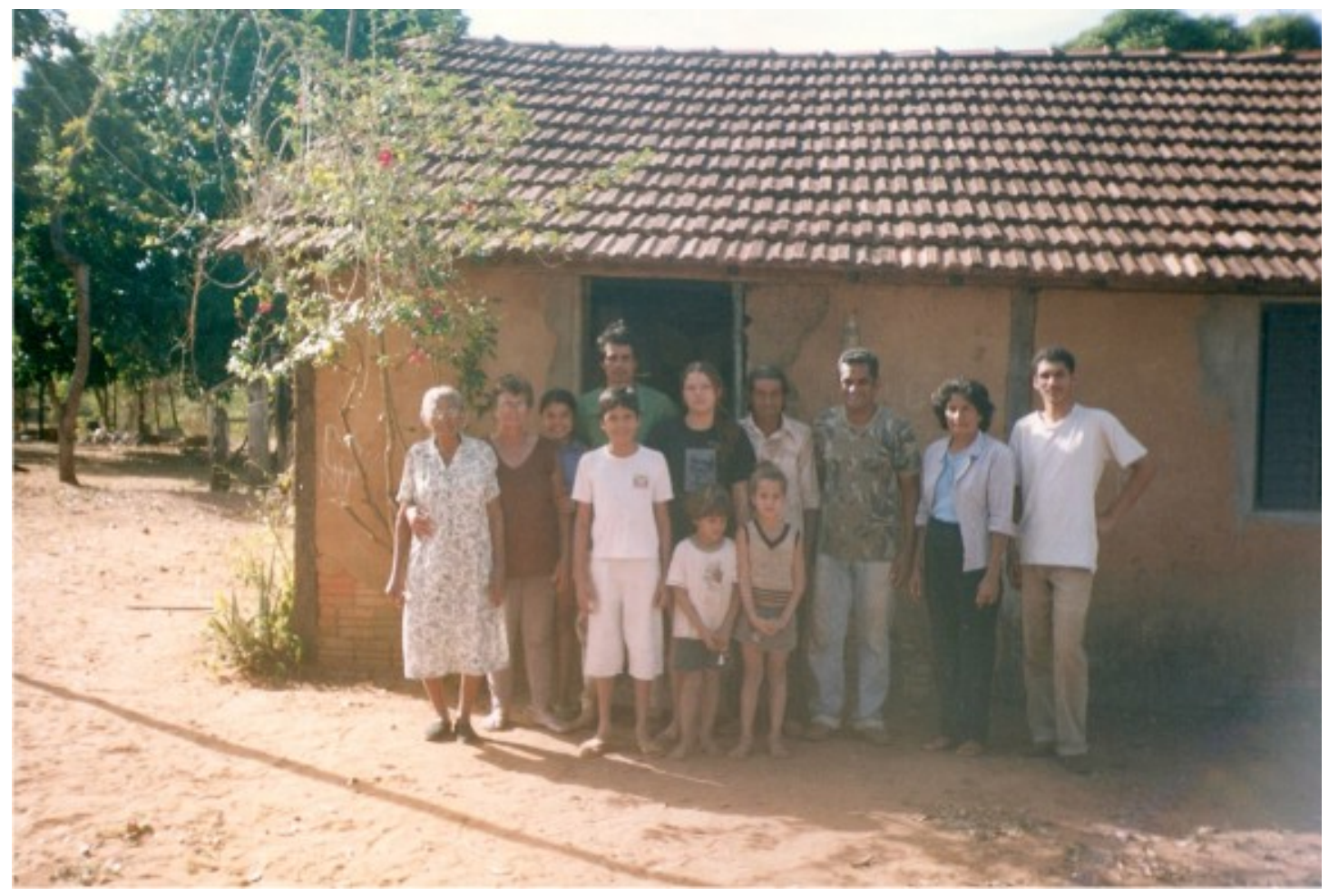

Foto 14 - Sede do Sítio Mamona. Da esquerda para direita: dona Leonila, Olga, Josiane, Marcos, Camila, Silvio, Jorge, Elizete, Eduardo, Lucas, Marcos Antônio e Milene Lúcia. (LIMA, LMS//2005).

Em relação à produção agrícola do sítio, Silvio esclareceu que:

Tenho umas vaquinhas cujo leite é vendido para o Laticínio Nutribom, que nos paga $R \$ 0,30$ o litro. Agora no período da seca tiramos mais ou menos 30 litros por dia. Além das vacas, criamos porcos e galinhas somente para o consumo. No quintal tem mandioca, milho, alguns pés de frutas para os netos. Praticamos, na realidade, uma agricultura de subsistência. Só vivemos com a renda do sítio, em torno de uns $R \$ 300,00$. Nunca recebemos ajuda ou incentivo do governo, trabalhamos sempre em família e por conta própria.

Pela fala de Silvio, percebe-se que, em termos de infra-estrutura, o sítio está bem servido.

Aqui a gente tem luz elétrica, comprei o transformador para fazer o rebaixamento da rede. Temos água encanada que vem da mina, nascente. As crianças vão no ônibus escolar, é grátis. A escola fica a uns cinco quilômetros daqui, lá no Chico Mendes e tem até o segundo grau. Tem um ônibus de linha que passa por aqui três vezes por semana. Quando a gente precisa de médico ou dentista, vai até o PS do Chico Mendes, é uma vez por mês que o médico vem ali. Quando não consegue vamos até a cidade, mas é muito difícil precisar. Temos uma televisão colorida sem antena parabólica, e um telefone celular com antena, para comunicarmos com os parentes na cidade e mesmo nos sítios vizinhos. 
Em se tratando de lazer, tanto para os adultos quanto para as crianças, Silvio comentou "existe no sítio um time de futebol, o Vasquinho do Brocodoro, que inclusive meu filho joga e muito bem, faz gol adoidado, poderia até ir jogar no Rio de Janeiro. Outra diversão no sítio é a cachoeira no córrego Mamona. É outra forma de lazer pra nós".

Sobre o meio ambiente, deixou claro que: "faço queimada só na época certa. Não desmatei as margens do Córrego Mamona e fiz questão de preservar as nascentes".

Por meio da seguinte fala, percebe-se que Silvio não vê muita esperança para os camponeses, por parte das políticas públicas governamentais: "Para nós camponeses, os pequenos, falta muito apoio. Fazem muita promessa mas não cumprem nada. Envolvem muito com a soja, mas o preço cai e não vira nada."

Quanto ao lazer, é comum as famílias numerosas fazerem festas que envolvam a todos e inclusive a comunidade. Juntamente com a ajuda da esposa e dos netos Silvio salientou:

Juntamos a família todo ano para comemorar o aniversário de minha mãe, que fez 94 anos este ano, no dia 16 de janeiro. Ela nasceu em 1913. Cada ano comemora no sítio de um dos irmãos. Além dessa, tem as festas de natal e ano novo. A festa das crianças na antiga escolinha da Aldeinha, onde a Cida minha filha, a esposa do Jorge reúne a criançada dos sítios vizinhos e faz várias brincadeiras. Tem também as festas da Igreja Sagrada Família, a Essiene que é muito católica e devota de Nossa Senhora ajuda nessas festas, aonde o padre Lothar da Igreja São José Operário vem rezar missa de dois em dois meses.

Sobre a fragmentação da terra entre os descendentes, que vem acontecendo em sua família desde a época de seu avô, não relutou em responder que: "foi muito bom e por isso, o ano passado, fiz a divisão com os meus filhos também, só falta fazer as escrituras".

A seguir, será apresentada a Planta do Lote 6 - Sítio Mamona e os cinco mapas (Mapa XII, Mapa XIII, Mapa IV, Mapa V e Mapa VI) das áreas que foram fragmentadas. 
PLANTA 10 - PLANTA DO LOTE 6 DESMEMBRADO DO LOTE BELÉM EM CONJUNTO NA FAZENDA CAMPO ALEGRE - SÍTIO MAMONA
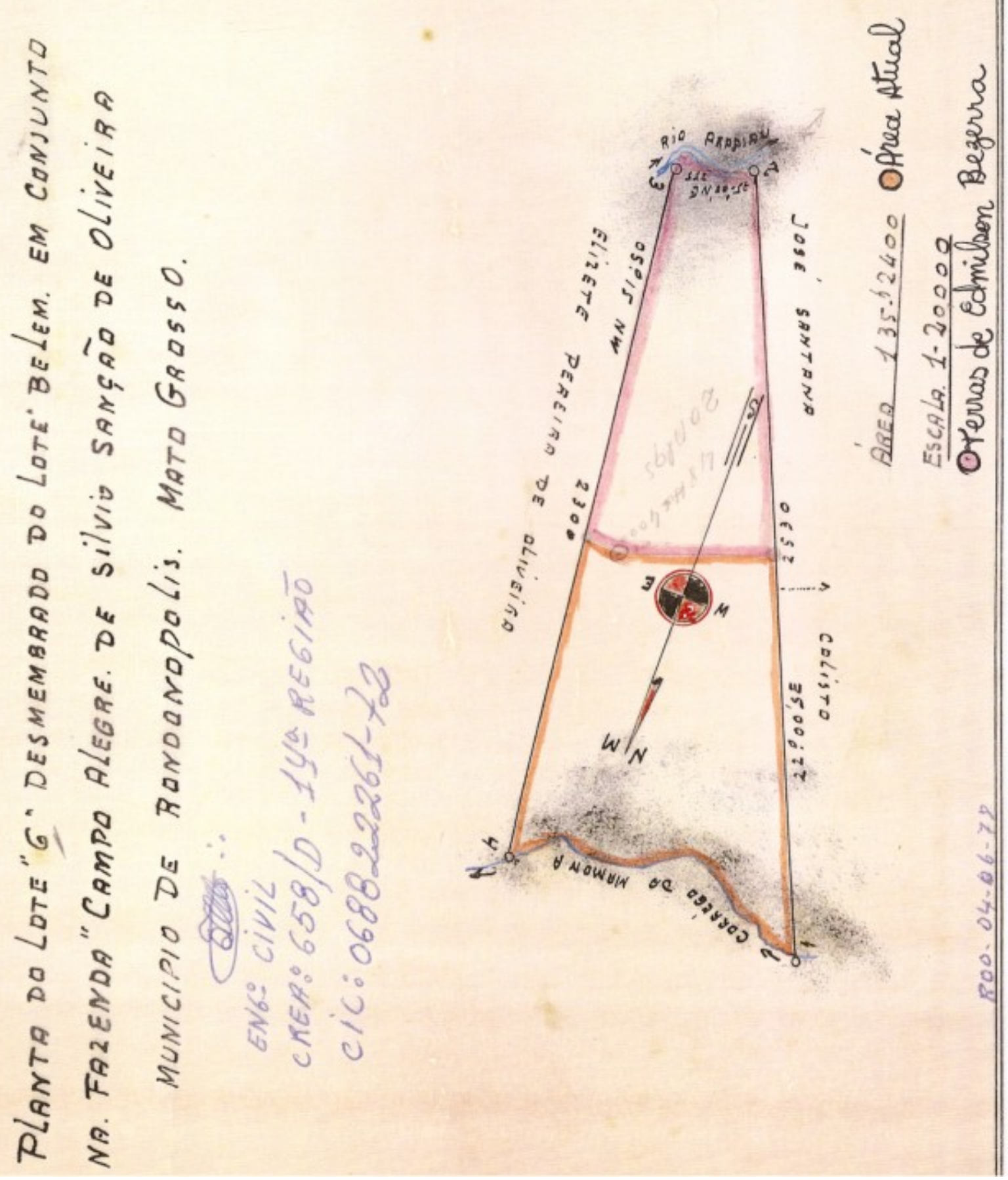


\section{MAPA XII - ESTÂNCIA SÃO FRANCISCO}
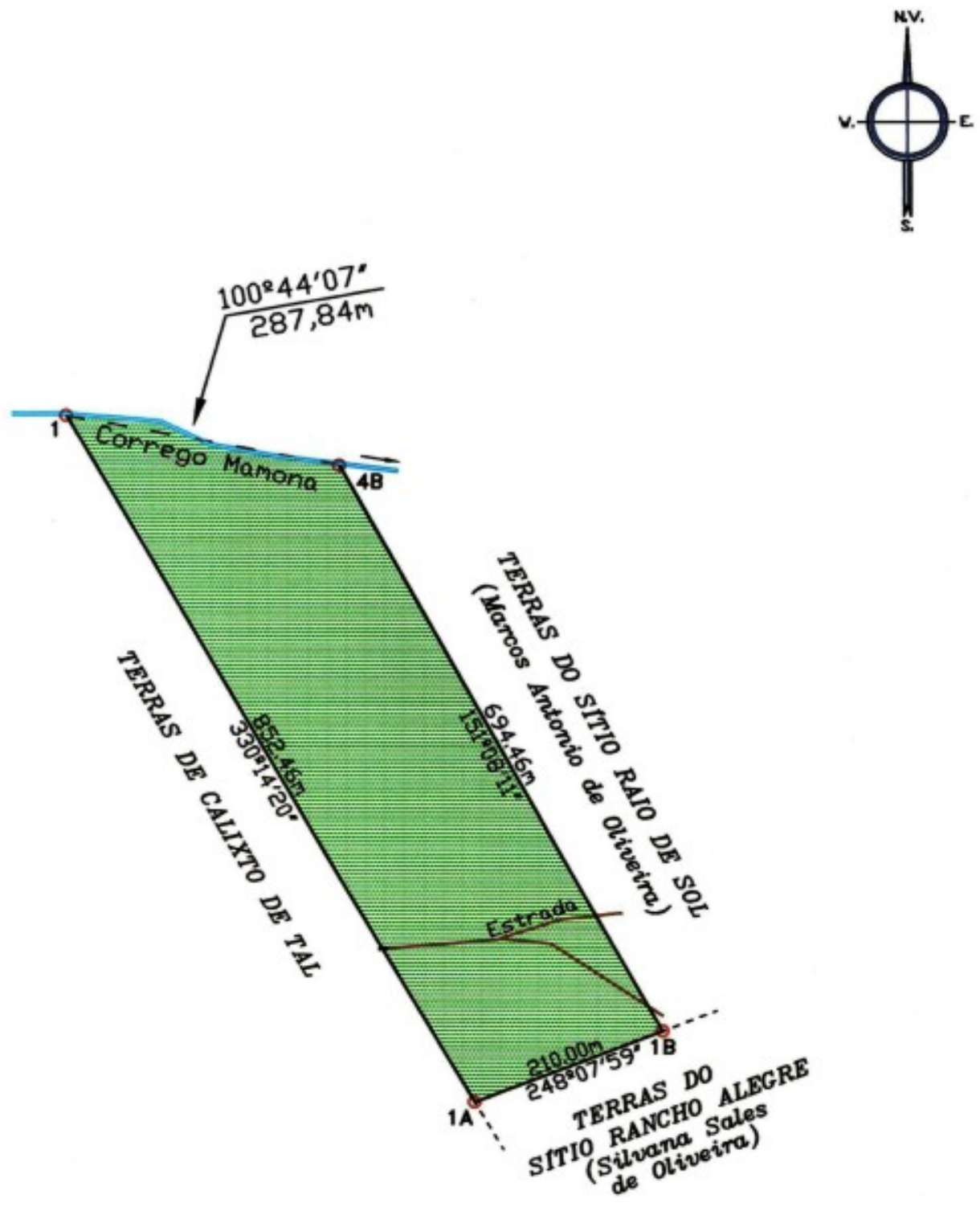

Obs: Área encontrada em campo - $16,5881 \mathrm{ha}$

\begin{tabular}{|c|c|c|c|}
\hline \multicolumn{3}{|c|}{ ESTÂNCIA S ÃO F RANCISCO } & RONDONÓPOLIS - MT. \\
\hline $\begin{array}{l}\text { ORIGEM: } \\
\text { LEVANTAMENTO TOPOGRAFICO }\end{array}$ & $\begin{array}{l}\text { PROPRIETARRIA: } \\
\text { Silvan } \\
\end{array}$ & es de Oliveira & Q \\
\hline $\begin{array}{r}\text { AREA DA MATRICULA: } \\
17,368 \mathrm{ha}\end{array}$ & $\begin{array}{l}\text { ESCALA: } \\
\qquad 1: 7.500\end{array}$ & $\begin{array}{l}\text { DATA: } \\
20 / 12 / 2006\end{array}$ & \\
\hline
\end{tabular}


MAPA XIII - SÍTIO RAIO DE SOL
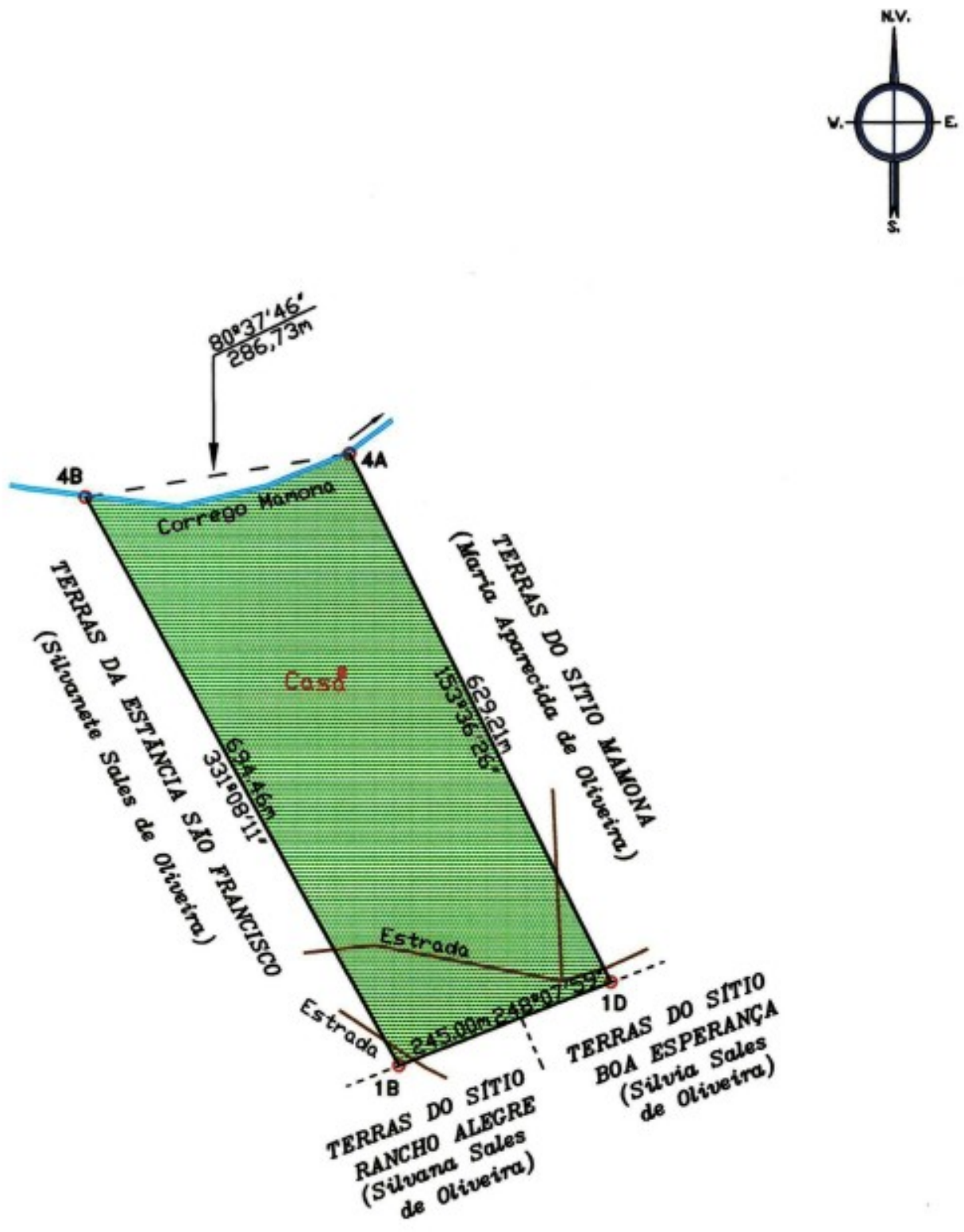

Obs: Área encontrada em campo - 16,5881ha

\begin{tabular}{|c|c|c|c|}
\hline \multicolumn{3}{|c|}{ SÍTIO RAIO DE SOL } & $\begin{array}{l}\text { MUNICIP1O: } \\
\text { RONDONÓPOLIS - MT. }\end{array}$ \\
\hline $\begin{array}{l}\text { ORIGEM: } \\
\text { LEVANTAMENTO TOPOGRAFICO }\end{array}$ & \multicolumn{2}{|c|}{$\begin{array}{l}\text { PROPRIETARIO } \\
\text { Marcos Antonio de Oliveira }\end{array}$} & \\
\hline $\begin{array}{r}\text { AREA DA MATRicul. } \\
17,368 \text { ha }\end{array}$ & $\begin{array}{ll}\text { escala: } & \\
& 1: 7.500\end{array}$ & DATA $20 / 12 / 2006$ & 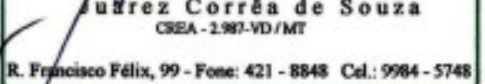 \\
\hline
\end{tabular}




\section{MAPA XIV - SÍTIO MAMONA}

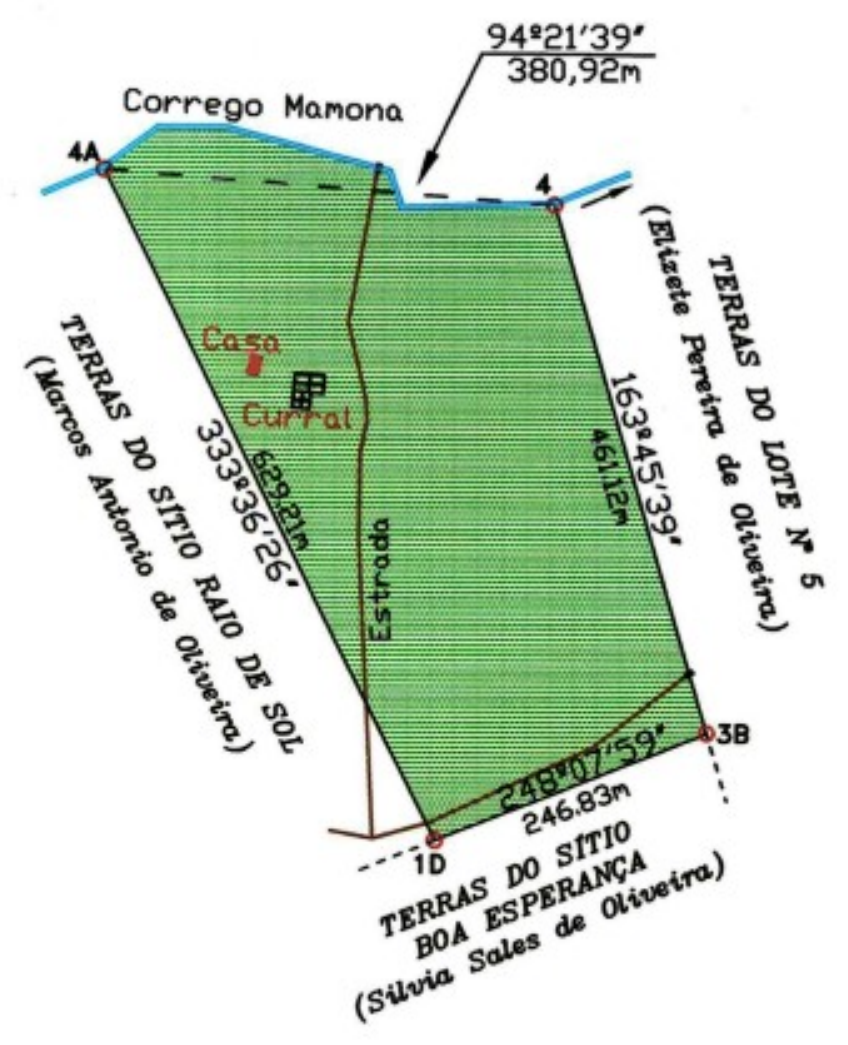

Obs: Área encontrada em campo - 16,5881ha

\begin{tabular}{|c|c|c|c|}
\hline \multicolumn{3}{|c|}{ SÍTIO MAMONA } & $\begin{array}{l}\text { MUNICIPIO- } \\
\text { RONDONÓPOLIS - MT. }\end{array}$ \\
\hline $\begin{array}{l}\text { ORIGEM: } \\
\text { LEVANTAMENTO TOPOGRAFICO }\end{array}$ & \multicolumn{2}{|c|}{$\begin{array}{l}\text { PROPRIETÁRIA: } \\
\text { Maria Aparecida de Oliveira }\end{array}$} & \\
\hline $\begin{array}{r}\text { AREA DA MATRICULA: } \\
17,368 \mathrm{ha}\end{array}$ & $\begin{array}{l}\text { ESCALA: } \\
1: 7.500\end{array}$ & $\begin{array}{l}\text { DATA: } \\
20 / 12 / 2006\end{array}$ & 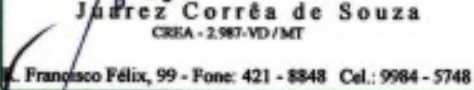 \\
\hline
\end{tabular}


MAPA XV - SÍTIO RANCHO ALEGRE
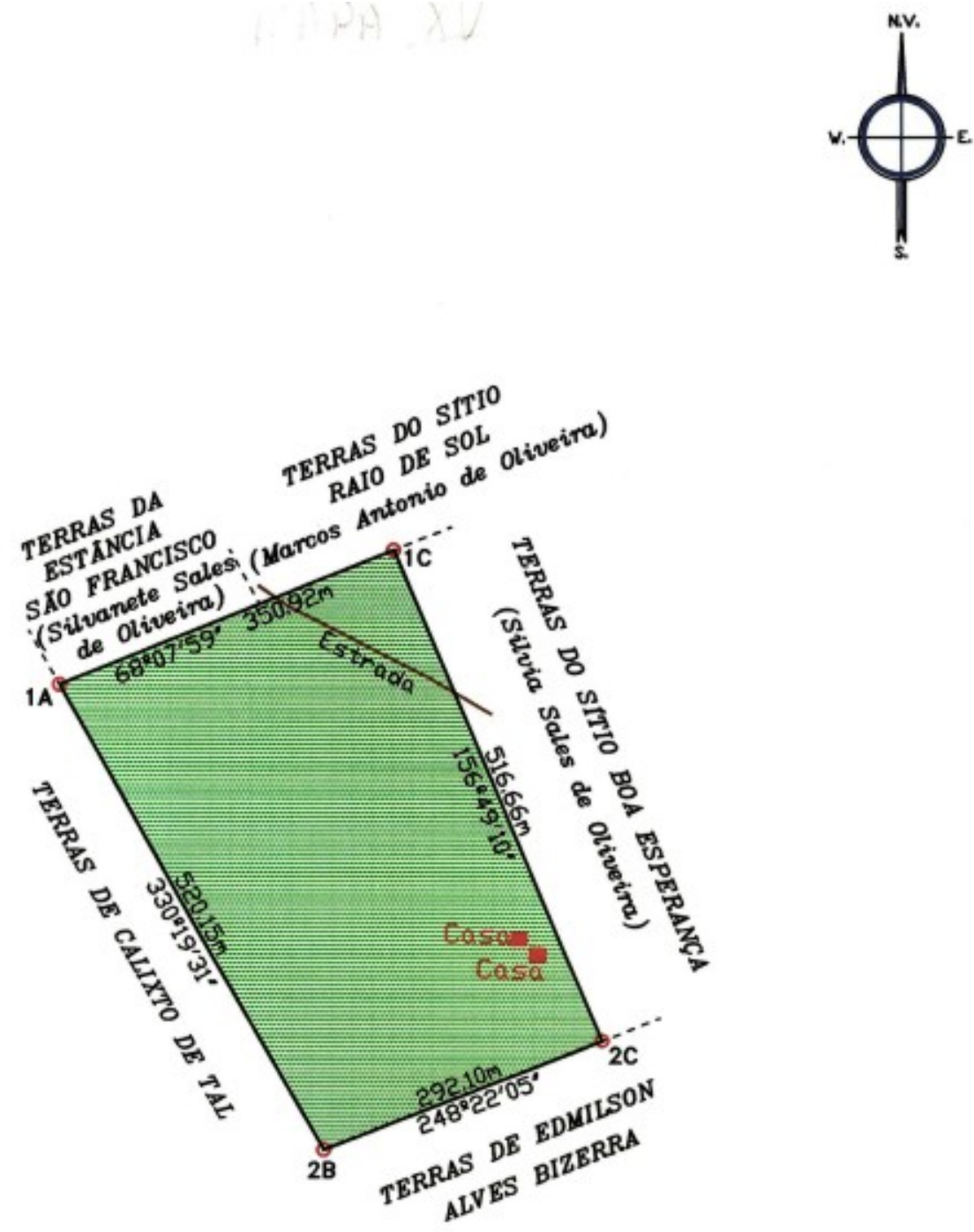

Obs: Área encontrada em campo - 16,5881ha

\begin{tabular}{|c|c|c|c|}
\hline \multicolumn{3}{|c|}{ SÍTIO RANCHO ALEGRE } & $\begin{array}{l}\text { MUNICIPIO. } \\
\text { RONDONÓPOLIS - MT. }\end{array}$ \\
\hline $\begin{array}{l}\text { ORIGEM: } \\
\text { LEVANTAMENTO TOPOGRAFICO }\end{array}$ & \multicolumn{2}{|c|}{$\begin{array}{l}\text { PROPRIETARIA: } \\
\text { Silvana Sales de Oliveira }\end{array}$} & Cocng \\
\hline $\begin{array}{r}\text { AREA DA MATRICULA } \\
17,368 \mathrm{ha}\end{array}$ & $\begin{array}{ll}\text { ESCALA: } & \\
& 1: 7.500\end{array}$ & $20 / 12 / 2006$ & $\begin{array}{l}\text { Ca de Souza } \\
\text { VD/mT }\end{array}$ \\
\hline
\end{tabular}




\section{MAPA XVI - SÍTIO BOA ESPERANÇA}
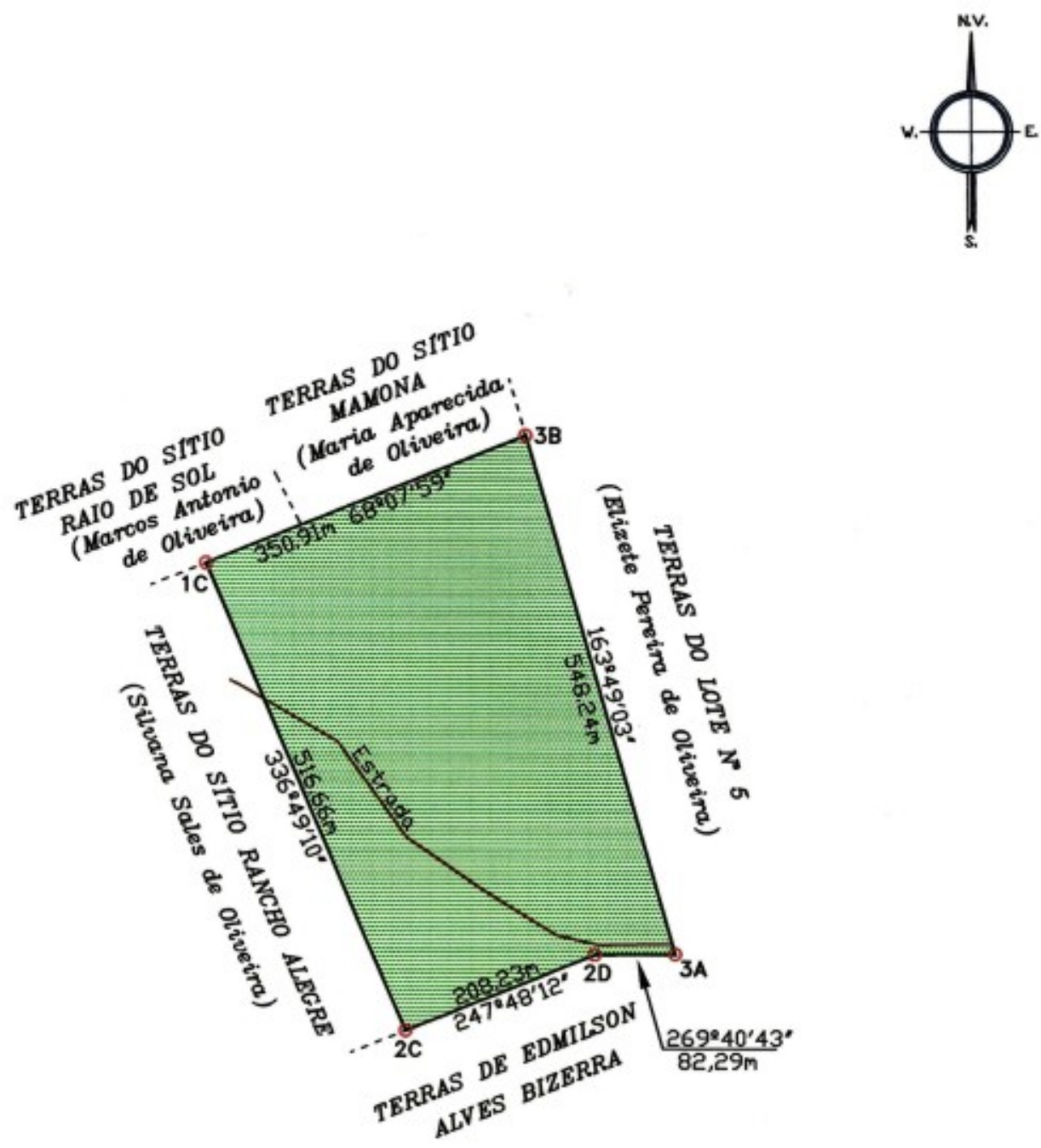

Obs: Área encontrada em campo - 16,5881ha

\begin{tabular}{|c|c|c|c|}
\hline \multicolumn{3}{|c|}{ SÍTIO BOA ESPERANCAA } & RONDONÓPOLIS - MT. \\
\hline \begin{tabular}{|l|} 
ORIGEM: \\
LEVANTAMENTO TOPOGRAFICO
\end{tabular} & \multicolumn{2}{|c|}{ Silvia Sales de Oliveira } & $\alpha$. \\
\hline $\begin{array}{r}\text { AREA DA MATRICULA: } \\
17,368 \text { ha }\end{array}$ & $\begin{array}{l}\text { ESCALA: } \\
\\
\\
1: 7.500\end{array}$ & $\begin{array}{l}\text { DATA } \\
20 / 12 / 2006\end{array}$ & R fraftisco Felix, $99-$ Pone: $421-8848$ Cel:-9984-5748 \\
\hline
\end{tabular}


Rita de Oliveira Siqueira, casada com senhor Benigno Nunes Siqueira desde 1959, recebeu como doação de seus pais o "Lote 7" com uma área de 135,24 ha, (Planta 11), desmembrado da Fazenda Campo Alegre, na região da Aldeinha que, a partir de então, passou a chamar-se "Sítio Três Marias". Na época da doação, Rita vendeu para seu irmão Teodoro uma área equivalente a 4,84 ha da porção desmembrada da Aldeinha, cuja área não está mencionada nesta Planta.

Rita e Benigno tiveram seis filhos, três homens Milton Jorge, Benigno e José Antônio e três mulheres Sandra Maria, Rute Maria e Maria Auxiliadora. O único que mora na propriedade é o Jorge, atualmente casado com Maria Aparecida Oliveira sua prima, ambos trabalham na Escola Municipal Rural 14 de Agosto, no assentamento Chico Mendes, onde ela é Diretora e ele professor. Ele é licenciado em Geografia e ela em Pedagogia, com especialização em Psicopedagogia. Tanto um quanto o outro já foram casados anteriormente. Ela tem três filhos (um casal do primeiro casamento e uma menina filha do Jorge) que moram com eles no Sítio e o Jorge tem três filhos: dois homens e uma mulher; o mais velho mora com a mãe em Campo Grande/MS e os dois mais novos com a avó Rita em Cuiabá. Os filhos da Cida estudam na Escola onde os pais trabalham.

A propriedade é banhada pelo Córrego Mamona na margem direita, que inclusive serve de área de limite com a propriedade de seu irmão Silvio, cujo rio tem uma cachoeira (Foto 04) que serve de área de lazer para todos os familiares, bem como aos amigos que os visitam. Não se pode esquecer do Morro da Cotia (Foto 05) que, segundo aqueles que conseguiram escalá-lo, a paisagem vista dali é maravilhosa. De acordo com Milton Jorge, filho de Rita, a propriedade está a $32 \mathrm{~km}$ da cidade (Ver Mapa XX- Croqui de Localização, p: 248).

A região é conhecida como Aldeinha e, de acordo com o Jorge e $D^{a}$. Leonila, porque, em tempos idos, existia naquela região uma tribo indígena; daí a alcunha. Acredita-se ser a mesma mencionada por Benedita e seus tios Valdivino e Gerson, família Ferreira.

Utilizam, como meio de transporte, o ônibus do Bananal que leva as crianças para a escola no Assentamento Chico Mendes (é grátis), além do ônibus de linha que passa três vezes por semana indo até a cidade. Sem contar que possuem um carro (da época do senhor Benigno) e uma moto, usados tanto para ir trabalhar, quanto para ir à cidade ou mesmo passear na casa dos tios que moram nos sítios na redondeza. 
A casa de morada (Foto 15) é de alvenaria, com peças amplas bem arejadas, banheiro interno, água encanada da mina/nascente, vinda pela força da gravidade, fornecendo aos moradores certo conforto.

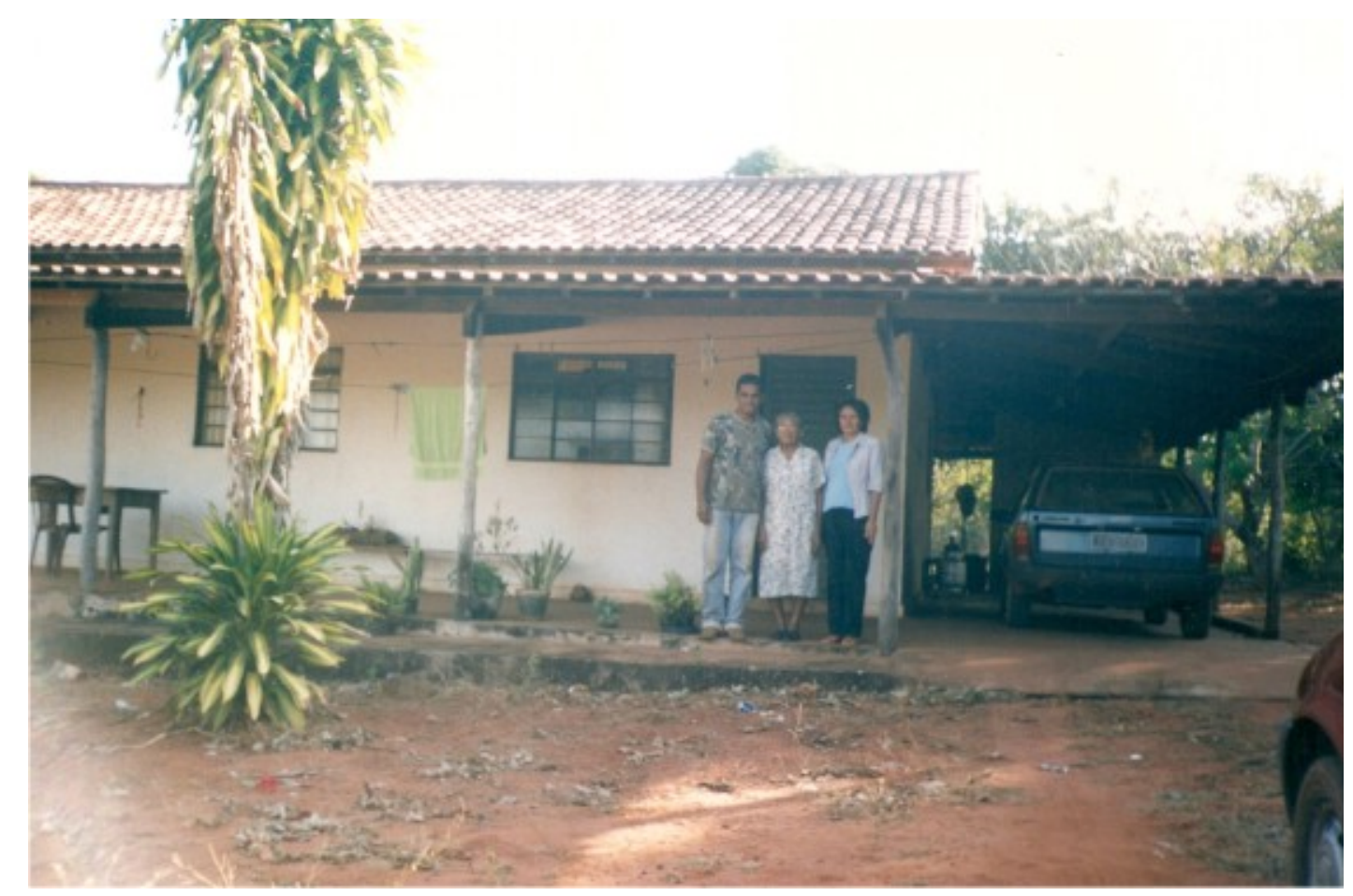

Foto 15 - Sede do Sítio Três Marias. Milton Jorge, Da․ Leonila e Elizete. (LIMA, LMS//2005).

São usuários de televisão colorida com antena parabólica, aparelho de som, celular rural e celular com antena. Na propriedade tem luz elétrica desde 1997. Em entrevista, Jorge informou que: "o prefeito Percival Muniz beneficiou-nos trazendo a rede-mestra, naquela época $11 \mathrm{Km}$ e hoje já possui mais ou menos uns $70 \mathrm{Km}$ de rede, indo da Aldeinha até a Cabeceira do Café, o rebaixamento foi feito particular, cada um comprou seu transformador".

A fala a seguir é parte da entrevista realizada com Milton Jorge em 1998, para meu trabalho de mestrado, na qual ele tece comentários sobre a Associação:

A Associação de Pequenos Produtores Rurais Aldeinha surgiu aos 30/11/86, com um grupo de 20 produtores. Daí pra cá, fizemos vários trabalhos, inclusive a ajuda na implantação da rede de energia elétrica - a princípio, só a Aldeinha. Atualmente, estende-se para a região do Bananal e Cabeceira do Café. Resolvemos um problema de mais de 30 anos. A Associação está com um projeto junto ao governo do Estado, para adquirir um trator com implementos agrícolas a fim de modernizar cada vez mais a pequena propriedade. (Lima, 2000: 76) 
De acordo com Jorge, são filiados ao Sindicato dos Trabalhadores Rurais de Rondonópolis, onde o mesmo já trabalhou várias vezes, tendo sido, inclusive, presidente por três anos, no período de $1^{\circ}$ de maio de 2001 até $1^{\circ}$ de maio de 2004 . Comentou ele:

Enquanto presidente consegui juntamente com os demais membros da diretoria um trator para o Sindicato, que pode ser utilizado por todos os associados; uma máquina de beneficiamento de arroz para o Assentamento João Pessoa (feito pelo Sindicato somente para filhos de Assentados); houve intensa participação no Conselho Municipal de Saúde, onde Cosmo Damião de Freitas um dos membros da diretoria fazia parte do conselho de saúde. Neste período, foram criados vários PSF - Posto de Saúde Familiar na zona rural, onde com isso passou a existir a visita de médicos e odontólogos nessas áreas, bem como o aumento das mesmas em determinadas regiões; trouxemos (o Sindicato e o vereador Juca Lemos) no $1^{\circ}$ semestre de 2004, no Canadá Country Clube, o Presidente do INCRA para uma audiência pública, onde o mesmo fez esclarecimentos ou procedimentos para que os agricultores familiares assentados pudessem saber como ficaria a questão da venda de terras em assentamentos; foi feita a reforma do prédio do Sindicato; houve a regularização do pagamento tanto de funcionários quanto da diretoria; criou-se o Conselho Municipal Rural Sustentado - em atividade até hoje e realizamos em 26/03/2004 o I Seminário de Agricultura Familiar - Rondonópolis/MT - Por Custeio/Financiamento e Assistência Técnica para Produção e Criação da Secretaria Municipal de Desenvolvimento Rural, onde o palestrante principal: Dr. José Batista - Assessor Especial do Ministério do Desenvolvimento Agrário - MDA, fez uma exploração sobre as políticas agrícola e agrária (crédito fundiário, custeio/investimento para produção e infra-estrutura) do Governo Federal. Todos esses benefícios estão a disposição de todos os agricultores, principalmente os filiados ao Sindicato.

$\mathrm{Na}$ fala transcrita acima, Jorge expõe os benefícios que o Sindicato dos Trabalhadores Rurais oferece aos seus associados, e a participação dos membros desse sindicato em outros conselhos existentes no município, garantindo amplitude nas vantagens que poderão ser usufruídas por seus contribuintes. A criação de PS Posto de Saúde - na zona rural foi uma conquista muito grande, uma vez que a maioria dos moradores não tem meio de transporte para vir até a cidade à procura de médicos. Além disso, a agente de saúde comunitária realiza visitas nas residências, dando assistência aos casos mais graves.

O trabalho realizado por Milton no Sindicato teve seu reconhecimento. Em 20/03/2004 recebeu uma Moção de Aplauso concedida pela Câmara dos Vereadores de Rondonópolis, pelos relevantes serviços prestados frente ao Sindicato de Trabalhadores Rurais de Rondonópolis com extensão a São José do 
Povo e Itiquira durante seus três anos de mandato. Isso por solucionar, desde problemas básicos de gerenciamento interno da própria instituição até a realização de diversos convênios, parcerias e acordos, que dinamizaram e renovaram os ânimos de todos os associados.

Em 1998, o Sítio Três Marias foi beneficiado com dois programas: um municipal e outro federal. Destacarei aqui parte de sua entrevista citada em meu trabalho de mestrado.

Jorge comentou que terem sido beneficiados com dois projetos da PRONAF Programa Nacional de Fortalecimento da Agricultura Familiar que é um programa Nacional e o Programa Lavouras Comunitárias - Estadual. Disse ele:

Do PRONAF, recebemos um custeio para plantio de subsistência, investimento (reformas, construção de curral, barracão, irrigação e cercas). Já do Programa Lavouras Comunitárias recebemos muda, adubos, inseticidas, fungicidas e o preparo do solo. No princípio, receberíamos o dinheiro, mas posteriormente recebemos as mudas e fizemos as plantações. Neste projeto a devolução é feita em produtos e, graças a DEUS, já pagamos com as próprias frutas produzidas na localidade. (Lima, 2000: 73)

Optaram pelo plantio do maracujá e abacaxi e a dívida já havia sido paga a PROSOL com as próprias frutas. Esclareceu que, com o apoio do governo e dos órgãos estaduais, os pequenos agricultores reunidos em associações teriam condições de progredir. Disse ainda:

Voltando a falar do PRONAF, fizemos um projeto via EMPAER, junto com o técnico Benjamim. Recebemos um montante de $10 \mathrm{mil}$ reais (5 mil reais para irrigação, 4 mil para rebaixamento da rede de energia elétrica e mil reais para o preparo da terra). A dívida é com o Banco do Brasil e começará a ser paga no ano 2002 - temos cinco anos de carência. Tanto o Programa Lavouras Comunitárias como o PRONAF só foi possível graças à existência de grupos de pequenos produtores organizados em Associações. Apesar de que os projetos foram individuais. (Lima, 2000: 73)

Essa fala é importante, pois demonstra a necessidade de uma organização camponesa, unindo-se em associações para poder conquistar força e espaço.

A credibilidade que Milton Jorge demonstrava em relação ao poder público em 1989, hoje mudou, espera que a política agrícola dos governos federal, estadual e municipal, venha realmente ao encontro das necessidades e anseios da população rural, em especial aos menos favorecidos:

Espero que desenvolvam uma política que venha de encontro com as necessidades do trabalhador rural. Tanto o proprietário como 
alguém que não é, quando consegue alguma coisa tipo financiamento, ou o juro é muito alto ou demora a sair. Quando saí, já não dá mais para fazer o que foi proposto, sem contar que parte do dinheiro fica para o banco. Existem muitos casos de conhecidos nossos endividados com o banco e correndo o risco de perder a terra, muitos nem arriscam fazer financiamentos por medo. Não existe programa de governo destinado a esse pequeno produtor. Ele sobrevive por sua garra. Fico horrorizado com tanta falcatrua, com o desperdício do dinheiro público. Segundo um gerente do Banco do Brasil, é mais fácil fazer um projeto de 200 mil reais para um grande produtor do que fazer 20 projetos para pequenos produtores. Estão sempre inviabilizando, dizendo que a terra é fraca, etc. Faz programas excluindo alguém que tenha vocação, compromisso com a terra. Tem muita propaganda enganosa.

Nota-se nessa fala de Jorge algo muito importante, o descaso do poder público pelos projetos do pequeno produtor, em que o gerente do banco deixa clara a preferência em trabalhar em prol do grande produtor. A fala também revela que o camponês percebe que o governo está do lado do capital.

A preocupação dos camponeses em relação a financiamentos realizados em banco foi discutida por Bombardi (2004:257) em seu trabalho com os sitiantes do Bairro Reforma Agrária:

Os bancos, ao concederem empréstimos, no procedimento normal e legal que fazem, ficam com uma parte da renda da terra camponesa. Entretanto, têm também realizado procedimentos ilegais de cobranças de juros e multas impraticáveis do ponto de vista da legislação especifica de credito rural, o que tem acarretado praticamente a impossibilidade da familia camponesa quitar seu debito ano após ano. Vi, pelo menos dois casos em que os camponeses venderam uma faixa de terra de seus sítios para quitar suas dívidas com o banco.

Em relação ao exposto por Bombardi, pode-se citar o caso de Eliete, que realizou um empréstimo no banco, pelo Pronaf, para comprar quatro vacas leiteiras, com intuito de aumentar seu plantel e foi obrigada a vender duas vacas mais velhas por um preço irrisório a fim de saldar a dívida.

O sítio Três Marias já foi referência no município de Rondonópolis pelas atividades que a família desenvolvia, Hoje, por conta da morte do Sr. Benigno, as atividades cessaram. E a terra já foi fragmentada. Nesta fala, Jorge expõe os motivos.

Após o falecimento de meu pai em 2001, minha mãe não quis mais morar no sítio, agora ela mora em Cuiabá/MT com dois de meus filhos, mas também passa boa parte do tempo em Campo Grande/MS, onde moram três de meus irmãos. Sendo assim, 
achamos melhor dividir o sítio, só que nem todos vão ficar com a terra, somente nós, eu e Sandra ficaremos. Assim mesmo, se conseguir um dinheiro, vou comprar a parte dela. Ela só venderá se for pra mim, pelo contrário continuará com a propriedade, pois não quer que saia das mãos da família. Acho um absurdo, pois fui à procura de um empréstimo pelo Banco da Terra, mas não posso fazer porque sou herdeiro direto. Quanto à questão da repartição natural é bom, pois assim garante o trabalhador no campo.

A divisão foi realizada no papel e Rita entrou como herdeira juntamente com os filhos. Como a intenção dela e dos quatro filhos é vender suas áreas, a propriedade foi dividida em três lotes. Uma área de 96,52 ha, denominada Sítio Nossa Senhora Aparecida, que se encontra em nome de Rita de Oliveira Siqueira e duas áreas de 19,36 ha cada, em nome de Milton Jorge de O. Siqueira, Sítio Três Marias I, e outra área em nome de Sandra Maria de O. Siqueira, Sítio Três Marias II. Como o Milton Jorge mora no sítio, ficou com a parte da sede.

O sítio, em relação aos grandes latifúndios existentes em Rondonópolis, é pequeno e o que produze atualmente é apenas para subsistência. A renda maior fica por conta do leite, que é vendido para o Laticínio Nutribom de Rondonópolis. A produção é pouca neste período do ano, devido à seca, chegando a mais ou menos 30 litros diários, vendidos por bagatela. Vendem também ovos caipiras na cidade e contam com o salário de professor de ambos.

Além de trabalhar fora, o pouco tempo que lhe sobra, Jorge cuida dos afazeres do sítio, contando com a ajuda do tio/sogro, que é seu vizinho mais próximo. Possui muita garra e amor em relação ao trabalho que desenvolve, tanto quanto professor como camponês, ou seja, trabalhador rural. Pode-se dizer que se orgulha de ser homem do campo.

A seguir, está exposta a Planta XI do Lote 7 - Sítio Três Marias, os Mapas XVII, XVIII e XIX da divisão da propriedade e o Mapa XX - Croqui de Localização (que foi elaborado para anexar ao projeto de irrigação desenvolvido em 1997) onde se encontra em destaque o Sítio Santa Adriana de Teodoro, antiga Escola Municipal Rural Aldeinha, e funciona, hoje, a Associação e o Sítio Três Marias. 
PLANTA 11 - PLANTA DO LOTE 7 DESMEMBRADO DA FAZENDA CAMPO ALEGRE - SÍTIO TRÊS MARIAS

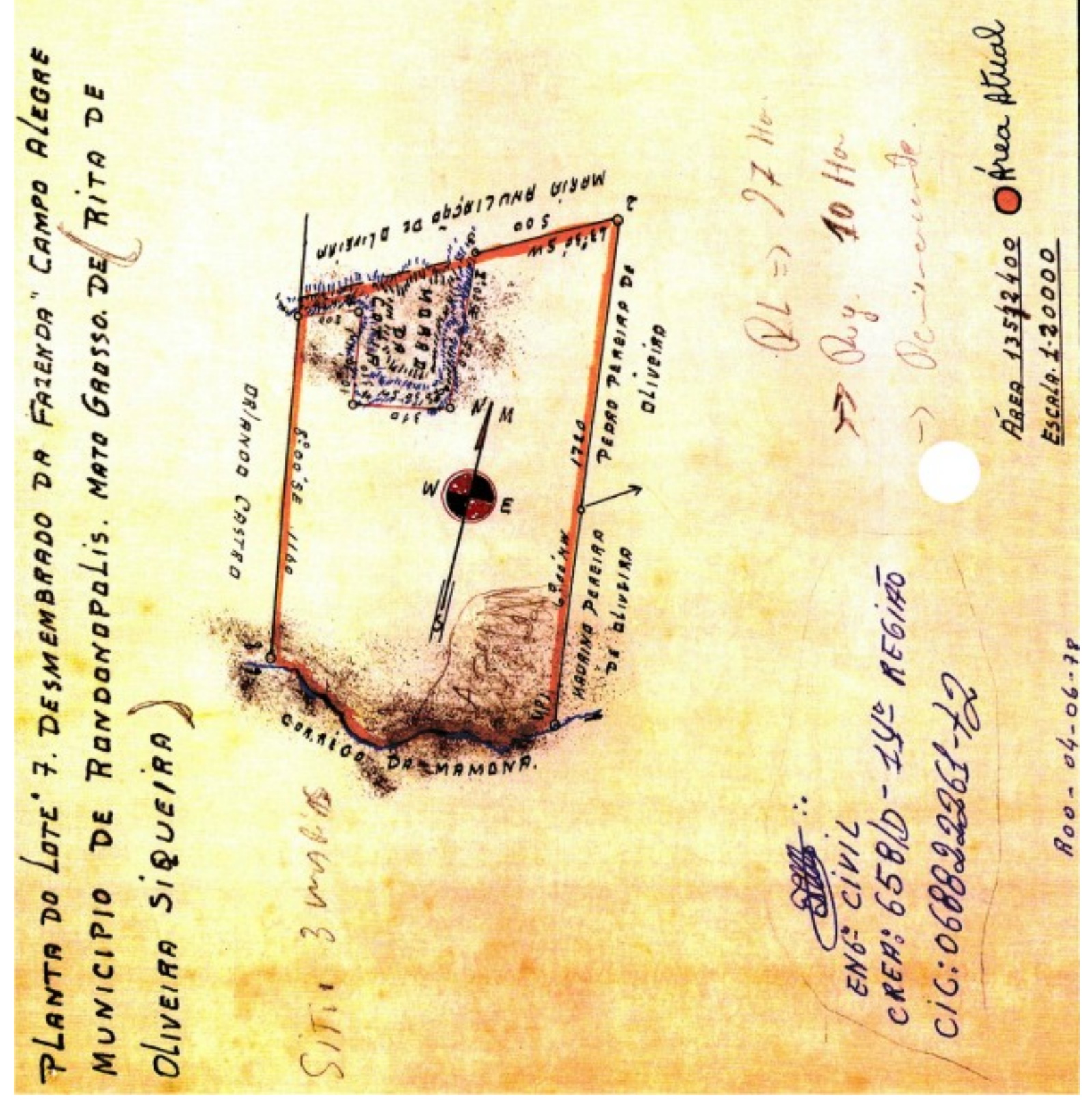


MAPA XVII - SÍTIO NOSSA SENHORA APARECIDA
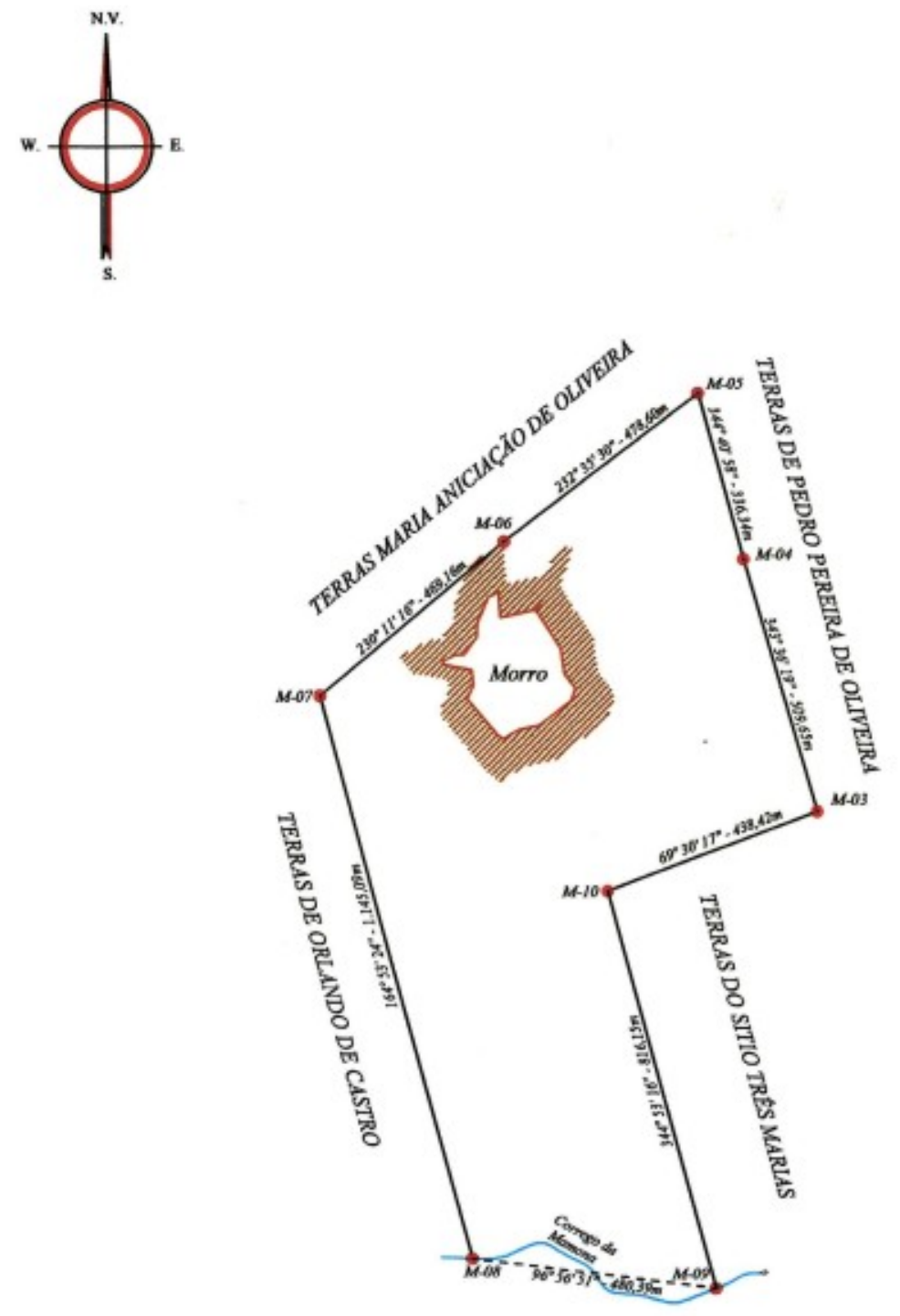

DECLARAÇÃO:

Eu, Rita de Oliveira Siqueira e eu, Milton de Oliveira Siqueira, declaramos estar

ciente que a área constante neste mapa inclui-se o morro da Cutia para diminuir

a diferença entre a área medida e a da escritura, que mesmo assim faltam 03,26ha

Escala Gráfica:

Rita de Oliveina Siqueira

Miltan Jarge de Oliveira Siquetina

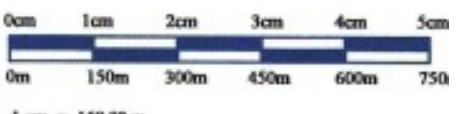

$1 \mathrm{~cm}=150,00 \mathrm{~m}$

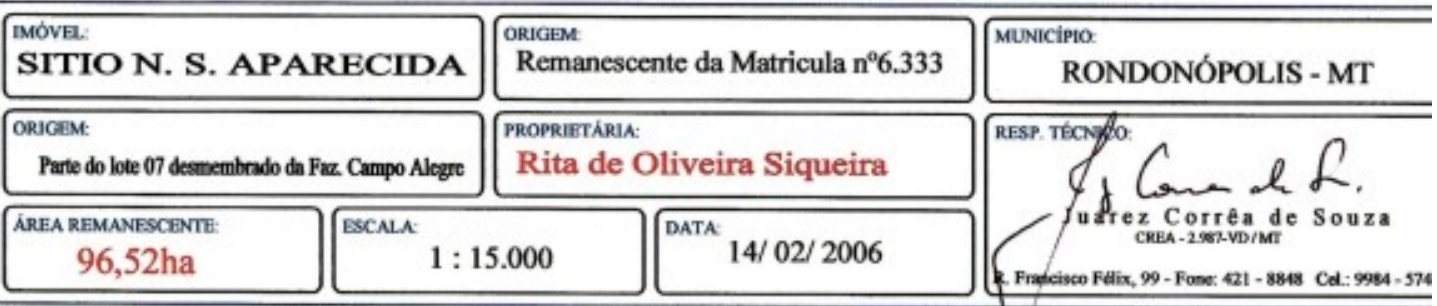


MAPA XVIII - SÍTIO TRÊS MARIAS I

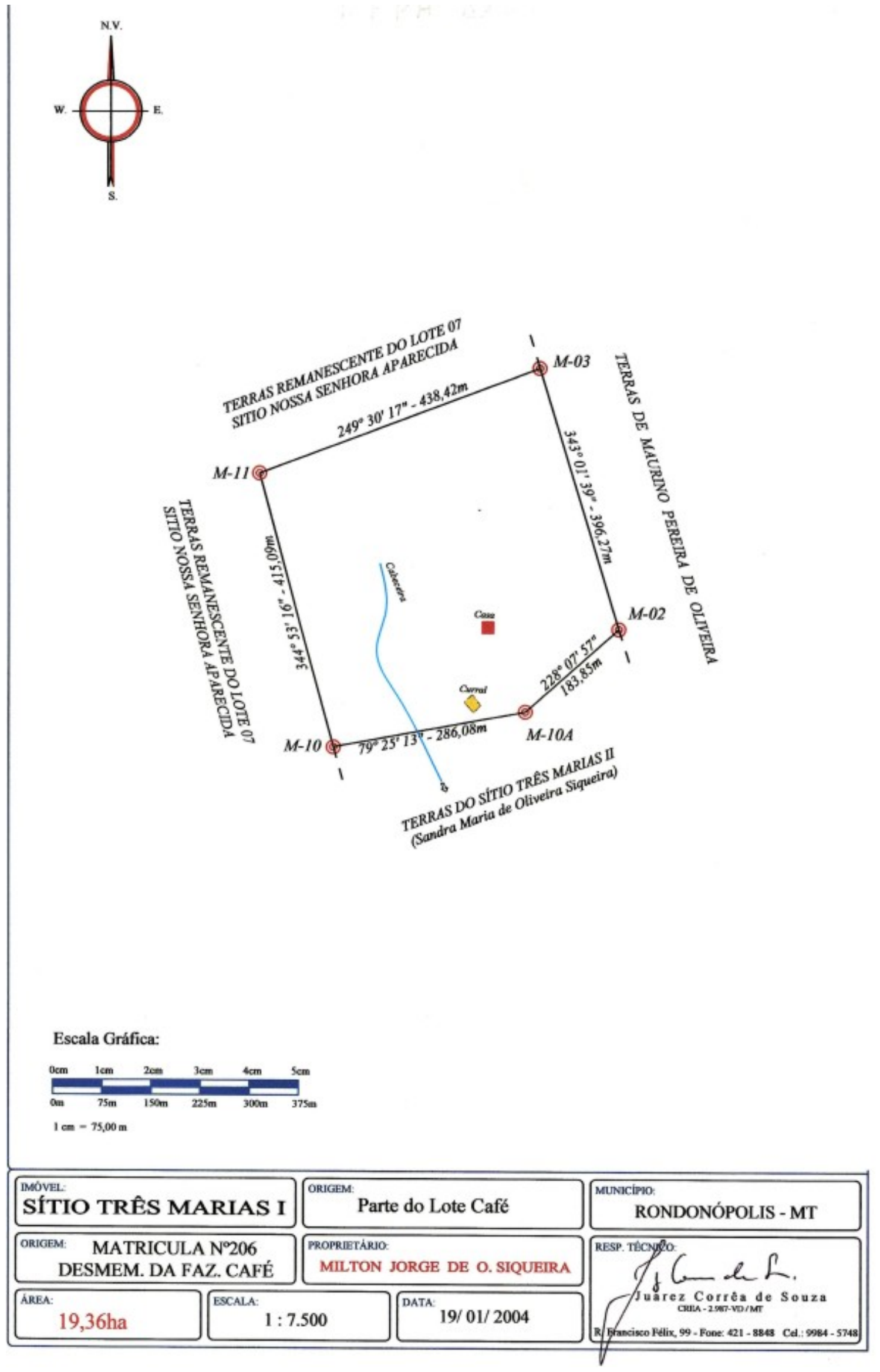


MAPA XIX - SÍTIO TRÊS MARIAS II
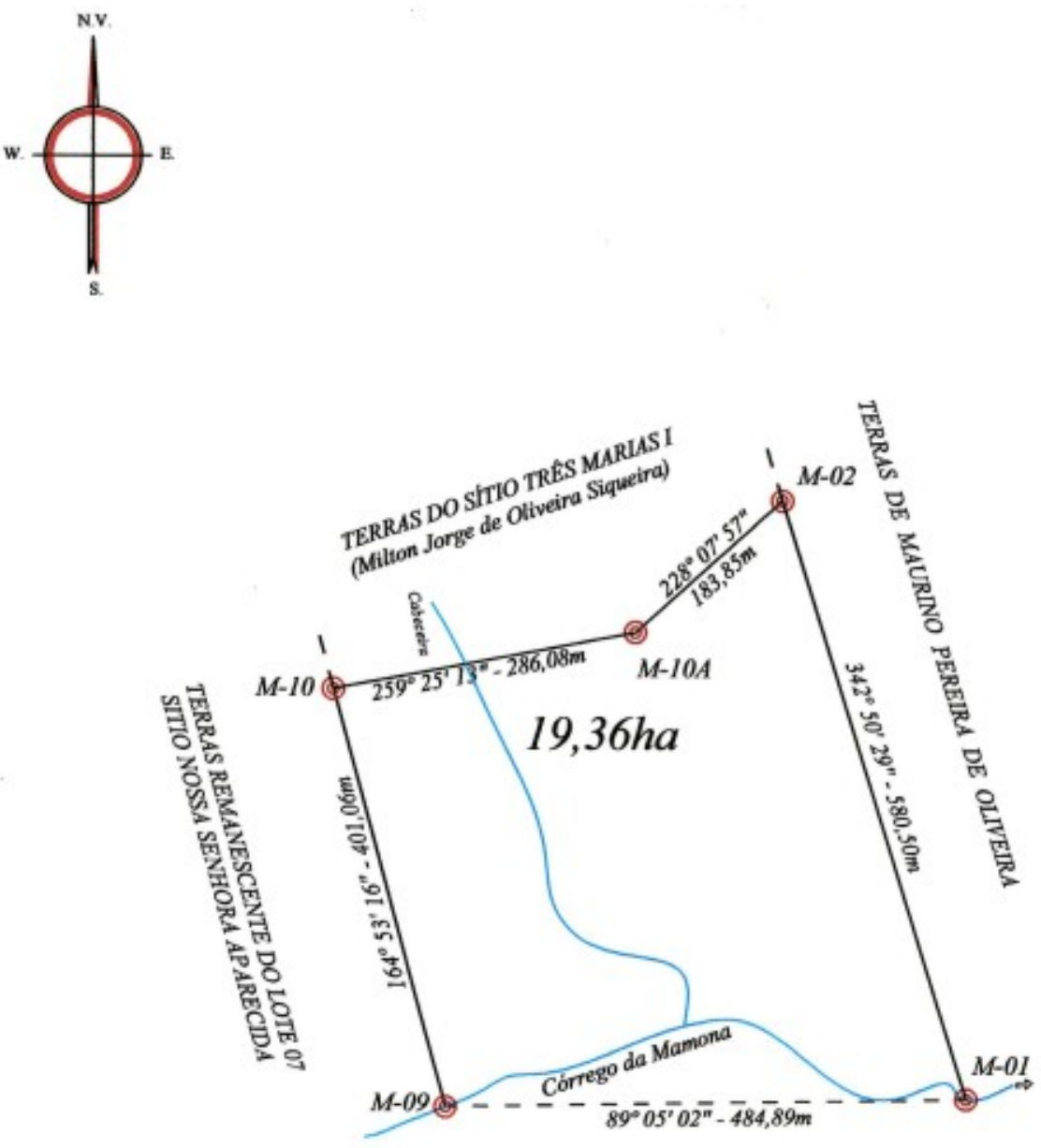

Escala Gráfica:

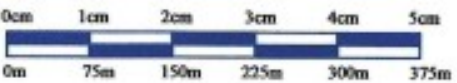

$1 \mathrm{~cm}=75,00 \mathrm{~m}$

Obs: Planta elaborada apartir de dados da matricula n 206, e do mapa da aquopecuaria Morro Vermelho, fornecida pelo proprietario.

\begin{tabular}{|c|c|c|c|}
\hline \multicolumn{2}{|c|}{$\begin{array}{l}\text { IMÓVEL: } \\
\text { SITTIO TRÊS MARIAS II }\end{array}$} & $\begin{array}{l}\text { ORIGEM: } \\
\text { Parte do Lote Café }\end{array}$ & $\begin{array}{l}\text { MUNICiP10: } \\
\text { RONDONÓPOLIS - MT }\end{array}$ \\
\hline $\begin{array}{r}\text { ORIGEM: MATR } \\
\text { DESMEM }\end{array}$ & 06 & $\begin{array}{l}\text { PROPRITT́RIO. } \\
\text { SANDRA MARIA DE O. SIQUEIRA }\end{array}$ & \\
\hline ÁREA: 19,36 ha & $\begin{array}{r}\text { ESCALA: } \\
1: 7\end{array}$ & DATA: $19 / 01 / 2004$ & $\begin{array}{l}\text { de Souza } \\
\text { ner } \\
-8948 \text { Ced: } 9984-5748\end{array}$ \\
\hline
\end{tabular}




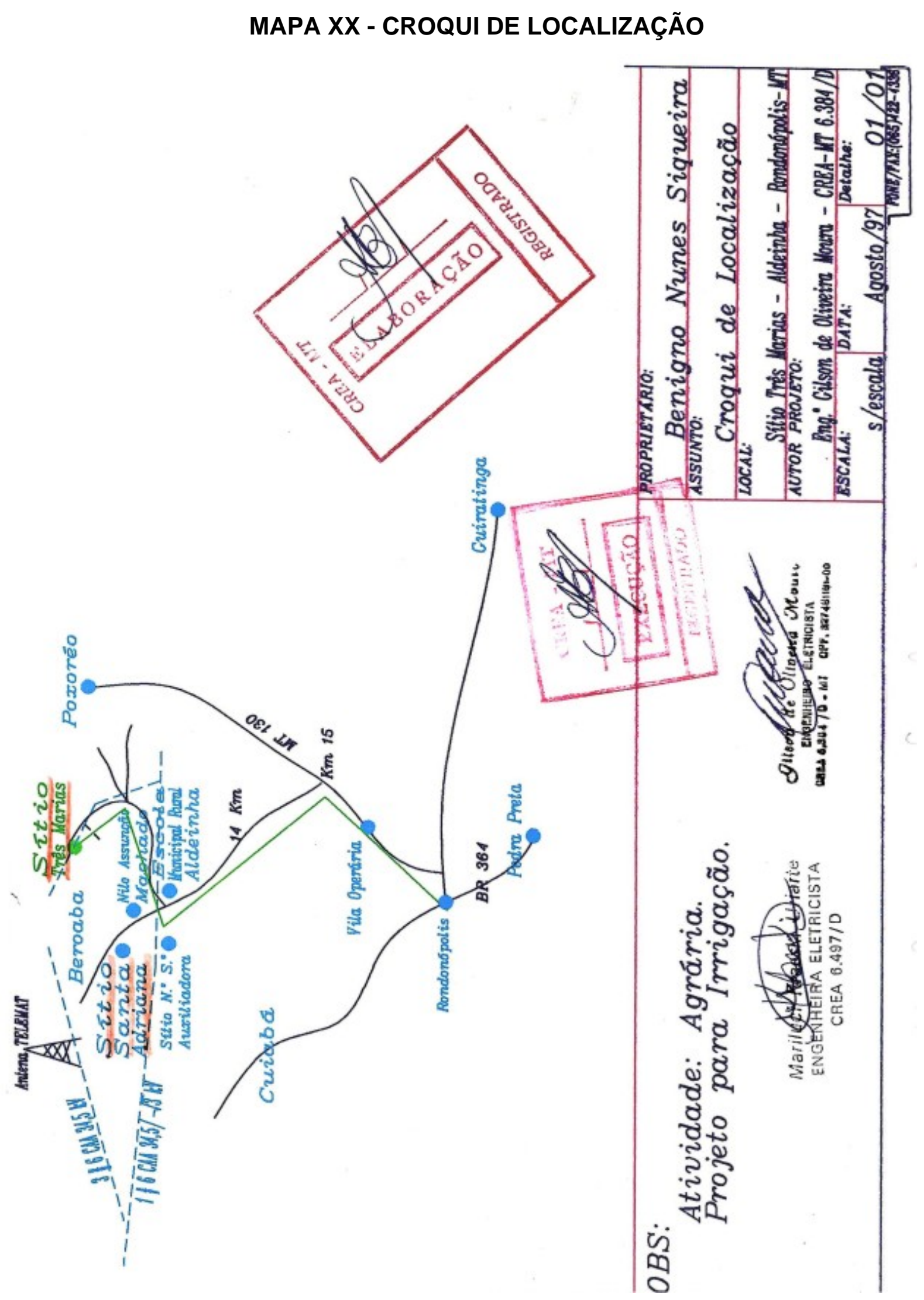




\section{FAMÍLIA FERREIRA}

\section{Saudadede Minha Terra}

Composição: Goiás / Belmonte

De que me adianta viver na cidade Se a felicidade não me acompanhar Adeus, paulistinha do meu coração Lá pro meu sertão quero voltar Ver a madrugada, quando a passarada Fazendo alvorada começa a cantar Com satisfação arreio o burrão Cortando o estradão saio a galopar E vou escutando o gado berrando Sabiá cantando no jequitibá

Por nossa senhora, meu sertão querido Vivo arrependido por ter te deixado Esta nova vida aqui na cidade De tanta saudade, eu tenho chorado Aqui tem alguém, diz que me quer bem Mas não me convém, eu tenho pensado Eu digo com pena, mas essa morena Não sabe o sistema que eu fui criado Tô aqui cantando de longe escutando Alguém está chorando com o rádio ligado

Que saudade imensa do campo e do mato Do manso regato que corta as campinas Aos domingos ia passear de canoa Nas lindas lagoas de águas cristalinas Que doce lembrança daquelas festanças Onde tinham danças e lindas meninas Eu vivo hoje em dia sem ter alegria O mundo judia, mas também ensina Estou contrariado, mas não derrotado Eu sou bem guiado pelas mãos divinas

Pra minha mãezinha já telegrafei E já me cansei de tanto sofrer Nesta madrugada estarei de partida Pra terra querida, que me viu nascer Já ouço sonhando o galo cantando Inhambu piando no escurecer A lua prateada clareando a estrada A relva molhada desde o anoitecer Eu preciso ir pra ver tudo ali Foi lá que nasci, lá quero morrer 
A propriedade da família Ferreira teve sua origem em Rondonópolis com o patriarca João Nunes Ferreira, casado em regime de comunhão de bens com $\mathrm{D}^{\mathrm{a}}$. Aurora Rosa Batista, goianos de Rio Verde, ocuparam as terras do Bananal em 1921, em busca de uma vida melhor.

De acordo com documento (Título Definitivo Processo $n^{\circ} .11891$ ) arquivado no Intermat, o Sr. João Nunes Ferreira solicitou, no dia 05/11/1932, a compra de um lote de terras devolutas com aproximadamente 300 hectares. Após medição realizada em 23/12/1934, concluiu-se que a área total era igual a 874 hectares.

Então, vistos e examinados os autos de medição e demarcação e comprovar que tudo estava de acordo com as formalidades legais, foi feito o despacho aprovando o presente processo e expedido em 12/12/1939 o Título Definitivo de propriedade ao adquirente, pela Diretoria de Terras e Obras Públicas, conforme Registro de Imóveis $n^{0}$. 3.026. Essa primeira propriedade passou a se chamar Fazenda Bananal (Planta 12).

A segunda propriedade, uma área de terras com 500 hectares, denominada de "Santa Paz" foi comprada do Estado de Mato Grosso pelo Sr. José Eloy da Silva, conforme Título Definitivo expedido pela Comissão de Terras e Colonização de 14/02/1948, devidamente transcrito sob nº. 2.826, fls. 294 do livro $n^{\circ}$. 3-B. O Sr. João Nunes Ferreira adquiriu-a através de Escritura de compra e venda de 23/02/1949, fls. $6 V^{\circ}-7 V^{\circ}$, do livro $n^{0} 13$ das notas do Cartório do $2^{\circ}$ Ofício da comarca de Poxoréo, conforme Registro de Imóvel - Cartório do $1^{0}$ Ofício comarca de Rondonópolis-MT. Registro nº 3.027. Registro Geral livro 3-C, fls. 47.

Com a morte do Sr. João Nunes Ferreira em 1959, sua esposa Da. Aurora Rosa Batista dividiu as propriedades com os filhos em 1963, e cada herdeiro recebeu 140 ha e $6000 \mathrm{~m}^{2}$, com exceção de sua filha Erontina Nunes Batista, que ficou com 108 ha e $6.000 \mathrm{~m}^{2}$, registrados nas transcrições $\mathrm{n}^{\circ}$. 3.026 e 3.027 (Registros 01 e 02), transcrição nº 3.050, fls. 53 do livro 3-C.

Em entrevista, Valdivino e Gerson informaram que, pelo fato de sua irmã ter ficado com as melhores terras (localidade, água) da propriedade, pegou uma área menor e que a divisão foi feita com o consenso de todos. 
Planta 12 - Planta do Lote Bananal

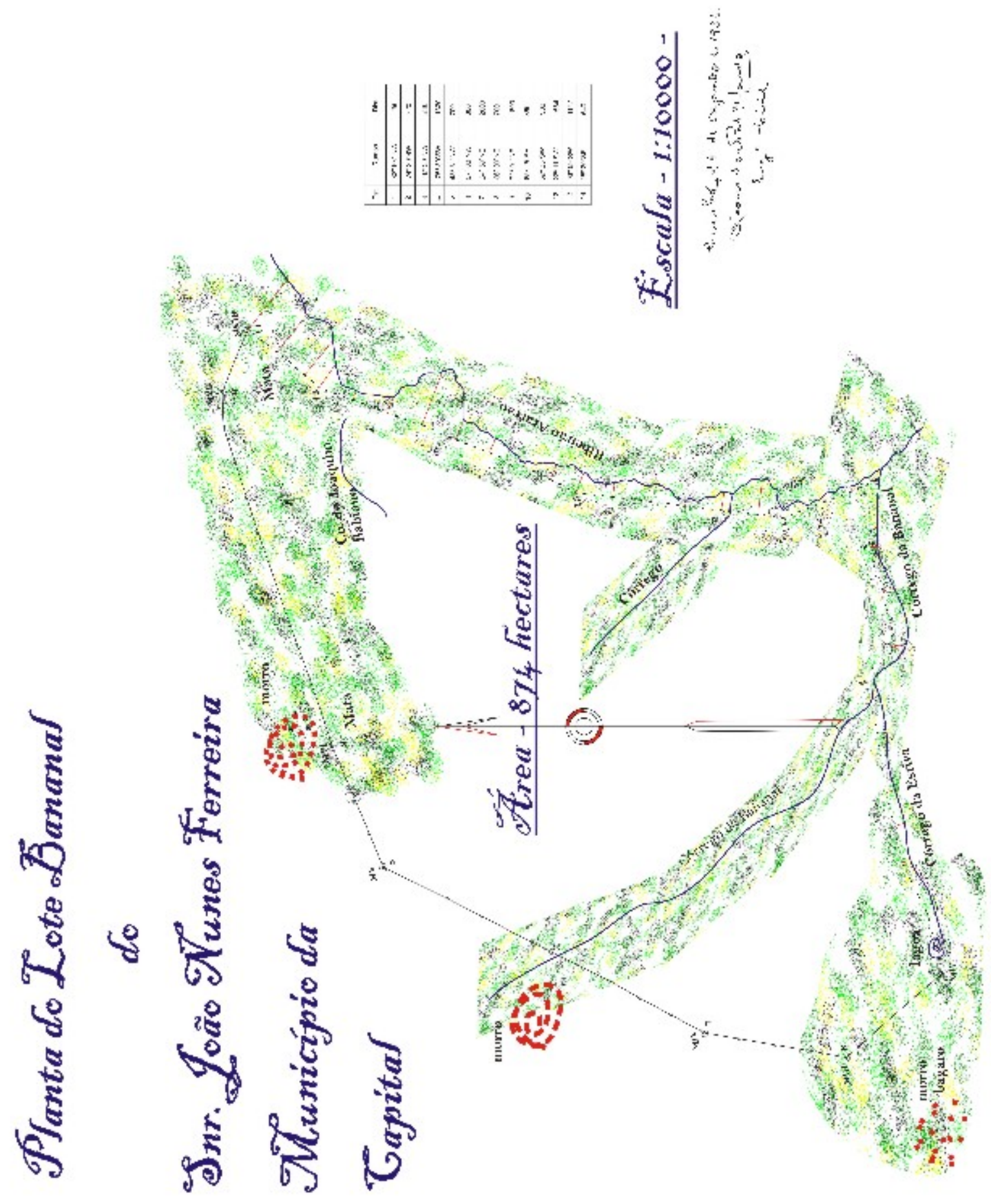




\section{Registro 01- No. 3.026 - Fazenda Bananal}

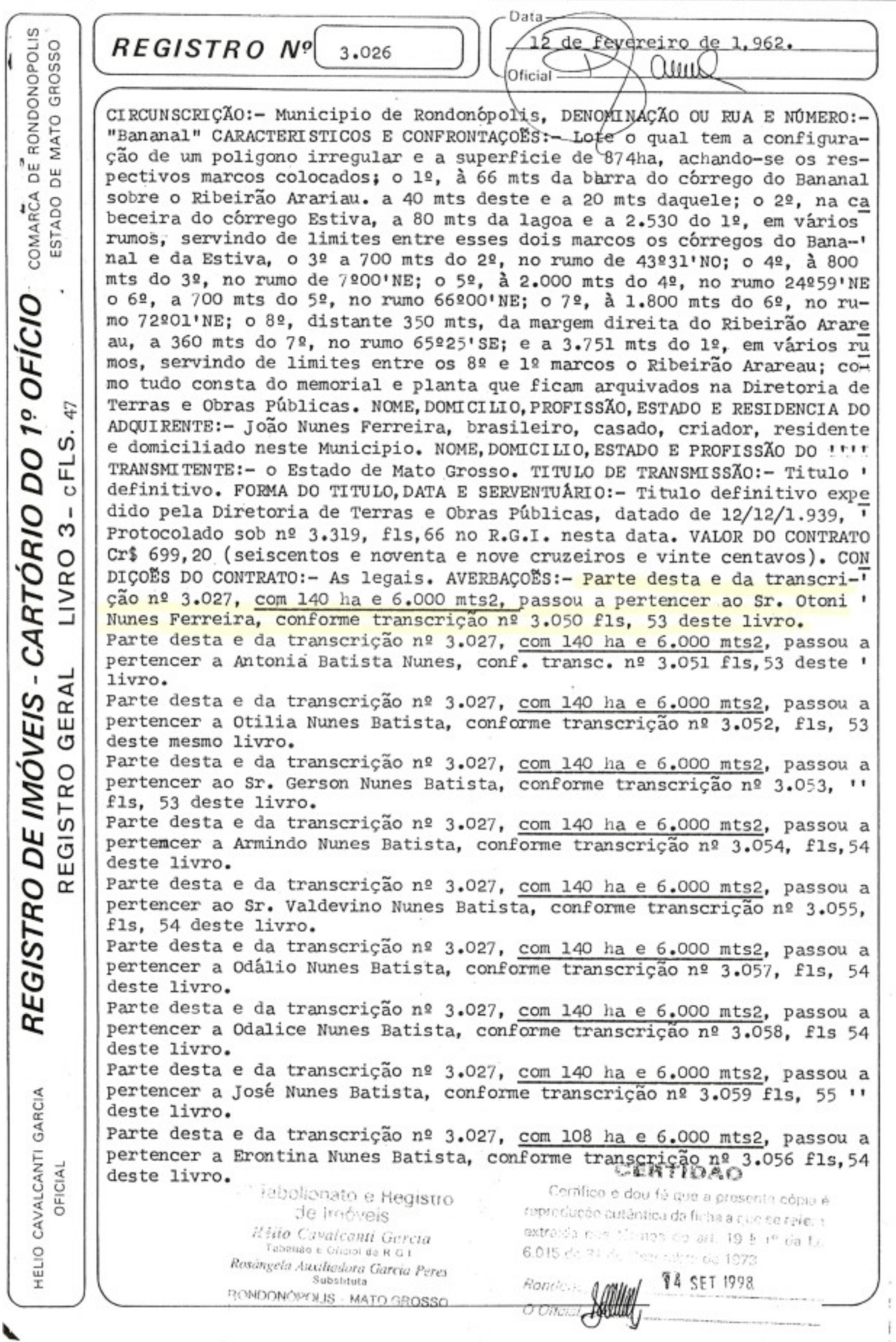




\section{Registro 02- No. 3.027 - Fazenda Santa Paz}

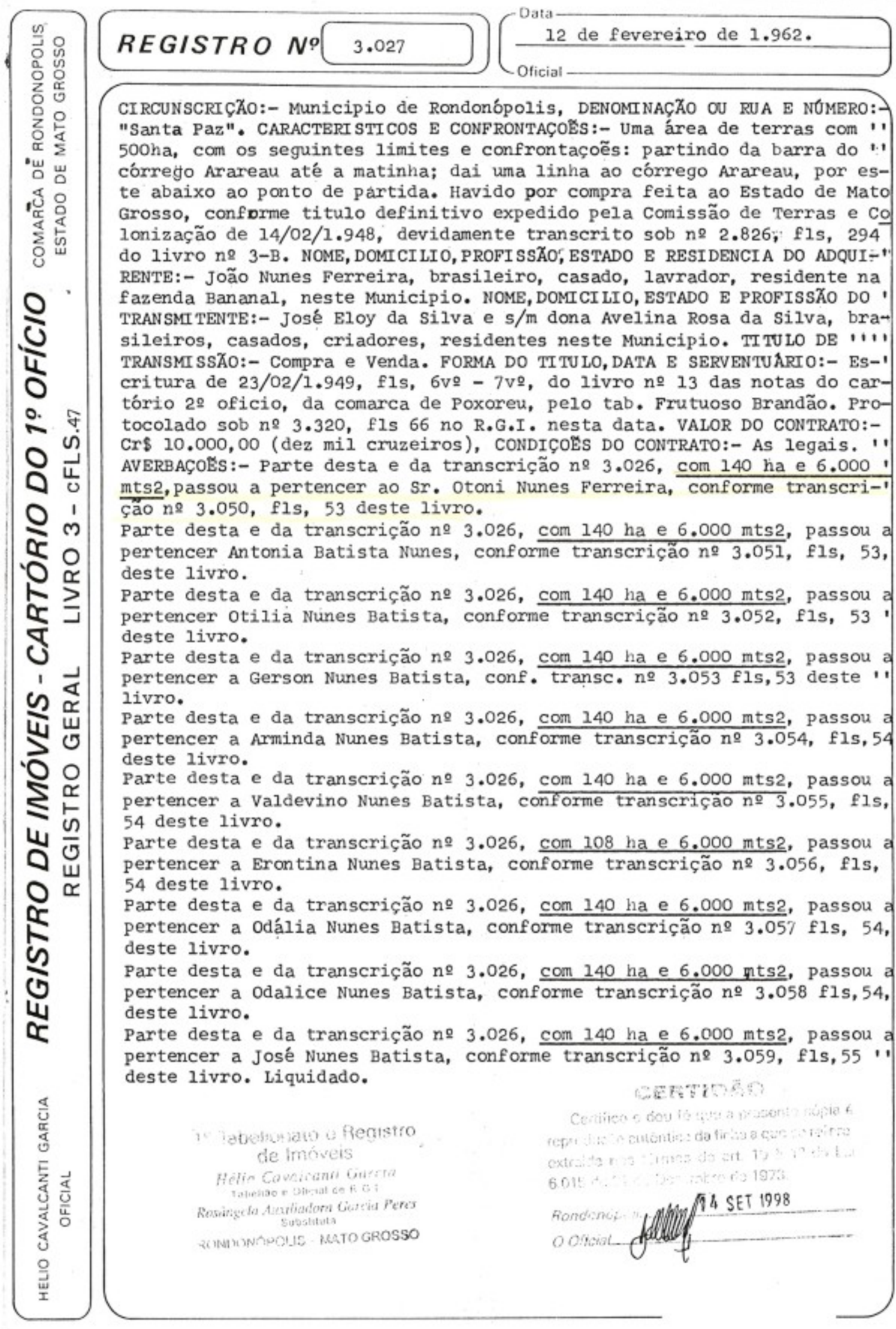


O Sr. Otoni Nunes Ferreira, um dos herdeiros, casado com dona Maria Rodrigues Ferreira com quem teve 11 filhos: seis homens e cinco mulheres. Conseguiu construir seu patrimônio, ou seja, sua propriedade através de compra e doação.

De acordo com o processo nº 15.199 - Título Definitivo, arquivado no Intermat, o Sr. Otoni Nunes Ferreira (na época solteiro) solicitou à Diretoria de Terras e Obras Públicas do Estado de Mato Grosso a compra do lote denominado "Beroaba" com área de 500 hectares (terras devolutas), recebendo um título provisório em 10/06/1942, ao pagar a $1^{a}$ prestação.

Conforme Protocolo 477, no dia 02/02/1951, o Sr. Otoni pediu a concessão de seis meses de prazo para dar entrada aos autos de medição, sujeitando-se ao pagamento da $2^{\mathrm{a}}$ prestação. O prazo foi concedido tendo em vista o disposto no Artigo 159 do Código de Terras ${ }^{182}$. Após medição, constatou-se que a área do lote era de 735 ha, (Mapa XXI) ${ }^{183}$.

Considerando que o processo obedeceu a todas as exigências regulamentares, sem que nada fosse reclamado contra a legitimação do referido lote, que tanto a parte técnica, como a processual foram julgadas boas, e concordando com os pareceres do auxiliar técnico e procurador fiscal do Estado, o Departamento de Terras e Colonização aprovou e expediu em 18 de junho de 1954, o título definitivo de propriedade ao Sr. Otoni Nunes Ferreira (01 - Título Definitivo e Certidão 03- Retificação de Nome).

Além do lote Beroaba com 735 ha, e da doação feita pela mãe, de uma área de 140 ha e $6.000 \mathrm{~m}^{2}$, registrado nas transcrições $\mathrm{n}^{\circ}$. 3.026 e 3.027, o Sr. Otoni comprou a parte de doação de dois irmãos e mais 28 ha de sua irmã Erontina, perfazendo $1.184,8000$ ha. Desse total, vendeu o equivalente a 298,0765 ha, restando-Ihe 886,7235 ha.

\footnotetext{
${ }^{182}$ Artigo 159. - Ficam revalidados todos os títulos provisórios de terras devolutas, cujos portadores hajam incidido em comisso, desde que continuem de posse dessas terras e não se encontrem as mesmas compreendidas em áreas reservadas para a colonização.

Parágrafo Único - os portadores de títulos provisórios revalidados na forma do artigo precedente deverão promover as medições e a extração dos respectivos títulos definitivos dentro do prazo de dezoito (18) meses, contados da publicação do presente Código, sob pena de nulidade de revalidação dos títulos acima referidos. (ver Leis: 1.142, de 20/7/51; 466 de 7/7/52; 502 de 21/10/52; 563 de 1/7/53; 697 de 12/12/53; 824 de 30/7/56; 864 de 30/7/56; 927 de 14/11/56; 955 de 8/8/57 e 1.175 de 16/12/58). Código de Terras e Leis Complementares. Estado de Mato Grosso - Departamento de Terras e Colonização, 1959, página 30.

${ }^{183}$ No mapa expedido pelo Departamento de Terras o nome do adquirente está grafado errado Otonio Batista Nunes. No Cartório do $1^{\circ}$ Ofício comarca de Rondonópolis foi feita a retificação para Otoni Nunes Ferreira, conforme transcrição 10.288 à folha 241 do livro nº 3-I, de 02/07/1968.
} 
MAPA XX I- Planta do Lote Beroaba

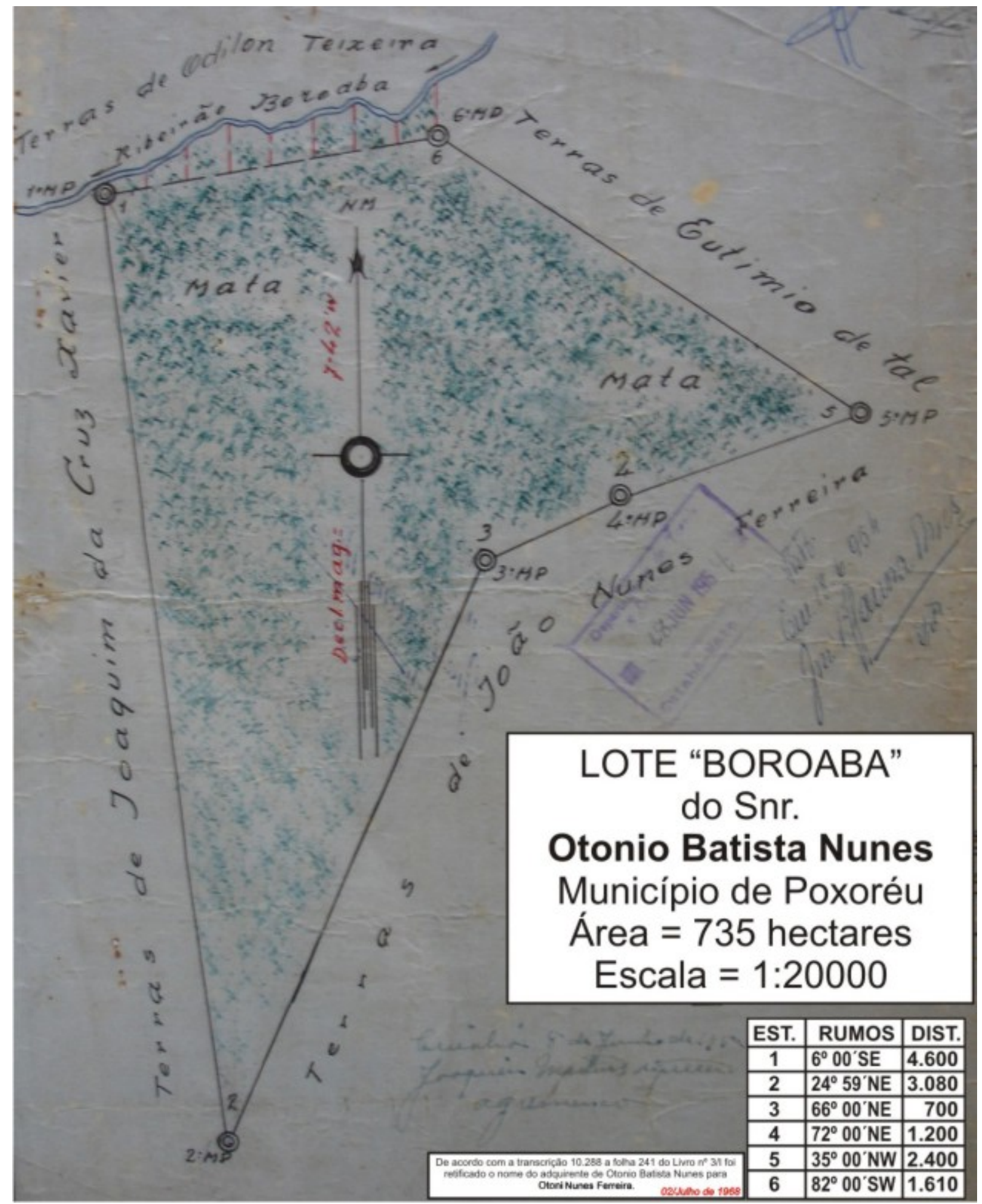




\section{1- Título Definitivo do Lote Beroaba}

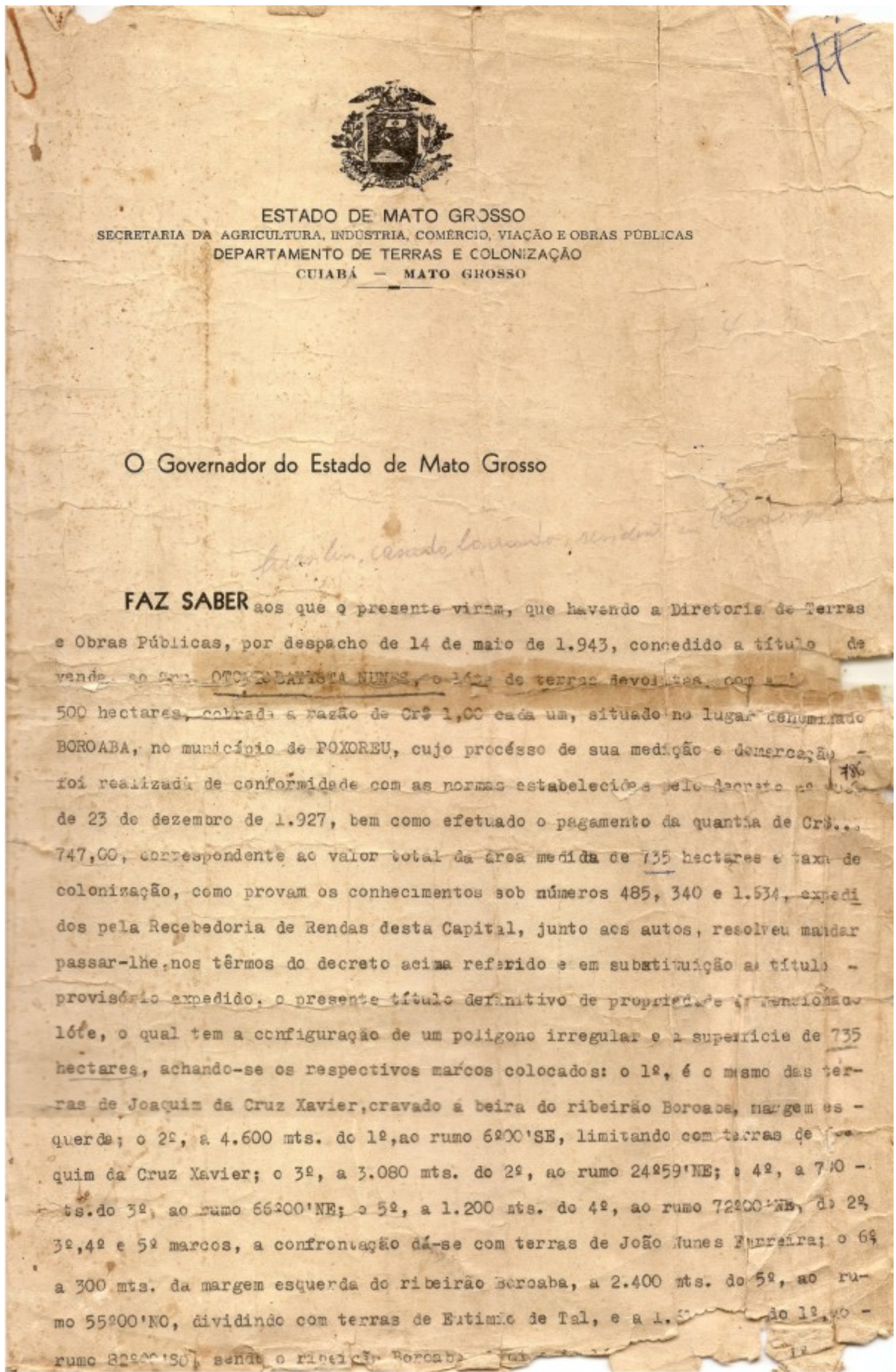




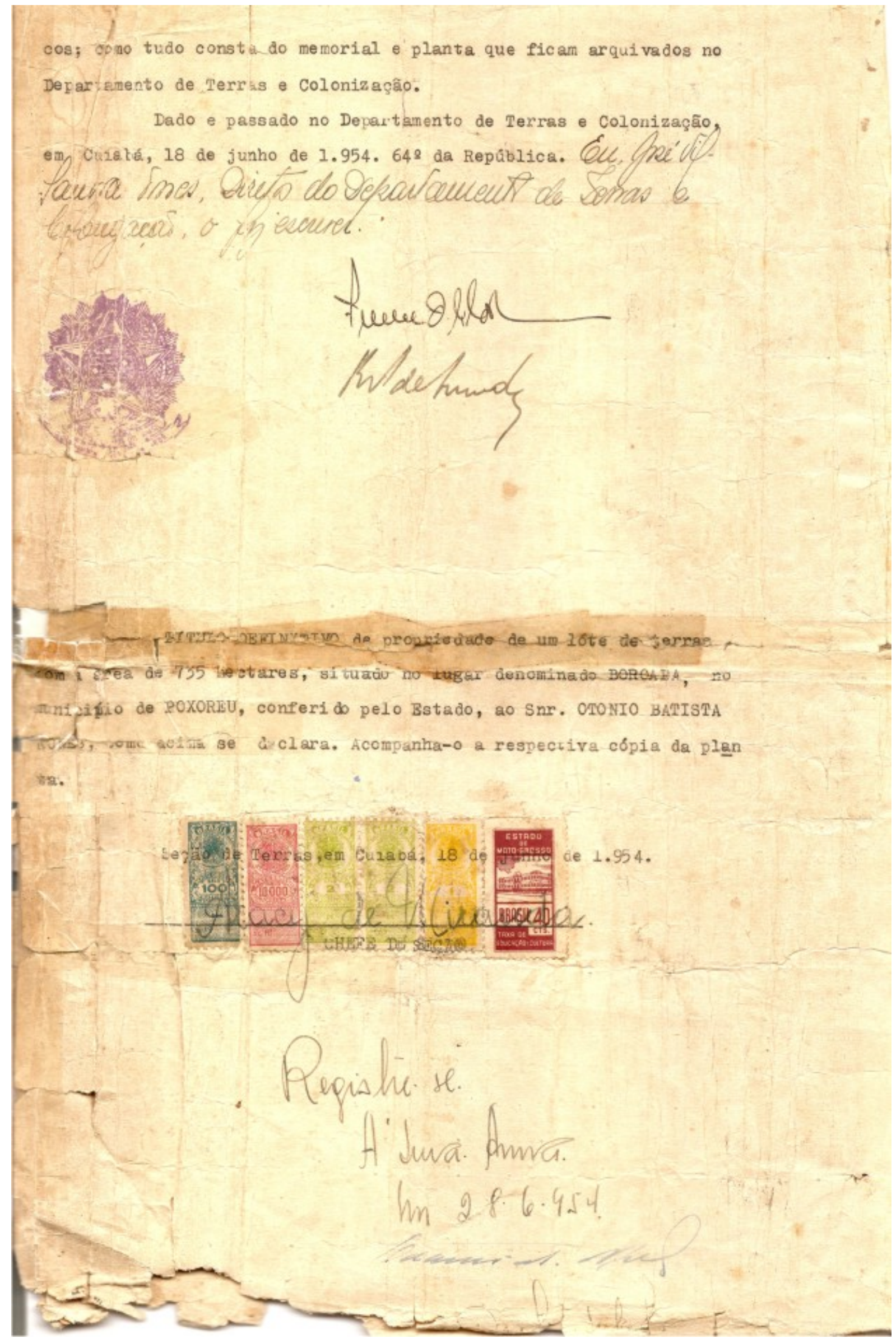


Certidão 03 - Retificação de Nome

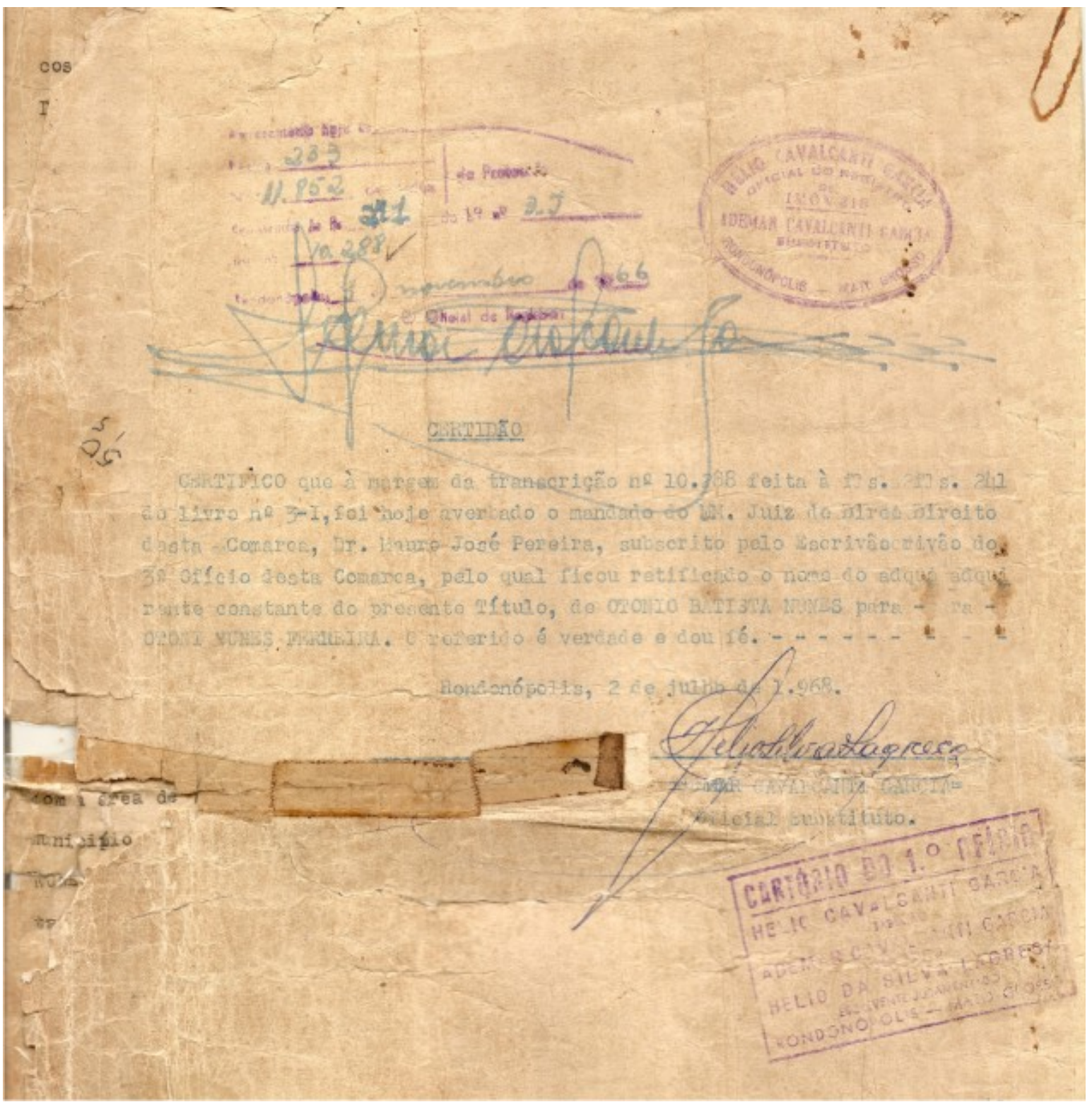


Sobre a propriedade, em entrevista, Benedita informou que em tempos remotos:

Meu pai tinha em suas propriedades (Bananal e Beroaba), tanto arrendatário como meeiro, sem contar as famílias que moravam de favor, ou seja, produziam sem pagar nada. Recordo-me bem do Sr. Antonio Sacramento que era compadre de meu pai. Os arrendatários e meeiros ficavam no máximo dois anos na fazenda. Saindo aqueles vinham outros. Tanto arrendatários quanto meeiros tocavam roça e pagavam em mantimentos, ou seja, parte da colheita. No final, meu pai plantava capim.

A fala de Benedita, quando disse "pagavam em mantimentos", remete aos estudos de Oliveira (1995:77) sobre a renda-em-produto, presente na agricultura brasileira em que, através de parceria, o proprietário recebe-a convertida em produto. Destaca-se, aí também, a "morada de favor" e o apadrinhamento discutido por Martins, Oliveira, Moura, entre outros. Nota-se também, em sua fala, que já começa a troca da agricultura pela pecuária: "no final meu pai plantava capim", onde o boi entra a agricultura e o homem sai.

Continuando a entrevista, Benedita acrescentou que:

A gente fazia muita festa. Muitas vezes era realizada tanto a traição ("treição"/surpresa) como o mutirão. Isso era tanto para as roças dos meeiros e arrendatários como para as do papai. Era feito tanto para descoivarar como para roçar, plantar e colher. Essas festas eram realizadas nas fazendas dos vizinhos também.

O relato de Benedita mostra que sua família utilizava o sistema de ajuda mútua, e isso, segundo Oliveira (1991:56), "aparece como relações que garantem a complexidade de relações na produção camponesa (...) quando não consegue completar totalmente a sua necessidade de trabalho".

Existia a preocupação por parte dos pais em colocar os filhos para estudar, alguns eram enviados para os colégios internos, outros estudavam em casa mesmo. Benedita expõe a preocupação de seu pai nesse caso:

Morávamos na fazenda e as duas filhas mais velhas estudaram dois anos (1959 a 1961) em Fátima de São Lourenço/MT, depois vieram para Rondonópolis em 1962. Neste mesmo ano, meu pai contratou um professor particular por um período de três anos para dar aulas para nós e os filhos das famílias que moravam na fazenda. Nós fomos crescendo e alguns foram morar na cidade de Rondonópolis, enquanto outros ficaram na fazenda. Em 1969, meu pai faleceu e minha mãe fez a partilha dos bens. 
No depoimento a seguir, Benedita deixa transparecer que, mesmo viúva e com uma prole numerosa, sua mãe ainda adotou uma menina.

\begin{abstract}
Minha mãe cuidou da Zuleide, filha de um dos arrendatários da fazenda. Com a morte da mãe, na partilha do gado, reunimos os irmãos e decidimos doar parte deste gado para ela. Cada irmão doou uma cabeça para Zuleide. Eu e Clarinda doamos duas, para a Letícia filha de Zuleide. Esse gado, a Zuleide vendeu uma parte para reformar sua casa na cidade, o restante eu e o José cuidamos e não cobramos nada. A casa que minha mãe morava na cidade, quando for vendida (no momento não temos interesse em vendê-la, pois além de ser o ponto de encontro dos irmãos, é onde fica os filhos dos que moram no sitio para estudar), nós já decidimos que o dinheiro será dividido em 12 partes iguais, contando com a Zuleide.
\end{abstract}

O Sr. Otoni faleceu em 21/10/1969 e só em 23/12/1980 o inventário foi realizado. Os 886,7235 ha foram divididos para $D^{a}$. Maria Rodrigues, meeira que recebeu 435,7235 ha e cada um dos onze filhos ficou com 41 ha. Na época da realização do inventário, a Clarinda, a Benedita, o Luiz, o Orlando, e a Emília já estavam casados, os demais eram solteiros.

A Benedita casou-se em 1970 e foi morar num barraco de palha onde o esposo já plantava roça. Nove anos depois, com a divisão da terra, foi para seu local definitivo. A Clarinda contraiu matrimônio em 1972, foi morar em um barraco de palha onde tem a terra hoje, posteriormente, construiu casa de alvenaria. O Luiz casou-se em 1979 e morou mais de ano na sede com a mãe, para depois construir sua casa na parte que lhe coube na herança. A Laurinda contraiu matrimônio em 1983 e ficou morando na cidade; hoje mora no Sítio, na parte que recebeu de doação da mãe. O José casou-se em 1986 e ficou morando na sede que lhe coube na partilha dos bens. O Nelson casou-se em 1989, morou em Rondonópolis, em Paranatinga (MT) e hoje mora no Sítio, na parte que lhe restou. O Gerson, ao se casar em 1990, foi morar no sítio, na parte que recebeu de herança e doação; hoje mora na cidade.

De acordo com Benedita, depois que receberam a herança do pai, a Emília vendeu sua parte para o Luiz, o Pedro vendeu para o José; o Orlando vendeu 11 ha para a Benedita, 15 hectares para o Luiz e 15 ha para o José e o Nelson vendeu 15 ha para o José. O acordo foi feito entre os irmãos, pois esses três queriam ir para Rondônia. A venda foi feita para que as terras que estavam com a família há (88 anos, período em que foi ocupada pelo avô João Nunes Ferreira) tantos anos não fosse parar nas mãos de terceiros. 
O Pedro vendeu a terra de Rondônia, voltou para Rondonópolis, e comprou de sua mãe e outros irmãos uma área com 85,0603 ha, por compra feita, registrada como n.2 da matrícula 48.560 em 24/06/1997.

Em 1999, Da. Maria adoeceu e, por isso, resolveu fazer a doação de sua parte. A divisão foi realizada com usufruto, ficando o José com a sede e a parte maior, pois cuidava do gado da mãe. Da doação da mãe, todos continuam com a terra. As propriedades em fotos satélites estão nos ANEXOS - $U$ à Z .

Em entrevista, o agrimensor Juarez Corrêa de Souza relatou que, na divisão, o Nelson e a Laurinda receberam 1,00 hectare de cada um dos nove irmãos, para não serem prejudicados por conta do morro que fica na propriedade dos dois. Segundo ele, tudo foi feito de acordo com os herdeiros e nos documentos aparece como compra, porque o gasto é menor. Acontece que, desde a morte do Sr. Otoni, a divisão havia sido feita no papel, mas não de fato. E quando o Pedro voltou de Rondônia e comprou a parte da mãe, ele quis separar as áreas, até porque facilitaria para fazer empréstimo em Banco para realizar benfeitorias na área. Sendo assim, entrou como comprador, antes de se fazer a divisão com os irmãos, por isso ficou fora da extinção de Condômino (ANEXO - G 1 a 4, todas as áreas adquiridas).

Um dos objetivos da pesquisa era o de conhecer, através dos relatos de campo, as condições gerais de vida dos herdeiros ou donatários que de filhos passaram a sucessores na propriedade. Por intermédio dos pareceres que seguem, é possível saber de que maneira os filhos do Sr. Otoni e $D^{a}$. Maria conseguiram se integrar e se manter na propriedade. Serão destacados também os mapas das propriedades e algumas fotos selecionadas por eles.

Benedita Nunes Ribeiro é casada com Natalino Alves Ribeiro desde 1970, e dessa união nasceram quatro filhos: Reginaldo, Regina, Reinaldo e Reginei. Em entrevista, Benedita relatou que:

Quando meu pai faleceu em 21 de outubro de 1969, minha mãe ficou com onze filhos e grávida de seis meses (a criança nasceu morta). Eu era a segunda filha, estava com 19 anos e de casamento marcado. Como minha mãe necessitava muito de minha presença para ajudar e auxiliar no cuidado com os irmãos mais novos, 0 casamento foi adiado. Em 05 de dezembro de 1970, me casei no regime de Comunhão Parcial de Bens e fui morar num barraco de palha que o Natalino já havia feito na propriedade de meu pai, onde ele estava tocando uma roça. Lá, nós moramos nove anos. Nesse período as terras foram divididas, somente no papel. E eu achei por bem mudar para o local que deveria ser meu (Mapa XXII). 
MAPA XXII - Sítio IV Irmãos

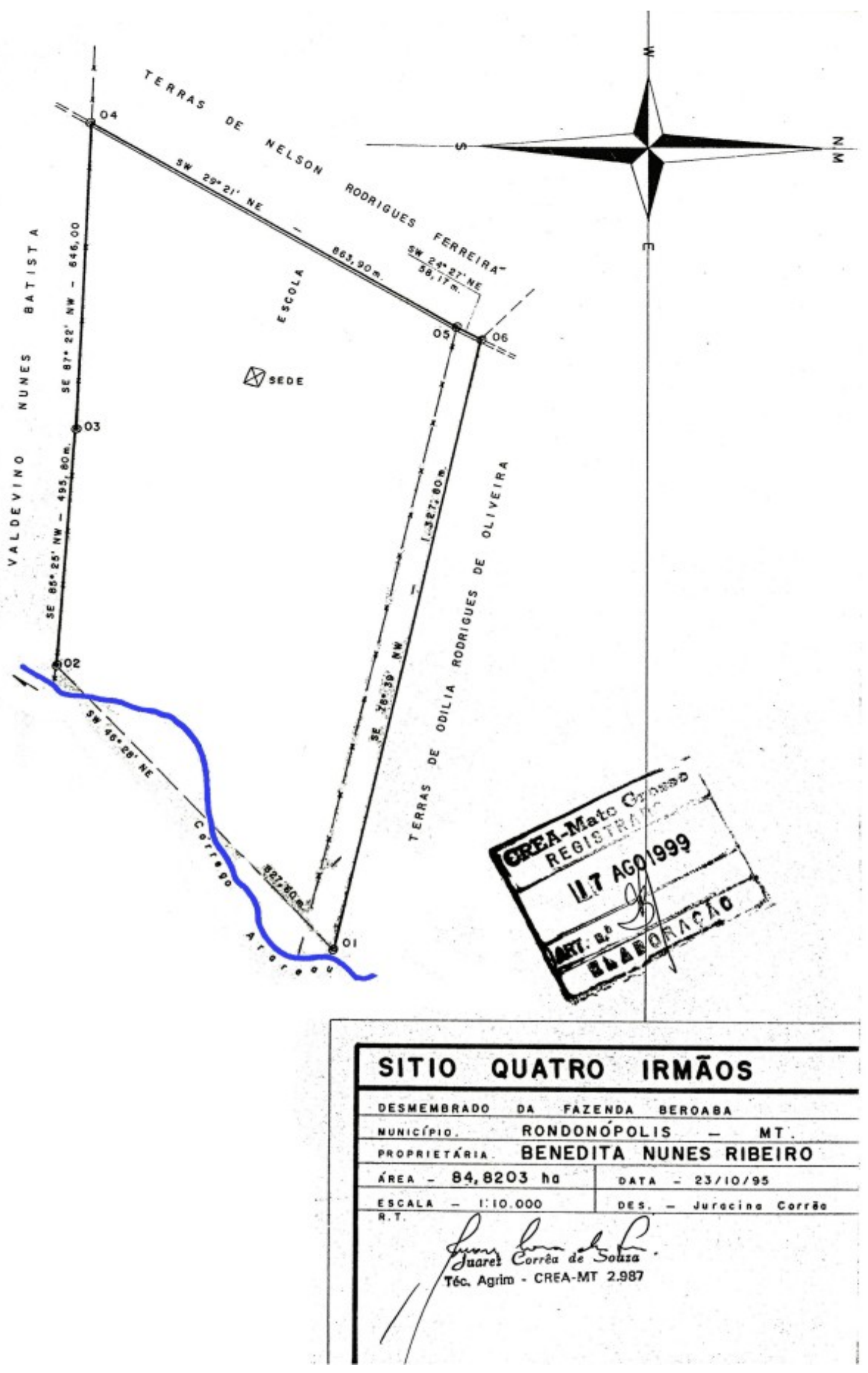


Foto 16 - Família da Benedita, no jardim de sua residência quando os filhos eram pequenas. Cedida por Ribeiro, B.N.

Como já tinha meus quatro filhos (Foto 16), precisava de um espaço maior, por isso, construímos uma casa pequena de alvenaria (Foto 17), que foi modificada mais tarde (Foto 18).

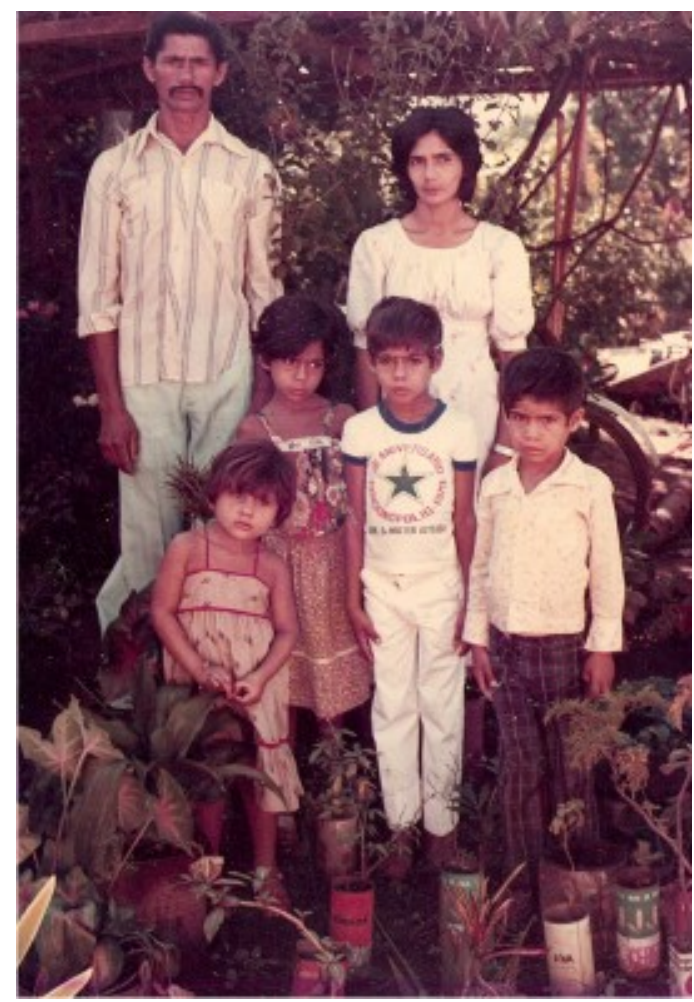

Foto 17 - Sede da segunda residência de Benedita e Natalino. (Ribeiro, B.N.)

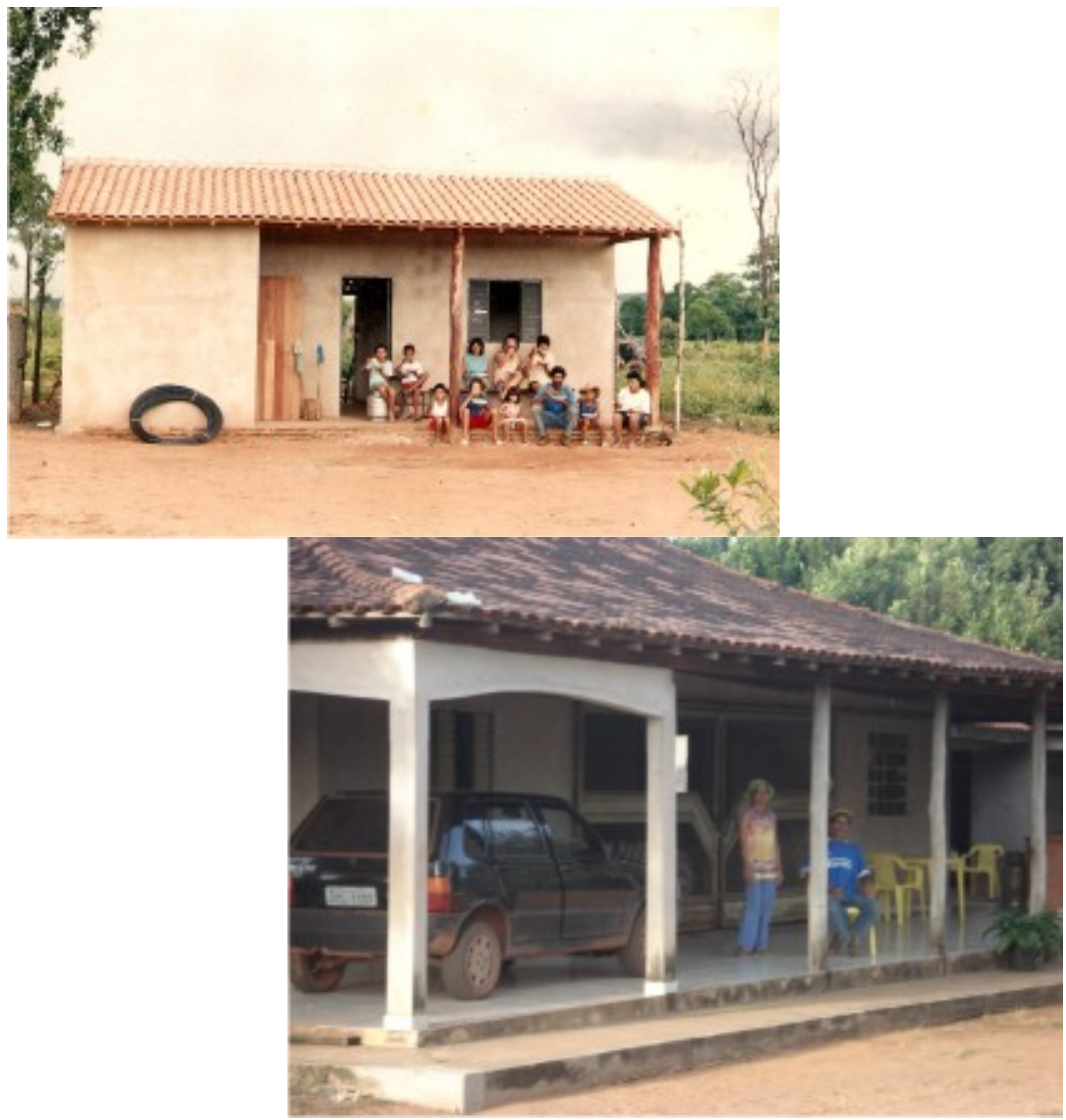

Foto 18 - Sede da residência de Benedita e Natalino depois de ampliada. (Ribeiro, B.N.) 
Minhas crianças estudavam em uma escola de palha perto da casa de minha mãe, mas por falta de professor a escola foi fechada. Fui à Secretaria reivindicar professor e eles me convidaram pra lecionar. Era muito difícil pra mim, mas acabei aceitando. Eu dava aula particular para os filhos dos moradores da região, como eram lavradores e não tinham renda, na maioria das vezes o pagamento era feito em alimentos. Mas a alegria em ensinar era grande. Com o incentivo de meu esposo e determinada a construir uma escola, fui procurar autorização da prefeitura e juntamente coma comunidade, construímos um barraco de palha onde lecionava os dois períodos da $1^{\mathrm{a}}$ a $4^{\mathrm{a}}$ série. As exigências foram surgindo e como eu só tinha a $4^{\mathrm{a}}$ série apareceu a oportunidade de fazer o LOGUS $^{184}$. Estudava em casa e ia à cidade só para fazer as provas. Às vezes caminhava $15 \mathrm{~km}$ a pé, ou ia no caminhão do leiteiro que demorava cinco horas para chegar (uma viagem que hoje fazemos de 20 a 30 minutos), assim, conclui o magistério. Minha casinha de palha de quatro cômodos parecia um orfanato, às vezes tinha até dez crianças morando lá, os pais as deixavam para estudar. O Natalino me ajudava muito, tanto cuidava dos nossos filhos como dos filhos dos outros que lá moravam. Do Bananal a escola foi transferida para a Aldeinha e junto veio a noticia de que teria que fazer a faculdade para continuar dando aulas. Prestei vestibular e passei em $49^{\circ}$ lugar eram 50 vagas, mas para mim e minha família, foi como se tivesse passado em primeiro. Trabalhava durante o período letivo e estudava nas férias. Foram quatro anos de muito choro, dificuldades e preconceitos, mas venci. Da Aldeinha a escola foi transferida para o Assentamento Chico Mendes, Escola 14 de Agosto. No início senti um pouco a diferença, escola maior, vários professores, mas aos poucos fui me acostumando e hoje já encerrei minha carreira no magistério e estou usufruindo uma nova fase de minha vida, dedicar mais a família e aos netos. Nós vivíamos da produção de arroz, feijão, milho, mandioca, banana e cana-de-açúcar. Fazíamos rapadura, açúcar mascavo e açúcar de barro. Assim que retiravam a produção, a terra foi sendo formada e passamos a criar gado. Com a ajuda de um empréstimo do PRONAF feito pelo Banco do Brasil, a renda foi melhorando cada vez mais e hoje estamos com a terra formada em pastagem, com algumas divisões, com cerca de arame liso e casa de alvenaria. Em 1982, meus filhos foram morar na cidade para estudar, ficaram na casa de tios e avós. Em 1987, o Reginaldo foi para o Colégio Agrícola em São Vicente e fez Técnico Agrícola. A Regina completou o Ensino Médio, o Reinaldo estudou até a $8^{a}$ série na Escola Agrotécnica em São José do Povo-MT, e a Reginei fez o curso de Contabilidade. Nessa ida dos meus filhos para a cidade, adotei uma menina de oito anos que foi abandonada pela mãe. Incentivei-a a estudar e dei todo o apoio até a idade de 18 anos, quando ela se casou. Hoje ela tem sua família, um casal de filhos e uma netinha linda. Em nosso sítio temos hoje duas casas de alvenaria, uma nossa e outra que morava nosso filho casado, um salão aonde era a escolinha, que agora funciona o Posto de Saúde que recebeu o nome da mamãe: "P.S.F. Maria Rodrigues Ferreira", o médico Dr. Afrânio vem duas vezes por mês, e nesse mesmo prédio, funciona a Associação da nossa comunidade, ao lado tem o

\footnotetext{
${ }^{184}$ No setor público, o maior treinamento em serviço para professores primários - o projeto LOGUS - foi implementado através de estudo por correspondência e qualificou mais de 40.000 professores leigos por ano.
} 
campo de futebol onde o pessoal se reúne para jogar. Temos água encanada, e com a luta dos pequenos produtores da região do Café, da Aldeinha, do Bananal e Beroaba, por intermédio da Associação dos Pequenos Produtores Rurais de Beroaba, através do programa PRODREAGO, conseguimos a energia elétrica; temos também telefone celular, um carro que veio facilitar nossa vida e me dar dor de cabeça para aprender dirigir, mas hoje as coisas estão bem mais fáceis. Vivemos com a minha aposentadoria. O trabalho no sítio é feito por mim e pelo Natalino, às vezes contratamos um diarista. Quase não praticamos mais agricultura, e os porcos e galinhas que criamos é só para o gasto. Essa terra que tenho é uma Benção de Deus, deixada pelo meu pai e não tem dinheiro que pague, pois a mesma serve para a minha sobrevivência. Pretendo dividi-la com os meus filhos ainda em vida, com direito a usufruto da mesma.

Transcrevi essa longa fala, porque é um "longa metragem" da vida de Benedita no campo. Retrata, exatamente, como uma família camponesa encara os acontecimentos e o que ela determina do ponto de vista familiar.

Percebe-se pela fala que era uma família extensa e com idade variada, Benedita com "19 anos e sua mãe grávida de seis meses". A perda do pai cujo falecimento a fez adiar o casamento que estava marcado para o final daquele ano, mostrando a importância das filhas mais velhas dentro do lar, responsabilizando-se não só com o trabalho doméstico, como também pela educação dos irmãos mais novos.

E expressão "morar num barraco de palha onde ele tocava roça" significa ficar mais próximo da produção, evitando a destruição por parte dos "bichos do mato", pois teriam que garantir a alimentação para si e para os filhos que foram chegando.

A preocupação em colocar os filhos na escola fez com que Benedita "forçosamente" escolhesse uma profissão que não fosse diretamente com trabalho no campo: professora primária. Pelo depoimento, nota-se que as dificuldades foram muitas, mas os resultados foram gratificantes.

Dois fatos nessa fala chamaram minha a atenção: um deles, a forma de pagamento pelas aulas particulares: "muitas vezes o pagamento era feito em alimentos"; como Benedita não podia ajudar seu esposo no trabalho da roça e os filhos eram pequenos, sem contar as crianças que lá moravam pra estudar, essa forma de pagamento comum entre os camponeses era bem vinda. Vê-se aí uma troca de favores entre vizinhos.

Outro fator foi a determinação em construir uma escola em sua propriedade. Por que em sua propriedade? Como lecionava os dois períodos e existiam mais de 
10 crianças morando em sua casa, além de seus filhos, esse fator ajudaria a todos. Vê-se aí a preocupação em ajudar a comunidade, cujo sonho foi possível ser realizado com a doação do lote por sua mãe. Atualmente, onde era a Escola, funciona o Posto de Saúde e a Associação.

Clarinda Nunes da Silva é casada com Sebastião Pereira da Silva no regime de Comunhão Universal de Bens desde 1972 e são proprietários do sítio Santa Clara (Mapa XXIII).

Sou a filha mais velha e fui alfabetizada por minha mãe em casa. Depois fui para o Colégio de Fátima de São Lourenço, onde fiz a $1^{a}$ série. No ano seguinte mudei para Rondonópolis onde cursei a $2^{a}$ série. Como as dificuldades eram muitas, tive que parar de estudar. Sempre ajudei meus pais nas atividades que aparecia, seja na lavoura de arroz, feijão, de cana-de-açúcar e também nas atividades do lar. Estudei o corte e costura por correspondência, passando a confeccionar roupas para a família e as pessoas da região. Aos 21 anos meu pai faleceu e com isso, minha dedicação ao trabalho teve que aumentar. No ano seguinte à morte de meu pai, surgiu a Escola Rural Mista e aí voltei a estudar e concluí a $4^{a}$ série. Em 10/12/1972, me casei com Sebastião e tivemos seis filhos, dois faleceram ao nascer, ficaram quatro (Foto 19), o Dioncindo, casado e pai de uma menina, ele trabalha de vaqueiro; o Deocleciano trabalha é formado em Biologia; o Keiderson casado, trabalha, é formado em contabilidade e a Sandra é solteira, já concluiu o ensino médio e está cursando o técnico em segurança de trabalho.

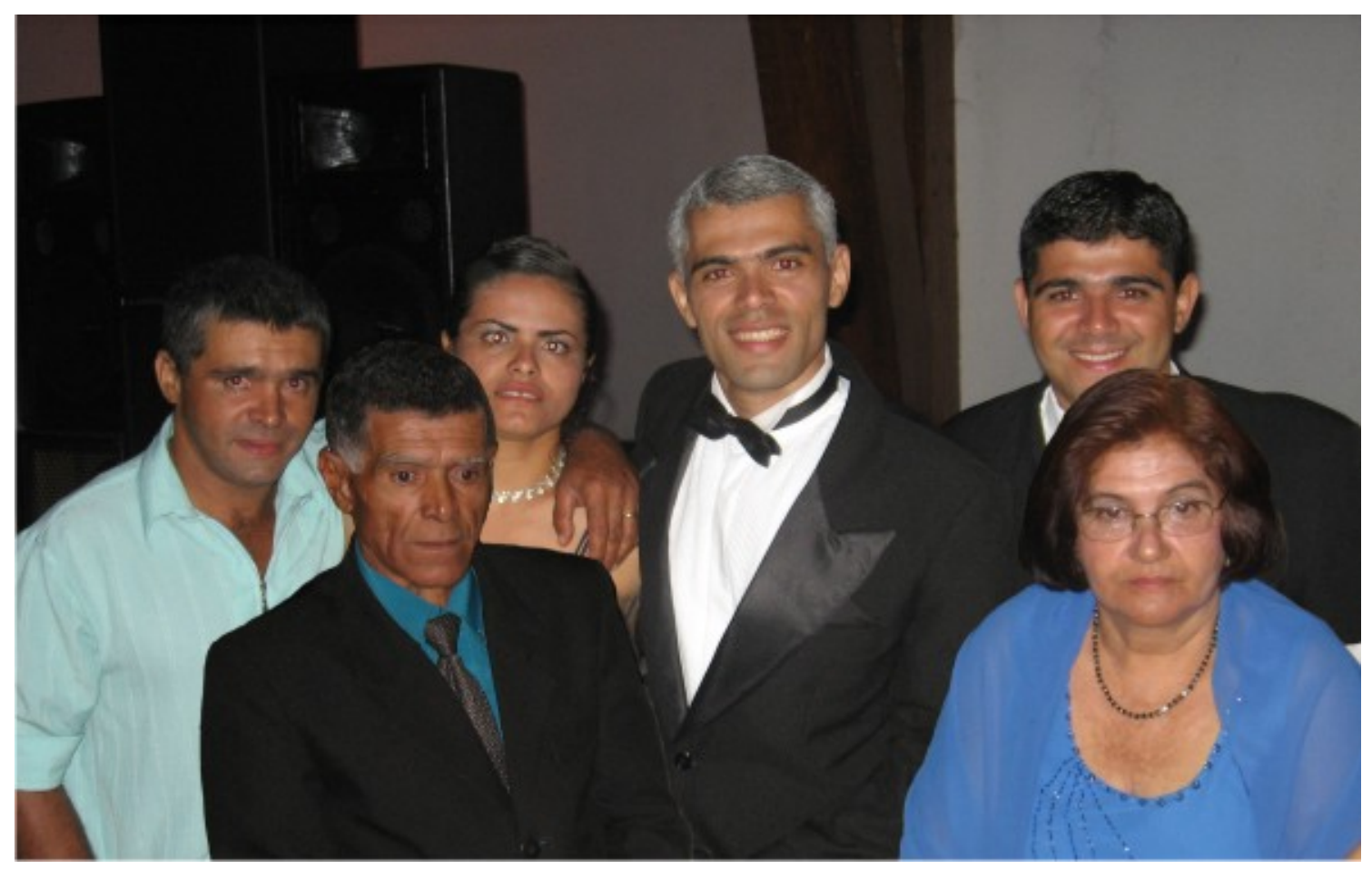

Foto 19 - Clarinda e Família. (Cedida por Clarinda) 
Em 2004 eu me aposentei, mas continuo colaborando com o meu trabalho para uma vida digna. Quando minha mãe fez o inventário, foram feitas as divisões só no papel, não foi localizado o lugar certo para cada um, então eu escolhi o lugar e fui morar perto do Córrego Bananal, onde estou até hoje. No início, plantávamos arroz, milho, banana, mandioca e hortaliças. Hoje a renda é da pecuária e alguns cultivos de hortaliças. Por ter nascido e vivido sempre nesse lugar não pretendo mudar daqui. Tenho intenção de dividir as terras ainda em vida, com direito de usufruto.

Nota-se pela fala de Clarinda que, por ser a filha mais velha, além de exercer as atividades domésticas, também "lidava" nos afazeres do campo. E, fato comum em famílias camponesas extensas, aprendeu o "corte e costura" por correspondência, pois como a família era numerosa, necessitava de uma costureira em casa, fator que contribuiria para amenizar os gastos extras e, ao mesmo tempo, aumentar a renda, já que a profissão de costureira lhe traria "lucros".

O leitor pode perceber o entusiasmo de Clarinda ao mencionar o fato de terminar a $4^{\text {a }}$ Série Primária aos 21 anos de idade; aliado a ele veio o namoro, 0 casamento e a constituição da família. 
MAPA XXIII - Sítio Santa Clara
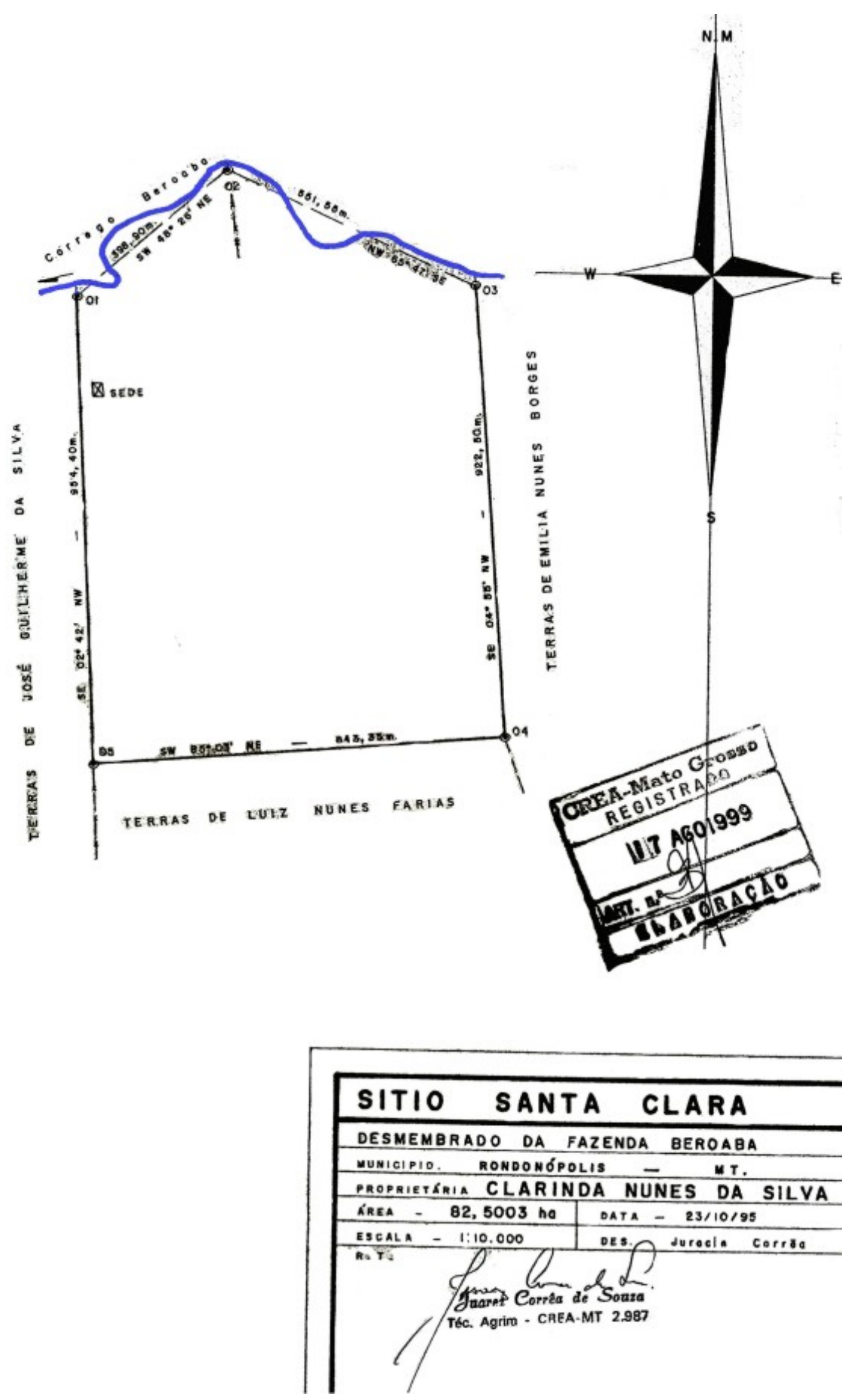
Luiz Nunes de Farias, casado com Keila Aparecida Nogueira Farias desde 1979, donos do Sítio São Luiz (Mapa XXIV). Dessa união nasceram três filhos, Luismar, Kellton e Neviton. (Foto 20)

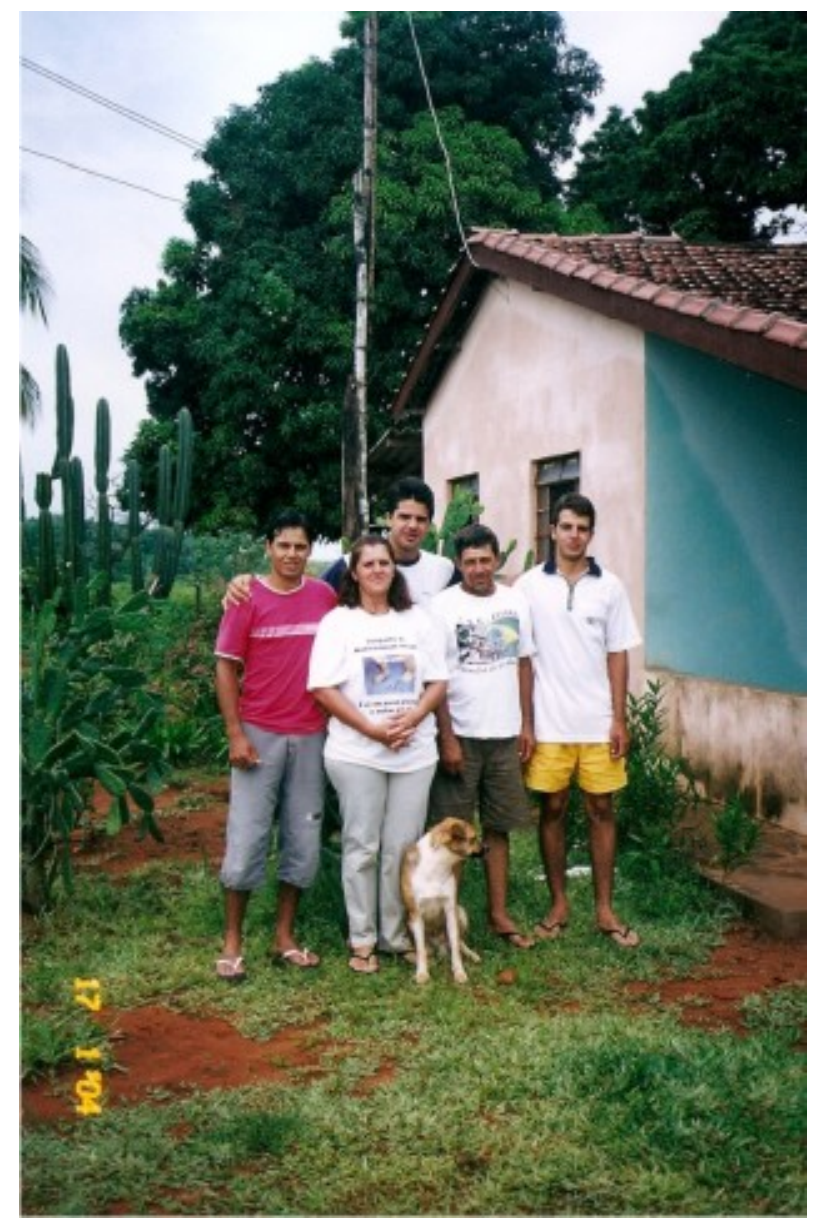

Foto 20 - Família do Sr. Luiz. Em Frente à residência atual do Sítio São Luiz. (Cedida por: Farias, L.N)

Quando casei, morei mais de ano na sede junto com minha mãe, aqui mesmo no sítio Beroaba. Enquanto morávamos aqui, nasceu em 1980, nosso primeiro filho, a partir daí, fomos para onde hoje é nosso cantinho. No início, a casa era um ranchinho de palha de duas peças (Foto 21), nesse ranchinho moramos um ano e meio, trabalhando com roça, fazendo cerca e na produção do leite, enquanto isso ia formando os pastos. Em 1982 nasceu nosso segundo filho, nessa época, compramos mais 7 alqueires de terra com a renda do sítio que era da produção de leite, de bezerros, de alguns frangos e roças. Nesse período, fomos como toda família passando por fases difíceis mais de ano. Quando o tempo ruim passou, já que depois da tempestade vem a bonança, fomos abençoados com a chegada de mais um rebento que veio completar nossa família em 1985, foi então que começamos a fase dos estudos dos filhos na Escola Rural Mista do Bananal, onde cursaram a $1^{a}$ e $2^{a}$ série. Vendo a necessidade de levá-los para estudar na 
cidade, passaram um tempo morando na casa de tios e avós, até construirmos uma casa lá, onde minha esposa e filhos passaram a morar e estudar. Fiquei no sítio seis anos, trabalhando e lutando sozinho. Quando os filhos foram estudar na Escola Agrotécnica de São Vicente e o caçula no internato em Chapada dos GuimarãesMT, minha esposa retornou. Aqui no sítio sempre na mesma luta entre leite, roça e horta. Agora, com a aquisição de um trator MF 65 eu trabalho para mim e para os outros. Nessa luta conseguimos estudar os filhos, os dois mais velhos com a graça de Deus já estão formados, o Luismar é Engenheiro Agrônomo e o Kellton é Engenheiro Florestal e o Neviton como técnico agrícola, tem sua firma de tecnologia agrícola (Solus) de mapeamento para análise de solo. Com a Benção Divina são nossos orgulhos. Através de nosso trabalho, em nossa propriedade a qual tem um peso muito significativo na nossa vida e para nossa família, onde já estamos há 25 anos construindo nossa história e tirando nosso sustento e as condições para formar os filhos graças a Deus e suas grandestbênçãos sobre nosso pequeno sítio que hoje é um pedaço de terra muito bonito com 54 alqueires com metade das terras planas e outra com declividade, onde se encontra cerrado e campo e terra boa de cultura. Nossa propriedade é simples, mas muito aconchegante, com um bom pomar, bananal, é agraciada com bastante água, apesar de não ter rio, cachoeiras, mas em compensação temos várias nascentes as quais são significantes para nos abastecer e abastecer vários vizinhos. Só isso já seria o suficiente, pois água é o bem mais precioso.Temos um clima ótimo, uma bela vista (Foto 22), os pastos formados bem divididos, com ótimo curral, enfim, se quiséssemos fazer dele um sítio turístico, poderíamos. É um pedacinho abençoado por Deus onde podemos trabalhar e colher muitos frutos. O sucesso de nossos filhos, por exemplo, o que para nós é de maior importância pois estão agora, encaminhados na vida. O Luismar trabalhando no INCRA, já começando a batalhar pelo seu futuro. Sempre ficamos nós aqui no sítio, eu e a esposa, lutando e tirando dessa luta nosso pão de cada dia. Fiz um custeio para a propriedade no valor de $R \$ 18$ mil para a reforma e forma de pastos, foram três anos de carência e cinco anos para pagar, termino este ano. Somos gratos a Deus pela saúde e pelo sucesso de nossos filhos, por nosso pedaço de chão, onde vivemos e onde eu nasci e somos hoje uma família feliz. Onde cada planta, cada árvore frutífera, cerca de arame, represa, enfim cada coisa construída aqui foi por nós e tem uma história em especial as quais têm suas glórias para serem lembradas por nossa família que mora nesse sítio chamado São Luiz, localizado na região do Bananal /Beroaba, no município de Rondonópolis no Estado de Mato Grosso - Brasil; com muito orgulho!

A morada na casa dos pais, após o casamento, é outro fator comum em famílias numerosas, diferente do caso estudado por Woortmann (1995) onde não poderia ter mais que um chefe; no caso aqui estudado, representado pela mãe. 
não se transformou em auxiliar da nora, já que esta moraria foi por pouco tempo, até construírem sua residência no lote herdado.

Outro elemento comum às famílias do campo é a vinda da mãe para a cidade, a fim de colocar os filhos para estudar. As famílias geralmente vão educando os filhos de forma que estes continuem a perpetuar o trabalho. Os filhos do Sr. Luiz foram direcionados a procurar uma profissão que thes garantisse um futuro promissor, direcionado ao campo, o que lhes pode garantir não só o sustento familiar como manter a terra que herdarão a qual foi de seu bisavô.

Quando diz "cada planta, cada árvore, cada cerca, cada represa... tem sua história em especial", deixa transparecer a luta do trabalhador rural para construir seu espaço digno de morada e convivência com os demais. Está se referindo ao trabalho coletivo familiar, no qual esposa e filhos construíram cada pedacinho que hoje é motivo de orgulho para todos.

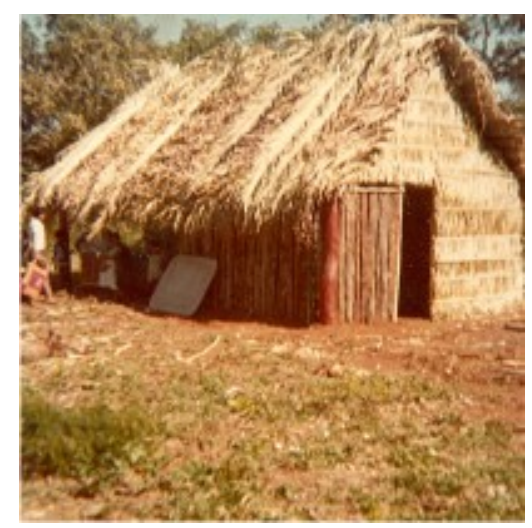

Foto 21 - Primeira residência no Sítio São Luiz. (Cedida por: Farias, L.N.)

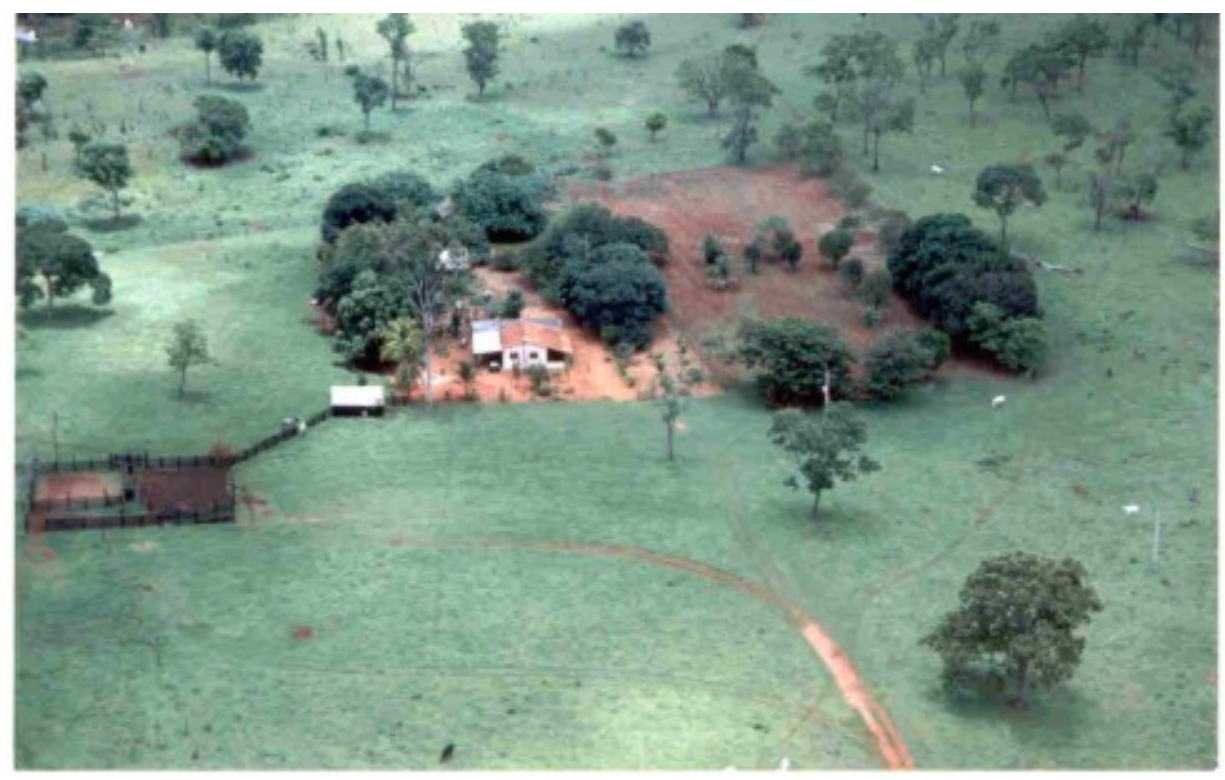

Foto 22 - Vista aérea do Sítio São Luiz. (Cedida por: Farias, L.N.) 


\section{MAPA XXIV - Sítio São Luiz}

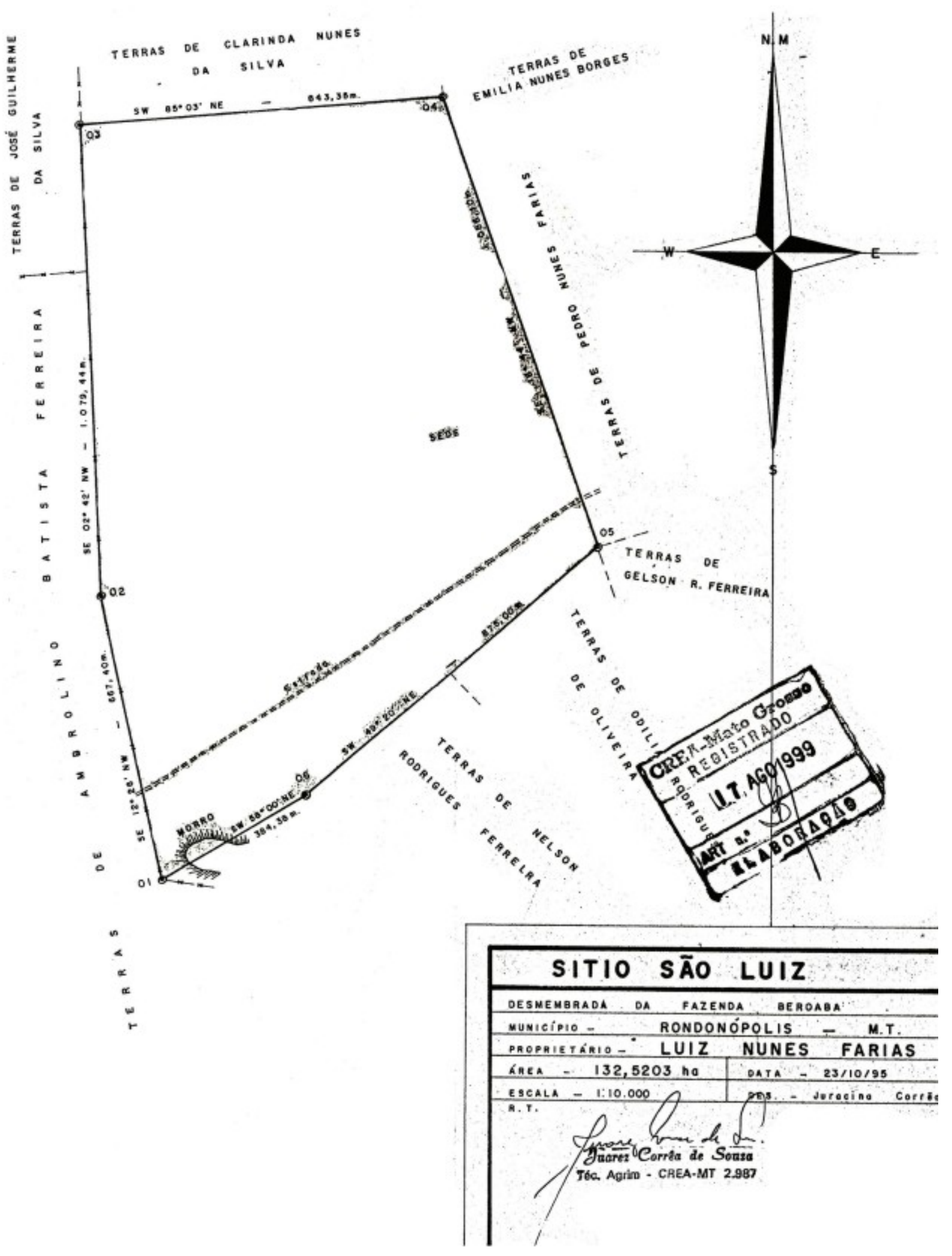


Laurinda Rodrigues Ferreira é dona da Estância Ouro Fino, com 63,1403 hectares (Mapa XXV).

Nasci em 1963, na fazenda Beroaba, onde tinha uma vida muito feliz; em 1969 meu pai faleceu e isso tornou nossa vida difícil, porém com fartura. Estudei na zona rural até os 14 anos, após vim morar com minha avó (Clotilde) aqui na cidade, para trabalhar e continuar meus estudos. Com 20 anos me casei e tive duas filhas: Michele e Suellen (Foto 23). Com nove anos de casamento, ocorreu a separação. Criei minhas filhas que agora, a mais velha já está formada em Enfermagem, trabalha na Santa Casa de Rondonópolis e a caçula faz Matemática na UFMT de Rondonópolis.

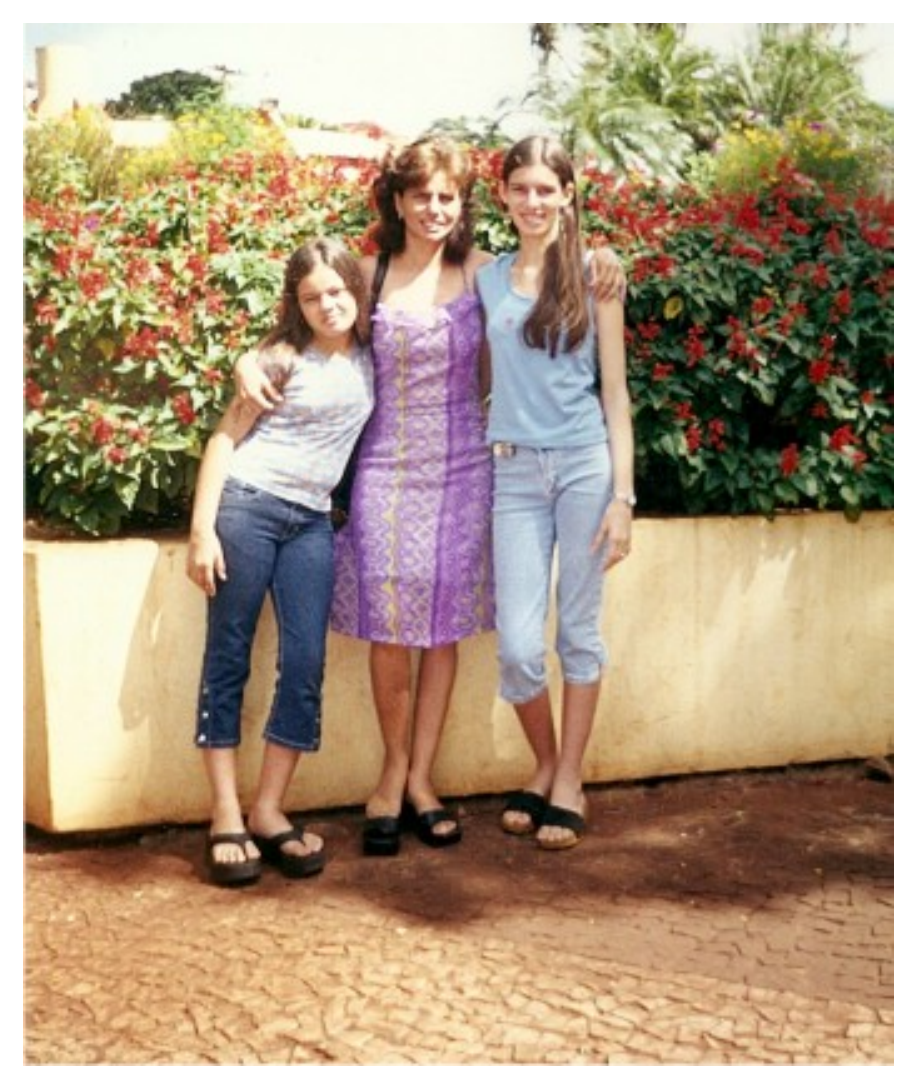

Foto 23 - Laurinda e filhas: Michele e Suellen/era adolescente. (Cedida por: Laurinda)

Quando recebi as terras da herança, de 1999 até 2005, arrendei minhas terras para meu irmão José, que me pagava em gado. Como me casei de novo, fui embora para Campo Grande -MS, onde tínhamos uma casa de comércio (é do esposo), fomos assaltados várias vezes. Quando voltei para Rondonópolis e fui morar no campo, até engordei. Faz dois anos que voltei para Rondonópolis e estou morando no sítio. Construímos um barraco, uma peça, mas tem água encanada e luz elétrica. Precisamos construir uma casa com urgência. Tenho medo de fazer empréstimo, utilizar créditos, para isso tem que ter pé no chão. Estamos começando agora e não temos nada, quando precisamos de qualquer ferramenta, equipamento, vamos atrás dos irmãos. Estamos engordando boi no sistema de porcentagem de engorda. São 60 bois, em um ano e meio, onde o dono vende e dá a porcentagem em dinheiro, que varia entre 20 a 25\%. Até hoje não vendeu ainda, faz pouco tempo 
que começamos. Portanto, por enquanto estamos vivendo com a renda do aluguel de uma casa e do salão comercial que meu esposo tem em Campo Grande. O sítio está com mais ou menos 75\% formado de capim, tem a área de reserva obrigatória, criamos galinhas só para o uso, temos algumas cabeças de gado, mas não tiramos leite. Sou adepta à natureza, já plantei mais de 250 mudas de guanandi/mangui, para preservar a área das nascentes. Hoje moro no sítio e as meninas na cidade, mas elas não gostam nem que fala de vender o sítio. Como estou nova e usufruindo, no futuro vou dividir para elas e quero mesmo é que elas vivam ou na cidade ou no campo, onde na realidade elas se sintam bem.

$\mathrm{Na}$ fala transcrita acima, Laurinda se refere às idas e vindas à procura dos ideais da família. Migrou para Campo Grande-MS, a fim de a filha fazer faculdade. Retornou e se mudou para o sítio, onde, para viver, realiza um sistema de "engorda de gado na porcentagem". É uma prática arriscada, mas a interlocutora arrisca, para poder "começar a vida no campo", acha melhor do que fazer empréstimo em banco, onde poderia estar colocando a terra em risco.

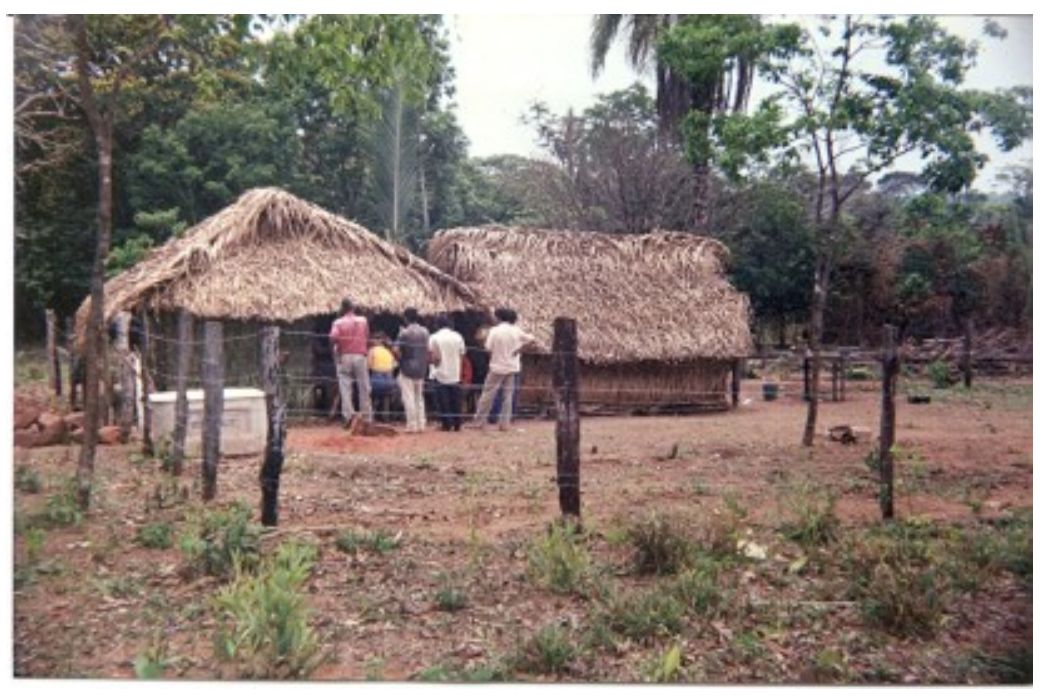

Foto 24 - Rancho de palha, $1^{\text {a }}$ casa do Sítio Ouro Fino. (Cedida por Laurinda)

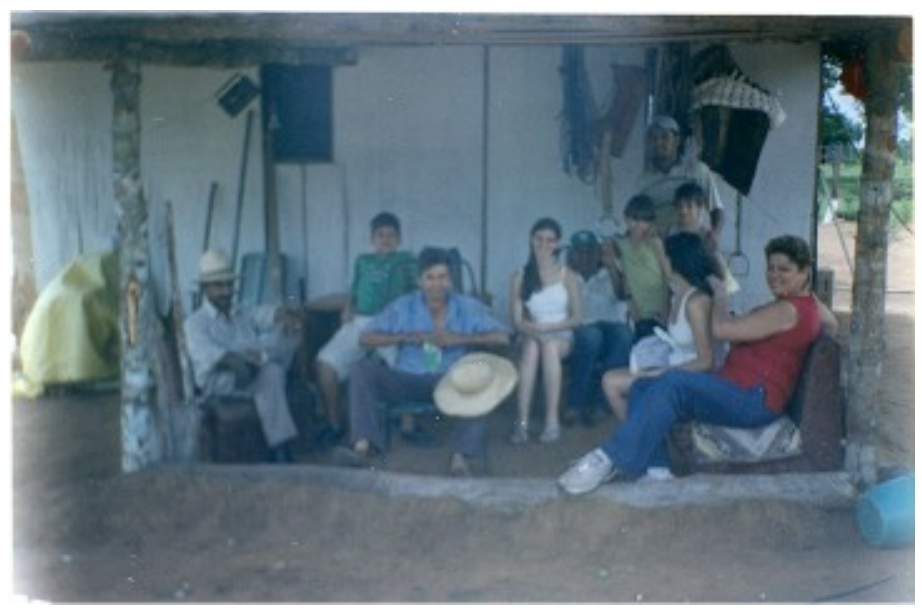

Foto 25 - Varanda da casa atual do Sítio Ouro Fino. (Cedida por Laurinda) 


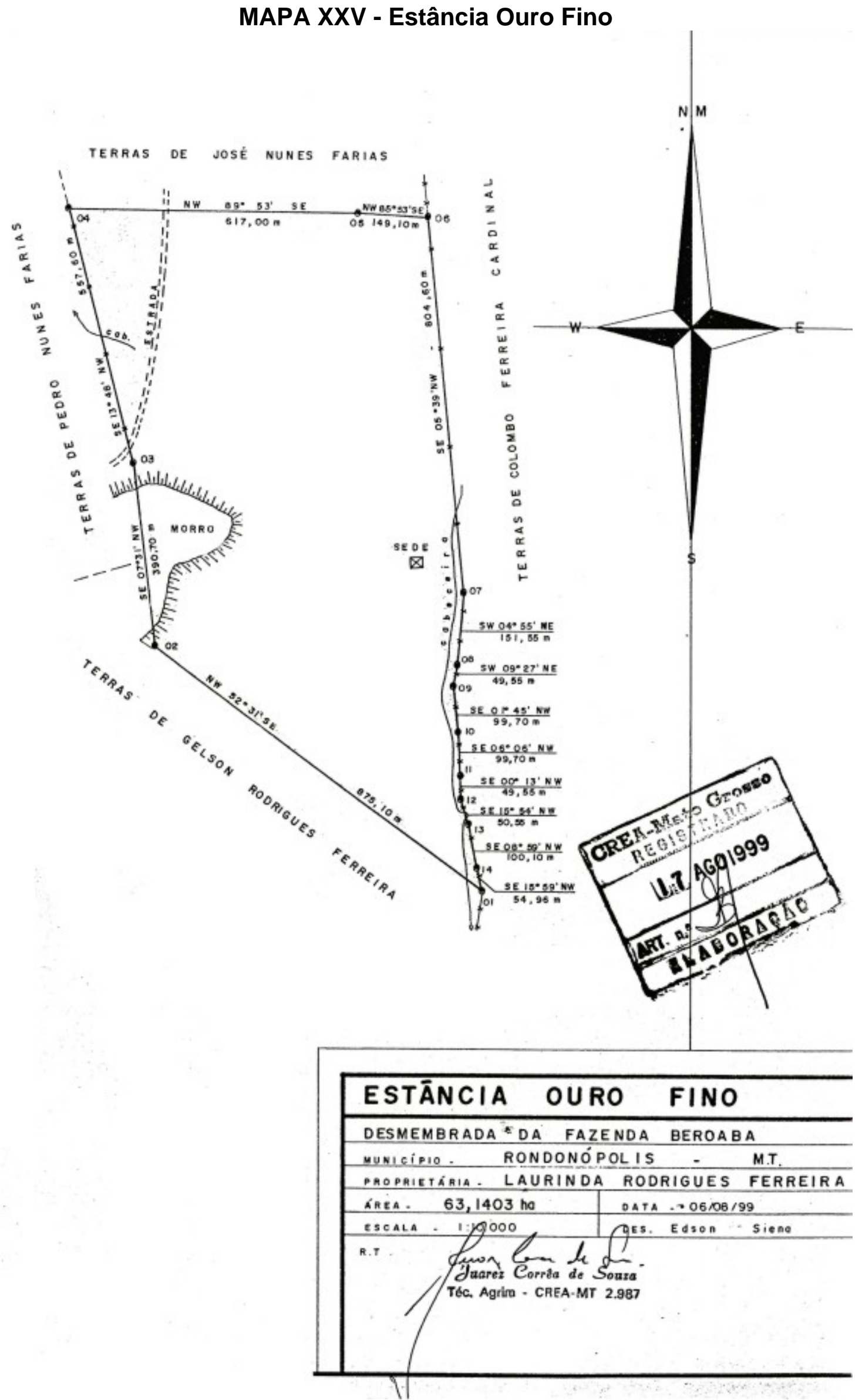


Pedro Nunes Farias, casado com Analice Antoninha Farias desde 1983, tem dois filhos: Edmar e Kátia e são donos do Sítio São Pedro (Mapa XXVI).

Recebi de herança de meu pai, uma área com 41 hectares, que vendi para meu irmão José, para ir embora para Rondônia. Lá comprei uma propriedade, depois me casei e fui tocando a vida. Quando voltei para Rondonópolis em 1990, vendi as terras de lá e comprei 85 ha de minha mãe e alguns irmãos. De quando meu pai faleceu, a divisão, ou seja, a partilha dos bens foi feita só no papel, e não na terra. Como precisava da escritura da terra para fazer financiamento e poder tocar minha propriedade, entrei como comprador antes de fazer a divisão com os irmãos, providenciando as escrituras para extinção de condomínio. Faz 17 anos que estou na propriedade. Já desenvolvi pelo projeto Lavouras Comunitárias, uma plantação de banana e abacaxi, montamos, com recurso da Confederação Cooperativas da Alemanha, com apoio da EMATER e da Secretaria Municipal de Agricultura, uma Indústria de Passas de Frutas, cujo projeto foi desenvolvido por conta da Associação de Pequenos Produtores do Bananal, só que infelizmente não obtivemos sucesso, por conta das máquinas (estufas) que não funcionavam direito, vivia queimando. O projeto acabou e hoje não desenvolvo mais nada. No início, construímos uma casa grande de palha que aos poucos fomos substituindo por essa de alvenaria, com água encanada, luz elétrica e que nos proporciona um pouco mais de conforto. Estou preparando um terreno com 2 ha, onde vou plantar melancia para comercializar. Hoje, temos novilhas, bezerros e vacas secas, quando estão no ponto, a gente vende. Nossas aves são poucas, só para o gasto. Com o financiamento do FCO que eu fiz, no valor de $R \$ 33 \mathrm{mil}$, construí cercas, fiz desmatamento, bebedouros, represas e um hectare de irrigação. Foram quatro anos de carência e quatro para pagar, termino este ano. O trabalho aqui é realizado só pela família, principalmente eu e a esposa, quando é necessário contratamos um diarista, mas é difícil. Quando cheguei aqui, pegava gado a meia e arrendado, o que plantava era só para o consumo. Tudo que tem hoje foi construído com nosso esforço e com o financiamento. No momento tenho um ônibus e presto serviço para a COTERMAT, uma Empresa de Transporte Escolar Rural do Sul de Mato Grosso. Trabalho o dia todo e à noite, portanto, só trabalho no sítio final de semana. Pretendo dividir a terra com meus filhos, da mesma maneira que meus pais, como eles moram na cidade, onde trabalha e estuda, não quero interferir, pois hoje viver em sítio é muito difícil, o melhor é ter um emprego e viver na cidade.

Nosso interlocutor expõe em seu depoimento a decepção pelo fato de não ter dado certo o projeto que seria desenvolvido com apoio da Secretaria de Agricultura do Município e EMPAER, patrocinado pela Alemanha. Hoje, realiza um trabalho extra à propriedade, para ajudar no aumento da renda familiar. As atividades na propriedade durante a semana estão a cargo de sua esposa, que realiza dupla jornada de trabalho, tanto nas afazeres do lar quanto nas tarefas do campo, na lida com a terra. 


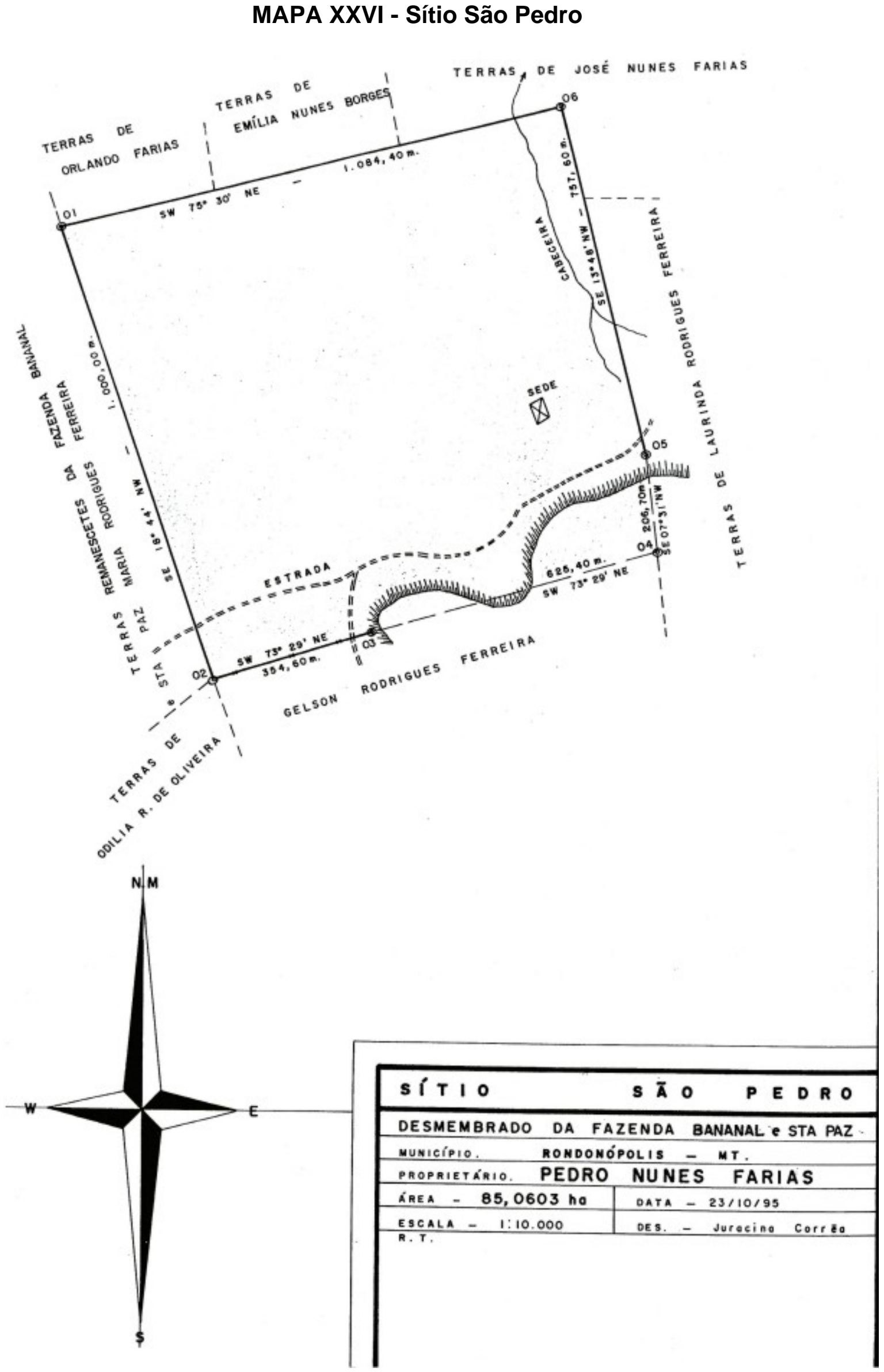


José Nunes Farias, casado em regime de Comunhão Universal de Bens com Lucilene Nascimento Farias, desde 1986, são pais de Lorraine e Lorran (Foto 26) e donos do Sítio Beroaba que possui hoje 156.5803 hectares (Mapa XXVII).

Quando meu pai faleceu, eu tinha 15 anos e estudava a $3^{a}$ série primária em Rondonópolis. Devido à falta do pai, fiquei sem estudar no ano seguinte, voltando novamente em 1971 e 1972. Desde então, não voltei mais a estudar, porque minha mãe ficou viúva com onze filhos de várias idades diferentes e necessitava de minha presença por ser um dos mais velhos para trabalhar na lavoura e na pecuária junto com os outros irmãos. Permanecemos juntos até o momento do casamento de cada um. Em 1986, casei-me com a Lucilene e ficamos morando na sede principal. Quando casamos, a residência da fazenda era bem humilde (Foto 27). Meu pai foi sepultado em frente a nossa residência. Depois, com o passar dos anos construímos outra casa grande, de alvenaria (Foto 28) onde vivemos até hoje. Tem luz elétrica e água encanada. Minha filha Lorraine está fazendo o $3^{\circ}$ semestre de Agronomia no CESUR faculdade particular, o Lorran está cursando o $3^{\circ}$ ano do Ensino Médio na EEMOP, escola do Estado e ainda não definiu a faculdade que deseja cursar. Vivemos com a renda da venda do gado de engorda e do leite, que nessa época é em torno de uns 140 litros por dia, como não tenho resfriador próprio, levo todos os dias para o resfriador do Laticínio que fica no Assentamento Olga Benário. É uma pena que o Laticínio Nutribon paga apenas $R \$ 0,30$ o litro. Criamos porcos e galinhas, somente para o nosso consumo. Construí uma represa, mas este ano não mexi ainda, mas vou trabalhar com piscicultura a partir do ano que vem. Fiz um custeio de $R \$ 3$ mil para ajudar nas benfeitorias do sítio. Aqui, o trabalho é realizado por mim e minha esposa, uma vez ou outra a gente contrata um diarista, no mais é a família mesmo. $O$ trator que usamos aqui é de sociedade com o Luiz, os outros equipamentos e ferramentas de trabalho são meus. Temos um carro pequeno que utilizamos para ir à cidade e visitar os parentes, todos (irmãos) moram meio perto. Essa terra aqui era do meu avô, passou para meu pai e agora é nossa. No futuro pretendo passar a terra para meus filhos, ainda em vida. Para toda a família a terra tem grande importância para o presente e para o futuro dos filhos também.

As frases: "não tive mais como voltar pra escola", "irmãos com várias idades", "permanecemos juntos até o momento do casamento de cada um" são reveladoras da imagem que José tinha de si mesmo com relação à família. Parou de estudar para trabalhar na roça, pois, dos filhos homens era o mais velho e se sentia na obrigação de ajudar a mãe no sustento da família e de manter a união de todos. $\mathrm{O}$ fato de dizer "casei e fui residir na sede principal" soa como um orgulho por ter conseguido levar adiante, mesmo com dificuldades, os projetos desenvolvidos pelos pais. 


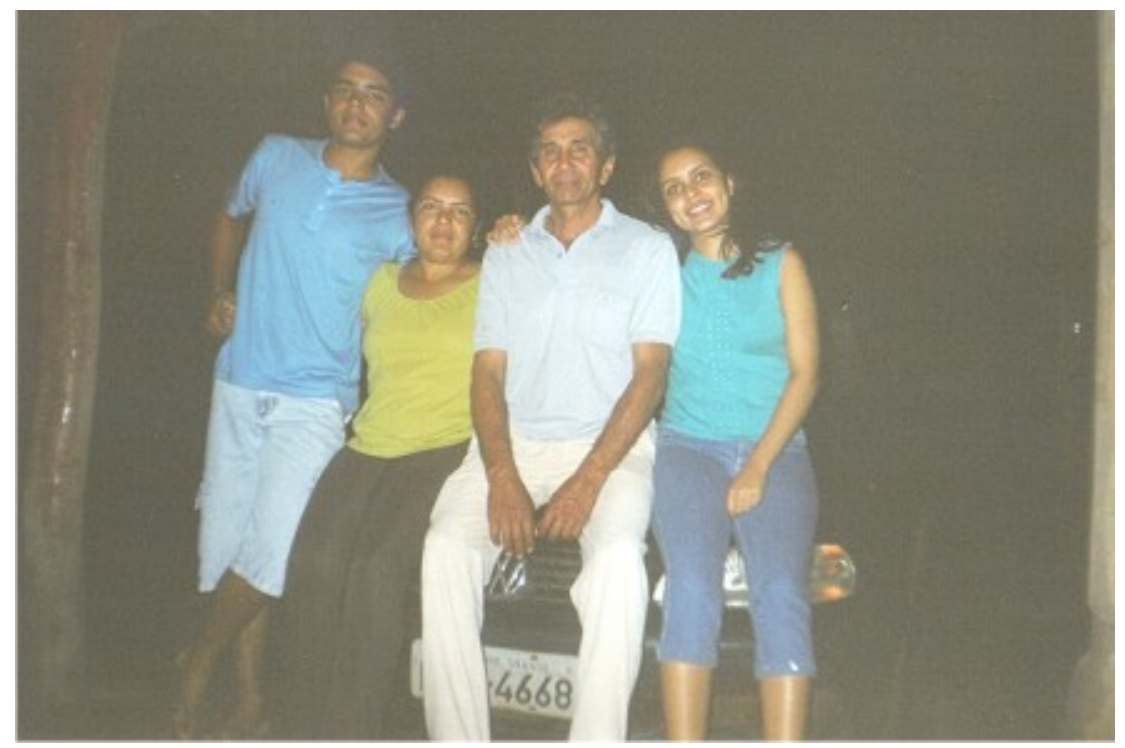

Foto 26 - Família do Sr. José Nunes Farias. Cedida por Farias. J.N.

Foto 27 - Sede da Fazenda Beroaba. (Cedida por Farias. J.N.)
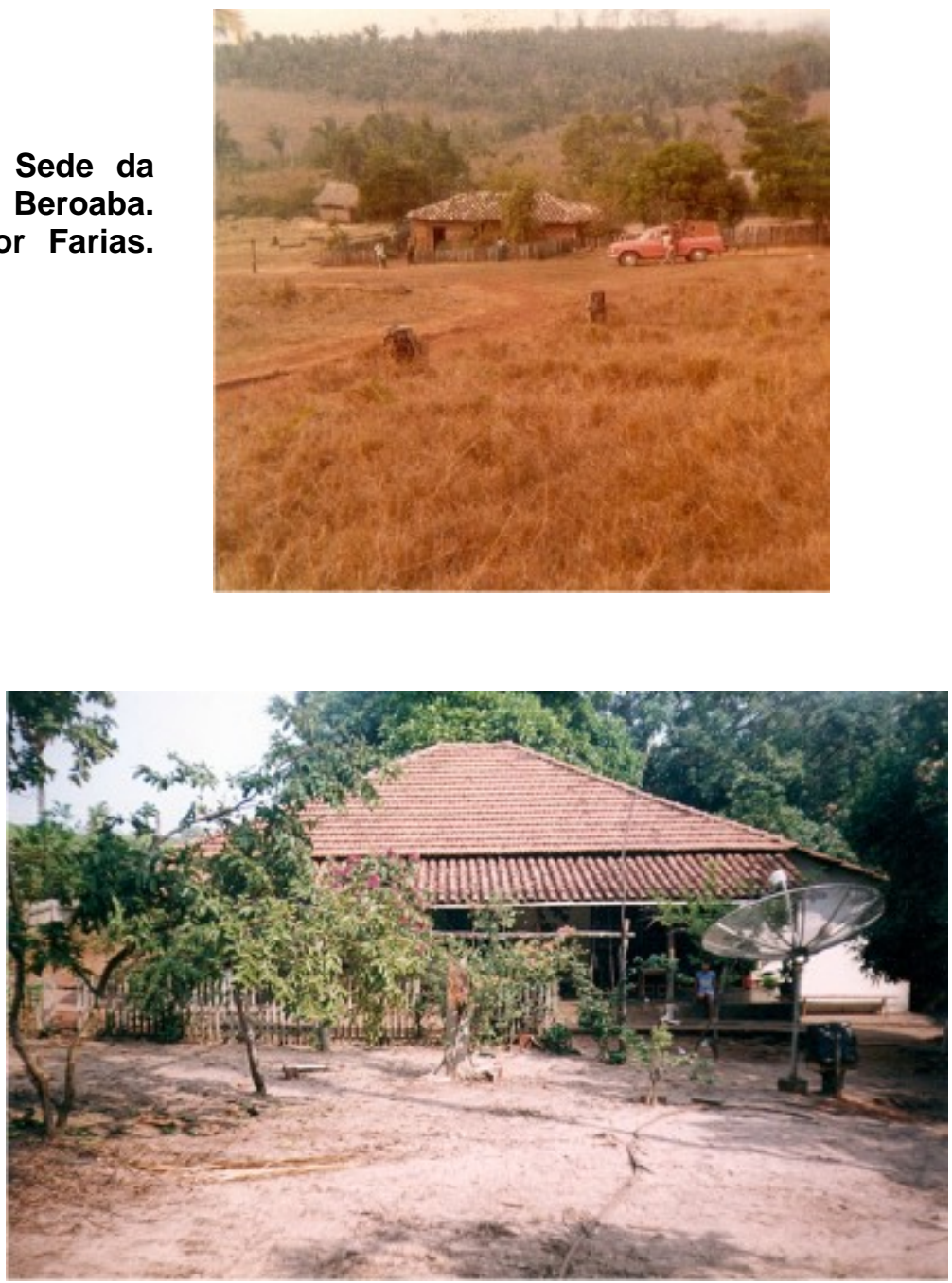

Foto 28 - Sede do Sítio Beroaba. (Cedida por Farias. J.N.) 


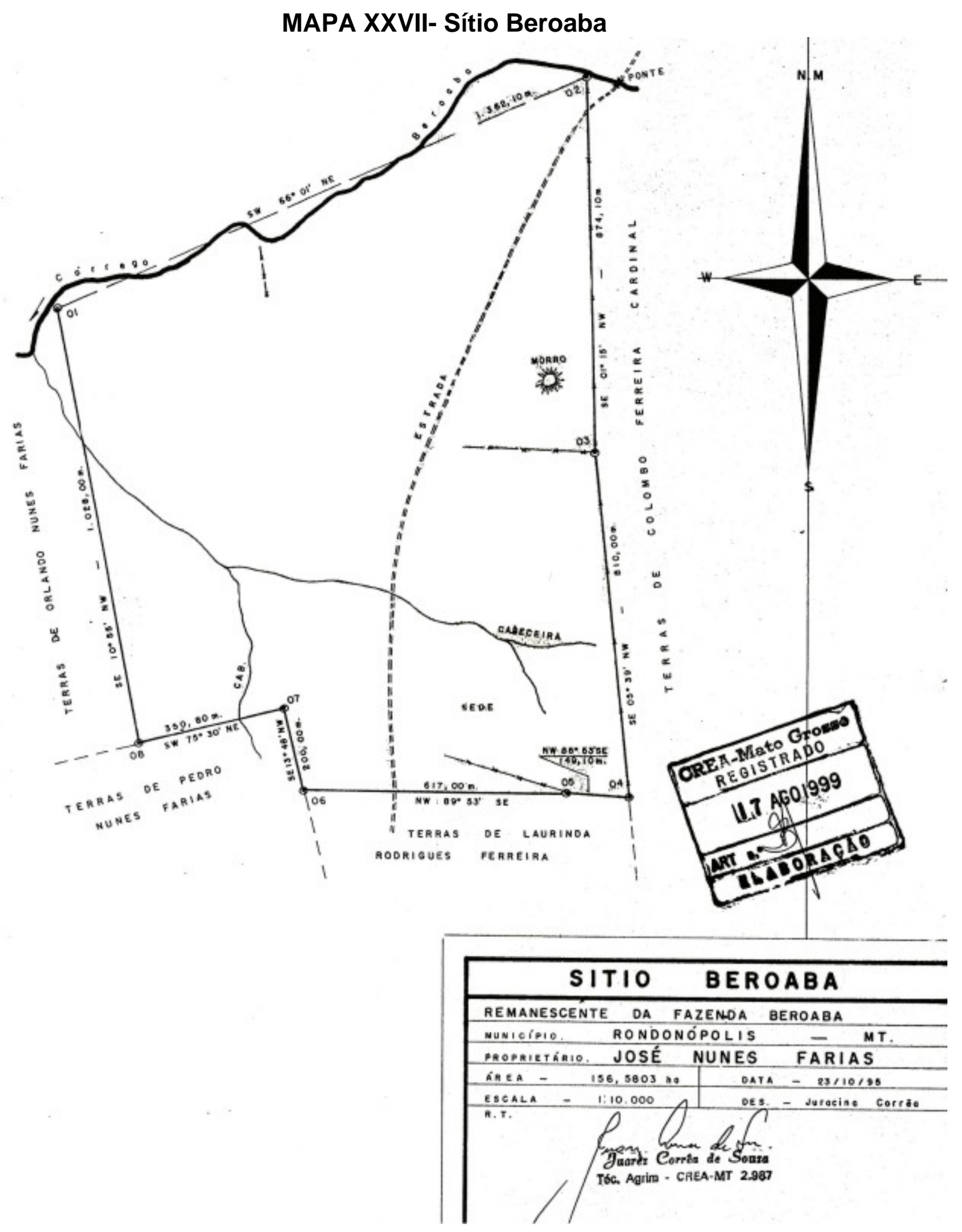


Nelson Rodrigues Ferreira e Dircilei Honório Ferreira (Foto 29) casaram-se no regime de Comunhão de Bens, no ano de 1989 e são donos do Sítio Cristandade, com área de 72,8203 ha. (Mapa XXVIII).

Quando casamos, fomos morar em Rondonópolis, no Conjunto São José, depois, mudamos para Paranatinga/MT onde moramos durante seis meses. De lá voltamos para Rondonópolis e viemos embora aqui pro Sítio, onde estamos há 18 anos. Tivemos três filhos (Foto 30), a Hellen (18), o Jhonatan (17), e a Magda (14), além deles criamos um sobrinho, o Alexandre (16). Todos estão estudando. Assim que viemos pra cá, formamos pastos, fizemos roça de arroz e criamos gado, o trabalho é realizado só pela família. Fiz também um custeio no valor de 18 mil reais para formar pastos, construir cercas e outras benfeitorias. Minha esposa resolveu estudar e prestou vestibular para o curso de letras na Unic Universidade de Cuiabá, e estudou durante quatro anos. Hoje ela é professora em duas escolas, no Assentamento 17 de março em Juscimeira/MT e na escola 14 de agosto do Assentamento Chico Mendes. Ela vai de moto para o serviço. Eu comprei uma Kombi para transportar alunos e há dois anos estou associado na Cotemat trabalhando no transporte escolar. A propriedade está mais ou menos $70 \%$ formada em capim, pastagem para o gado. Por enquanto, estamos vivendo com o dinheiro do arrendamento dos pastos, do salário da minha esposa como professora e da prestação de serviço para a Cotemat. Como o Sítio é pequeno e a renda é pouca, vivemos do trabalho extra. Pretendo criar peixes para comercializar, para aumentar a renda familiar. E a terra, venderia se fosse para comprar uma melhor, ou seja, de cultura. Gostaria que nossos filhos vivessem no campo, mas como a terra é pouca, acho melhor que eles vivam na cidade, para poderem estudar e trabalhar.

Da fala anterior, há dois pontos a serem destacados: o primeiro é referente à migração: "moramos em Rondonópolis, depois em Paranatinga, voltamos para Rondonópolis", o que significa a busca pelo local ideal para a formação da família, o resultado foi a volta para o campo, ocupando o que era seu por direito. O segundo é morar no campo e exercer profissões não relacionadas à terra. Quando o Nelson diz "por enquanto... vivemos do trabalho extra", está afirmando que o trabalho é fora da terra camponesa, da terra de morada, e constitui um trabalho acessório. E esse fato nos remete a Oliveira (1991:57), quando diz que "essa transformação periódica constitui-se em fonte de renda monetária que suplementa o rendimento com as culturas em suas propriedades". 


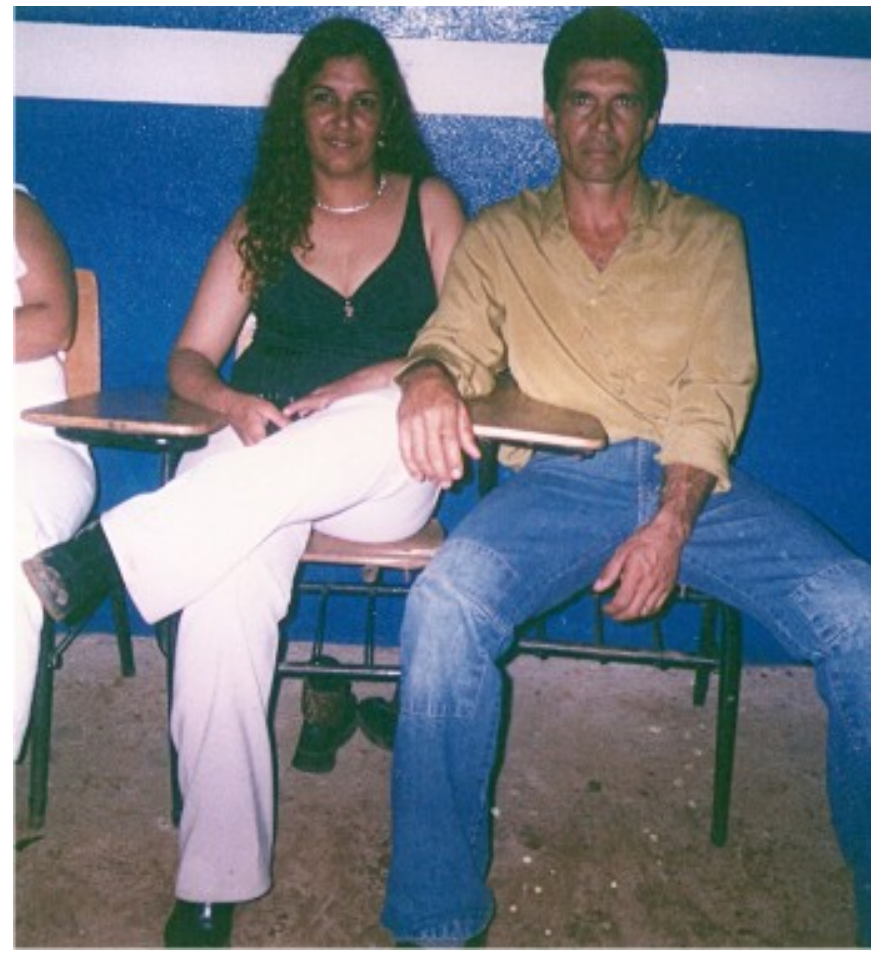

Foto 29- Nelson e sua esposa Dircilei. (Cedida por: Ferreira, N.R)

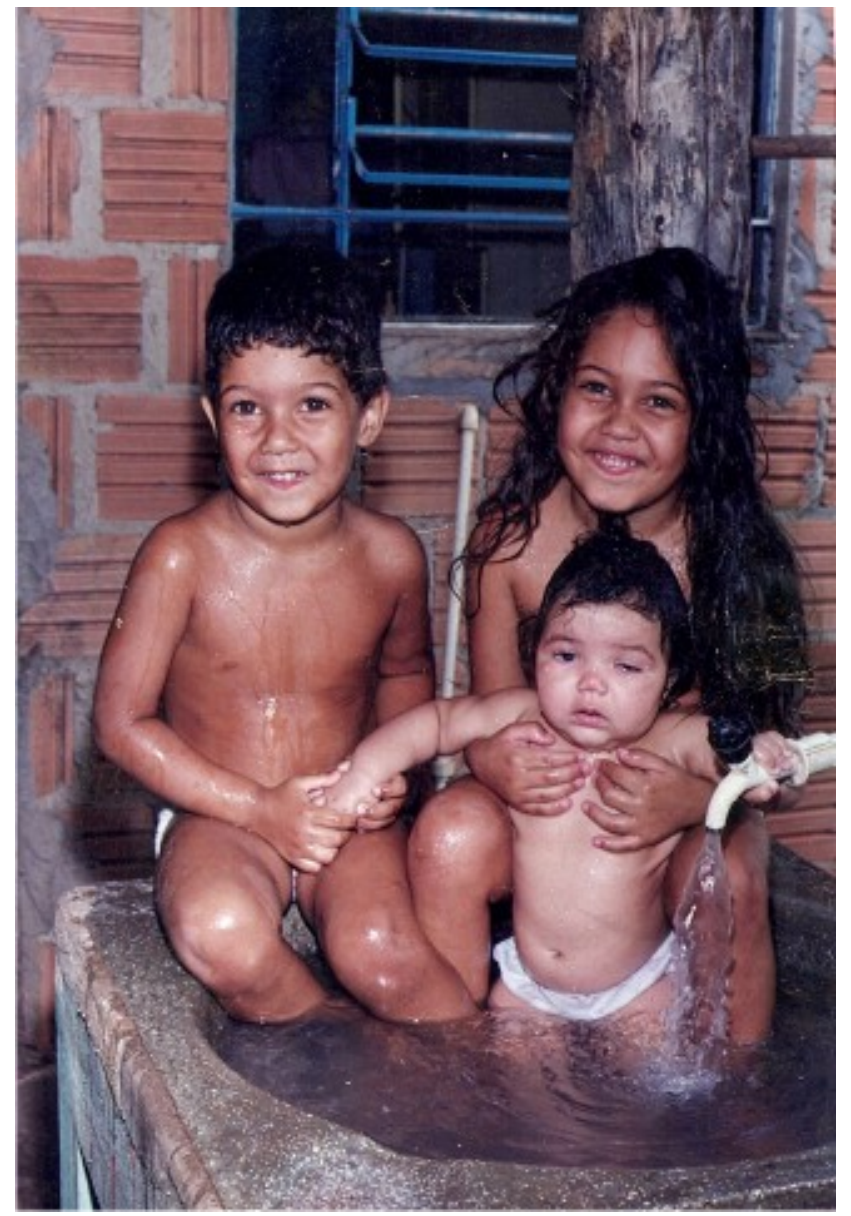

Foto 30- Os três filhos de Nelson, quando crianças. (Cedida por: Ferreira, N.R) 
MAPA XXVIII - Sítio Cristandade

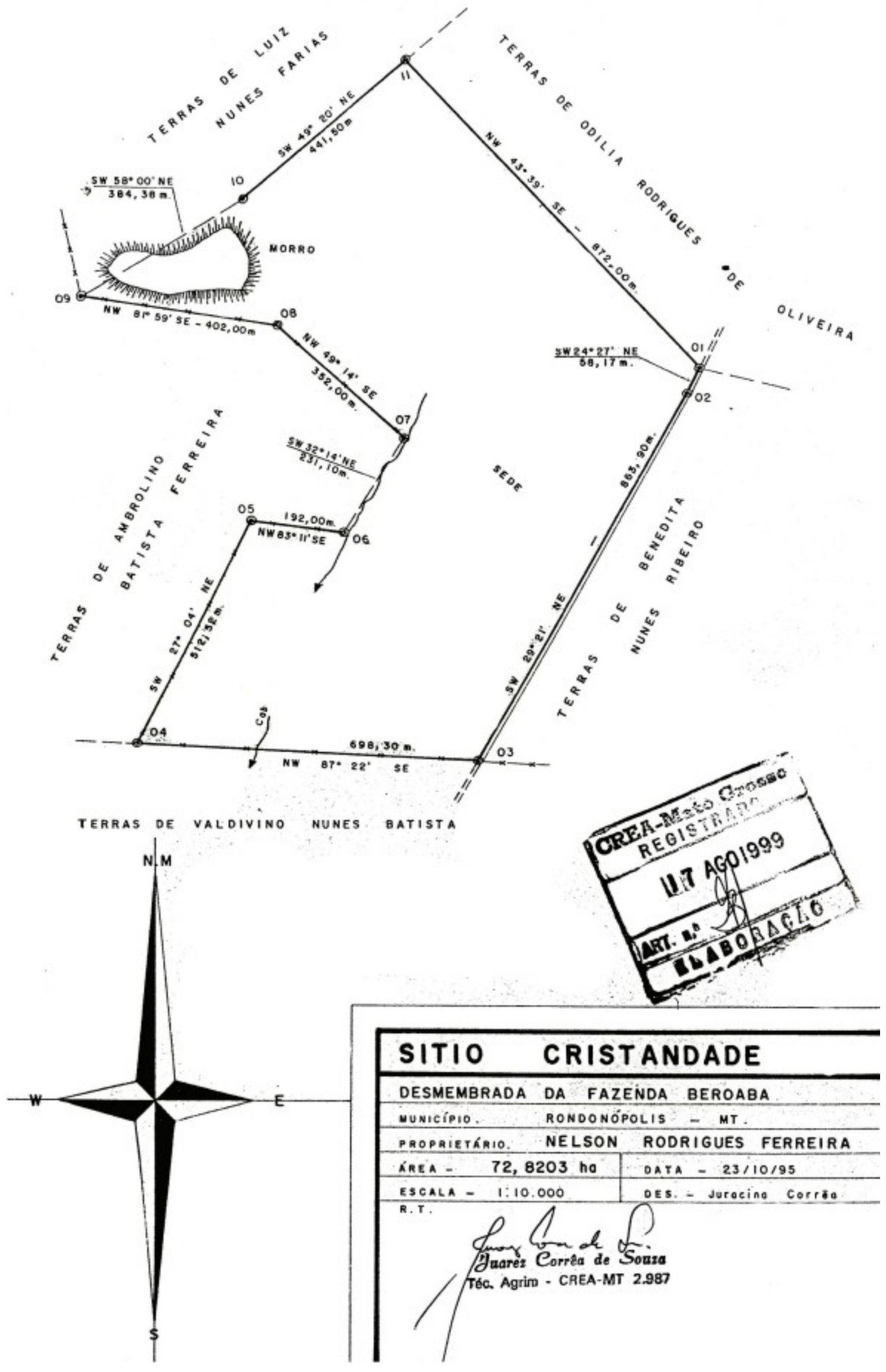


Gerson Rodrigues Ferreira é casado com Maria Aparecida Martins Ferreira desde 1990 e são donos do Sítio Dhessyka e Maryelle (Mapa XXIX).

Assim que casamos, moramos dois anos no sítio em uma casa pequena, de madeira (Foto 31). Com água encanada e luz elétrica. A propriedade está praticamente toda formada de pastagem para $o$ gado. Deixamos uma parte, $20 \%$ da área de reserva. O sítio tem quatro nascentes e fizemos questão de preservá-las. Voltei para a cidade com a família (Foto 32) em 1992, pois o que produz no sítio é pouco e as despesas são grandes, aqui ficou mais fácil. Primeiro morávamos de aluguel, hoje temos casa própria. Vim trabalhar como vendedor de uma distribuidora. Hoje trabalho com vendas autônomas de materiais para gráficas. Montei a Empresa Representações GR - Impressos gráficos, onde trabalhamos eu, minha esposa e nossa filha. Minhas filhas Mayra Dhessyka e Jessyka Maryelle estudam na escola EEMOP - Escola Estadual Major Otavio Pitaluga, fazem o $2^{\circ} \mathrm{grau}$. Atualmente arrendo o sítio anualmente. Ninguém mora na casa, vamos para lá nos finais de semana, para descansar. O pagamento do arrendamento é equivalente a 8 mil reais anualmente. Não compensa, mas pego o dinheiro e aplico em benfeitorias no próprio sitio, em formações de pastos, cercas, roçado e também na casa aqui na cidade. Vou construir um curral com embarcador e fazer mais repartições de pastos, enfim, melhorar. Pra eu vender o sítio só se tiver uma coisa muito boa na cidade, mas para ter uma vida melhor para as filhas, já que não tive filhos acho melhor construir kitinetes aqui na cidade. As meninas não interferem e pedem para que eu faça o que for melhor.

Em sua fala, Gerson confirma a condição de morador temporário no sítio, aonde vai apenas final de semana e nas férias. Deixou transparecer que, ao mesmo tempo em que pretende vendê-lo para construir algo na cidade, onde acredita que o futuro será melhor, também tem projetos para construção de benfeitorias na propriedade.

Quando diz "já que não tive filhos", é perceptível pela frase que a presença masculina para dar continuidade ao patrimônio seria mais garantida; por isso, 0 interesse em construir algo na cidade. 


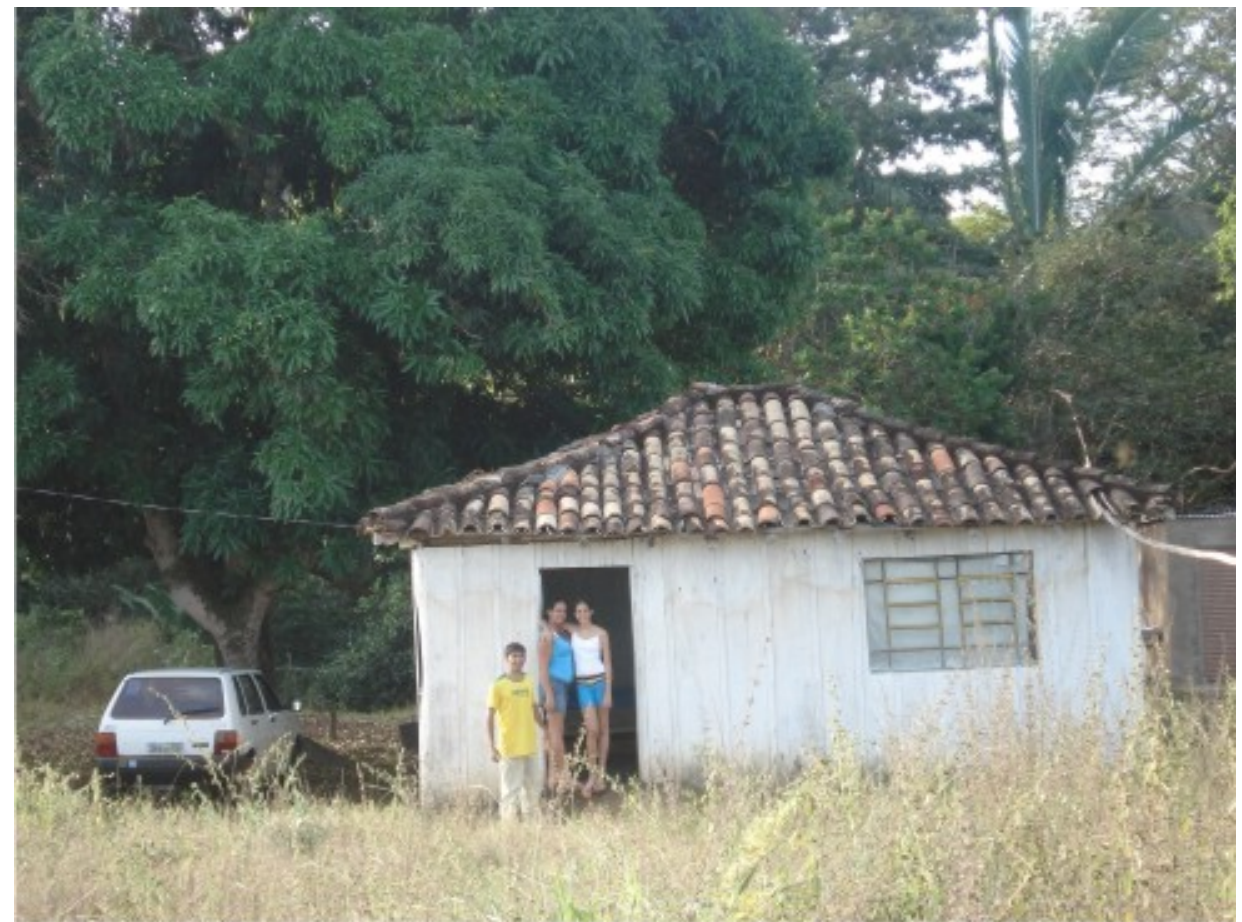

Foto 31 - Sede do Sítio Dhessyka e Maryelle. (Cedida por: Ferreira, G. R).

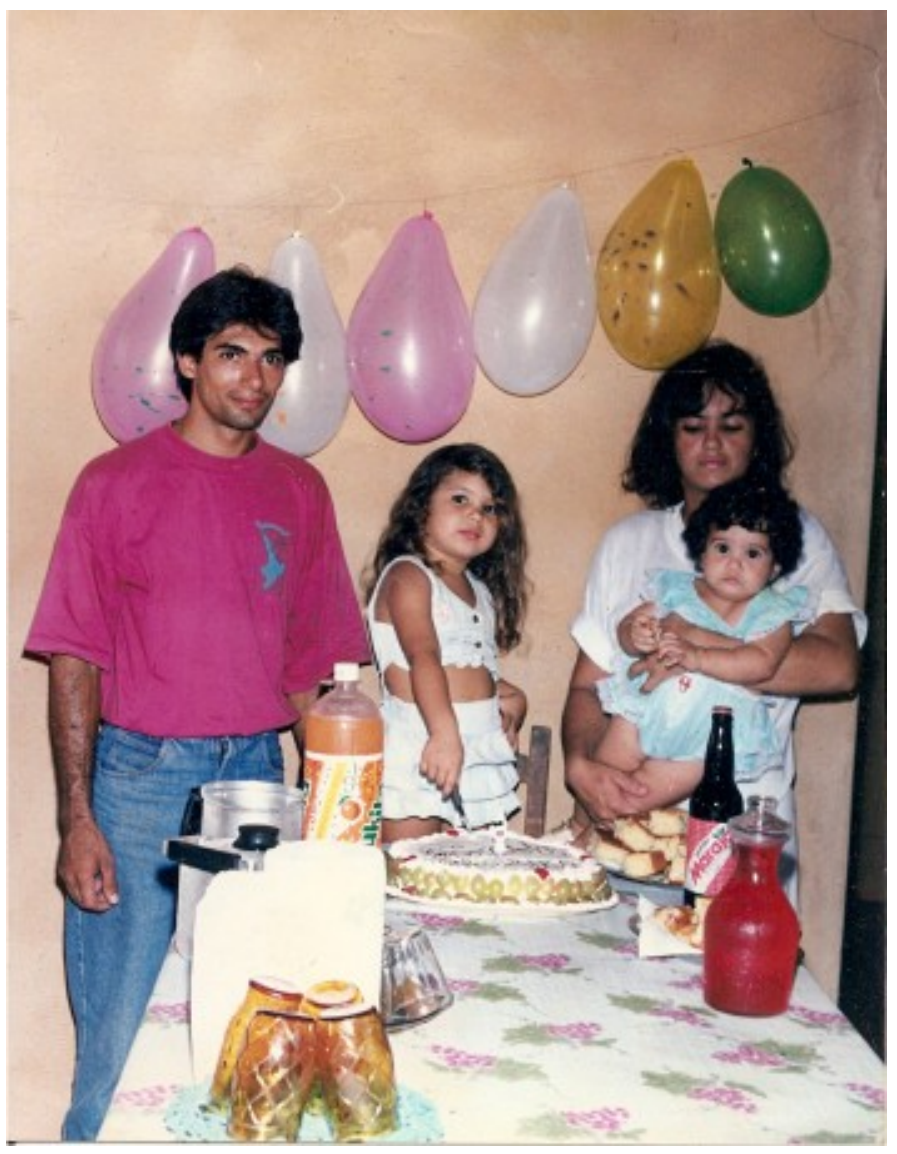

Foto 32 - Gerson a esposa Maria Aparecida e as filhas Dhessyka e Maryelle quando eram crianças. (Cedida por: Ferreira, G. R). 
MAPA XXIX- Sítio Dhessyka e Maryelle

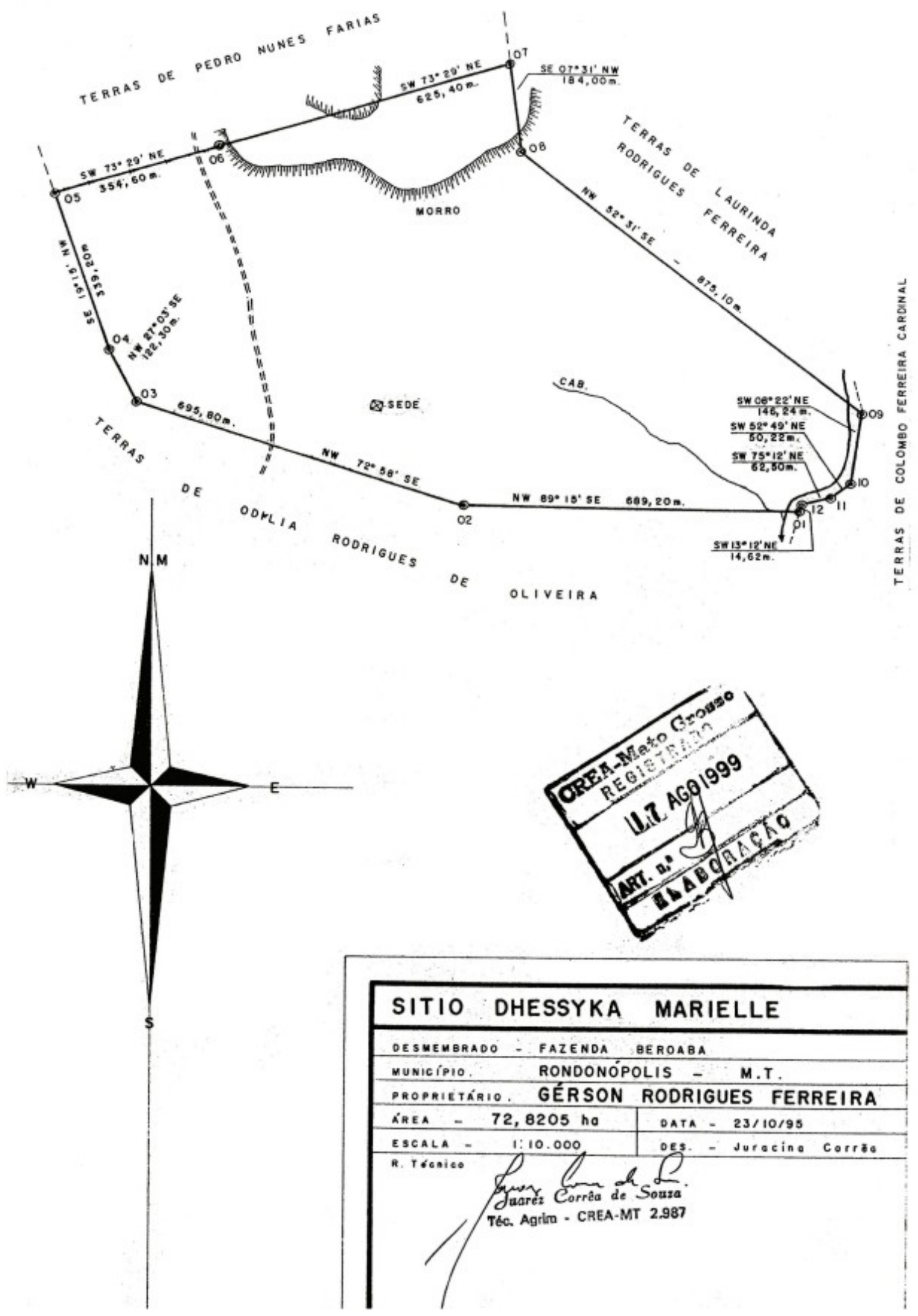


Emília Nunes Farias, mãe de Gleyce e de Gleydson (Foto 33), é proprietária do Sítio Dois Irmãos (Mapa XXX) com 31,8203 hectares.

Nasci na fazenda Bananal, onde passei minha infância. Iniciei meus estudos na casa dos meus pais, onde fui alfabetizada. Com a morte do meu pai, quando completaria 11 anos, vim morar na cidade junto com meus quatros irmãos, na casa de nossa avó materna, onde continuei os estudos. Em minha vida, estudo e trabalho sempre caminharam juntos, lado a lado. Dos doze aos quatorze anos trabalhei de babá em um período e estudava no outro. Com 15 anos, me ofereci para trabalhar voluntariamente como estagiária em um hospital infantil. Depois de um ano sem remuneração e como aprendiz, fui contratada como enfermeira, trabalhei ali até os 17 anos. Com 18 anos fiz teste e fui trabalhar no Banco Bradesco, trabalhava durante o dia e fazia magistério a noite. Aos 21 anos me casei, deixei de ser bancaria e fui trabalhar como professora (interina) nas séries iniciais. Tive um casal de filhos. Mudamos para Colorado do Oeste, em Rondônia, portanto, vendi para meu irmão Luiz, os 41 hectares que recebi da herança de meu pai e compramos terra lá (Foto 34). Trabalhei em Rondônia como professora concursada durante cinco anos, então, meu ex-marido ficou desempregado e resolveu voltar para Rondonópolis. Vendemos o que tínhamos lá e compramos aqui dois terrenos, onde construímos uma casa e um sobrado (2 pisos), na separação ficou para ele que comprou minha parte. Formei-me em Pedagogia e continuo dando aulas como professora contratada. Moro na cidade com meu filho de 23 anos que é formado em Agronomia. Minha filha é casada, tem quatro filhos (dois casais), é formada em Letras e é professora. Das terras do Beroaba, vendi a parte que recebi do meu pai e hoje tenho o que ganhei de doação de minha mãe. Nunca morei lá no sítio, mas temos uma casa, aonde vamos aos finais de semana para cuidar do gado e também ficamos lá durante as férias. Já pensei em vender. Mas fui aconselhada pela minha irmã a desistir, pois as coisas estão difíceis e mais para frente meus filhos podem querer uma terra e não ter condições de comprar. No futuro, vou dividir com os filhos com direito a usufruto.

Minha interlocutora mostrou pelo depoimento, sua trajetória de vida na cidade, migrando em busca de uma vida melhor. A troca de profissões e a mudança de Estado, Mato Grosso por Rondônia, expõe a insatisfação da família e a necessidade do retorno para garantir a parte da terra que a mãe doou, já que a herança do pai ela havia vendido.

Em partes do depoimento, era perceptível a magoa em relação ao ex-marido, pelo fato de ter que voltar de Rondônia onde era professora concursada para trabalhar como professora contratada até hoje em Rondonópolis. 


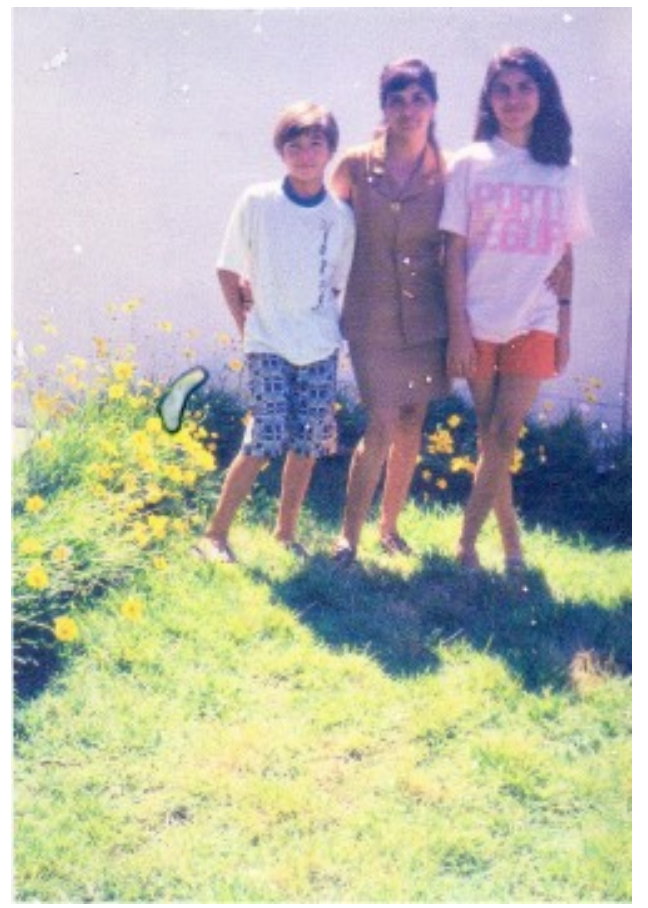

Foto 33 - Emília e os filhos: Gleyce e Gleydson quando eram adolescentes. (Cedida por: Farias, E. N).

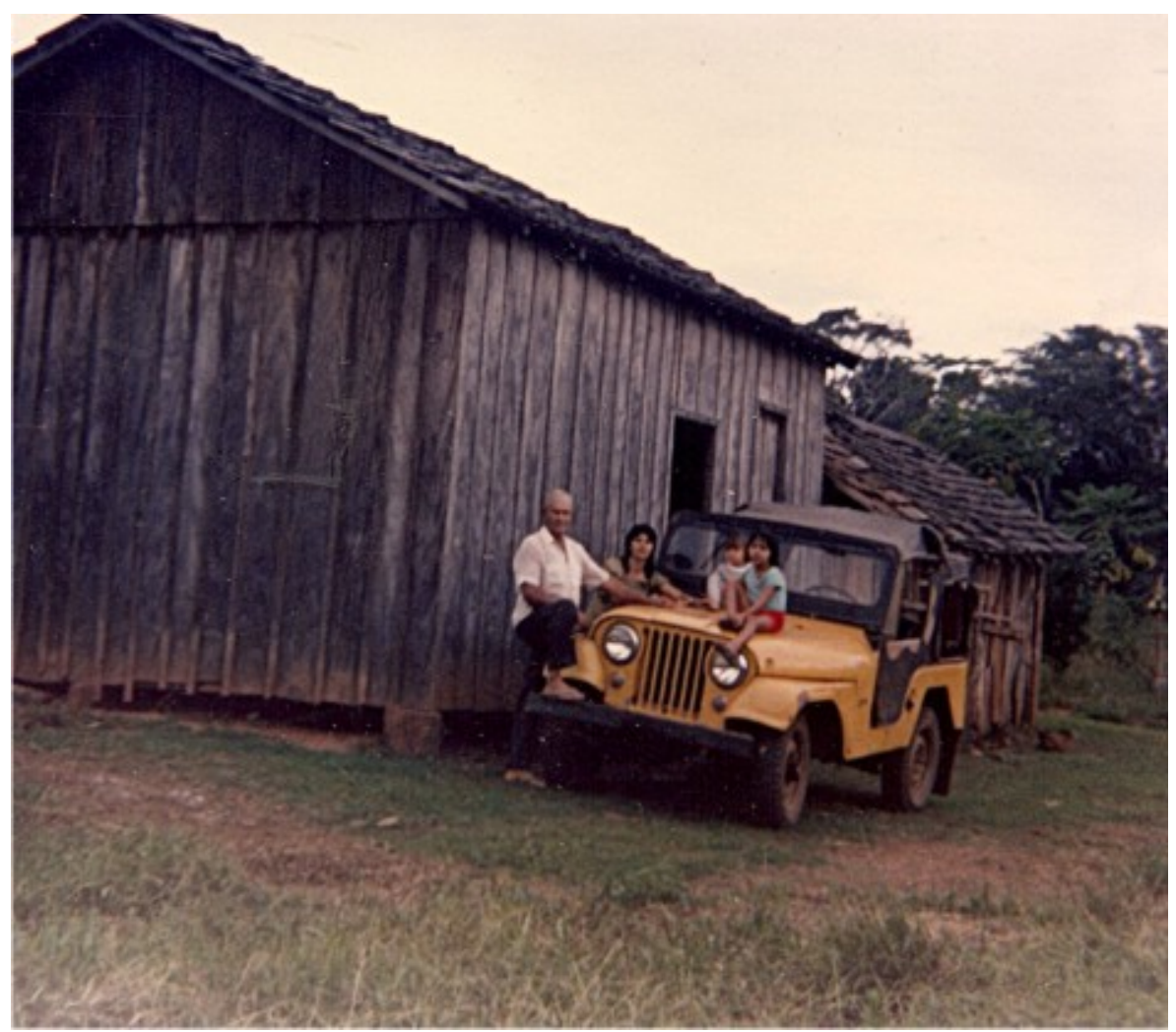

Foto 34 - Sede da ex-Fazenda de Emília em Rondônia. (Cedida por Farias, E. N.) 


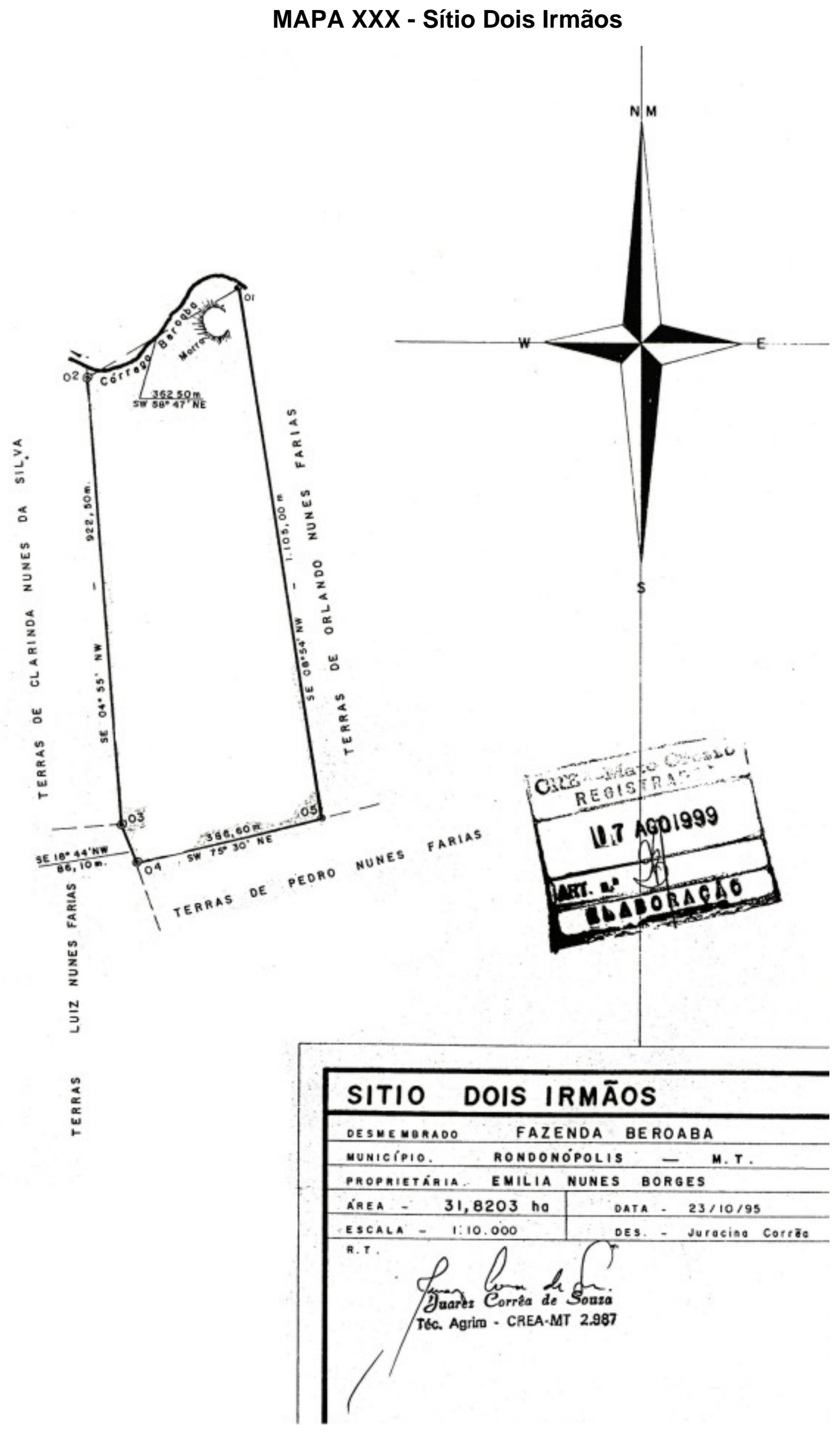


Orlando Nunes Farias é casado com Maria de Fátima Oliveira Farias e são donos do Sítio Nossa Senhora de Fátima, com 31,8203 hectares (Mapa XXXI).

Em entrevista, Benedita informou que Orlando vendeu os 41 hectares que recebera de herança do pai para três de seus irmãos. O José e o Luiz compraram 15 hectares cada e ela comprou 11 hectares. Com o dinheiro da venda, ele foi embora para Rondônia e comprou 80 hectares em Vilhena. A terra da doação da mãe ele tem até hoje, não tem casa no sítio, só tem pasto formado, que o Pedro arrenda para pôr o gado dele. O arrendamento é mensal. Orlando e Maria tiveram dois filhos, a moça já é casada e o rapaz é solteiro.

Benedita afirma que Orlando foi o único dos três irmãos que migrou para Rondônia e conseguiu prosperar. Tem aqui em Rondonópolis a terra de doação da mãe, que arrenda para o irmão Pedro.

Odília Rodrigues de Oliveira é casada com Ademar Rodrigues de Oliveira e tiveram três filhas: Aline, Bruna e Camila. São proprietários do Sítio A.B.C., com 72,8203 hectares (Mapa XXXII). Moram na cidade, onde ele exerce a profissão de serralheiro e ela é professora. No sítio, há uma casa com luz elétrica, água encanada e está sendo ampliada. Todo final de semana e férias eles vão para tomar conta do gado, das aves e das plantações.

Pelos depoimentos anteriores, nota-se que a prática de arrendamento de pastos é comum entre os proprietários da família Ferreira; quando não é para os irmãos acontece com terceiros, que pode ser mensal ou anual, dependendo do combinado. Outro fator notável entre eles é o sistema de adoção que começou por $D^{\mathrm{a}}$. Maria ao adotar Zuleide (Foto 35), assim como Benedita e Nelson. Casos que nos remetem aos depoimentos do Sr. Valdivino e Gerson, ao exporem a história de seu pai/João Nunes Ferreira (Foto 36) e tios, que foram criados por terceiros. 


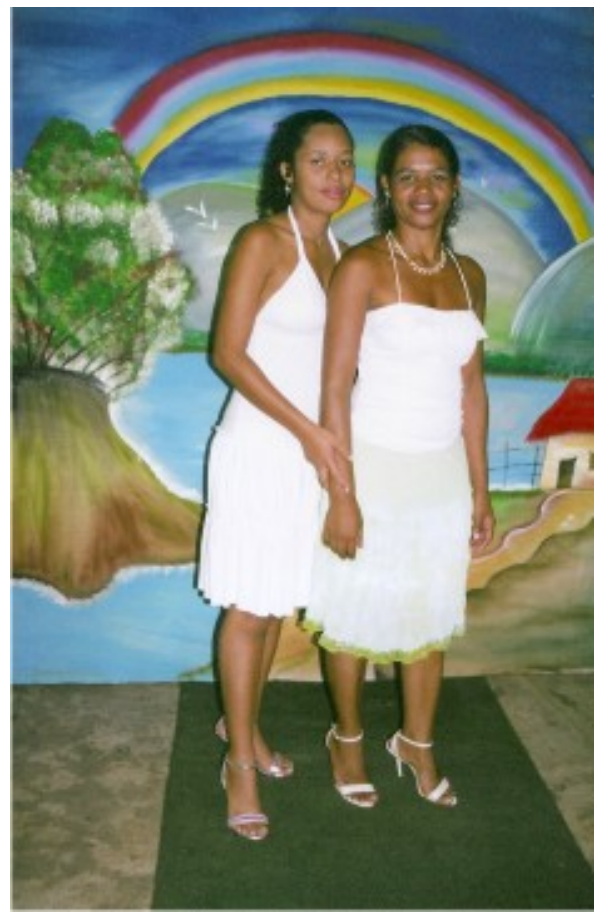

Foto 35 - Zuleide e sua filha Letícia. (Cedida por: Ribeiro, B.N.)

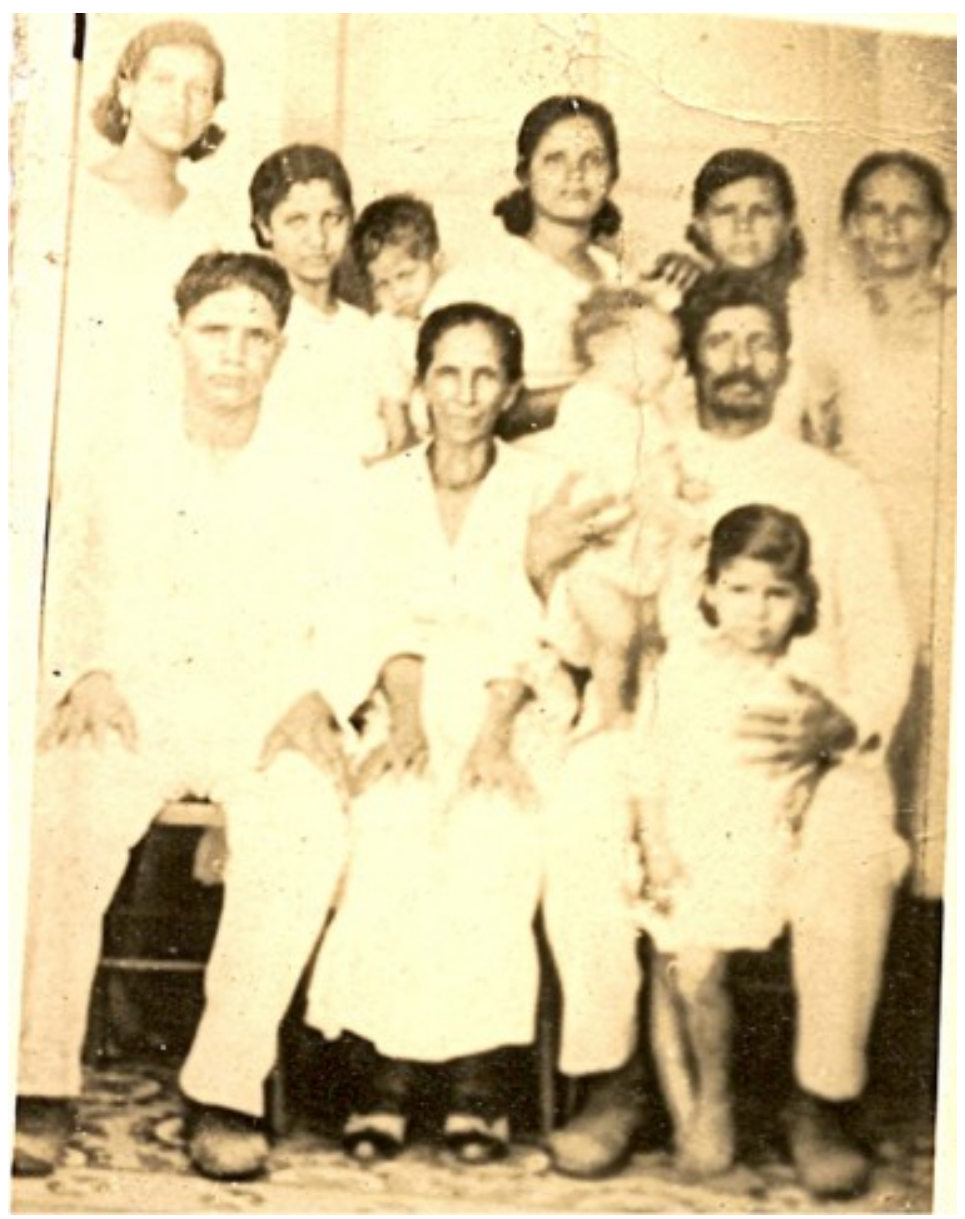

Foto 36- Sr. João Nunes Ferreira e Família. (Cedida por Farias, E. N.) 
MAPA XXXI - Sítio Nossa Senhora Aparecida

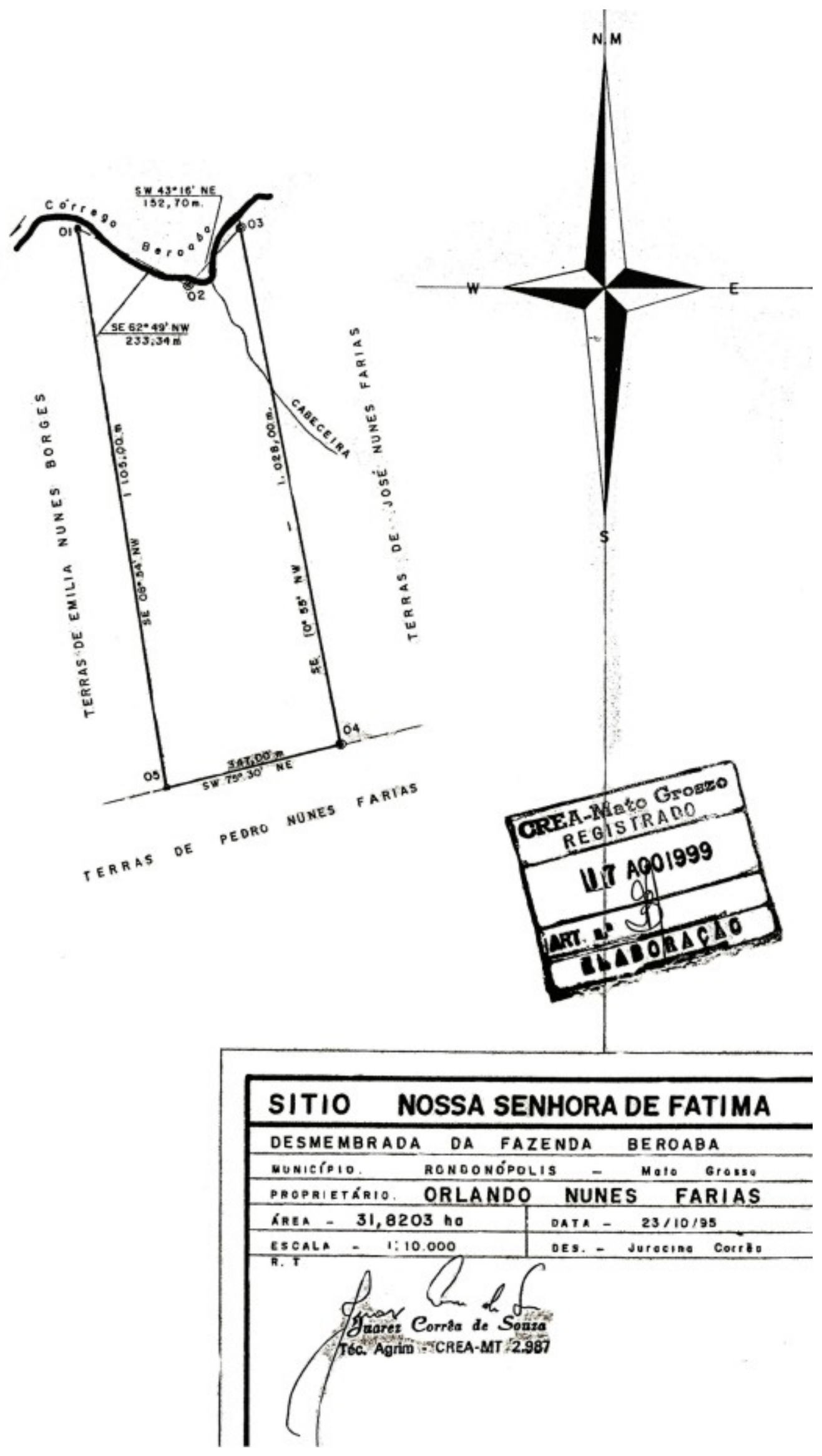


MAPA XXXII - Sítio A. B.C.

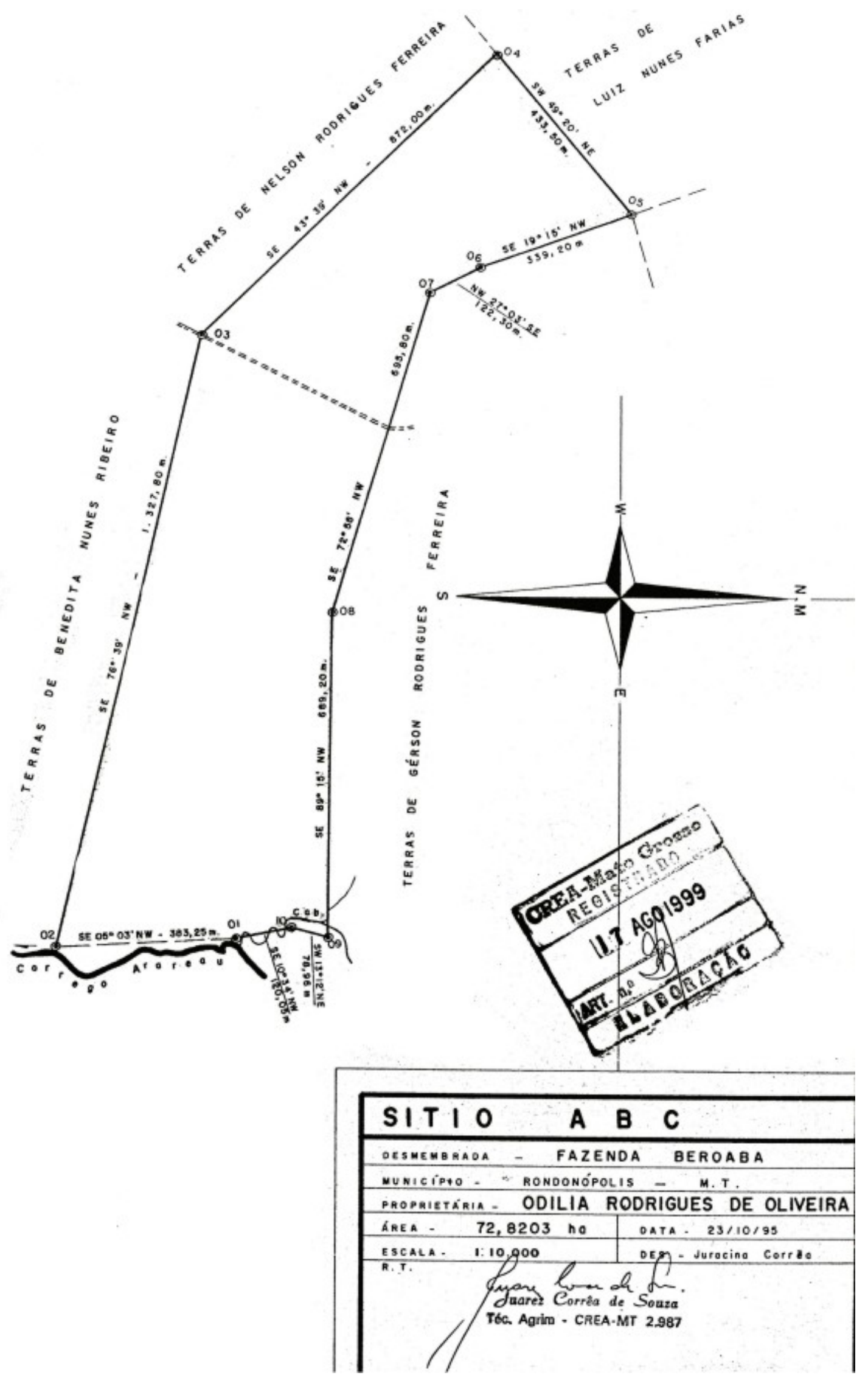


Em relação a essa família, no contexto geral, nota-se ser "unida", dá valor e respaldo maior para o sucesso da propriedade como um todo (divisível). A união dos irmãos fez com que a terra permanecesse entre a família mesmo depois de fragmentada por duas vezes: herança do pai e doação da mãe.

Existiu a saída dos filhos para estudar, trabalhar e morar fora da propriedade, do sítio, mas também o caminho inverso, o retorno para o campo, para a terra de trabalho, onde a ajuda mútua, diferente da época do pai, realiza-se entre os irmãos. E aquela que está fora da propriedade arrenda para outro da própria família.

Pelos depoimentos, pode-se perceber que a vida dessas pessoas está permeada pela vivência na fazenda em que nasceram, cresceram, viram o pai ser sepultado, onde muitos conheceram seus esposos e esposas e tiveram seus filhos (no início em barracos de palha) e, com eles, por intermédio de herança e doação, adquiriram um lote, um sítio. 
FAMÍLIA SILVA

\section{Sete Palavras \\ PedroBentoeZéda estrada}

Composição: Pedro Bento E Zé Da Estrada

Deus amou tanto este mundo,

o mundo não correspondeu, então Deus mandou os profetas, mas ninguém obedeceu, Deus mandou seu próprio filho, mas ninguém não conheceu, quando ele perambulou, teve porta que fechou na hora que ele bateu.

Pra salvar a humanidade, o nosso Senhor nasceu, 33 anos de idade, neste mundo ele viveu, Deus de infinita bondade, do mundo compadeceu, ele deu a própria vida, pra juntar a ovelha querida

Na hora da santa ceia, que do rebanho se perdeu.

beijou os pés dos discípulos seus,

em seguida ele falou, vocês façam como eu, vou pra casa de meu Pai, da onde a gente desceu, um de vós vai me trair até Pedro vai fingir que nunca me conheceu.

Levantou os olhos pro céu, pegou o pão e benzeu, esse pão é o meu corpo, cada díscipulo comeu, esse vinho é o meu sangue, cada díscipulo bebeu, Judas atirou no chão, aquele pedaço de pão saiu da mesa e correu.

30 moedas de prata,

foi o quanto recebeu, no horto da oliveiras, levou soldado e prendeu, Jesus preso e amarrado, calado permaneceu, depois de tanto maltrato, já gritaram a Pilatos, crucifique o galileu.

Na hora da sua morte,

a Terra empalideceu, trovejou de sul a norte, Judeia toda tremeu, o véu do templo rasgou, 


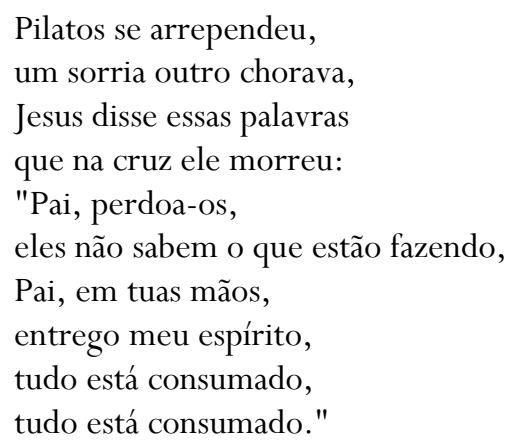

A propriedade do Sr. Antônio Alves da Silva, em Rondonópolis, originou-se com a compra, em sociedade, de uma área de 502 ha denominada Miranda que, após a divisão, cada sócio recebeu 83 ha e 6.666 m² (Certidão 04). Em 19/08/1948, solicitou a compra de um lote de terras devolutas, por ele já ocupado, situado no Naboreiro com mais ou menos 300 hectares. Em 15/01/1949, a venda foi concedida pelo Departamento de Terras de Cuiabá.

O agrimensor concluiu, em 19/08/1949, que a área era equivalente a 294 hectares (Mapa XXXIII). Em 22/02/1952, o Auxiliar Técnico informou que, após verificar a medição do lote, constatou que o mesmo se encontrava em área reservada pelo Decreto $n^{\circ} .526$, de 19/08/1948 e nos termos dos Artigos $2^{\circ}$ e $3^{\circ}$ do Decreto $n^{\circ}$. 526; por isso optou-se pela anulação do referido processo de medição.

Em 15/02/1954, o Sr. Antônio Alves da Silva entrou com um documento justificando o uso adequado do lote por ele, no qual vinha investindo em benfeitorias e realizando seu trabalho e de cujo lugar tirava provento para manutenção da família.

Em 03/06/1954, o Auxiliar Técnico informa, através de documento, que a Gleba do Norte da linha telegráfica deixou de ser loteada, conforme consta do projeto aprovado, não só por ter um título provisório, cuja medição se encontrava no respectivo departamento, como também, por ter benfeitorias do requerente dentro dessa Gleba. À vista dessas considerações, a solicitação do Sr. Antônio foi atendida.

Assim sendo, nos termos do título provisório, foi expedido em 23/02/1949, uma vez que a taxa de colonização já estava paga integralmente (Despacho de 23/02/1954). Em 08/09/1955, foi dada a autorização para expedição do título definitivo de propriedade, emitido pelo Departamento de Terras e Colonização em 22/10/1995 (Certidão 05). 


\section{CERTIDÃO 04 - LOTE MIRANDA 83,6.6666 Ha}

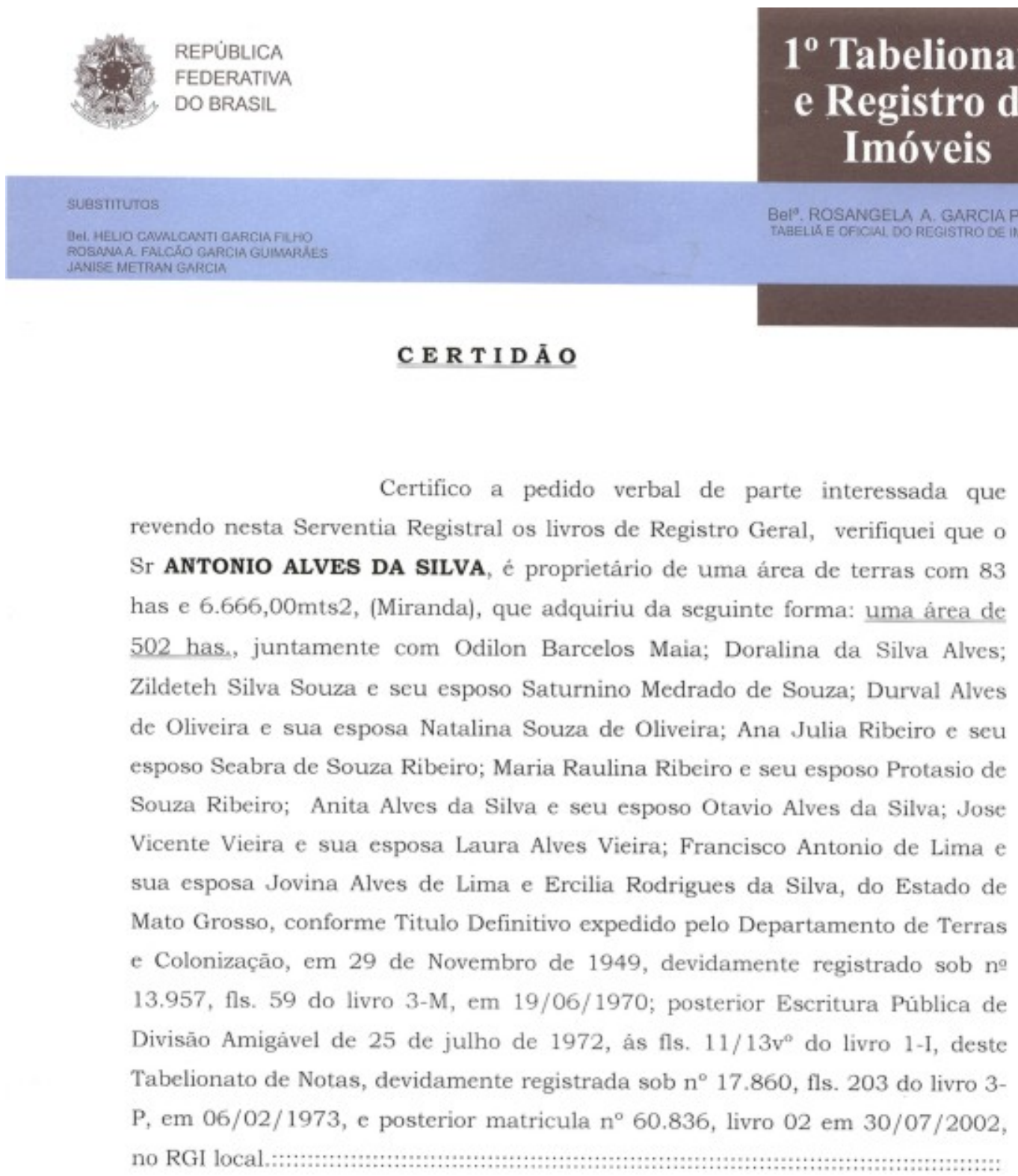

O referido é verdade e dou fé.

Rondonópolis-MT, 30 de Março de 2007.

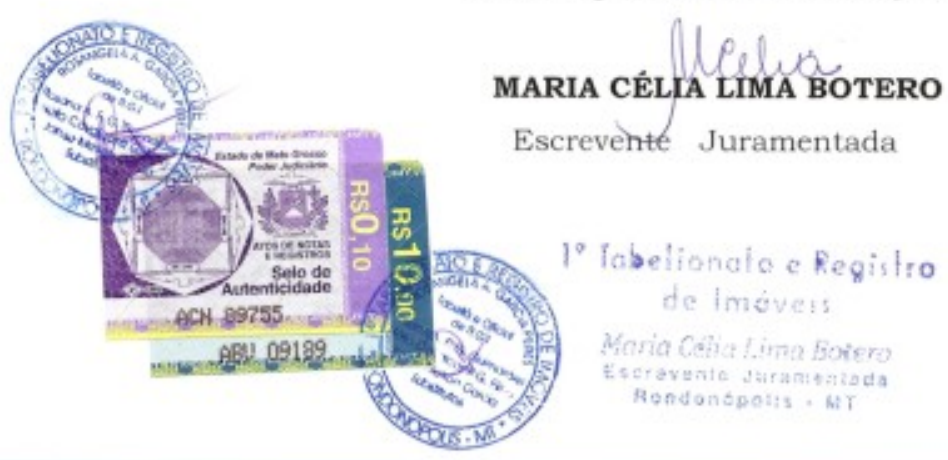

AV. MARECHAL DUTRA, 1093 - ESQ. CI ARNALDO ESTLVAN - FONE: (66) 3439-2400 - FAX: (66) $3439-2406$ MUNICIPIO E COMARCA DE RONDONOPOLIS - ESTADO DE MATO GROSSO - E-MAIL: rgi.roo@terra.com.br 
MAPA XXXIII - Fazenda NABOREIRO - $294 \mathrm{Ha}$
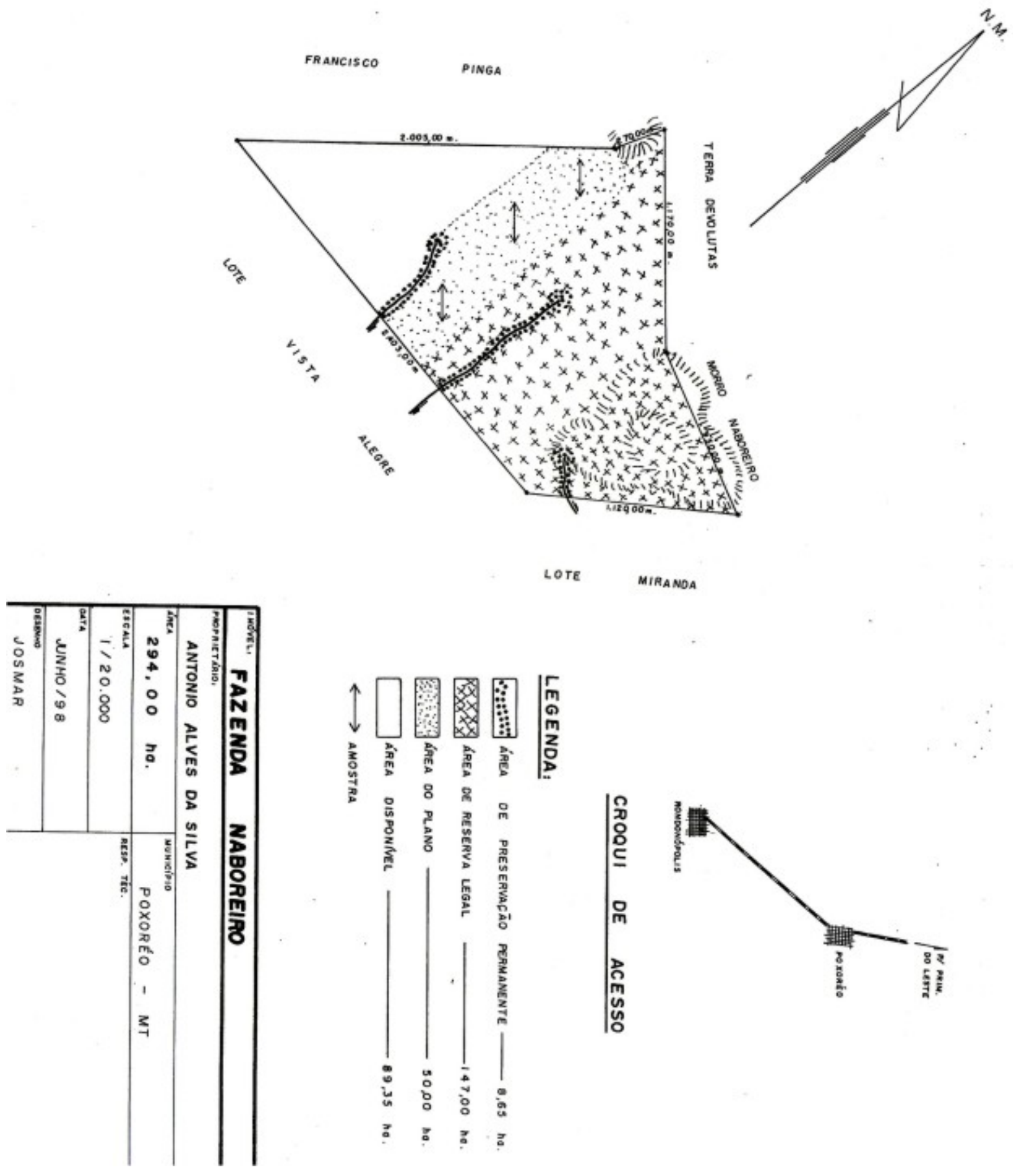


\section{CERTIDÃO 05 - LOTE NABOREIRO - $294 \mathrm{Ha}$} Imóveis

\section{E R T I D Ão}

Certifico a pedido verbal de parte interessada que revendo nesta Serventia Registral os livros de Registro Geral, verifiquei que o Sr. ANTONIO ALVES DA SILVA, é proprietário de uma área de terras pastais e lavradias com área de 294,00 has, denominado Naboreiro, situada na zona rural deste Município, que adquiriu do Estado de Mato Grosso, conforme Titulo Definitivo expedido pelo Departamento de Terras e Colonização, em 22 de Outubro de 1955, devidamente registrado sob no 4.605, fls. 220/2201 do livro 3-D, em 07/12/1962; e posteriormente matriculado sob $\mathrm{n}^{\circ} 49.665$, livro 02, em 26/06/1998, no RGI local.:

O referido é verdade e dou fé.

Rondonópolis-MT, 30 de Março de 2007.
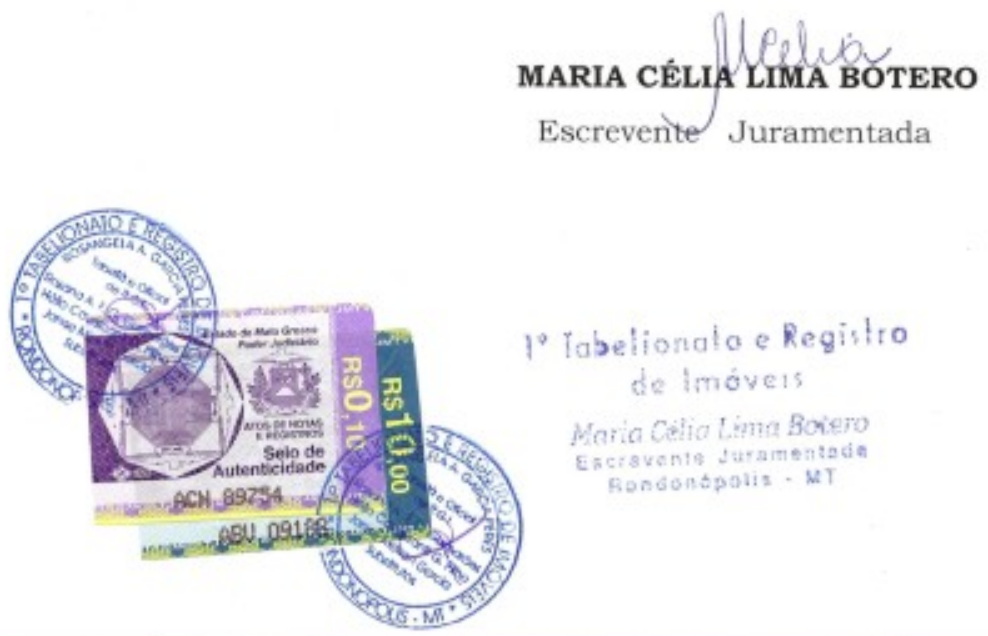

$$
\begin{aligned}
& 1 \text { Tabelionato e Registro } \\
& \text { de imóvers } \\
& \text { Maria Celia Lima Bonero } \\
& \text { Faria crith Lumamentade } \\
& \text { Bongondpolis - MT }
\end{aligned}
$$




\section{CERTIDÃO 06 - LOTE 107 NÚCLEO COLONIAL DE NABOREIRO - 50 Ha}

REPÜBLICA

FEDERATIVA

DO BRASIL $1^{\circ}$ Tabelionato

e Registro de

Imóveis

\section{E R T I D Ã O}

Certifico a pedido verbal de parte interessada que revendo nesta Serventia Registral os livros de Registro Geral, verifiquei que o Sr ANTONIO ALVES DA SILVA, é proprietário de uma área de terras com 83 has c $6.666,00 \mathrm{mts} 2$, (Miranda), que adquiriu da seguinte forma: uma àrea de 502 has., juntamente com Odilon Barcelos Maia; Doralina da Silva Alves; Zildeteh Silva Souza e seu esposo Saturnino Medrado de Souza; Durval Alves de Oliveira e sua esposa Natalina Souza de Oliveira; Ana Julia Ribeiro e seu esposo Seabra de Souza Ribeiro; Maria Raulina Ribeiro e seu esposo Protasio de Souza Ribeiro; Anita Alves da Silva e seu esposo Otavio Alves da Silva; Jose Vicente Vicira e sua esposa Laura Alves Vieira; Francisco Antonio de Lima e sua esposa Jovina Alves de Lima e Ercilia Rodrigues da Silva, do Estado de Mato Grosso, conforme Titulo Definitivo expedido pelo Departamento de Terras e Colonização, em 29 de Novembro de 1949, devidamente registrado sob no 13.957, fls. 59 do livro 3-M, em 19/06/1970; posterior Escritura Pública de Divisão Amigável de 25 de julho de 1972 , âs fls, $11 / 13 \mathrm{v}^{\circ}$ do livro $1-\mathrm{I}$, deste Tabelionato de Notas, devidamente registrada sob $\mathrm{n}^{\circ} 17.860$, fls. 203 do livro 3 -

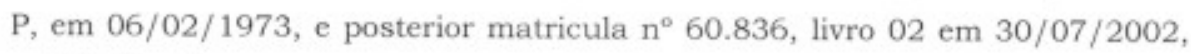
no RGI local

O referido è verdade e dou fé.

Rondonópolis-MT, 30 de Março de 2007.

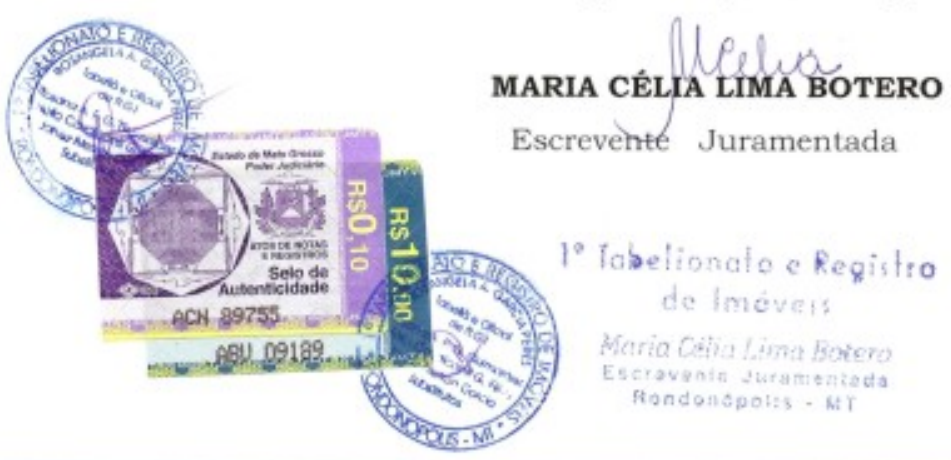


Além dessas duas áreas, requereu o lote 107 da quadra $n^{\circ} .1$ da Colônia de Naboreiro (Certidão 06, à página anterior), nos termos dos Art. 52, 53 e 54 da Lei 336 de 05/12/1949 (Código de Terras) ${ }^{185}$. Em 14/12/1955, foi emitido o título provisório de uma área de 50 ha do lote citado. Após constatar que o Sr. Antônio ocupava e beneficiava o lote, a Comissão de Planejamento da Produção conferiu, em 10/05/1957, o título definitivo de doação ao colono Antônio Alves da Silva, que assinou o Recibo de Doação do Título no dia 07/12/1957.

Anexo a essas áreas, o Sr. Antônio adquiriu, através de compra, mais duas: uma de 20,00 ha desmembrado da gleba "São Francisco" (ANEXO - H), e outra de $27 \mathrm{ha}, 8,888 \mathrm{mts}^{2}$, parte do Lote Miranda (ANEXO - I). Essas áreas unificadas passaram a se chamar Fazenda Naboreiro ou Pé da Serra, perfazendo um total de 475,5554 ha, doada posteriormente aos seus filhos.

A Fazenda está localizada ao lado da Rodovia MT 130, que corta a propriedade (5 ha do lado esquerdo, sentido Rondonópolis/Poxoréo onde fica 0 morro Pirogeiro/menor e o restante da terra do lado direito, onde fica o morro Naboreiro). A casa do Sr. Milton foi construída na parte mais alta (Foto 37), de onde se avistam as casas de alguns dos irmãos (Foto 38), bem como a casa da Ilza (a sede) construída em 1969, na qual nasceram e cresceram os filhos, ou seja, onde o Sr. Antônio e $D^{a}$. Rosa constituíram sua família. É nela que o Sr. Antônio mora até hoje, juntamente com a Ilza e mais dois filhos solteiros (Foto 39). A casa, o barracão, o curral (tem 58 anos e passou por várias reformas), a casa da farinha (Foto 40, 41 e 42), as árvores frutíferas são bem antigos.

A paisagem e as construções antigas chamam a atenção. A vista panorâmica na frente da casa é o Morro Naboreiro (Foto 43), embora na época desta entrevista chovesse muito e não permitiu que fôssemos até lá.

A família sempre trabalhou unida e, no depoimento, Milton lembrou da história da roça e o Sr. Antônio contou que:

Todo ano eu plantava 2 alqueires de arroz e milho. Lá na roça tinha um barraquinho de palha onde eu ficava desde a época em que o milho começava a penduar (não sei se a senhora sabe o que é?) até colher, isso durava mais ou menos uns três meses, senão os bichos comiam tudo. Após a colheita colocava no paiol lá mesmo na roça

\footnotetext{
${ }^{185}$ Artigo 52 - A concessão de lotes de terras devolutas, a título gratuito, só poderá ser feita em núcleos coloniais. Artigo 53 - Os lotes serão concedidos gratuitamente a nacionais ou estrangeiros, que desejarem se estabelecer como agricultores no Estado, tendo preferência os primeiros. Artigo 54 - a área de cada lote colonial não poderá exceder de cinqüenta (50) hectares, quando destinados exclusivamente à lavoura, podendo ser concedida área maior de acordo com a qualidade das terras e o fim a que se destina. Lei $\mathrm{N}^{\circ}$. 336, de 6 de dezembro de 1949. Dispõe sobre o Código de Terras do Estado. Capítulo IV - Da Concessão Gratuita. Código de Terras e Leis Complementares. Departamento de Terras e Colonização Mato Grosso, 1959, página 14.
} 
pra depois voltar de vez aqui pra casa. Mesmo assim, achava que era muito bom, principalmente porque não existia bandido.

Nessa fala, percebe-se o zelo do Sr. Antônio ao cuidar da "roça", não que os bichos não pudessem comer, mas sua prole era grande e necessitava de todo alimento produzido no campo naquela época. E os "bichos", portanto, eram concorrentes fortes. Observa-se também que, ao falar "mesmo assim era muito bom", está indicando que ter sido difícil viver esses três meses em um barraquinho longe da casa, no meio do mato. Nota-se que foram anos marcados por dificuldades, mas valia a pena quando via a família e os viajantes que por lá passavam se alimentavam. Quanto a mencionar o fato de não existir bandido, refere-se aos assaltos que ultimamente vêm acontecendo na zona rural, principalmente na região onde moram, que fica próxima à rodovia.

No relato a seguir, o Sr. Antônio fala a respeito do sistema de arrendamento realizado em sua propriedade: "no período de 1962 a 1967 eu arrendava parte de minhas terras para terceiros, que vinham e arrendavam por quatro anos. Pagavam 10 sacos de mantimentos por alqueire, na época era só agricultura. Um ano fiquei no prejuízo ai não quis mais". Assim como na família Oliveira, aqui também se utilizou a forma da renda em produto, ou seja, a "forma da renda da terra pré-(não)-capitalista" apresentada por Oliveira (1986:81). Quando o Sr.Antônio diz "fiquei no prejuízo", não está querendo dizer que visava a lucro, pois esse não era o objetivo, mas sim o fato de não ter recebido as sacas de mantimento esperadas, comprometendo a alimentação da família e dos viajantes que lá paravam.

A educação das crianças também era uma preocupação por parte do Sr. Antônio, que construiu uma escolinha:

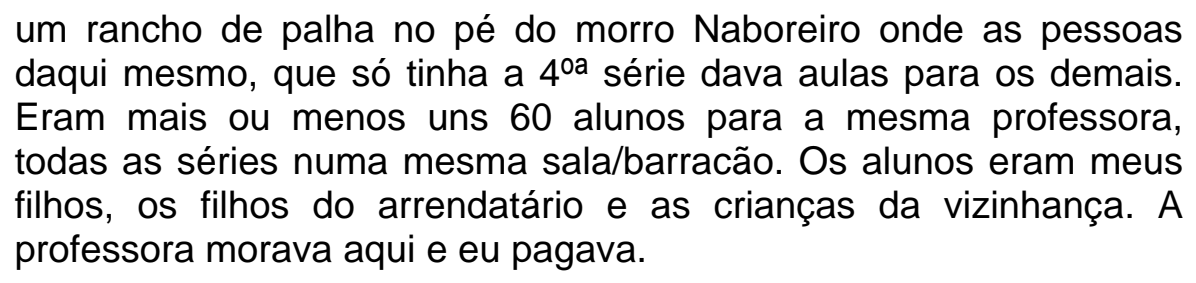

Este é outro exemplo do passado recente e, mesmo nos dias de hoje, pois priorizam a "educação escolar", na qual o importante é aprender a ler e escrever e as quatro operações.

Será apresentada a seguir uma seção com as Fotos de nº 37 a 43. 


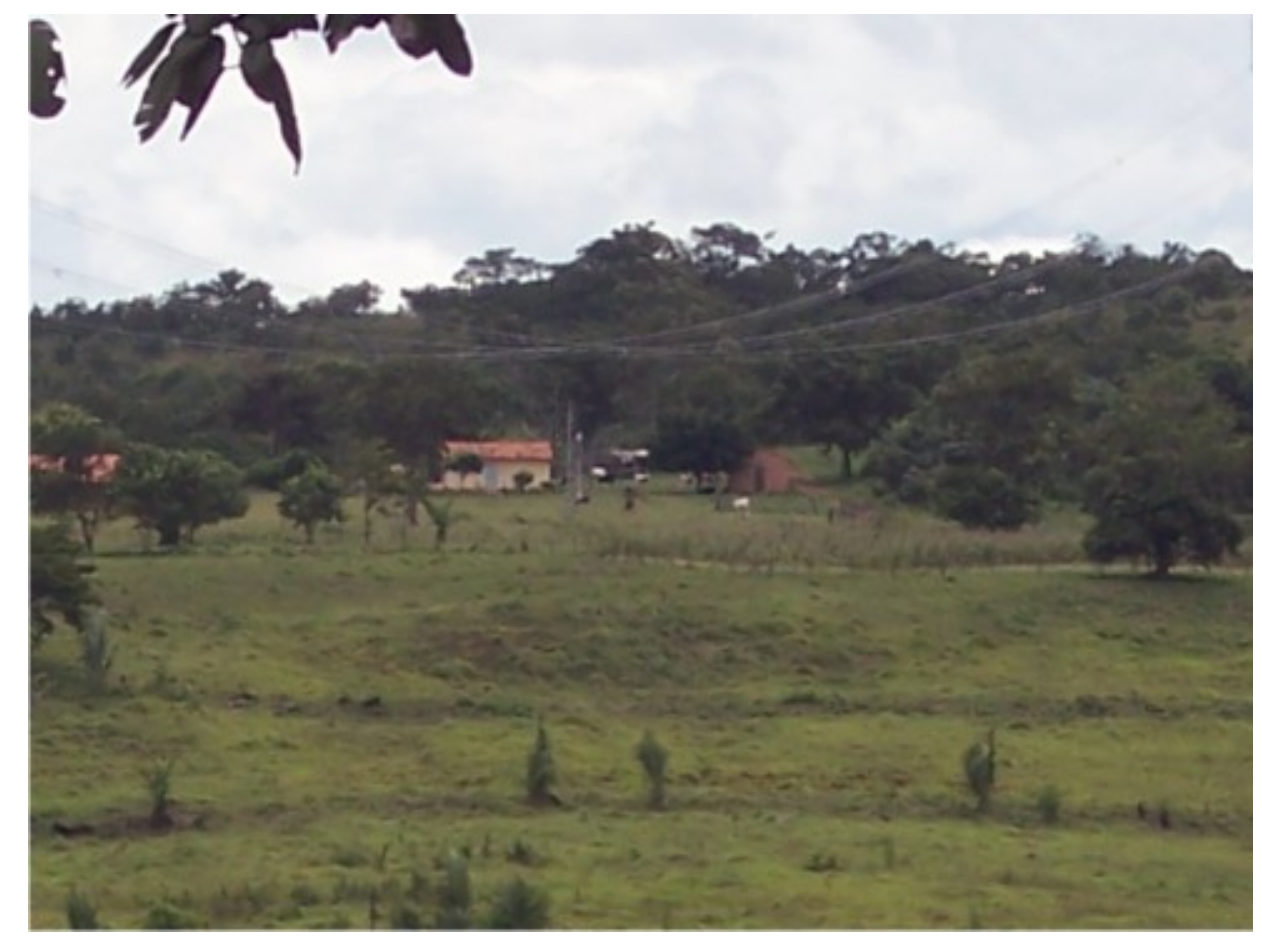

Foto 37 - Vista da Residência do Sr. Milton. (Freitas, Pedro Henrique Barboza. 11/02/07).

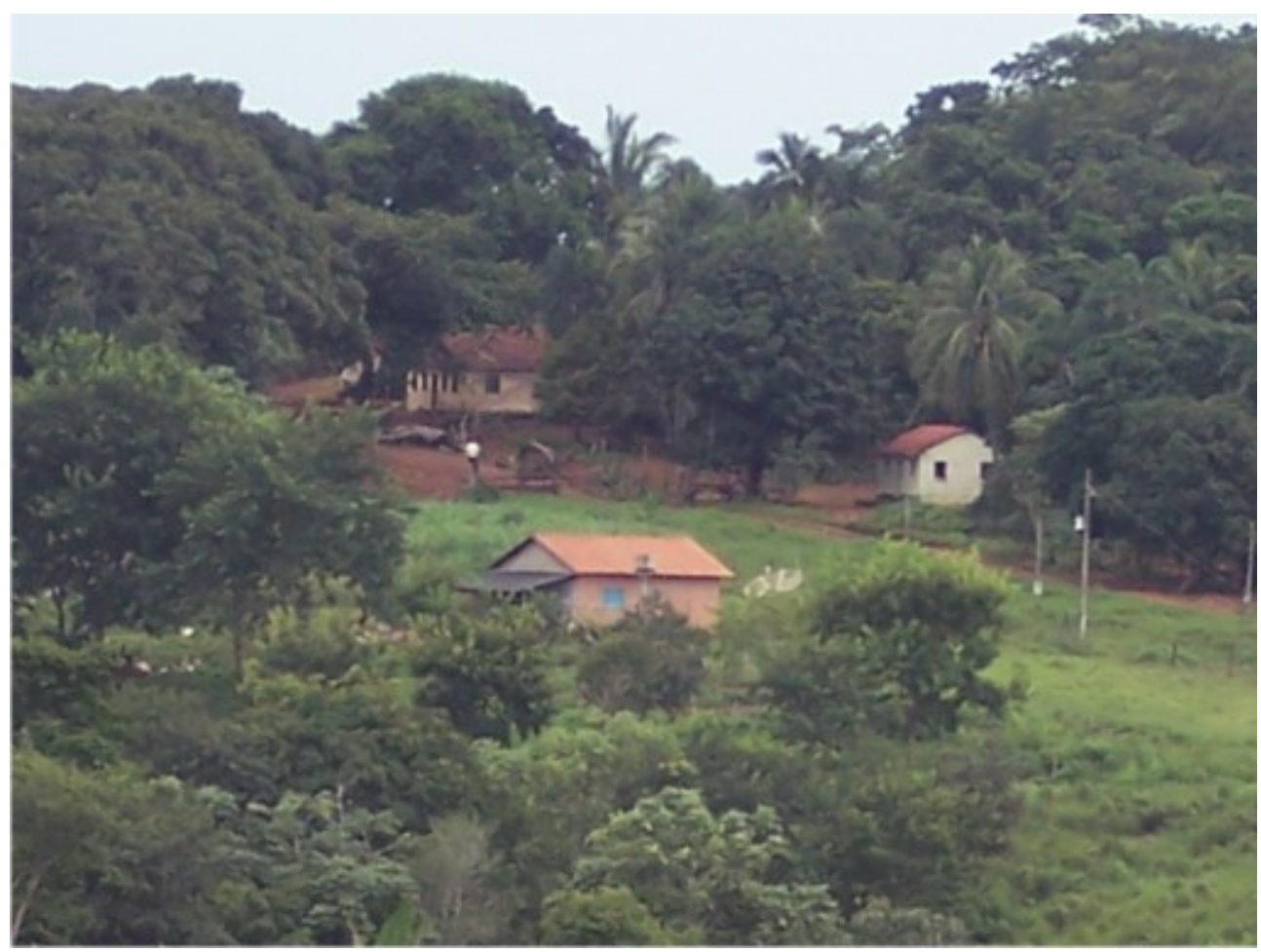

Foto 38 - Vista da Residência de alguns dos irmãos. (Freitas, P.H.B. 11/02/07). 


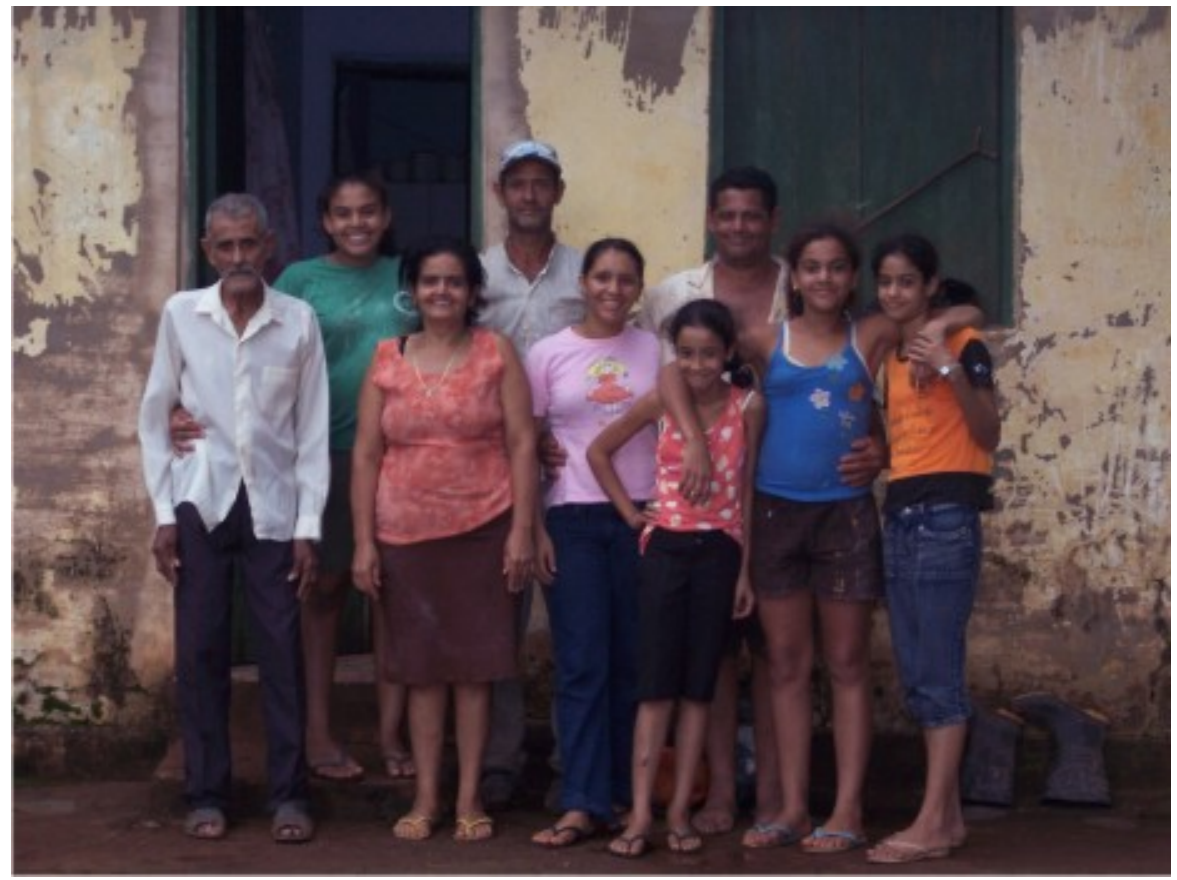

Foto 39 - Casa da Sede. Sr. Antônio, com algumas netas e os filhos Ilza (blusa estampada), Milton (boné) e Aurino. (Freitas, P.H.B. 11/02/07).

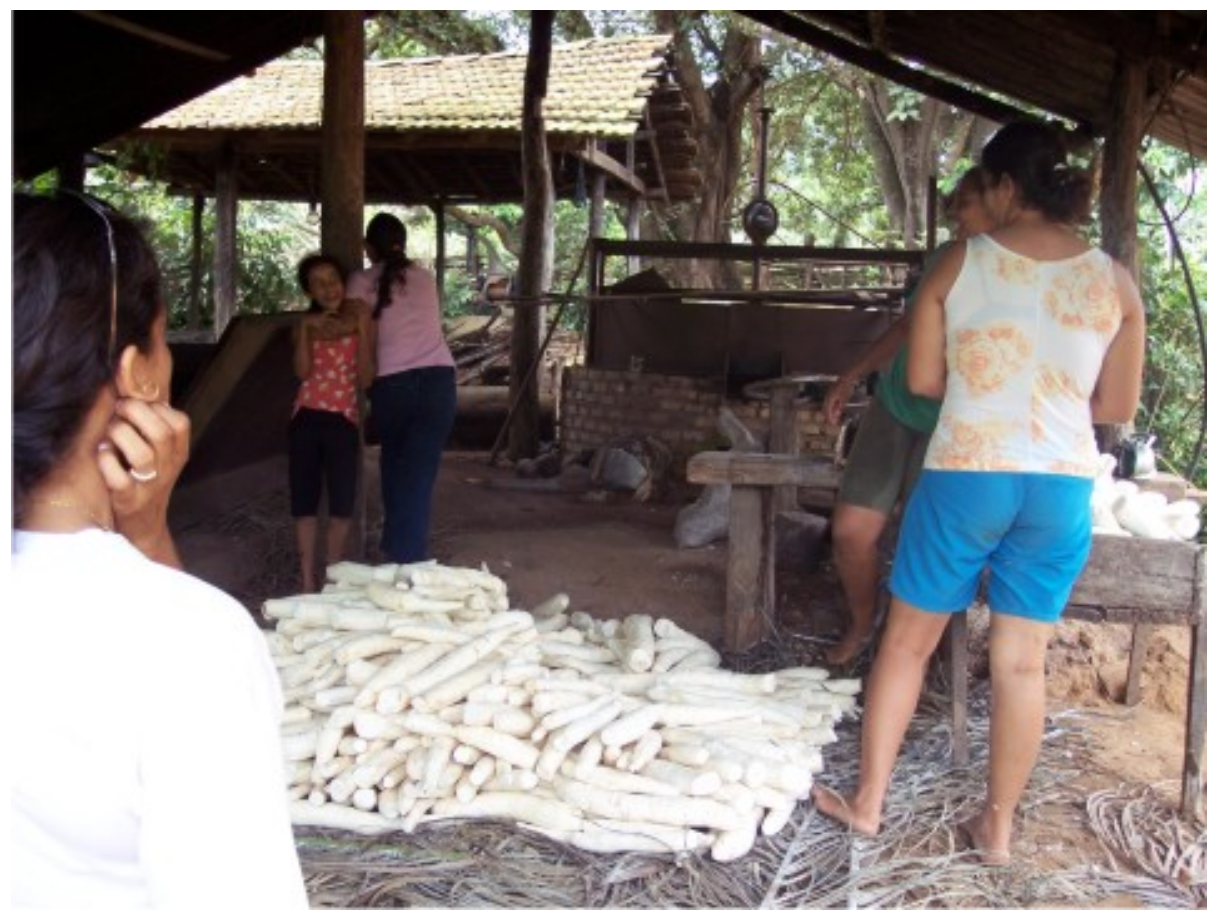

Foto 40 - Casa da farinha. Algumas netas do Sr. Antônio preparando a mandioca para ser transformada. (Freitas, P.H.B. 11/02/07). 
Foto 41 - Casa da farinha. Milton triturando a mandioca para o fabrico da farinha e do polvilho. (Freitas, P.H.B. 11/02/07).

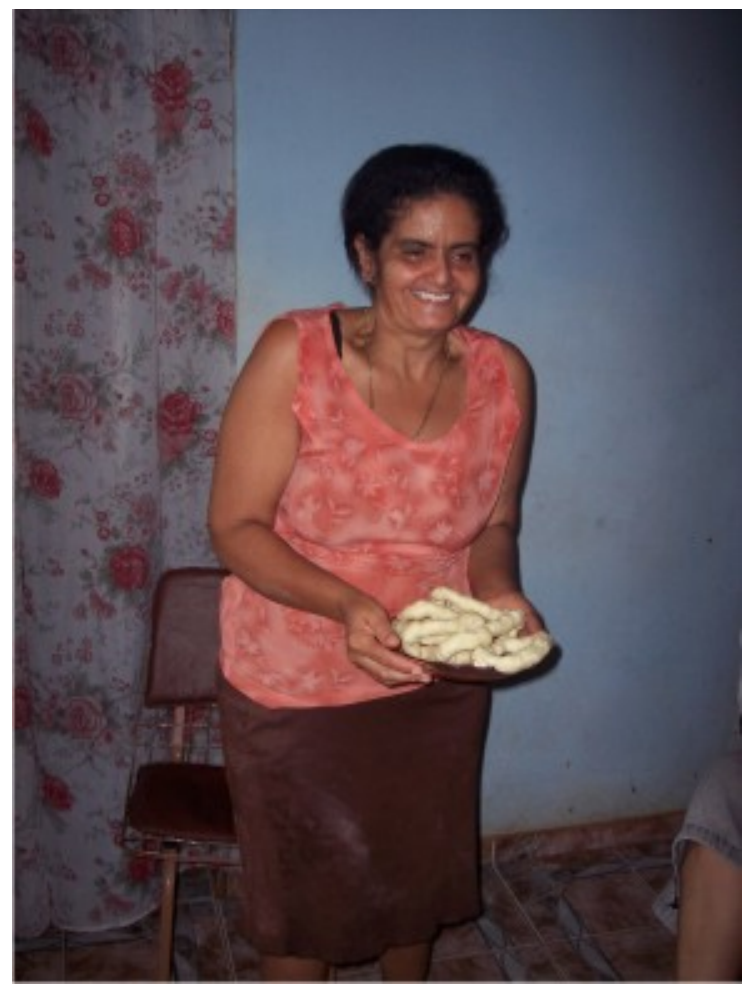

Foto 42 - Ilza mostrando com orgulho os biscoitos de polvilho feitos por ela. Tudo do sítio: ovos, polvilho, banha de porco. (Freitas, P.H.B. 11/02/07). 


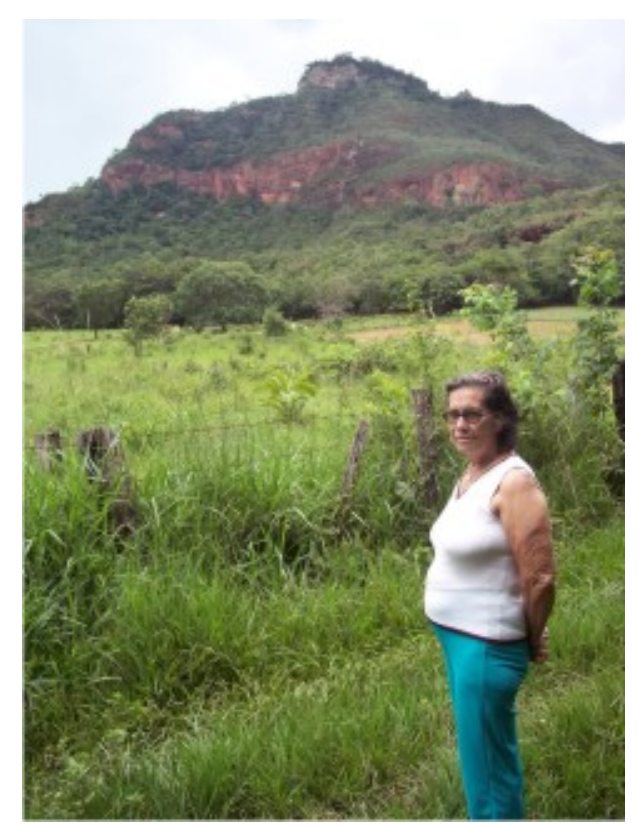

Foto 43 - Morro Naboreiro. Chama a atenção por sua beleza cênica, pode ser visto de vários pontos da cidade. (Freitas, P.H.B. 11/02/07).

Pela Foto 40, percebe-se que o trabalho da lida com a mandioca (descascar e lavar) é realizado pelas crianças e adolescentes, inseridos desde cedo no trabalho. Freqüentam a escola de manhã e, à tarde, ajudam nos afazeres domésticos.

Antigamente, as pessoas realizavam muitas festas populares com intuito de cumprir determinadas "tarefas" na agricultura. Tanto o Sr. Antônio quanto o Milton lembraram-se do tempo bom na época em que realizavam os mutirões e treições.

Desde 1953 a gente já fazia os mutirões e treições, onde as pessoas ajudavam nos trabalhos (roçada de pastos, colheita do arroz que era o maior foco) durante o dia e festavam à noite. Tanto no mutirão, mas principalmente na treição, a pessoa que pegou a treição e não deu conta de terminar o serviço era amarrada e levada para sua casa, só depois que serviam o café ou a pinga (risos) para todas as pessoas ele era liberado. A tarefa que não foi cumprida, depois era terminada pelo dono da propriedade.

Da fala acima, há pelo menos dois pontos a serem destacados; o primeiro é referente à ajuda mútua, um símbolo de forma de vida entre os camponeses, fundamentado no relacionamento das pessoas, ou seja, entre parentes e vizinhos. $\mathrm{O}$ segundo denota que, ao mesmo tempo em que trabalhavam, também se divertiam. Era, assim, um elo de ligação entre trabalho e diversão.

A religiosidade é marca constante na vida dos camponeses e é uma prática contínua e é cultuada desde tempos remotos. Ela aproxima os vizinhos e as relações entre eles são intensas e, por intermédio da mesma, tentam resolver os 
problemas coletivos. Pelos depoimentos, a seguir, de Milton e do Sr. Antônio, percebe-se que isso envolve todas as demais famílias pesquisadas.

A região do Naboreiro recebia a visita dos padres constantemente. O Sr. Antônio relatou que:

Padre Saturnino foi o primeiro a vir visitar a região do Naboreiro, isso em 1953. Nesse tempo o padre mandava uma carta em meu nome (Antônio), para avisar o dia e a hora que aconteceria a celebração da missa. Após o recebimento desta carta, eu ou os meninos saia avisando a população da região que se acumulavam em nossa casa, onde todo mundo rezava e almoçava. Além do padre Saturnino, vinham o Frei Servácio ${ }^{186}$, o Patrício, o Antonino ${ }^{187}$, eles vinham da Chapada dos Guimarães pra cá. Quando acabava a missa daqui, eles iam pra casa do Ildefonso e Leonila, lá na região do Bananal. Todo esse processo era feito a cavalo, pois naquela época não tinha carro. Os meninos acompanhavam eles até lá e depois voltavam.

Pelo relato acima se percebe o orgulho de Sr. Antônio ao dizer "o padre mandava a carta em meu nome" o que significa dizer que foi uma pessoa responsável e respeitada, e que receberia a todos, inclusive, com refeição para esse compromisso social. Deve-se destacar o papel e a importância dos filhos: "os meninos saiam pra avisar"; além das tarefas nas lidas do dia-a-dia, esta também era função dos filhos. Eram uma espécie de pombos-correios e guia turísticos. Essa prática também existia na região do Bananal, da qual participavam não só a família Oliveira (Sr. Ildefonso e Leonila), mas a família Ferreira também, pois a região da Aldeinha é próxima ao Bananal.

O Milton, o Sr. Antônio e o Sr. Osvaldo Giovanine iam relembrando os fatos ocorridos e o Sr. Antônio informou que:

Em 1962 o Sr. José Corrêa (um fazendeiro que tinha aqui na época) mandou construir uma igrejinha de tábua na Vila Bueno e assim as missas daqui se transferiram para lá. Em 1965 o Padre Lothar ${ }^{188}$ iniciou suas atividades aqui na região e com a ajuda da Alemanha e dos proprietários da comunidade, construíram a igreja de alvenaria que tem hoje lá na Vila. As missas que eram anuais, agora são realizadas todo segundo domingo do mês às 14 horas.

\footnotetext{
${ }^{186}$ Frei Servácio Schultc foi o primeiro padre a se fixar em Rondonópolis, em 1953. Foi o primeiro pároco da cidade.

${ }^{187}$ Frei Antonino Schwenger arquitetou o prédio da atual Igreja Matriz, cujo projeto trouxe da Alemanha. Graças aos seus esforços a Matriz foi construída. As obras foram iniciadas em 1963 e concluídas em 1966.

${ }^{188}$ Padre Lothar Bauchrawt, foi o responsável pela inauguração da Igreja da Paróquia São José Operário em 15/08/1964. Desde essa época vem prestando um gigantesco trabalho social nesta cidade, com a construção de inúmeras casas, em regime de mutirão, para pessoas carentes, além de lhes fornecer creches, remédios, alimentos e cursos profissionalizantes, visando à preparação para o mercado de trabalho. Recursos de empresas locais, de associações beneficentes da Alemanha (sua terra natal) e de políticos locais. Carmo, Ailon. Religiões: religião em Rondonópolis. Especial para o A TRIBUNA. Edição Ouro. Documento Histórico. Rondonópolis 50 anos. Realização A TRIBUNA. Rondonópolis-MT, quarta-feira, 10 de dezembro de 2003, pág. 32.
} 
Sabe-se que o local apropriado para que a missa aconteça é a igreja. Como o número de famílias na região foi aumentando e a necessidade de se construir uma igreja também, assim, de acordo com o relato acima, a necessidade foi aos poucos sendo concretizada.

Milton complementa que "pra nóis é uma festa, todos ficam ansiosos esperando esse dia. Além das missas, tem as palestras, onde pessoas da comunidade de Rondonópolis são convidadas para falar de diversos assuntos", sem contar os terços em família que rezam pelo menos uma vez na semana. O Sr. Osvaldo Giovanini informou que "todas as quartas-feiras à noite, reunimos os parentes e os vizinhos e vamos rezar o terço na casa do Sr. Antônio".

Pelos relevantes serviços prestados à comunidade, o Sr. Antônio já foi agraciado com dois Títulos de Cidadão Rondonopolitano, ambos concedidos pela Câmara Municipal de Rondonópolis (Foto 44), e um Título de Cidadão MatoGrossense, concedido a pedido do Deputado Estadual J. Barreto. São honrarias que os enchem de orgulho, fizeram questão de colocá-las na moldura e dependurá-los na parede da sala de visitas.

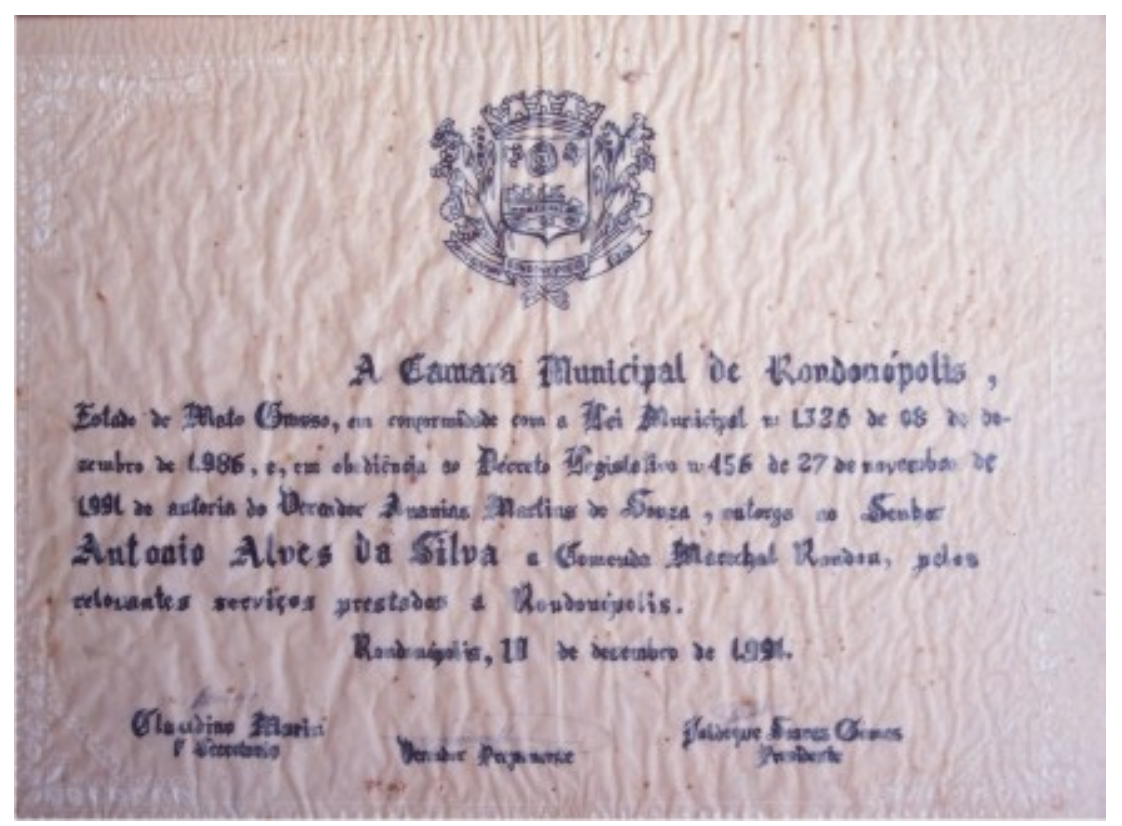

Foto 44 - Comenda Marechal Rondon (Freitas, P.H.B. 11/02/07).

Dos 11 filhos, cinco moram na cidade (quatro tem sua parte na fazenda, 0 Nilson vendeu para os irmãos antes de fazer a partilha, doação) e seis moram na 
fazenda. O Aurino também vendeu sua parte (24 hectares) para o José seu irmão, a fim de comprar 41 hectares do vizinho (João Borges).

Em entrevista, o Aurino relatou sua vida através do trecho da conversa a seguir:

Faz 51 anos que moro aqui na fazenda, desde que nasci. Me casei duas vezes. Do primeiro casamento tive dois filhos, um tem 27 e o outro 26 anos, moram com a mãe na cidade. Já tem 20 anos que me casei de novo e desse casamento tive duas filhas uma tem 13 a outra 17 anos, essa é a Simoni já é casada e também mora aqui. Nossas casas, a minha e da minha filha são aquelas ali (mostrou ele) é tudo nas terras de Ilza, como ela é solteira, vou acabar ficando com elas pra mim, vou fazer usucapião (risos). Eu vendi os 24 ha que ficaria pra mim, pro meu irmão José. E comprei 41 hectares do vizinho aqui do lado, então, a minha terra lá não tem nada, ou seja, não é da herança, só o dinheiro que foi (risos). Mas lá eu só tenho a terra, moro mesmo e na terra da llza. Os irmãos que moram na cidade e tem terra aqui, só têm pasto na propriedade, não tem casa. Eles têm gado e quem cuida somos nós que moramos aqui, por isso nosso gado come os pastos deles em troca do roçado.

Pela fala acima, Aurino deixa transparecer o desejo de possuir uma terra maior, aproveitando a venda da que recebeu de doação para comprar parte da área do vizinho (latifundiário bem sucedido que se encontrava em dificuldade) onde as terras são melhores. Nota-se também o casamento em idade precoce, a filha de 16 anos já se casou e tem uma filha. Ambos, pai e filha moram em casas na parte da fazenda que, na divisão, ficou para Ilza, que fez uma brincadeira dizendo que: "vou fazer as contas e cobrar o aluguel dele e da filha que já é casada (risos)".

Retornando a entrevista, sobre a divisão das terras, Aurino informou que:

O Nilson (mora em Cuiabá) vendeu sua parte para os outros irmãos antes de fazer a divisão, por isso não tem o nome dele nos mapas. Meu nome vai aparecer no mapa do lote 07 - área com 89,00 ha, onde fica o morro Naboreiro (toda essa área é de reserva natural) e nos dois mapas (croqui de localização dos lotes feito pelo Juarez agrimensor, na área de 111,5554 ha e no outro de 364,00 ha), como proprietário e outros. Isso foi uma divisão amigável, onde o pai doou tudo pra gente. Se fosse pra fazer inventário ficaria muito caro, então fizemos isso e todos concordaram e a divisão foi feita no terreno e no papel (mapinhas). Ninguém tirou a escritura ainda, por isso que nos mapas está escrito lote $n^{\circ}$. tal etc. (Mapas XXXIV e $X X X V)$. A história da divisão foi confirmada por Milton e por Juarez, o agrimensor. (Ver ANEXOS de $\mathrm{J}$ a $\mathrm{S}$ ).

Sebastião que também é solteiro mora na casa com o pai e a Ilza. Assim como os demais que têm terra e moram na cidade, só tem pasto em sua propriedade. 
$\mathrm{Na}$ partilha, o José ficou com 59,00 ha, porque, além dos 35,00 ha que recebeu de doação, comprou mais 24,00 ha que era a parte do Aurino.

A área com 5 hectares localizada à esquerda da Rodovia MT 130, ao Norte do Mapa XXXIV - Fazenda Pé do Morro, foi vendida pelo Sr. Antônio, ao Sr. Waldemar Pereira Sobrinho e, acordo com o documento: "Instrumento Particular de Compromisso de Cessão de Direitos de Meação com Relação à Imóvel Rural, feito em caráter irrevogável e irretratável, acha-se registrada no Cartório de Registro Geral de Imóveis de Rondonópolis, Estado Mato Grosso, na matrícula 49.665, livro $\mathrm{n}^{\circ}$. 02, do Cartório de Rondonópolis".

A divisão da fazenda do Sr. Antônio foi realizada em março de 2006 e, nesse período, cinco de seus onze filhos já moravam na cidade, onde trabalham e seus filhos estudam; um deles mora em Cuiabá e, no ato da divisão, vendeu a parte que Ihe coube por direito a seu irmão José, que também comprou a parte do Aurino.

Dos que ficaram com a doação, nem todos têm casa na propriedade, até porque a divisão foi feita recentemente a ainda não tiveram condições de construir. Dos seis filhos que residem no campo, três já moravam nas áreas que receberem de doação e três estão agregados na parte que coube à Ilza.

O Valdemir, o Eduardo, o José e a Ilza fizeram o PRONAF em 2003, com objetivo de comprar gado; todos realizados com prazo de seis anos, com carência de quatro anos para pagar.

O trabalho na propriedade é todo realizado pela família, uma vez ou outra contratam um diarista. Os maquinários como trator, carreta, pulverizador, resfriador de leite são de propriedades do Sr. Antônio e de uso coletivo dos filhos. A agricultura praticada é só de subsistência, o carro chefe da propriedade é a pecuária, onde a venda de leite é expressiva.

A família utiliza, quando necessário, o Posto de Saúde na Vila Bueno, onde também freqüentam a Igreja católica. Já os netos que ainda estudam vão para a Escola São Domingos Sávio na Vila Naboreiro.

Serão apresentados a seguir os mapas com as divisões das propriedades. No Mapa XXIII estão em destaque os lotes de №. 01 a 07 e, no Mapa XXIV, encontramse os lotes de $N^{0}$. 08 a 10 . Os mapas com cada uma das divisões entrarão nos anexos. 


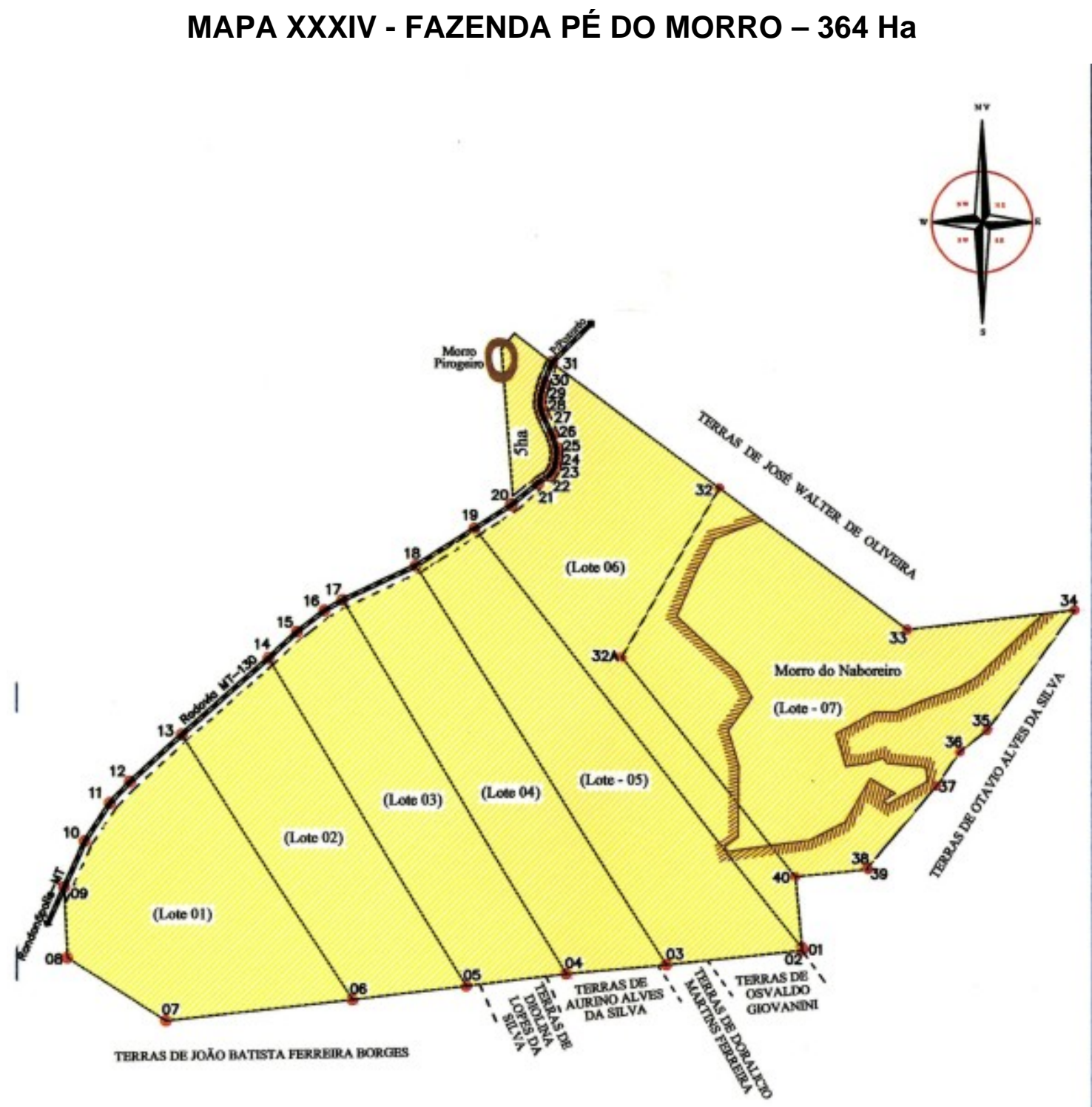

Escala Grafica:

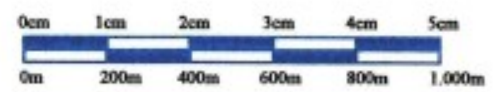

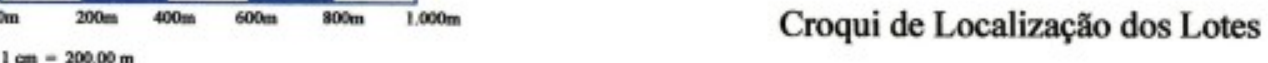

\begin{tabular}{|c|c|c|c|c|}
\hline FAZENDA & MORRO & $\mathrm{AU}$ & LVES DA SILVA E OUTROS & MUNíimo: \\
\hline \multicolumn{4}{|c|}{ Matriculas de $\mathrm{n}^{\circ} 12.229,17.860$ e 49.665} & RESP. TÉCNICO: \\
\hline $\begin{array}{l}\text { AREA TOTAL: } \\
364, \text { oOha }\end{array}$ & ESCALA & & $20 / 03 / 2006$ & 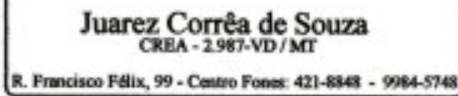 \\
\hline
\end{tabular}


MAPA XXXV - FAZENDA PÉ DO MORRO - 111,5554 Ha
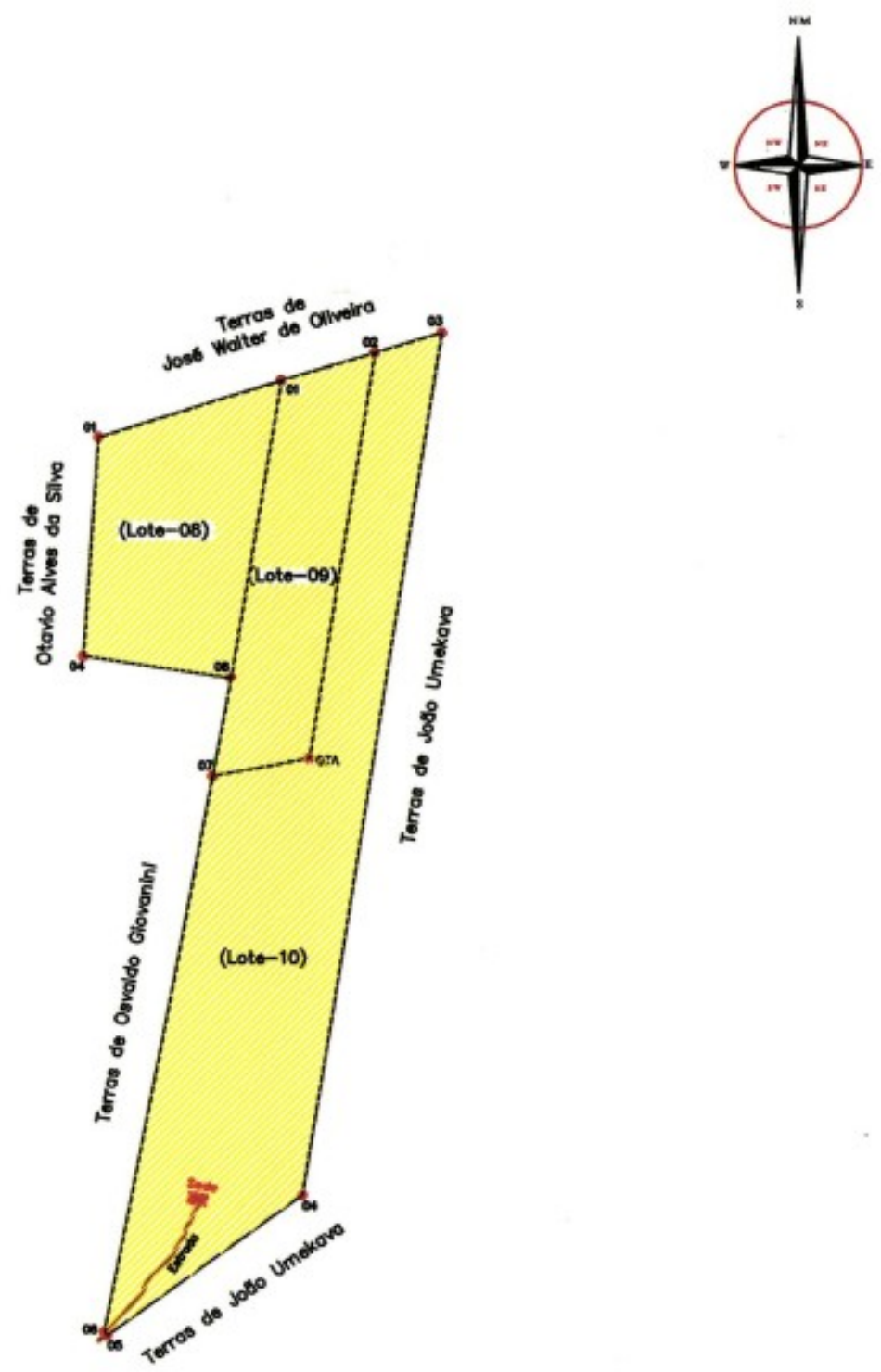

Escala Gráfica:

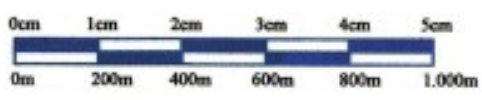

$1 \mathrm{~cm}=200,00 \mathrm{~m}$

Croqui de Localização dos Lotes

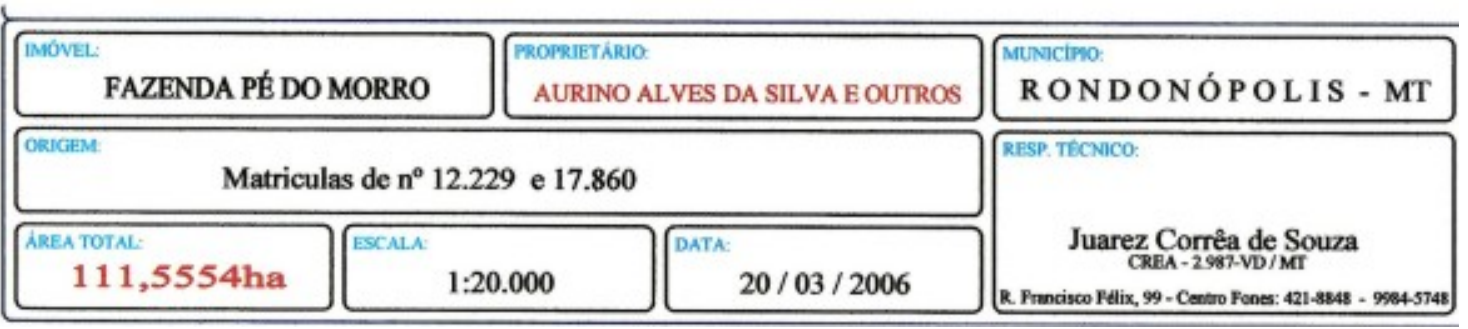


Meu Reino Encantado

FAMÍபAAQUINO

Daniel Composição: Valdemar Reis e Vicente F. Machado

Eu nasci num recanto feliz

Bem distante da povoação

Foi ali que eu vivi muitos anos

Com papai mamãe e os irmãos

Nossa casa era uma casa grande

$\mathrm{Na}$ encosta de um espigão

Um cercado pra guardar bezerro

E ao lado um grande mangueirão

No quintal tinha um forno de lenha

E um pomar onde as aves cantava

Um coberto pra guardar o pilão

E as traias que papai usava

De manhã eu ia no paiol

Um espiga de milho eu pegava

Debuiava e jogava no chão

Num instante as galinhas juntava

Nosso carro de boi conservado

Quatro juntas de bois de primeira

Quatro cangas, dezesseis cansis

Encostados no pé da figueira

Todo sabado eu ia na vila

Fazer compras para semana inteira

O papai ia gritando com os bois

Eu na frente ia abrindo as porteiras.

Nosso sítio que era pequeno

Pelas grandes fazendas cercado

Precisamos vender a propriedade

Para um grande criador de gado

E partimos pra a cidade grande

A saudade partiu ao meu lado

A lavoura virou colonião

E acabou-se meu reino encantado

Hoje ali só existe três coisas

Que o tempo ainda não deu fim

A tapera velha desabada

E a figueira acenando pra mim

E por último marcou saudade

De um tempo bom que já se foi

Esquecido em baixo da figueira

Nosso velho carro de boi. . 
A propriedade da família Aquino, em Rondonópolis, originou-se com 0 patriarca Domingos de Aquino, casado com $\mathrm{D}^{\mathrm{a}}$. Orinda Souza Aquino, nordestinos de Piauí e Bahia, que compraram de Elpídio Nunes de Souza e outros, em 1951, uma área denominada Barreiro com 390,00 ha (Planta 13 - Planta do Lote Barreiro), registro no. 701, fls. $178 / 179$ do livro no.3 em 20/08/1951, no Registro de Imóveis de Poxoréo, do Cartório do $1^{\circ}$ Ofício, conforme Matrícula nº 16.864.

Esse Lote foi adquirido por dona Olímpia Ferreira de Souza, através de compra do Estado de Mato Grosso, tendo recebido o Título Definitivo do Departamento de Terras e Colonização em 11 de julho de 1940 (02 - Título Definitivo Lote Barreiro). O Sr. Elpidio e demais irmãos receberam o Lote por herança de dona Olímpia, por meio de partilha amigável, em 15 de março de 1951, transcrita no Registro Geral de Imóvel de Poxoréo.

Em entrevista, Maria Dolores informou que:

Por ser uma pessoa muito conhecida e estimada, quando veio embora trouxe com ele, cunhados, sobrinhos e amigos, ao todo, umas oito famílias, que ficou morando nas terras dele como agregado. Era tipo uma colônia. Eles construíam seus barracos e trabalhavam a meia. O que produziam, ou seja, os mantimentos eram repartidos com meu pai em produto e não em dinheiro. Em 1955, infelizmente meu pai faleceu, algumas famílias ainda ficaram depois da morte dele, outros se mudaram. Na época da colheita principalmente faziam os mutirões, onde as pessoas trabalhavam o dia todo e a noite era só festa. Os vizinhos de outras fazendas que ficavam sabendo vinham, ajudavam e à noite festava.

Em sua fala esta interlocutora esclarece que as famílias vindas com seus pais eram conhecidas, isto é significativo, pois revela que o pai, como dissera: "era uma pessoa conhecida e estimada", fator determinante na vida do ser humano. Essas famílias viam no Sr. Domingos a imagem da pessoa paterna, daquele que não lhes deixaria faltar o pão de cada dia.

Pelo depoimento de Dolores, percebe-se que, ao utilizar o sistema de agregamento, ou seja, do trabalho livre (pois essas oito famílias de trabalhadores moravam nas terras da Fazenda Barreiro, mas não faziam parte da família nem do quadro de trabalhadores) é, sem dúvida, a constatação da relação não-capitalista de produção. Não percebo aí, exploração do trabalhador pelo Sr. Domingos, mas sim um exemplo de morada de favor, em que o agregado pagava o aluguel da morada com mantimentos. 
PLANTA 13 - Planta do Lote Barreiro

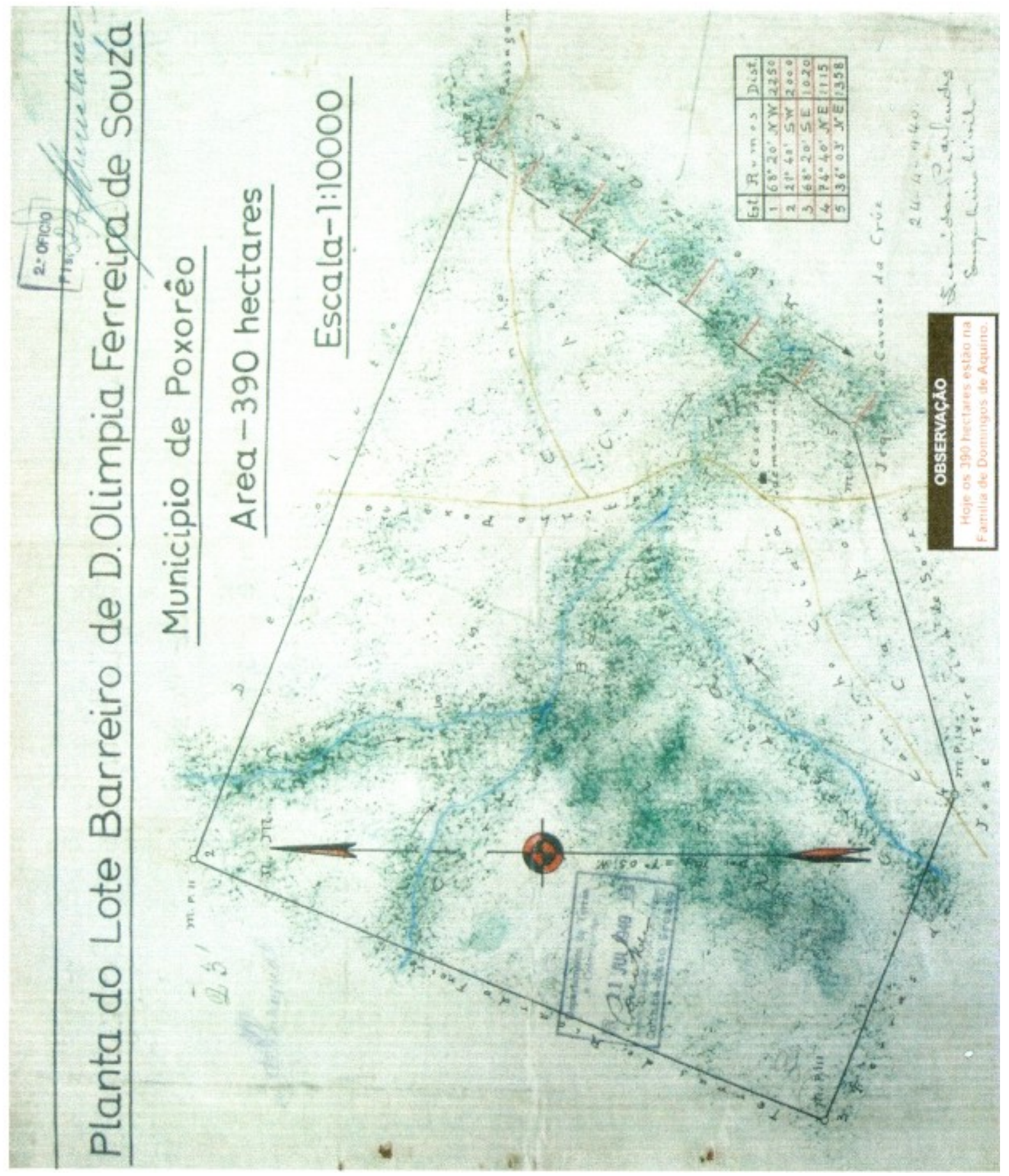




\section{TíTULO 02 - Título Definitivo do Lote Barreiro}

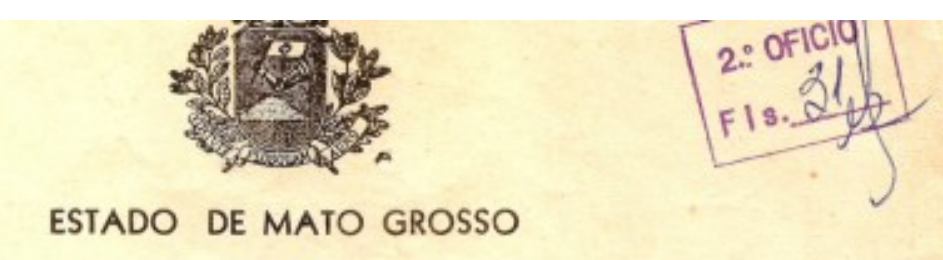

\section{O Governador do Estado de Mato Grosso}

FAZ SABER,

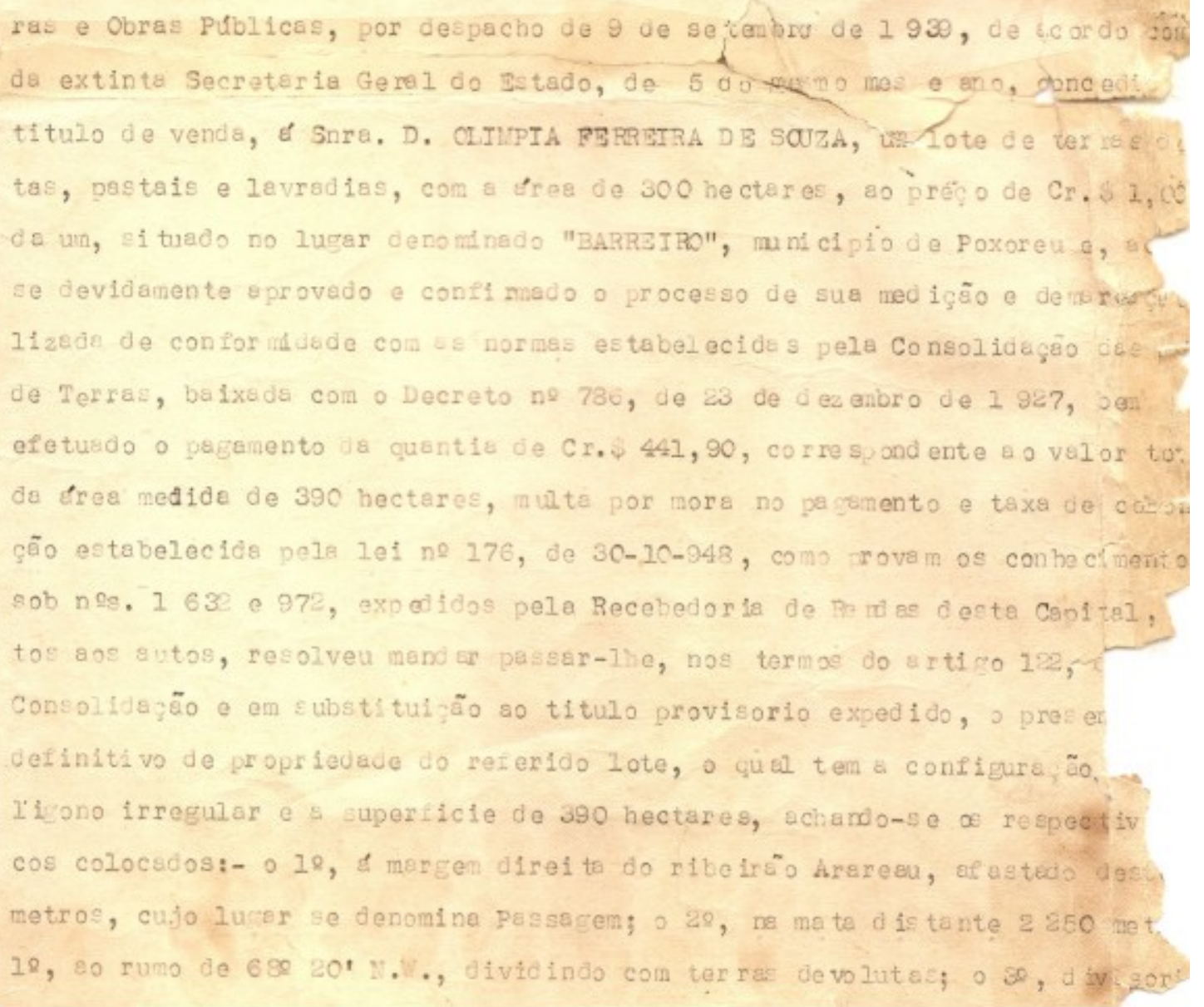




\section{TíTULO 02 - Título Definitivo do Lote Barreiro}

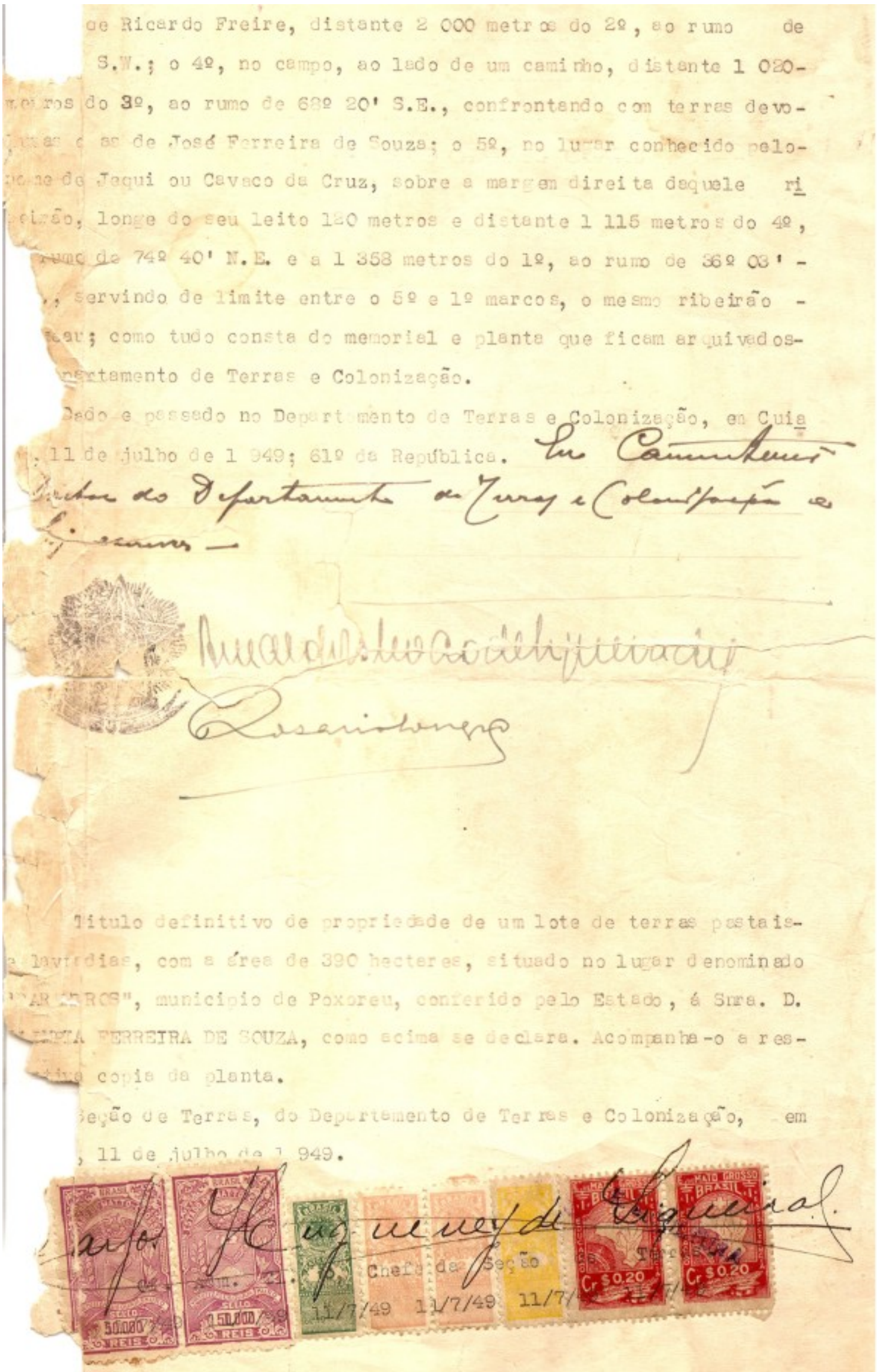


A frase de Dolores: "infelizmente meu pai faleceu, algumas famílias ainda ficaram depois da morte dele, outros se mudaram" é reveladora da dor e sentimento pela perda do pai e, com ele, os amigos, os filhos dos agregados que conviviam na "colônia" juntamente com os filhos do Sr. Domingos. Percebe-se que, com a morte do patriarca, todos se sentiram desamparados, desprotegidos, migraram à procura de um novo amparo, onde pudessem encontrar mecanismos de sustentação.

Essa migração do agregado pode significar, também, a falta de confiança no potencial feminino, pois, com a morte do esposo, o comando, ou seja, a administração da propriedade passou para as mãos de $D^{a}$. Orinda que ficou com dez filhos pequenos e grávida de quatro meses. Após cinco anos de viuvez, $D^{a}$. Orinda concubinou-se e teve mais cinco filhos, sendo que um deles faleceu.

Com o passar do tempo, realizou-se a partilha dos bens deixados pelo $\mathrm{Sr}$. Domingos. A fragmentação das terras da Fazenda Barreiro, que já está com eles desde 1951 (Certidão 07- Transmissão do Lote Barreiro), ou seja, há 56 anos, deuse pelo processo de herança e doação: $1^{\mathrm{a}}$ parte $-177,2720 \mathrm{Ha}$ da herança do pai foi dividida para os dez filhos do primeiro casamento de dona Orinda, em que cada um recebeu $17,7272 \mathrm{Ha}$; a $2^{\mathrm{a}}$ parte, ou seja, o que a mãe recebeu de herança pela morte do esposo e do filho, um lote com 212,7280 $\mathrm{Ha}$, ela doou para os quatorze filhos (ANEXO - T), sendo que cada um recebeu 15, Ha e 1.948,57 m. A terra que cada um possui hoje é de herança, doação e compra feita dos irmãos e de terceiros.

Nem todos os filhos possuem a propriedade recebida por herança ou doação. E são poucos os que moram na propriedade. A Dolores/Bia é aposentada e mora no sítio "Rancho Três Aros", a Domingas/Minga mora no sítio "São Domingos" e trabalha no INSS, por isso vai e volta todos os dias para a cidade.

O Gilberto mora na cidade, é aposentado e se desloca todos os dias para o sítio, onde cuida também do gado da Bia. Os irmãos Gervásio, Gildásio e Benedito trabalham em escritório de Contabilidade, sendo os dois primeiros proprietários individuais e o terceiro funcionário em outro escritório. Foram unânimes em dizer que como a terra é pequena, os recursos são poucos e os gastos são muitos. Então, é preferível viver na cidade para trabalhar e ir para o campo nos finais de semana e nas férias. O que ganham na cidade é aplicado em benfeitorias no campo, para garantir-Ihes uma aposentadoria mais tranqüila 


\section{CERTIDÃO 07 - Transmissão do Lote Barreiro}

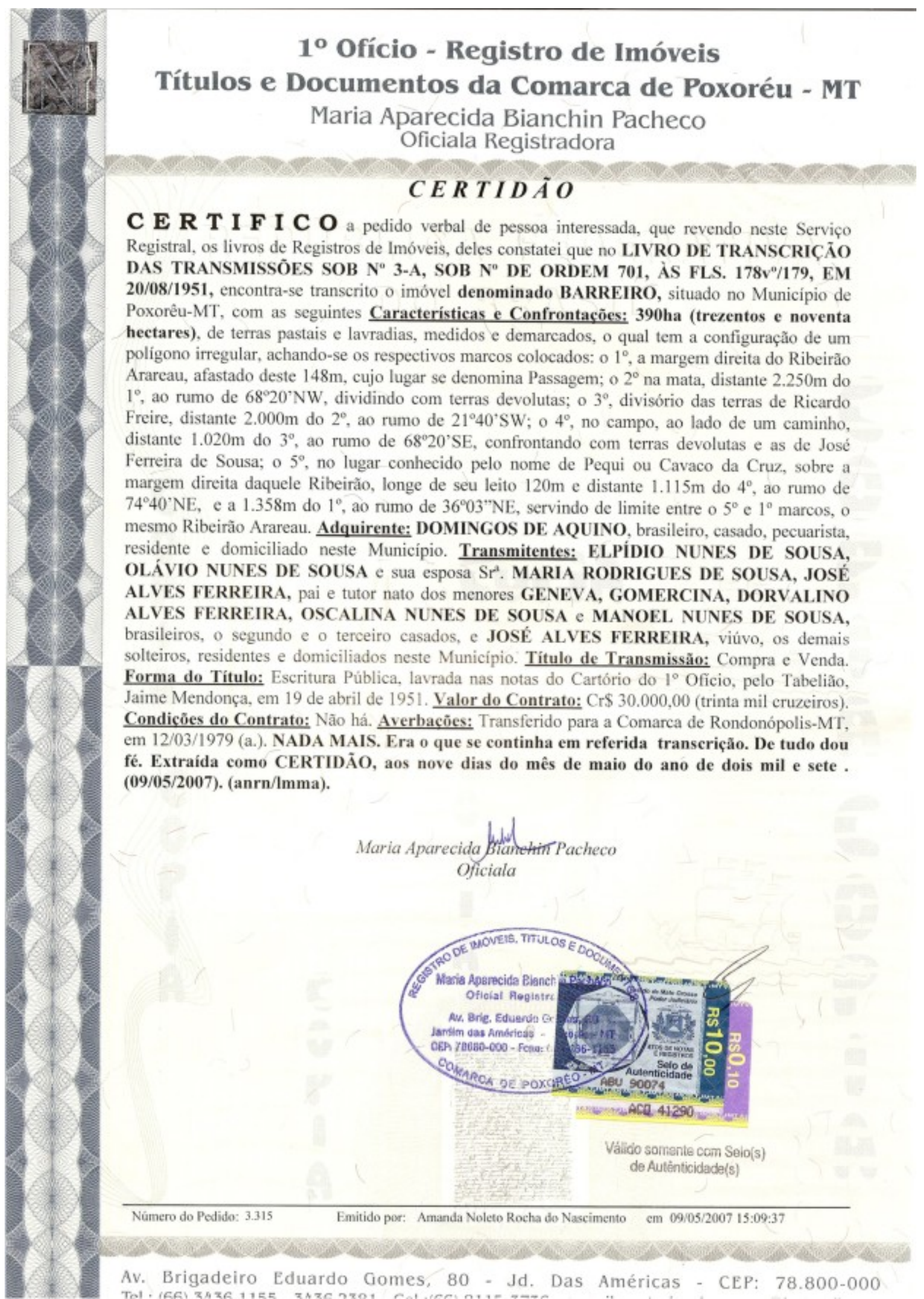

Av. Brigadeiro Eduardo Gomes, 80 - Jd. Das Américas - CEP: 78.800-000 
Nas entrevistas, todos disseram que a terra não é para ser vendida, "pois possui valor sentimental" e, futuramente, quando estiverem aposentados, farão a migração contrária, isto é, o retorno para o campo, para as terras onde nasceram, onde o pai foi enterrado, onde cresceram e, mesmo passando por dificuldades, pois ficaram órfãos de pai muito cedo, de lá têm recordações memoráveis.

Nenhum deles pratica agricultura. Plantam o básico: milho e mandioca somente para o consumo, assim como os porcos e galinhas no quintal. A não ser a Domingas que possui pequena criação de porcos e de ovelhas para comercializar, principalmente, nos finais de ano.

As residências são de alvenaria, com luz elétrica conseguida através do Programa Luz no Campo, pela qual os irmãos e alguns vizinhos, juntamente com a empreiteira, compraram o material e depois doaram para a REDE/CEMAT - Centrais Elétricas Mato-Grossenses S/A, que passou a dar assistência aos sitiantes. A água encanada é obtida através de bomba, ora do córrego Barreiro, ora das muitas nascentes existentes nas propriedades.

São poucos os que possuem equipamento como trator, grade, roçadora, triturador e outros. Sendo assim, na maioria das vezes, utilizam dos irmãos que possuem. Todo o trabalho é realizado pela família. Uma vez ou outra contratam um trabalhador temporário, ou seja, um diarista.

A Dolores e o Benedito são solteiros e não possuem filhos. O Gilberto é casado, mas não tem filhos legítimos, cria uma sobrinha de sua esposa que hoje tem dez anos e que os chamam de pais. O filho de Domingas é formado em Educação Física, mora e trabalha na cidade. O Gervásio tem dois filhos: a moça formada em Letras pela UFMT/CUR, é professora no CESUR, faculdade particular; o rapaz faz Ciências Contábeis na UFMT/CUR.

Expressaram sua indignação em relação à política agrícola em prol dos pequenos produtores. Afirmam ser uma pena o governo não investir mais na pequena produção, não valorizar os produtores de uma maneira geral, pois garantem que os assentados têm mais privilégios que eles, em relação à ajuda governamental. "Enquanto os assentados por um ou outro movimento recebem ajuda de custo a fundo perdido, nós, pequenos produtores, quase perdemos o que temos para fazer um financiamento", comentou Gilberto.

O objetivo dos que têm filhos é passar o direito a eles no futuro, os demais disseram que ainda é muito cedo para tomarem tal decisão. 


\section{FAMIIILA GIOVANIINII}

\section{COURO DE BOI}

Autor(es): Palmeira e Teddy Vieira

Declamado:

"Conheço um velho ditado que é do tempo do Zé Gaio

Diz que um pai trata dez filhos, dez filhos não trata um pai

Sentindo o peso dos anos sem poder mais trabalhar

$\mathrm{O}$ velho peão estradeiro com seu filho foi morar

O rapaz era casado e a mulher deu de implicar

Você manda o velho embora se não quiser que eu vá

E rapaz coração duro com seu velho foi falar":

Cantado:

Para o senhor se mudar meu pai eu vim lhe pedir Hoje aqui da minha casa o senhor tem que sair Leva este couro de boi que eu acabei de curtir Pra lhe servir de coberta onde o senhor dormir

O pobre velho calado pegou o couro e saiu Seu neto de oito anos que aquela cena assistiu Correu atrás do avô seu paletó sacudiu

Metade daquele couro chorando ele pediu

O velhinho comovido pra não ver o neto chorando Partiu o couro no meio e ao netinho foi dando

O menino chegou em casa, seu pai foi perguntando

Pra que você quer este couro que seu avô ia levando

Disse o menino ao pai um dia vou me casar

O senhor vai ficar velho e comigo vem morar

Pode ser que aconteça de nós não se combinar

Esta metade do couro vou dar pro senhor levar.

A propriedade da família Giovanini teve sua origem em Rondonópolis com a chegada do Sr. José Giovanini ${ }^{189}$, casado em regime de comunhão de bens com $D^{a}$. Maria da Encarnação Giovanini, migrantes paulistas radicados em solo rondonopolitano desde 1961, onde compraram três lotes (Escritura de Doação) na região de Naboreiro e Vila Bueno e ali construíram suas vidas.

\footnotetext{
${ }^{189}$ Os pais do Sr. José Giovanini eram imigrantes italianos, a mãe de Da. Maria Encarnação era italiana e o pai era português.
} 
Durante entrevista, o Sr. Osvaldo fez um relatório sobre a vida deles na propriedade e em comunidade:

Aqui na Vila tinha muitas crianças e meu pai achava que deveria ter uma escola, então, vindo de Cuiabá, encontrou o Sr. Zanete Cardinal que na época era candidato a prefeito de Rondonópolis e fez essa cobrança, ou seja, comentou sobre a necessidade desse benefício para as crianças da Vila Bueno. O Zanete disse que se ganhasse a eleição esta seria uma de suas primeiras obras como prefeito. E ele foi eleito e cumpriu o prometido. Acho que a escola foi construída em 1972. Meu pai entrou com o terreno e tanto ele quanto outros moradores ajudaram com material de construção, o restante foi a prefeitura. Depois de um tempo, outro prefeito, o Walter Ulysséa construiu mais duas salas de aula. Como a segunda parte (duas salas) ficou um pouco separada da primeira, esta passou a funcionar como Posto de Saúde aqui da Vila, onde o médico vem uma vez por mês. A escola funcionou até o ano passado (2006), esse ano fechou e os alunos foram transferidos para a escola da Vila Naboreiro, que é administrada pelos italianos. A prefeitura paga uma VAN que leva e busca os alunos nos três períodos.

O convívio intenso entre os vizinhos levou o Sr. José a tomar uma decisão em relação à educação para seus filhos e dos demais vizinhos, exigindo providências por parte da prefeitura em relação à construção de uma escola na "vila". Assim, como a posteriori, lutaram pela edificação de uma igreja e de um posto de saúde, onde toda comunidade rural daquela região seria beneficiada.

Como já foi dito nas caracterizações gerais das famílias, o Sr. José e $D^{a}$. Maria compraram terras em Rondonópolis e Planalto da Serra que, posteriormente, foram doadas aos seus oito filhos. As terras de Rondonópolis foram doadas aos filhos e as terras de Planalto da Serra às três filhas.

Em entrevista, o Sr. Osvaldo comentou que entraram em um acordo pra ninguém ficar prejudicado:

As terras daqui ficaram para os homens, e as mulheres, ficaram com as terras de lá. Como eram três filhas, a Fazenda recebeu o nome de Três Irmãs. Na doação do pai aqui em Rondonópolis, cada um dos filhos recebeu $25,46 \mathrm{Ha}$, no total $127,30 \mathrm{Ha}$. E as terras do Planalto foram divididas com as meninas. O Renato vendeu a parte dele para os irmãos e foi embora para o Planalto da Serra e comprou terras de terceiros. A Lourdes vendeu as terras dela para a Alzira e a Irene e veio embora para Rondonópolis e comprou 35 alqueires de terra na região da Cabeceira do Café. A Irene está com toda sua terra de lá mais 11,7857 Ha aqui (da herança de meu irmão), então ela tem terra nos dois municípios. Quem cuida lá pra ela é o filho da Lourdes. A Alzira faleceu o ano passado. Ela já era separada/divorciada e tinha só um filho, a terra está em processo de inventário, pois a escritura é a mesma para as três irmãs. O Edson 
faleceu de acidente de carro aqui na Rodovia MT 130, em setembro de 2001, após seu falecimento o pai foi ficando triste desgostoso e acabou falecendo também em novembro, ou seja, dois meses depois que meu irmão faleceu. Com a morte de meu irmão e do meu pai, minha mãe ficou doente, ela quase não conversa mais. A Irene (que é solteira) tinha vindo embora do Planalto da Serra para Rondonópolis, e mora com a mãe pra cuidar dela. Elas moram ali na Vila (o sítio do Sr. Osvaldo é apenso à Vila Bueno). Como o Edson era casado com Comunhão Parcial de Bens e não tinha filhos, as terras dele, 126,00 Ha, foram divididas entre minha mãe e a viúva. Minha mãe recebeu 82,50 Ha (remanescentes da Fazenda "Corguinho") e minha cunhada ficou com 43,50 Ha. A parte de minha mãe ela doou para os sete filhos, recebendo cada um 11,7857 Ha. Fora a parte de doação de nossos pais, mais a herança do Edson, nós fomos comprando de terceiros e hoje temos um pouco a mais".

Na fala transcrita acima, há algo interessante que é o fato da divisão das terras, ou seja, da doação ou antecipação de legítima. Quando diz "as terras daqui ficaram para os homens, e as mulheres, ficaram com as terras de lá", soa como se tivesse ocorrido uma diferenciação de partilha por sexo.

Percebe-se, também, que a negociação das mesmas foi feita entre os descendentes, e isso significa, segundo Moura (1978:58), que "as vendas de terra entre parentes são explicadas como atitudes de 'preferência', de 'união' ou de 'consideração"', pela qual a propriedade sai das mãos de um parente para o outro, e não para pessoas estranhas a eles, o que de acordo com a tradição dos entrevistados de Woortmann (1995:198), "vendê-la a estranhos, não colonos, 'é crime', 'é uma traição' às tradições".

Quando o interlocutor diz "fora a parte de doação de nossos pais, mais a herança do Edson, nós fomos comprando de terceiros e hoje temos um pouco a mais", esse "pouco a mais" não demonstra a intenção de acumular riqueza ou capital, mas de possuir uma porção de terra maior, onde possa continuar trabalhando com a família e vivendo com dignidade. De acordo com Oliveira (1991:21):

"Através do trabalho familiar eles podem aumentar sua produção, mesmo sem ampliar suas terras. Dessa forma, uma família camponesa pode estar produzindo muito além do necessário a sua sobrevivência e com isso acumulando. Esse dinheiro poderá ser destinado a aumentar suas terras e/ou contratar trabalhadores assalariados para trabalhar para ela. Quando isso ocorre, seus membros (filhos, pai e mãe) deixam de trabalhar na produção, passando a cuidar apenas das tarefas da administração e 
comercialização da produção, tornando-se, pois, pequenos capitalistas".

Ainda não é o caso da família Giovanini, até porque, na Fazenda Naboreiro (354 ha) do Sr. Osvaldo Giovanine, casado com D. Nizete da Silva Giovanine, (bem como nas terras de seus irmãos), todas as atividades ainda são realizadas por ele, a esposa e um filho casado que também mora na propriedade. O forte na propriedade é a produção de leite onde retiram em torno de 200 litros por dia. $\mathrm{Na}$ propriedade do Sr. Osvaldo fica um resfriador do Laticínio Nutribom, com capacidade para 1.150 litros de leite.

Esse resfriador recebe o leite do Sr. Osvaldo (200 L), do Odair (70 L), do José Cândido (120 L) e do Félix Bispo (11 L), sendo que estes dois últimos são vizinhos. O Sr. Osvaldo faz a entrega e o recebimento do leite, repassando o dinheiro de todos após a divisão pela quantidade de litros depositados durante o mês. O leite é recolhido de dois em dois dias, a limpeza do resfriador fica por conta do Sr. Osvaldo e sua esposa. O laticínio paga $\mathrm{R} \$ 0,40$ por litro, porém o Sr. Osvaldo recebe, do Laticínio, R\$ 0,03 a mais por cada litro de leite, para ajudar no pagamento da energia elétrica.

Na fazenda Naboreiro há três casas de morada, uma está fechada, na outra mora o filho casado e na sede moram ele e sua esposa, pois os dois filhos solteiros, um trabalha na cidade onde reside numa residência que possuem e a moça faz faculdade de enfermagem em Fernandópolis/SP.

As casas são simples, de alvenaria, com luz elétrica e água encanada, são bastante arejadas, cercadas por árvores frutíferas em todos os lados. Ao lado da casa, fica o barracão onde guarda as ferramentas, a caminhonete, o trator e outros equipamentos utilizados para a realização das tarefas na propriedade.

O Sr. Osvaldo cria gado de corte e de leite, há, também, em sua propriedade uma represa com 3.000 peixes, além dos porcos e galinhas.

Não tem intenção de vender a terra, mas, caso o fizesse, só se fosse para comprar uma área maior e melhor. E, se acaso tivesse uma economia, usaria para instalar os filhos, pois afinal essa é uma preocupação por parte dos pais. No futuro pretendo dividir a terra com eles.

A fazenda Boa Esperança é de responsabilidade do Sr. Nelson Giovanini, que vive maritalmente com Renilda. Todas as atividades da propriedade são 
realizadas pelos dois. A retirada do leite (50 litros por dias) é feita por Renilda, sendo colocado em um tambor na porta da casa onde o leiteiro passa recolhendo. Além desse e de outros afazeres, ainda aproveita o cordão que vem costurado nos sacos de sal e ração. Ela amarra os fios um ao outro, separado-os da cor mais clara a mais escura e, quando tem uma quantia razoável, lava-os, enrola-os em novelos e depois os transforma em peças de crochê (colchas, caminhos de mesa, forros para as mesas e estante, cortinas, blusas etc.). Os vizinhos já sabem de suas habilidades e juntam os fios de cordões para que ela possa manuseá-los. Vivem da renda do leite e de pecuária, pois possuem desde touros, a novilhas, vacas de lactação e secas, alguns suínos e aves, sendo estes dois últimos para o gasto.

A propriedade possui uma casa bem simples, mas com luz elétrica e água encanada de poço artesiano. O curral é coberto e fica bem próximo à residência, que é cercada por muitas plantas. A fazenda está formada com capim para o gado, não se pratica nenhum tipo de agricultura, somente pecuária. Contam com um trator e um carro pequeno.

Se um dia vendesse a terra, com certeza, seria para comprar outra maior e melhor. E, no futuro, pretende deixar para os filhos.

A Fazenda São João 183,92 ha é de propriedade do Sr. Odair Giovanini, casado com Ednalva com quem tem duas filhas: uma de oito e outra de cinco anos que estudam na Escola em Naboreiro que é administrada por italianos.

A renda da fazenda de Odair é referente à venda do leite e do gado de corte, pois possui algumas cabeças entre novilhas, bezerros, vacas leiteiras e vacas secas. As aves e os ovos são para o consumo da família. Em se tratando de agricultura, planta milho para o consumo.

Possui, na propriedade, trator, grade, sulcadora, semeadora, trator, carro pequeno e outras ferramentas e utilitários usados nos afazeres da propriedade. Tem uma residência com energia elétrica, água encanada e um curral sem cobertura.

No futuro, pretende dividir as terras com as filhas, para ajudá-las a se instalar e, se dependesse dele, elas viveriam sempre no campo, pois é mais seguro.

Em relação à propriedade, em entrevista, Irene Giovanini informou que: "como sou solteira, e não tenho filhos, minha propriedade, só tem pasto para o gado. No futuro, vou doar tudo que tenho aos irmãos e sobrinhos, pois são eles que vão cuidar de mim". A Lourdes tem propriedade fora da região do Naboreiro e Vila 
Bueno, suas terras ficam na região do Café. Ela vendeu a doação que recebeu em Planalto da Serra e comprou aqui a parte de seu ex-marido.

Das cinco famílias entrevistadas, esta é a única que não requereu terras diretamente do Estado. A propriedade dos pais foi constituída por três áreas compradas de terceiros: Primeira, uma área de terras com 36,30 $\mathrm{Ha}$, localizada na Fazenda Miranda (Certidão 08); Segunda, um lote de terras pastais e lavradias, com área de terras de 44, Ha, lote no. 86, do Núcleo Colonial de Naboreiro (Certidão 09), e a Terceira, um lote de terras sob $n^{\circ}$. 87, do Núcleo Colonial de Naboreiro, com área de 47 Ha (Certidão 10), todas no município de Rondonópolis/MT. 


\section{CERTIDÃO 08 - Lote com 36,30 Ha, localizada na Fazenda Miranda}

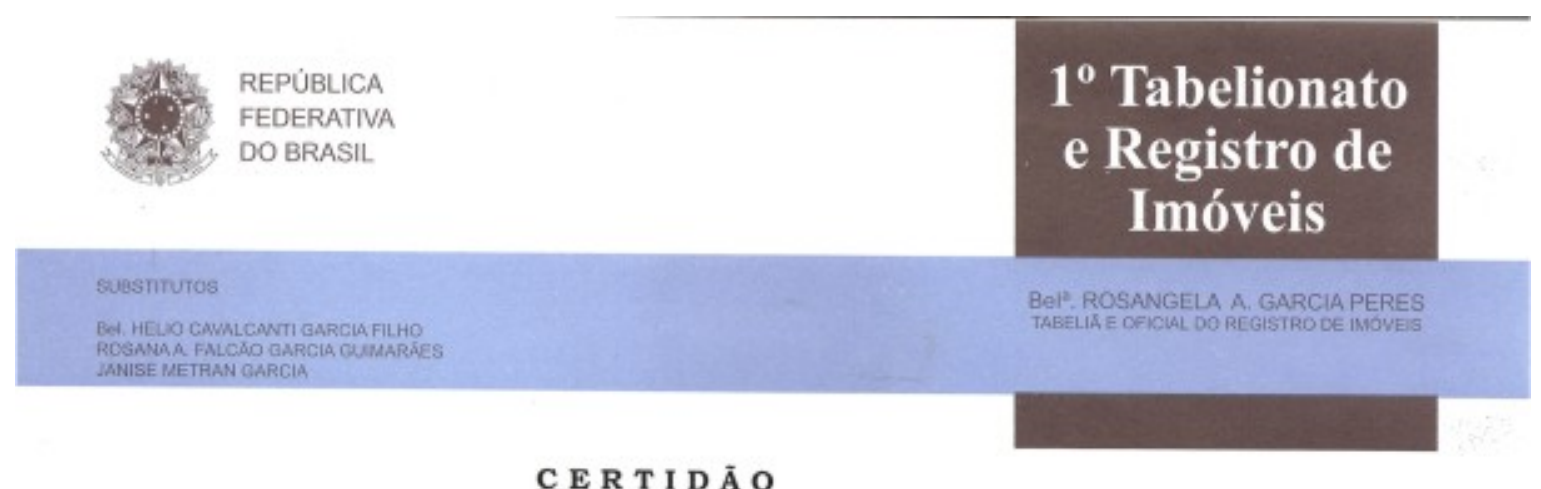

C E R T I D Ã O

Certifico a pedido verbal de parte interessada que revendo nesta Serventia Registral os livros de Registro Geral, verifiquei que o Sr OSVALDo GIOVANINE e sua esposa NIZETE DA SILVA GIOVANINE; RENATO ENCARNAC̣Ão GIOVANINE e sua esposa VILMA GAVIGLIA GIOVANINI; LURDES GIOVANINE VIEIRA e seu esposo MANOEL DA ASSUNÇÃO VIEIRA; ALZIRA GIOVANINI; ODAIR GIOVANINI; EDSON CARLOS GIOVANINE; NELSON GIOVANINI E IRENE GIOVANINI, adquiriram uma área de terras com 36,30 has localizada na fazenda denoninada Miranda, situada na zona rural deste Municipio, por doação de Jose Giovanini e sua esposa Maria da Encarnação Giovanini, conforme Escritura Pública de Doação de 03 de Maio de 1994, ás fls. $184 / 185 v^{\circ}$ do livro $2-\mathrm{F}$, das Notas deste Tabelionato, devidamente registrada sob $\mathrm{n}^{\circ} 01$ na matricula 2001, livro $02 \mathrm{em}$ 04/05/1994, no RGI local.

JOSE GIOVANINI, adquiriu 36,30 há, por compra feita de Francisco Antonio de Lima e sua esposa Jovina Alves da Silva, conforme Escritura de 11 de Outubro de 1976 , ás fls. $141 / 142 v^{\circ}$ do livro 32 , das Notas deste Tabelionato, devidamente registrada sob $\mathrm{n}^{\circ} 01$ na matricula 2001, livro 02, em 14/10/1976, no RGI local.

FRANCISCO ANTONIO DE LIMA, adquiriu 502 has., juntamente com Odilon Barcelos Maia; Doralina da Silva Alves; Zildeteh Silva Souza e seu esposo Saturnino Medrado de Souza; Durval Alves de Oliveira e sua esposa Natalina Souza de Oliveira; Ana Julia Ribeiro e seu esposo Seabra de Souza Ribeiro; Maria Raulina Ribeiro e seu esposo Protasio de Souza Ribeiro; Anita Alves da Silva e seu esposo Otavio Alves da Silva; Jose Vicente Vieira e sua esposa Laura Alves Vieira; e Ercilia Rodrigues da Silva, do Estado de Mato Grosso, conforme Titulo Definitivo expedido pelo Departamento de Terras e Colonização, em 29 de Novembro de 1949, devidamente registrado sob no 13.957, fls. 59 do livro 3-M, em 19/06/1970; e posterior Escritura Pública de Divisão Amigável de 25 de julho de 1972, ás fls. 11/13v ${ }^{\circ}$ do livro 1-I, deste 


\section{CERTIDÃO 09- Lote $n^{\circ} .86$ com $44 \mathrm{Ha}$, do Núcleo Colonial de Naboreiro}

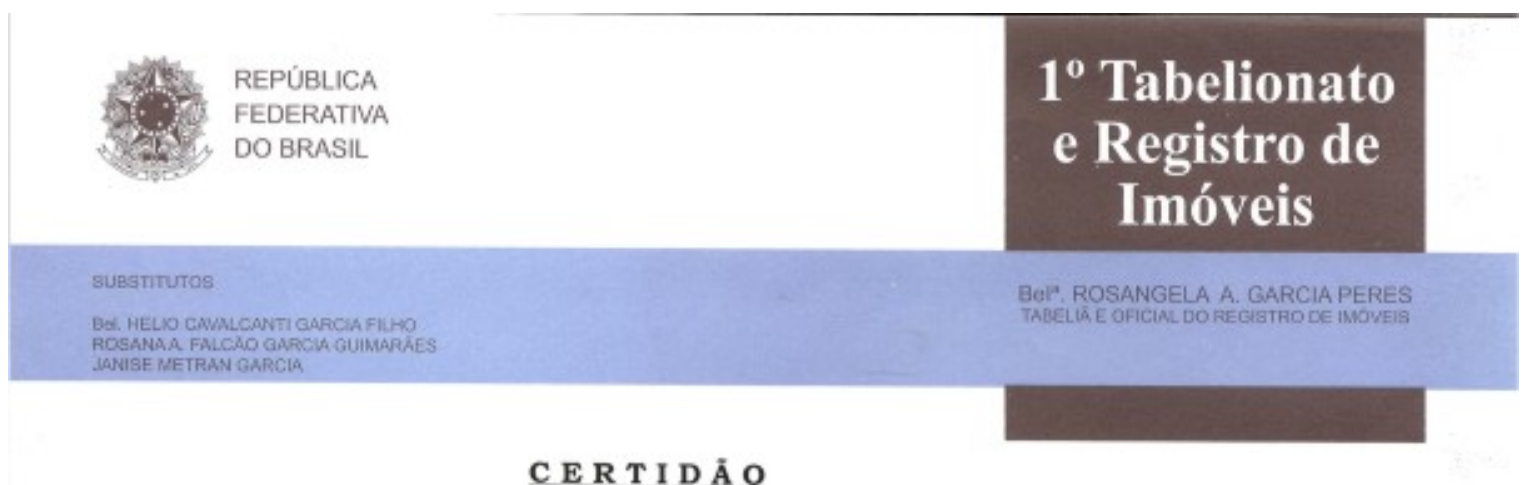

Certifico a pedido verbal de parte interessada que revendo nesta Serventia Registral os livros de Registro Geral, verifiquei que o Sr OSVALDO GIOVANINE e sua esposa NIZETE DA SILVA GIOVANINE; RENATO ENCARNAĈ̣̃o GIOVANINE e sua esposa VILMA GAVIGLIA GIOVANINI; LURDES GIOVANINE VIEIRA e seu esposo MANOEL DA ASSUNÇÃO VIEIRA; ALZIRA GIOVANINI; ODAIR GIOVANINI; EDSON CARLOS GIOVANINE; NELSON GIOVANINI e IRENE GIOVANINI, adquiriram uma área de terras pastais e lavradias 44 has, Lote 86 do Núcleo Colonial de Naboreiro, situada na zona rural deste Municipio, que adquiriram por doaçāo de Jose Giovanini e sua esposa Maria da Encarnação Giovanini, conforme Escritura Pública de Doação de 03 de Maio de 1994, ás fls. 184/185vo do livro $2-\mathrm{F}$, das Notas deste Tabelionato, devidamente registrada sob $\mathrm{n}^{\circ} 01$ na matricula 45.309, livro 02 em 04/05/1994, no RGI local.

JOSE GIOVANINI, adquiriu 44 há, por compra feita de Vinarde Queiroz, conforme Escritura de 17 de Setembro de 1965, ás fls. 19 do livro 01, do $3^{\circ}$ Tabelionato de Notas local, devidamente registrada sob $n^{\circ} 8.927$, fls. 203 do livro 3-H, em 06/11/1965, no RGI local.

VINARDE QUEIROZ, adquiriu 44 has,, por compra feita de Manoel Ferraz da Costa, conforme Escritura Pública de 11 de Julho de 1959, do $2^{\circ}$ Tabelionato de Notas local, devidamente registrada sob $n^{\circ} 194$, fls. 29 do livro 3-A, em 22/07/1959, no RGI local.

MANOEL FERRAZ DA COSTA, adquiriu 44 has., do Estado de Mato Grosso, conforme Titulo Definitivo expedido pela Comissão de Planejamento da Produção, em 10 de Maio de 1957, devidamente registrado sob no 193, fls. 29 do livro 3-A, em 22/07/1959, no RGI local

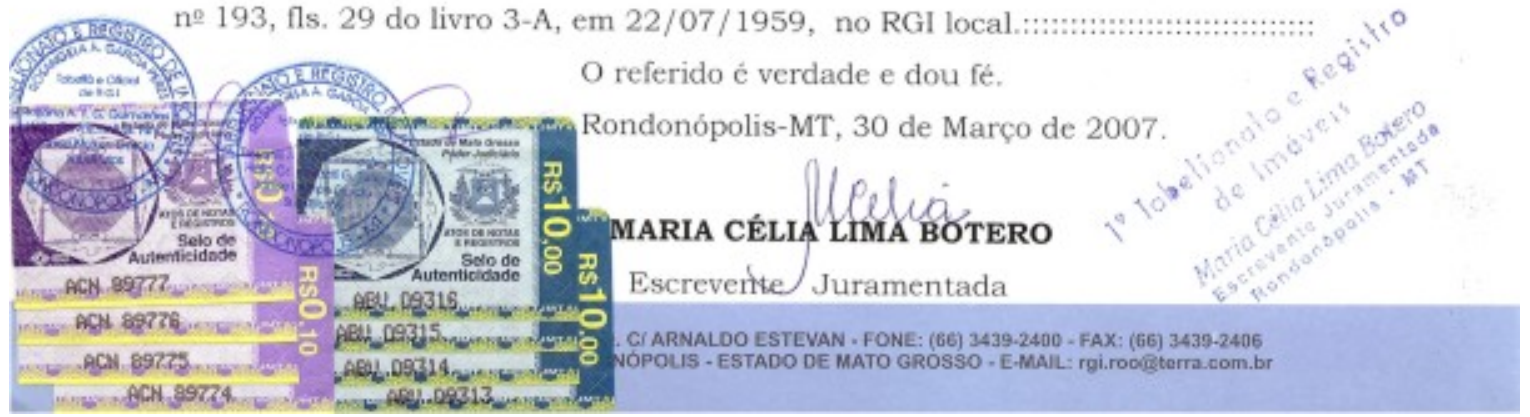




\section{CERTIDÃO 10- Lote $n^{\circ} .87$ com 47 Ha do Núcleo Colonial de Naboreiro}

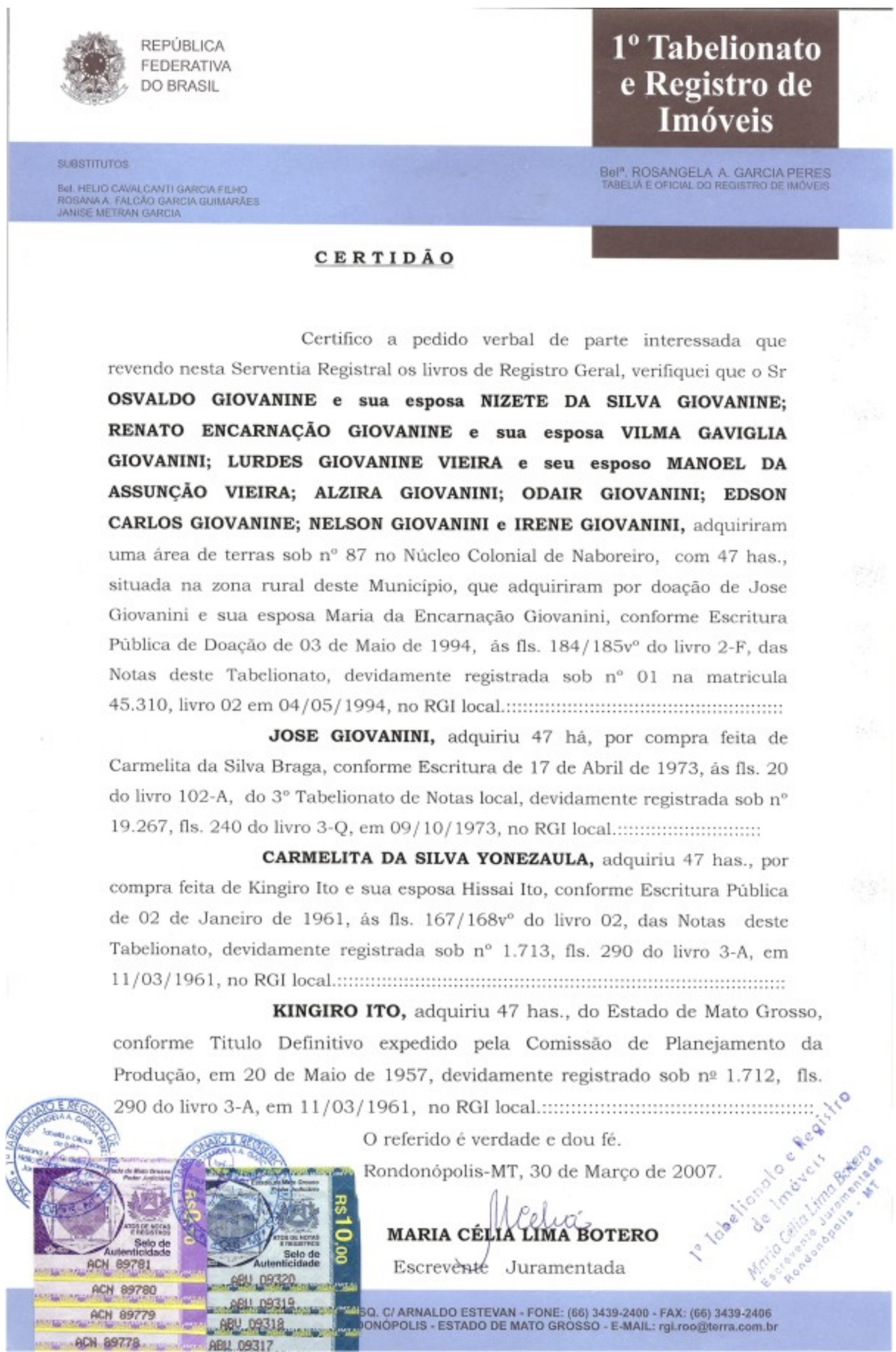


6- FRAGMENTAÇÃO DA TERRA POR HERANÇA E DOAÇÃO 
Ao analisar o processo de ocupação e fragmentação da terra através da sucessão por herança ou doação nas regiões do Bananal, Beroaba, Belém, Aldeinha, Pequi, Naboreiro e Vila Bueno, foi possível identificar e separar nossos entrevistados em dois grupos: o da fragmentação por herança e doação e o grupo da fragmentação por doação.

Sendo assim, no primeiro grupo a passagem do patrimônio para as famílias Ferreira e Aquino ocorreu por conta do falecimento do Sr. Domingos de Aquino e do Sr. Otoni Nunes Ferreira, portanto, sucessão causa mortes, onde as viúvas entraram como meeiras e receberam parte da herança juntamente com os filhos, e a posteriori, fizeram a doação da parte que lhes coube por direito, ou seja, a antecipação ou adiantamento de legitima.

No segundo grupo, as famílias Oliveira, Silva e Giovanini tiveram acesso à terra por intermédio da doação, onde os pais ainda em vida resolveram antecipar aos filhos o que de fato Ihes pertenceria como herança, portanto, o processo de fragmentação, ou a sucessão foi realizada inter vivos.

Tanto no primeiro como no segundo grupo, evitou-se a expropriação dos filhos mantendo sua reprodução física e social como camponês, daí, a importância desse processo, dessa sucessão.

Nas famílias Ferreira e Aquino, o cônjuge sobrevivo, ou seja, as viúvas por serem casadas com comunhão de bens, tiveram direito à meação, isto é, a percepção da metade dos bens deixados pelos seus esposos falecidos. A meação é distinta da herança, pois conforme Oliveira (2003:4) "decorre do regime de bens e pré-existe ao óbito do outro cônjuge, devendo ser apurada sempre que dissolvida a sociedade conjugal". Fato ocorrido com $\mathrm{D}^{\mathrm{a}}$. Maria Rodrigues Ferreira e $\mathrm{D}^{\mathrm{a}}$. Orinda Souza Aquino, onde ao ser excluída a meação, o patrimônio restante deixado pelos seus falecidos passou a constituir a herança que foi atribuída aos sucessores legítimos ou testamentários.

O caso de $D^{a}$. Orinda, difere de $D^{a}$. Maria, pois quando fez o testamento, um de seus filhos que era solteiro e não tinha filhos, já era falecido, portanto coube a ela a parte da herança que este teria em relação aos bens deixados pelo pai. Como não havia descendente por parte de seu filho Adão com direito à sucessão, $D^{a}$. Orinda foi chamada para receber a herança do filho, que a posteriori doou para os demais juntamente com a metade que recebeu do marido. 
Tanto os filhos do Sr. Otoni como os do Sr. Domingos, herdaram em igualdade de condições com os demais, ou seja, a partilha foi igualitária, como prevê o Código Civil Brasileiro. Tanto no caso do Sr. Otoni como em relação aos filhos do Sr. Domingos, a herança foi atribuída aos herdeiros por direito próprio, ou por cabeça. Não registramos nessas famílias nenhum caso de herança por direito de representação, ou seja, por estirpe.

O Direito das Sucessões é fundamentado na Constituição Federal e consagra o direito de herança, portanto, não pode ser negado pela legislação infraconstitucional.

Nas famílias Ferreira e Aquino a sucessão causa mortis legítima ou testamentária, isto é, a transmissão dos bens do Sr. Otoni e Domingos, por força da lei ou do testamento ocorreu da seguinte maneira:

O Sr. Domingos de Aquino faleceu em 30/10/1955, com 45 anos de idade deixando viúva $\mathrm{D}^{\mathrm{a}}$. Orinda Souza de Aquino com dez filhos e grávida de quatro meses de sua filha Domingas. Em 1960, Da . Orinda uniu-se em concubinato e desta união nasceram mais quatro filhos, tendo falecido um de cada casamento.

A partilha dos bens, uma propriedade com 390 ha denominada Barreiro, situado no município de Poxoréo (hoje Rondonópolis), deixado pelo Sr. Domingos de Aquino, de acordo com inventário $N^{\circ} 93 / 73$ e registro $N^{\circ} 5$, matrícula 16.864 de 19/04/1983 (anexo), obedeceu aos seguintes critérios: a viúva meeira e herdeira ascendente haverá de acordo com o título formal de Partilha uma área com 212,7280 ha, referente à metade do espólio do Sr. Domingos mais a parte que lhe coube da herança de seu filho Adão, e a outra parte aos herdeiros em comum com a viúva meeira a área de 177,2720 ha, cabendo a cada herdeiro 17,7272 ha.

Da. Orinda Souza Aquino em 14/02/1991, conforme matrícula 16.864, a título de doação, passa aos Donatários, dez filhos de seu primeiro casamento e quatro do segundo, a área de 121,7280 ha que lhe coube da herança de seu esposo e filho, onde cada um recebeu uma área equivalente a 15 ha e 1.948,57 metros quadrados.

Pela árvore genealógica da família Aquino e de acordo com Averbação $\mathrm{n}^{\circ}$.. 6/16.864 de 02/04/1991 e pela Escritura de Divisão Amigável para Extinção de Condomínio, foi feita a divisão do imóvel ficando os filhos de $\mathrm{D}^{\mathrm{a}}$. Orinda e Sr. Domingos com 32 ha e 9.220,57 $\mathrm{mts}^{2}$, enquanto aos filhos do segundo casamento coube uma parcela de 15 ha e 1.948,57 ha. 


\section{ÁRVORE GENEALÓGICA FAMÍLIA AQUINO}

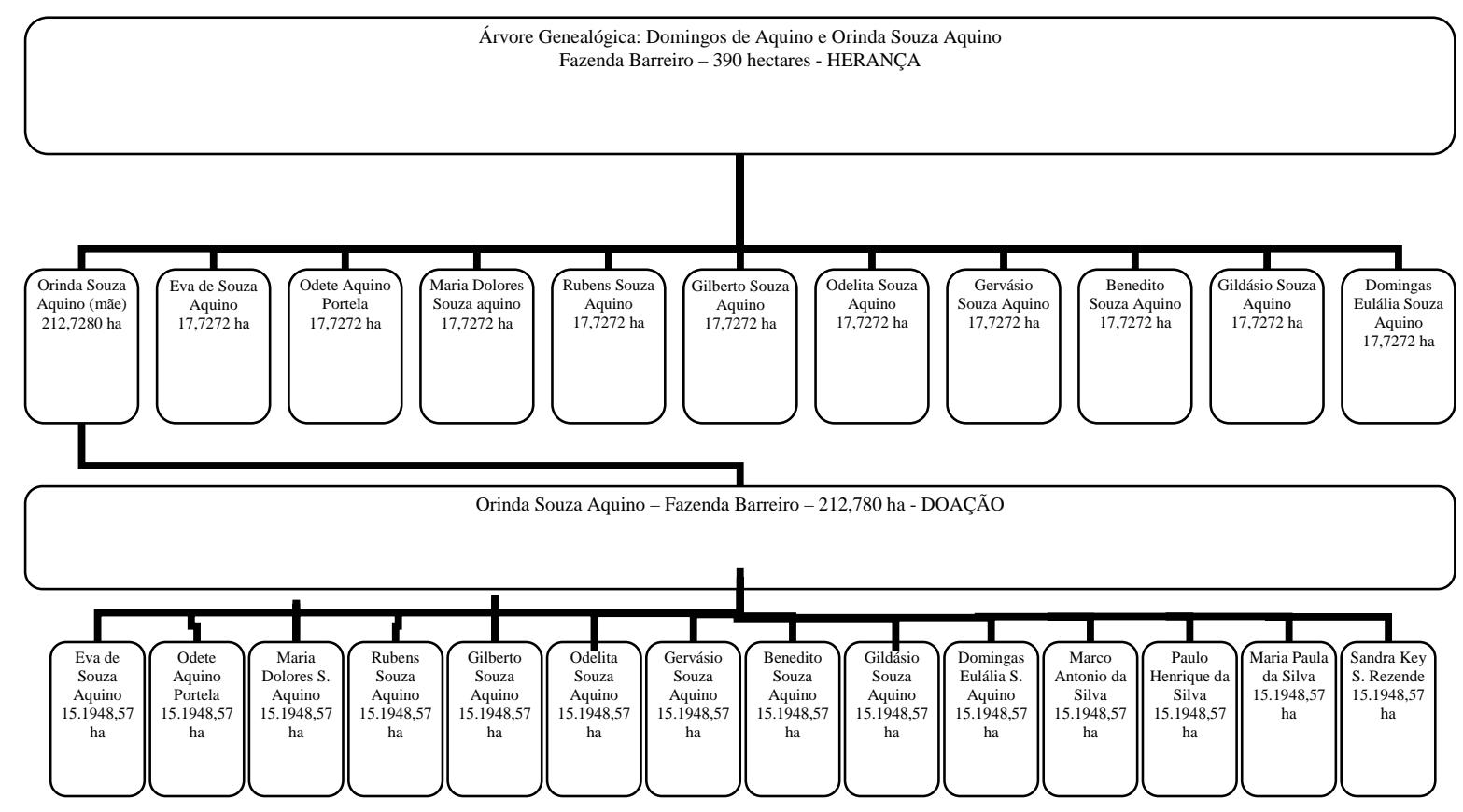


A representação gráfica acima caracteriza a fragmentação das terras da Fazenda Barreiro por herança e doação, onde o destaque é dado a $D^{\mathrm{a}}$. Orinda, que por força da lei entrou como meeira e herdeira juntamente com os demais filhos. Aqui, o topo da árvore é representado pelos pais e deles emergem seus troncos, correspondendo aos descendentes. Hoje essa representação está alterada, a partir do momento que os herdeiros Donatários venderam seus lotes.

Pelas datas expostas anteriormente, conclui-se que a família Aquino realizou o que é comum em vários casos, ou seja, um "arranjo entre a família". Nota-se que o inventário foi feito em 1973, dezoito anos após a morte do Sr. Domingos. Primeiro realizou-se a "partilha aritmética (simplesmente teórica) dos bens, só em 1991 foi feita a partilha geodésica", isto é a partilha de fato.

Da parte da herança do pai, a Domingas e a Odete venderam seus lotes ao Rubens e este vendeu a parte dos três a uma pessoa fora da família, o que acabou deixando os demais contrariados, pois a este coube a parte da propriedade onde existia a sede, onde todos nasceram e cresceram. A Eva e a Odelita venderam suas propriedades ao Benedito. Dos filhos do segundo casamento nenhum tem a parte da doação. A Maria Paula, o Marco Antônio e o Paulo Henrique, venderam seus direitos ao Gildásio e a Sandra realizou a venda da terra com alguém fora da família.

A preferência era para que essa venda ocorresse somente entre os membros da família, para que não perdessem o domínio do patrimônio que principalmente para os filhos do primeiro casamento possuí um valor estimativo muito grande. Esse fato nos remete a Moura (1978:45) quando expõe que: "as transações de terra favorecem consangüíneos e não um que não é parente. Quando isto não é possível, pode gerar-se um rancor recíproco que escapa nos relatos". E esse rancor foi possível perceber não só nos relatos da família Aquino, mas também em alguns dos irmãos da família Oliveira pelo fato da venda da terra a não parentes, principalmente a área onde se localizava a sede.

Com a morte do Sr. Otoni Nunes Ferreira (48) em 21/10/1969, fica viúva Da. Maria Rodrigues Ferreira, com onze filhos e grávida de seis meses de uma criança que faleceu ao nascer.

A partilha dos bens dessa família começou quando $\mathrm{D}^{\mathrm{a}}$. Aurora Rosa Batista ao ficar viúva passa aos filhos conforme formal de Partilha de 11/01/1962 do espólio de seu esposo João Nunes Ferreira, uma área com 140,60 ha, desmembrado das fazendas Bananal (Registro $N^{\circ}$ 3.026) e Santa Paz (Registro $N^{\circ} 3.026$ ) ambos em 
anexo, a cada um de seus filhos, sendo o Sr. Otoni um dos beneficiários, o que pode ser observado pela arvore genealógica abaixo.

\section{ÁRVORE GENEALÓGICA FAMÍLIA FERREIRA}

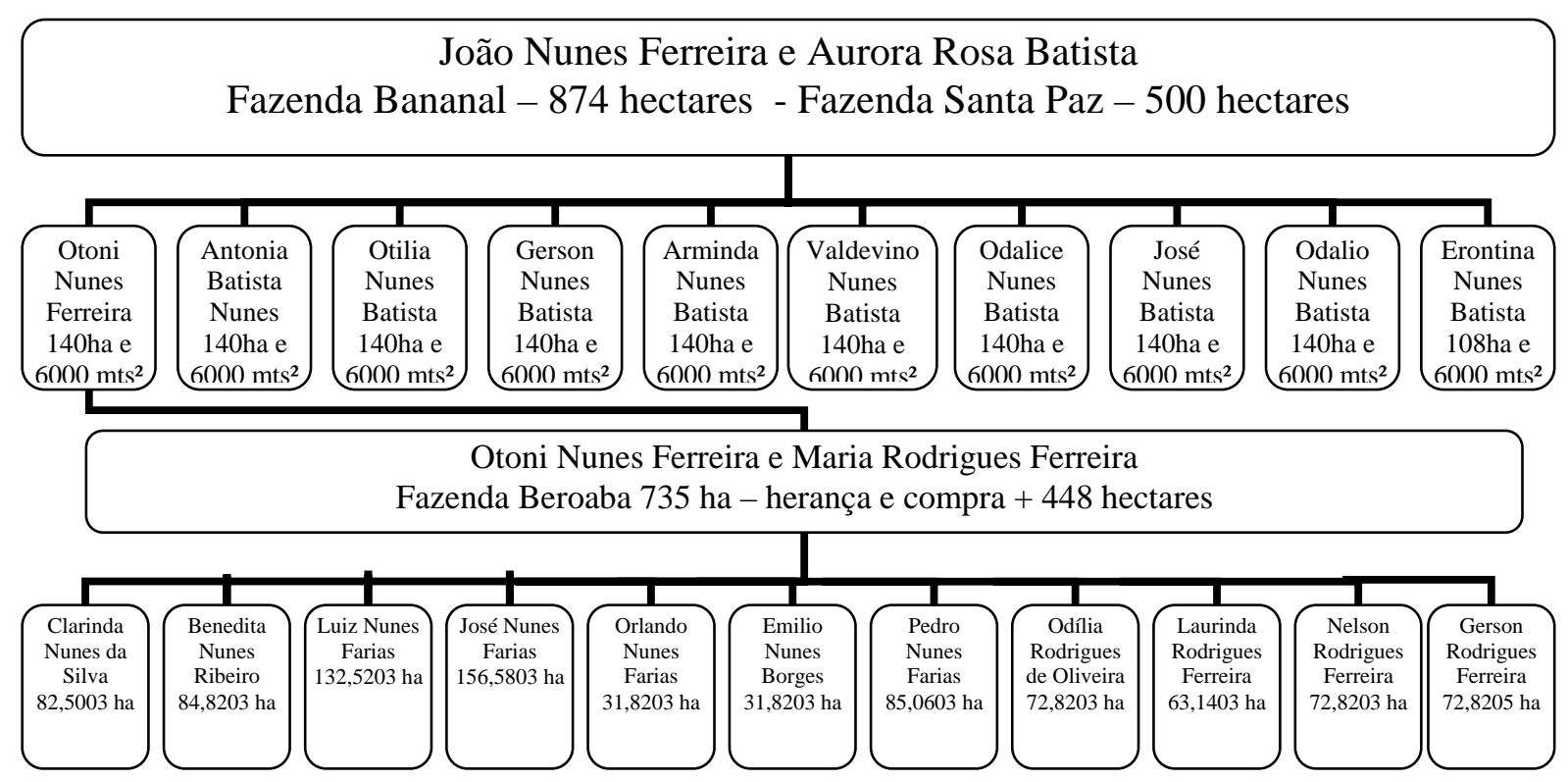


Além dessa transmissão, o Sr. Otoni como já vimos, era detentor de outras áreas, que foram divididas entre os seus familiares com o seu falecimento. O espólio do Sr. Otoni era constituído de terras que foram adquiridas por solicitação de compra ao governo como também por compra realizada entre irmãos e terceiros, sendo assim, coube a $\mathrm{D}^{\mathrm{a}}$. Maria, viúva meeira, de acordo com Escritura de Formal de Partilha e com base no inventário N 154/80, uma área com 350 ha e $6632 \mathrm{mts}^{2}$, e aos onze filhos herdeiros descendentes uma porção com 451 ha., onde cada um recebeu o correspondente a 41 ha.

Realizou-se o inventário, mas não a divisão de fato, ou como diz Moura (1978:56-7):

O resultado do inventário 'herança' pára na divisão teórica dos lotes
que caberiam aos herdeiros", (...) com isso o patrimônio em terra
continua único, isto é, 'em comum', já que todos que (os varões) que
já usufruíram independentemente dessa terra ou que passam a
usufruir respeitam seus respectivos limites através arranjos orais.

No item anterior, nos relatos da família Ferreira, mencionado por eles esse ocorrido, esse "arranjo oral" aonde cada filho ia casando e construindo suas casas de morada no local que lhe caberia por direito.

$D^{a}$. Maria por livre e espontânea vontade decide em 1999 passar aos filhos por doação, com usufruto (gado e casa de morada na cidade), os 350 ha. $6.632 \mathrm{mts}^{2}$ que lhe coube por direito do espólio do Sr. Otoni, onde cada um dos Donatários recebeu 31 ha e $8203 \mathrm{mts}^{2}$. Essa partilha também foi um arranjo oral entre eles que concordaram inclusive em doar a porção maior para o José que ficou cuidando do gado da mãe. $D^{a}$. Maria ficou com bens em espécie (gado) e não em terra.

A divisão de fato, ou seja, a "partilha geodésica" para extinção de condomínio foi realizada em 30/12/2000, conforme Escritura de Divisão Amigável, onde Laurinda Rodrigues Ferreira e outros entraram como outorgante, ou seja, declararam em escritura pública os bens que possuíam e José Nunes Farias como outorgado, concordando e confirmando com o que foi citado pelos irmãos.

A árvore genealógica da família Ferreira é um demonstrativo da distribuição dos bens dos Sr.es João Nunes Ferreira e Aurora Rosa Batista, e na ramificação abaixo o espólio do Sr. Otoni Nunes Ferreira e a doação de $\mathrm{D}^{\mathrm{a}}$. Maria Rodrigues Ferreira, onde os números correspondem à quantidade de área (ha) que cada filho possuía na época da realização da "partilha geodésica". Na "partilha aritmética", todos (homens e mulheres) receberam partes totalmente iguais, na época da 
"partilha geodésica", alguns já haviam vendido partes da herança e outros adquirido mais, o que justifica a diferenciação na quantidade de área (ha) expressa.

A propriedade pelo direito hereditário (ou das sucessões), tanto na família Aquino como na Ferreira, está associada à morte do pai/proprietário, ocorrendo a cessou de seus bens em função de sua morte e passando a sucessão aos filhos (herdeiros legítimos e testamentários) de acordo com artigos 1572 e 1574 do Código Civil. Portanto, os herdeiros legítimos, isto é, as esposas, os descendentes (Art.1603) e os ascendentes (Art.1606), no caso $\mathrm{D}^{\mathrm{a}}$. Orinda, de acordo com as regras do Código Civil passaram a sucessores dos bens do espólio de seus esposos, pais e filhos.

Falamos no decorrer do texto em inventário e formal de partilha, que são caracterizados como dois momentos diversos em um processo de herança, onde o primeiro leva à descrição de todos os bens de herança e, é com base nesse processo que se realiza a "partilha aritmética - teórica" já, a partilha nos remete à divisão "geodésica", a divisão física dos imóveis, no caso aqui descrito, as áreas de terra desmembradas das fazendas Barreiro/Aquino e Beroaba/Ferreira.

Esses dois momentos distintos, ou seja, a partilha aritmética e geodésica é fato comum e decorrente em várias partes do país, o que não foi diferente com as famílias de nosso primeiro grupo, onde $\mathrm{D}^{\mathrm{a}}$. Orinda e $\mathrm{D}^{\mathrm{a}}$. Maria realizaram a "partilha aritmética", adiando a "geodésica" para acarretar menor gastos aos herdeiros, poupando-Ihes gastos supérfluos se a mesma fosse feita duas vezes. Os arranjos orais deram acesso à terra aos herdeiros que passaram a trabalhar, a construir benfeitorias na propriedade herdada, onde puderam constituir suas famílias e lhes proporcionar, mesmo com sacrifícios, uma vida digna.

Esse primeiro grupo teve acesso a terra por conta da transação causa mortis (falecimento do pai) bem como por contrato inter vivos, doação da mãe. Pelo Código Civil Brasileiro, tanto ocorreu o direito à herança, partilha igualitária sem distinção de sexo, como adiantamento de legítima - doação.

Nosso segundo grupo, formado pelas famílias Oliveira, Silva e Giovanini tiveram acesso a terra por intermédio de doação, da antecipação ou adiantamento de herança, frequentemente confundido na prática por alguns institutos da doação, que possuí conceito e limitações impostas por lei. 
O artigo 1165 do Código Civil conceitua o instituto nos seguintes termos: "Considera-se doação o contrato em que uma pessoa, por liberdade, transfere do patrimônio bens ou vantagens para o de outrem, que os aceita".

O conceito de doação, com base em estudos realizados por Araújo, Luciano Vianna ${ }^{190}$, é quase que semelhante aos conceitos utilizados no direito português (art. 940), no direito francês (art. 894), no direito espanhol (art. 618) e no direito italiano (art. 769).

Na realidade, o artigo 1171 do Código Civil prescreve que a doação dos pais aos filhos importa em adiantamento de legítima, ou seja, à parte do patrimônio que constitui a herança dos descendentes, e na falta deles, dos ascendentes.

Pelo Código Civil, o artigo 1721, prescreve que "o testador que tiver descendente ou ascendente sucessível não poderá dispor de mais da metade de seus bens", mas nos casos aqui estudados, todos dispuseram de seus bens totais.

$\mathrm{Na}$ família Oliveira o processo de adiantamento de legítima iniciou por parte do Sr. Antônio Pereira dos Santos ao transmitir na forma de doação à sua filha Leonila Pereira de Oliveira, conforme escritura pública de doação de 31/12/60 uma área correspondente a 305 ha do imóvel rural denominado Belém, que juntamente a outras áreas adquiridas por seu esposo Ildefonso Bernardino de Oliveira, passou a constituir a Fazenda Campo Alegre, que foi doada aos filhos em 1978, conforme averbação especificada no registro número 1556 (anexo), onde aparece as partes cabíveis a cada um, que foram retiradas do registro acima mencionado, bem como dos registros $n^{\circ} . .8884$ (lote Aldeinha com 48,40 ha), nº. 9939 (Fazenda Belém com 711 ha), no.. 11579 (Fazenda Barra da Estiva com 27 ha) e no.. 21921 (Fazenda Aldeinha com $406 \mathrm{ha}$ ), caracterizados nas certidões (cadeia dominial) da família Oliveira, em nome de Ildefonso Bernardino de Oliveira.

Conforme iam se casando, os filhos do Sr. Ildefonso e $D^{a}$. Leonila construíram sua "casas de morada" ou "roça" na propriedade dos pais, caso observado nas demais famílias, onde foi "acionada com a concessão por parte do pai de uma parcela de terra dentro da sua propriedade ao filho" (MOURA, 1978:53), o que difere do caso de São João da Cristina por ela pesquisado, pois enquanto lá essa concessão era feita aos homens, aqui as mulheres também se beneficiaram. $O$ fato de estar cultivando uma terra "dada" pelo pai, não os desobrigava de ajudá-los em suas atividades, em seus trabalhos eventuais na sede, até porque, com a idade

\footnotetext{
${ }^{190}$ Professor da Pontifícia Universidade Católica - PUC/RJ.
} 
avançada o Sr. Ildefonso foi adoecendo e não conseguia mais executar suas tarefas sozinho, mas conforme Elizete, "se dependesse dele, continuava fazendo cercas de arame e outras atividades existentes na fazenda, mesmo com o problema no coração que ele havia contraído".

Quando perguntavam ao Sr. Ildefonso o que ele entendia por reforma agrária, respondia por brincadeira que "esta era feita na cama e não na terra", e pelo fato de ter dez filhos. Por conta dos problemas de saúde, resolveu em 1978 fazer a "reforma agrária" de suas terras aos seus descendentes, evitando à sua família gastos posteriores com testamento. Tanto ele quanto $\mathrm{D}^{\mathrm{a}}$. Leonila decidiram doar em vida todos os bens que Ihes pertenciam. Aqueles que já haviam construído suas "casas de morada", suas "roças" permaneceram no local onde já estavam instalados. Por isso, quando faleceu em 1990, seus filhos que já haviam recebido a antecipação de legítima, não tiveram que se preocupar e gastar com inventário, pois os bens já haviam sido distribuídos, inclusive seu direito a usufruto por parte do que permanecesse vivo.

$D^{a}$. Leonila, hoje com 94 anos vive na casa de sua filha solteira, com o salário da pensão do marido e de sua aposentadoria e aprovando a distribuição inter vivos que já está sendo realizada por seus filhos, conforme árvore genealógica da Família Oliveira, onde se destaca o tronco: Sr. Ildefonso e $\mathrm{D}^{\mathrm{a}}$. Leonila - Fazenda Campo Alegre e as ramificações, as doações a filhos e netos, onde todos (homens e mulheres) foram beneficiados com partes exatamente iguais, com exceção do sítio Três Marias, onde Rita ao ficar viúva, entra como herdeira (não foi feita a "partilha geodésica") juntamente com seus filhos, fragmentando a propriedade em três áreas e não em sete, pois como é intenção dela e mais quatro filhos vender sua parte, desta maneira segundo eles, facilita a negociação, no contexto geral, cada um recebeu exatamente a mesma área (ha) inclusive a mãe/Rita. As doações da fazenda Oriente e do sítio Mamona foi inter vivos, com direito a uso e fruição da casa de morada. 


\section{ÁRVORE GENEALÓGICA FAMÍLIA OLIVEIRA}

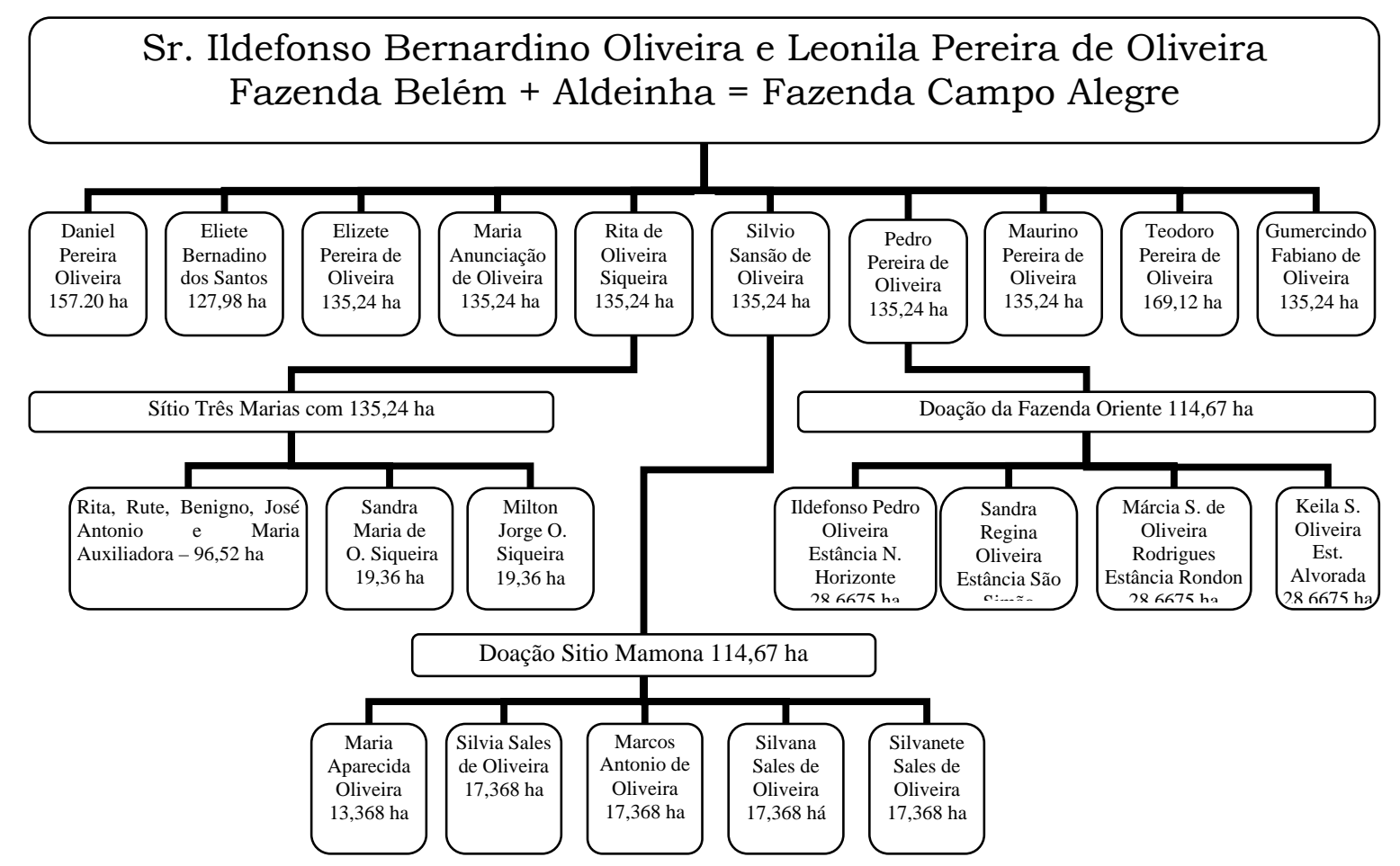


O Sr. Antônio Alves da Silva ficou viúvo em 14/02/1989, tornando-se, portanto Senhor legítimo e único possuidor dos imóveis devidamente registrados sob $\mathrm{n}^{0}$.. 13957 o lote Miranda com 83 ha e 6.666 mts²; uma área com 294 ha denominado Naboreiro, registrado sob o n. 4605; o lote de $\mathrm{n}^{\circ}$. 107 do Núcleo Colonial de Naboreiro (doação) com 50 ha registrado sob n. 4604; uma área com 20 ha porção da Gleba São Francisco, registrado sob nº 4602 e uma área com 27 ha 8888 mts², parte do lote Miranda, da Colônia Naboreiro, registrada sob o $\mathrm{n}^{\circ}$. 01 na matrícula 12229, que unificadas passaram a se chamar Fazenda Naboreiro ou Pé do Morro, com área equivalente a 475 ha $554 \mathrm{mts}^{2}$, que, conforme árvore genealógica da família Silva foi doada a seus filhos.

Com a morte de Da. Maria Rosa, o Sr. Antônio resolveu em 22/07/2006 fazer o inventário e doação dos seus bens, passando a cada filho a parte que lhes caberia na herança de sua mãe e fazendo doação de sua parte, por ser ele "Senhor legítimo e único possuidor"191 desses bens.

Antes de se fazer a distribuição das terras no papel, isto é, a divisão física dos imóveis, o Nilson e o Aurino venderam a parte que lhes caberia ao seu irmão José. Poucos dias antes (13/03/2006), o Sr. Antônio havia vendido 5 ha a um vizinho, documento (citado em rodapé), onde a Quinta Cláusula estabelece que: "na hipótese de morte ou invalidez permanente, de quaisquer dos contratantes, seus herdeiros e/ou sucessores se comprometem a cumprir o estabelecido nas cláusulas contratuais do presente compromisso", sendo assim ocorreu a partilha aritmética, ou seja, no papel, a partilha teórica para a extinção de condomínio, de acordo com repartição amigável.

No lote $n^{0} .07$ onde aparece o nome de Aurino Alves da Silva encontra-se o morro Naboreira, com área correspondente a 89 ha, esta parte é reserva legal da propriedade toda, foi inclusive fator que atrasou na efetivação e entrega do título definitivo do Sr. Antônio por parte do Departamento de Terras e Colonização, até ser comprovado que a área não estava sendo usada indevidamente pela família.

Pelo que se observa na árvore genealógica da família Silva e pelos mapas com lotes de $n^{\circ} .1$ a 10, percebe-se que encerra para o Sr. Antônio e inicia para seus filhos a sucessão dos bens (terras) que estavam em seu poder de fato (fora o período de ocupação) desde 1949, época em que requereu do governo do estado

${ }^{191}$ Conforme documento de instrumento particular de compromisso de cessão de direitos de meação com relação à imóvel rural, feito em caráter irrevogável e irreparável, que fizeram os Senhores Antônio e Waldemar Pereira Sobrinho, por conta da venda de 5 ha do lote Naboreiro. 
juntamente com outros, uma área de 502 ha, de onde recebeu na divisão amigável, conforme escritura pública de 25/07/1972, uma área com 83 ha e 6666 mts².

\section{ÁRVORE GENEALÓGICA FAMÍLIA SILVA}

Antonio Alves da Silva e Maria Rosa da Silva

Fazenda Naboreiro ou Pé do Morro - 475,5554 ha

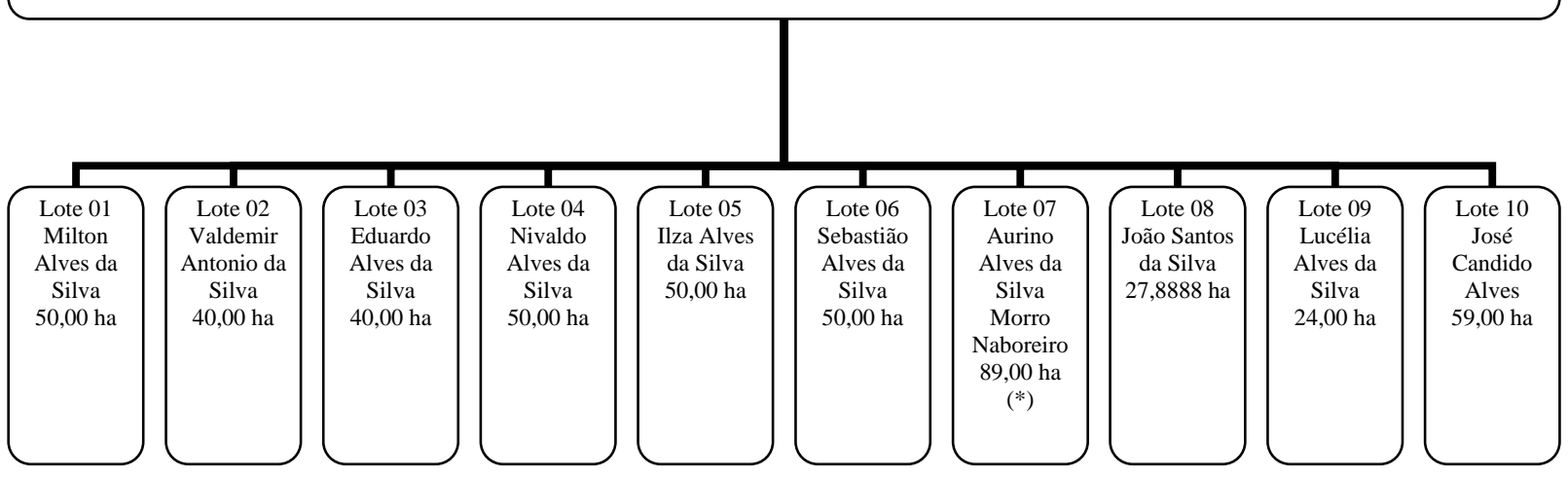

(*) Essa área é correspondente ao Morro Naboreiro que ficou como reserva da propriedade toda, correspondendo a 8,9 ha para cada um dos donatários, por isso está no mapa de localização em nome de Aurinn $\Delta$ lvac da Silva a Mutrne 
Como o Sr. Antônio é meeiro de $\mathrm{D}^{\mathrm{a}}$. Maria Rosa da Silva, ele distribuiu por contrato inter vivos todos os seus bens, o que significa que seus herdeiros descendentes receberam antes do óbito dele, a legítima, que foi devidamente calculada no momento da partilha em vida, isto é, da partilha aritmética.

Deixei para encerrar o grupo da fragmentação da terra por doação com a família Giovanini, pois nesta existem dois fatores distinto das demais, que são: a localização das áreas de doação em municípios diferenciados, Rondonópolis e Planalto da Serra e a herança que $D^{a}$. Maria da Encarnação recebeu por conta da morte de seu filho Edson Carlos Giovanini, em setembro de 2001.

De acordo com a escritura pública de doação de 03/05/1994, os senhores José Giovanini e Maria da Encarnação Giovanini eram legítimos possuidores de três áreas no município de Rondonópolis assim descritas, Lote Miranda com 36,30 ha, registrado sob o $n^{\circ}$. 01 na matrícula 2001; Lote $n^{\circ} .86$ do Núcleo Colonial de Naboreiro, sob o $\mathrm{n}^{\circ}$. 01 na matrícula 45307, com área equivalente a 44 ha e o Lote $n^{\circ}$. 87 no Núcleo Colonial de Naboreiro com 47 ha, registrado sob o $n^{\circ}$. 01 na matrícula 45310, que decidiram em comum acordo passar aos seus donatários toda a posse, domínio, direito e ação que antes exerciam. Os filhos/donatários aceitaram o que lhes foi proposto e a escritura foi lavrada de acordo com os termos expressos.

No município de Planalto da Serra, o Sr. José Giovanini era possuidor de uma área com 285 ha e de acordo com Lourdes, "somente 90 alqueires eram documentados".

Pela árvore genealógica elaborada com base nos dados da escritura de doação e nas três certidões em nome do Sr. Osvaldo Giovanini e outros, a propriedade Miranda, ou seja, as terras do Sr. José no município de Rondonópolis era equivalente a 127,30 ha, que na partilha ficou para os filhos (homens), pois conforme informação do Sr. Osvaldo Giovanini e confirmação de Odair Giovanini, cada um dos irmãos (cinco na época) recebeu o equivalente a 24,46 ha. Já as filhas que eram três acabaram não recebendo terras em Rondonópolis e sim no Planalto da serra. Percebe aí uma discrepância entre as informações contidas na escritura de doação e os relatos e dados passados pelos irmãos, pois na escritura consta que os outorgados donatários: Osvaldo Giovanine (casado), Renato Encarnação Giovanini (casado), Lourdes Giovanine Vieira (casada), Alzira Giovanini (desquitada), Odair Giovanini (solteiro), Edson Carlos Giovanine (solteiro), Nelson Giovanini (solteiro) e 
Irene Giovanini, que receberiam por doação três áreas que equacionadas perfaziam o total de 127,30 ha, justamente o total que foi repassado aos filhos (homens).

\section{ÁRVORE GENEALÓGICA FAMÍLIA GIOVANINI}

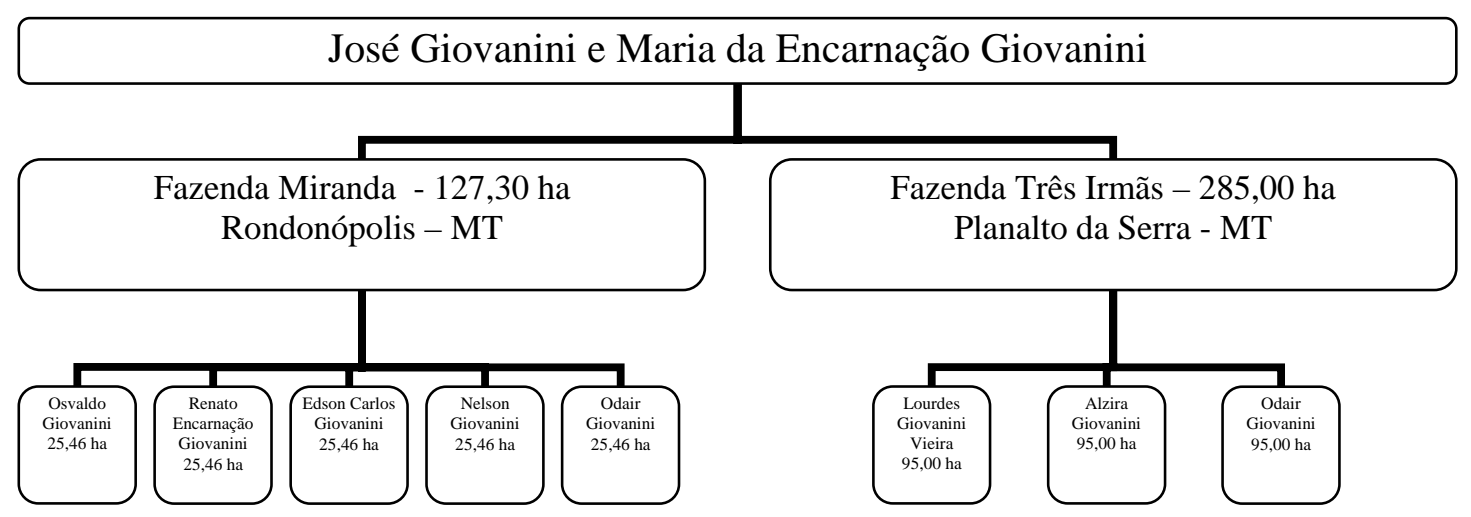


$\mathrm{Na}$ árvore genealógica acima se encontra nas ramificações as propriedades e as divisões das áreas, conforme informações colhidas nas entrevistas, já que na escritura de doação não estão expressos a quantidade de terras que coube a cada donatário. Pela ramificação da árvore, correspondente à doação das terras do Planalto, 285 ha cada filha recebeu 95 ha, sendo destes somente 90 ha regularizados, o que nos induz a acreditar que novamente algo esta errado. Em entrevista uma das irmãs informou que:

Quando o pai comprou essa terra, uma parte tinha escritura e outra não. Na divisão, a terra foi doada em partes diferentes no termo de valor. Aceitamos (as mulheres), para não causar problemas com os irmãos, mas na realidade fomos prejudicadas, pois as terras daqui são mais valorizadas e já escrituradas. Na verdade, somos descendentes de italianos e a Senhora já viu né? Na hora da partilha os homens são mais valorizados. Mudei-me, mas acabei voltando, pois não sentia firmeza, havia certos empecilhos. Vendi e me mudei para cá, onde hoje estou no paraíso, no meu canto sossegada. A escritura é no nome das três irmãs e como minha outra irmã que era separada legalmente, com um único filho, faleceu as terras estão em inventário.

A fala acima, soou-nos mais como um desabafo, pelo fato não ter recebido de doação dos pais, as terras de Rondonópolis, bem como pelo fato de não terem documentação das terras que lhes passou a pertencer por conta da doação.

Embora a lei proteja os direitos dos futuros herdeiros ao se realizar a doação inter vivos, ou seja, no momento que os pais outorgantes doadores, passaram para os filhos os bens que a eles pertenciam, estes não poderão contestar, até porque não há herança de pessoa viva.

Edson era casado em regime de comunhão parcial de bens ${ }^{192}$, com sua morte, como este não tinha filhos (herdeiros ascendentes), coube à sua mãe Maria da Encarnação Giovanini, herdeira descendente, a parte que havia recebido por doação de seus pais, bem como outras que foi adquirindo e que a posteriori, $\mathrm{D}^{\mathrm{a}}$. Maria doou em partes iguais aos seus filhos. Desta maneira, extinguiu-se o condomínio dos bens dos Sr. José Giovanini, sua esposa Maria da Encarnação Giovanini e do filho Edson Carlos Giovanini.

Tanto o grupo da fragmentação da terra por herança e doação, como no grupo da fragmentação por doação, os viúvos meeiros, os herdeiros ascendentes e

\footnotetext{
192 Onde o patrimônio particular de cada um dos cônjuges, se constitui daqueles bens havidos antes do casamento, bem como daqueles obtidos na constância do casamento, que não sejam fruto do esforço comum do casal. Exemplos seriam as heranças e doações. Fiúza (2000: 616)
} 
descendentes e os Donatários tem seus direitos garantidos, amparados e assegurados pelo Código Civil Brasileiro, que disciplina a condição de proprietário privado a qualquer indivíduo. E que nos casos aqui estudados, todos os filhos herdeiros e donatários, passaram a novos proprietários jurídicos de bens.

Em todos os casos estudados foi possível detectar o surgimento de uma nova família nuclear em formação, dentro das terras do pai com a sua permissão, é o caso dos filhos que foram se casando e construíram as "casas de morada" e as "roças", para essa nova família. Por conta disso, no direito da divisão por herança ou doação, acabavam ficando com a parte onde já habitava.

Um fato que chama a atenção é a venda das partes recebidas por herança ou doação entre os parentes. Na família Ferreira, a venda foi realizada somente entre os irmãos, nas demais famílias um ou outro vendeu a terceiros e os demais deram preferência aos irmãos. Nessa mesma família, um dos herdeiros ao receber sua parte através da partilha aritmética, vendeu para um de seus irmãos e migrou, enquanto solteiro, para outra região. Ao retornar, vendeu as terras de lá e comprou aqui uma parte da mãe, portanto, na escritura de divisão amigável para extinção de condomínio, aparece o nome dos irmãos e as quantidades de terras de cada um, o nome dele não está incluso, pois por conta da compra feita das terras da mãe, realizou a transação e de imediato a escritura. Sendo assim, na certidão encontra-se lavrado que os filhos da família Ferreira "adquiriram uma área de terras (...) juntamente com Maria Rodrigues Ferreira e Pedro Nunes Ferreira", o que o qualificou como outorgante juntamente com a mãe.

Os nossos entrevistados que realizaram a antecipação de legítima, o fizeram praticamente sem usufruto, o que Ihes foi deixado de reserva para garantir a sobrevivência foi à casa de morada e o gado. Na caso da família Ferreira $D^{a}$. Maria Rodrigues ficou com o gado e uma casa na cidade, com seu falecimento os filhos dividiram o gado em partes iguais e decidiram, em comum acordo, doar cada um uma cabeça de rês a Zuleide, que foi criada por $\mathrm{D}^{\mathrm{a}}$. Maria. E, também já decidiram que no momento que a casa da cidade, for vendida o dinheiro será repartido em partes iguais entre doze pessoas, incluindo Zuleide na partilha.

Cumpre-se destacar neste item que no Direito das Sucessões, seja por intermédio de causa mortis - herança ou inter vivos - doação ou antecipação de legítima, no contexto geral, com exceção de uma família que utilizou regras do código local, as regras do Código Civil foram respeitadas e novos patrimônios foram 
surgindo através da sucessão. O que nos remete e faz concordar com Oliveira (2003) quando disse que "a lei estende seus efeitos para depois da morte da pessoa", É quase que uma imortalidade. Pela esfera patrimonial e da sucessão hereditária, as terras da família Oliveira está em suas mãos, passando de geração a geração a noventa e sete anos, pois foram ocupadas pelo Sr. Antônio Pereira dos Santos desde 1910. Vê-se aí uma quase continuidade à vida do Sr. Antônio, no que se refere aos seus bens que hoje se encontram em mãos dos bisnetos. 


\section{CONSIDERAÇÕES FINAIS}

O estudo sobre o processo de (re) criação do campesinato em áreas do latifúndio: a fragmentação da terra em Rondonópolis implicou necessariamente considerar não só as ações resultantes desse processo, mas o significado da terra para seus agentes. Logo, a fragmentação da terra é muito mais que ter um pedaço de chão, é se ver reproduzido neste chão.

Nesse sentido, para entender o processo de fragmentação da terra, isto é, a transformação do latifúndio em áreas de (re) criação do campesinato, procurei saber como se deu a ocupação desse latifúndio, em que época e condições, para depois estudar a sua fragmentação.

A pesquisa possibilitou constatar que a ocupação da terra em Rondonópolis iniciou através de um processo de migração, aonde pessoas de várias regiões do país vieram em busca do "eldorado", das "terras de Rondon", terras de fartura e principalmente em abundância e, o mais atrativo "terras baratas".

Sendo assim, correntes e mais correntes de migrantes foram chegando e se acomodando, ocupando áreas devolutas, alguns por intermédio de compra que já havia sido realizada, outros vinham a esmo com base em "conversas de compadres".

Verificando o processo de migração e ocupação do território rondonopolitano foi possível perceber que as áreas pesquisadas foram palco de ocupação por trabalhadores sem-terra e/ou com pouca terra, onde passaram de empregados a proprietários.

Essa nova realidade pode ser gerada a partir da busca da identidade social desses trabalhadores, que cansados pela exploração de seu trabalho, ou pelas adversidades climáticas saíram e caminharam a procura de um local onde pudesse construir e viver dignamente com a família.

Não ocuparam terras de sesmarias e nem dos megaprojetos de colonização que existiram no estado, nem tampouco são membros deste ou daquele movimento social que se constituíram em determinados períodos no país e saíram ocupando terras em busca de um local de morada. São, pois, trabalhadores (não que os outros 
não o sejam) que se viram no direito de conquistar uma terra com o seu suor, onde pudesse chamar de seu e sem que ninguém lhes expropriasse da área.

Durante o Brasil colônia, só poderia requerer terras mediante a autorização do representante do rei, durante o Brasil independente, deve-se requerer terras por intermédio da autorização de um representante do estado. Foi o que aconteceu com essas famílias, que após anos de ocupação, vivendo como posseiro, para ter seus direitos garantidos, passaram a requerer do Instituto da Terra em Mato Grosso, a solicitação para a compra da terra devoluta que ocupava com sua família, onde fizera benfeitorias e da qual tirava o sustento para todos.

Devido aos vazios demográficos e as "grandes distâncias" das áreas ocupadas em relação à capital, os processos demoravam meses. Após verificação e mediante pagamento da primeira parcela recebia o título provisório e bem a posteriori o título definitivo.

Nosso grupo de estudo é caracterizado por migrantes goianos, baianos, piauiense e paulistas que chegaram em Rondonópolis no período de 1910 a 1961, ocupando áreas de terras devolutas que hoje são conhecidas como "a região" de Belém e Aldeinha, do Bananal e Beroaba, do Naboreiro e Vila Bueno e da região do Pequi, geralmente os nomes remetem-se a algum rio ou morro existente naquela região, bem como a área onde existia grupos indígenas e até mesmo a sobrenome de alguns ocupantes da área.

Os motivos da migração foram variados, mas o objetivo era o mesmo - a busca pela terra de ninguém para dar o sustento a alguém. A busca pelo novo, pelo promissor, por outro estilo de vida.

Das cinco famílias, quatro eram consideradas posseiros, pois ocuparam terras devolutas para depois solicitar sua compra. As terras que foram ocupadas desde 1912, passaram a ter um amparo legal quando entrou em vigor o Decreto que dispunha sobre as formas de reserva (área do Naboreiro), tipo de venda, aforamento, concessão gratuita (Colônia Naboreiro), arrendamento, legitimação, medição, demarcação e preços das terras devolutas e públicas. Como o Código Civil Brasileiro já estava em vigência, o respaldo a esses posseiros era maior, uma vez que as modificações introduzidas nas formas de alienação e uso das terras públicas e devolutas iria contribuir para a regularização da propriedade.

Levando-se em conta a extensão da propriedade, isto é, a quantidade de área adquirida pela maior parte desses posseiros, pode-se em primeiro momento 
confundi-lo com um latifundiário com um proprietário de terras para especulação, e não para produção. Não só pela quantidade de hectares, mas pelo fato de ter em sua propriedade a presença do meeiro, do arrendatário ou do agregado. Porém, ao ouvir seus relatos, visualizar seu estilo de moradia, saber como ocorreu a ocupação, quais e como eram suas formas de produzir, e de trabalho, totalmente realizado pela família nuclear que era grande, e como se deu o processo de fragmentação dessa terra, reafirmamos nossa teoria de que ali estava se (re) criando o campesinato.

Fragmentação essa, ocorrida através do direito das sucessões - direito da herança, da sucessão legítima e testamentária realizada inter vivos ou causa mortis.

O processo de fragmentação provocou nas áreas de origem uma subtração dessa grande propriedade, em conseqüência tendo o surgimento das pequenas áreas, por outro lado ocorreu uma redução econômica, a partir do momento que as áreas foram sendo parceladas e os herdeiros/donatários foram substituindo a agricultura pela pecuária.

Detectamos que com esse fracionamento, com essa substituição de atividade econômica, ocorreu um processo migratório principalmente por parte dos jovens, que mudam para a cidade onde vão em busca de estudo e trabalho e acabem sendo absorvidos pelos encantos, pelos atrativos que esta lhe oferece.

Por conta da insustentabilidade dessas áreas, ocorre a migração dos jovens para a cidade. Porém, em determinada época, aqueles que migraram quando jovens retornaram para o campo, onde conservou a propriedade que lhe coube por direito.

Outro fator negativo da fragmentação em excesso é a dificuldade ou impedimento à adoção de práticas diferenciadas de produção, bem como para a aquisição de recursos, financiamentos por parte dos cofres públicos para que possa se manter no campo.

A frase de Milton Jorge ao dizer que "segundo um gerente do Banco do Brasil, é mais fácil fazer um projeto de duzentos mil reais para um grande produtor do que fazer vinte projetos para pequenos produtores" está revelando e reafirmando que os recursos financeiros são bem quistos pelos latifundiários, pelos grandes produtores.

Esse tipo de entendimento, na qual o gerente do banco afirma que é "mais fácil trabalhar com o grande produtor", expressa uma visão, segundo a qual, o camponês com sua diminuta parcela de terras "está com os dias contados". Contudo, nesta pesquisa não foi isso que ocorreu; muito pelo contrário, os 
camponeses continuam se reproduzindo em áreas onde a fragmentação por herança ou doação, adiantamento de legítima está ocorrendo.

As áreas que foram fragmentadas devem ser entendidas como uma expressão de que o campesinato não pode ser engolido pelo capitalismo e nem tão pouco desaparecer com ele; pois o mesmo faz parte de uma realidade concreta que vem se evidenciando nessas famílias desde 1960, quando o Sr. Antônio Pereira dos Santos doou à sua filha Leonila Pereira dos Santos uma área de 305 ha, remanescente da fazenda Belém 3.194 ha que foi ocupada por ele em 1910, tendo sido requerida em 1936, recebendo o título definitivo em 1947, expedido pelo Departamento de Terras e Colonização e que hoje 97 anos depois continua nas mãos de seus descendentes.

Constatou-se com a pesquisa, que o trabalho é realizado pela família e só uma vez ou outra alguém contrata um diarista. Aquele camponês bucólico de tempos idos com casebre de palha, chão batido, paredes de pau-a-pique, fogão a lenha, água de bica ou de poço e iluminação a lamparina, quase não existe mais. Até porque com a modernização, os benefícios da cidade (luz elétrica, água encanada, telefone, televisão) já são evidentes e marcantes no campo, mas nem por isso, deixa de ser uma classe e procura manter-se articulada em relação aos seus interesses privados.

O fato de ocorrer o processo de fragmentação, não foi entendido como um desarranjo na estrutura dessas famílias, pelo contrário, o valor sentimental pela terra os mantêm firmes em suas propriedades.

Tudo isso revela a importância desse processo de fragmentação que para muitos pode ser entendido como um passo para o desaparecimento desse produtor, mas as evidências estão aí e comprovam que existe um movimento de retorno ao campo, uma migração cidade campo. Percebe-se a importância dessa fragmentação para as famílias, quando se observa em números. Iniciamos nossa pesquisa comentando a respeito de cinco propriedades onde uma foi compra, e as demais, primeiro foram ocupadas para depois serem requeridas. Desses cinco troncos $\left(1^{\mathrm{a}}\right.$ geração) ramificaram-se cinqüenta e duas propriedades (2a geração), de duas dessas, já passaram a existir mais vinte e três propriedades ( $3^{a}$ geração) totalizando sessenta e cinco propriedades fragmentadas de cinco áreas. 
Dentro da lógica da fragmentação, os ganhos advindos do processo são reduzidos conforme queixas de alguns entrevistados, mas nenhum quer se indispor totalmente da propriedade.

Do ponto de vista econômico essa fragmentação pode não ser muito rentável, mas garante-lhes uma vida tranqüila, uma paz interior, o abastecimento do dia-a-dia, como muitos disseram. Do ponto de vista social, a fragmentação significou a possibilidade de esses descendentes terem acesso a terra e se (re) produzirem como camponeses em terras próprias, constituindo assim, uma fração do território camponês entendida por muitos em vias de extinção. 


\section{REFERÊNCIAS BIBLIOGRÁFICAS}

ABRAMOVAY, R. et al. Agricultura Familiar e Sucessão Profissional: Novos Desafios. XXXIX Congresso da SOBER - Sociedade Brasileira de Economia e Sociologia Rural. Recife, 2001.

ABRAMOVAY, R. Paradigmas do Capitalismo Agrário em Questão. São Paulo: Hucitec, 1992.

AGRICULTURA Familiar - Pequenos Notáveis. In: Revista A Tribuna - Agrishow Cerrado. Edição Especial. Rondonópolis. Ano 35 n.6017, p. 32, 33 e 34, abr. 2005.

ALMEIDA, Rosemeire A. Identidade, Distinção e Territorialização: O Processo de (Re)Criação Camponesa no Mato Grosso do Sul. 2003. Tese Doutorado. UNESP Presidente Prudente/SP

AMIN, S. Imperialismo e Desenvolvimento Desigual. São Paulo: Vértice/ed. Ver. dos Tribunais, 1987

ANDRADE, Maria M. de. Introdução à Metodologia do Trabalho Científico. São Paulo: Atlas, 1995.

ANDRADE Manuel C. de. A Questão do Território no Brasil. São Paulo/ Recife: Hucitec/IPESPE, 1995.

. O Sentido da Colonização. Recife: Comunicação e Editora, 1994.

. Lutas Camponesas no Nordeste. 2. ed. São Paulo: Ática, 1989.

. A Terra e o Homem no Nordeste: Contribuição ao Estudo da Questão Agrária no Nordeste. 5. ed. São Paulo: Atlas, 1986.

- O Processo de Modernização Agrícola e a Proletarização do Trabalhador Rural no Brasil. Geografia. São Paulo: Hucitec, v. 3, n. 5, p. 31-41, abr.1978.

ARAÚJO, L. Vianna. Doação, Antecipação de Legítima e Partilha em Vida. In: Artigos Clássicos. Direito Civil. Rio de Janeiro/RJ. 07/10/2001.

ARAÚJO, T. B de. Herança de Diferenciação e Futuro de Fragmentação. Dossiê Nordeste I. Estudos Avançados. Vol. 11, n² 29. São Paulo. Jan./Abr. 1997.

BARBOSA, Y. M. Conflitos Sociais na Fronteira Amazônica: O Projeto Rio Formoso. Campinas: Papirus, 1996.

BECKER, Bertha K. Amazônia. 3. ed. São Paulo: Ática, 1994.

BERGAMASCO, Sônia M. P.P. \& PINASSI, Maria O. Movimentos Sociais: Lições e 
Esperança. Reforma Agrária: Revista da Associação Brasileira de Reforma Agrária/ABRA. v. 19, N. 2, ago. / nov. 1989.

BOLETIM Agrishow Cerrado. Jornal A Tribuna. Rondonópolis. 20/04/2006.

BOMBARDI. Larissa, M. Campesinato, Luta de Classe e Reforma Agrária. (A Lei de Revisão Agrária em São Paulo). 2005. Tese de Doutorado. FFLCH/USP/SP

- O Bairro Reforma Agrária e o Processo de Territorialização Camponesa. São Paulo: Annablume, 2004.

BRUMER, A. A Problemática dos Jovens Rurais na Pós-Modernidade. VII Congresso Latino americano de Sociologia Rural. Equador/Quito, 2001.

CAJANGO, Sebastião. Colonização e Reforma Agrária em Mato Grosso. Departamento de Geografia/ICHS/UFMT. Cuiabá, 1992. Trabalho de Conclusão de Curso de Bacharelado em Geografia.

CANDIDO, Antonio. Os Parceiros do Rio Bonito. $3^{a}$ ed. São Paulo: Duas Cidades, 1975.

CARNEIRO, M. J. Herança e Gênero entre Agricultores Familiares. Revista Estudos Feministas. V.9, nº1. Florianópolis/SC, 2001.

CARMO, Ailon. Reminiscências de Rondonópolis. $1^{\mathrm{a}}$ ed. Rondonópolis-MT: Gráfica Modelo Ltda. 2001.

CARVALHO, João C. M. Camponeses no Brasil. Petrópolis-RJ: Vozes, 1978.

CASTRO, Sueli Pereira et al. A Colonização Oficial em Mato Grosso: a Nata e a Borra da Sociedade. Cadernos do NERU. Cuiabá-MT: EDUFMT, 1994.

CENSO Agropecuário 1995-1996/Mato Grosso. Rio de Janeiro: IBGE, №24 1998.

CHAYANOV, A.V. Sobre a Teoria dos Sistemas Economicos Não Capitalistas. In: SILVA, J. G. da. \& STOLKE, V. A Questão Agrária. São Paulo: Brasiliense, 1981.

CHAYANOV, A.V. La Organizacion de la Unidad Econômica Campesina. Buenos Aires: Nueva Vision. 1974.

CONSTITUIÇÃO: 1988: Texto Constitucional de 5 de outubro de 1988 com as Alterações Adotadas pelas Emendas Constitucionais de $n^{\circ}$. 1/92 a 15/96 e Emendas Constitucionais de Revisão n .1 à 6/94. Brasília: Senado Federal, Subsecretaria de Edições Técnicas, 1996.

COSTA, Wanderley M. da. Geografia Política e Geopolítica: Discursos sobre o Território e o Poder. São Paulo: Hucitec, 1992. 
CURTY, Marlene G. et al. Apresentação de Trabalhos Acadêmicos, Dissertações e Teses. $3^{a}$ Reimpr. Maringá, PR: Dental Press, 2005.

CURY, Carmelita. Do Bororo ao Prodoeste. Cuiabá-MT: Gráfica Alvorada, 1973. DEPARTAMENTO de Terras e Colonização. Estado de Mato Grosso. Código de Terras e Leis Complementares. 1959.

DIEGUES, Antônio Carlos (orgn.). Desmatamento e Modos de Vida na Amazônia. NUPAUB-USP, São Paulo: Gráfica e Editora Alves, 1999.

DINCAO, Maria Conceição. Nós Cidadãos: Aprendendo e Ensinando Democracia. Petrópolis-RJ: Vozes, 1994.

ELI, Deise F. Compartimentação e Estruturação da Paisagem do município de Rondonópolis-MT. 1998. 116f. Dissertação (Mestrado) - Universidade Federal de Goiás, Goiânia, 1998.

ENGELS, Friedrich. O Problema Camponês na França e na Alemanha. $\underline{\text { A Questão }}$ Agrária. São Paulo: Brasiliense, 1981.

FERNANDES, Otávia. A Questão Agrária no Brasil. Ensaios Sobre as Lutas Sociais no Meio Rural. Belo Horizonte: SIMPRO-MG, 1997.

FERNANDES, Bernardo M. MST: Movimento dos Trabalhadores Rurais Sem-Terra Formação e Territorialização em São Paulo. São Paulo: Hucitec, 1996.

A Formação do MST no Brasil. Petrópolis-RJ: Vozes, 2000.

FERREIRA, Eudson de Castro. Posse e Propriedade Territorial: A Luta pela Terra em Mato Grosso. Campinas: Editora da UNICAMP, 1986.

FIGUEIREDO, Aline. A Propósito do Boi. Cuiabá-MT: EDUFMT, 1994.

FIUZA, César. Direito Civil: Curso Completo. 3ª ed. Belo Horizonte: Del Rey, 2000.

FOWERAKER, Joe. A Luta Pela Terra: a Economia Política da Fronteira no Brasil de 1930 aos dias atuais. Rio de Janeiro: Zahar, 1982.

FURTADO, Celso. Formação Econômica da América Latina. Rio de Janeiro: Lia, 1970.

FRAGA NETO, Armindo (Presidente). PRONAF - Programa Nacional de Fortalecimento da Agricultura Familiar. Resolução Nº02629. Brasília. 10 de agosto de 1999.

GANCHO, Candido Vilares et al. A Posse da Terra. São Paulo: Ática, 1991.

GNACCARINI, José César. Latifúndio e Proletariado. Formação da Empresa e Relações de Trabalho no Brasil Rural. São Paulo: Polis, 1980. 
GOMES, Horieste. A Produção do Espaço Geográfico no Capitalismo. $2^{\mathrm{a}}$ ed. São Paulo: Contexto, 1991.

GRZYBOWSKI, Candido. Caminhos e Descaminhos dos Movimentos Sociais no Campo. 2. ed. Petrópolis-RJ: Vozes, 1990.

GUIMARÃES, Alberto P. A Crise Agrária. 3. ed. Rio de Janeiro: Paz e Terra, 1989. . Quatro Séculos de Latifúndio. 6. ed. Rio de Janeiro: Paz e Terra, 1989.

GUIMARÃES, Maria C. S. Gleba Selva de Pedra: Pequena Produção em Área de Assentamento. Rondonópolis-MT DH/ICHS/CUR/UFMT, set./97. Monografia de Especialização em História de Mato Grosso.

IANNI, Octávio. A Luta Pela Terra: História Social da Terra e da Luta pela Terra numa Área da Amazônia. 3. ed. Petrópolis-RJ: Vozes, 1981.

Vozes, 1979.

Colonização e Contra-Reforma Agrária na Amazônia. Petrópolis-RJ:

KAUTSKY, K. A Questão Agrária. São Paulo: Proposta Editorial, 1980.

LAMARCHE, Hugues (Coord.). A Agricultura Familiar: Comparação Internacional. Do Mito à Realidade. Campinas/SP: UNICAMP, v. 2, 1998.

LAMARCHE, Hugues (Coord.). A Agricultura Familiar. Comparação Internacional. Uma Realidade Multiforme. Campinas/SP: UNICAMP, v. 1, 1993.

LAMBERT, Jacques. Os Dois Brasis. 10ª ed. São Paulo: Nacional, 1978.

LEFEBVRE, Henri. La Survie du Capitalisme: La re-production des rapports de production. Paris: Anthropos, 1973.

LEFF, Enrique. Saber Ambiental: Sustentabilidade, Racionalidade, Complexidade, Poder. Petrópolis/RJ: Vozes, 2001.

LENIN, V. I. O Desenvolvimento do Capitalismo na Rússia. São Paulo: Abril Cultural, 1981.

LIMA, Cleonice M. A Pecuária de Corte em Rondonópolis no Processo de Expansão Capitalista de Produção. Rondonópolis-MT, DH/ICHS/CUR/UFMT, set./97. Monografia de Especialização em História de Mato Grosso.

LIMA, Leida M. de S. A Produção Camponesa e a Modernização da Agricultura em Rondonópolis-MT Estudo em Áreas de Assentamento de Reforma Agrária: Gleba Cascata e Projeto de Assentamento Chico Mendes/Vale do Bacuri. São Paulo: USP, 2000. Dissertação de Mestrado.

- Marginalizados da Rodovia BR 364 - Trecho Rondonópolis a Serra da Petrovina. Rondonópolis-MT. DEGEO/ICEN/CUR/UFMT, 1995. Monografia de 
Especialização em Produção e Organização do Espaço.

LINHARES, Ma. Yedda et al. História da Agricultura Brasileira: Combates e Controvérsias. São Paulo: Brasiliense, 1981.

LUXENBURG, Rosa. A Acumulação do Capital: Contribuição ao Estudo Econômico do Imperialismo; Anticrítica. 2a ed., São Paulo: Nova Cultura, 1985.

MARCHA Nacional. Sem-Terra fazem ato em prol à reforma agrária. Jornal A Tribuna. Rondonópolis. Ano 35, n.6025, p. A-8, abr. 2005.

MARIGHELLA, Carlos et al. A Questão Agrária no Brasil: Textos dos Anos Sessenta. 2. ed. São Paulo: Brasil Debates, 1980.

MARTINS, José de Souza. Impasses Sociais e Políticos em Relação à Reforma Agrária e à Agricultura Familiar no Brasil. Texto apresentado no Seminário Interno sobre: Dilemas e Perspectivas para o Desenvolvimento Regional no Brasil, com Ênfase no Agrícola e Rural na Primeira Década do Século XXI. Santiago do Chile, 11-13 der dezembro de 2001. Disponível em: www.nead.gov.br

- Uma Correção Histórica na Política Fundiária Brasileira. In: Grilagem de Terra. Balanço da Grilagem no Brasil. O Livro Branco da Grilagem de Terra no Brasil. Balanço Final. Brasília, 2000.

Hucitec, 1997.

Fronteira: A Degradação do Outro nos Confins do Humano. São Paulo:

. Revisando a Questão Agrária. Debate sobre os Problemas Brasileiros e a Necessidade de Mudança Social. Boletim do Militante. Movimento dos Trabalhadores Rurais Sem-Terra - MST. No. 27, dez./96.

. Os Camponeses e a Política no Brasil. 5. ed. Petrópolis/RJ: Vozes, 1995. Hucitec, 1994.

- O Poder do Atraso: Ensaios de Sociologia da História Lenta. São Paulo: . A Chegada do Estranho. São Paulo: Hucitec, 1993.

. Caminhada no Chão da Noite: Emancipação política e Libertação nos Movimentos Sociais no Campo. São Paulo: Hucitec, 1989.

Não Há Terra Para Plantar Neste Verão: o Cerco das Terras Indígenas e das Terras de Trabalho no Renascimento Político do Campo. 2. ed. Petrópolis RJ: Vozes, 1988.

A Reforma Agrária e os Limites da Democracia na "Nova República".

São Paulo: Hucitec, 1986. 
A Militarização da Questão Agrária no Brasil. Terra e Poder: o Problema da Terra na Crise Política. 2. ed. Petrópolis-RJ: Vozes, 1985.

. Expropriação e Violência. A Questão Política no Campo. 2. ed. São Paulo: Hucitec, 1982.

. A Sujeição da Renda da Terra ao Capital e o Novo Sentido da Luta Pela Reforma Agrária. Boletim de Geografia Teorética. Rio Claro: 1980, v. 10, n. 19, p. 31-47.

- Capitalismo e Tradicionalismo: Estudos sobre as Contradições da Sociedade Agrária no Brasil. São Paulo: Pioneira, 1975.

MARX, Karl. O Capital. Livro I. Capítulo VI (Inédito). São Paulo: Livraria Editora Ciências Humanas. 1978.

MARX, Karl. Manuscritos Econômico-Filosóficos e Outros Textos Escolhidos. Os Pensadores. Seleção de Textos de José Arthur Giannotti. Tradução de José carlos Bruni. Et al. $2^{\mathrm{a}}$ ed. São Paulo: Abril Cultural, 1978.

MARX, Karl \& ENGELS, Friedrich. A Ideologia Alemã. Porto/Lisboa: Editorial Presença LTDA, 1974.

MATO Grosso - A Justiça reduz indenizações pagas pelo Incra. Jornal A Tribuna. Rondonópolis. Ano 35, n.5937, p. A-8, jan. 2005.

MELLO, M. A. et al. Sucessão Hereditária e Reprodução Social da Agricultura Familiar. Agricultura em São Paulo, São Paulo, v. 50, n. 1, p. 11-24, 2003.

MENDRAS, H. Sociedades Camponesas. Rio de Janeiro, 1978.

MICHAELIS: Moderno Dicionário da Língua Portuguesa. São Paulo: Melhoramentos, 1998.

MÜLLER, Nice Lecoq. Sítios e Sitiantes no Estado de São Paulo. São Paulo: USP, 1951.

MINC, Carlos. A Reconquista da Terra: Estatuto da Terra, Lutas no Campo e Reforma Agrária. 2. ed. Rio de Janeiro: Zahar, 1985.

MORAES, Antônio Carlos Robert. Território e História no Brasil. São Paulo: Hucitec, 2002.

MORAR no Campo Virou Boa Alternativa. Jornal do Progresso. Rondonópolis. v.1, n.2, p. 07, dez. 1997.

MOREIRA, Ruy. O Plano Nacional de Reforma Agrária em Questão. Terra Livre AGB. São Paulo, v. 1, n. 01, p. 6-19, 1986.

MORENO, Gilda. Terra e Poder em Mato Grosso: Política e Mecanismo de Burla/1892-1992. Cuiabá/MT: Entrelinhas: EdFMT, 2007. 
MORENO, Gilda \& HIGA, Tereza Cristina S. (Orgs.). Geografia de Mato Grosso: Território, Sociedade e Ambiente. Cuiabá: Entrelinhas, 2005.

MORENO, Gilda. Os (Des)Caminhos da Apropriação Capitalista da Terra em Mato Grosso". Tese de Doutorado. FFLCH. USP. São Paulo, 1993.

MORISSAWA, Mitsue. A História da Luta pela Terra e o MST. São Paulo: Expressão Popular, 2001.

MONTEIRO, Cleidaizy M. A. Reforma Agrária em Região de Latifúndio, Sucesso ou Fracasso: Estudo de Caso do Assentamento da Gleba Rio Vermelho Rondonópolis-MT. DEGEO/ICEN/CUR/UFMT, 1995. Rondonópolis-MT. Monografia de Especialização em Produção e Organização do Espaço.

MOURA, Carmen L. S. Itaborai. Homens Sem Terra Para Terra Sem Homens: Os Posseiros da Gleba Cascata, Rondonópolis, MT, 1975 - 1985. PUC-SP, 1992, Dissertação de Mestrado.

MOURA, Margarida Maria. Os Deserdados da Terra; a Lógica Costumeira e Judicial dos Processos de Expulsão e Invasão da Terra Camponesa no Sertão de Minas Gerais. Rio de Janeiro: Bertrand Brasil, 1988.

. Camponeses. São Paulo: Ática, 1986, n. 52.

. Os Herdeiros da Terra: parentesco e herança numa área rural. São Paulo: Hucitec, 1978.

MULLER, G. O Complexo Agroindustrial. São Paulo: FGV, 1981.

NASCIMENTO, Flávio A. da Silva. Aceleração Temporal na Fronteira: Estudo de Caso de Rondonópolis-MT. FFLCH/USP. São Paulo, 1997. Tese de Doutorado.

NEUMANN, P. S. O Impacto da Fragmentação e do Formato das Terras nos Sistemas Familiares de Produção. UFSC. Florianópolis, 2003. Tese de Doutorado.

NEVES, Pedro Novis (Coord.) et al. Diagnóstico Econômico. III B Colonização. Diagnóstico da Colonização no Estado de Mato Grosso. Secretaria de Planejamento e Coordenação Geral, 1973.

OLIVEIRA, Ariovaldo Umbelino de \& MARQUES, Marta Inez Medeiros (orgs.) $\underline{0}$ Campo no Século XXI: Território de Vida, de Luta e de Construção da Justiça Social. São Paulo: Casa Amarela e Paz e Terra, 2004.

- A Fronteira Amazônica Matogrossense: Grilagem, Corrupção e Violência. Tese de Concurso de Livre Docência. São Paulo: FFLCH-USP, 1997.

A Geografia das Lutas no Campo. 6a ed. São Paulo: Contexto, 1996.

- Modo Capitalista de Produção e Agricultura. $4^{\mathrm{a}}$ ed. São Paulo: Ática,

1995. 
. Agricultura Camponesa no Brasil. São Paulo: Contexto, 1991.

Campinas/SP: Papirus, 1991.

.Integrar para não Entregar: Políticas Públicas e Amazônia. 2. ed.

. Amazônia: Monopólio, Expropriação e Conflitos. $3^{a}$ ed. Campinas/SP: Papirus, 1990.

- Renda Capitalista da Terra Diferencial, Absoluta e de Monopólio e Preço da Terra. Revista Orientação. N. 6 e 7. São Paulo: IGEOG/DG/USP, 1985 e 1986.

OLIVEIRA, Bernadete A. C. Castro. Tempo de Travessia, Tempo de Recriação: Profecia e Trajetória Camponesa. 1998. Tese de Doutorado. FFLCH/USP/SP.

Camponês. Revista Orientação. Instituto de Geografia DG/FFLCH/USP. São Paulo, n. 8, dez. 1990.

OLIVEIRA, Euclides B. de. Direito das Sucessões - "Direito de Herança - Sucessão Legitima e Testamentária". A Reforma do Código Civil Repercussões na Administração Pública e no Externo, abril de 2003.

. Sucessão Hereditária - Noções Gerais. Curso: "O Novo Código Civil na Atividade Notarial". Novembro de 2003.

OLIVEIRA, Francisco de. Elegia para uma Re(li)gião: SUDENE, Nordeste. Planejamento e Conflitos de Classes. 3. ed. Rio de Janeiro: Paz e Terra, 1981.

OLIVEIRA, Kênia de Lima G. Introdução à Questão da Escravidão por Dívidas em Rondonópolis-MT 1960-1980. Monografia de Especialização em Teoria e História Econômica / Depto. História/CUR. 1999.

O INCRA em Mato Grosso. INCRA SR 13. Superintendência Regional de Mato Grosso. Assessoria de Comunicação Social. Ministério do Desenvolvimento Agrário. CPA - Centro Político Administrativo. Cuiabá-MT.

O Programa que está Mudando a Cara de Mato Grosso. Revista Nossa Terra Nossa Gente. Publicação Intermat - Instituto de Terras de Mato Grosso. Ano I - No. 1. Abril de 2005.

PALHETA, Iraci G. de V. O Novo Brasil Agrário Moderno e... do Atraso. In: Boletim Paulista de Geografia. No. 77, São Paulo-SP, abril de 2001.

PAULINO, Eliane T. A Geografia dos Camponeses no Norte do Paraná. 2003. Tese de Doutorado. UNESP - Presidente Prudente/SP.

PEIXINHO, Dimas. Onças Vermelhas e Amarelas: a Ocupação dos Cerrados e a Dinâmica Social - Espacial em Rondonópolis - MT. São Paulo: USP, 1998. Dissertação de Mestrado. 
PEREIRA, Lindanice C. Cultura do Algodão em Rondonópolis no Período de 1990 a 2001 - Uma Contribuição para a História Econômica de Rondonópolis. Monografia de Especialização. Rondonópolis: CUR/UFMT, 2001.

PIAIA, Ivane Inêz. Geografia de Mato Grosso. $3^{\mathrm{a}}$ ed. Cuiabá: EDUNIC, 2003.

PIATO, Djanira B. N. O Ambiente Vivenciado. Rondonópolis-MT. Secretaria Estadual de Educação do Estado, 1986.

POLÍTICA Agrícola e Agricultura de Baixa Renda. XV Reunião Anual da Sociedade Brasileira de Economia Rural/SOBER. Viçosa/MG: UFV, 1977. Vol. 1.

POVOAS, Lenine C. Mato Grosso: Um Convite à Fortuna. Rio de Janeiro: Guavira, 1977.

PRADO JÚNIOR, C. Formação do Brasil Contemporâneo. 24a ed. São Paulo: Brasiliense, 1996.

. A Questão Agrária no Brasil. São Paulo: Brasiliense, 1979.

QUEIROZ, Maria I. P. de. Variações sobre a técnica de gravador no registro da informação viva. São Paulo: T. A. Queiroz, 1991.

. O Campesinato Brasileiro. Petrópolis-RJ: Vozes, 1973.

RIBEIRO, Iselda Correa. Sesmeiros. Cuiabá: EDUFMT, 1998.

SANTOS, J. V. T. dos. Matuchos: Exclusão e Luta: do Sul para a Amazônia. Petrópolis-RJ: Vozes, 1993.

SANTOS, M. O. Sucessão e Herança: Como Dividir Igualmente Mantendo a Desigualdade. VII Congresso Latino americano de Sociologia Rural. Equador: Quito, 2001.

. A Vivência Camponesa da Insuficiência Econômico-Social. Debate e Crítica. São Paulo, 1975.

SETTE, Dense M. \& TARIFA, José R. Clima e Ambiente Urbano tropical: O Caso de Rondonópolis -MT. In: Revista INTERGEO - Interação no Espaço Geográfico. Departamento de Geografia do Instituto de Ciências Exatas e Naturais. Campus Universitário de Rondonópolis da Universidade Federal de Mato Grosso. Ano 1, nº 1 Cuiabá: Editora Universitária, 2001.

SCHLOTTFELDT, Carlos. Editorial. Jornal da Extensão. Brasília. v.2, n. 17, p. 2, dez. 1997.

SHANIN, Teodor. A Definição de Camponês: Conceituação e Desconceituação. Estudos CEBRAP, n. 26, São Paulo: 1980. 
SHANIN, Teodor. La Clase Incómoda: Sociologia Política del Campesinado en una Sociedad en Desarrollo (Rusia 1910-1925). Madrid: Alianza, 1983.

SIQUEIRA, Elizabeth M. História de Mato Grosso: Da Ancestralidade aos Dias Atuais. Cuiabá: Entrelinhas, 2002.

SIQUEIRA, Elizabeth M. et al. O Processo Histórico de Mato Grosso. UFMT, Cuiabá: Guaicurus, 1990.

SILVA, Advair M. O Migrante Rondonopolitano. Rio Claro/SP: UNESP, 1988. Dissertação de Mestrado.

SILVA, C. A. F. da. Grupo André Maggi: Corporação e Rede em Áreas de Fronteira. Cuiabá: Entrelinhas, 2003.

SILVA, José G. da. O Que é Questão Agrária. 17. ed. São Paulo: Brasiliense, 1993. Progresso Técnico e Relações de Trabalho na Agricultura. São Paulo: Hucitec, 1981.

SILVA, J. G. \& STOLCKE, Verena (Organs.). A Questão Agrária. São Paulo: Brasiliense, 1981.

SILVA, S. Sérgio. Valor e Renda da Terra. O Movimento do Capital no Campo. Coleção Teoria e História - 10. São Paulo: Polis, 1981.

SoUZA, José C. C. Geografia Regional (Centro-Oeste e Mato Grosso). $4^{\mathrm{a}}$ ed. Cuiabá-MT: Atalaia, maio 95.

SOUZA, V. F. Agricultura Familiar: Permanência e/ou Resistência num Bairro Rural de Araraquara/SP. UEC. Campinas/SP. Dissertação de Mestrado, 2002.

STÉDILE, João P (Org.). A Questão Agrária no Brasil: O Debate Tradicional - 15001960. $1^{a}$ ed. São Paulo: Expressão Popular, 2005.

. A Questão Agrária no Brasil: O Debate na Esquerda - 1960-1980. $1^{\text {a }}$ ed. São Paulo: Expressão Popular, 2005.

A Questão Agrária no Brasil: Programas de Reforma Agrária 1946-2003. $1^{\text {a }}$ ed. São Paulo: Expressão Popular, 2005.

Popular, 2002.

- História e Natureza das Ligas Camponesas. São Paulo: Expressão . Questão Agrária no Brasil. 5. ed. São Paulo: Atual, 1997 (Espaço e Debate).

SUZUKI, Júlio C. De Povoado a Cidade. A Transição do Rural ao Urbano em Rondonópolis. São Paulo, USP/FFLCH, 1996. Dissertação de Mestrado. 
TERRITÓRIO e Cidadania: Da Luta pela Terra ao Direito à Vida. Terra Livre - AGB. São Paulo: Marco Zero, n. 6, ago. 1989.

TESORO, L.L.L.M. Rondonópolis-MT - Um Entroncamento de Mão Única. Lembranças e Experiências. São Paulo: 1993.

VELHO, O.G. Capitalismo Autoritário e Campesinato. São Paulo: Difel, 1979.

VENOSA, Silvio de S. (org.). Brasil. Novo Código Civil: Texto Comparado: Código Civil de 2002, Código Civil de 1916. $2^{a}$ ed. São Paulo: Atlas, 2002.

VILARINHO NETO, Cornélio S. A Produção do Espaço do Estado de Mato Grosso. 1985. Apostila utilizada no Curso de Especialização em Produção e Organização do Espaço. Rondonópolis-MT: DEGEO/ICEN/CUR/UFMT, 1994.

- Projeto CURA Cuiabá, um Exemplo da Intervenção do Estado nas Transformações do Espaço Urbano. UNESP: Rio Claro-SP, 1983. Dissertação de Mestrado.

WAIBEL, Leo. Geografia Tropical e do Brasil. Rio de Janeiro: Conselho Nacional de Geografia, 1958.

WANDERLEY, Maria de N. B. Raízes Históricas do Campesinato Brasileiro. XX Encontro Anual da ANPOCS. GT. Processos Sociais Agrários. Caxambu/MG. 1996.

- Capital e Propriedade Fundiária: suas Articulações na Economia Açucareira de Pernambuco. Rio de Janeiro: Paz e Terra, 1979.

WOLF, E. R. Sociedades Camponesas. Rio de Janeiro: Zahar, 1970.

WOORTMANN, Ellen F. Herdeiros, Parentes e Compadres: Colonos do Sul e Sitiantes do Nordeste. São Paulo: Hucitec, 1995.

ZENUM, Augusto. Legislação Agrária e sua Aplicação. Rio de Janeiro: Forense de Artes Gráficas, 1970. 


\section{FONTES}

\section{1- FONTES IMPRESSAS}

01- Arquivo do Acervo Fundiário do INTERMAT/Cuiabá/MT

02- Arquivos da AGROSERV - Serviços Agronômicos e Topográficos S/C LTDA Rondonópolis/MT

03- Arquivo da Assessoria Legislativa da Prefeitura Municipal de Rondonópolis

04- Arquivo do Cartório do $1^{\circ}$ Ofício de Poxoréo/MT

05- Arquivo do Cartório do $1^{\circ}$ Ofício de Rondonópolis/MT

06- Arquivo do Jornal A TRIBUNA - Rondonópolis/MT

07- Arquivo do Setor de Cadastro do INCRA/Cuiabá/MT

08- Constituição Federal do Brasil 1988

09- Novo Código Civil Brasileiro 2002

10- Revista da Associação Brasileira de Reforma Agrária/ABRA. v. 19, N. 2, ago. I nov. 1989.

11- Revista Cidadania, Legislação e Trabalho Rural. Cuiabá: Governo de Mato Grosso, 2005.

12- Revista Nossa Terra Nossa Gente. Publicação do INTERMAT. Ano I - No. 1, 2005

13- Revista A TRIBUNA - Edição Especial. Documento Histórico: Rondonópolis 50 Anos. 10 de dezembro de 2003

14- Revista A TRIBUNA - Edição Especial. 32ª EXPOSUL. Ano 35 - Rondonópolis / MT, 2004

15- Revista A TRIBUNA - Edição Especial. AGRISHOW CERRADO. Ano 35 - No. 6017 - Rondonópolis / MT, abril de 2005

16- Revista A TRIBUNA - Edição Especial. AGRISHOW CERRADO. Ano 36 - No. 6317 - Rondonópolis / MT, abril de 2006 


\section{2- FONTES ORAIS}

01- Antonio Alves da Silva - 89 anos - Fazenda Naboreiro. Entrevista em 19/02/07

02- Deralício Martins Ferreira - 72 anos - Lote 100 Naboreiro. Entrevista 08/04/07

03- Gerson Nunes Batista - 79 anos. Bairro Cascalinho. Entrevista 27/03/07

04- Hermínio José Barreto - ex-prefeito de Rondonópolis e ex-Deputado Estadual. Entrevista 08/04/07

05- Juarez Corrêa de Souza - Técnico Agrimensor. Entrevista 26/02/07

06- Leonila Pereira de Oliveira - hoje 94 anos. (Faz. Belém + Faz. Aldeinha) Fazenda Campo Limpo. Entrevista 06/03/05. Na época 92 anos.

07- Maria da Encarnação Giovanini - 83 anos. Vila Bueno. Entrevista 18/02/07

08- Valdivino Nunes Batista - 73 anos. Aldeinha. Entrevista 03/02/07

09- Além dos filhos das Famílias Ferreira, Oliveira, Silva, Aquino e Giovanini que responderam o questionário e fizeram os relatos de vida. 
APÊNDICE 


\section{APÊNDICE A: QUESTIONÁRIO INFORMATIVO ${ }^{193}$}

\section{1 - CARACTERIZAÇÃO DA PROPRIEDADE/PARA OS PAIS:}

Família de onde originou a propriedade:

Fazenda Denominação:

Área:

Ano que Requereu:

Forma de Transmissão:

Ano Título Definitivo:

Órgão Expedidor:

02 - CARACTERIZAÇÃO DAS FAMÍLIAS/ORIGEM:

FAMÍLIA:

Nome da Propriedade:

De onde veio:

Por que veio:

Ano que chegou em Mato Grosso:

$\mathrm{N}^{\circ}$. de Filhos:

Tempo no Local e na Propriedade:

03 - CARACTERIZAÇÃO DA PROPRIEDADE/PARA OS HERDEIROS OU DONATÁRIOS Família de onde originou a propriedade:

Fazenda Denominação:

Área:

Ano da Divisão:

Forma de Transmissão:

$N^{\circ}$. de Filhos:

Tempo no Local e na Propriedade:

04 - CARACTERIZAÇÃO DAS FAMÍLIAS/HERDEIROS OU DONATÁRIOS

Associativismo: ( ) Sindicato ( ) Cooperativa ( ) Associação

Utiliza Crédito em Banco: ( ) Sim ( ) Não Qual:

Trabalho Assalariado:

Recebe Assistência Técnica:

Rendimentos: Aposentadoria/Pensão

Serviços Prestados:

Arrendamento Terra da Propriedade:

Aluguel de imóveis, máquinas, etc.:

Venda da produção agrícola:

Venda da produção pecuária:

Poupança:

Outros:

\footnotetext{
${ }^{193}$ Questionário adaptado do trabalho de mestrado de Vanilde Ferreira de Souza, intitulado: “Agricultura Familiar: Permanência e/ou Resistência num Bairro Rural de Araraquara-SP”. Campinas/SP-2002.
} 
05- USO DO SOLO:

\begin{tabular}{|l|l|}
\hline Especificação & Área (ha) \\
\hline Área Total & \\
\hline Área Cultivada & \\
\hline Lavoura Permanente & \\
\hline Lavoura Temporária & \\
\hline Mata Natural/Reserva & \\
\hline Pastagem & \\
\hline Várzea & \\
\hline Sede e Benfeitorias & \\
\hline
\end{tabular}

06- PRODUÇÃO VEGETAL E SEU DESTINO:

\begin{tabular}{|l|l|l|l|l|l|l|l|}
\hline \multicolumn{3}{|c|}{} & \multicolumn{5}{c|}{ Quantidade Vendida } \\
\hline Espécie & $\begin{array}{l}\text { Área } \\
\text { Plantada }\end{array}$ & $\begin{array}{l}\text { Qtde. } \\
\text { Prod. }\end{array}$ & $\begin{array}{l}\text { Qtde. } \\
\text { Cons. }\end{array}$ & Cooperativa & Interm. & Varejo & Valor \\
\hline & & & & & & & \\
\hline & & & & & & & \\
\hline & & & & & & & \\
\hline
\end{tabular}

07- PRODUÇÃO ANIMAL E SEU DESTINO:

\begin{tabular}{|c|c|c|c|c|c|c|}
\hline & & & & uantidac & endida & \\
\hline Espécie & $\begin{array}{l}\text { Qtde. } \\
\text { Prod. }\end{array}$ & $\begin{array}{l}\text { Qtde. } \\
\text { Cons. }\end{array}$ & Cooperativa & Interm. & Varejo & Valor \\
\hline Boi & & & & & & \\
\hline Touro & & & & & & \\
\hline Novilha (o) & & & & & & \\
\hline Bezerra (o) & & & & & & \\
\hline Vaca Lactac & & & & & & \\
\hline Vaca Seca & & & & & & \\
\hline Suíno & & & & & & \\
\hline Leitão & & & & & & \\
\hline Caprino & & & & & & \\
\hline Ovino & & & & & & \\
\hline Eqüino & & & & & & \\
\hline Piscicultura & & & & & & \\
\hline Aves & & & & & & \\
\hline
\end{tabular}

08- PRODUÇÃO DE DERIVADOS DE ORIGEM ANIMAL:

\begin{tabular}{|l|l|l|l|l|l|l|}
\hline \multicolumn{9}{|c|}{} & \multicolumn{3}{c|}{ Quantidade Vendida } \\
\hline Espécie & $\begin{array}{l}\text { Qtde. } \\
\text { Prod. }\end{array}$ & $\begin{array}{l}\text { Qtde. } \\
\text { Cons. }\end{array}$ & Cooperativa & Interm. & Varejo & Valor \\
\hline Leite & & & & & & \\
\hline Derivados do Leite & & & & & & \\
\hline Ovos & & & & & & \\
\hline Derivados Suínos & & & & & & \\
\hline Consumo Próprio & & & & & & \\
\hline
\end{tabular}


09- Máquinas e Implementos

\begin{tabular}{|l|l|l|}
\hline \multicolumn{1}{|c|}{ Tipo } & Qtde. & Idade \\
\hline Arado animal & & \\
\hline Carroça animal & & \\
\hline Distribuidor de calcário & & \\
\hline Subsolador/escarificador & & \\
\hline Arado & & \\
\hline Grade & & \\
\hline Sulcador & & \\
\hline Semeadora e/ou adubadora & & \\
\hline Equipamento de irrigação & & \\
\hline Carpideira & & \\
\hline Roçadora & & \\
\hline Pulverizador tratorizado & & \\
\hline Pulverizador costal & & \\
\hline Batedeira/debulhadeira & & \\
\hline Colhedora & & \\
\hline Carreta & & \\
\hline Picador triturador & & \\
\hline Ordenhadora & & \\
\hline Caminhonete/utilitário & & \\
\hline Caminhão & & \\
\hline Trator & & \\
\hline
\end{tabular}

10- Benfeitorias.

\begin{tabular}{|l|l|l|}
\hline \multicolumn{1}{|c|}{ Espécie } & Qtde. & Idade \\
\hline Residência & & \\
\hline Rede de energia elétrica & & \\
\hline Estábulo (com e sem cobertura) & & \\
\hline Terreiro alvenaria & & \\
\hline Galpão (máquinas, material) & & \\
\hline Silo (silagem) & & \\
\hline Aviário & & \\
\hline Pocilga & & \\
\hline Resfriador de leite (próprio) & & \\
\hline Outros & & \\
\hline
\end{tabular}

11- NÍVEL TECNOLÓGICO:

\begin{tabular}{|l|l|l|}
\hline \multicolumn{1}{|c|}{ Especificação } & Sim & Não \\
\hline Análise de solo & & \\
\hline Adubação química & & \\
\hline Adubação orgânica & & \\
\hline Calagem & & \\
\hline Plasticultura & & \\
\hline Irrigação & & \\
\hline Inseminação artificial & & \\
\hline Silagem & & \\
\hline Sementes certificadas & & \\
\hline Confinamento & & \\
\hline Agrotóxicos/ Controle de pragas & & \\
\hline Beneficia algum produto? Qual? & & \\
\hline
\end{tabular}




\begin{tabular}{|l|l|l|}
\hline Vacinação & & \\
\hline Ração & & \\
\hline Antibióticos e Hormônios & & \\
\hline Tração animal & & \\
\hline Área de preservação & & \\
\hline Áreas com erosão & & \\
\hline Curva de nível & & \\
\hline Quebra de vento & & \\
\hline Rotação de culturas & & \\
\hline Rotação de terras & & \\
\hline Consorciação & & \\
\hline Terraceamento & & \\
\hline Esterco & & \\
\hline
\end{tabular}

12- EQUIPAMENTOS SOCIAIS:

\begin{tabular}{|l|l|l|}
\hline \multicolumn{1}{|c|}{ Equipamentos Sociais } & Sim & Não \\
\hline Energia elétrica & & \\
\hline Água encanada & & \\
\hline Área de lazer & & \\
\hline Armazém & & \\
\hline Telefonia & & \\
\hline Posto de saúde & & \\
\hline Escola & & \\
\hline Outros & & \\
\hline
\end{tabular}

\section{3- ATIVIDADES SOCIAIS:}

O que costumam fazer nas horas de folga?

( )descansar em casa ( ) ir à Igreja ( ) conversar com os amigos

( )jogar futebol ( )Assistir televisão ( ) ouvir rádio

( )leituras. O quê? ( )Jornal ( )Revistas ( )Romances ( )Gibis

( )Outros:

14- Para continuar vivendo no campo, deve-se:

\begin{tabular}{|l|l|l|l|l|}
\hline Opções na & $\begin{array}{l}\text { Muito } \\
\text { Import. }\end{array}$ & $\begin{array}{l}\text { Pouco } \\
\text { Import. }\end{array}$ & $\begin{array}{l}\text { Mais ou } \\
\text { Menos }\end{array}$ & $\begin{array}{l}\text { Não } \\
\text { Sabe }\end{array}$ \\
\hline $\begin{array}{l}\text { Investir constantemente } \\
\text { propriedade }\end{array}$ & & & & \\
\hline Diversificar a produção & & & & \\
\hline Ter boa formação técnica & & & \\
\hline $\begin{array}{l}\text { Ter uma renda extra à unidade de } \\
\text { produção }\end{array}$ & & & & \\
\hline Se organizar com outros agricultores & & & & \\
\hline Utilizar créditos sempre que possível & & & \\
\hline
\end{tabular}

15- Se modificasse o estabelecimento seria para:

( )Melhorar condições de trabalho ( )Melhorar condições de moradia

( )Aumentar a renda ( )Futuro dos Filhos 
16- Como se deu a transmissão da propriedade?

( )Todos os herdeiros, homens e mulheres, receberam uma parte igual da herança;

( )Apenas os homens receberam uma parte da herança, e as mulheres não receberam nada;

( )Apenas os homens receberam uma parte da herança e houve uma compensação para as mulheres;

( )A partilha não foi igualitária e não houve um sistema de compensação para os outros;

( )A partilha não foi igualitária e houve um sistema de compensação para os outros;

( )Um sucessor designado recebeu a terra e não houve compensação importante para os outros;

( )Houve uma transmissão a certos herdeiros;

( )Houve a compra de terras por parte de alguns herdeiros;

( )Foi tudo de acordo com a Lei.

Observações:

17- Pretende repartir a terra da mesma maneira que seu pai/mãe?

18- ESTRATÉGIA FUNDIÁRIA:

Obtenção das terras: ( )Herança ( )Doação ( )Herança e Doação

( ) Doação e compra ( )Doação por família ( )Doação pelo governo

( )Compra de parentes ( )Compra de terceiros

19- Admitiria vender a terra:

( )Por falta de sucessor

( )Para comprar uma área maior em outro lugar

( )Para comprar uma terra melhor em outro lugar

( )Para mudar de profissão

( )Para pagar dívidas

( )Para ajudar os filhos

( )Para investir em outra atividade fora da agricultura

20- Se tivesse uma economia, utilizaria para:

( )Comprar equipamentos agrícolas

( )Melhorar a casa

( )Ajudar os filhos a se instalar

( )Comprar um carro

( )Colocar dinheiro na poupança

( )Comprar uma terra

( )Investir em casas, imóveis

( )Fazer uma viagem

( )Pagar dívidas 


\section{1- ESTRATÉGIAS FAMILIARES:}

- Como vai se dar a transmissão da propriedade?

- Preferiria que seus filhos vivessem:

\begin{tabular}{|l|l|l|l|}
\hline Filhos & Cidade & Campo & Indiferente \\
\hline Homens & & & \\
\hline Mulheres & & & \\
\hline
\end{tabular}

22- RELAÇÃO ENTRE A UNIDADE FAMILIAR E O ESTADO:

- Em sua opinião, você viveria melhor:

( )Na cidade ( )No campo ( )É igual ( )Não sabe

- Em sua opinião, qual é a situação da maioria dos pequenos agricultores desta região?

( )Muito boa ( )Boa ( )Mais ou menos ( )Ruim ( )Muito ruim ( )Não sabe

- Qual dos seguintes termos é o mais correto para designá-lo:
( )Agricultor Familiar
( )Empresário Agrícola
( )Trabalhador Rural
( )Produtor Rural
( )Pequeno Produtor
( ) Sitiante
( )Camponês Parcelar
( )Camponês

- A Política atual do governo para os agricultores é:
( )Muito favorável
( )Relativamente favorável
( )Relativamente desfavorável
( )Muito desfavorável

- A atual política agrícola do governo:

( )Favorece apenas certos grupos de agricultores. Quem?

( )Trata todos os agricultores da mesma maneira

- Em sua opinião, o futuro dos agricultores depende:
( )Dos próprios agricultores
( )Do Estado (Governo)
( )Da situação do Mercado Mundial

- Em sua opinião, qual tem sido o papel dos agricultores no desenvolvimento do país?
( )Muito importante ( )Relativamente importante
( )Pouco Importante ( )Nada Importante/Insignificante
( )Não sabe 


\section{APÊNDICE B: HISTÓRIAS DE VIDA}

A história de vida dos herdeiros que receberam a terra através da herança foi obtida partindo do seguinte roteiro:

1) Como era a propriedade no tempo dos pais?

2) Como se deu a aquisição da propriedade?

3) Quais as pessoas que saíram e quais as que ficaram na propriedade?

4) Pessoas que trabalhavam na propriedade.

5) Plantações que existiam na propriedade.

6) Comercialização dos produtos.

7) Qual a importância da terra para a família?

8) Como se deu a fragmentação da terra?

9) Todos os irmãos receberam lotes iguais/hectares? Homens e mulheres na mesma proporção?

10) Foi herança ou doação?

11) Se foi herança, quem faleceu? O sobrevivente ficou com a metade ou entrou como herdeiro?

12) Se foi doação, é pura e simples ou com usufruto?

13) É a favor de dividir a propriedade (fragmentação da terra) antes do falecimento dos proprietários?

14) Como é o trabalho realizado na propriedade?

15) Qual o tipo de assistência técnica realizada? 
A NEXOS 
ANEXO A: Registro $\mathrm{n}^{\circ} 1.293$

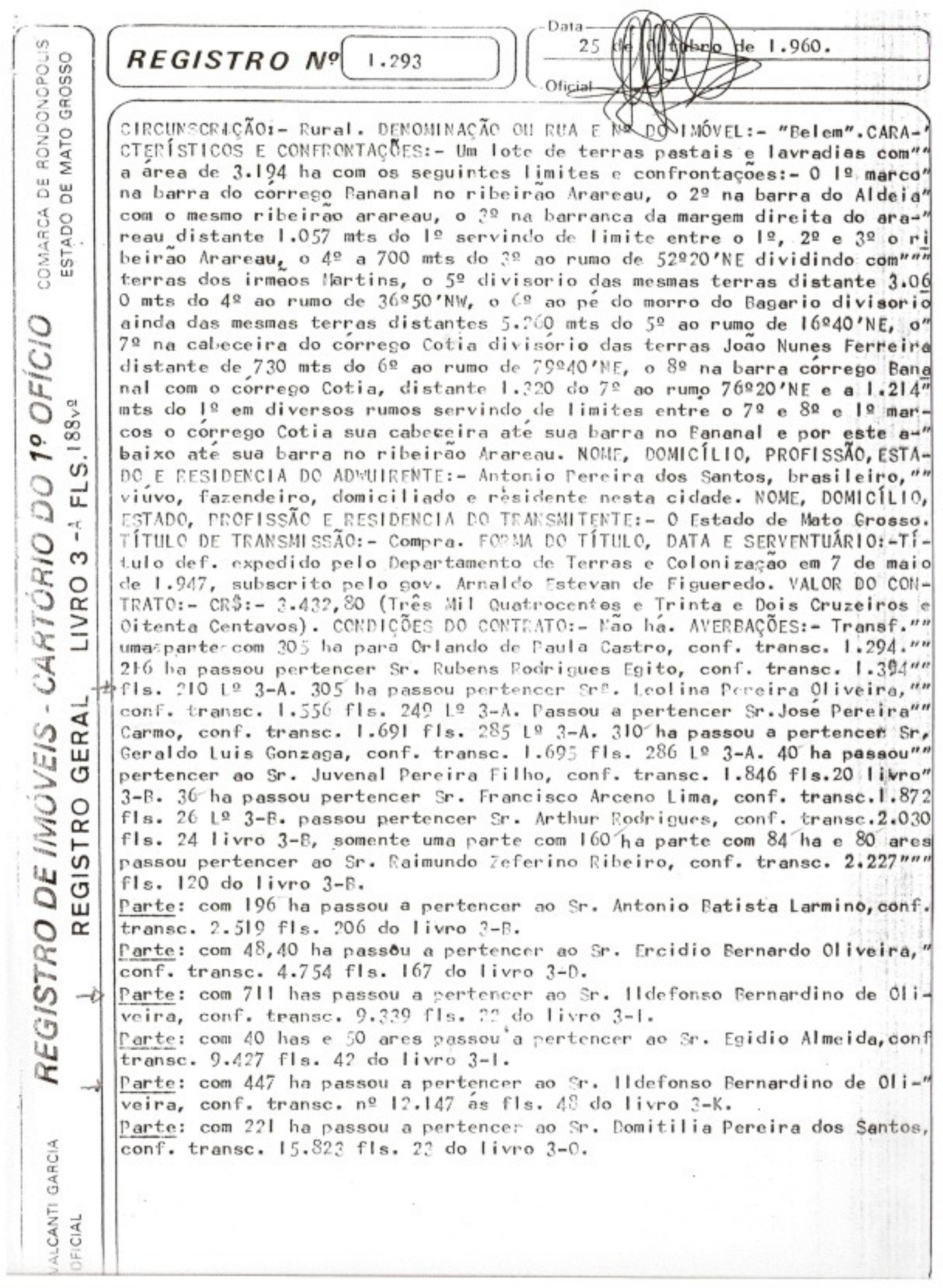


ANEXO B: Registro $n^{\circ} 1.556$

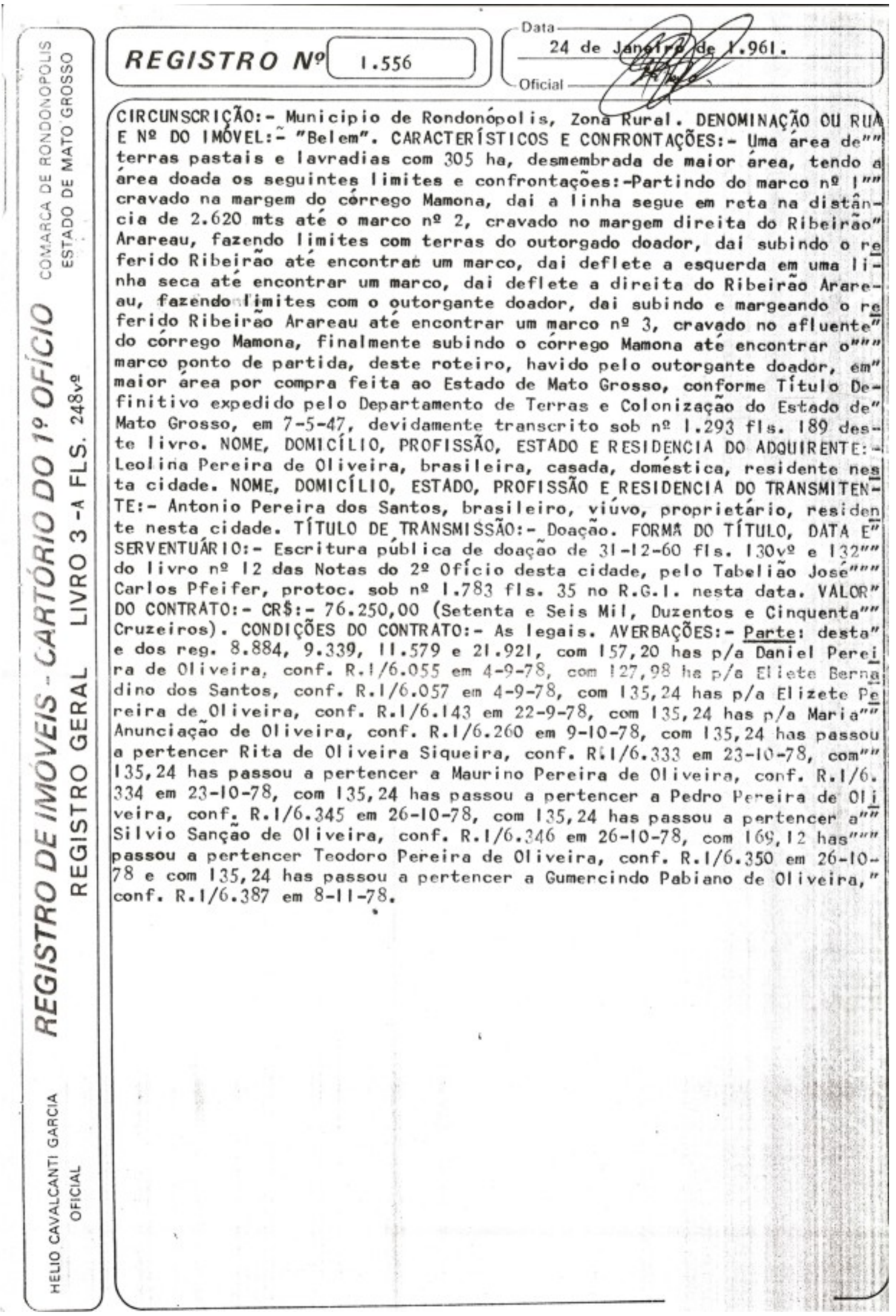




\section{ANEXO C: Certidão - Ildefonso Bernardino Oliveira - Área 711 ha}

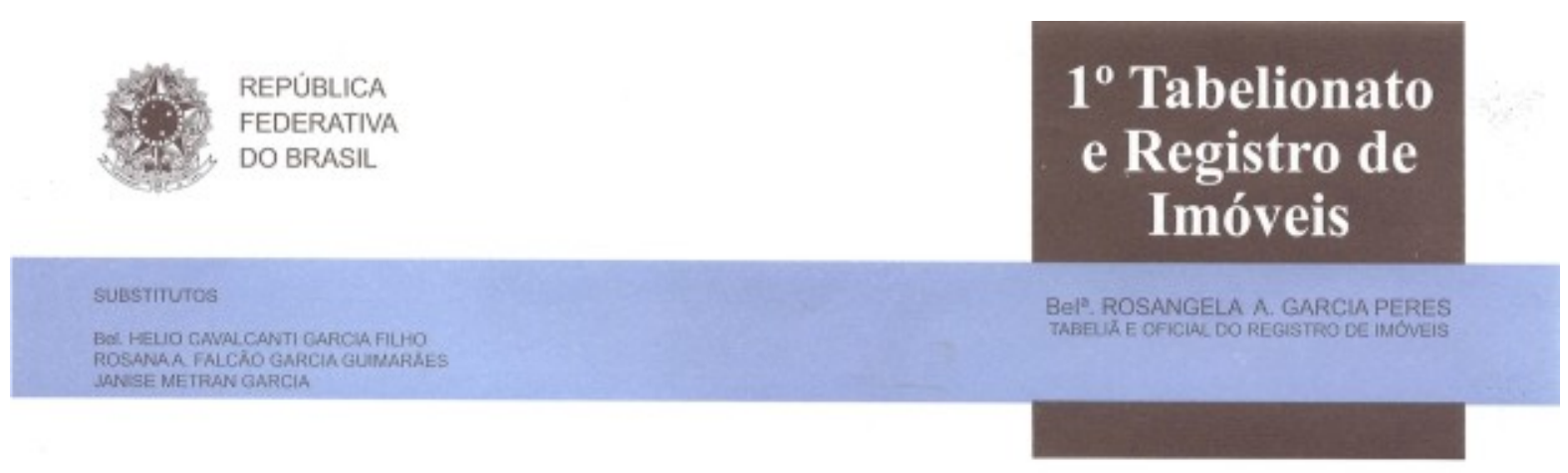

\section{E R T I D Ã O}

Certifico a pedido verbal de parte interessada que revendo nesta Serventia Registral os livros de Registro Geral, verifiquei que o Sr IDELFONSO BERNARDINO DE OLIVEIRA, adquiriu uma área de terras com 711 has., destacado da Fazenda denominada Belém, situada na zona rural deste Município, que adquiriu por Compra feita de Antonio Pereira dos Santos, conforme Escritura de 26 de Abril de 1956, âs fls. 178 do livro 4 , do $2^{\circ}$ Tabelionato de Notas local, devidamente registrada sob n 9.339 , fls. 22 livro 3 I, em 09/02/1966, no RGI local.

ANTONIO PEREIRA DOS SANTOS, adquiriu 3.194 has., do Estado de Mato Grosso, conforme Titulo Definitivo expedido pelo Departamento de Terras e Colonização, em 07 de Maio de 1947, devidamente registrado sob no

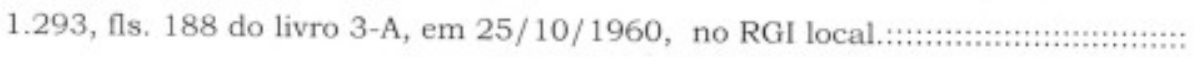

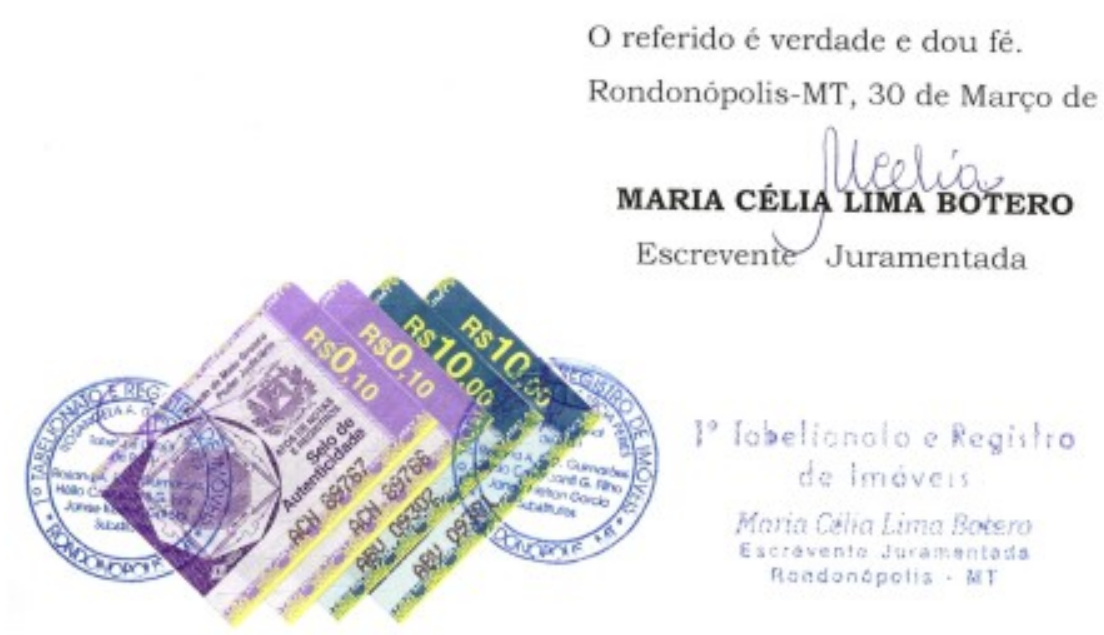




\section{ANEXO D: Certidão - Ildefonso Bernardino Oliveira - Área 447 ha}

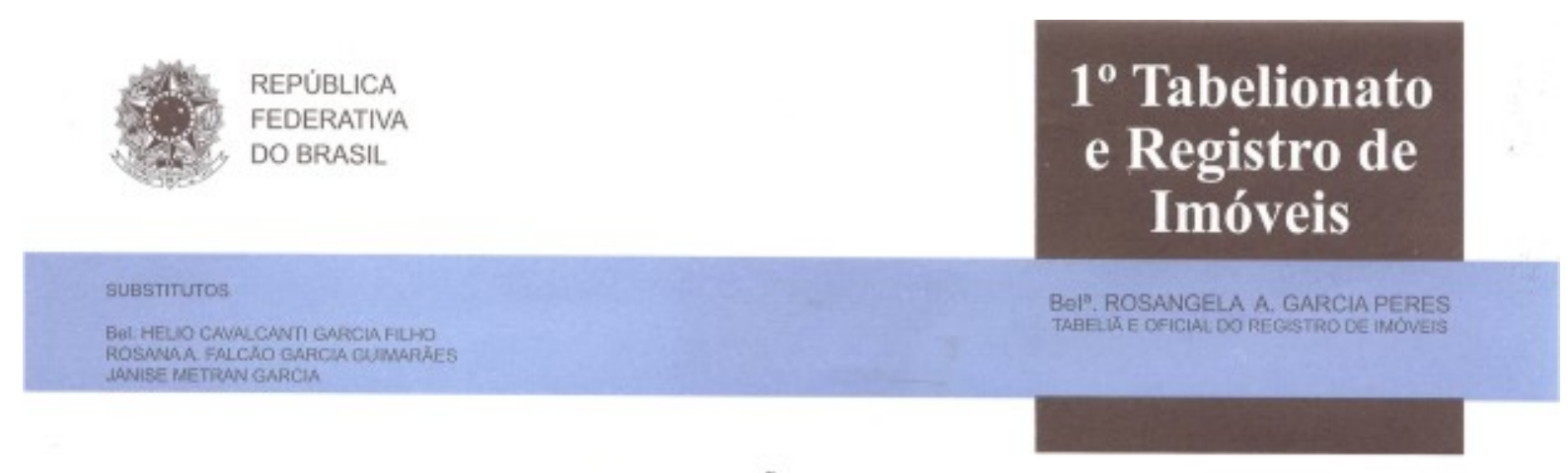

\section{E R T I D Ã O}

Certifico a pedido verbal de parte interessada que revendo nesta Serventia Registral os livros de Registro Geral, verifiquei que o Sr IDELFONSO BERNARDINO DE OLIVEIRA, adquiriu uma ărea de terras com 447 has., destacado da Fazenda denominada Belèm, situada na zona rural deste Município, que adquiriu por Compra feita de Antonio Pereira dos Santos, conforme Escritura de 25 de Abril de 1968, ás fls. $51 / 52$ do livro 6 , do $3^{\circ}$ Tabelionato de Notas local, devidamente registrada sob $\mathrm{n}^{\circ} 12.147$, fls. 48 livro 3-K, em 04/07/1968, no RGI local.

ANTONIO PEREIRA DOS SANTOS, adquiriu 3.194 has., do Estado de Mato Grosso, conforme Titulo Definitivo expedido pelo Departamento de Terras e Colonizaçâo, em 07 de Maio de 1947, devidamente registrado sob nº 1.293 , fls. 188 do livro 3 -A, em 25/10/1960, no RGI local.

O referido è verdade e dou fé.

Rondonópolis-MT, 30 de Março de 2007.

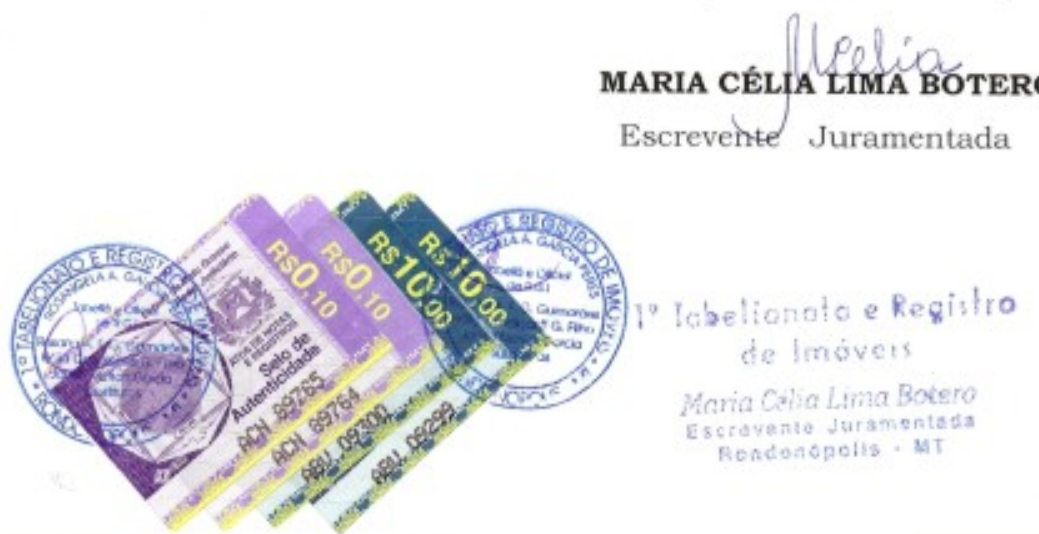

AV. MARECHAL DUTRA, 1093 - ESQ. CI ARNALDO ESTEVAN - FONE: (66) 3439-2400 - FAX: (66) $3439-2406$ MUNICIPIO E COMARCA DE RONDONÓPOLIS - ESTADO DE MATO GROSSO - E-MAIL: rgi.roogigterra.com.br 


\section{ANEXO E: Certidão - Ildefonso Bernardino Oliveira - Área 48,40 ha}

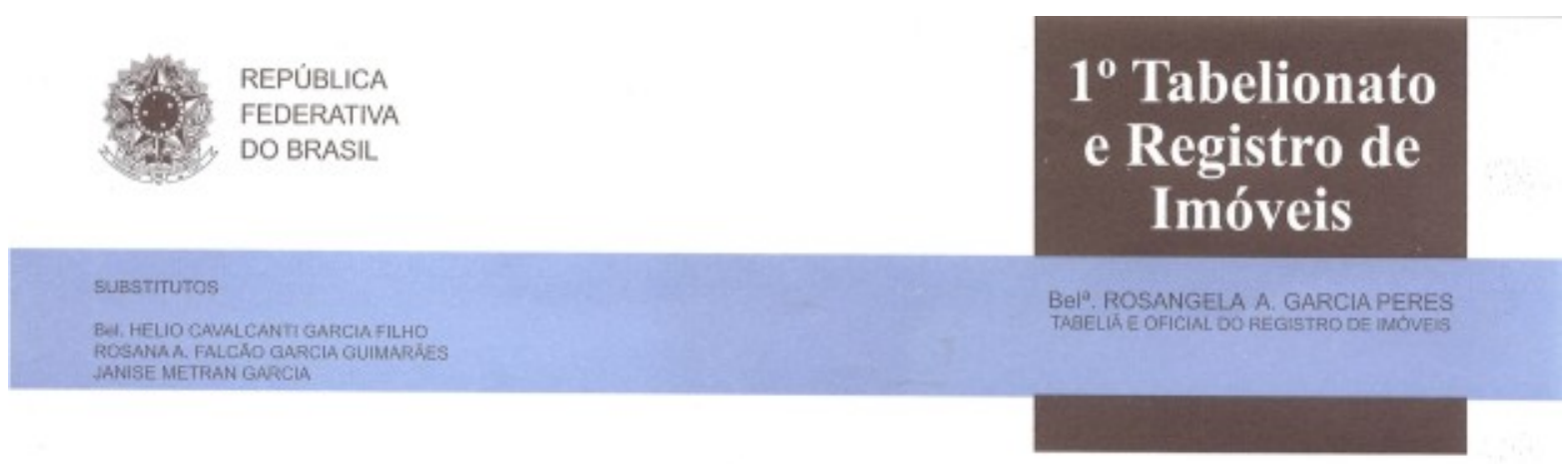

\section{E R T I Ã O}

Certifico a pedido verbal de parte interessada que revendo nesta Serventia Registral os livros de Registro Geral, verifiquei que o Sr IDELFONSO BERNARDINO DE OLIVEIRA, adquiriu um lote de terras pastais e lavradias denominado "Aldeinha", com 48,40 has, na zona rural deste Municipio, que adquiriu por compra feita de Maria Gomes de Jesus Ferreira, conforme Escritura de 19 de Outubro de 1965, ás fls. 99/100 do livro 37 , do $2^{\circ}$ Tabelionato de Notas local, devidamente registrada sob $n^{\circ} 8.884$, fls. 191 do livro 3-H, em 20/10/1965, no RGI local.

MARIA GOMES DE JESUS FERREIRA, por ser casada com SEBASTIĀO NUNES FERREIRA, adquiriram 858 has., do Estado de Mato Grosso, conforme Titulo Definitivo expedido pelo Departamento de Terras c Colonização, em 24 de Julho de 1954, devidamente registrado sob no 122, fls. 18 do livro 3-A, em 14/07/1959; posterior Escritura Certidão de Adjudicação de 712,80 has., em 29 de Março de 1962, devidamente registrada sob n ${ }^{\circ} 3.359$, fls. 137 do livro $3-\mathrm{C}$, em 03/05/1962, no RGI local.:.:

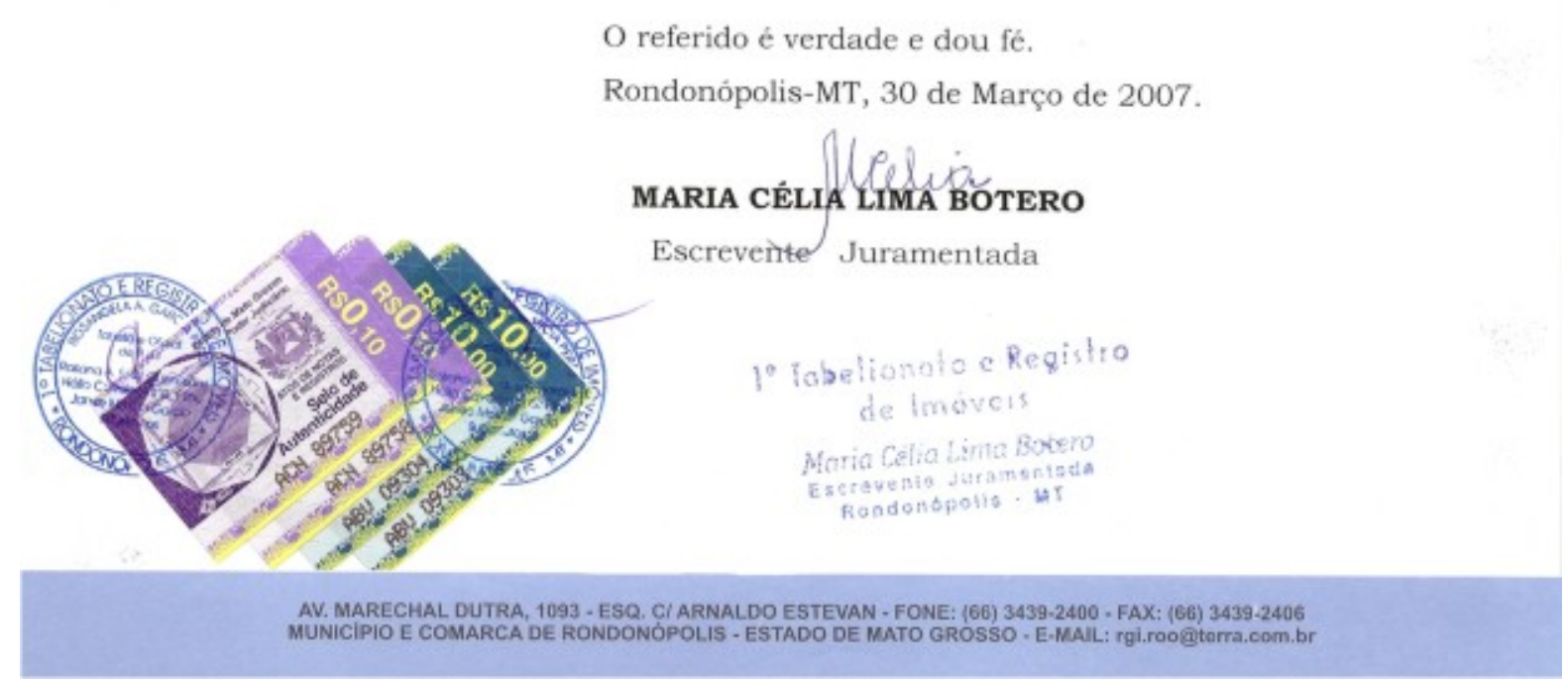




\section{ANEXO F: Certidão - Ildefonso Bernardino Oliveira - Área 27 ha}

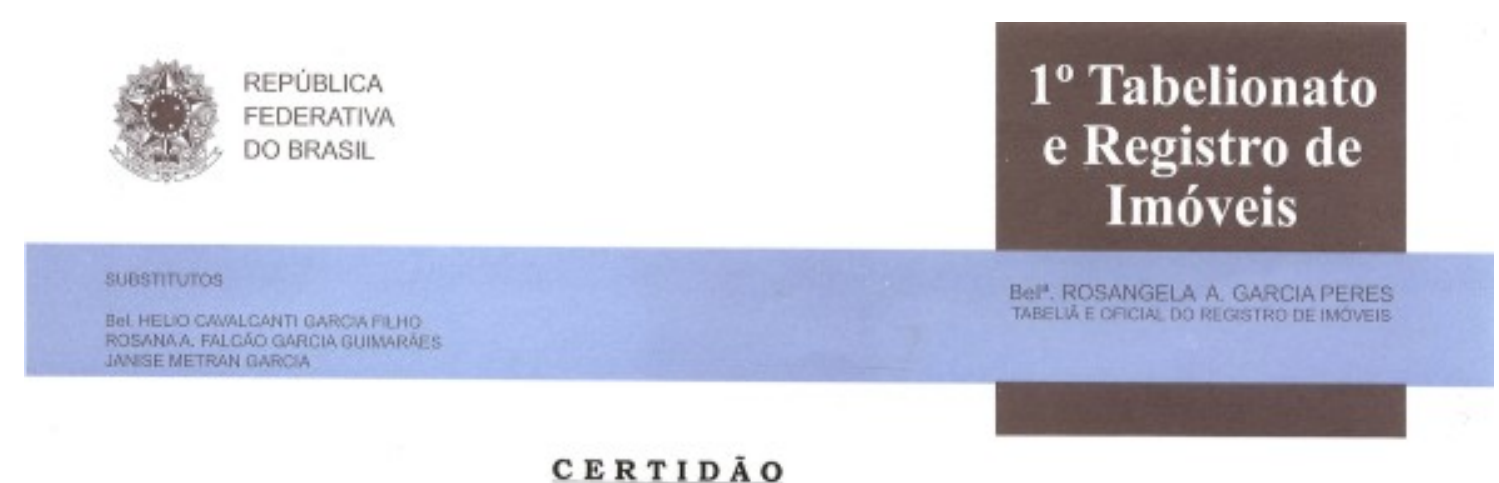

Certifico a pedido verbal de parte interessada que revendo nesta Serventia Registral os livros de Registro Geral, verifiquei que o Sr. IDELFONSO BERNARDINO DE OLIVEIRA, adquiriu duas áreas de terras com o total de 27 has., desmembrada da Fazenda "Barra da Estiva", na zona rural deste Município, por compra feita de Martinho de Oliveira Conceição e sua esposa Elza Rosa da Conceição, conforme Escritura de 14 de Dezembro de 1967, ás fls. 01/02v do livro $12-\mathrm{A}$, das Notas deste Tabelionato, devidamente registrada sob $\mathrm{n}^{\circ} 11.579$, fls. 218 do livro $3-\mathrm{J}$, em 28/12/1967, no RGI local.

MARTINHO OLIVEIRA DA CONCEIÇÃo, adquiriu 305 has., por compra feita de Joāo Antonio Fagundes e sua esposa Minervina Pereira Fagundes, conforme Escritura de 30 de Abril de 1963, ás fls. $123 / 124 \mathrm{v}^{\circ}$ do Iviro 6-A, das Notas deste Tabelionato, devidamente registrado sob n” 5.400 , fls, 158 do livro 3-E, em 10/05/1963, no RGI local.

Adquiriu mais $\mathbf{5 0 0}$ has., de Jose Eloy da Silva e sua esposa Avelina Rosa da Silva, conforme Escritura Pública de Doaçāo de 08 de Fevereiro de 1963, ás fls. $214 / 215$ do livro 1 das Notas deste Tabelionato, devidamente registrada sob $n^{\circ}$ 5.061 , fls. 59 do livro 3-E, em 28/02/1963, no RGI local.:

JOĀO ANTONIO FAGUNDES, adquiriu 305 has., por compra feita de Jose Eloy da Silva e sua esposa Avelina Rosa da Silva, conforme Escritura de 19 de Fevereiro de 1963, as fls. 51/52 do livro 6 das Notas deste Tabelionato, devidamente registrada sob $\mathrm{n}^{\circ} 5.115$, fls. 75 do livro $3-\mathrm{E}$, em 08/03/1963, no RGI local

JOSE ELOY DA SILVA, adquiriu 6.065 has., do Estado de Mato Grosso, conforme Titulo Definitivo expedido pela Comissão de Terras e Colonização, em 14 de Fevereiro de 1948, devidamente registrado sob n² 2.826, fls. 294 do livro 3-B, em 09/12/1961, no RGI local.

O referido é verdade e dou fé. 


\section{ANEXO G 1: Clarinda Nunes da Silva e Outros}

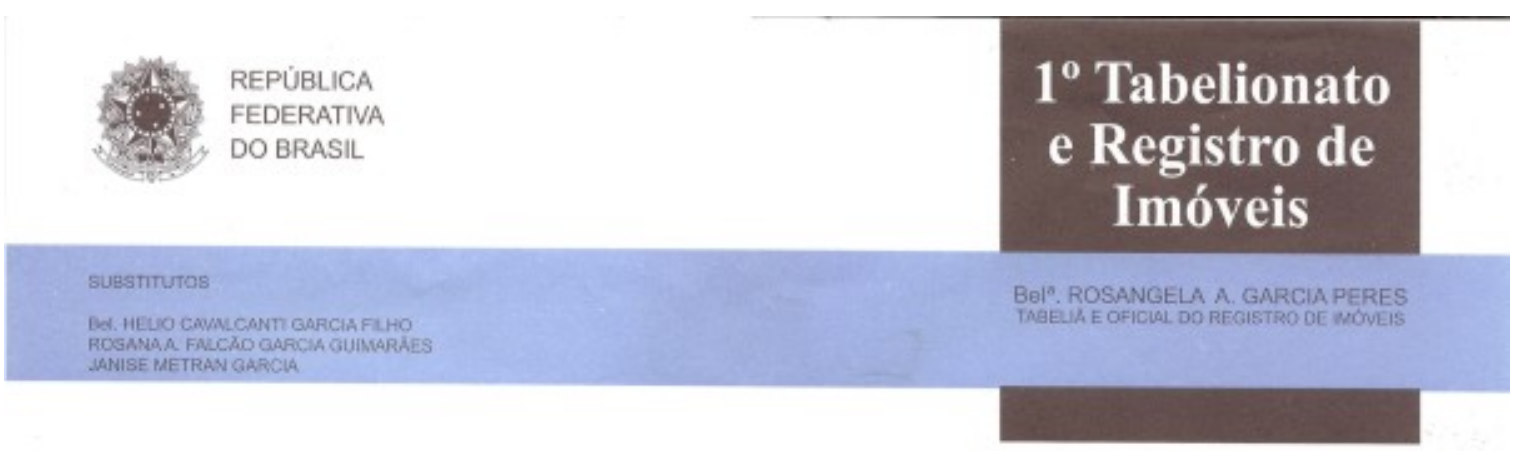

CERTI D ÃO

Certifico a pedido verbal de parte interessada que revendo nesta Serventia Registral os livros de Registro Geral, verifiquei que a Sra; CLARINDA NUNES DA SILVA e seu esposo SEBASTIÃo PEREIRA DA SILVA; BENEDITA NUNES RIBEIRO e seu esposo NATALINO ALVES RIBEIRO; LUIZ NUNES FARIAS e sUa esposa KEILA APARECIDA NOGUEIRA FARIAS; JOSE NUNES FARIAS; ORLANDO NUNES FARIAS e sua esposa MARIA DE FATIMA OLIVEIRA FARIAS; EMILIA NUNES BORGES e seu esposo LUIZ GONZAGA BORGES; ODILIA RODRIGUES FERREIRA; LAURINDA RODRIGUES FERREIRA; NELSON RODRIGUES FERREIRA $\mathrm{P}$ GERSON RODRIGUES FERREIRA, adquiriram uma ảrea de terras pastais c lavradias com $801,66,32$ has, denominda "Fazenda Beroaba", situada na zona rural deste Municipio, juntamente com MARIA RODRIGUES FERREIRA e PEDRO NUNES FARIAS, da seguinte forma: MARIA RODRIGUES FERREIRA, por ser casada com OTONI NUNES FERREIRA, adquiriram uma ärea de 735 has., do Estado de Mato Grosso, conforme Titulo Definitivo de 18 de Junho de 1954, expedido pelo Departamento de Terras e Colonização do Estado, devidamente registrada sob $\mathrm{n}^{\circ} 10.288$, fls. 241 do livro $3-\mathrm{I}$, em 03/11/1966..... Adquiriu mais por ser casada com Otoni Nunes Ferreira, 140,60 has., do Espólio de Joāo Nunes Ferreira, conforme Formal de Partilha de 11 de Janeiro de 1962 , processado pelo $2^{\circ}$ Oficio local, devidamente registrada sob $\mathrm{n}^{\circ} 3.050$, fls. 53 do livro 3-C, em 13/02/1962; e posterior no Formal de Partilha a árca de 43,52,35 has, em 23 de Dezembro de 1980, processado pelo $4^{\circ}$ Oficio e Juízo de Justiça desta Comarca, devidamente registrada sob $\mathrm{n}^{\circ} 01$ na matricula 11.886, livro 02, em 13/02/1981, no RGI local.:..............................................

Adquiriu mais por ser casada com Otoni Nunes Ferreira, 140,60 has., por compra feita de Sidney Manoel de Lima e sua esposa Cleonice Santos de Lima, conforme Escritura de 12 de Novembro de 1968, ás fls. 139140v do livro 15, das Notas deste Tabelionato, devidamente registrada sob $\mathrm{n}^{\circ} 12.724$, fls. 9 do livro 3-L, em 22/11/1968; e posterior no Formal de Partilha a área de 140,60 has, em 23 de Dezembro de 1980, processado pelo $4^{\circ}$ Oficio e Juizo de Justiça 


\section{ANEXO G 2: Clarinda Nunes da Silva e Outros}

desta Comarca, devidamente registrada sob $\mathrm{n}^{\circ} 01$ na matricula 11.887 , livro 02, em 13/02/1981, no RGI local.

Adquiriu mais por ser casada com Otoni Nunes Ferreira, 140,60 has., por compra feita de Jose Nunes Batista, conforme Escritura de 06 de Março de 1966, ás fls. 163 do livro 24 , do $2^{\circ}$ Tabelionato de Notas local, devidamente registrada sob $\mathrm{n}^{\circ} 10.297$, fls. 243 do livro 3 -I, em 07/11/1966; e posterior no Formal de Partilha a área de 140,60 has., em 23 de Dezembro de 1980, processado pelo $4^{\circ}$ Oficio e Juízo de Justiça desta Comarca, devidamente registrada sob $\mathrm{n}^{\circ} 01$ na matricula 11.888, livro 02, em 13/02/1981, no RGI local

Adquiriu mais por ser casada com Otoni Nunes Ferreira, 28 has, por compra feita de Erontina Nunes Batista e seu esposo Jorge Alves Cardoso, conforme Escritura de 09 de Março de 1965, ás fls. 165 do livro 33, do $2^{\circ}$ Tabelionato de Notas local, devidamente registrada sob $\mathrm{n}^{\circ} 10.292$, fls. 242 do livro 3-I, em 04/11/1966; e posterior no Formal no Partilha a área de 28 has., em 23 de Dezembro de 1980, processado pelo $4^{\circ}$ Oficio e Juizo de Justiça desta Comarca, devidamente registrada sob $\mathrm{n}^{\circ} 01$ na matricula 11.889 , livro 02, em 13/02/1981, no RGI local.

MARIA RODRIGUES FERREIRA juntamente com os demais herdeiros, adquiriram do Espólio de Otoni Nunes Ferreira, parte com 534 has, conforme Formal de Partilha de 23 de Dezembro de 1980, processado pelo $4^{\circ}$ Oficio e Juizo desta Comarca, devidamente registrada sob $\mathrm{n}^{\circ} 01$ na matricula 11.885, livro 02 em 13/02/1981, no RGI local

As áreas acima adquiridas nos Formais de Partilha foram posteriormente matriculadas sob $n^{\circ}$ 54.596, livro 02 em 22/08/2000, no RGI local.......................

SIDNEY MANOEL DE LIMA, adquiriu 140,60 has., por compra feita de Manoel Alves de Souza e sua esposa Francisca Alves de Souza, conforme Escritura de 26 de Outubro de 1967, ás fls. 195/196 do livro 43, do $2^{\circ}$ Tabelionato de Notas local, devidamente registrada sob $n^{\circ} 11.437$, fls. 191 do livro 3-J, em 22/11/1967, no RGI local.

MANOEL ALVES DE SOUZA, adquiriu 140,60 has., por compra feita de Odalice Nunes Batista e seu esposo Abdias Vieira da Silva, conforme Escritura de 09 de Novembro de 1965, às fls. 169/170 do livro 37, do 


\section{ANEXO G 3: Clarinda Nunes da Silva e Outros}

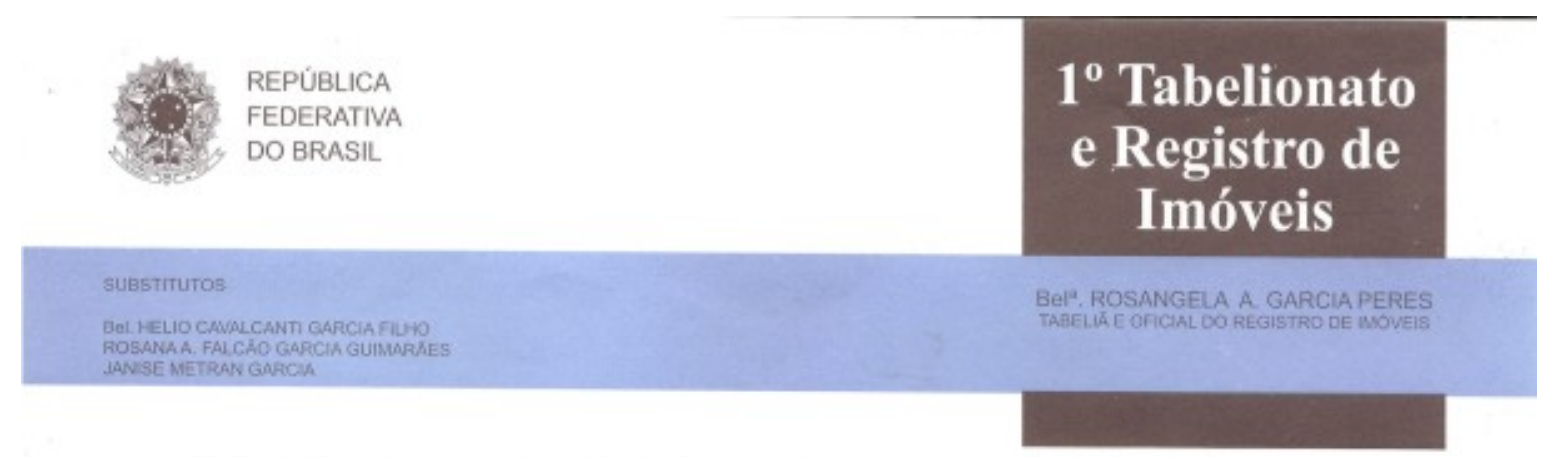

$2^{\circ}$ Tabelionato de Notas local, devidamente registrada sob n ${ }^{\circ} 9.032$, fls. 237 do livro 3-H, em 09/12/1965, no RGI local.

ODALICE NUNES BATISTA, adquiriu 140,60 has., do espólio de João Nunes Ferreira, conforme Formal de Partilha de 11 de Janeiro de 1962, dos Autos de Inventário processado pelo $2^{\circ}$ Oficio desta cidade, devidamente registrada sob $n^{\circ} 3.058$, fls. 54 do livro $3-\mathrm{C}$, em 13/02/1962, no RGI local.:

JOSE NUNES BATISTA, adquiriu 140,60 has., do espólio de João Nunes Ferreira, conforme Formal de Partilha de 11 de Janeiro de 1962, dos Autos de Inventário processado pelo $2^{\circ}$ Oficio desta cidade, devidamente registrada sob $\mathrm{n}^{\circ} 3.059$, fls. 55 do livro $3-\mathrm{C}$, em 13/02/1962, no RGI local.:

ERONTINA NUNES BATISTA, adquiriu 108,60 has,, do espólio de João Nunes Ferreira, conforme Formal de Partilha de 11 de Janeiro de 1962, dos Autos de Inventário processado pelo $2^{\circ}$ Oficio desta cidade, devidamente registrada sob $\mathrm{n}^{\circ} 3.056$, fls. 54 do livro $3-\mathrm{C}$, em 13/02/1962, no RGI local.

JOÃO NUNES FERREIRA, adquiriu 874 has., do Estado de Mato Grosso, conforme Titulo Definitivo expedido pela Diretoria de Terras e Obras Públicas, em 12 de Dezembro de 1939, devidamente registrado sob no 3.026, fls, 47 do livro 3-C, em 12/02/1962, no RGI local............................ Adquiriu mais $\mathbf{5 0 0}$ has., por compra feita de Jose Eloy da Silva e sua esposa Avelina Rosa da Silva, conforme Escritura de 23 de Fevereiro de 1949, ás fls. $6 / 7$ do livro 13 das Notas do $2^{\circ}$ Oficio de Poxoreo-MT, devidamente registrada sob $n^{\circ} 3.027$, fls. 47 do livro 3-C, em 12/02/1962, no RGI local............................. Adquiriu mais 8 has., por compra feita de João Soares Dias e sua esposa Adelina Soares de Resende, conforme Escritura de 17 de Junho de 1953, ás fls. $106 / 107 \mathrm{v}^{\circ}$ do livro 02 do $2^{\circ}$ Tabelionato de Notas local, devidamente registrada sob $n^{\circ} 3.029$, fls, 48 do livro 3-C, em 12/02/1962, no RGI local................................

JOSE ELOY DA SILVA, adquiriu 6.065 has., do Estado de Mato Grosso, conforme Titulo Definitivo expedido pela Comissāo de Terras e Colonizaçāo, em 14 de Fevereiro de 1948, devidamente registrado sob no 2.826 , fls. 294 do livro 3-B, em 09/12/1961, no RGI local.:.:..............................................: 


\section{ANEXO G 4: Clarinda Nunes da Silva e Outros}

JOÃo SOARES DIAS, adquiriu 8 has., do Estado de Mato Grosso, conforme Certidão de 09-02-1962, do Titulo Definitivo expedido pelo Departamento de Terras e Colonização em 16 de Abril de 1952, devidamente registrado sob $\mathrm{n}^{\mathrm{o}} 3.028$, fls. 48 do livro $3-\mathrm{C}$, em 12/02/1962, no RGI

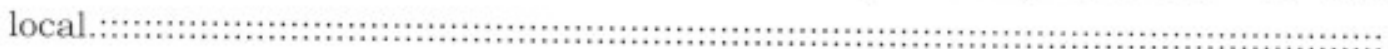

O referido é verdade e dou fé.

Rondonópolis-MT, 30 de Março de 2007.

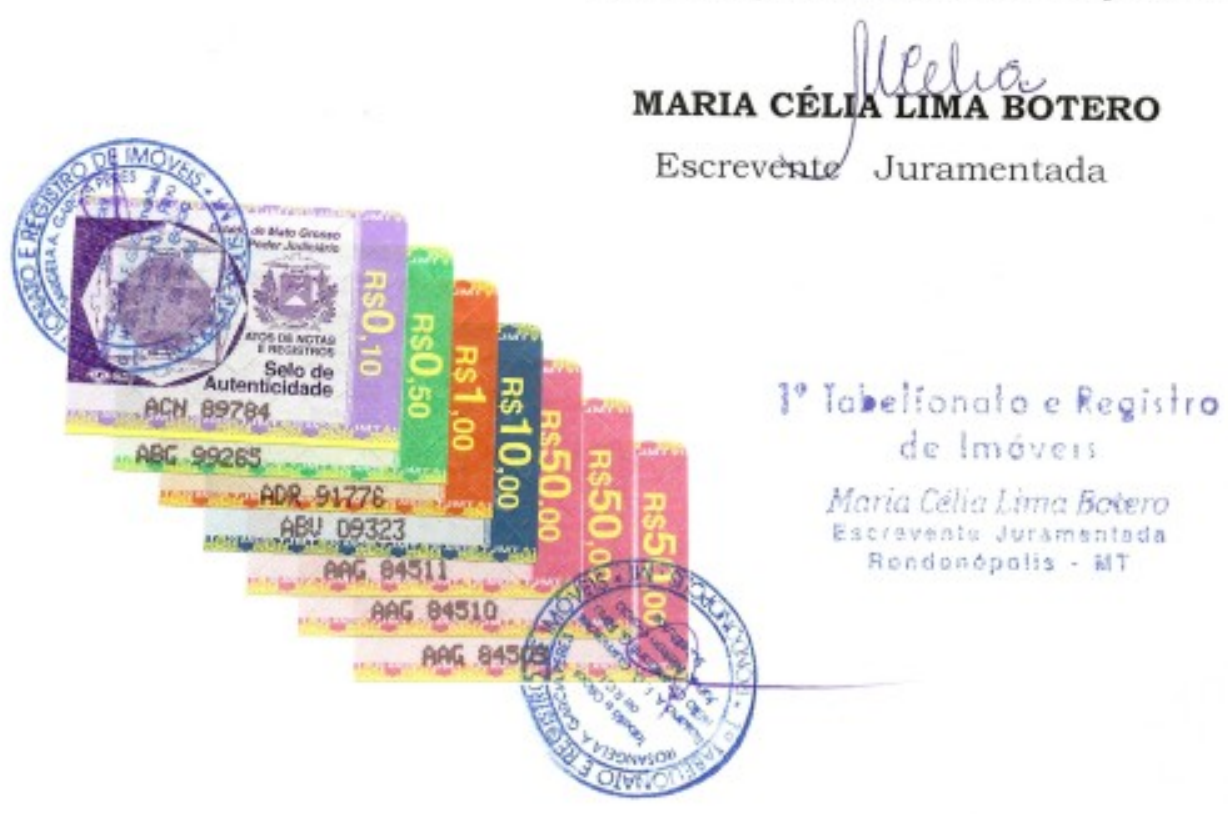




\section{ANEXO H: Antônio Alvez da Silva - Área 20 ha}

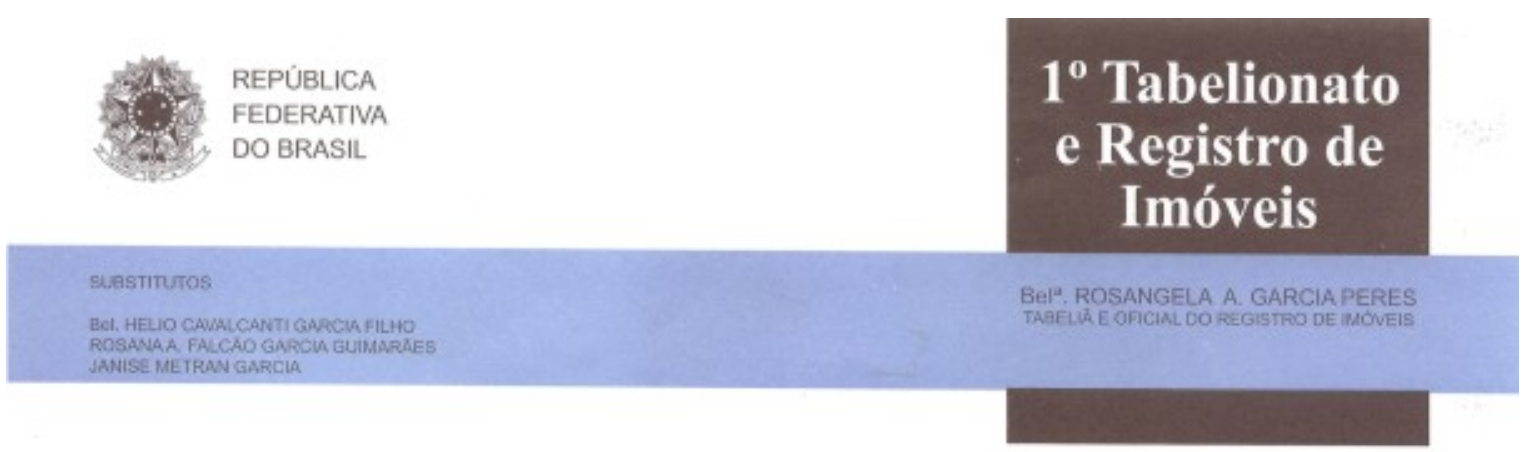

C E R T I D A O

Certifico a pedido verbal de parte interessada que revendo nesta Serventia Registral os livros de Registro Geral, verifiquei que o Sr. ANTONIO ALVES DA SILVA, é proprietário de uma ărea de terras pastais e lavradias com área de 20,00 has, desmembrada de maior porção da gleba denominada "São Francisco", situada na zona rural deste Municipio, que adquiriu por compra feita de Francisco Vieira da Silva e sua esposa Maria Jose de Jesus, conforme Escritura de 31 de Outubro de 1961, ás fls. 13 do livro 19, do $2^{\circ}$ Tabelionato de Notas local, devidamente registrada sob $\mathrm{n}^{\circ} 4.602$, fls. 219/220 livro 3D, em 07/12/1962; e posteriormente matriculado sob $\mathrm{n}^{\circ}$

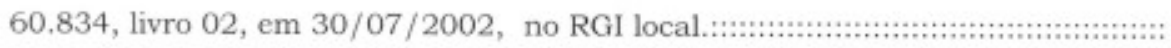

FRANCISCO VIEIRA DA SILVA, adquiriu 3.058 has, do Estado de Mato Grosso, conforme Titulo Definitivo expedido pelo Departamento de Terras e Colonização, em 25 de Setembro de 1952, devidamente registrado sob no 3.101, fls. 65 do livro 3-C, em 01/03/1962, no RGI local.:...........................:

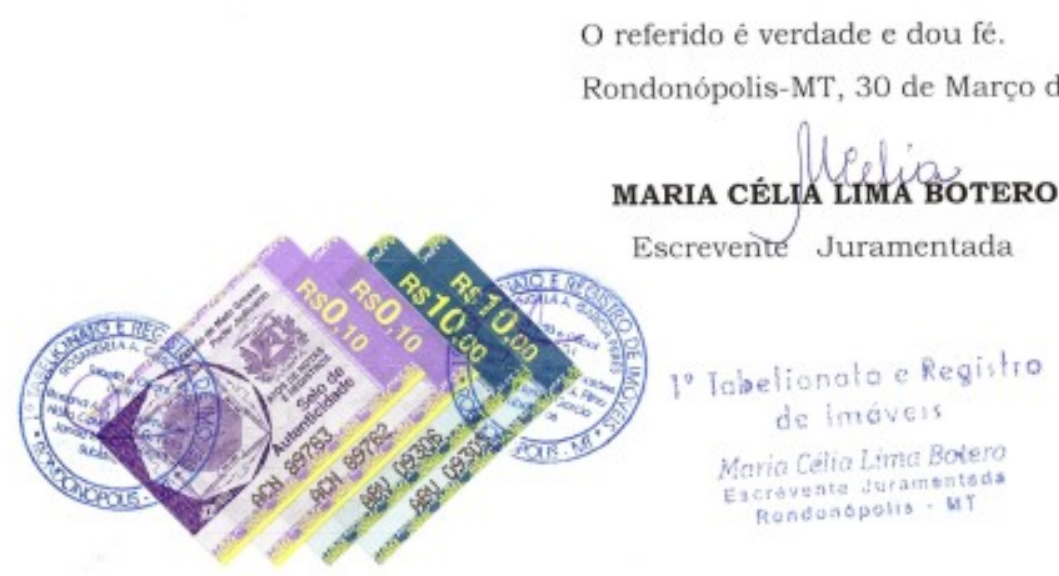




\section{ANEXO I: Antônio Alvez da Silva - Área 27 ha e 8.888 mts ${ }^{2}$}

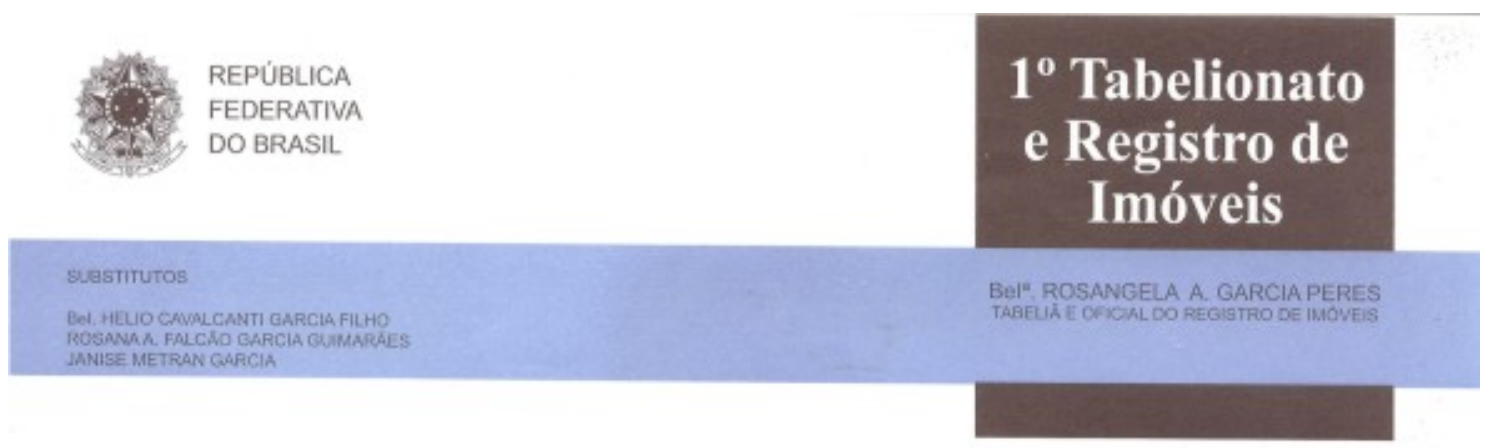

C E R T I Ã O

Certifico a pedido verbal de parte interessada que revendo nesta Serventia Registral os livros de Registro Geral, verifiquei que o Sr ANTONIo ALVES DA SILVA e sua esposa MARIA ROSA DA SILVA, é proprietário de uma área de terras pastais e lavradias, caracterizada como parte do lote Miranda, da Colônia do Naboreiro, neste Município, com 27 has e $8.888 \mathrm{mts} 2$, que adquiriram por compra feita de Nelson Giovanini, conforme Escritura de 02 de Abril de 1981, ás fls. 29/30v do livro 46-A, das Notas deste Tabelionato, devidamente registrada sob $\mathrm{n}^{\circ} 01$ na matricula 12.229 , livro 02 , em 13/04/1981, no RGI local.:

NELSON GIOVANINI, adquiriu juntamente com OSVALDO GIOVANINE e sUa esposa NIZETE DA SILVA GIOVANINE; RENATO ENCARNAÇÃO GIOVANINE e sua esposa VILMA GAVIGLIA GIOVANINI; uma ảrea de terras com $83,6.666$ has, por compra feita de Jose Vicente Vieira e sua esposa Laura Alves Vieira, conforme Escritura Pública de 29 de Março de 1977, ás fls. $31 / 32 \mathrm{v}^{\circ}$ do livro 34 , das Notas deste Tabelionato, devidamente registrada sob $\mathrm{n}^{\circ} 01$ na matricula 3.186 , livro 02 em 20/04/1977, no RGI local.

JOSE VICENTE VIEIRA, adquiriu 502 has, juntamente com Odilon Barcelos Maia; Doralina da Silva Alves; Zildeteh Silva Souza e seu esposo Saturnino Medrado de Souza; Durval Alves de Oliveira e sua esposa Natalina Souza de Oliveira; Ana Julia Ribeiro e seu esposo Seabra de Souza Ribeiro; Maria Raulina Ribeiro e seu esposo Protasio de Souza Ribeiro; Anita Alves da Silva e seu esposo Otavio Alves da Silva; Francisco Antonio de Lima e sua esposa Jovina Alves de Lima e Ercilia Rodrigues da Silva, do Estado de Mato Grosso, conforme Titulo Definitivo expedido pelo Departamento de Terras e Colonização, em 29 de Novembro de 1949, devidamente registrado sob no 13.957, fls. 59 do livro 3-M, em 19/06/1970; posterior Escritura Publica de Divisão Amigável de 25 de Julho de 1972, âs fls. 11/13 do livro 1-I, das Notas deste Tabelionato, devidamente registrada sob $\mathrm{n}^{\circ} 17.861$, fls. 203 do livro 3-P, em 06/02/1973, no RGI local. 
ANEXO J: MAPA XXV- Lote 01 - Milton Alves da Silva

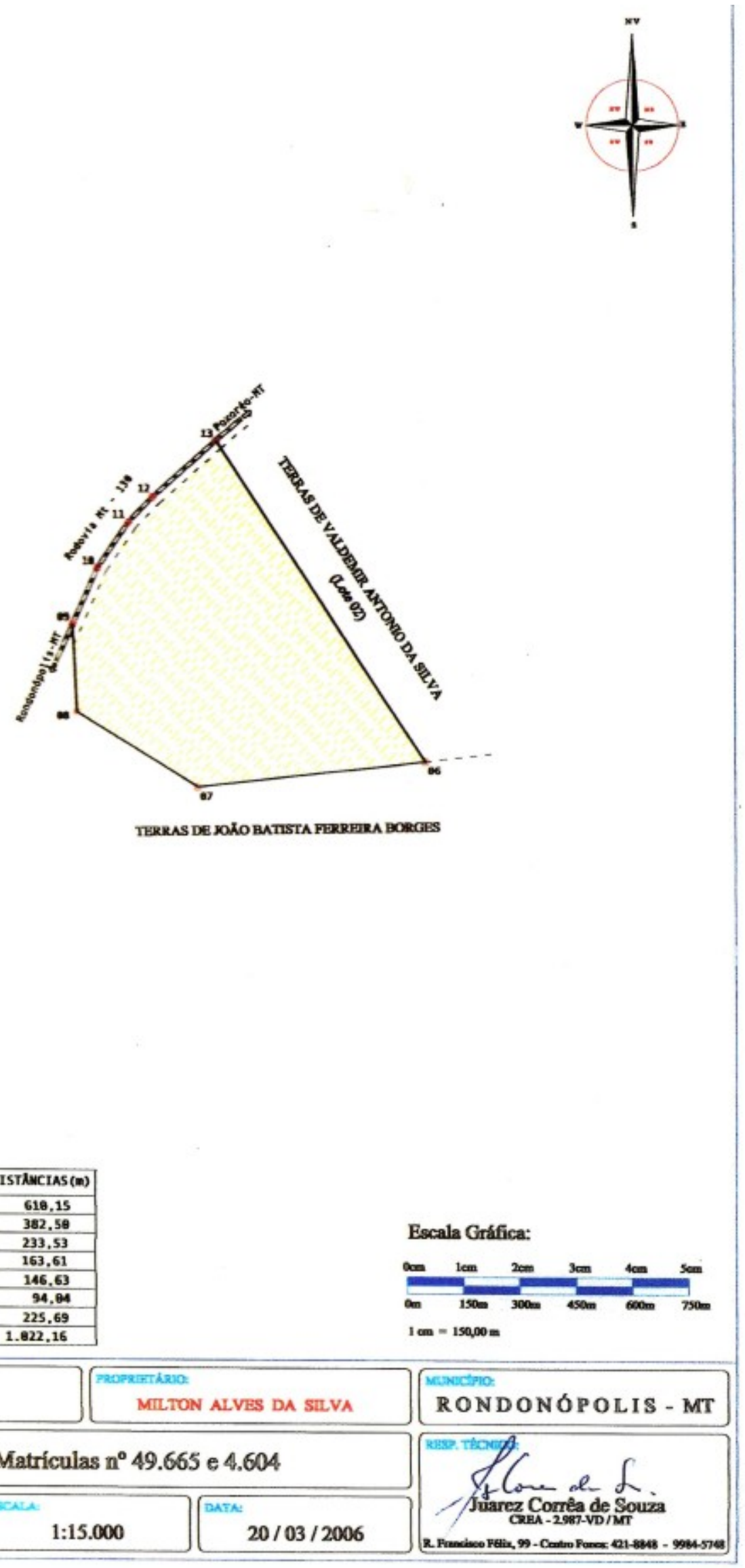


ANEXO K: MAPA XXVI- Lote 02 - Valdemir Antônio da Silva
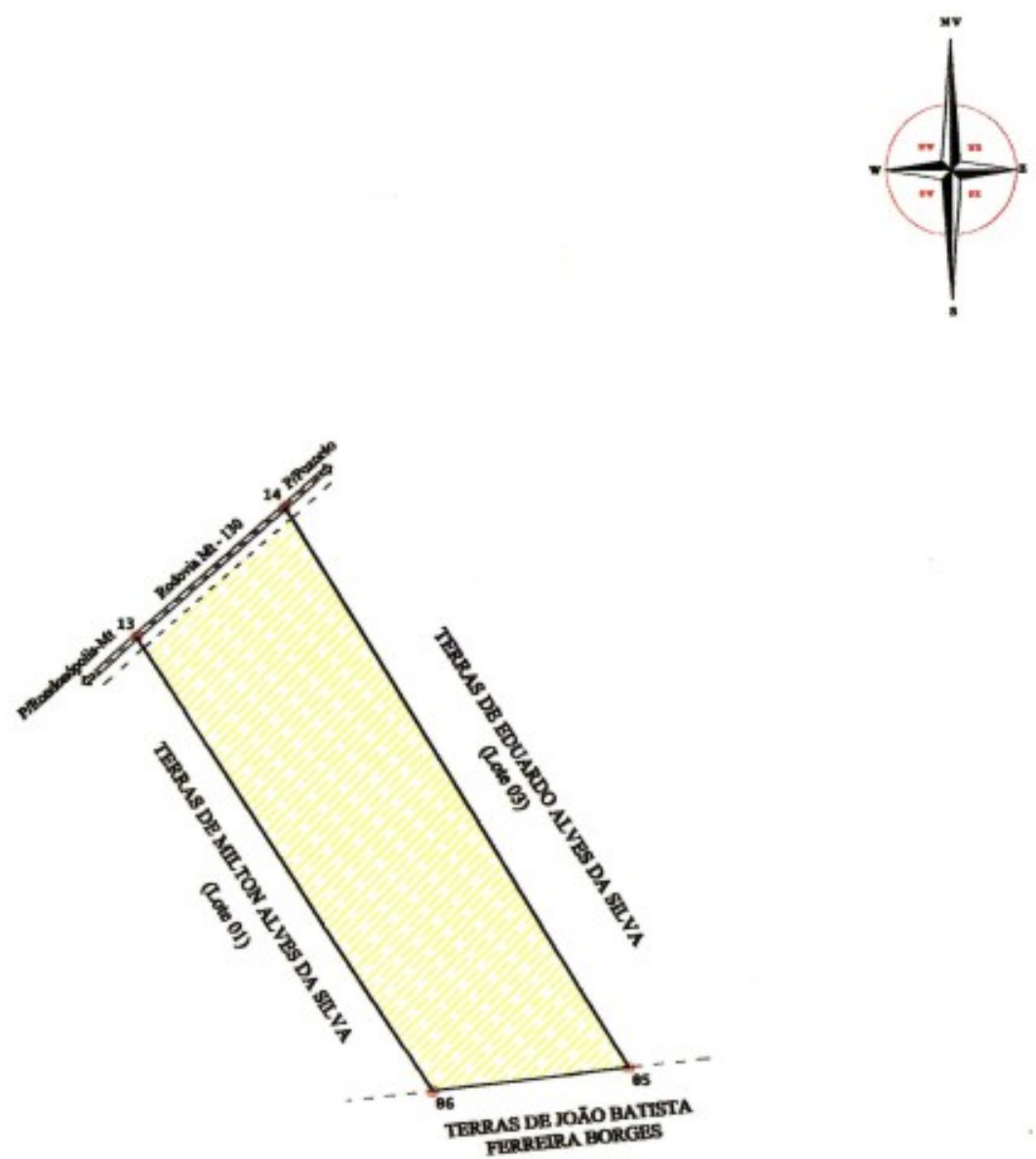

ROTEIRO

\begin{tabular}{|c|c|c|c|c|}
\hline Marcos & AZIMUTES VERD. & DISTANCIAS (m) & & Escala Grdfica: \\
\hline$\theta 5=06$ & $262^{\circ} 54^{\prime} 47^{\prime \prime}$ & 372,85 & & \multirow{2}{*}{ 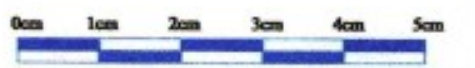 } \\
\hline$\theta 6-13$ & $327^{\circ} \theta 9^{\circ} \theta 5^{*}$ & $1.022,16$ & & \\
\hline $13-14$ & $48^{\circ} 58^{\prime} 16^{\prime \prime}$ & 374,46 & & \multirow{2}{*}{$\begin{array}{l}150 \mathrm{~m} \text { m } 300 \mathrm{~m} \quad 400 \mathrm{~m} \quad 600 \mathrm{~m} \quad 750 \mathrm{~m} \\
1 \mathrm{~cm}-150,00 \mathrm{~m}\end{array}$} \\
\hline $14-85$ & $148^{\circ} 45^{\circ} 29^{\prime \prime}$ & 1.238 .84 & & \\
\hline andvale & 0 TE - 02 & $\begin{array}{l}\text { PROFAIRTRRaC: } \\
\text { VALDEMII }\end{array}$ & R ANTONIO DA SILVA & RONDONOPOLIS - MT \\
\hline cancias: & \multicolumn{3}{|c|}{ Parte das Matrículas $n^{\circ} 49.665$ e 4.604} & \multirow{2}{*}{ 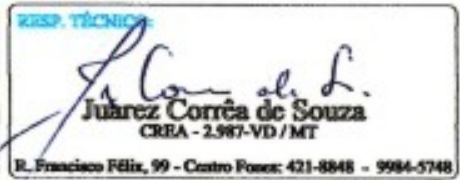 } \\
\hline $\begin{array}{l}\text { AREA TOTALA } \\
\text { aO, } 00\end{array}$ & Receld: & $1: 15.000$ & $20 / 03 / 2006$ & \\
\hline
\end{tabular}


ANEXO L: MAPA XXVII- Lote 03 - Eduardo Alves da Silva
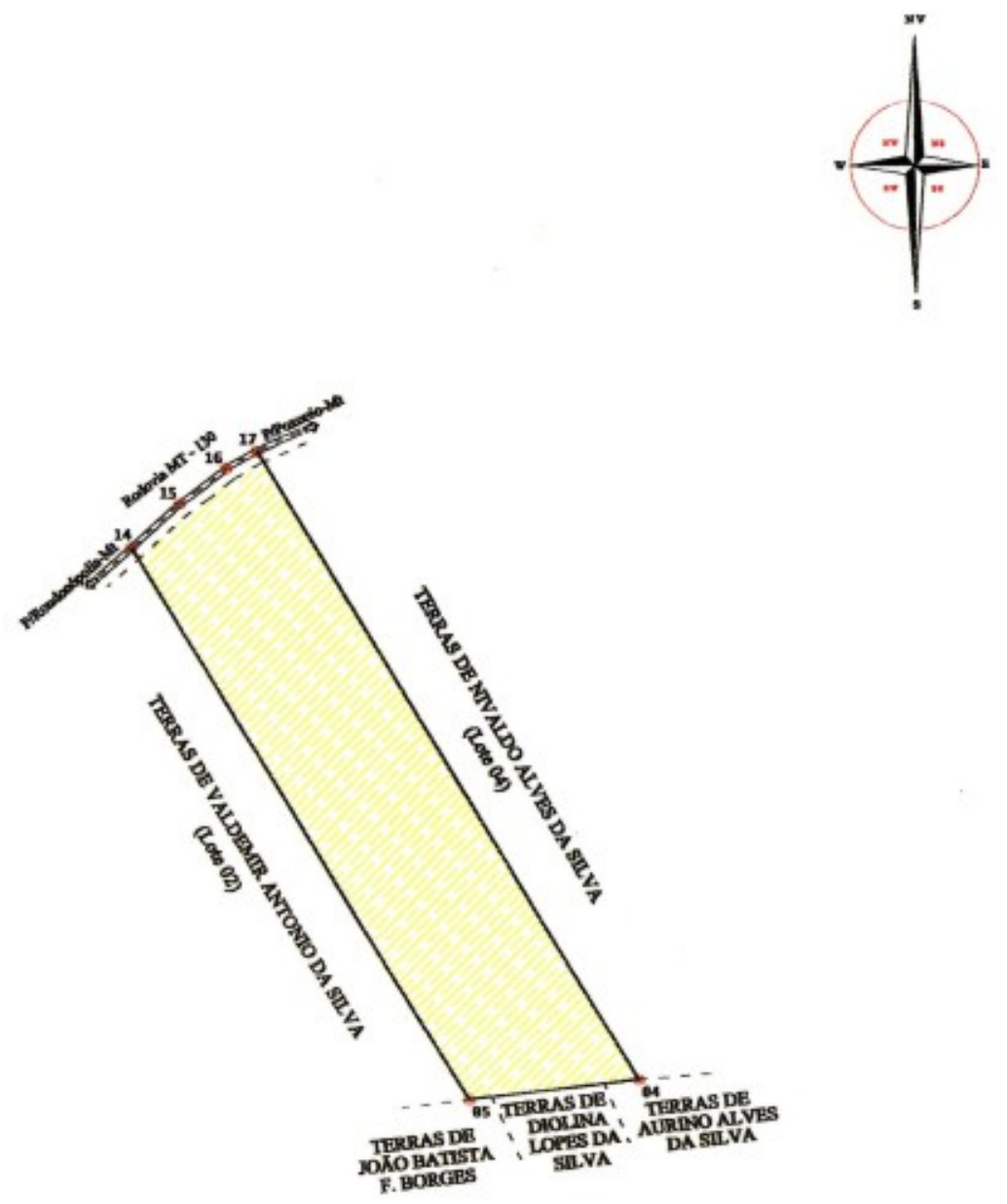

\section{ROTEIRO}

\begin{tabular}{|c|c|c|}
\hline MARCOS & AZIMUTES VERD. & DISTR̃NCIAS (m) \\
\hline $04-05$ & $262^{\circ} 59^{\prime} 61^{\prime \prime}$ & 327,45 \\
\hline$\theta 5=14$ & $328^{\circ} 45^{\prime} 29^{\prime \prime}$ & $1.238,84$ \\
\hline $14-15$ & $47^{\circ} 53^{\prime} 28^{\prime \prime}$ & 125,96 \\
\hline $15-16$ & $52^{\circ} 36^{\circ} 39^{\circ}$ & 111.69 \\
\hline $16-17$ & $68^{\circ} 24^{\prime} 38^{\prime \prime}$ & 68,39 \\
\hline $17-84$ & $148^{\circ} 56^{\prime} 28^{\prime \prime}$ & 1.406 .95 \\
\hline
\end{tabular}

Escala Cráfica:

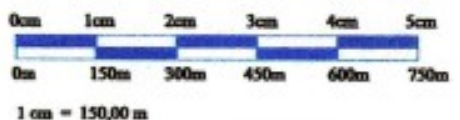

$1 \mathrm{~cm}=150,00 \mathrm{~m}$

\section{munectipo:}

RONDONÓPOLIS - MT Suarez Corréa de Souza 
ANEXO M: MAPA XXVIII- Lote 04 - Nivaldo Alves da Silva
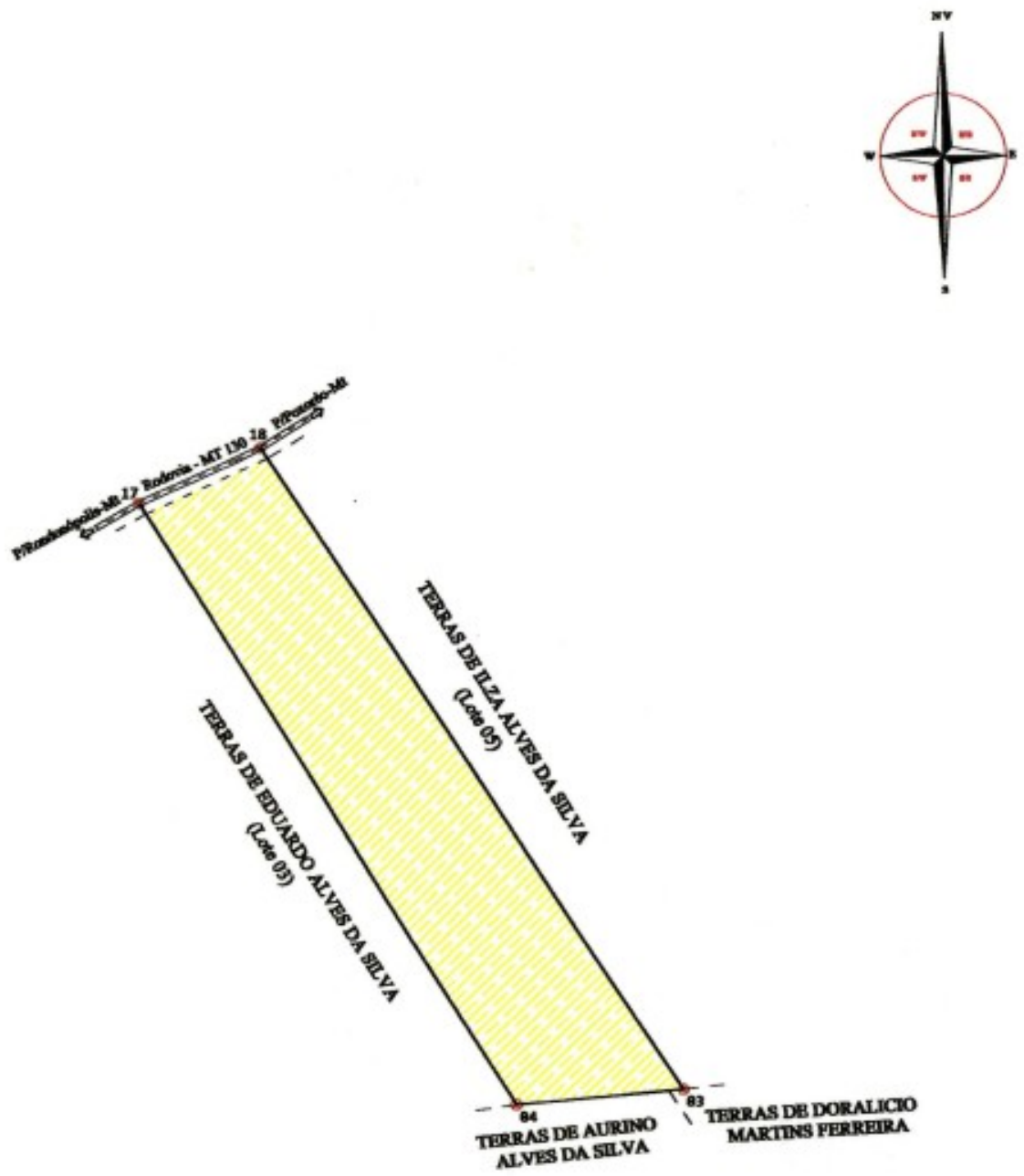

ROTEIRO

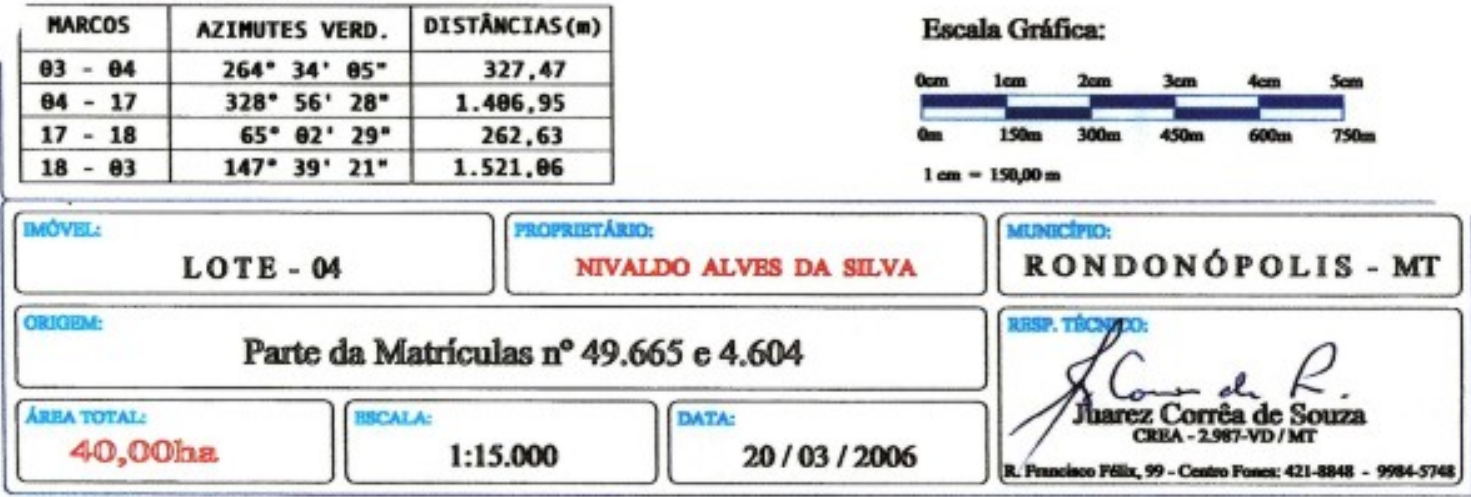


ANEXO N: MAPA XXIX- Lote 05 - Ilza Alves da Silva

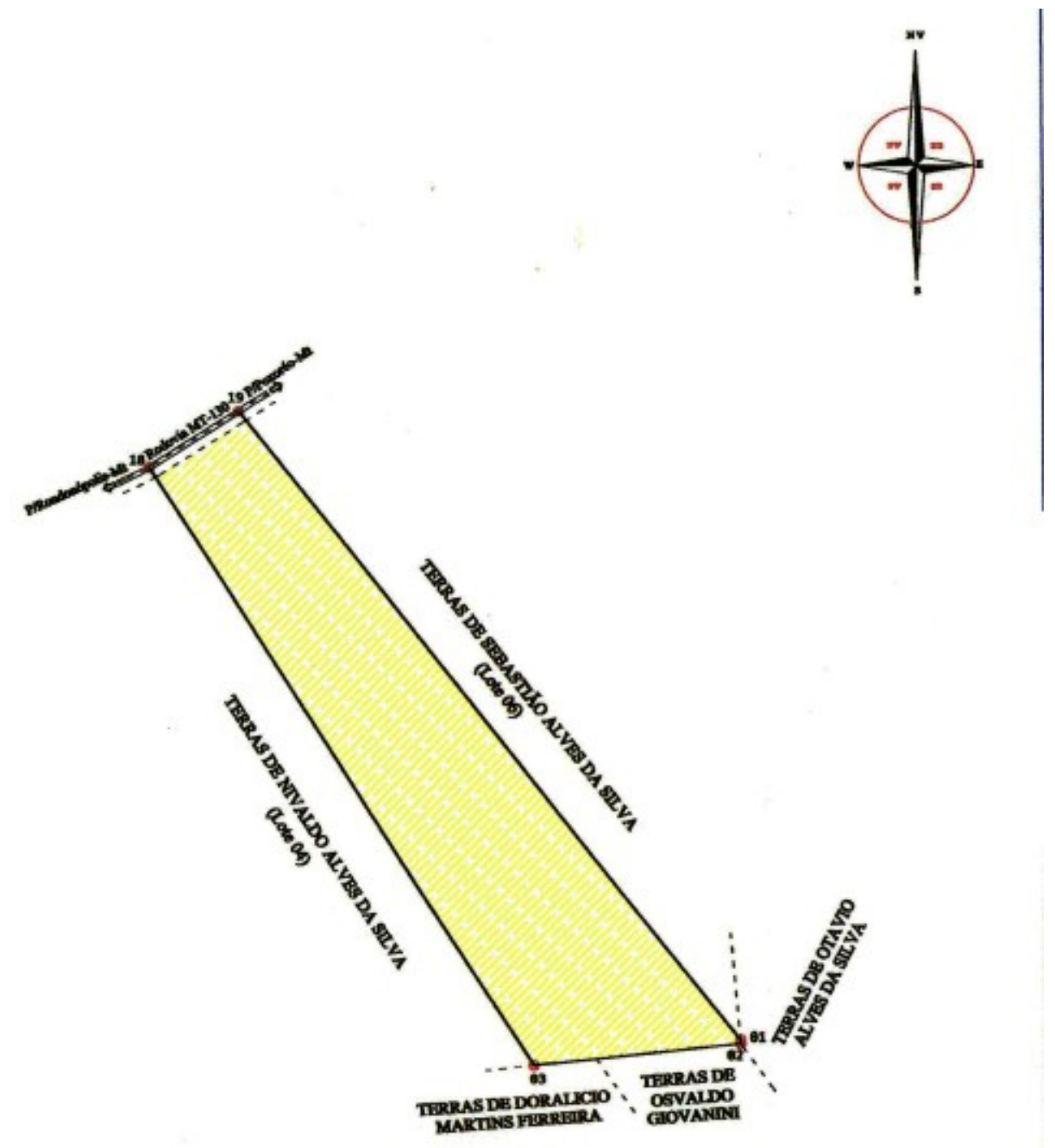

ROTEIRO

\begin{tabular}{|c|c|c|c|c|}
\hline MARCOS & AZIMUTES VERD. & DISTAMCIAS (m) & & \multirow{6}{*}{ 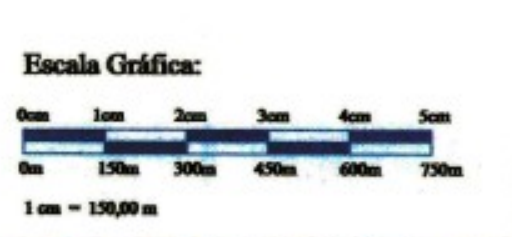 } \\
\hline$\theta 1-\theta 2$ & $175^{\circ} \theta 2^{\prime} 26^{\prime \prime}$ & 8,30 & & \\
\hline$\theta 2-\theta 3$ & $263^{\circ} 47^{\prime} 17^{\prime \prime}$ & 443,60 & & \\
\hline$\theta 3-18$ & $327^{\circ} 39^{\circ} 21^{\circ}$ & 1.521 .06 & & \\
\hline $18-19$ & $57^{\circ} 45^{\prime} 32^{\prime \prime}$ & 226.64 & & \\
\hline $19-01$ & $141^{\circ} 47^{\prime} 36^{\circ}$ & 1.717 .65 & & \\
\hline móvel: & LOTE - 05 & $\begin{array}{r}\text { momartikao: } \\
\text { IIZA A }\end{array}$ & LVBS DA sIIVA & 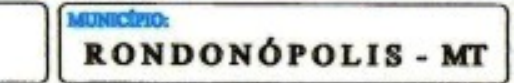 \\
\hline onucese: & Parte das Matr & fículas n' 49.66 & 5 e 4.604 & \\
\hline $\begin{array}{r}\text { Anen torzhl } \\
50,0\end{array}$ & SECNALt & $1: 15.000$ & $20 / 03 / 2006$ & \\
\hline
\end{tabular}


ANEXO O: MAPA XXX- Lote 06 - Sebastião Alves da Silva

\begin{tabular}{|c|c|c|}
\hline \multicolumn{3}{|c|}{ ROTEIRO } \\
\hline MARCOS & AZIMUTES vERO. & DISTANCIAS (m) \\
\hline 91 - 19 & $321^{*} 47^{\circ} 36^{*}$ & 1.717 .65 \\
\hline $19-2 \theta$ & $57 \times 19^{\circ} 15^{*}$ & 142,66 \\
\hline $2 \theta-21$ & $50^{*} 87^{\circ} 41^{\circ}$ & 110,75 \\
\hline $21=22$ & $57^{*}-61^{\prime} 50^{*}$ & $44,1 \theta$ \\
\hline $22-23$ & $33^{*} 10^{\circ} 43^{*}$ & 31,06 \\
\hline $23=24$ & $69^{\circ} 27^{\circ} 44^{\circ}$ & 30,41 \\
\hline $24-25$ & 01. 41. $65^{\prime \prime}$ & 34,01 \\
\hline $25-26$ & $342^{\circ} 48^{\circ} 65^{\circ}$ & 43,97 \\
\hline $26-27$ & $334^{\circ} 39^{\circ}$.99" & 72,01 \\
\hline $27-28$ & $342^{*} \theta 7^{*} 17^{*}$ & 32,57 \\
\hline $28-29$ & $85^{\circ} 11^{\prime} 49^{\circ}$ & 33,14 \\
\hline $29=39$ & $14^{\circ} 44^{\circ} 37^{\circ}$ & 39.29 \\
\hline $30-31$ & $22^{*}-66^{\circ} 34^{*}$ & 71,96 \\
\hline $31-32$ & $126^{\circ} 42^{\circ} 34^{\circ}$ & 678.50 \\
\hline $32-32 A$ & $210^{\circ} 19^{\circ} 58^{\circ}$ & 630,36 \\
\hline $32 A=4 \theta$ & $141^{*} 14^{\prime} 99^{*}$ & 902.91 \\
\hline $4 \theta-1$ & $175^{\circ} 62^{\circ} 26^{\circ}$ & 234,61 \\
\hline
\end{tabular}
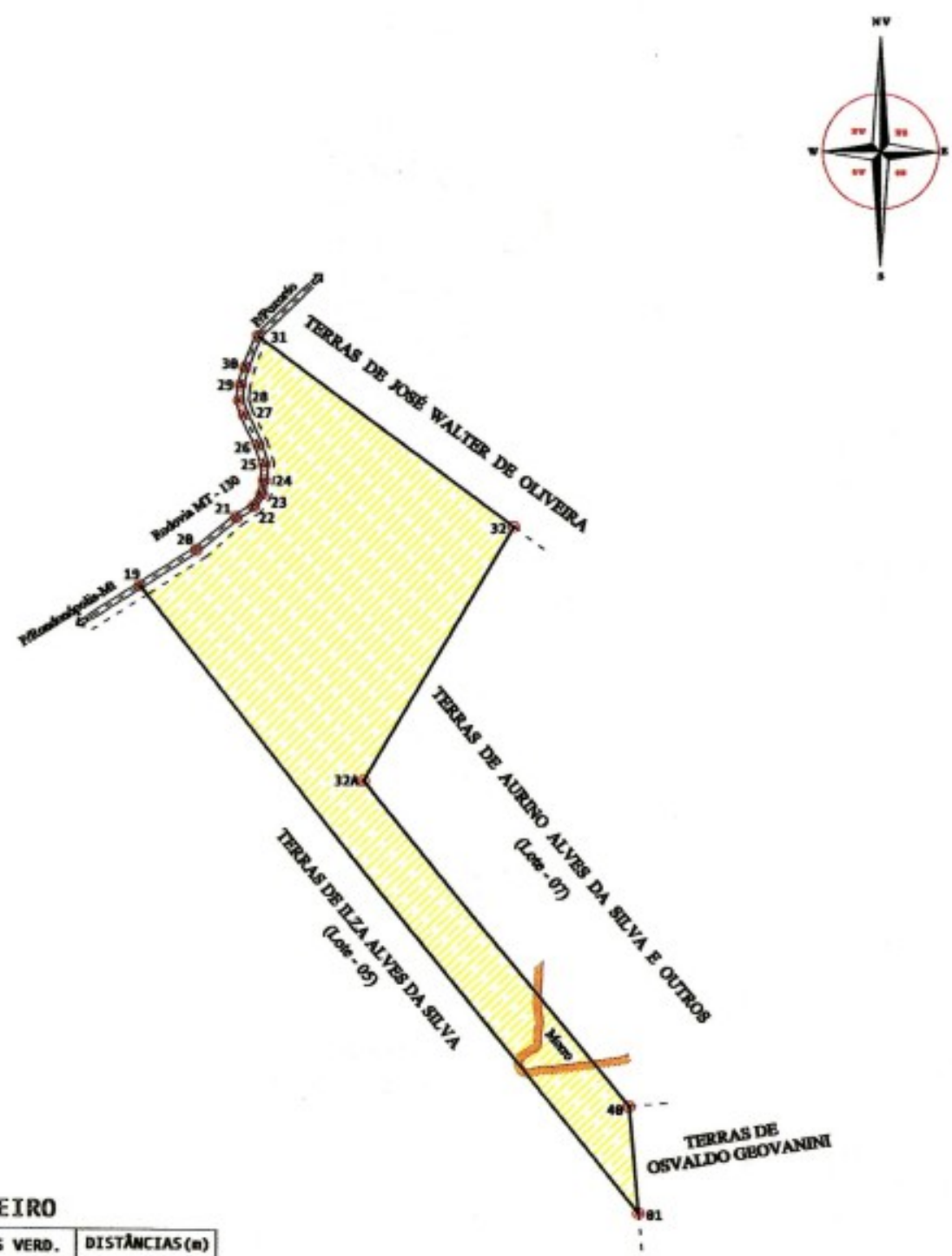

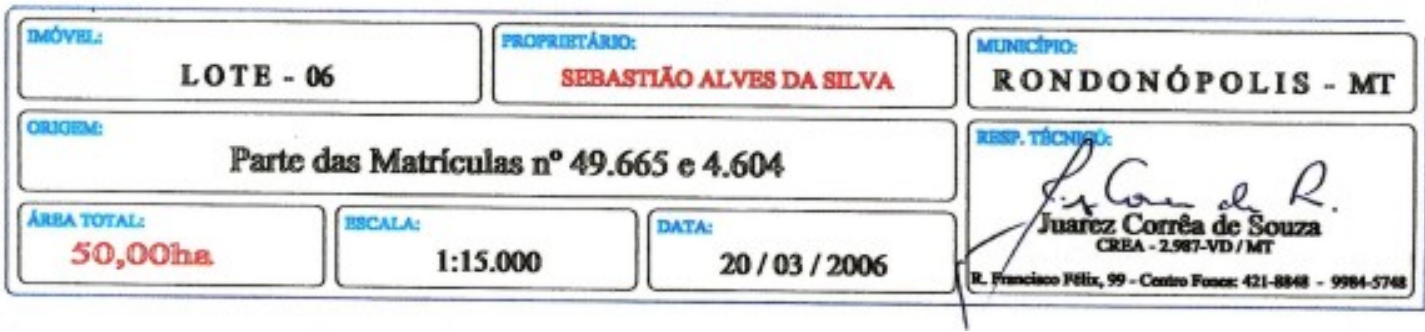


ANEXO P: MAPA XXXI- Lote 07 - Aurino Alves da Silva
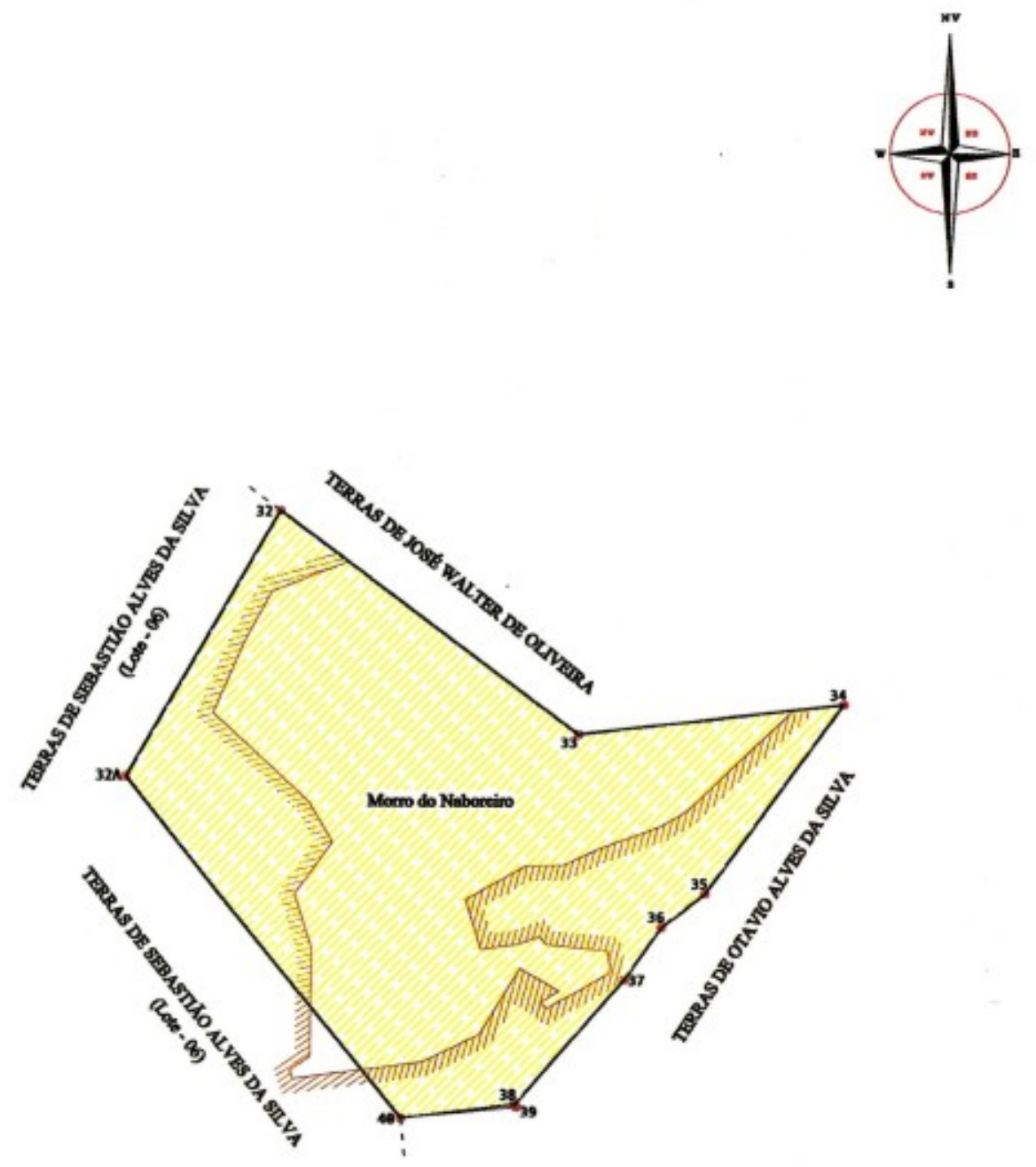

Escala Grafica:

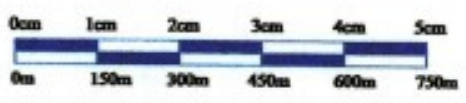

$1 \mathrm{~cm}=150,00 \mathrm{~m}$

\begin{tabular}{|c|c|c|c|}
\hline \multicolumn{4}{|c|}{ ROTEIRO } \\
\hline makcos & AZIMUTE: & ES VERB. & DISTKMCIAS (a) \\
\hline $32-33$ & $126^{*} 4$ & 22. $34^{*}$ & 761,99 \\
\hline $33-34$ & $83^{*} 2$ & $21^{*} \cdot 17^{*}$ & 547.79 \\
\hline $34-35$ & $216^{*} 2$ & $26^{\circ} 24^{\circ}$ & 479.81 \\
\hline $35-36$ & $232^{\circ} 1$ & $12^{\circ} 51^{*}$ & 112,61 \\
\hline $36-37$ & $214^{*} 31$ & $38^{\circ} 27^{\prime \prime}$ & 133.70 \\
\hline $37-38$ & $22 \theta^{*} 31$ & $38^{\circ} 15^{\circ}$ & 343.94 \\
\hline $38-39$ & $153^{\circ} 26$ & $26^{\circ} 96^{\circ}$ & 6.71 \\
\hline $39-4 \theta$ & $264^{*} 1$ & $13^{\circ} 63^{\circ}$ & 238,21 \\
\hline $40-321$ & $321 * 1$ & $14^{\prime} 69^{\circ}$ & 992.91 \\
\hline $32 A-32$ & $3 \theta^{*}-1$ & 19. $58^{\circ}$ & $63 \theta, 36$ \\
\hline
\end{tabular}

\begin{tabular}{|c|c|c|c|}
\hline LOTE - 07 & & $\begin{array}{l}\text { RRORUIRTRMO: } \\
\text { AURINO ALVES DA SILVA B OUTROS }\end{array}$ & $\begin{array}{l}\text { Municlino: } \\
\text { RONDONÓPOLIS - MT }\end{array}$ \\
\hline \multicolumn{3}{|c|}{ Parte da Matrícula n'49.665 e Matrícula $n^{\circ} 4.602$} & \\
\hline $\begin{array}{l}\text { AREA TOTAL: } \\
\text { 89,00has }\end{array}$ & 1:15.000 & $20 / 03 / 2006$ & Dentop Fonex: 421-88 \\
\hline
\end{tabular}


ANEXO Q: MAPA XXXII- Lote 08 - João Santos da Silva
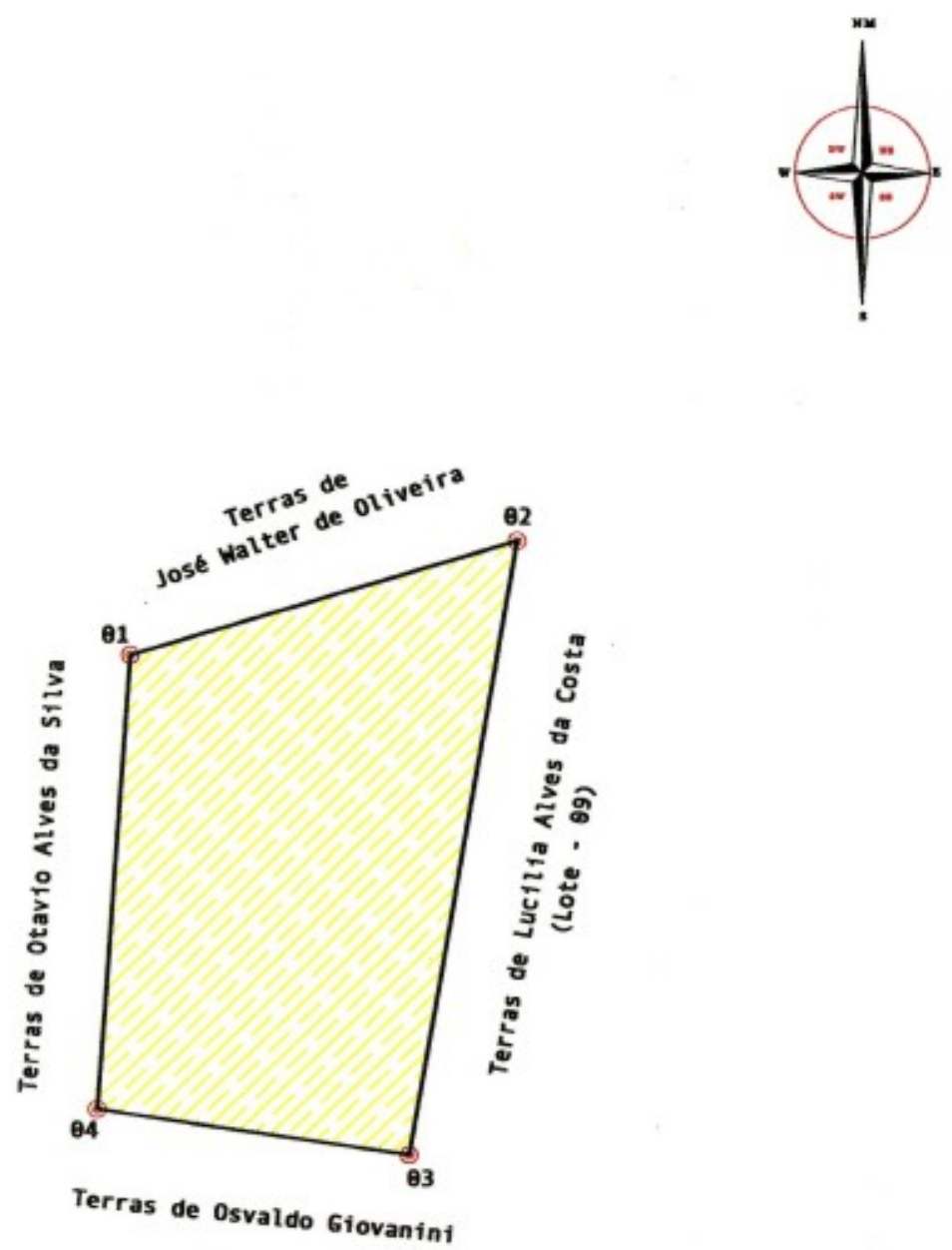

ROTEIRO

\begin{tabular}{|c|c|c|}
\hline MARCOS & RUMOS MAG. & DISTÂNCIAS (m) \\
\hline$\theta 1-\theta 2$ & $72^{\circ} 53^{\prime} 60^{\prime} \mathrm{NE}$ & 493,50 \\
\hline$\theta 2-\theta 3$ & $99^{\circ} 43^{\circ} \theta \theta^{\prime \prime} \mathrm{SW}$ & 776,00 \\
\hline$\theta 3-\theta 4$ & $81^{\circ} 43^{\prime} \theta 0^{\prime \prime} \mathrm{NW}$ & 384,80 \\
\hline$\theta 4-\theta 1$ & $\theta 4^{\circ} \theta 4^{\prime} \theta \theta^{\prime \prime N E}$ & $565,8 \theta$ \\
\hline
\end{tabular}

$1 \mathrm{am}-100,00 \mathrm{~m}$

\begin{tabular}{|c|c|c|c|}
\hline LOTE - 08 & $\begin{array}{r}\text { Propansti } \\
\text { Jo }\end{array}$ & SANTOS DA SILVA & \begin{tabular}{|l|} 
Munclino: \\
RON DON Ó POLIS - MT
\end{tabular} \\
\hline $\begin{array}{ll}\text { Oadoles: } & \\
& \text { Matricula ñ } 12.229\end{array}$ & orichese & lonia do Naboreiro & . \\
\hline $\begin{array}{l}\text { A.ru TOTAL: } \\
27,8888 \mathrm{he}\end{array}$ & $\begin{array}{r}\text { Hascula: } \\
1: 10.000 \\
\end{array}$ & $\begin{array}{l}\text { DATA: } \\
20 / 03 / 2006\end{array}$ & 20045748 \\
\hline
\end{tabular}


ANEXO R: MAPA XXXIII- Lote 09 - Lucilia Alves da Costa
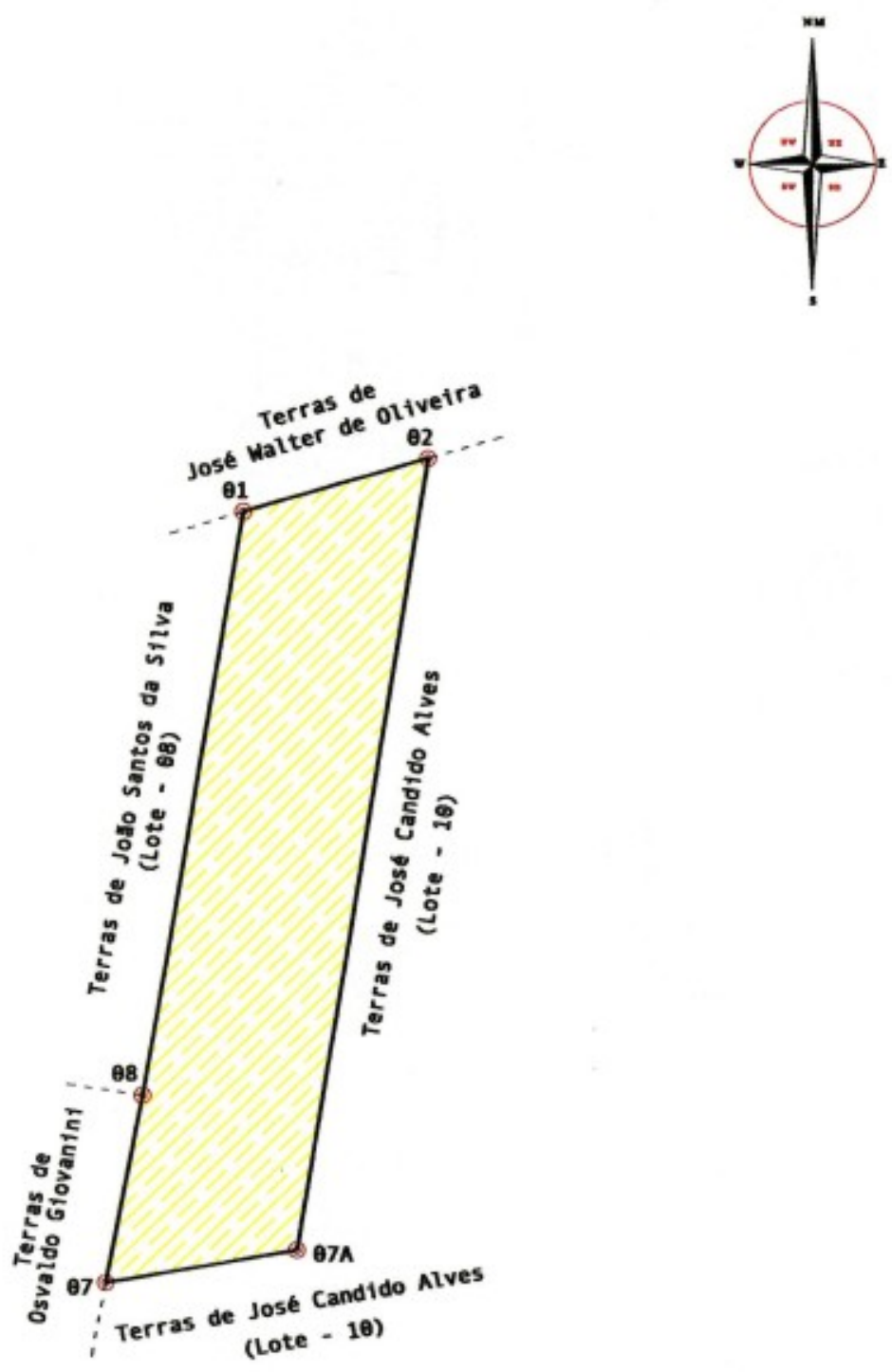

ROTEIRO

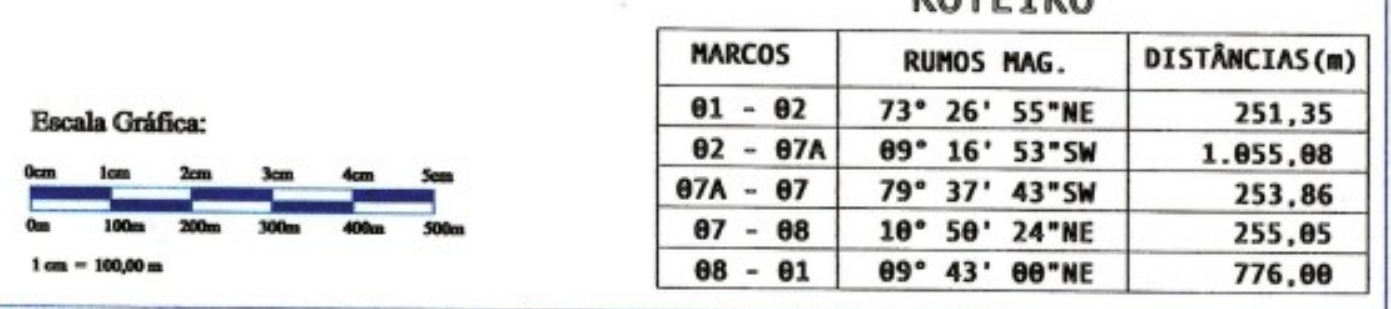

\begin{tabular}{|c|c|c|c|}
\hline LOTE -09 & & $\begin{array}{l}\text { momerethino: } \\
\text { LUCILIA ALVES DA COSTA }\end{array}$ & $\begin{array}{l}\text { Munictino: } \\
\text { RONDONÓPOLIS - MT }\end{array}$ \\
\hline \multicolumn{3}{|c|}{ Parte da Matricula n 17.860} & \\
\hline $\begin{array}{l}\text { Mrgu Torali } \\
24,00 \mathrm{hat}\end{array}$ & $1: 10.000$ & $20 / 03 / 2006$ & (c) \\
\hline
\end{tabular}


ANEXO S: MAPA XXXIV- Lote 10 - José Candido Alves

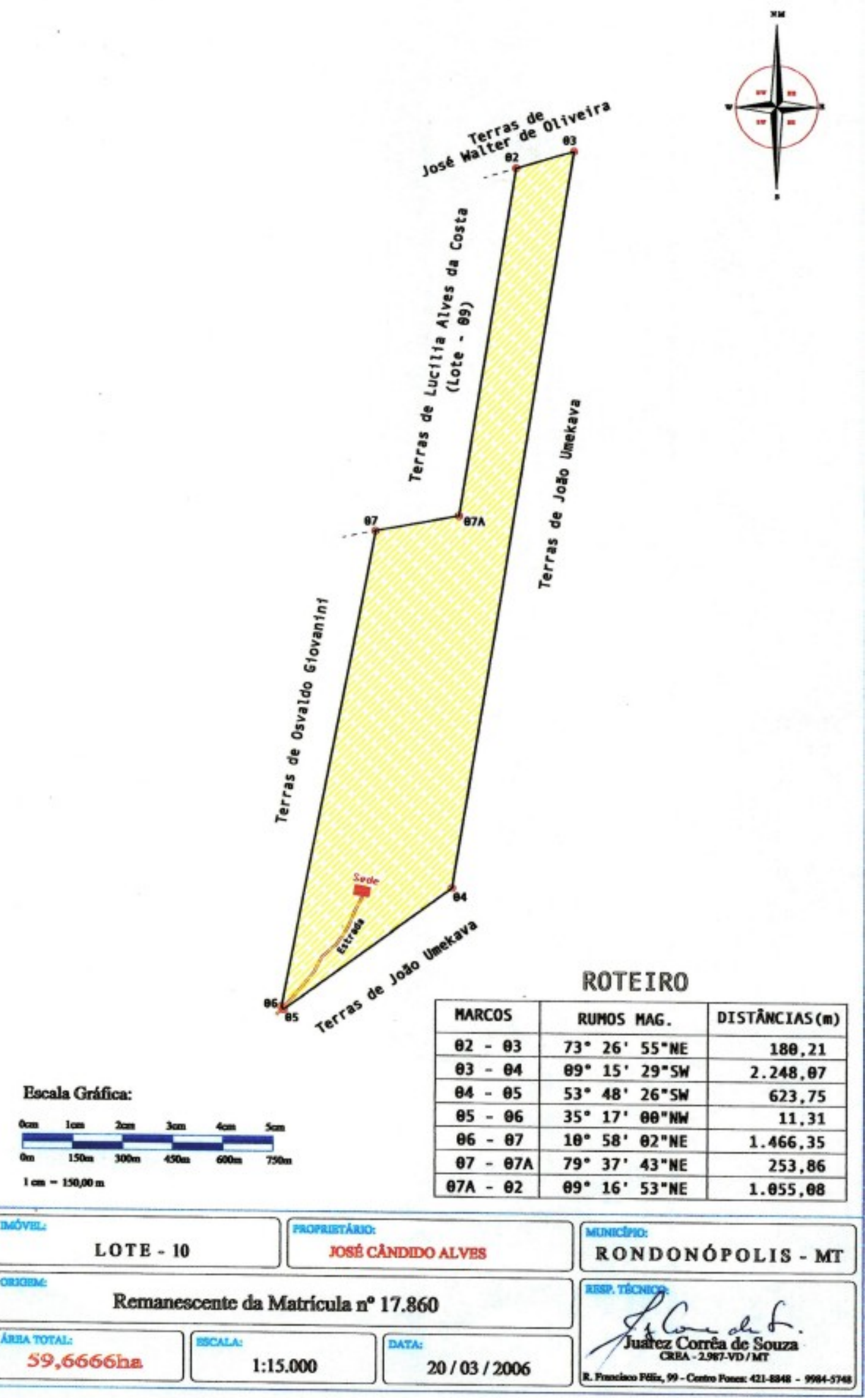


ANEXO T: Gildásio Souza Aquino e outros.

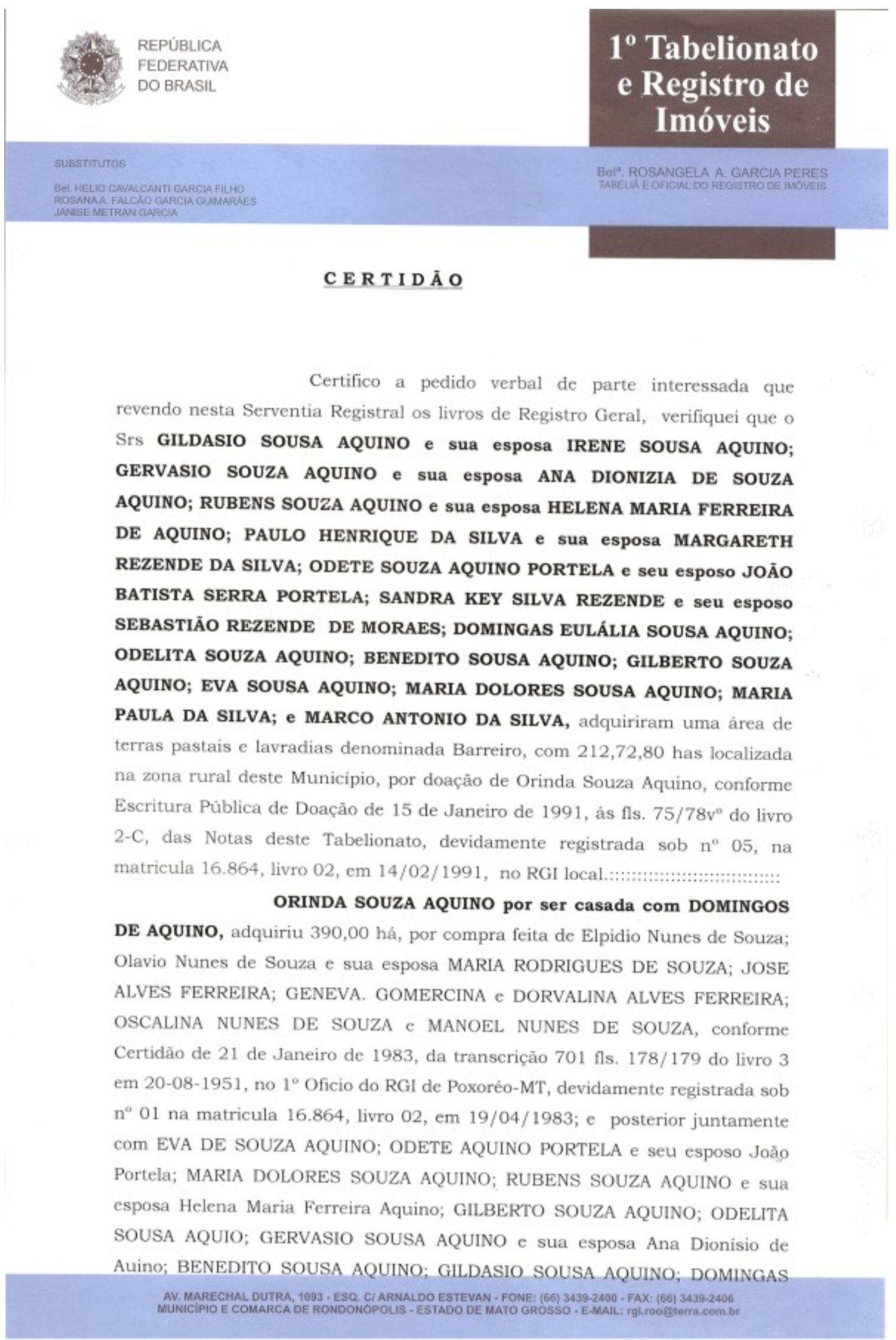


ANEXO U - Sítio IV Irmãos e Sítio Santa Clara
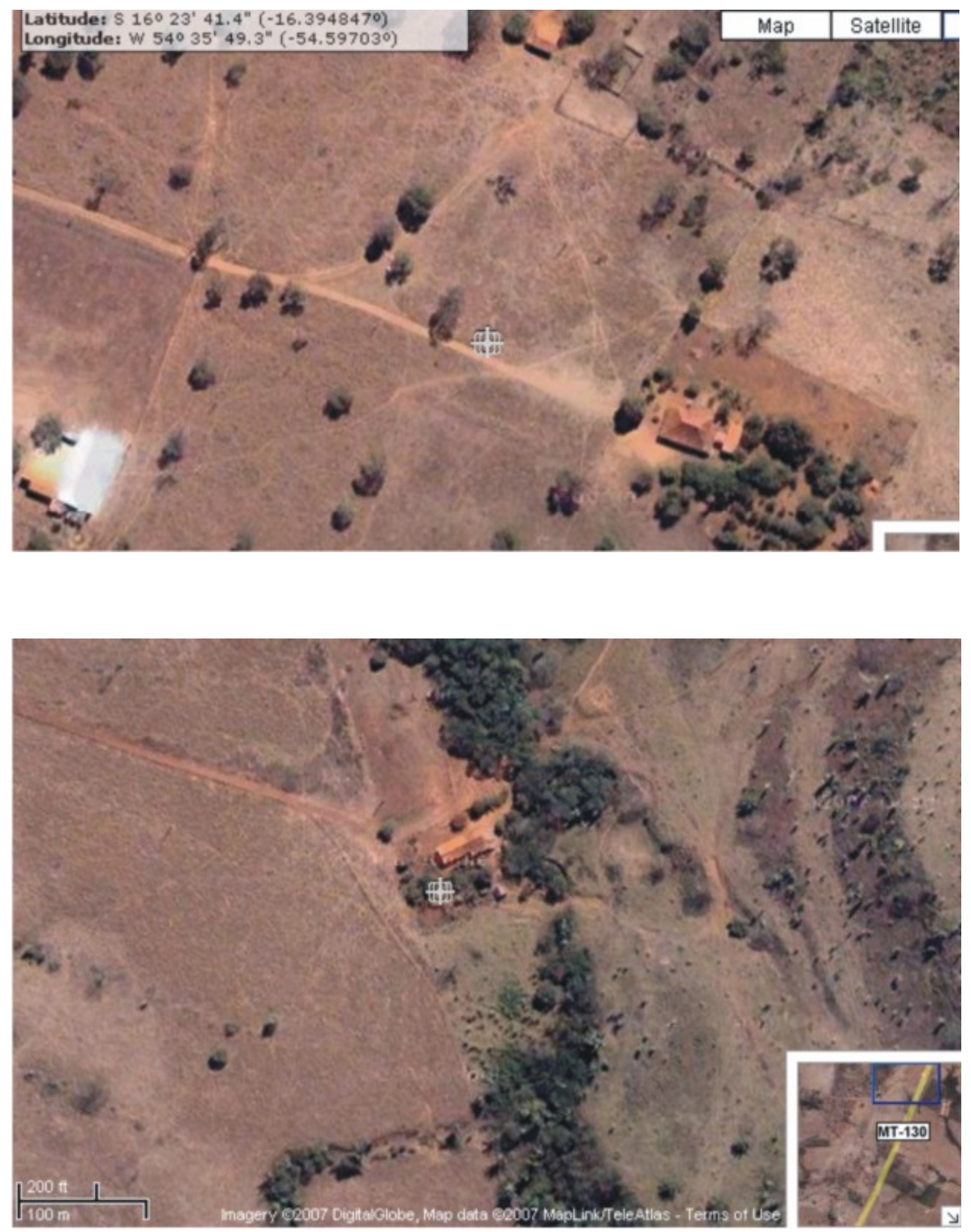
ANEXO V - Sítio São Luiz e Estância Ouro Fino
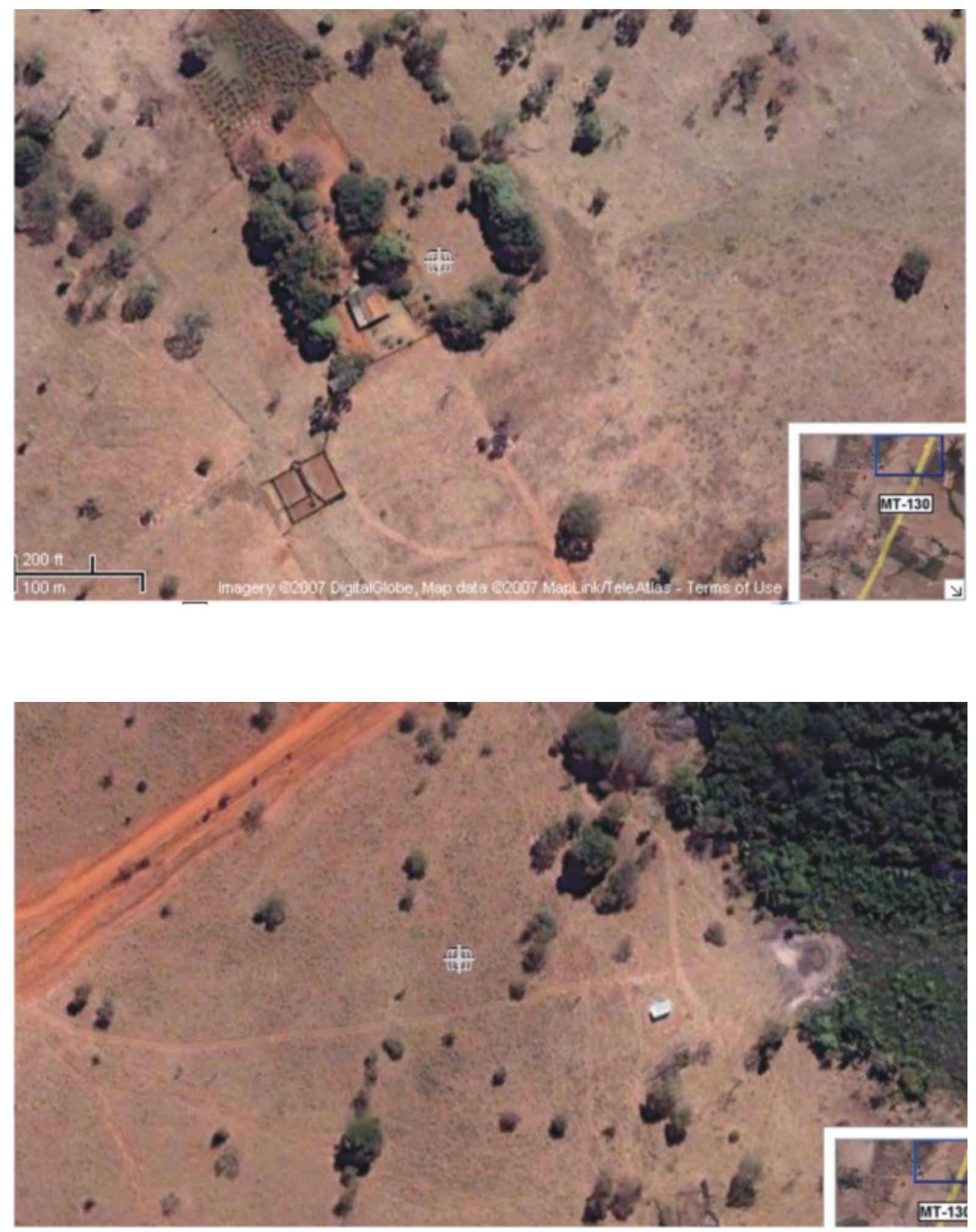
ANEXO X - Sítio São Pedro e Sítio Beroaba
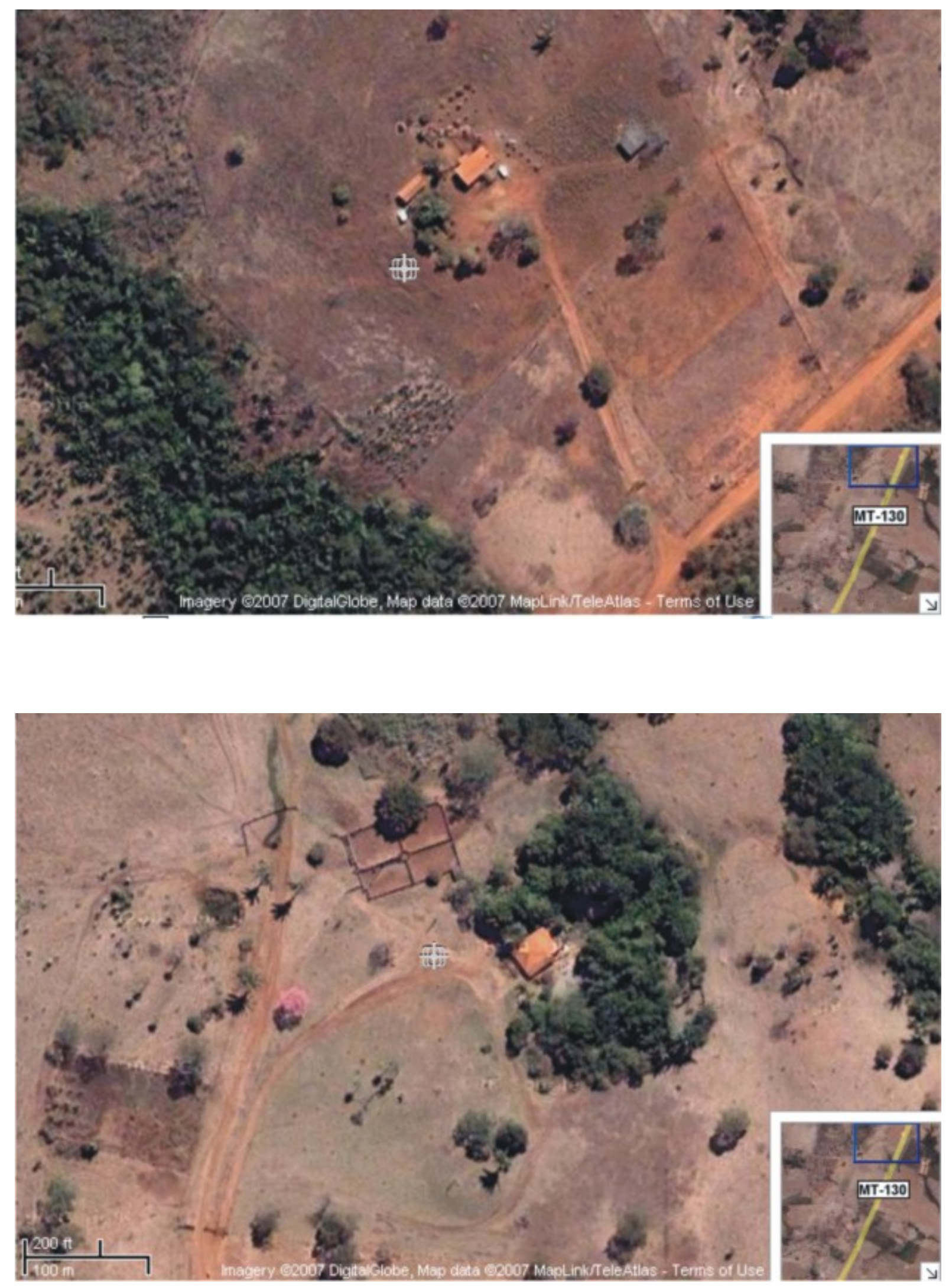
ANEXO Y - Sítio Cristandade e Dhessyka e Marryelle
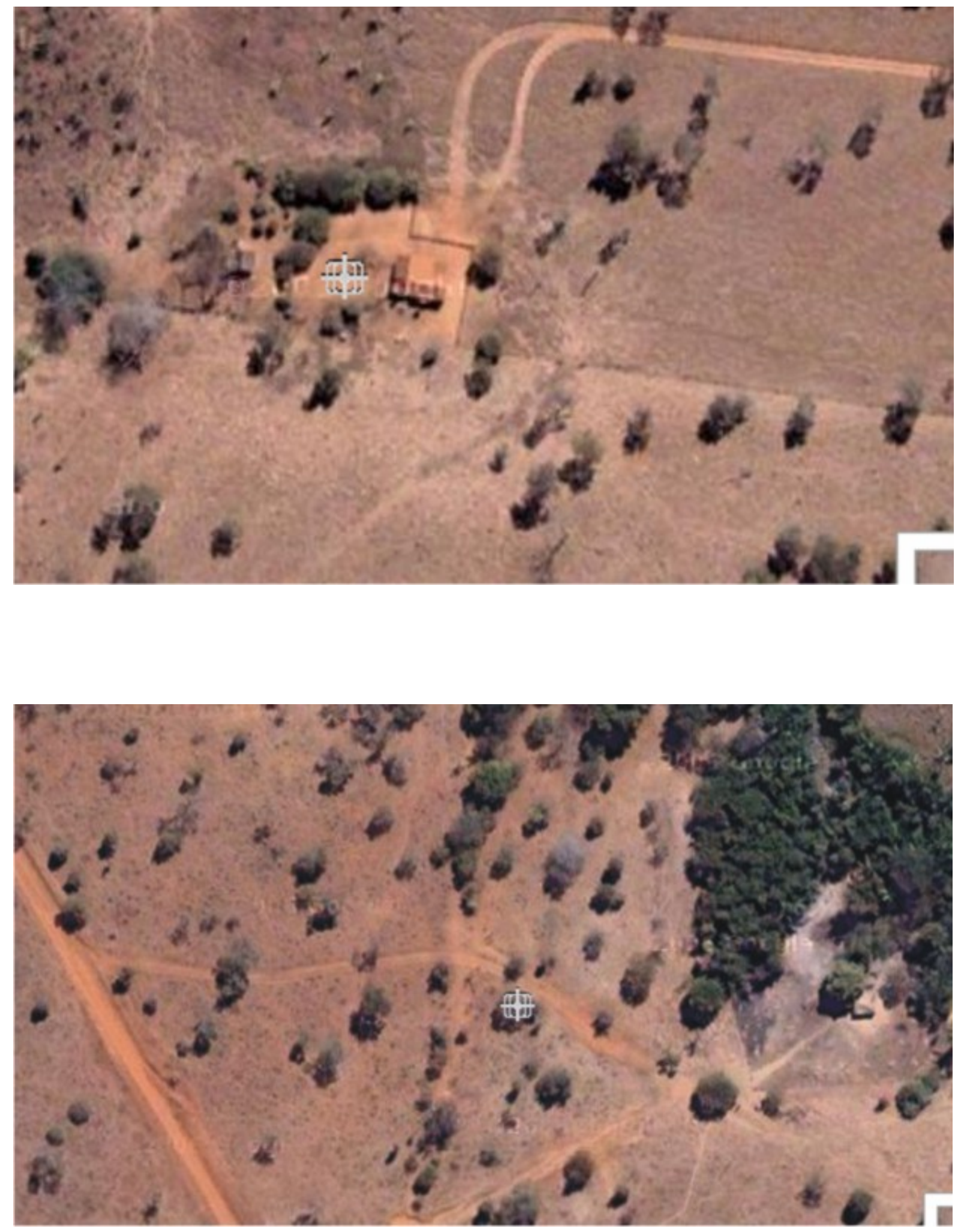
ANEXO Z - Sítio Dois Irmãos e Sítio A.B.C.
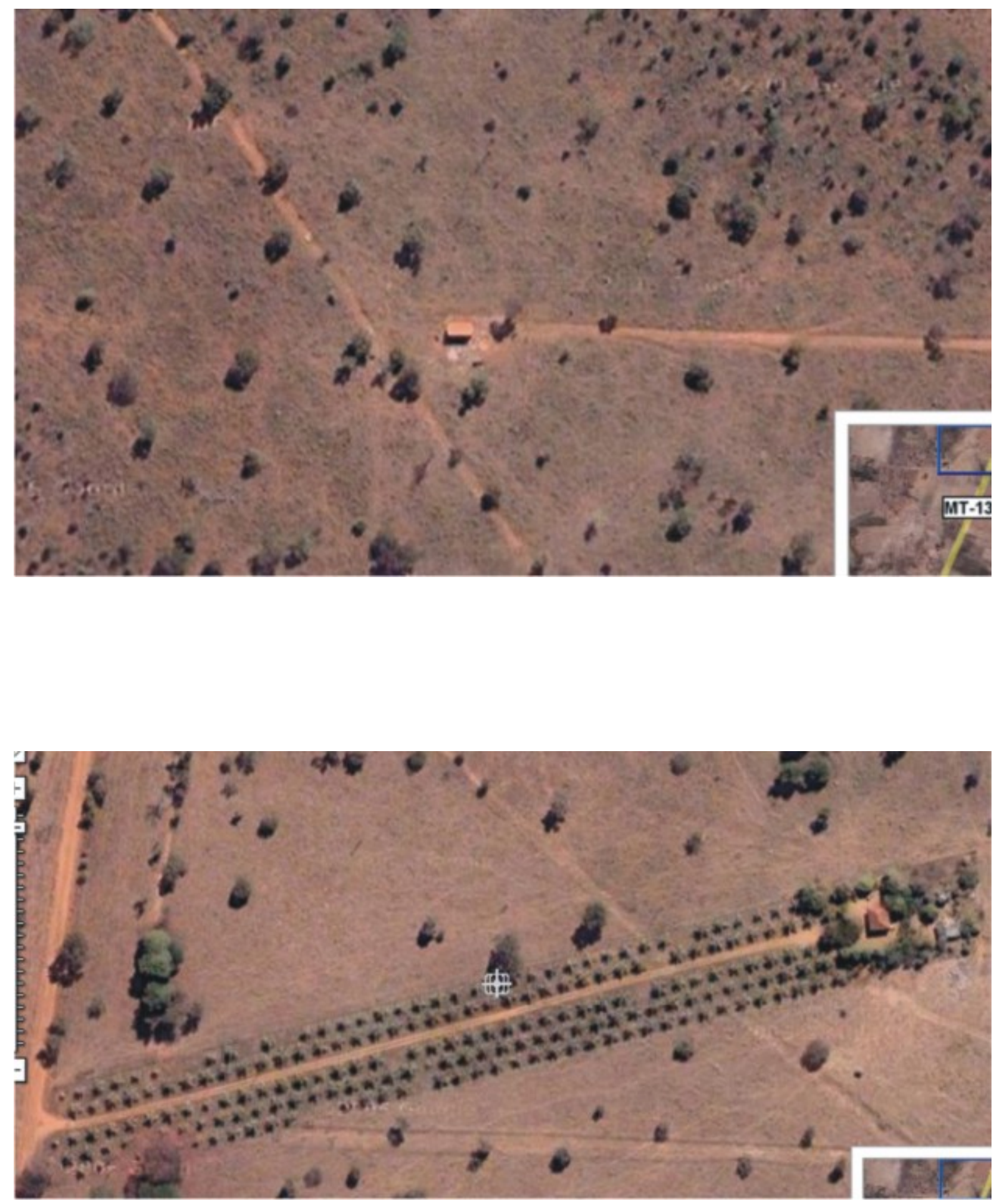